Prepared in cooperation with the Alabama Department of Economic and Community Affairs Office of Water Resources

\title{
Estimated Use of Water in Alabama in 2005
}


The coal-fired James $\mathrm{H}$. Miller Steam Plant employs a recirculating-induced draft tower to cool water before release as return flow to the Mulberry Fork of the Black Warrior River. (Photo courtesy of Sheila A. Garrett Alabama Power Company.)

A surface-water intake on the Tallapoosa River is one of several sources of water for the City of Montgomery Alabama. (Photo courtesy of Montgomery Water Works and Sanitary Sewer Board.)
Public suppliers and private

wells provide plentiful water to the residents and visitors of Alabama. (Photo courtesy of Glenn Phillips.)

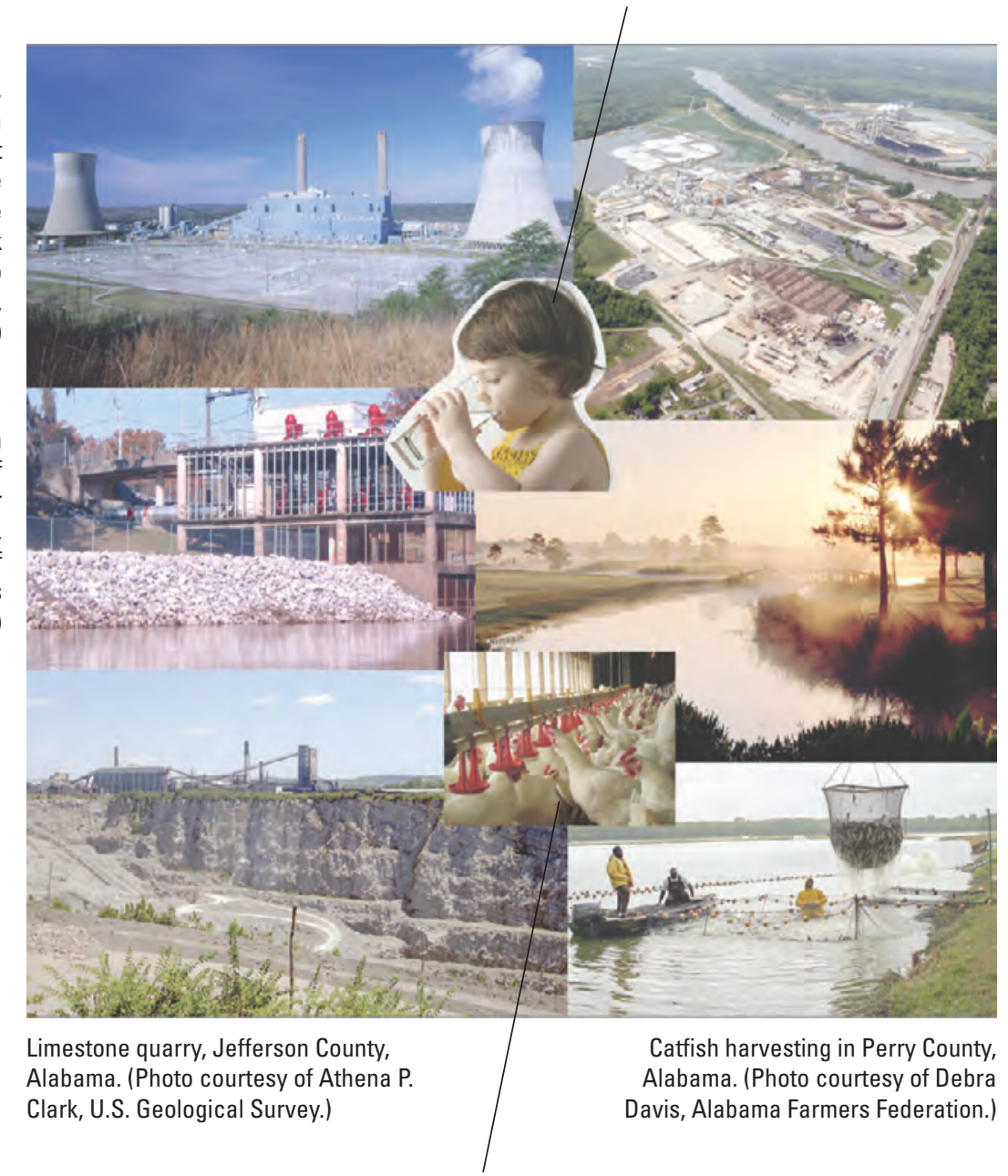

Breeder chickens in Cleburne County, Alabama. (Photo by Michael J. Harper, Alabama Office of Water Resources.)
Boise Paper Mill in Jackson, Alabama. (Photo courtesy of Boise Papers.)
Golf course ponds collect rainfall and runoff. Shown is Craft Farms Golf Resort, Cypress Bend Golf Course, Foley, Alabama. (Photo courtesy of Alabama Bureau of Tourism \& Travel.) 


\section{Estimated Use of Water in Alabama in 2005}

By Susan S. Hutson, Thomas M. Littlepage, Michael J. Harper, and James 0. Tinney

Prepared in cooperation with the Alabama Department of Economic and Community Affairs, Office of Water Resources

Scientific Investigations Report 2009-5163 


\title{
U.S. Department of the Interior \\ KEN SALAZAR, Secretary
}

\author{
U.S. Geological Survey \\ Suzette M. Kimball, Acting Director
}

U.S. Geological Survey, Reston, Virginia: 2009

For more information on the USGS - the Federal source for science about the Earth, its natural and living resources, natural hazards, and the environment, visit http://www.usgs.gov or call 1-888-ASK-USGS

For an overview of USGS information products, including maps, imagery, and publications, visit $h$ ttp://www.usgs.gov/pubprod

To order this and other USGS information products, visit http://store.usgs.gov

Any use of trade, product, or firm names is for descriptive purposes only and does not imply endorsement by the U.S. Government.

Although this report is in the public domain, permission must be secured from the individual copyright owners to reproduce any copyrighted materials contained within this report.

Suggested citation:

Hutson, S.S., Littlepage, T.M., Harper, M.J., and Tinney, J.0., 2009, Estimated use of water in Alabama in 2005:

U.S. Geological Survey Scientific Investigations Report 2009-5163, 210 p. 




\section{Contents}

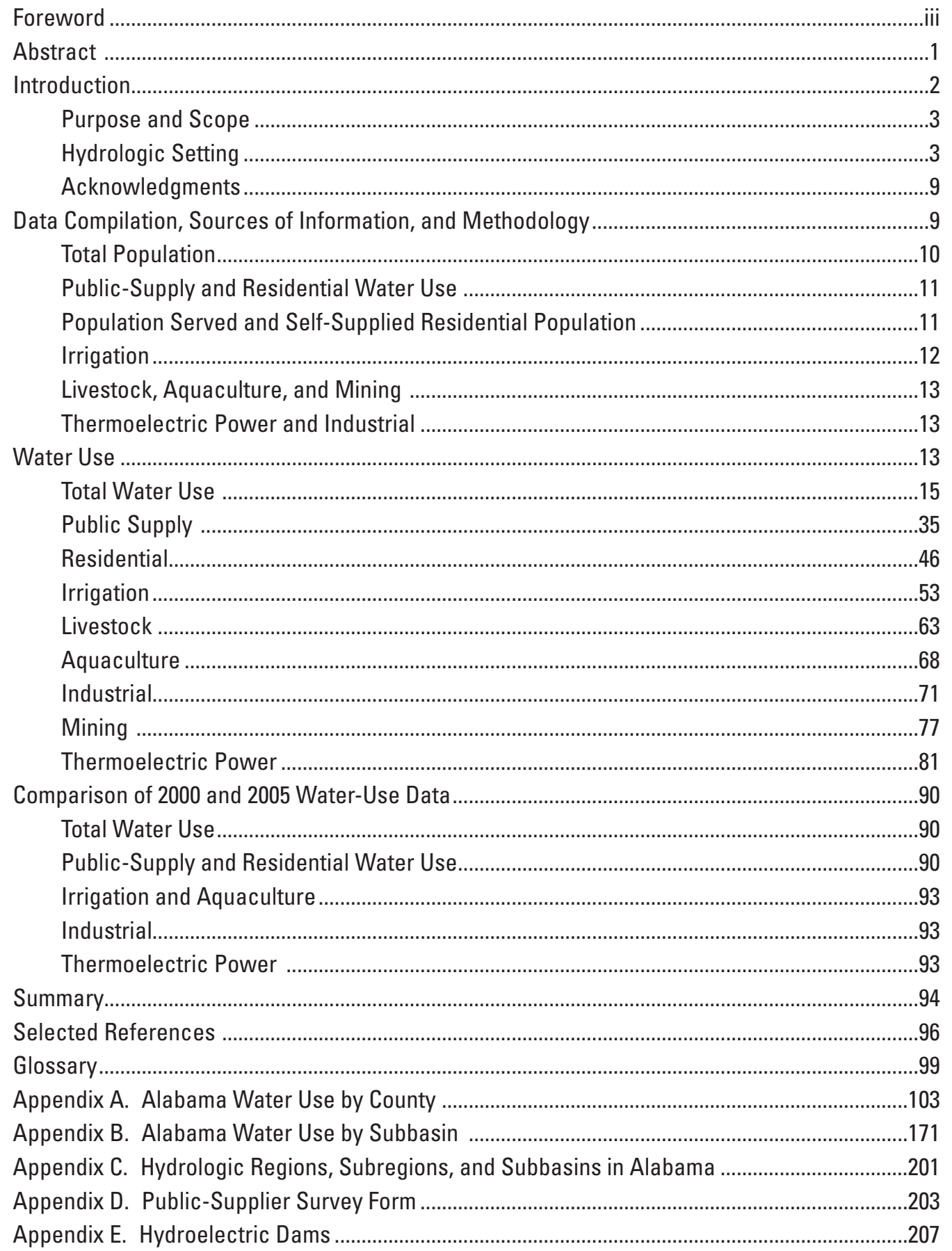




\section{Figures}

1. Graph showing freshwater withdrawals in Alabama, 1960 to 2005 ................................2

2-6. Maps showing-

2. Subregions in Alabama by county. .4

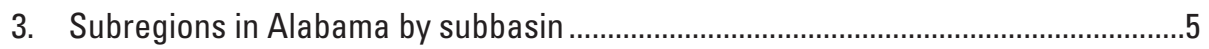

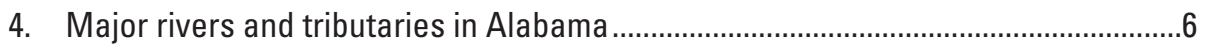

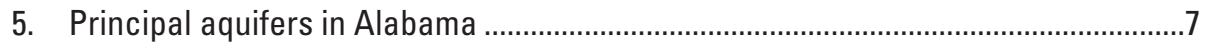

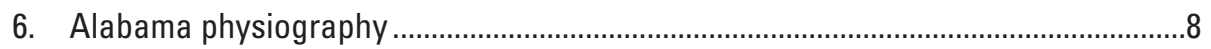

7. Schematic diagram showing the interrelation of water-using sites and water-use transactions to sources of supply ..................................................................14

8-9. Pie diagrams showing-

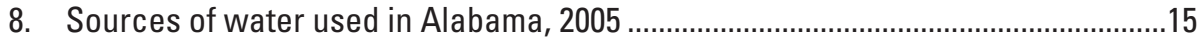

9. Comparison of freshwater withdrawals by category of use in Alabama, 2005.......15

10-11. Maps showing-

10. Total freshwater withdrawals by source and county in Alabama, 2005 .................16

11. Total freshwater withdrawals by source and hydrologic subbasin in Alabama, 2005

12. Schematic diagram showing sources and use of water in Alabama ...............................34

13. Pie diagram showing source and distribution of public-supply water in Alabama, 2005

14-16. Maps showing-

14. Percentage of population served by public suppliers in Alabama, 2005..................36

15. Public-supply withdrawals by source and county in Alabama, 2005........................37

16. Alabama cities with populations of 10,000 and greater, 2005 .................................42

17. Graph showing public-supply water withdrawals by rank and percentile

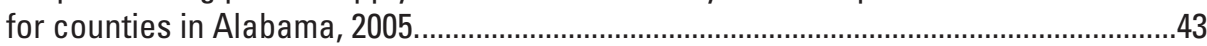

18. Map showing public-supply withdrawals by source and hydrologic subbasin in Alabama, 2005

19. Graph showing public-supply water withdrawals by rank and percentile for subbasins in Alabama, 2005

20-21. Maps showing-

20. Self-supplied residential ground-water withdrawals by county in Alabama, 2005

21. Self-supplied residential population as a percentage of total population and self-supplied residential population by county in Alabama, 2005 
22. Pie diagram showing source and distribution of water for irrigation use in Alabama, 2005.

23-24. Maps showing-

23. Irrigation withdrawals by source and county in Alabama, 2005.............................54

24. Irrigation withdrawals by source and subbasin in Alabama, 2005...........................55

25. Graph showing comparison of seasonal water use by golf course type in Alabama, 2005

26. Pie diagram showing source of water for livestock use in Alabama, 2005 ....................63

27-28. Maps showing-

27. Livestock freshwater withdrawals by source and county in Alabama, 2005 ..........64

28. Livestock freshwater withdrawals by source and subbasin in Alabama, 2005 ......65

29. Pie diagram showing source of water for aquaculture use in Alabama, 2005................68

30. Maps showing aquaculture freshwater withdrawals by source and county in Alabama, 2005

31. Pie diagram source of water for self-supplied industrial use in Alabama, 2005.............71

32-33. Maps showing-

32. Self-supplied industrial freshwater withdrawals by county in Alabama, 2005

33. Self-supplied industrial freshwater withdrawals by subbasin in Alabama, 2005

34. Graph showing distribution of total industrial withdrawals by Standard Industrial Classification grouping in Alabama, 2005 .76

35. Pie diagram showing source of water for mining use in Alabama, 2005 .........................77

36-38. Maps showing-

36. Mining freshwater withdrawals by county in Alabama, 2005 . .78

37. Thermoelectric-power freshwater withdrawals by source and county in Alabama, 2005.

38. Thermoelectric-power freshwater withdrawals by source and subbasin in Alabama, 2005.

D-1. Alabama Office of Water Resources, 2005 Alabama Water System Survey form.........204

E-1. Map showing hydroelectric dams in Alabama, 2005. 209 


\section{Tables}

1. Summary of data sources by category and type of data ...............................................10

2. Golf course classification and tier classification coefficients.........................................12

3. Total freshwater withdrawals by source and county, Alabama, 2005 ............................18

4. Total freshwater withdrawals by source and hydrologic subregion and

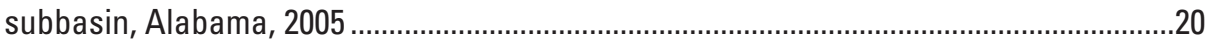

5. Total freshwater withdrawals by category of use and county, Alabama, 2005...............22

6. Total freshwater withdrawals by category of use and hydrologic subregion and subbasin, Alabama, 2005

7. Total fresh surface-water withdrawals by category of use and county, Alabama, 2005

8. Total fresh surface-water withdrawals by category of use and hydrologic subregion and subbasin, Alabama, 2005

9. Total fresh ground-water withdrawals by category of use and county, Alabama, 2005.

10. Total fresh ground-water withdrawals by category of use and hydrologic subregion and subbasin, Alabama, 2005

11. Public-supply freshwater use by county, Alabama, 2005 .

12. Public-supply freshwater use by hydrologic subregion and subbasin, Alabama, 2005

13. Residential freshwater use by county, Alabama, 2005.

14. Total irrigation freshwater withdrawals by county, Alabama, 2005 . .56

15. Total irrigation freshwater withdrawals by hydrologic subregion and subbasin, Alabama, 2005

16. Crop and golf course irrigated land and freshwater withdrawals by county, Alabama, 2005

17. Livestock freshwater withdrawals by county, Alabama, 2005.

18. Livestock freshwater withdrawals by hydrologic subregion and subbasin, Alabama, 2005.

19. Aquaculture freshwater withdrawals by county, Alabama, 2005...................................70

20. Self-supplied industrial freshwater withdrawals by county, Alabama, 2005 ..................74

21. Self-supplied industrial freshwater withdrawals by hydrologic subregion and subbasin, Alabama, 2005

22. Mining freshwater withdrawals by county, Alabama, 2005..........................................79

23. Total thermoelectric-power freshwater withdrawals by county, Alabama, 2005............84

24. Total thermoelectric-power freshwater withdrawals by hydrologic subregion and subbasin, Alabama, 2005

25. Thermoelectric-power freshwater withdrawals by cooling type and by county, Alabama, 2005

26. Thermoelectric-power freshwater withdrawals by cooling type and by hydrologic subregion and subbasin, Alabama, 2005.

27. Comparison of 2000 and 2005 public-supply water use and self-supplied industrial water use, Alabama

C-1. Eight-digit hydrologic unit codes and corresponding subbasin and subregion names, Alabama .202

E-1. Hydroelectric dams in Alabama, 2005. 


\section{Conversion Factors and Datums}

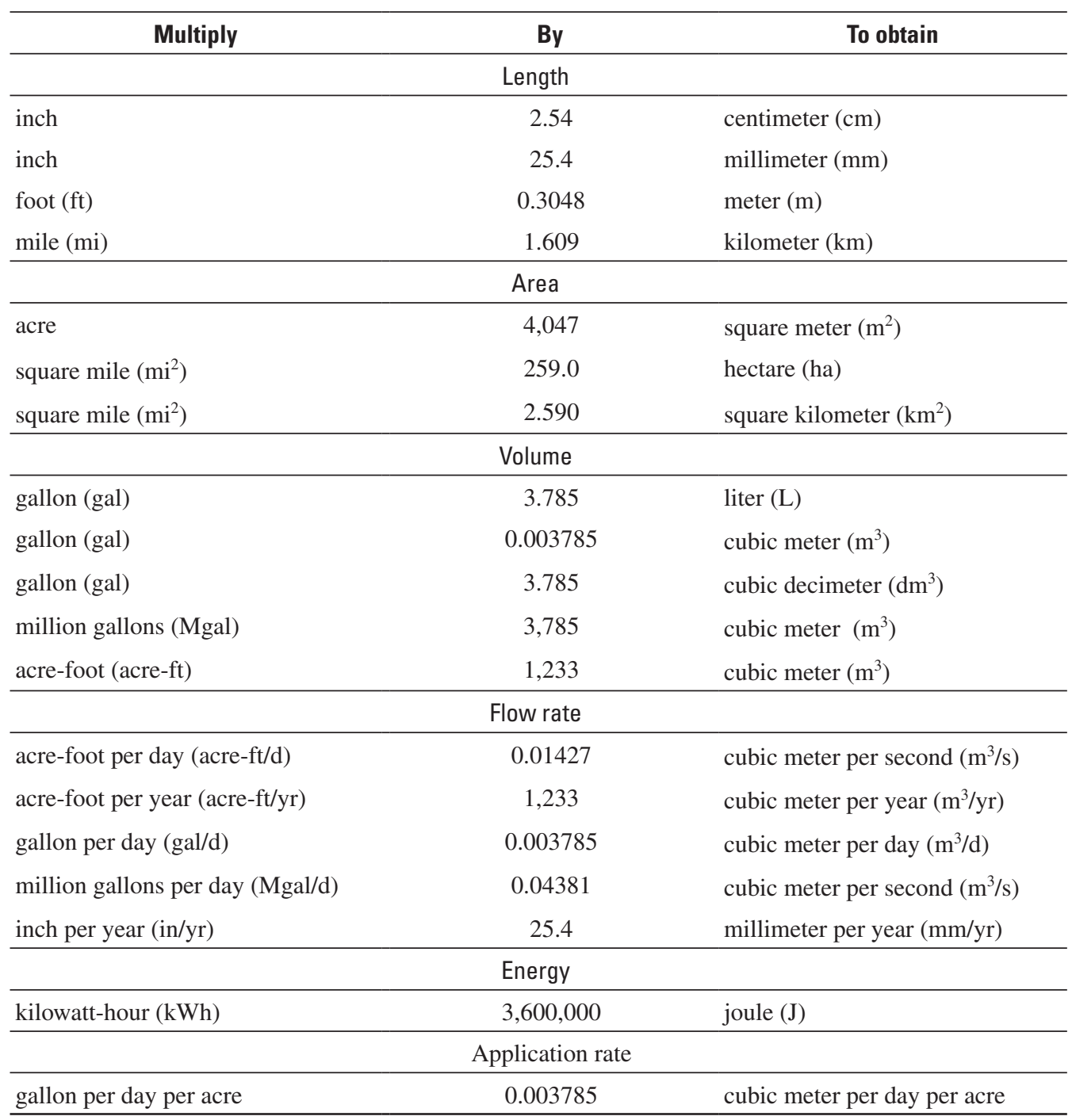

Temperature in degrees Celsius $\left({ }^{\circ} \mathrm{C}\right)$ may be converted to degrees Fahrenheit $\left({ }^{\circ} \mathrm{F}\right)$ as follows:

$$
{ }^{\circ} \mathrm{F}=\left(1.8 \times{ }^{\circ} \mathrm{C}\right)+32
$$

Temperature in degrees Fahrenheit $\left({ }^{\circ} \mathrm{F}\right)$ may be converted to degrees Celsius $\left({ }^{\circ} \mathrm{C}\right)$ as follows:

$$
{ }^{\circ} \mathrm{C}=\left({ }^{\circ} \mathrm{F}-32\right) / 1.8
$$

Vertical coordinate information is referenced to the North American Vertical Datum of 1988 (NAVD 88). Horizontal coordinate information is referenced to North American Datum of 1983 (NAD 83). 


\section{Abbreviations Used in this Report}

\begin{tabular}{|c|c|}
\hline ADECA & Alabama Department of Economic and Community Affairs \\
\hline ADEM & Alabama Department of Environmental Management \\
\hline AEC & Alabama Electric Cooperative \\
\hline AL & Alabama \\
\hline APCO & Alabama Power Company \\
\hline ARWA & Alabama Rural Water Association \\
\hline AWURP & Alabama Water Use Reporting Program \\
\hline $\mathrm{COU}$ & Certificate of Use \\
\hline CP & county population \\
\hline CWS & community water system \\
\hline DOE-EIA & Department of Energy, Energy Information Administration \\
\hline DWB-ADEM & Drinking Water Branch, Alabama Department of Environmental Management \\
\hline GA & Georgia \\
\hline GIS & geographic information system \\
\hline gped & gallons per capita per day \\
\hline GPCO & Georgia Power Company \\
\hline GW & ground water \\
\hline $\mathrm{HH}$ & housing unit \\
\hline HH-PS & number of housing units on public supply \\
\hline HUC & hydrologic unit code \\
\hline $\mathrm{mg} / \mathrm{L}$ & milligrams per liter \\
\hline MOR & monthly operating report \\
\hline NASS & National Agricultural Statistics Service \\
\hline NWUIP & National Water Use Information Program \\
\hline OWR & Office of Water Resources \\
\hline PCTHH-PS & percent of housing units on public supply \\
\hline $\mathrm{P}-\mathrm{HH}$ & persons per housing unit \\
\hline PP-PS & population served by public supply \\
\hline PWSID & Public Water System Identification \\
\hline SDWIS & Safe Drinking Water Information System \\
\hline SIC & Standard Industrial Classification \\
\hline SW & surface water \\
\hline TVA & Tennessee Valley Authority \\
\hline USACE & U.S. Army Corps of Engineers \\
\hline USDA & U.S. Department of Agriculture \\
\hline USGS & U.S. Geological Survey \\
\hline USEPA & U.S. Environmental Protection Agency \\
\hline
\end{tabular}




\title{
Estimated Use of Water in Alabama in 2005
}

\author{
By Susan S. Hutson, Thomas M. Littlepage, ${ }^{1}$ Michael J. Harper, ${ }^{1}$ and James 0. Tinney'
}

\section{Abstract}

Water use in Alabama was about 9,958 million gallons per day (Mgal/d) during 2005. Estimates of withdrawals by source indicate that total surface-water withdrawals were about 9,467 Mgal/d (95 percent of the total withdrawals) and the remaining $491 \mathrm{Mgal} / \mathrm{d}$ (5 percent) were from ground water. More surface water than ground water was withdrawn for all categories except aquaculture, mining, and self-supplied residential. During 2005, estimated withdrawals by category and in descending order were: thermoelectric power, 8,274 Mgal/d; public supply, $802 \mathrm{Mgal} / \mathrm{d}$; self-supplied industrial, $550 \mathrm{Mgal} / \mathrm{d}$; irrigation, $161 \mathrm{Mgal} / \mathrm{d}$; aquaculture, $75 \mathrm{Mgal} / \mathrm{d}$; self-supplied residential, $39 \mathrm{Mgal} / \mathrm{d}$; livestock, $28 \mathrm{Mgal} / \mathrm{d}$; and mining, $28 \mathrm{Mgal} / \mathrm{d}^{2}$

During 2005, about 83 percent of the water used in Alabama was for thermoelectric power to generate about 114,144 net gigawatt-hours of energy. Almost all of the thermoelectric-power water use (about 8,274 Mgal/d) was from surface water; nearly all of the water ( 98 percent) was used for once-through cooling, and most of that water was returned to a surface-water source.

Public-supply and self-supplied residential withdrawals were about 8 percent of total water withdrawals and about 50 percent of total water withdrawals for all categories excluding thermoelectric power. The combined public-supply and self-supplied residential ground-water withdrawals were about 64 percent of total ground-water withdrawals for Alabama. Public-supply deliveries to residential customers were 41 percent of total public-supply withdrawals, or about $326 \mathrm{Mgal} / \mathrm{d}$; combined industrial and commercial deliveries were 44 percent, or about $355 \mathrm{Mgal} / \mathrm{d}$; and public use and losses accounted for the remaining 15 percent, or about $120 \mathrm{Mgal} / \mathrm{d}$.

Self-supplied industrial (550 Mgal/d) and mining (28 Mgal/d) withdrawals were about 6 percent of total water withdrawals and about 33 percent of total water withdrawals for all categories excluding thermoelectric power. Paper and allied products accounted for the largest self-supplied industrial surface-water withdrawals (301 Mgal/d), and chemical and allied products (12 Mgal/d) accounted for the largest ground-water withdrawals.

\footnotetext{
${ }^{1}$ Alabama Department of Economic and Community Affairs, Office of Water Resources, Water Management Branch.

${ }^{2}$ Values may not sum to total estimated use(s) or acreage because of rounding.
}

Water withdrawals for the agricultural sector-irrigation (161 Mgal/d), aquaculture (75 Mgal/d), and livestock $(28 \mathrm{Mgal} / \mathrm{d})$ - were about 3 percent of total withdrawals and about 16 percent of total withdrawals for all categories excluding thermoelectric power. About 135,800 acres of crops, nursery stock, sod, and golf courses were irrigated in 2005. About 97 percent of these acres were irrigated with sprinkler irrigation systems. The statewide average application rate was 1.33 acre-feet per acre per year. The highest application rate, 3.74 acre-feet per acre per year, was for nursery stock.

The largest total water withdrawals by county occurred in Limestone, Jackson, Colbert, and Mobile Counties, and were 60 percent of the total; these withdrawals primarily were used to meet the cooling needs at thermoelectric-power plants. Excluding thermoelectric power, the largest withdrawals by county were in Morgan, Mobile, Jefferson, Talladega, and Madison Counties.

Water use was estimated at the hydrologic subbasin level for all categories except aquaculture, mining, and self-supplied residential. The Middle Tennessee-Elk subregion accounted for about 53 percent $(5,185 \mathrm{Mgal} / \mathrm{d})$ of the estimated total withdrawals by subbasin of 9,816 Mgal/d. About 92 percent of the water use in the Middle Tennessee-Elk subregion was for thermoelectric power, and more than 99 percent of the water was from surface water.

Gross per capita use for all offstream uses was 2,185 gallons per day (gal/d) for the estimated 4.56 million Alabama residents in 2005. Public-supply per capita use was $199 \mathrm{gal} / \mathrm{d}$ for the estimated 4.04 million residents served by a public supplier; public-supplied residential per capita use was $81 \mathrm{gal} / \mathrm{d}$. Self-supplied residential per capita use was $75 \mathrm{gal} / \mathrm{d}$ for the estimated 0.52 million self-supplied residential population. Average residential per capita use was $80 \mathrm{gal} / \mathrm{d}$.

Total water withdrawals decreased less than 1 percent from 9,990 Mgal/d in 2000 to 9,958 Mgal/d in 2005. Surfacewater withdrawals decreased less than 5 percent from $9,950 \mathrm{Mgal} / \mathrm{d}$ in 2000 to $9,467 \mathrm{Mgal} / \mathrm{d}$ in 2005. In contrast, ground-water withdrawals increased about 12 percent from $440 \mathrm{Mgal} / \mathrm{d}$ in 2000 to $491 \mathrm{Mgal} / \mathrm{d}$ in 2005. By category, increases in irrigation (118 Mgal/d, about 274 percent), thermoelectric power ( $84 \mathrm{Mgal} / \mathrm{d}$, about 1 percent $)$, and aquaculture (65 Mgal/d, 620 percent) were offset by declines in self-supplied industrial (283 Mgal/d, about 34 percent), self-supplied residential (40 Mgal/d, about 50 percent); and public supply (32 Mgal/d, about 4 percent) from 2000 to 2005. Water use for livestock and mining was not estimated in 2000. 


\section{Introduction}

A continuing assessment of water availability and water use is needed for resource management for the State of Alabama. Population growth in many parts of the State has resulted in increased competition for available water resources. This competition includes offstream use for residential, agricultural, and industrial use as well as instream use for maintenance of habitat and species diversity, navigation, power generation, recreation, and water quality. Accurate water-use information is required for sound management decisions within this competitive framework.

Since 1950 when the U.S. Geological Survey (USGS) first conducted water-use compilations, important changes in water use have occurred in Alabama. The early part of the history (1950 to 1980) showed a steady increase in water use (MacKichan, 1951, 1957; MacKichan and Kammerer, 1961; Murray, 1968; Murray and Reeves, 1972, 1977; Peirce, 1972; Baker and others, 1982; Solley and others, 1983). During this time, the expectation was that, as the population increased, so would water use. Contrary to this expectation, reported water withdrawals declined in 1985 , remained relatively stable through 1995, and are increasing again, nearing the 1980 levels (Baker and Mooty, 1987; Solley and others, 1988, 1993, 1998; Baker and Mooty, 1993; Hutson and others, 2004a). Changes in technology, in State and Federal laws, and in economic factors, along with increased awareness of the need for conservation, have resulted in more efficient use of water from the rivers, lakes, reservoirs, and ground water in Alabama. Some differences in the water withdrawal estimates over time also can be attributed to changes in data collection and methodologies used to evaluate, calculate, and estimate water use.

Water withdrawals have more than doubled in Alabama from 1960 to 2005 from about 4,220 million gallons per day (Mgal/d) to 9,958 Mgal/d (fig. 1). The entire increase in withdrawals actually occurred from 1960 to 1980 $(4,220 \mathrm{Mgal} / \mathrm{d}$ to more than $10,350 \mathrm{Mgal} / \mathrm{d})$, while withdrawals in subsequent years have declined somewhat, then increased slightly, but remained nearly constant from 2000 to 2005 (8,593 Mgal/d in $1985 ; 8,074 \mathrm{Mgal} / \mathrm{d}$ in $1990 ; 8,286 \mathrm{Mgal} / \mathrm{d}$ in $1995 ; 9,990 \mathrm{Mgal} / \mathrm{d}$ in 2000; and $9,958 \mathrm{Mgal} / \mathrm{d}$ in 2005). Population increased about 19 percent from 1960 to 1980 and increased another 17 percent from 1980 to 2005. As a result of the leveling off of withdrawals as population has increased, gross per capita use has declined. The data indicate that gross per capita water use increased from about 1,292 gallons per day (gal/d) for 1960 to a high of about 2,661 gal/d for 1980, and then decreased to about $2,185 \mathrm{gal} / \mathrm{d}$ for 2005 . The change in gross per capita water use is mainly attributable to the fluctuation in thermoelectricpower withdrawals for the period.

More water continues to be withdrawn for thermoelectricpower generation than for any other use. Thermoelectric-power withdrawals are large, nearly exclusively from surface water,

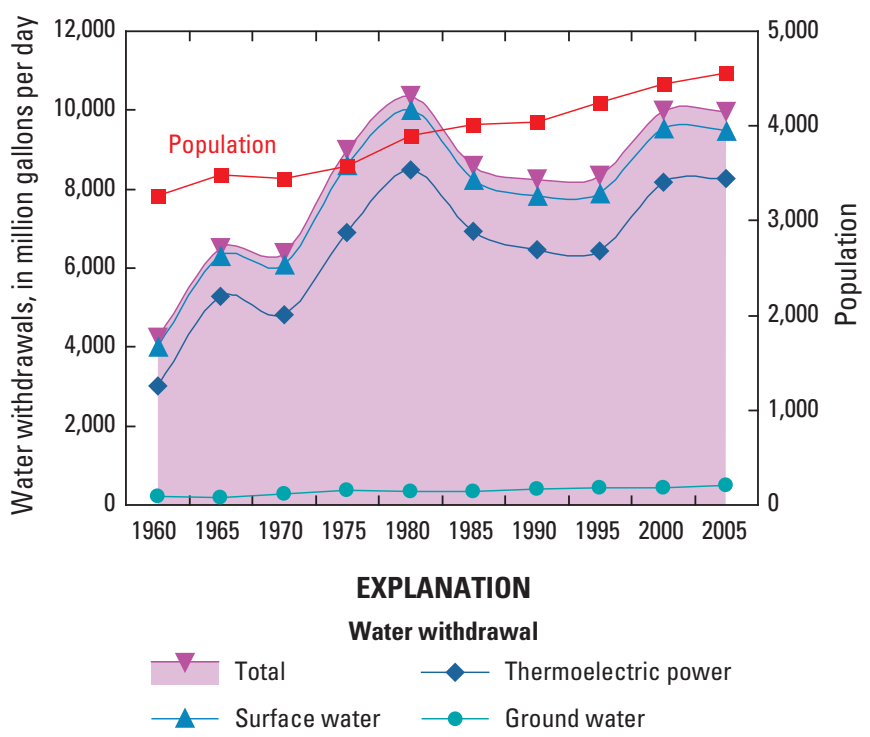

Figure 1. Freshwater withdrawals in Alabama, 1960 to 2005.

and, therefore, dominate the surface-water trends in Alabama. The dates of the operating schedules of the generating units at the power plants can be compared to the corresponding 5 -year water-use data-collection cycle to explain changes in the thermoelectric-power trend. For example, Browns Ferry Nuclear Plant in Athens, Alabama, began operation in 1974, closed for review of procedures in March 1985 (the average daily withdrawal was $1,165 \mathrm{Mgal} / \mathrm{d}$ in 1985), and began generating power for one unit in July 1991 and a second unit in December 1995 (the average daily withdrawal was $776 \mathrm{Mgal} / \mathrm{d}$ in 1995). The water withdrawal for Browns Ferry in 2000 was 2,107 Mgal/d, and in 2005 was $1,990 \mathrm{Mgal} / \mathrm{d}$. Commercial operation of a third unit, "Unit 1," began in May 2007.

Ground-water withdrawals slowly increased from 1960 to 2005, primarily because of increased ground-water withdrawals for public supply. Since 1985, public-supply withdrawals have accounted for more than 50 percent of groundwater withdrawals in the State.

With passage of the Alabama Water Resources Act in 1993, the State of Alabama established the Office of Water Resources (OWR) within the Alabama Department of Economic and Community Affairs (ADECA). Beginning in 1993, the State formalized a water-use registration, reporting, and data-collection program that has improved the accuracy and accounting of water use throughout the State. Administered by the OWR, the Alabama Water Use Reporting Program (AWURP) has become the repository of water-use data for the State.

The AWURP provides the framework and reporting structure for the collection of baseline water withdrawal information. Specifically, the AWURP requires that all public systems (community water systems, CWS) as well as non-public (commercial, industrial, mining, and thermoelectric-power facilities) and irrigation water users with a 
capacity to withdraw 100,000 gallons of water per day or greater obtain a Certificate of Use (COU). Each COU holder is required to annually report water withdrawals for average daily and peak day amounts for each month of the year. Each water-use report is signed and certified as to the accuracy of the data. The annually reported data are electronically stored in the eWater database.

An outreach effort has been made by the Alabama OWR to increase awareness of the reporting requirements. Although established in 1993, the program provided only minimal data for the 1995 USGS water-use compilation. A more complete reporting of public, non-public, and irrigation water-use entities improved the 2000 estimate of water use for Alabama. For this 2005 report, AWURP data were further supplemented by data from other governmental and nongovernmental agencies, greatly improving the comprehensiveness and accuracy of the water-use estimates.

This study of 2005 water use was conducted by the USGS in cooperation with the Alabama OWR, Water Management Branch to provide water-use data for local and State water managers. By examining historical and current water-use practices, more realistic projections of water needs can be made.

\section{Purpose and Scope}

This report presents water-use estimates by source of supply, by water-use category, by county, and by hydrologic subregion and subbasin for the State of Alabama for 2005 (figs. 2 and 3). Water-use estimates for Alabama have been part of the USGS effort to document similar water-use estimates every 5 years since 1950 (MacKichan, 1951, 1957; MacKichan and Kammerer, 1961; Murray, 1968; Murray and Reeves, 1972, 1977; Solley and others, 1983, 1988, 1993, 1998; and Hutson and others, 2004). The eight water-use categories are public supply, residential, irrigation, livestock, aquaculture, industrial, mining, and thermoelectric power. The report contains a section on total water use with more detailed information for each water-use category. A comparison of water-use estimates for total, public supply, residential, irrigation, aquaculture, self-supplied industrial, and thermoelectric power from 2000 to 2005 also is presented in this report. Appendixes A and B summarize water use by county and subbasin, respectively, according to source of water, water-use category, public supplier, and Standard Industrial Classification (SIC) code. Appendix C lists the hydrologic region, subregion, and subbasin names and corresponding eight-digit subbasin numbers. Appendix D presents the water-system survey form. Appendix E lists the hydroelectric dams and maps their location. Instream water use in Alabama is not assessed in this report.

\section{Hydrologic Setting}

The rainfall that replenishes the rivers (fig. 4) and aquifers (fig. 5) in Alabama varies annually, seasonally, and geographically. Local geology, geomorphology, and topography determine the short-term and long-term ground-water and surface-water availability within a watershed. The mean annual rainfall for Alabama is 54 inches (1895 to 2007) ranging from a low of slightly less than 34 inches in 1954 to a little more than 76 inches in 1975 (National Oceanic and Atmospheric Administration, 2008). In 2007, the third driest year on record, the average rainfall was a little more than 39 inches.

The Tennessee and Mobile Rivers along with numerous minor streams provide water to Alabama residents for a variety of offstream and instream uses (Lineback, 1973). The Tennessee River flows in a westerly direction through the Cumberland Plateau, the Highland Rim, and a small part of the East Gulf Coastal Plain (figs. 4 and 6). Total drainage area of the Tennessee River in Alabama is about 7,500 square miles (Alabama Department of Economic and Community Affairs, Office of Water Resources, 2002). The river is the only source of water used to supply communities such as Decatur and Sheffield and supports a robust thermoelectric power and industrial base. Wells and springs within the Cumberland Plateau and Highland Rim physiographic provinces (figs. 5 and 6) provide some limited ground water for aquaculture, industrial, irrigation, mining, livestock, and self-supplied residential uses (Baker, 1989; Baker and Moser, 1989; Hunter, 1991; Mooty and Richardson, 1998). Most of the ground water within the Cumberland Plateau and Highland Rim physiographic provinces is withdrawn for public supply.

The Lower Tombigbee River and its tributaries, the Upper Tombigbee and Black Warrior River, flow southward and join with the Alabama River and its tributaries, the Cahaba, Coosa, and Tallapoosa Rivers, to form the Mobile River (fig. 4). The rivers traverse the East Gulf Coastal Plain, Cumberland Plateau, Alabama Valley and Ridge, and Piedmont Upland and drain 32,207 square miles in Alabama. Supplemented by ground water, the rivers provide water to communities such as Birmingham, Mobile, Montgomery, and Tuscaloosa. Ground-water use is greatest in the East Gulf Coastal Plain with some locally productive aquifers in the Piedmont Upland, Alabama Valley and Ridge, and Cumberland Plateau areas that are used for various purposes (Journey and Atkins, 1997; Kidd and others, 1997; Mooty and Kidd, 1997; Robinson and others, 1997).

The Conecuh, Yellow, Pea, and Choctawhatchee Rivers, which originate in Alabama, and the Chattahoochee River that originates in Georgia, traverse southeastern Alabama. Ground water from the relatively unconsolidated Mesozoic and Cenozoic sediments underlying the Coastal Plain (DeJarnette, 1989; Chapman and Peck, 1997; Mayer, 1997) is the source of public supply for most southeastern Alabama communities, including Andalusia and Dothan; however, some surface water is used for aquaculture, industry (Conecuh River), irrigation, livestock, and mining. The cities of Opelika, Phenix City, Smiths, and the East Alabama Water, Sewer and Fire Protection District, which serves Chambers County, withdraw water from the Chattahoochee River. 


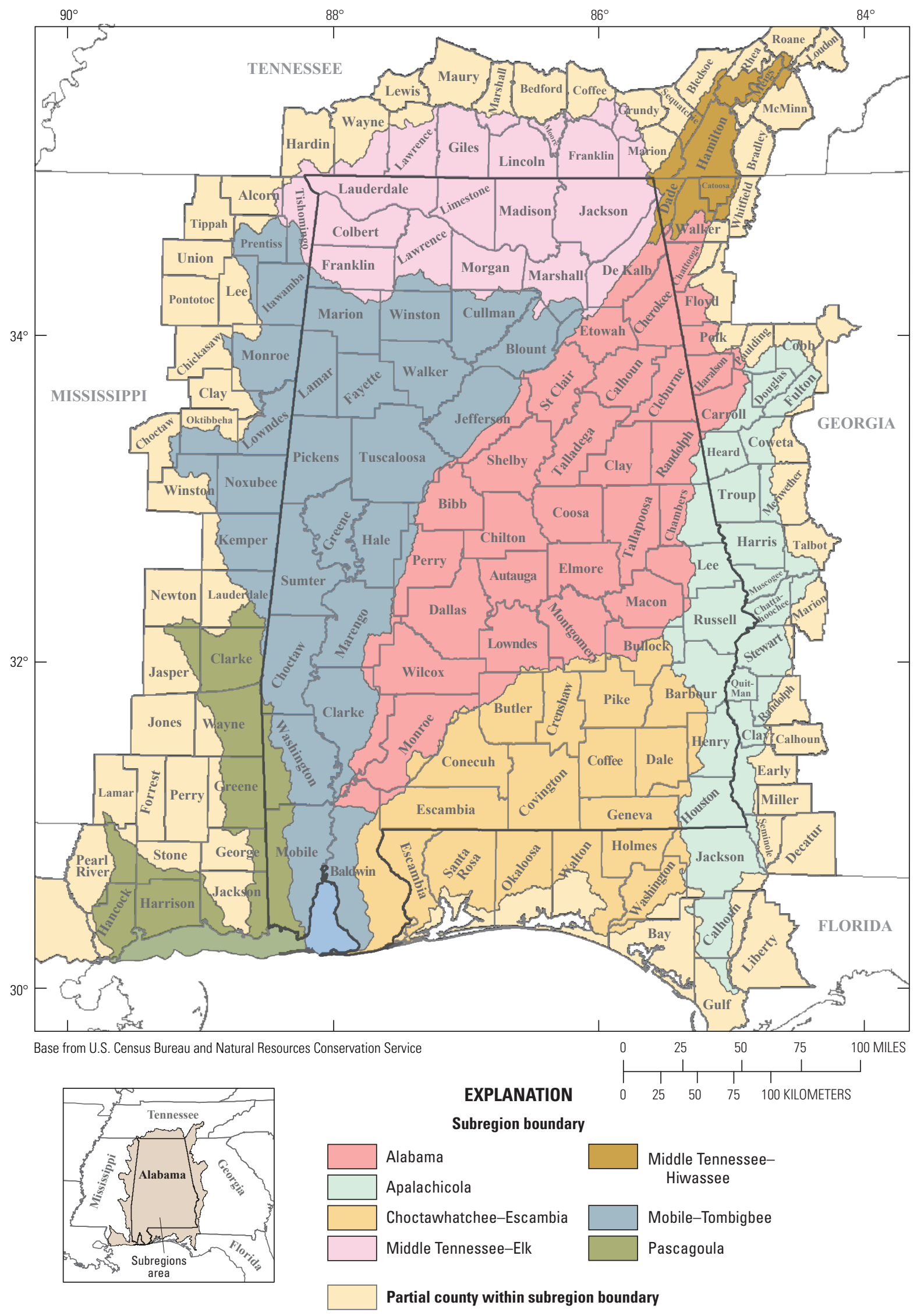

Figure 2. Subregions in Alabama by county. 


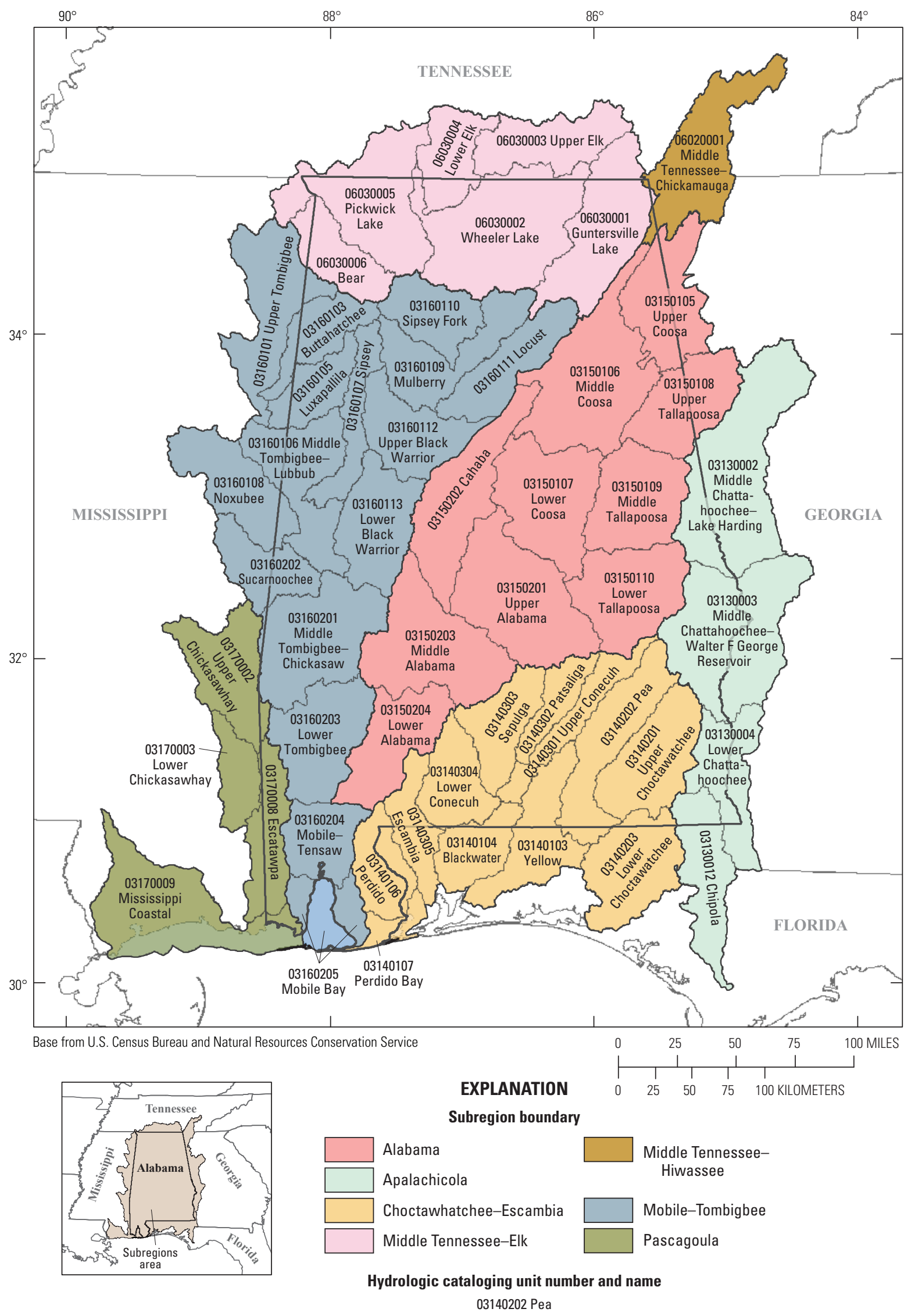

Figure 3. Subregions in Alabama by subbasin. 


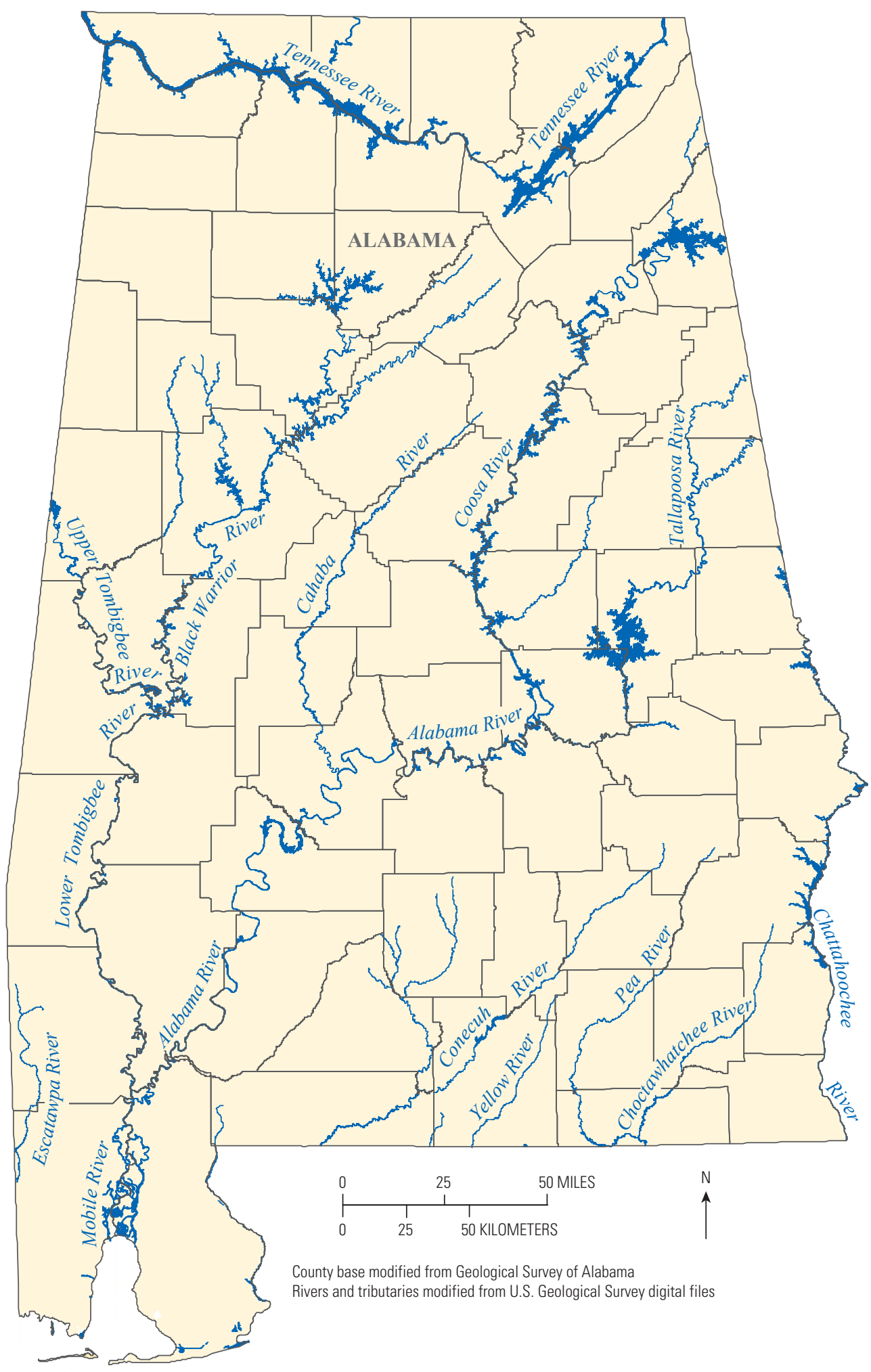

Figure 4. Major rivers and tributaries in Alabama. 


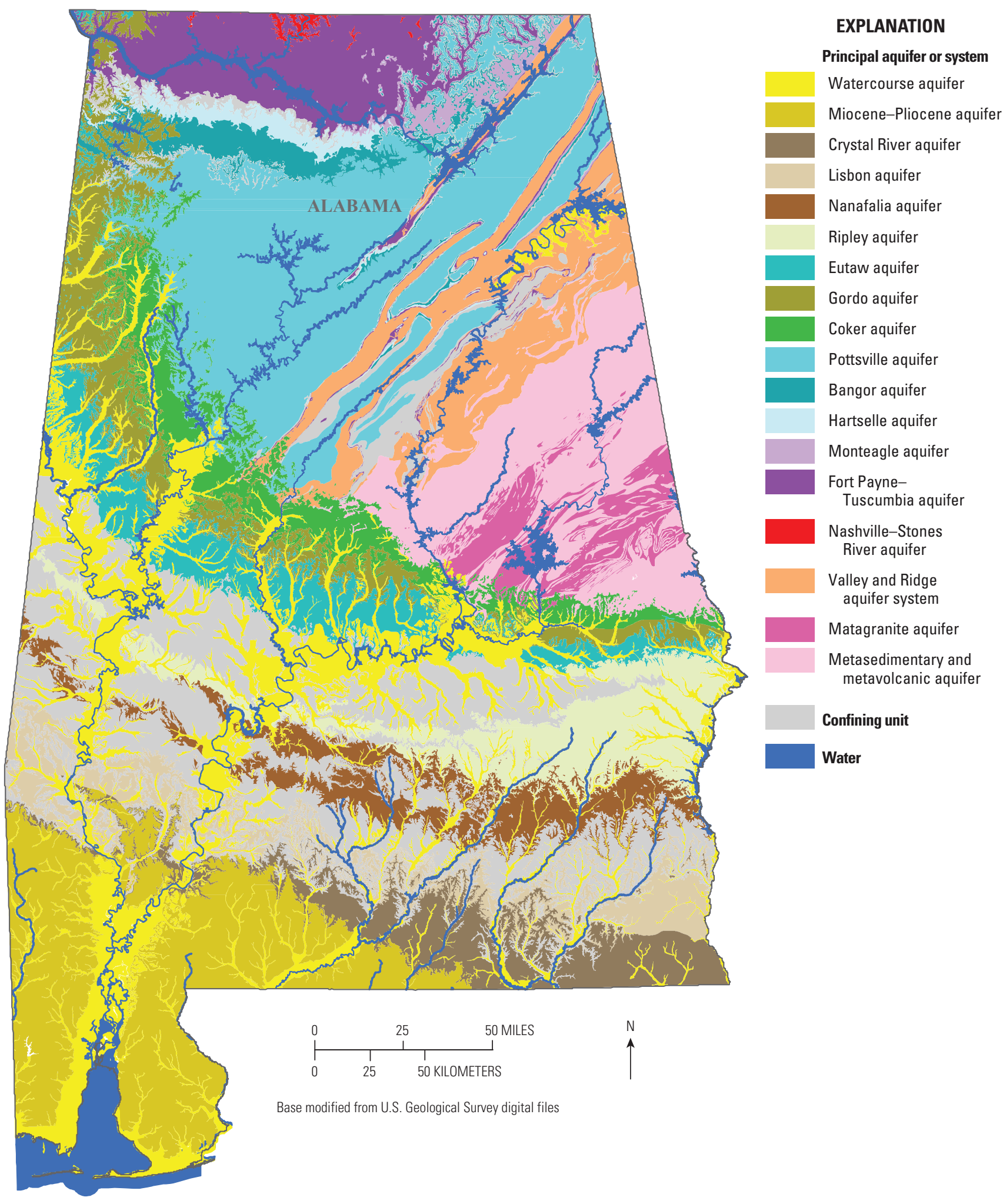

Figure 5. Principal aquifers in Alabama (provided by Geological Survey of Alabama, 2008). 


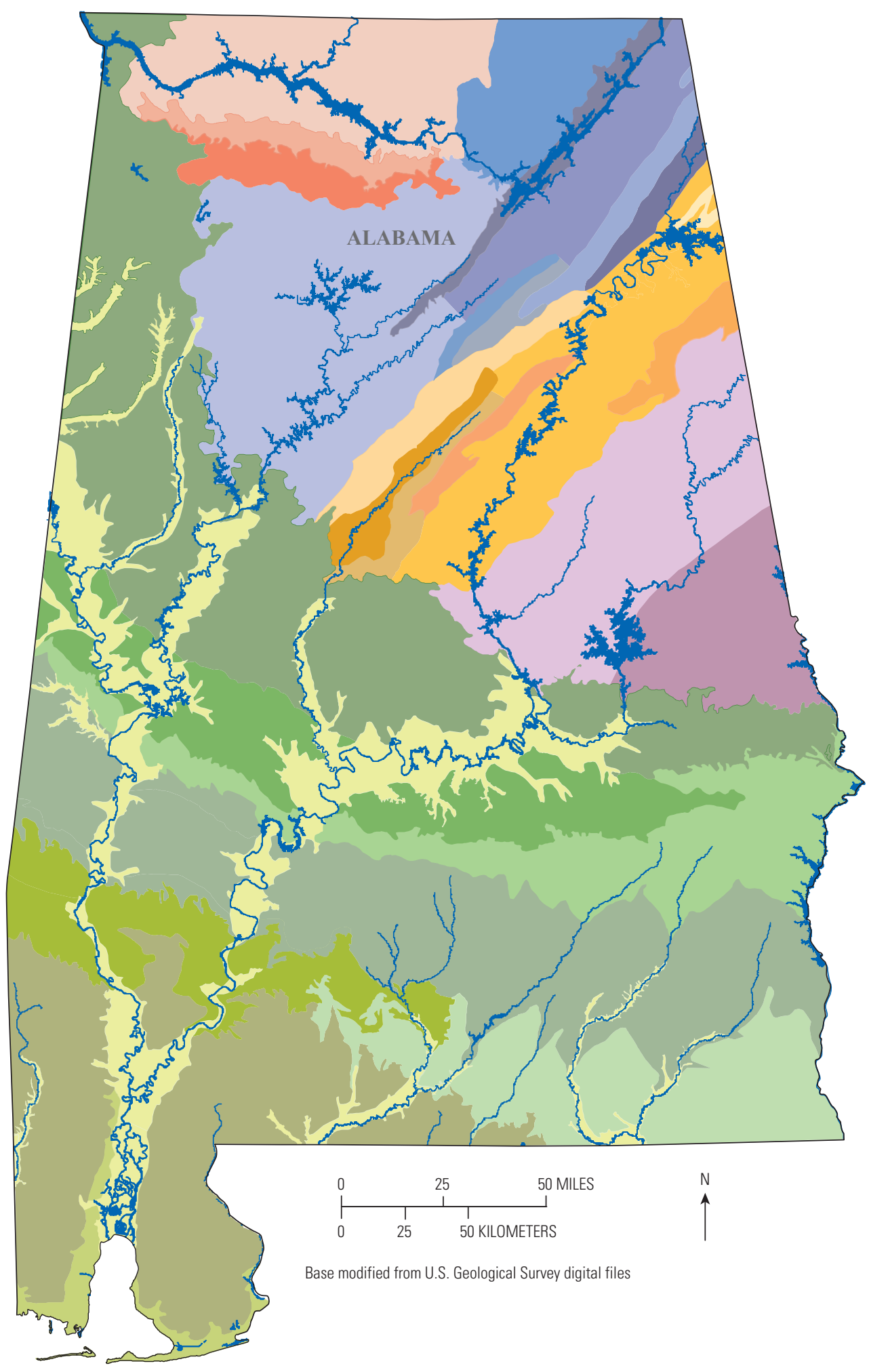

\begin{tabular}{|c|}
\hline EXPLANATION \\
\hline Highland Rim \\
\hline Tennessee Valley \\
\hline Little Mountain \\
\hline Moulton Vallley \\
\hline Cumberland Plateau \\
\hline Warrior Basin \\
\hline Jackson County Mountains \\
\hline Sequatchi Valley \\
\hline Sand Mountains \\
\hline Murphrees Valley \\
\hline Blount Mountain \\
\hline Wills Valley \\
\hline Lookout Mountain \\
\hline Alabama Valley and Ridge \\
\hline $\begin{array}{l}\text { Birmingham- } \\
\text { Big Canoe Valley }\end{array}$ \\
\hline Cahaba Ridges \\
\hline Cahaba Valley \\
\hline Coosa Ridges \\
\hline Coosa Valley \\
\hline Weisner Ridges \\
\hline Armatchee Ridges \\
\hline Piedmont Upland \\
\hline Northern Piedmont Upland \\
\hline Southern Piedmont Upland \\
\hline East Gulf Coastal Plain \\
\hline Fall Line Hills \\
\hline Black Belt \\
\hline Chunneneggee Hills \\
\hline Southern Red Hills \\
\hline Lime Hills \\
\hline Dougherty Plain \\
\hline Southern Pine Hills \\
\hline Coastal Lowlands \\
\hline Alluvial-deltaic Plain \\
\hline
\end{tabular}

Figure 6. Alabama physiography (provided by Geological Survey of Alabama, 2008). 


\section{Acknowledgments}

The authors thank the personnel from the many Federal, State, and local agencies and universities in Alabama that contributed data, maps, and photographs. In particular, the authors thank Kevin Pautler and Greg Herbek, U.S. Department of Agriculture, National Agricultural Statistics Service, Montgomery Office, for help in understanding the complexities of the 2002 Census of Agriculture and the 2003 Farm and Ranch Survey databases; Dennis Harrison and George Cox, Drinking Water Branch-Alabama Department of Environmental Management, for access to the U.S. Environmental Protection Agency 2005 public-supply monthly operation reports; Jared A. Bostic, GIS Specialist, Alabama Department of Economic and Community Affairs, Office of Water Resources, GIS Branch, for creating the base maps and choropleths; and Phillip Henderson, Chief, Alabama Department of Economic and Community Affairs, Office of Water Resources, GIS Branch, for the spatial analysis associated with the irrigation, livestock, and population datasets.

\section{Data Compilation, Sources of Information, and Methodology}

Water-use data were compiled for eight categories by county and for five categories by hydrologic subregion and subbasin (figs. 2 and 3; Appendix C). Site-specific data were used as a basis for estimates for public supply, publicsupplied deliveries, self-supplied industrial, mining, thermoelectric power, and golf course, nursery, and sod irrigation. Aggregated county-level data were used as a basis for estimates for self-supplied residential, crop irrigation, livestock, and aquaculture. This section contains a detailed description of the methodology and sources of data used for determining total population; public-supply and residential water-use amounts; population served and self-supplied residential population; irrigation withdrawals and irrigated acreage; livestock, aquaculture, and mining withdrawals; and thermoelectric-power and self-supplied industrial withdrawals.

Data category by source and type of data are listed in table 1. Some sources, such as Alabama OWR, provided sitespecific water withdrawal and source of water data for public suppliers, industries, and thermoelectric plants. Some sources, such as U.S. Department of Agriculture (USDA), provided county-level ancillary data, such as crop acreage, crop type, and crop application rate, which could be used to estimate an aggregated county irrigation water withdrawal. Some categories, such as irrigation, depended on several sources of data to estimate total water withdrawals. Sources of information are more specifically discussed in the following category sections.

The terms and units used in this report are similar to those used in previous USGS reports (MacKichan, 1951, 1957; MacKichan and Kammerer, 1961; Murray, 1968; Murray and Reeves, 1972, 1977; Solley and others, 1983,
1988, 1993, 1998; Hutson and others, 2004a) and are defined in the Glossary at the end of the report. For 2005, water use is defined as water withdrawals except for total residential water use (residential water use is used in place of domestic water use in this report) and total industrial water use. Total residential use is a combination of public-supplied residential deliveries and self-supplied residential withdrawals. Total industrial water use, calculated at the State level only, combines self-supplied industrial and commercial withdrawals and public-supplied industrial and commercial deliveries. The term "public supplier" is the preferred term used in place of either public water system or community water system. A public supplier is defined as a water system that furnishes water year-round to at least 25 people or has a minimum of 15 connections. All water withdrawals in this report were compiled as freshwater, although some lowsalinity and high-salinity withdrawals for aquaculture and low-salinity withdrawals for mining occurred in the State.

Water withdrawals are reported to the county, four-digit hydrologic subregion, and eight-digit subbasin level (U.S. Department of Agriculture, Soil Conservation Service, 1993; U.S. Department of Agriculture, 2004; U.S. Geological Survey, 2007). Annual water use is expressed in terms of million gallons per day. Irrigation application rate is expressed as acre-feet per acre. Water use is normalized as a per capita use statistic (gallons per capita per day) in five different ways.

- Total water use is divided by the total population to yield gross per capita use, and includes water used to generate electricity, support industrial and agricultural activities, and provide drinking water.

- Public-supply water use is divided by the population served by public suppliers to yield gross publicsupply per capita use and includes water delivered to the residential, industrial, commercial, and thermoelectric power sectors and public use and losses.

- Public-supply residential deliveries are divided by the population served to yield public-supplied residential per capita use.

- Self-supplied residential water withdrawals are divided by self-supplied population to yield self-supplied residential per capita use.

- Public-supplied residential deliveries plus selfsupplied residential withdrawals are divided by the total population to yield residential per capita use.

In the tables, State, county, subregion, subbasin, and facility data are presented to two-decimal places. In the text, water withdrawal totals are reported as whole numbers unless the use of decimals is needed to improve clarity. Percentages are based on the two-digit values in the tables and are expressed as whole numbers. All values are rounded independently; therefore, the sums of individually rounded numbers may not equal the totals given in this report. 


\section{Total Population}

The 2005 estimate of population by subbasin was derived from the 2000 and 2005 county census numbers (U.S. Census Bureau, Geography Division, 2001; U.S. Census Bureau, 2006). Using geographic information system (GIS) spatial techniques, a percent change in population was determined and the percent difference was applied to each 2000 census block group (table 1). The 2005 block-group population estimate then was converted to the geometric centroid and aggregated to the subbasin. Using this methodology, the total population summarized by subbasin was 0.3 percent $(14,638$ people) less than the population summarized by county. No attempt was made to balance the subbasin and county populations because the difference was due to methodology and the resulting rounding differences produced for 67 counties compared to 53 subbasins.

Table 1. Summary of data sources by category and type of data.

[OWR, Office of Water Resources; ADEM, Alabama Department of Environmental Management; ARWA, Alabama Rural Water Association; USEPA-SDWIS, U.S. Environmental Protection Agency, Safe Drinking Water Information System; USDA-NASS, U.S. Department of Agriculture, National Agricultural Statistics Service; ADAI, Alabama Department of Agriculture and Industries; USGS-NWUIP, U.S. Geological Survey; National Water Use Information Program; DOE-EIA, Department of Energy, Energy Information Administration]

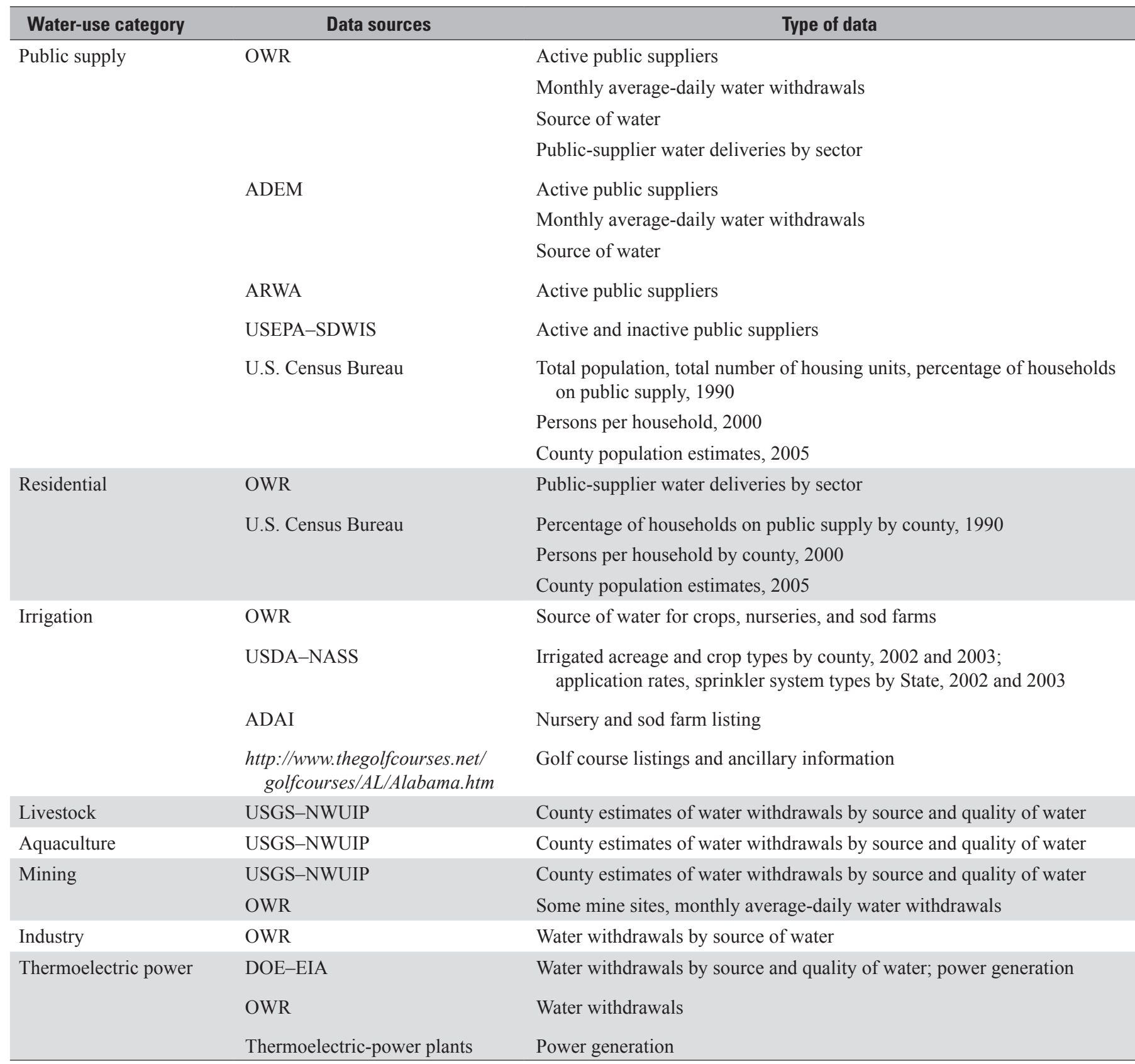




\section{Public-Supply and Residential Water Use}

For public supply, estimates were made for ground-water and surface-water withdrawals at the county and subbasin levels, for residential deliveries and population served at the county level, and for industrial and commercial deliveries and public use and losses at the State level. Public-supply withdrawal estimates mostly were based on site-specific data (table 1). Raw water pumpage, or the finished water production upon which water withdrawals were estimated, was metered and reported as monthly average-daily rates of withdrawal to Alabama OWR through mandatory yearly AWURP reports, and to the Drinking Water Branch-Alabama Department of Environmental Management (DWB-ADEM) through mandatory monthly operation reports (MORs). Water sold to or purchased from other public suppliers was not included in this study. To ensure that the water withdrawals were compiled for the geographical area in which the withdrawals occurred, the county and subbasin locations of the water plants, surfacewater intakes, wells, or well fields were verified using GIS techniques. A comprehensive list of public suppliers was compiled from records from Alabama OWR, DWB-ADEM, Alabama Rural Water Association (ARWA), and the webbased Safe Drinking Water Information System (SDWIS) maintained by U.S. Environmental Protection Agency (USEPA; U.S. Environmental Protection Agency, 2009).

Residential and industrial/commercial deliveries and public use and loss estimates were based on a survey of the public suppliers conducted by Alabama OWR (Appendix D, fig. D-1). More than 60 percent of the suppliers responded, including all of the suppliers serving 50,000 people or more. Responses from public suppliers were used to estimate residential deliveries for public suppliers with similar demographic and geographic characteristics who had not responded. Water withdrawals and residential deliveries were counted in the county or subbasin in which they occurred. Public use and losses were estimated at the county level and reported only at the State level. Industrial/commercial deliveries were calculated by subtracting total residential deliveries and public use and losses from total public-supply water withdrawals.

Residential water use is the sum of residential deliveries plus self-supplied residential withdrawals. Self-supplied residential withdrawals were not reported as part of the AWURP and were not collected as part of this study. Instead, selfsupplied residential withdrawals were estimated from a selfsupplied population and a per household use coefficient for each county. The self-supplied population was divided by the number of persons per household in 2000 to yield the number of self-supplied housing units in 2005. The per household use coefficients were derived from a subset of the OWR Alabama Water System Survey consisting of the small public suppliers with primarily rural residential deliveries. Self-supplied households were assumed to use the same amount of water as public-supplied rural households. For 2005, the average monthly rural household use by county ranged from 2,696 to 10,500 gallons per month.

\section{Population Served and Self-Supplied Residential Population}

No reliable estimates of population served by public supplier were available for 2005 (U.S. Environmental Protection Agency, 2009). Population served by public supplier, therefore, was estimated using the 1990 county census population numbers, number of housing units, and percentage of housing units on public supply (U.S. Census Bureau, 1992) and the 2005 county census population (U.S. Census Bureau, 2006; table 1). The change in county population from 1990 to 2005 is a proxy for the change in the number of housing units on public supply during the same period. The methodology for estimating the 2005 population served assumes that any population increase from 1990 to 2005 was served by a public supplier. A simplified example of this method is as follows. The percentage of population served by public supply in the following example county increased from 60 percent in 1990 to 73 percent $(11,000$ population served in 2005 divided by 2005 county population, 15,000) in 2005.

For any county in Alabama

$\begin{array}{ll}\text { Census Data } & \\ 1990 \mathrm{CP} & 10,000 \\ 1990 \mathrm{HH} \text {, total } & 2,000 \\ 1990 \mathrm{PCTHH}-\mathrm{PS} & 60 \\ 1990 \mathrm{P}-\mathrm{HH} & 5 \\ 2005 \mathrm{CP} & 15,000\end{array}$

Calculations

1990 HH-PS

$$
\begin{aligned}
& \mathrm{HH}_{1990} * \text { PCTHH}^{-P S} \\
& 1,200=2,000 * 0.6
\end{aligned}
$$

1990 PP-PS

HH-PS $_{1990} * \mathrm{P}-\mathrm{HH}$

$6,000=1,200 * 5$

2005 PP-PS

$$
\text { PP-PS }{ }_{1990}+\left(\mathrm{CP}_{2005}-\mathrm{CP}_{1990}\right)
$$

$$
11,000=6,000+(15,000-10,000)
$$

where,

$\mathrm{CP}$ is county population for years 1990 and 2005

$\mathrm{HH} \quad$ is number of housing units for year 1990

PCTHH-PS is percent housing units on public supply for year 1990

$\mathrm{P}-\mathrm{HH} \quad$ is persons per housing unit for year 1990

HH-PS is number of housing units on public supply in 1990, and

PP-PS is population served by public supply for years 1990 and 2005.

Self-supplied population was calculated as the difference between total county population and total county population served by public suppliers. 


\section{Irrigation}

The irrigation category consists of surface-water and ground-water withdrawals and the number of acres by irrigation-system type for crops, nurseries, sod farms, and golf courses. Estimates of water withdrawals by county for crops were derived from the estimated number of acres in 2002 and a statewide or watershed crop application rate by irrigation-system type (U.S. Department of Agriculture, National Agricultural Statics Service, 2004a; U.S. Department of Agriculture, National Agricultural Statistics Service, 2004b; table 1). Crop application rates for sprinkler irrigation systems ranged from 0.3 to 0.8 acre-feet per acre; microirrigation systems, from 1.1 to 2.1 acre-feet per acre; and for surface irrigation systems was 0.7 acre-feet per acre. The statewide average application rate for crops was 0.7 acre-feet per acre. Sprinkler systems typically were used to irrigate corn, cotton, soybeans, and vegetables; microirrigation systems typically were used to irrigate fruits, nuts, and vegetables; and surface systems typically were used to irrigate vegetables. In the short-term, application rates are likely to vary annually according to the amount and timing of precipitation, antecedent soil conditions, and crop type. Over the long-term, application rates are influenced by changes in technology and farming practices and climate.

Water withdrawals for nursery and sod farm operations were estimated from the number of acres per operation (Alabama Department of Agriculture and Industries, Division of Plant Industry, 2007) and by using the following annual application rates: for nurseries, 3.74 acre-feet per acre; for sod farms, $1,948 \mathrm{gal} / \mathrm{d}$ per acre. The nursery and sod farm application rates were derived from site-specific water withdrawals for 2005 as reported to AWURP and from additional information collected from owners of selected nurseries and sod farms about their irrigation practices. The percentage of surface-water and ground-water withdrawals by county was determined independently for crops, nurseries, and sod farms from site-specific data in eWater, local water-supply characteristics, and historical water-use patterns. Crop (food and feed crops), nursery, and sod farm water withdrawals and acreage by irrigation-system type were combined in the crop irrigation subcategory.

Water withdrawals for golf courses were estimated from site-specific data in eWater, a web search (TheGolfCourses. net, 2007), an Alabama OWR golf course water-use survey, and interviews with selected golf course staff on watering practices. All water withdrawals were assumed to be from surface water and applied with sprinkler systems because reliable source-of-supply data were limited; however, some golf courses were known to use ground water in 2005 . The 320 golf courses, covering approximately 26,720 acres, were classified into three tiers: Tier 1, extensive watering; Tier 2, frequent watering; and Tier 3, essential watering (table 2). A water withdrawal was estimated for each golf course based on a number of holes and a tier classification coefficient.
Table 2. Golf course classification and tier classification coefficients.

[Classification coefficient is amount applied, in million gallons per year]

\begin{tabular}{lcc}
\hline $\begin{array}{l}\text { Golf course } \\
\text { classification }\end{array}$ & $\begin{array}{c}\text { Tier classification } \\
\text { coefficients }\end{array}$ & $\begin{array}{c}\text { Acres } \\
\text { irrigated }\end{array}$ \\
\hline Tier 1 extensive watering & 0.106 & 110 \\
Tier 2 frequent watering & 0.063 & 100 \\
Tier 3 essential watering & 0.015 & 55 \\
\hline
\end{tabular}

For example, an 18-hole golf course in Tier 1 would have withdrawn $0.106 \mathrm{Mgal} / \mathrm{d}$ in 2005. Although the dataset from which the application rates were derived indicated individual differences in withdrawal amounts across the State according to geographic location, soil types, and management practices, the tier classification represents typical golf course usage based on watering practices.

In Alabama, some golf courses are able to water greens, tees, fairways, and, often, driving ranges, and ornamental plants and shrubs because of the installation of an extensive irrigation system and plentiful water (Tier 1). Other golf courses water less extensively, often only tees and greens (Tier 2). The remaining golf courses, because of cost or a limited water supply, confine watering to greens and sometimes tees and fairways if the viability of the turf is threatened and water is available (Tier 3). Generally, watering for all tiers occurs every 3 days; however, weather conditions can affect the watering schedule. Warmer and drier weather necessitates more watering and cooler or wetter weather necessitates less watering. Most of the watering occurs May through October; any additional watering from November through April is generally to aid in application of fertilizer or herbicides.

Water withdrawals by subbasin were determined for each subcategory crop, which includes crops, nurseries, and sod farms, by applying GIS techniques. The subbasin boundaries were superimposed on the county boundaries to create a subbasin/county areal unit. Each subbasin/county unit represents a percent of the subbasin area within a county. Surface-water and ground-water withdrawals were distributed among the subbasin/county units based on the assigned areal percentage. Water withdrawals for each subbasin/county unit were summarized by subbasin. The difference in the county and subbasin totals was $0.01 \mathrm{Mgal} / \mathrm{d}(-0.05 \mathrm{Mgal} / \mathrm{d}$ for ground water and $+0.04 \mathrm{Mgal} / \mathrm{d}$ for surface water). No attempt was made to balance the withdrawals because the difference in totals was due to methodology and the resulting rounding differences produced for 67 counties compared to 53 subbasins. Addresses obtained from the master list for golf courses were used to assign the estimated withdrawals for the specific sites to the correct subbasin. 


\section{Livestock, Aquaculture, and Mining}

County-level water withdrawals by source for livestock, aquaculture, and mining were from estimates determined by the USGS National Water Use Information Program (NWUIP) as part of the Federal effort to estimate water use for the United States for 2005. Livestock withdrawals are not reported as a specific category within the AWURP and were not collected as part of this study. Estimates of livestock withdrawals by county were calculated from the 2005 livestock census by U.S. Department of Agriculture, National Agricultural Statistics Service (USDA-NASS) and statewide drinking water-requirement coefficients, such as those for dairy cattle (35 gallons per capita per day [gpcd]), other cattle (12 gpcd), horses and other equine (12 gpcd), hogs (5 gpcd), sheep and goats ( 2 gpcd), and poultry ( 0.05 gpcd) (Kammerer, 1976; Mooty and Richardson, 1998). The coefficients do not reflect the effect of climate on animal watering across the State or facility maintenance needs.

Water withdrawals for livestock by subbasin were determined by applying GIS techniques. The subbasin boundaries were superimposed on the county boundaries to create a subbasin/county areal unit. Each subbasin/county unit represents a percent of the subbasin area within a county. Surface-water and ground-water withdrawals were distributed among the subbasin/county units based on the assigned areal percentage. Water withdrawals for each subbasin/county unit were summarized by subbasin. The difference in the county and subbasin totals was $0.05 \mathrm{Mgal} / \mathrm{d}(+0.02 \mathrm{Mgal} / \mathrm{d}$ for ground water and $+0.03 \mathrm{Mgal} / \mathrm{d}$ for surface water). No attempt was made to balance the withdrawals because the difference in totals was due to methodology and the resulting rounding differences produced for 67 counties compared to 53 subbasins.

Aquaculture withdrawals were estimated from the commercial and non-commercial operations datasets produced by USDA-NASS for the 2005 Census of Aquaculture. County-level data for commercial operations included number of raceways, average flow rates to raceways, pond acreage, number of tanks, average tank volumes, and the number of farms using ground water and surface water. Water-withdrawal estimates for local, State, and Federal hatcheries were based on the coefficients applied to the number of pounds and types of fish and eggs produced. Ground-water and surface-water data were divided according to the divisions for the commercial operation as reported to USDA-NASS or according to the USGS estimates for source of water for aquaculture for Alabama for 2000 (U.S. Geological Survey, 2004). Mining water use was estimated from per ton wateruse coefficients and crude ore production in tons for 2004 from the USGS Minerals Information Team, from coal production in tons from the Department of Energy, Energy Information Administration (DOE-EIA), and from sitespecific mining withdrawal data reported to the AWURP.

\section{Thermoelectric Power and Industrial}

Thermoelectric-power and industrial water use were estimated from site-specific data. The primary sources of data for thermoelectric-power water withdrawals and power produced were the DOE-EIA, the AWURP database - eWater, and the individual thermoelectric-power facilities (table 1). Water withdrawals were reported in the county or subbasin in which the withdrawals occurred. It was not possible to separate the power for a nuclear plant that used both once-through cooling and recirculating cooling. All power, therefore, was reported with the larger withdrawals associated with once-through cooling instead of the smaller withdrawals associated with recirculating cooling.

The AWURP database, eWater, stores monthly averagedaily water withdrawals, source of water, and location information. For 2005, steam-electric plants with a nameplate rating of 100 megawatts or more provided information about cooling type, water withdrawal, return flow, and consumptive use by generating unit (except for nuclear power plants) to DOE-EIA, and all power plants provided power generation by generating unit (Energy Information Administration, 2008; Energy Information Administration, 2009a; Energy Information Administration, 2009b).

Total industrial water use is the sum of self-supplied industrial and commercial withdrawals and public-supplied industrial and commercial deliveries. Monthly self-supplied industrial withdrawals by source were reported by individual industries to the AWURP for 2005. SIC codes for those industries were obtained from the Alabama Directory of Manufacturers (Alabama Development Office, 2004). One commercial facility reported withdrawals in 2005. Publicsupply deliveries to industrial and commercial users were determined at the State level from the OWR Alabama Water System Survey for 2005 (Appendix D, fig. D-1).

\section{Water Use}

Water in river and reservoir systems can be used instream for hydroelectric power generation, navigation, recreation, maintaining minimum streamflows to support fish and wildlife habitat, and for wastewater assimilation. Ground water provides flow to streams and rivers by discharging to seeps and springs. Water also can be withdrawn from the rivers, reservoirs, and aquifers to meet offstream needs for public supply, self-supplied residential, irrigation, livestock, aquaculture, self-supplied industrial, mining, and thermoelectric-power generation. The term "water use" in this report is limited to offstream wateruse transactions. The interrelation of water-using entities and water-use transactions to sources of supply is described in figure 7. Only the withdrawal-delivery transaction from either a ground-water or a surface-water source to a water-using entity is accounted for in this report ( $A$ to $B$ in fig. 7). Additional water-use transactions are delivery-release ( $B$ to $C$ ), release-delivery ( $C$ to $B$ ), and release-return ( $C$ to $D$, fig. 7 ). 
Instream use occurs without diverting or withdrawing water from surface-water sources. Although assessing instream water use in the Alabama subbasins was beyond the scope of this report, some hydroelectric power and navigation instreamuse statistics were included because instream uses compete with offstream uses and can affect the quality and quantity of available water. Hydroelectric power is generated in Alabama by the Alabama Electric Cooperative, Alabama Power Company, Tennessee Valley Authority (TVA), and U.S. Army Corps of Engineers (USACE)-Mobile District at 21 mainstem and tributary locations (Appendix E, table E-1; fig. E-1). Georgia Power Company and the USACE generate power from six facilities located on the Chattahoochee River bordering Alabama. Total generating capacity for the 27 plants is 3.55 gigawatts.

Navigation maintenance within Alabama is important for commercial shipping and recreational boating. USACE maintains a year-round 9-foot (ft) channel on the navigable stretches of the rivers in the Mobile watershed, TVA maintains an 11-ft channel on the mainstem of the Tennessee River, and the U.S. Coast Guard maintains a $12-\mathrm{ft}$ channel in the intracoastal waterway. Passage also is maintained on many miles of secondary channels for recreational use. The instream use of hydroelectric power and navigation does not affect consumptive use because the water remains in the river systems.

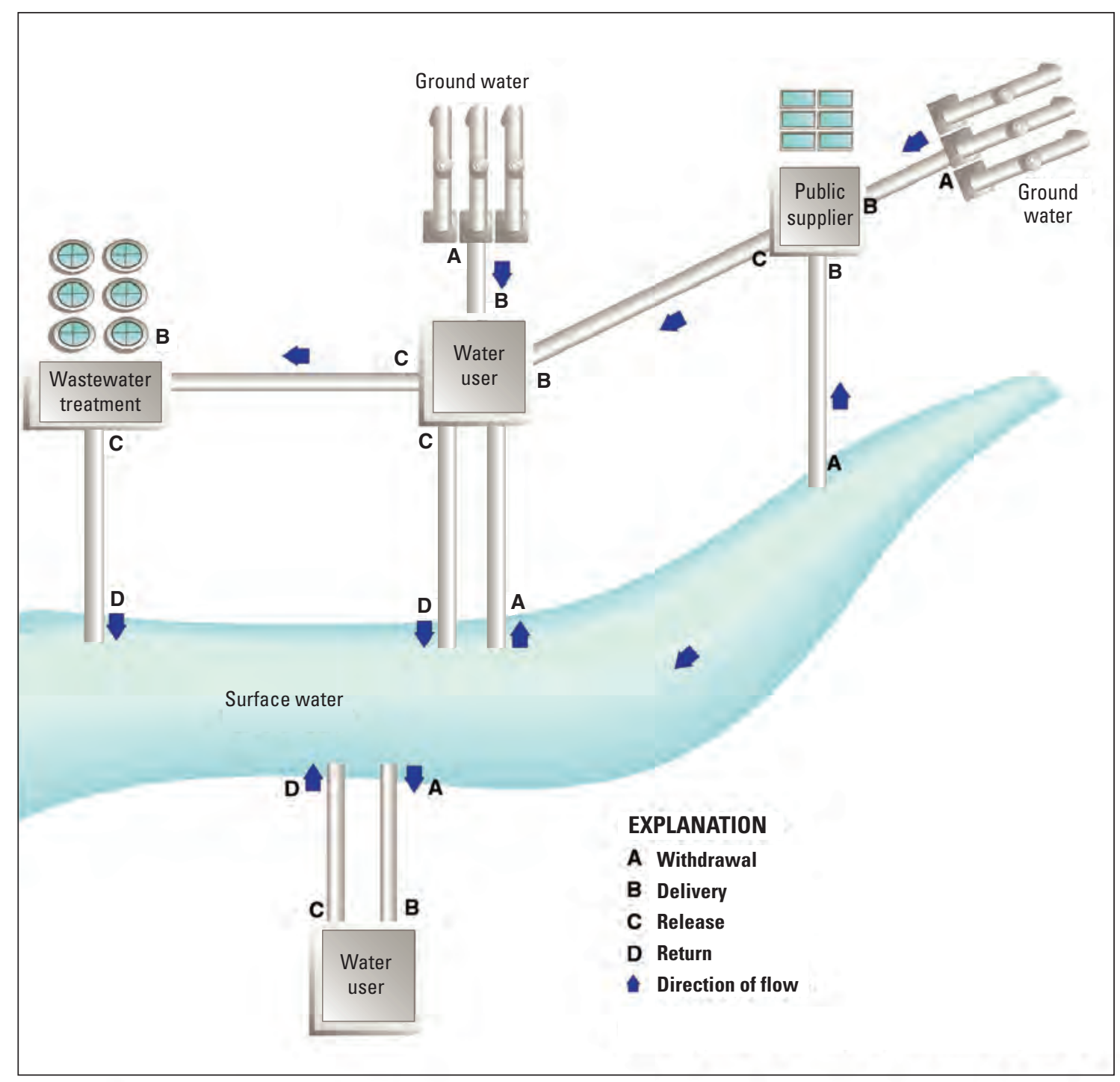

Figure 7. Schematic showing the interrelation of water-using sites and water-use transactions to sources of supply (modified from Hutson and others, 2004b). 


\section{Total Water Use}

Total water use in Alabama for 2005 was determined from estimates of water withdrawals for eight categoriespublic supply, self-supplied residential, irrigation, livestock, aquaculture, self-supplied industrial, mining, and thermoelectric power. Total freshwater withdrawals were estimated to be $9,958 \mathrm{Mgal} / \mathrm{d}$. Estimates of withdrawals by source indicate that total surface-water withdrawals were 95 percent of the total $(9,467 \mathrm{Mgal} / \mathrm{d})$, and the remaining 5 percent was from ground water (491 Mgal/d; fig. 8). Gross per capita use averaged 2,185 gal/d for the 4,557,808 residents in Alabama (U.S. Census Bureau, 2006). Gross per capita use is the total water withdrawn divided by the total population. The large per capita use is a result of the large thermoelectric-power withdrawals in relation to the population size. Values may not sum to total estimated use(s) because of rounding.

Total residential water use, which is a combination of public-supplied residential deliveries and self-supplied residential withdrawals, was $365 \mathrm{Mgal} / \mathrm{d}$ (see the "Residential" section in this report). Total industrial water use, which is a combination of self-supplied industrial and commercial withdrawals (550 Mgal/d) and public-supplied industrial and commercial deliveries (355 Mgal/d), was $906 \mathrm{Mgal} / \mathrm{d}$ (see the "Industrial" section in this report).

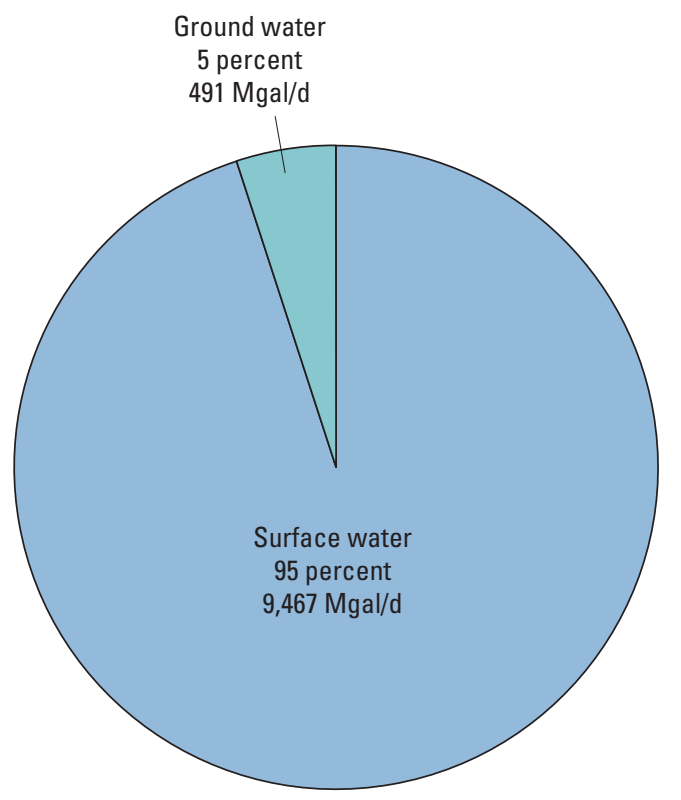

Figure 8. Sources of water used in Alabama, 2005. $[\mathrm{Mgal} / \mathrm{d}$, million gallons per day; values may not sum to total estimated use because of rounding]
Total withdrawals by source and category for counties and hydrologic subbasins are listed in tables 3-6. For 2005, thermoelectric power accounted for 83 percent of the total water withdrawals or $8,274 \mathrm{Mgal} / \mathrm{d}$ (table 5; fig. 9). Combined, the public supply and self-supplied industrial categories accounted for about 14 percent of the total withdrawals (802 Mgal/d and $550 \mathrm{Mgal} / \mathrm{d}$, respectively) and irrigation, aquaculture, self-supplied residential, livestock, and mining the remaining approximate 3 percent. More surface water than ground water was used in all categories except aquaculture, mining, and self-supplied residential (tables 7-10). About 87 percent of the surface-water withdrawals were for thermoelectric power, and the largest surface-water withdrawals were in Limestone County (table 7). About 63 percent of the surface-water withdrawals - primarily for thermoelectric power-occurred in Limestone, Jackson, Colbert (Middle Tennessee-Elk subregion), and Mobile (MobileTombigbee subregion) Counties. Most of the ground-water withdrawals, 56 percent, were for public supply (table 9). About 13 percent $(62 \mathrm{Mgal} / \mathrm{d})$ of the statewide ground-water use was in Baldwin County; about 60 percent of Baldwin County's ground-water use was for irrigation, and 35 percent was for public supply. The 10 counties withdrawing $10 \mathrm{Mgal} / \mathrm{d}$ or more of ground water, primarily for public supply and irrigation, accounted for 51 percent of the total ground-water withdrawals in the State (table 9).

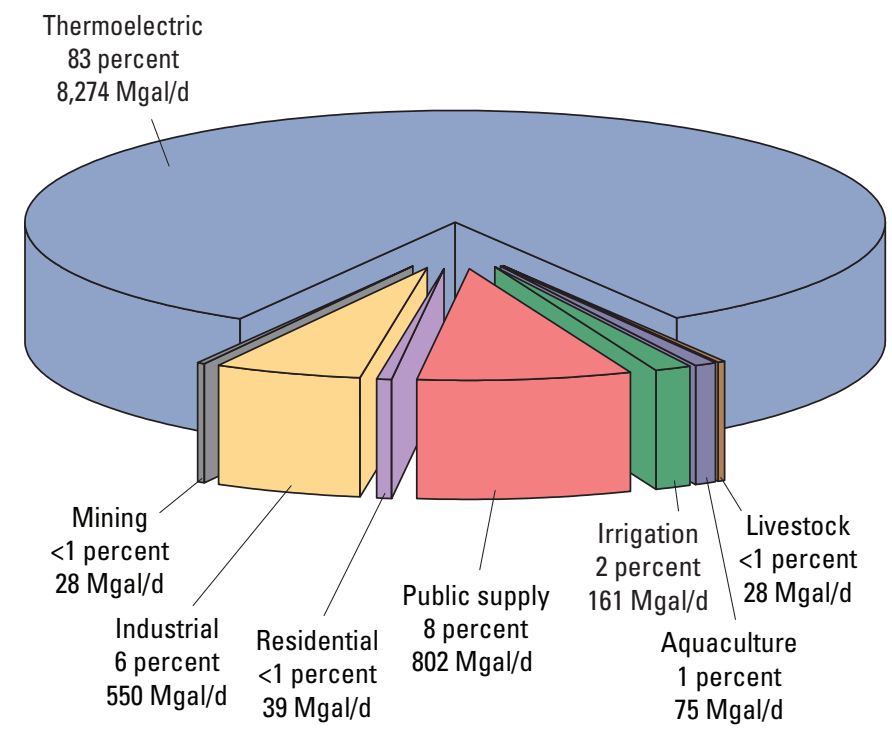

Figure 9. Comparison of freshwater withdrawals by category of use in Alabama, 2005. [Values may not sum to total estimated use because of rounding] 
The geographic distribution of total, ground-water, and surface-water withdrawals by county and by hydrologic subbasin is shown in figures 10 and 11 . The largest total water withdrawals occurred in Limestone, Jackson, Colbert, and Mobile Counties, 60 percent of the total, primarily to meet the cooling needs at thermoelectric-power plants. Excluding thermoelectric power, the largest withdrawals occurred in
Morgan, Mobile, Jefferson, Talladega, and Madison Counties (table 5).

Estimates of public supply, irrigation, livestock, selfsupplied industrial, and thermoelectric-power withdrawals by source of water for hydrologic subregion and subbasin and are shown in tables 6,8 , and 10 . These categories accounted for nearly 99 percent $(9,816 \mathrm{Mgal} / \mathrm{d})$ of the total estimated

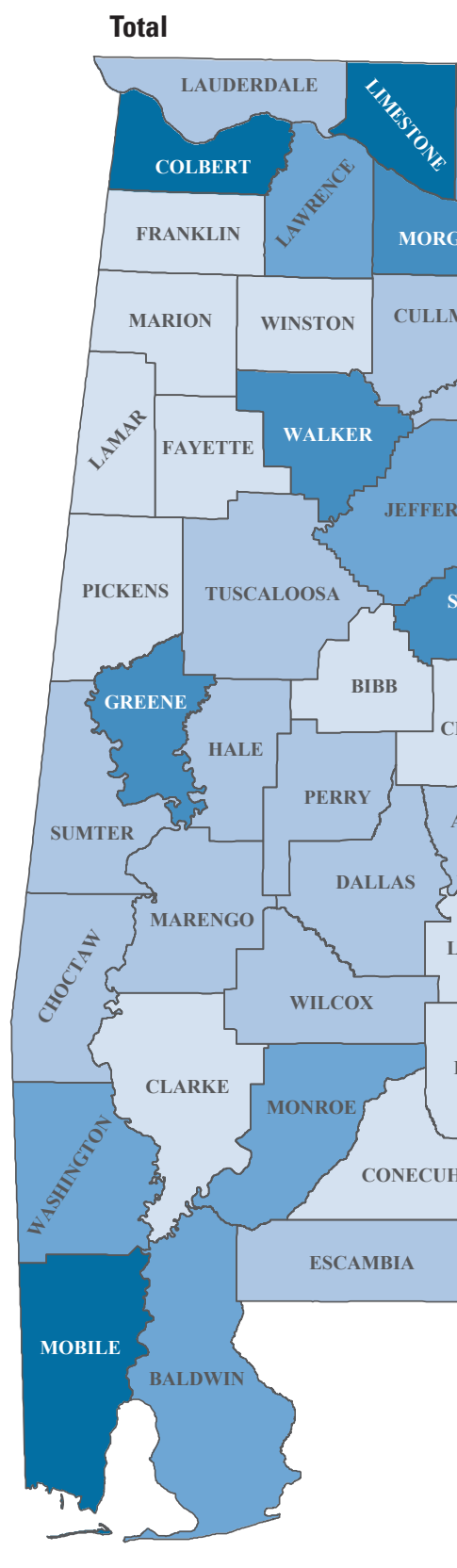

Figure 10. Total freshwater withdrawals by source and county in Alabama, 2005.

\section{EXPLANATION}

Freshwater withdrawals by county, in million gallons per day

\begin{tabular}{|c|}
\hline 0.01 to 10 \\
\hline 10 to 50 \\
\hline 50 to 100 \\
\hline 100 to 1,000 \\
\hline 1,000 to 2,015 \\
\hline
\end{tabular}

\section{Ground water}
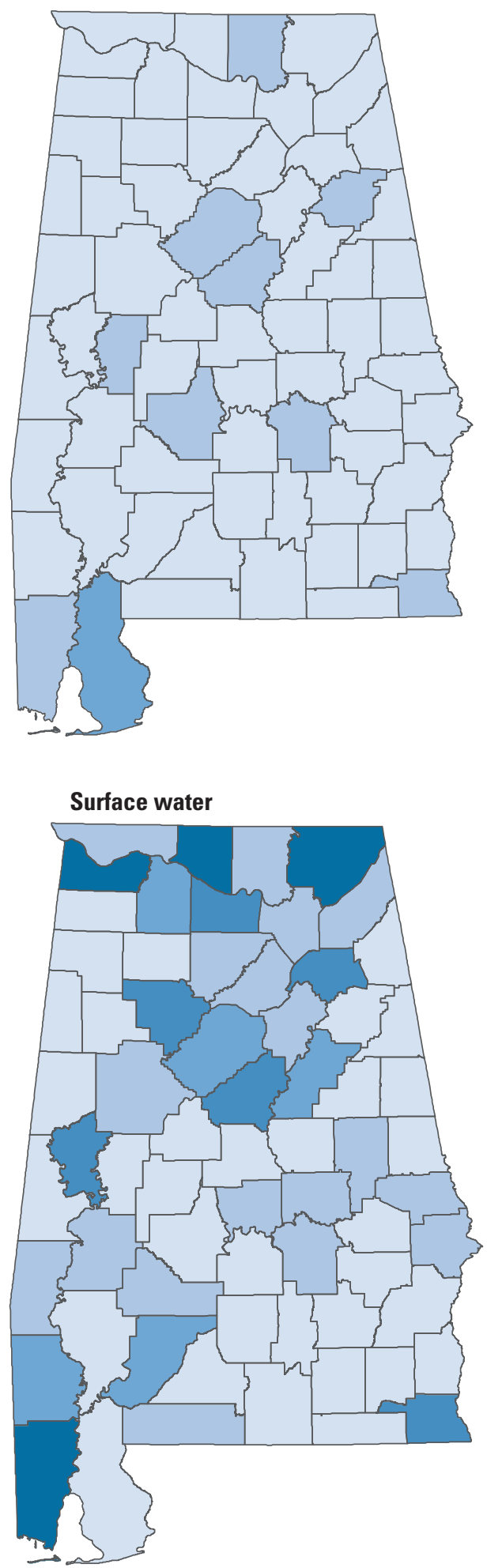
withdrawals. The exclusion of the small unestimated withdrawal amounts by subbasin - for aquaculture $(75 \mathrm{Mgal} / \mathrm{d}$ in 2005), mining (28 Mgal/d in 2005), and self-supplied residential (39 Mgal/d in 2005) - does not affect the understanding of the overall distribution pattern of water use in the State. The Middle Tennessee-Elk subregion accounted for about 53 percent $(5,184 \mathrm{Mgal} / \mathrm{d})$ of the $9,816 \mathrm{Mgal} / \mathrm{d}$ total estimated withdrawals.
About 92 percent of that water was for thermoelectric power, and nearly all of the water was surface water. Excluding thermoelectric power, the Middle Tennessee-Elk subregion accounted for 27 percent of the water withdrawals statewide. The second largest use category in the Middle Tennessee-Elk subregion was self-supplied industrial, about 51 percent $(214 \mathrm{Mgal} / \mathrm{d})$ of the nonpower water withdrawal in the subregion.
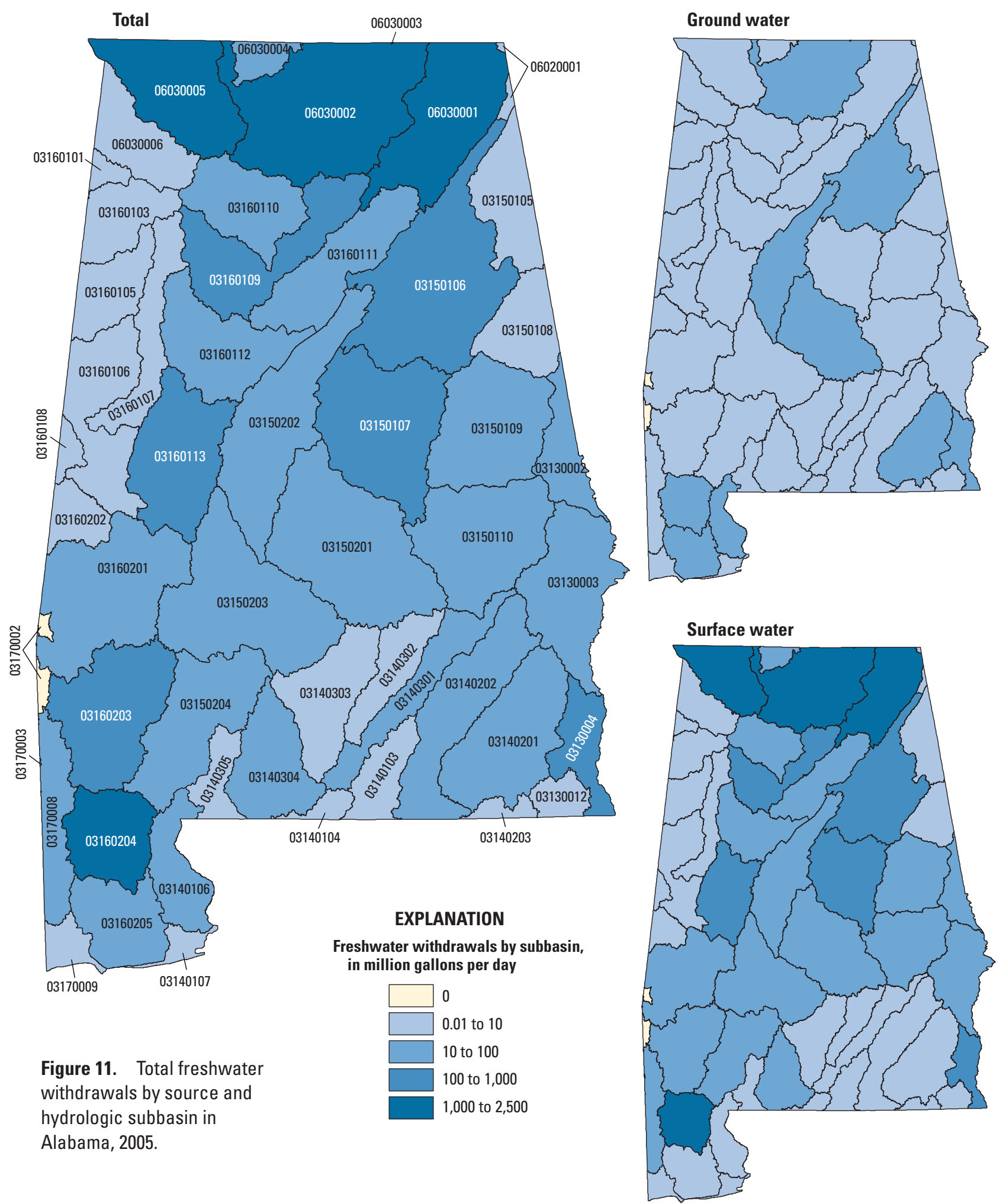
Table 3. Total freshwater withdrawals by source and county, Alabama, 2005.

[Values may not sum to total estimated use(s) because of rounding]

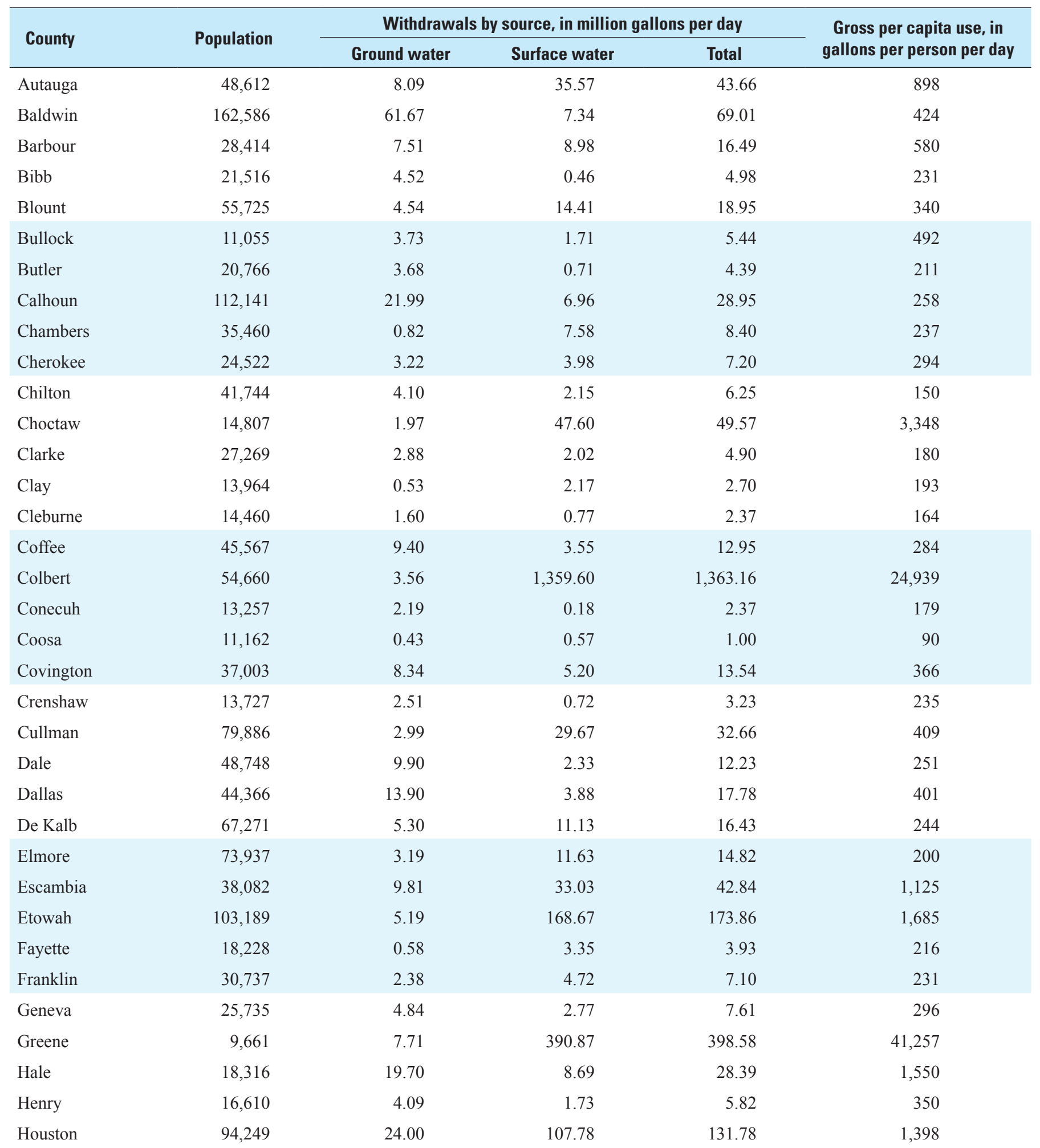


Table 3. Total freshwater withdrawals by source and county, Alabama, 2005.-Continued

[Values may not sum to total estimated use(s) because of rounding]

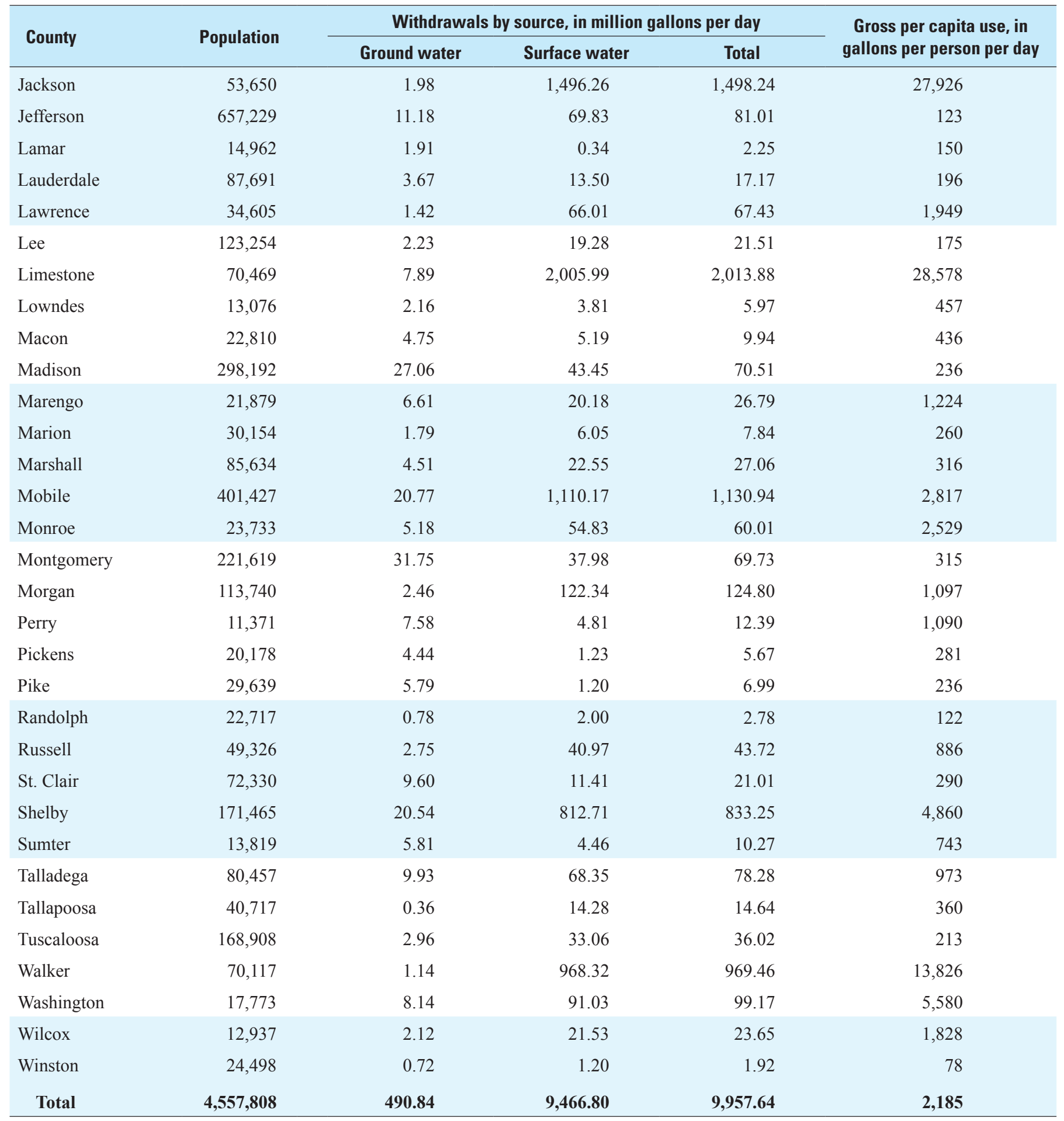


Table 4. Total freshwater withdrawals by source and hydrologic subregion and subbasin, Alabama, 2005.

[Values may not sum to total estimated use(s) because of rounding]

\begin{tabular}{|c|c|c|c|c|}
\hline \multirow{2}{*}{$\begin{array}{l}\text { Hydrologic subregion } \\
\text { and subbasin }\end{array}$} & \multirow{2}{*}{ Population } & \multicolumn{3}{|c|}{ Withdrawals by source, in million gallons per day } \\
\hline & & Ground water & Surface water & Total \\
\hline \multicolumn{5}{|l|}{ Apalachicola } \\
\hline 03130002 & 52,842 & 0.27 & 14.54 & 14.81 \\
\hline 03130003 & 95,496 & 6.72 & 42.93 & 49.65 \\
\hline 03130004 & 37,036 & 12.33 & 107.40 & 119.73 \\
\hline 03130012 & 24,348 & 4.46 & 1.08 & 5.54 \\
\hline Subtotal & 209,722 & 23.78 & 165.95 & 189.73 \\
\hline \multicolumn{5}{|c|}{ Choctawhatchee-Escambia } \\
\hline 03140103 & 19,015 & 2.62 & 0.44 & 3.06 \\
\hline 03140104 & 584 & 0.26 & 0.12 & 0.38 \\
\hline 03140106 & 34,750 & 16.03 & 2.41 & 18.44 \\
\hline 03140107 & 25,801 & 8.61 & 0.61 & 9.22 \\
\hline 03140201 & 146,125 & 27.23 & 6.16 & 33.39 \\
\hline 03140202 & 50,881 & 9.72 & 4.78 & 14.50 \\
\hline 03140203 & 6,195 & 1.01 & 0.61 & 1.62 \\
\hline 03140301 & 27,731 & 8.02 & 5.55 & 13.57 \\
\hline 03140302 & 13,291 & 2.02 & 0.73 & 2.75 \\
\hline 03140303 & 23,353 & 3.89 & 0.81 & 4.70 \\
\hline 03140304 & 26,655 & 5.81 & 32.68 & 38.49 \\
\hline 03140305 & 16,443 & 2.51 & 0.25 & 2.76 \\
\hline Subtotal & 390,824 & 87.73 & 55.15 & 142.88 \\
\hline \multicolumn{5}{|l|}{ Alabama } \\
\hline 03150105 & 41,579 & 2.49 & 5.62 & 8.11 \\
\hline 03150106 & 335,013 & 40.17 & 250.54 & 290.71 \\
\hline 03150107 & 123,826 & 5.82 & 829.62 & 835.44 \\
\hline 03150108 & 23,143 & 1.40 & 1.45 & 2.85 \\
\hline 03150109 & 68,184 & 0.36 & 19.93 & 20.29 \\
\hline 03150110 & 160,180 & 7.83 & 44.95 & 52.78 \\
\hline 03150201 & 322,442 & 47.92 & 49.85 & 97.77 \\
\hline 03150202 & 376,792 & 27.30 & 56.64 & 83.94 \\
\hline 03150203 & 30,670 & 4.24 & 23.25 & 27.49 \\
\hline 03150204 & 24,347 & 7.17 & 55.27 & 62.44 \\
\hline Subtotal & $1,506,176$ & 144.70 & $1,337.12$ & $1,481.82$ \\
\hline \multicolumn{5}{|l|}{ Mobile-Tombigbee } \\
\hline 03160101 & 3,832 & 0.31 & 0.09 & 0.40 \\
\hline 03160103 & 23,300 & 0.68 & 2.32 & 3.00 \\
\hline 03160105 & 19,232 & 1.64 & 2.80 & 4.44 \\
\hline
\end{tabular}


Table 4. Total freshwater withdrawals by source and hydrologic subregion and subbasin, Alabama, 2005.-Continued [Values may not sum to total estimated use(s) because of rounding]

\begin{tabular}{|c|c|c|c|c|}
\hline \multirow{2}{*}{$\begin{array}{l}\text { Hydrologic subregion } \\
\text { and subbasin }\end{array}$} & \multirow{2}{*}{ Population } & \multicolumn{3}{|c|}{ Withdrawals by source, in million gallons per day } \\
\hline & & Ground water & Surface water & Total \\
\hline \multicolumn{5}{|c|}{ Mobile-Tombigbee (Continued) } \\
\hline 03160106 & 28,333 & 4.67 & 0.79 & 5.46 \\
\hline 03160107 & 16,506 & 0.79 & 0.85 & 1.64 \\
\hline 03160108 & 949 & 0.25 & 0.05 & 0.30 \\
\hline 03160109 & 132,396 & 2.20 & 984.37 & 986.57 \\
\hline 03160110 & 51,869 & 1.27 & 16.00 & 17.27 \\
\hline 03160111 & 329,844 & 4.41 & 14.67 & 19.08 \\
\hline 03160112 & 280,509 & 0.97 & 43.08 & 44.05 \\
\hline 03160113 & 101,984 & 6.52 & 388.83 & 395.35 \\
\hline 03160201 & 36,189 & 4.75 & 65.98 & 70.73 \\
\hline 03160202 & 7,296 & 0.07 & 1.34 & 1.41 \\
\hline 03160203 & 37,199 & 8.79 & 92.96 & 101.75 \\
\hline 03160204 & 195,350 & 22.08 & $1,046.11$ & $1,068.19$ \\
\hline 03160205 & 234,104 & 24.52 & 2.28 & 26.80 \\
\hline Subtotal & $1,498,892$ & 83.92 & $2,662.52$ & $2,746.44$ \\
\hline \multicolumn{5}{|l|}{ Pascagoula } \\
\hline 03170002 & 0 & 0.00 & 0.00 & 0.00 \\
\hline 03170003 & 0 & 0.00 & 0.00 & 0.00 \\
\hline 03170008 & 64,253 & 2.79 & 65.33 & 68.12 \\
\hline 03170009 & 14,406 & 0.66 & 0.17 & 0.83 \\
\hline Subtotal & 78,659 & 3.45 & 65.50 & 68.95 \\
\hline \multicolumn{5}{|c|}{ Middle Tennessee-Hiwassee } \\
\hline 06020001 & 2,482 & 0.77 & 0.16 & 0.93 \\
\hline Subtotal & 2,482 & 0.77 & 0.16 & 0.93 \\
\hline \multicolumn{5}{|l|}{ Middle Tennessee-Elk } \\
\hline 06030001 & 139,796 & 5.32 & $1,519.77$ & $1,525.09$ \\
\hline 06030002 & 513,383 & 34.67 & $2,223.58$ & $2,258.25$ \\
\hline 06030003 & 0 & 0.00 & 0.00 & 0.00 \\
\hline 06030004 & 16,750 & 0.81 & 10.93 & 11.74 \\
\hline 06030005 & 152,863 & 4.84 & $1,375.27$ & $1,380.11$ \\
\hline 06030006 & 33,623 & 1.67 & 8.12 & 9.79 \\
\hline Subtotal & 856,415 & 47.31 & $5,137.67$ & $5,184.98$ \\
\hline Total & $4,543,170$ & 391.66 & $9,424.07$ & $9,815.73$ \\
\hline
\end{tabular}


Table 5. Total freshwater withdrawals by category of use and county, Alabama, 2005.

[Values may not sum to total estimated use(s) because of rounding]

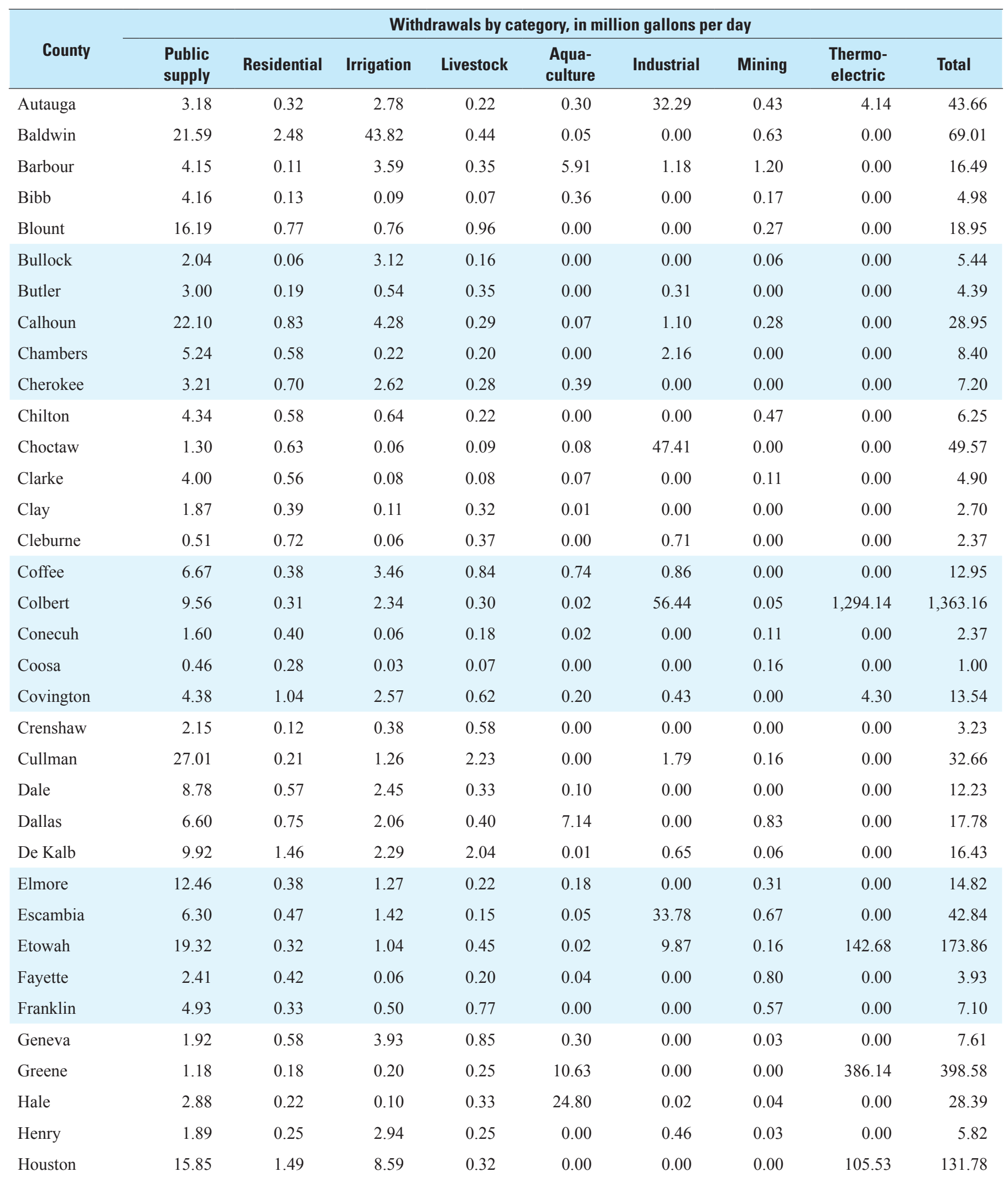


Table 5. Total freshwater withdrawals by category of use and county, Alabama, 2005.-Continued

[Values may not sum to total estimated use(s) because of rounding]

\begin{tabular}{|c|c|c|c|c|c|c|c|c|c|}
\hline \multirow[b]{2}{*}{ County } & \multicolumn{9}{|c|}{ Withdrawals by category, in million gallons per day } \\
\hline & $\begin{array}{l}\text { Public } \\
\text { supply }\end{array}$ & Residential & Irrigation & Livestock & $\begin{array}{l}\text { Aqua- } \\
\text { culture }\end{array}$ & Industrial & Mining & $\begin{array}{l}\text { Thermo- } \\
\text { electric }\end{array}$ & Total \\
\hline Jefferson & 73.34 & 0.39 & 2.82 & 0.08 & 0.58 & 0.40 & 3.40 & 0.00 & 81.01 \\
\hline Lamar & 1.47 & 0.30 & 0.28 & 0.13 & 0.00 & 0.07 & 0.00 & 0.00 & 2.25 \\
\hline Lawrence & 6.91 & 0.49 & 1.79 & 0.75 & 0.08 & 57.18 & 0.23 & 0.00 & 67.43 \\
\hline Lee & 16.35 & 0.70 & 1.60 & 0.10 & 0.15 & 2.23 & 0.38 & 0.00 & 21.51 \\
\hline Limestone & 13.39 & 1.05 & 8.26 & 0.44 & 0.00 & 0.00 & 0.50 & $1,990.24$ & $2,013.88$ \\
\hline Lowndes & 0.96 & 0.06 & 3.84 & 0.65 & 0.02 & 0.00 & 0.44 & 0.00 & 5.97 \\
\hline Marengo & 2.71 & 0.55 & 0.15 & 0.38 & 3.64 & 19.08 & 0.28 & 0.00 & 26.79 \\
\hline Marion & 6.30 & 0.92 & 0.08 & 0.41 & 0.00 & 0.00 & 0.13 & 0.00 & 7.84 \\
\hline Marshall & 24.15 & 0.38 & 0.68 & 1.20 & 0.01 & 0.36 & 0.28 & 0.00 & 27.06 \\
\hline Mobile & 76.82 & 3.01 & 1.10 & 0.27 & 0.00 & 5.67 & 0.46 & $1,043.61$ & $1,130.94$ \\
\hline Monroe & 3.85 & 0.31 & 0.46 & 0.20 & 0.07 & 55.01 & 0.11 & 0.00 & 60.01 \\
\hline Montgomery & 64.47 & 0.36 & 1.17 & 0.66 & 1.14 & 0.01 & 1.92 & 0.00 & 69.73 \\
\hline Morgan & 30.42 & 0.30 & 0.86 & 0.73 & 0.10 & 90.65 & 0.54 & 1.20 & 124.80 \\
\hline Perry & 1.82 & 0.32 & 0.05 & 0.21 & 9.99 & 0.00 & 0.00 & 0.00 & 12.39 \\
\hline Shelby & 14.12 & 0.52 & 2.19 & 0.15 & 0.05 & 0.00 & 3.90 & 812.32 & 833.25 \\
\hline Sumter & 1.82 & 0.10 & 0.10 & 0.35 & 4.29 & 1.22 & 2.39 & 0.00 & 10.27 \\
\hline Talladega & 18.48 & 1.26 & 2.53 & 0.29 & 0.00 & 54.62 & 1.10 & 0.00 & 78.28 \\
\hline Tallapoosa & 12.55 & 0.28 & 0.39 & 0.12 & 1.30 & 0.00 & 0.00 & 0.00 & 14.64 \\
\hline Tuscaloosa & 28.29 & 0.84 & 4.44 & 0.21 & 0.07 & 1.92 & 0.25 & 0.00 & 36.02 \\
\hline Walker & 40.34 & 0.54 & 0.49 & 0.31 & 0.09 & 0.00 & 0.41 & 927.28 & 969.46 \\
\hline Washington & 1.19 & 0.51 & 0.11 & 0.19 & 0.08 & 9.64 & 0.91 & 86.54 & 99.17 \\
\hline Wilcox & 1.02 & 0.34 & 0.36 & 0.21 & 0.68 & 21.04 & 0.00 & 0.00 & 23.65 \\
\hline Winston & 0.89 & 0.44 & 0.06 & 0.47 & 0.00 & 0.00 & 0.06 & 0.00 & 1.92 \\
\hline Total & 801.66 & 39.12 & 161.20 & 28.11 & 74.89 & 550.42 & 27.82 & $8,274.42$ & $9,957.64$ \\
\hline
\end{tabular}


Table 6. Total freshwater withdrawals by category of use and hydrologic subregion and subbasin, Alabama, 2005.

[Statewide, total freshwater withdrawals for self-supplied residential, aquaculture, and mining were 39.12 million gallons per day (Mgal/d), $74.89 \mathrm{Mgal} / \mathrm{d}$, and $27.82 \mathrm{Mgal}$, respectively. Values may not sum to total estimated use(s) because of rounding]

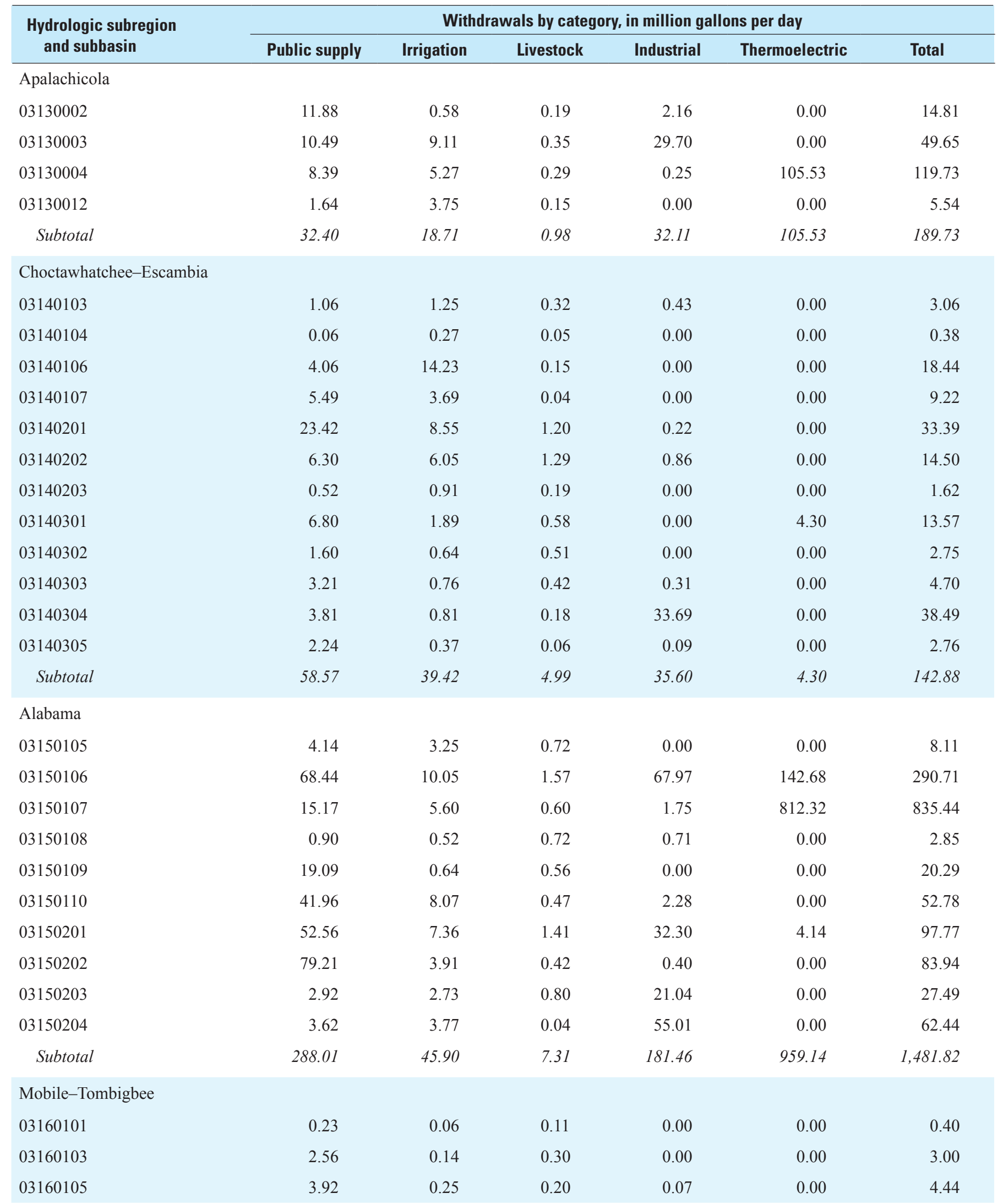


Table 6. Total freshwater withdrawals by category of use and hydrologic subregion and subbasin, Alabama, 2005.-Continued

[Statewide, total freshwater withdrawals for self-supplied residential, aquaculture, and mining were 39.12 million gallons per day (Mgal/d), $74.89 \mathrm{Mgal} / \mathrm{d}$, and 27.82 Mgal, respectively. Values may not sum to total estimated use(s) because of rounding]

\begin{tabular}{|c|c|c|c|c|c|c|}
\hline \multirow{2}{*}{$\begin{array}{l}\text { Hydrologic subregion } \\
\text { and subbasin }\end{array}$} & \multicolumn{6}{|c|}{ Withdrawals by category, in million gallons per day } \\
\hline & Public supply & Irrigation & Livestock & Industrial & Thermoelectric & Total \\
\hline \multicolumn{7}{|c|}{ Mobile-Tombigbee (Continued) } \\
\hline 03160107 & 0.55 & 0.79 & 0.30 & 0.00 & 0.00 & 1.64 \\
\hline 03160108 & 0.22 & 0.03 & 0.05 & 0.00 & 0.00 & 0.30 \\
\hline 03160110 & 14.87 & 0.93 & 1.47 & 0.00 & 0.00 & 17.27 \\
\hline 03160111 & 15.56 & 2.20 & 1.00 & 0.32 & 0.00 & 19.08 \\
\hline 03160112 & 40.43 & 3.21 & 0.21 & 0.20 & 0.00 & 44.05 \\
\hline 03160113 & 5.49 & 1.46 & 0.52 & 1.74 & 386.14 & 395.35 \\
\hline 03160203 & 5.08 & 0.29 & 0.20 & 9.64 & 86.54 & 101.75 \\
\hline 03160204 & 8.72 & 10.27 & 0.19 & 5.40 & $1,043.61$ & $1,068.19$ \\
\hline 03160205 & 13.85 & 12.50 & 0.18 & 0.27 & 0.00 & 26.80 \\
\hline Subtotal & 173.43 & 34.38 & 7.80 & 87.26 & $2,443.57$ & $2,746.44$ \\
\hline \multicolumn{7}{|l|}{ Pascagoula } \\
\hline 03170002 & 0.00 & 0.00 & 0.00 & 0.00 & 0.00 & 0.00 \\
\hline 03170003 & 0.00 & 0.00 & 0.00 & 0.00 & 0.00 & 0.00 \\
\hline 03170008 & 67.65 & 0.34 & 0.13 & 0.00 & 0.00 & 68.12 \\
\hline Subtotal & 0.66 & 0.14 & 0.13 & 0.00 & 0.00 & 0.93 \\
\hline \multicolumn{7}{|l|}{ Middle Tennessee-Elk } \\
\hline 06030001 & 35.38 & 2.22 & 2.37 & 8.82 & $1,476.30$ & $1,525.09$ \\
\hline 06030002 & 103.13 & 12.62 & 2.34 & 148.72 & $1,991.44$ & $2,258.25$ \\
\hline 06030003 & 0.00 & 0.00 & 0.00 & 0.00 & 0.00 & 0.00 \\
\hline 06030004 & 8.84 & 2.72 & 0.18 & 0.00 & 0.00 & 11.74 \\
\hline 06030005 & 25.07 & 3.42 & 1.04 & 56.44 & $1,294.14$ & $1,380.11$ \\
\hline 06030006 & 7.87 & 1.17 & 0.75 & 0.00 & 0.00 & 9.79 \\
\hline Subtotal & 180.29 & 22.15 & 6.68 & 213.98 & $4,761.88$ & $5,184.98$ \\
\hline Total & 801.63 & 161.21 & 28.06 & 550.41 & $8,274.42$ & $9,815.73$ \\
\hline
\end{tabular}


Table 7. Total fresh surface-water withdrawals by category of use and county, Alabama, 2005.

[Values may not sum to total estimated use(s) because of rounding]

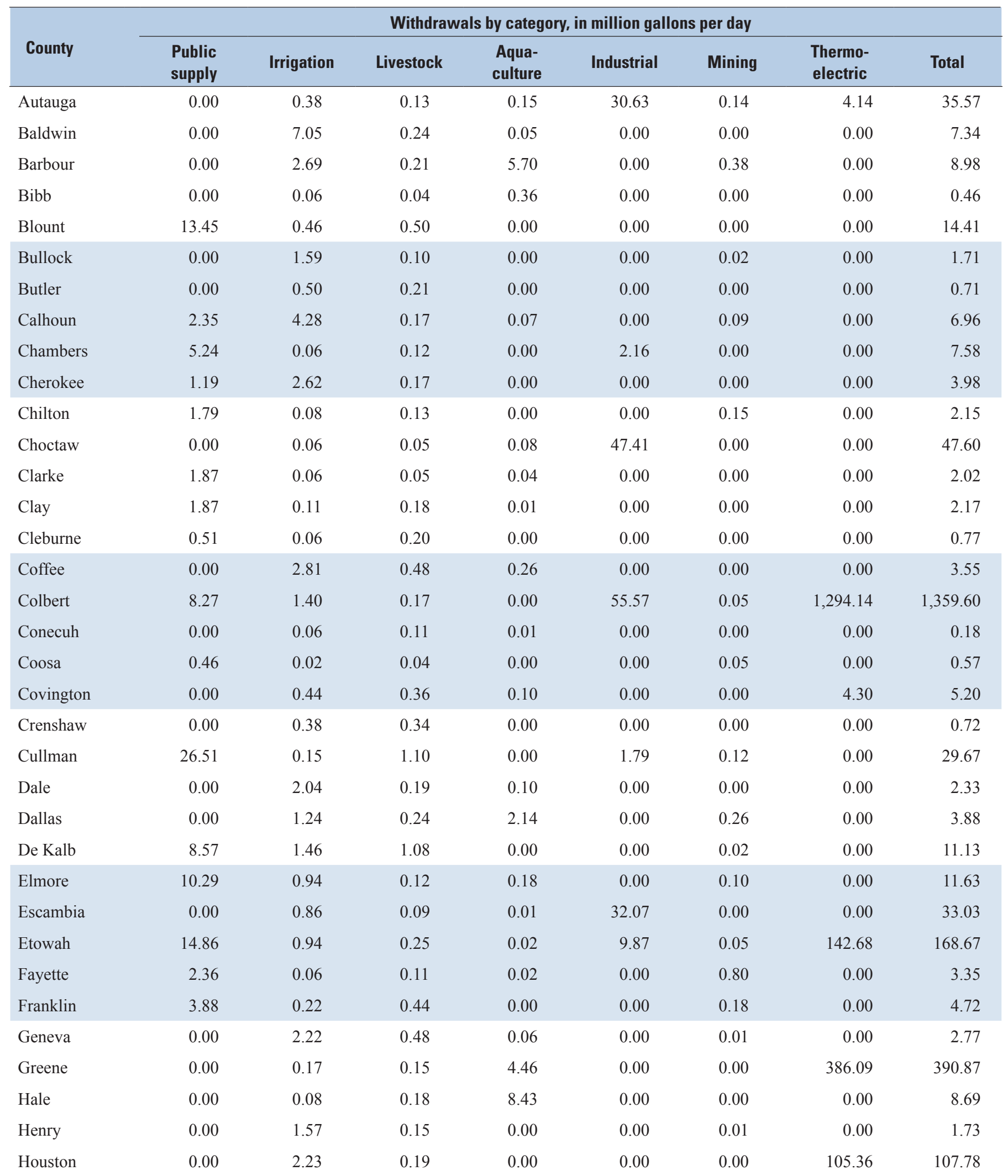


Table 7. Total fresh surface-water withdrawals by category of use and county, Alabama, 2005.-Continued

[Values may not sum to total estimated use(s) because of rounding]

\begin{tabular}{|c|c|c|c|c|c|c|c|c|}
\hline \multirow[b]{2}{*}{ County } & \multicolumn{8}{|c|}{ Withdrawals by category, in million gallons per day } \\
\hline & $\begin{array}{l}\text { Public } \\
\text { supply }\end{array}$ & Irrigation & Livestock & $\begin{array}{l}\text { Aqua- } \\
\text { culture }\end{array}$ & Industrial & Mining & $\begin{array}{l}\text { Thermo- } \\
\text { electric }\end{array}$ & Total \\
\hline Jefferson & 65.02 & 2.73 & 0.05 & 0.56 & 0.00 & 1.47 & 0.00 & 69.83 \\
\hline Lamar & 0.00 & 0.27 & 0.07 & 0.00 & 0.00 & 0.00 & 0.00 & 0.34 \\
\hline Lawrence & 6.91 & 1.42 & 0.43 & 0.00 & 57.18 & 0.07 & 0.00 & 66.01 \\
\hline Lee & 15.53 & 1.24 & 0.06 & 0.10 & 2.23 & 0.12 & 0.00 & 19.28 \\
\hline Limestone & 8.84 & 6.16 & 0.25 & 0.00 & 0.00 & 0.50 & $1,990.24$ & $2,005.99$ \\
\hline Lowndes & 0.00 & 3.26 & 0.39 & 0.02 & 0.00 & 0.14 & 0.00 & 3.81 \\
\hline Marengo & 0.00 & 0.14 & 0.23 & 1.64 & 18.08 & 0.09 & 0.00 & 20.18 \\
\hline Marion & 5.66 & 0.06 & 0.24 & 0.00 & 0.00 & 0.09 & 0.00 & 6.05 \\
\hline Marshall & 21.17 & 0.68 & 0.60 & 0.01 & 0.00 & 0.09 & 0.00 & 22.55 \\
\hline Mobile & 65.45 & 0.96 & 0.15 & 0.00 & 0.00 & 0.00 & $1,043.61$ & $1,110.17$ \\
\hline Monroe & 0.00 & 0.06 & 0.12 & 0.04 & 54.61 & 0.00 & 0.00 & 54.83 \\
\hline Montgomery & 35.57 & 0.82 & 0.39 & 0.59 & 0.00 & 0.61 & 0.00 & 37.98 \\
\hline Morgan & 30.42 & 0.74 & 0.40 & 0.05 & 89.36 & 0.17 & 1.20 & 122.34 \\
\hline Perry & 0.00 & 0.02 & 0.12 & 4.67 & 0.00 & 0.00 & 0.00 & 4.81 \\
\hline Shelby & 0.00 & 0.25 & 0.09 & 0.05 & 0.00 & 0.00 & 812.32 & 812.71 \\
\hline Sumter & 0.00 & 0.08 & 0.21 & 2.19 & 1.22 & 0.76 & 0.00 & 4.46 \\
\hline Talladega & 12.12 & 2.36 & 0.16 & 0.00 & 53.36 & 0.35 & 0.00 & 68.35 \\
\hline Tallapoosa & 12.55 & 0.39 & 0.07 & 1.27 & 0.00 & 0.00 & 0.00 & 14.28 \\
\hline Tuscaloosa & 27.49 & 4.06 & 0.12 & 0.00 & 1.14 & 0.25 & 0.00 & 33.06 \\
\hline Walker & 40.22 & 0.26 & 0.18 & 0.07 & 0.00 & 0.31 & 927.28 & 968.32 \\
\hline Washington & 0.00 & 0.08 & 0.10 & 0.00 & 4.31 & 0.00 & 86.54 & 91.03 \\
\hline Wilcox & 0.00 & 0.02 & 0.13 & 0.34 & 21.04 & 0.00 & 0.00 & 21.53 \\
\hline Winston & 0.89 & 0.06 & 0.25 & 0.00 & 0.00 & 0.00 & 0.00 & 1.20 \\
\hline Total & 524.46 & 86.98 & 15.72 & 34.38 & 522.80 & 8.26 & $8,274.20$ & $9,466.80$ \\
\hline
\end{tabular}


Table 8. Total fresh surface-water withdrawals by category of use and hydrologic subregion and subbasin, Alabama, 2005.

[Statewide, total fresh surface-water withdrawals for aquaculture and mining were 34.38 million gallons per day (Mgal/d) and 8.29 Mgal, respectively. Values may not sum to total estimated use(s) because of rounding]

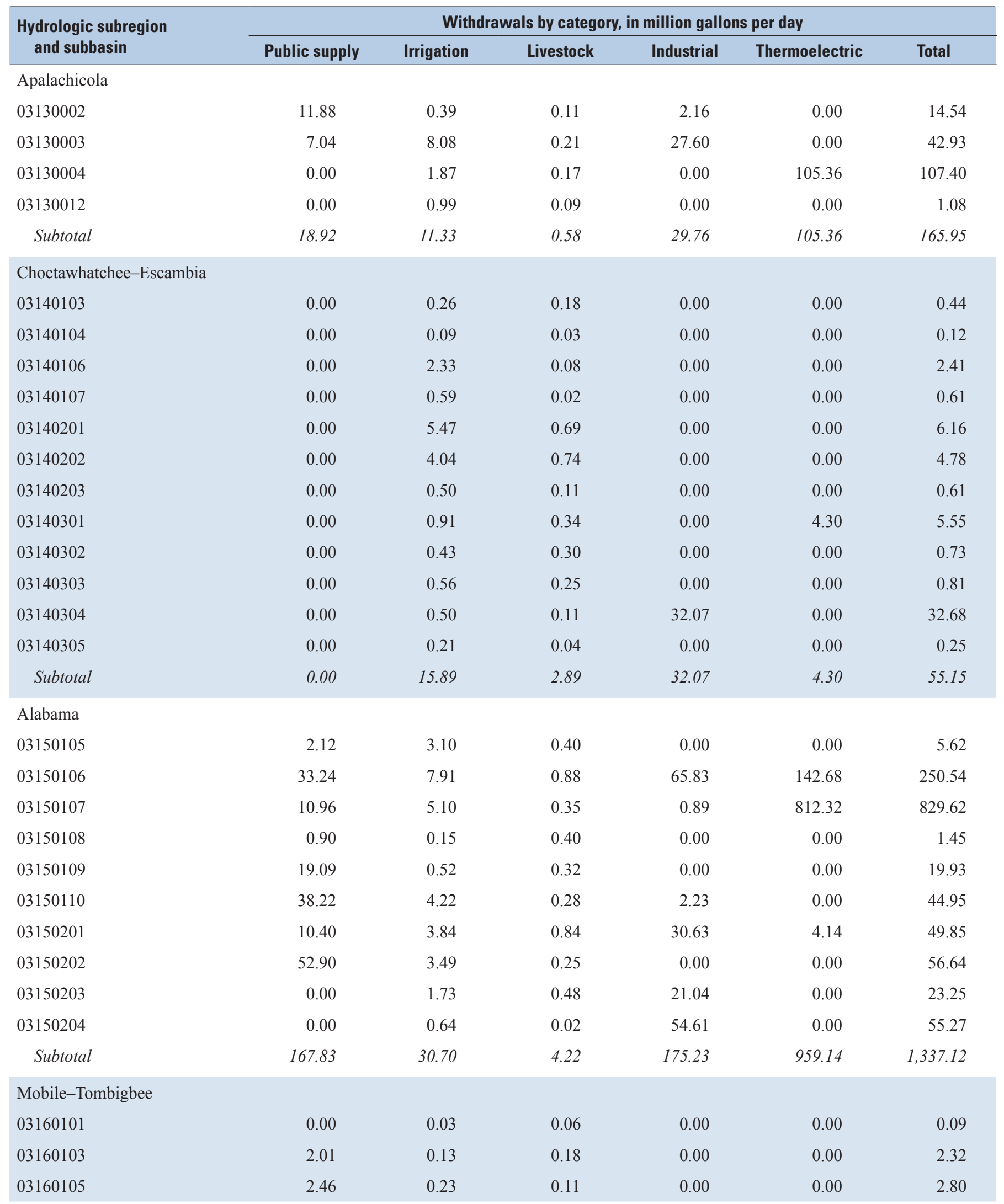


Table 8. Total fresh surface-water withdrawals by category of use and hydrologic subregion and subbasin, Alabama, 2005.—Continued [Statewide, total fresh surface-water withdrawals for aquaculture and mining were 34.38 million gallons per day (Mgal/d) and 8.29 Mgal, respectively. Values may not sum to total estimated use(s) because of rounding]

\begin{tabular}{|c|c|c|c|c|c|c|}
\hline \multirow{2}{*}{$\begin{array}{l}\text { Hydrologic subregion } \\
\text { and subbasin }\end{array}$} & \multicolumn{6}{|c|}{ Withdrawals by category, in million gallons per day } \\
\hline & Public supply & Irrigation & Livestock & Industrial & Thermoelectric & Total \\
\hline \multicolumn{7}{|c|}{ Mobile-Tombigbee (Continued) } \\
\hline 03160106 & 0.00 & 0.41 & 0.38 & 0.00 & 0.00 & 0.79 \\
\hline 03160107 & 0.00 & 0.68 & 0.17 & 0.00 & 0.00 & 0.85 \\
\hline 03160108 & 0.00 & 0.02 & 0.03 & 0.00 & 0.00 & 0.05 \\
\hline 03160109 & 53.96 & 0.46 & 0.88 & 1.79 & 927.28 & 984.37 \\
\hline 03160110 & 14.87 & 0.38 & 0.75 & 0.00 & 0.00 & 16.00 \\
\hline 03160111 & 12.24 & 1.91 & 0.52 & 0.00 & 0.00 & 14.67 \\
\hline 03160112 & 39.99 & 2.97 & 0.12 & 0.00 & 0.00 & 43.08 \\
\hline 03160113 & 0.00 & 1.31 & 0.29 & 1.14 & 386.09 & 388.83 \\
\hline 03160201 & 0.00 & 0.20 & 0.29 & 65.49 & 0.00 & 65.98 \\
\hline 03160202 & 0.00 & 0.03 & 0.09 & 1.22 & 0.00 & 1.34 \\
\hline 03160203 & 1.87 & 0.13 & 0.11 & 4.31 & 86.54 & 92.96 \\
\hline 03160204 & 0.48 & 1.92 & 0.10 & 0.00 & $1,043.61$ & $1,046.11$ \\
\hline 03160205 & 0.00 & 2.18 & 0.10 & 0.00 & 0.00 & 2.28 \\
\hline Subtotal & 127.88 & 12.99 & 4.18 & 73.95 & $2,443.52$ & $2,662.52$ \\
\hline \multicolumn{7}{|l|}{ Pascagoula } \\
\hline 03170002 & 0.00 & 0.00 & 0.00 & 0.00 & 0.00 & 0.00 \\
\hline 03170003 & 0.00 & 0.00 & 0.00 & 0.00 & 0.00 & 0.00 \\
\hline 03170008 & 64.97 & 0.29 & 0.07 & 0.00 & 0.00 & 65.33 \\
\hline 03170009 & 0.00 & 0.15 & 0.02 & 0.00 & 0.00 & 0.17 \\
\hline Subtotal & 64.97 & 0.44 & 0.09 & 0.00 & 0.00 & 65.50 \\
\hline \multicolumn{7}{|c|}{ Middle Tennessee-Hiwassee } \\
\hline 06020001 & 0.00 & 0.09 & 0.07 & 0.00 & 0.00 & 0.16 \\
\hline Subtotal & 0.00 & 0.09 & 0.07 & 0.00 & 0.00 & 0.16 \\
\hline \multicolumn{7}{|l|}{ Middle Tennessee-Elk } \\
\hline 06030001 & 31.72 & 1.72 & 1.25 & 8.78 & $1,476.30$ & $1,519.77$ \\
\hline 06030002 & 74.26 & 9.17 & 1.28 & 147.43 & $1,991.44$ & $2,223.58$ \\
\hline 06030003 & 0.00 & 0.00 & 0.00 & 0.00 & 0.00 & 0.00 \\
\hline 06030004 & 8.84 & 1.99 & 0.10 & 0.00 & 0.00 & 10.93 \\
\hline 06030005 & 22.98 & 1.98 & 0.60 & 55.57 & $1,294.14$ & $1,375.27$ \\
\hline 06030006 & 7.05 & 0.64 & 0.43 & 0.00 & 0.00 & 8.12 \\
\hline Subtotal & 144.85 & 15.50 & 3.66 & 211.78 & $4,761.88$ & $5,137.67$ \\
\hline Total & 524.45 & 86.94 & 15.69 & 522.79 & $8,274.20$ & $9,424.07$ \\
\hline
\end{tabular}


Table 9. Total fresh ground-water withdrawals by category of use and county, Alabama, 2005.

[Values may not sum to total estimated use(s) because of rounding]

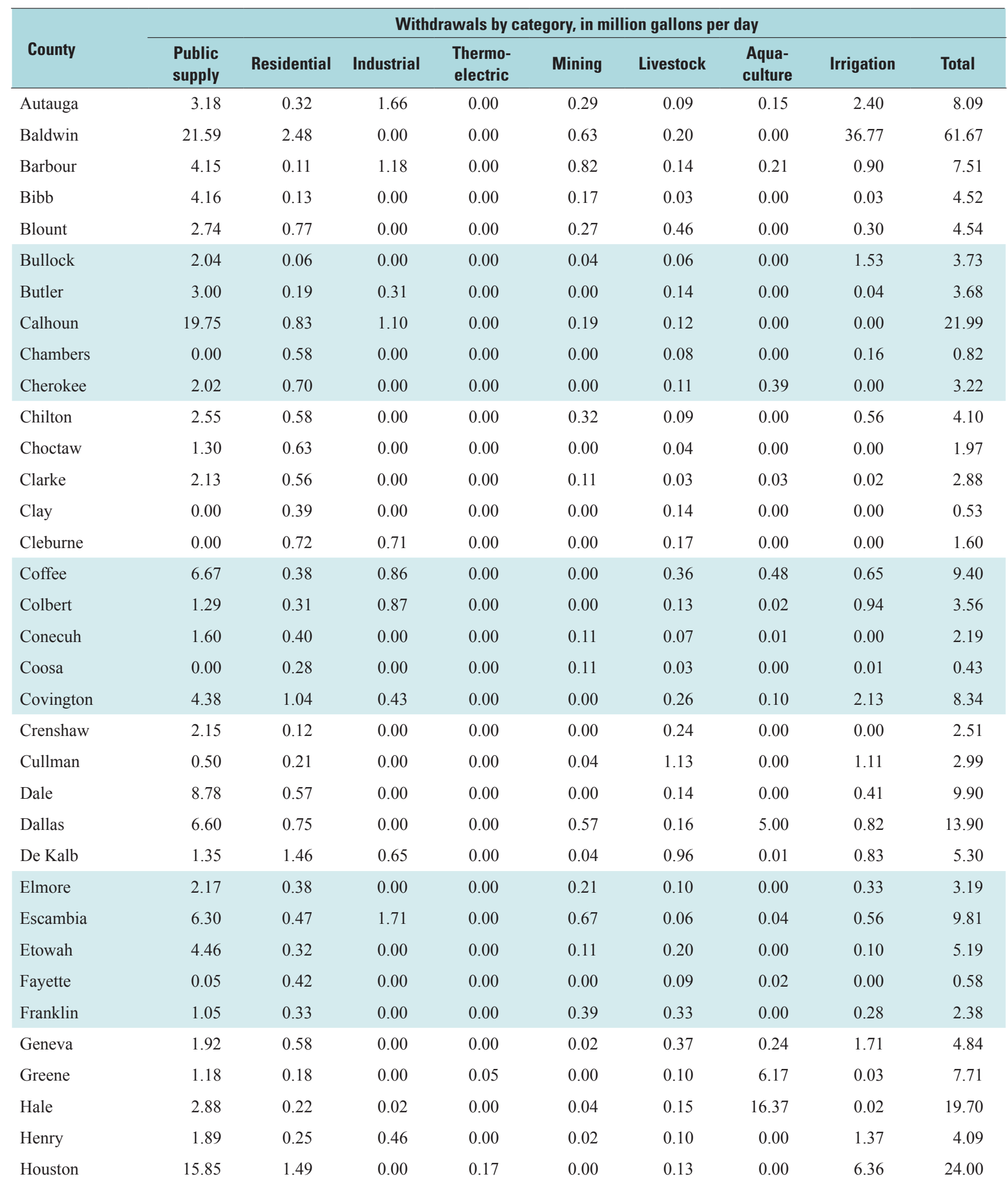


Table 9. Total fresh ground-water withdrawals by category of use and county, Alabama, 2005.-Continued

[Values may not sum to total estimated use(s) because of rounding]

\begin{tabular}{|c|c|c|c|c|c|c|c|c|c|}
\hline \multirow[b]{2}{*}{ County } & \multicolumn{9}{|c|}{ Withdrawals by category, in million gallons per day } \\
\hline & $\begin{array}{l}\text { Public } \\
\text { supply }\end{array}$ & Residential & Industrial & $\begin{array}{l}\text { Thermo- } \\
\text { electric }\end{array}$ & Mining & Livestock & $\begin{array}{l}\text { Aqua- } \\
\text { culture }\end{array}$ & Irrigation & Total \\
\hline Jefferson & 8.32 & 0.39 & 0.40 & 0.00 & 1.93 & 0.03 & 0.02 & 0.09 & 11.18 \\
\hline Lamar & 1.47 & 0.30 & 0.07 & 0.00 & 0.00 & 0.06 & 0.00 & 0.01 & 1.91 \\
\hline Lawrence & 0.00 & 0.49 & 0.00 & 0.00 & 0.16 & 0.32 & 0.08 & 0.37 & 1.42 \\
\hline Lee & 0.82 & 0.70 & 0.00 & 0.00 & 0.26 & 0.04 & 0.05 & 0.36 & 2.23 \\
\hline Limestone & 4.55 & 1.05 & 0.00 & 0.00 & 0.00 & 0.19 & 0.00 & 2.10 & 7.89 \\
\hline Lowndes & 0.96 & 0.06 & 0.00 & 0.00 & 0.30 & 0.26 & 0.00 & 0.58 & 2.16 \\
\hline Marengo & 2.71 & 0.55 & 1.00 & 0.00 & 0.19 & 0.15 & 2.00 & 0.01 & 6.61 \\
\hline Marion & 0.64 & 0.92 & 0.00 & 0.00 & 0.04 & 0.17 & 0.00 & 0.02 & 1.79 \\
\hline Marshall & 2.98 & 0.38 & 0.36 & 0.00 & 0.19 & 0.60 & 0.00 & 0.00 & 4.51 \\
\hline Mobile & 11.37 & 3.01 & 5.67 & 0.00 & 0.46 & 0.12 & 0.00 & 0.14 & 20.77 \\
\hline Monroe & 3.85 & 0.31 & 0.40 & 0.00 & 0.11 & 0.08 & 0.03 & 0.40 & 5.18 \\
\hline Montgomery & 28.90 & 0.36 & 0.01 & 0.00 & 1.31 & 0.27 & 0.55 & 0.35 & 31.75 \\
\hline Morgan & 0.00 & 0.30 & 1.29 & 0.00 & 0.37 & 0.33 & 0.05 & 0.12 & 2.46 \\
\hline Perry & 1.82 & 0.32 & 0.00 & 0.00 & 0.00 & 0.09 & 5.32 & 0.03 & 7.58 \\
\hline Shelby & 14.12 & 0.52 & 0.00 & 0.00 & 3.90 & 0.06 & 0.00 & 1.94 & 20.54 \\
\hline Sumter & 1.82 & 0.10 & 0.00 & 0.00 & 1.63 & 0.14 & 2.10 & 0.02 & 5.81 \\
\hline Talladega & 6.36 & 1.26 & 1.26 & 0.00 & 0.75 & 0.13 & 0.00 & 0.17 & 9.93 \\
\hline Tallapoosa & 0.00 & 0.28 & 0.00 & 0.00 & 0.00 & 0.05 & 0.03 & 0.00 & 0.36 \\
\hline Tuscaloosa & 0.80 & 0.84 & 0.78 & 0.00 & 0.00 & 0.09 & 0.07 & 0.38 & 2.96 \\
\hline Walker & 0.12 & 0.54 & 0.00 & 0.00 & 0.10 & 0.13 & 0.02 & 0.23 & 1.14 \\
\hline Washington & 1.19 & 0.51 & 5.33 & 0.00 & 0.91 & 0.09 & 0.08 & 0.03 & 8.14 \\
\hline Wilcox & 1.02 & 0.34 & 0.00 & 0.00 & 0.00 & 0.08 & 0.34 & 0.34 & 2.12 \\
\hline Winston & 0.00 & 0.44 & 0.00 & 0.00 & 0.06 & 0.22 & 0.00 & 0.00 & 0.72 \\
\hline Total & 277.20 & 39.12 & 27.62 & 0.22 & 19.56 & 12.39 & 40.51 & 74.22 & 490.84 \\
\hline
\end{tabular}


Table 10. Total fresh ground-water withdrawals by category of use and hydrologic subregion and subbasin, Alabama, 2005.

[Statewide, total fresh ground-water withdrawals for self-supplied residential, aquaculture, and mining were $39.12 \mathrm{million}$ gallons per day (Mgal/d), $40.51 \mathrm{Mgal} / \mathrm{d}$, and $19.56 \mathrm{Mgal}$, respectively. Values may not sum to total estimated use(s) because of rounding]

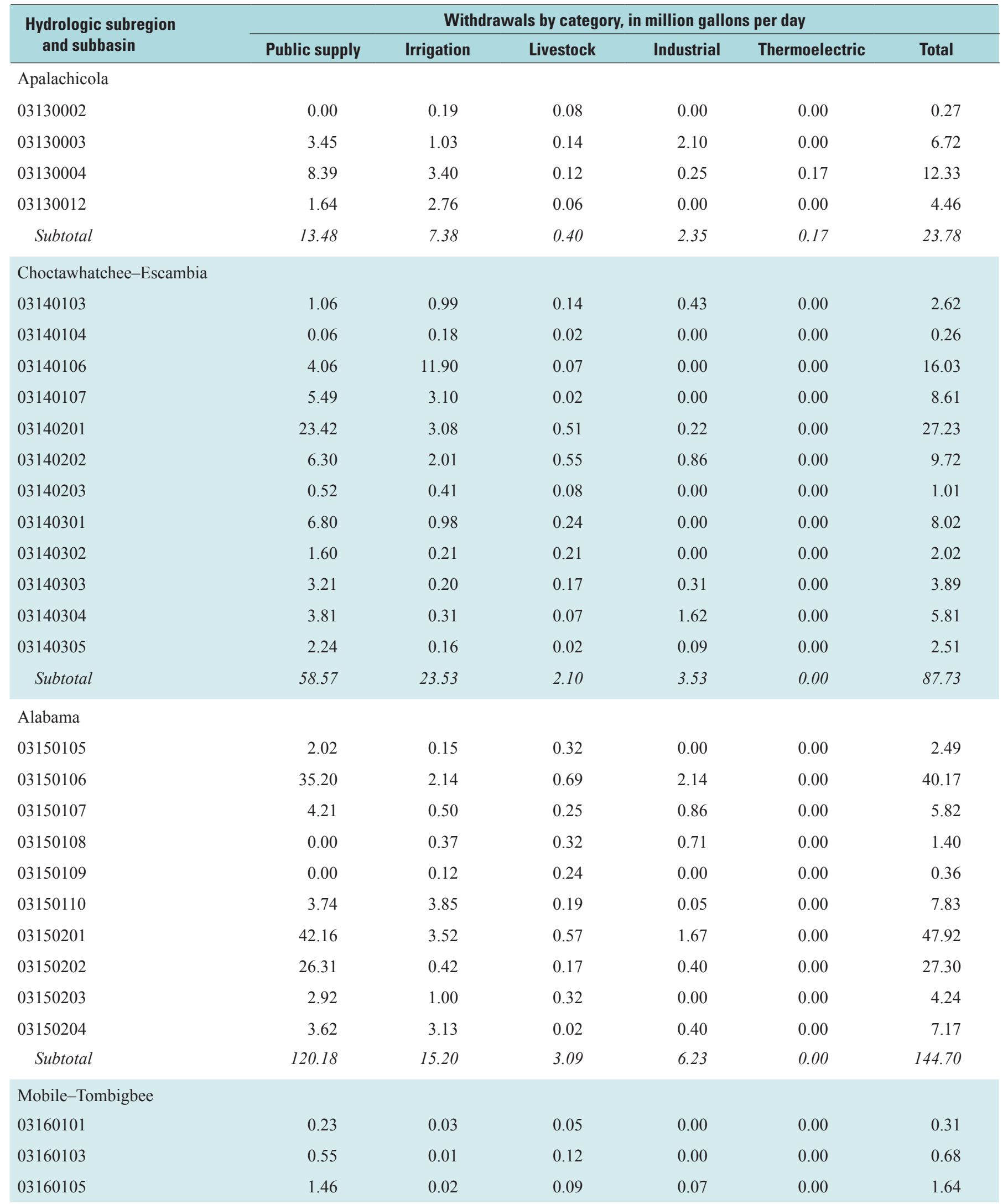


Table 10. Total fresh ground-water withdrawals by category of use and hydrologic subregion and subbasin, Alabama, 2005. - Continued

[Statewide, total fresh ground-water withdrawals for self-supplied residential, aquaculture, and mining were $39.12 \mathrm{million}$ gallons per day (Mgal/d), 40.51 Mgal/d, and 19.56 Mgal, respectively. Values may not sum to total estimated use(s) because of rounding]

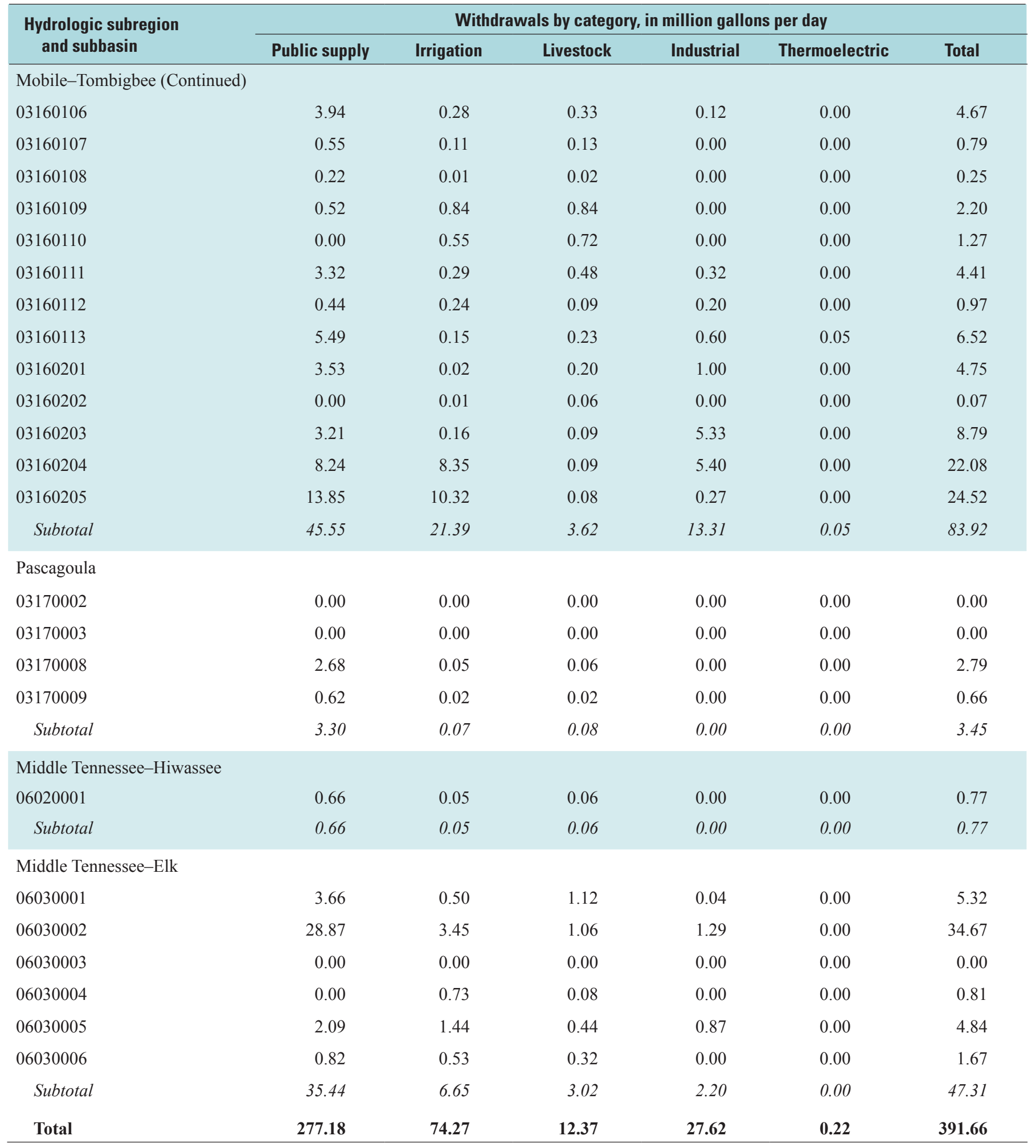


Figure 12 provides an overview of the sources and use of water in Alabama. In this figure, the eight water-use categories mentioned above have been grouped into four categories of similar water uses: thermoelectric power, industrial (combined self-supplied industrial, commercial, and mining withdrawals and industrial, commercial, and thermoelectric-power deliveries), residential (combined self-supplied residential withdrawals, public-supplied residential deliveries, and public use and losses), and agriculture (aquaculture, irrigation, and livestock). The figure shows that surface water was the source for 9,467 Mgal/d (table 7); of this total, $8,274 \mathrm{Mgal} / \mathrm{d}$ was used for thermoelectric power. The $802 \mathrm{Mgal} / \mathrm{d}$ (table 5) withdrawn by public supply was distributed to industrial users $(355.47 \mathrm{Mgal} / \mathrm{d})$ and residential users (446 Mgal/d - 325.94 Mgal/d total residential deliveries [table 11] and 120.25 Mgal/d public use and losses; selfsupplied residential withdrawals, 39.12 Mgal/d [table 9]). Ground water was a source for thermoelectric, industrial, residential, and agriculture water.

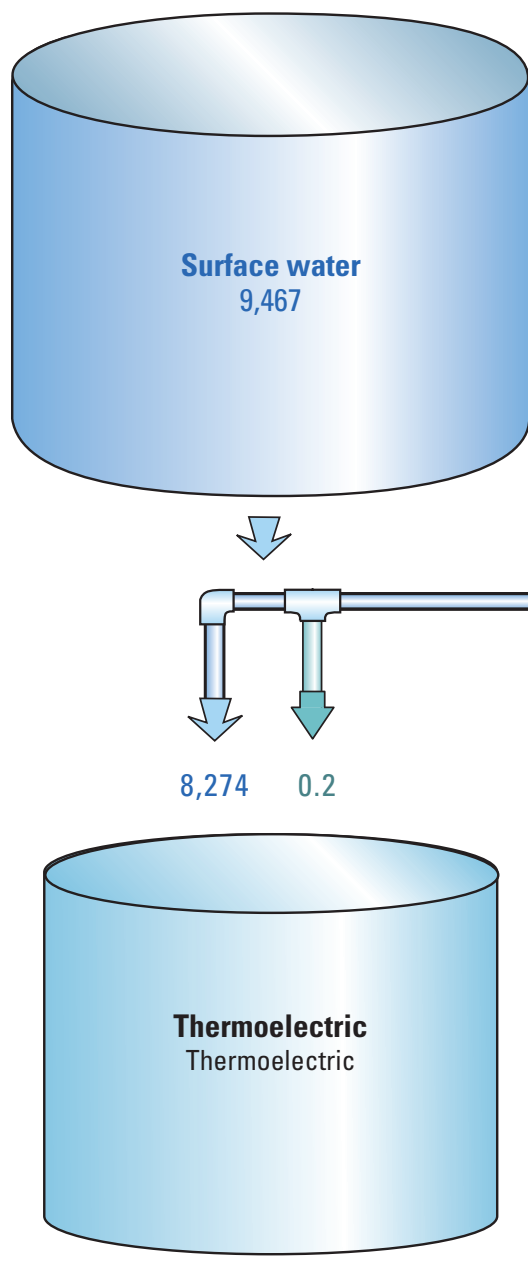

Public supply

802

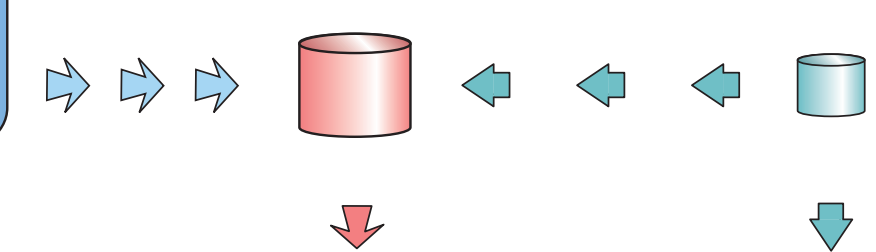

$\Rightarrow \vec{V}$

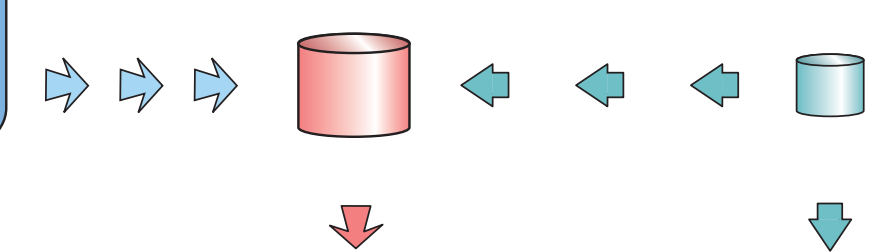

Ground water

491

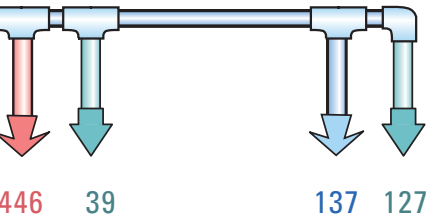

\section{Residential \\ Residential \\ Public use and \\ losses from \\ public supply}

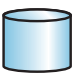

Agriculture

Irrigation

Livestock

Aquaculture

EXPLANATION

Water use, in million gallons per day-Values are rounded

Surface water

531

Public supply

355
Ground water

47

Figure 12. Sources and use of water in Alabama. 


\section{Public Supply}

Public supply refers to water that is withdrawn, treated, and distributed by public suppliers. Public suppliers provide water for a variety of uses, such as residential, commercial, industrial, thermoelectric power, and public-water use. Thermoelectric-power delivery amounts have not been estimated separately for this report, but are included in the industrial/commercial deliveries.

Public-supply withdrawals, residential deliveries, and population served are listed by county in table 11 and by hydrologic subbasin in table 12. For 2005, public-supply withdrawals were $802 \mathrm{Mgal} / \mathrm{d}$. Public-supply withdrawals were 8 percent of total withdrawals and about 48 percent of total withdrawals for all categories excluding thermoelectric power (table 5). The majority of the public-supply water (524 Mgal/d, or 65 percent) was withdrawn from surface-water sources (fig. 13). The remaining $277 \mathrm{Mgal} / \mathrm{d}$, or 35 percent, was withdrawn from wells and springs. In 2005, about 4.04 million people, or 89 percent of the population, depended on water from public suppliers. The percentage of population served by public supply by county is shown in figure 14 . The total delivery to residential customers was $326 \mathrm{Mgal} / \mathrm{d}$, or about 41 percent of the total withdrawals by public suppliers; combined industrial and commercial deliveries were $355 \mathrm{Mgal} / \mathrm{d}$, or 44 percent; and public use and losses accounted for the remaining $120 \mathrm{Mgal} / \mathrm{d}$, or 15 percent (fig. 13). See the "Residential" and "Industrial" sections for additional details.

The geographic distribution of the total, ground-water, and surface-water withdrawals for public supply by county is shown in figure 15. Counties containing cities with large populations had the largest amounts of withdrawal. Mobile (City of Mobile), Jefferson (Birmingham), Montgomery (City of Montgomery), Madison (Huntsville), and Walker (source of water for metropolitan Birmingham) Counties accounted for 40 percent of the water withdrawn and 39 percent of the population served by public suppliers (figs. 15 and 16, table 11). Jefferson County had the highest percentage of population served by a public supply (99 percent) and was 1 of 20 counties whose public suppliers collectively served more than 90 percent of their respective county populations (fig. 14). The largest surface-water withdrawals occurred in Mobile and Jefferson Counties (combined $130 \mathrm{Mgal} / \mathrm{d}$ ), and the largest ground-water withdrawals were in Montgomery and Madison Counties (combined $53 \mathrm{Mgal} / \mathrm{d}$ ).
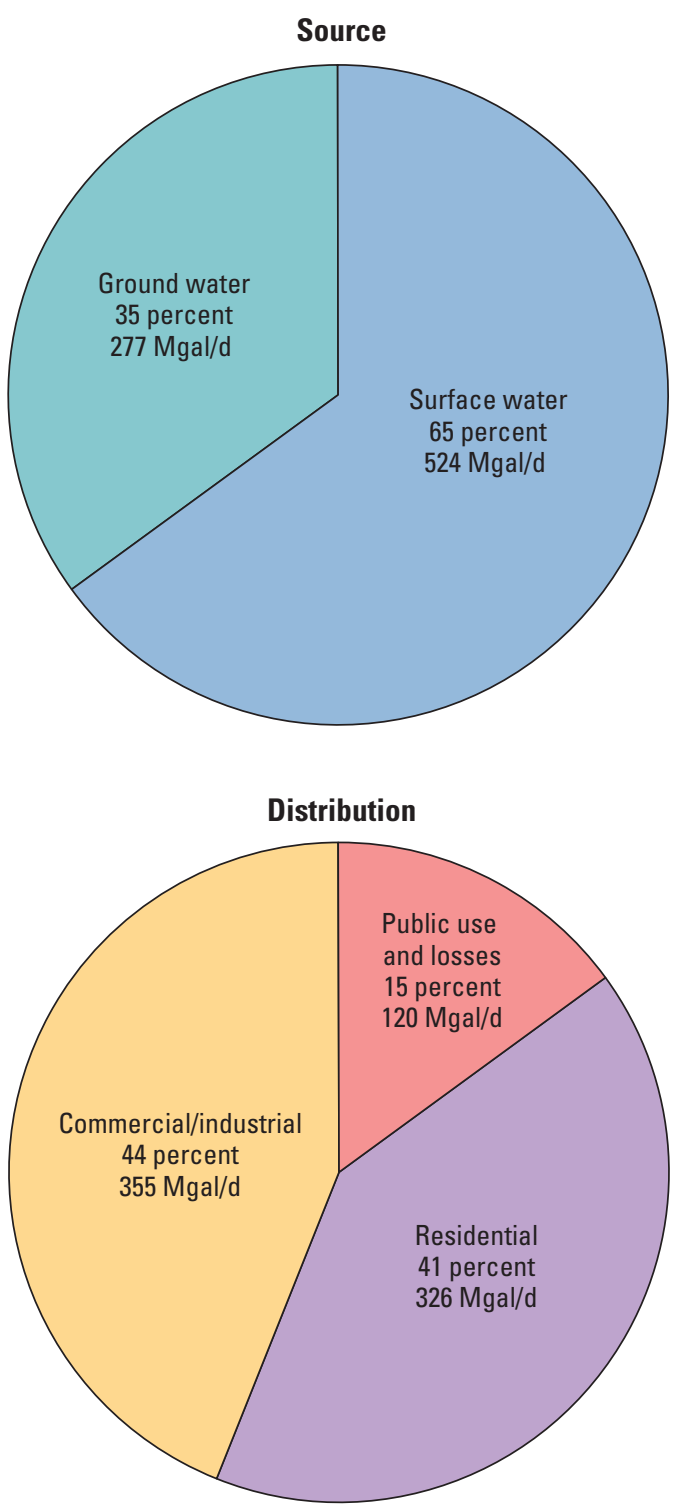

Figure 13. Source and distribution of public-supply water in Alabama, 2005. [Mgal/d, million gallons per day; values may not sum to total estimated use because of rounding] 


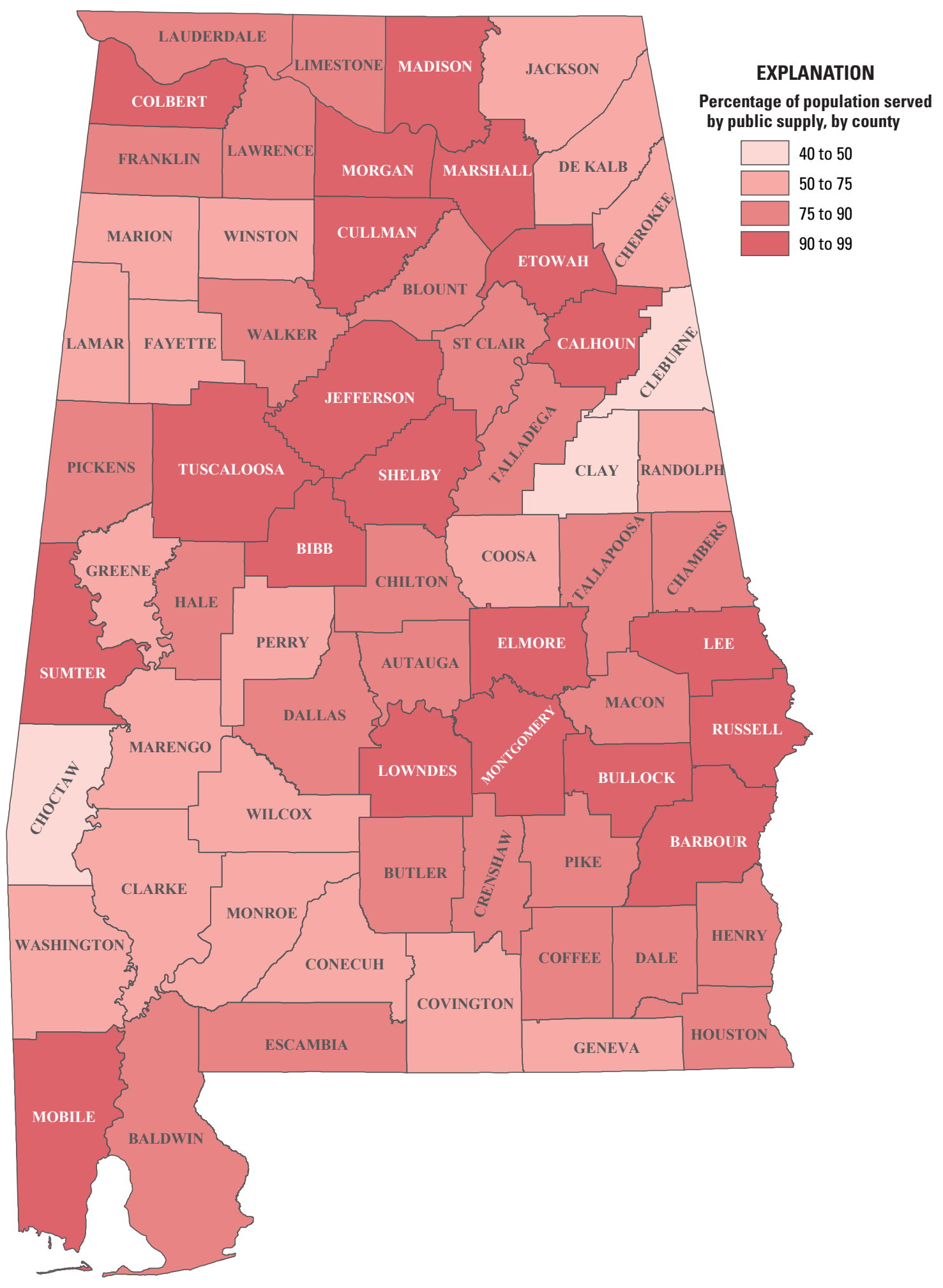

Figure 14. Percentage of population served by public suppliers in Alabama, 2005. 

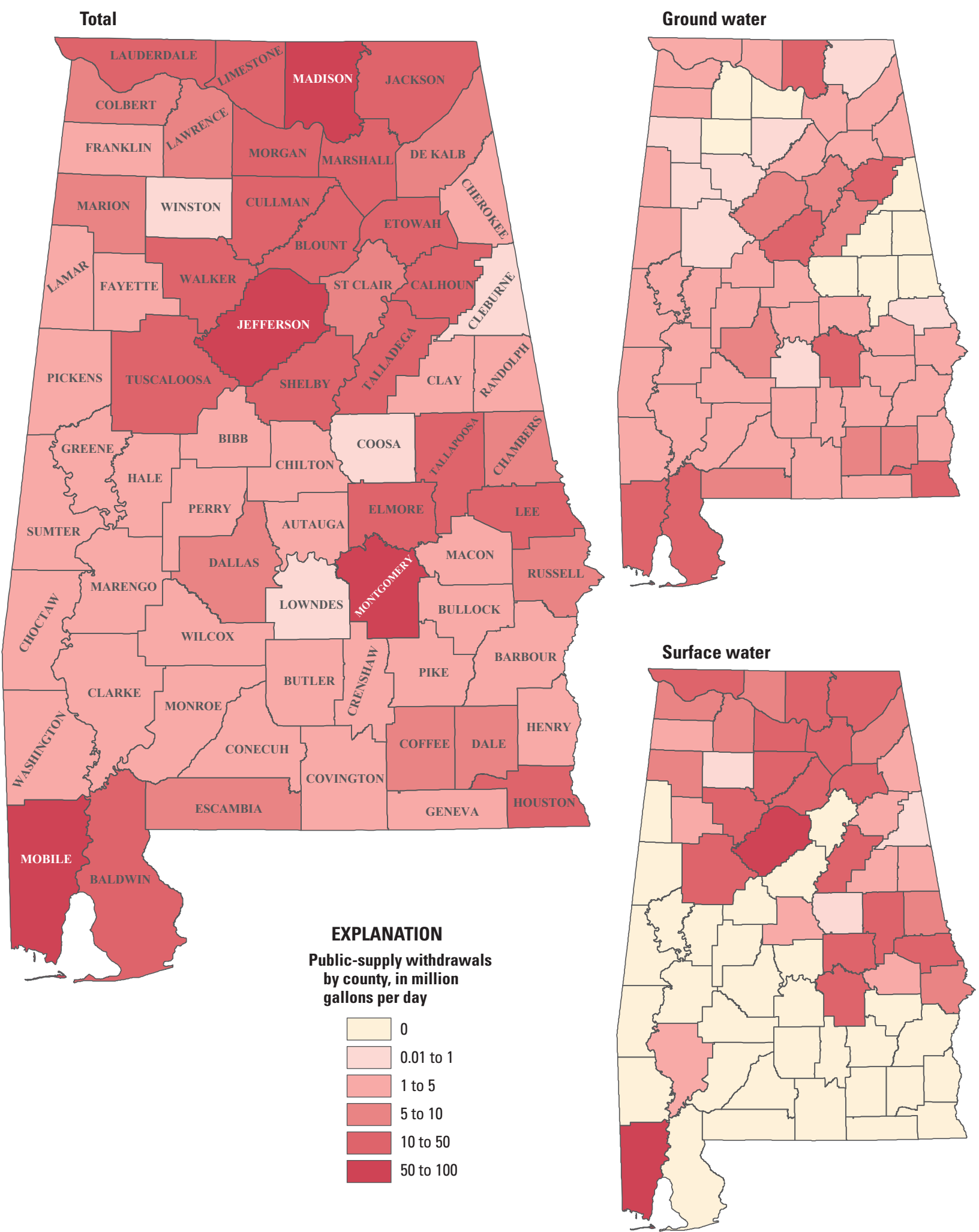

Figure 15. Public-supply withdrawals by source and county in Alabama, 2005. 
Table 11. Public-supply freshwater use by county, Alabama, 2005.

[Values may not sum to total estimated use(s) because of rounding]

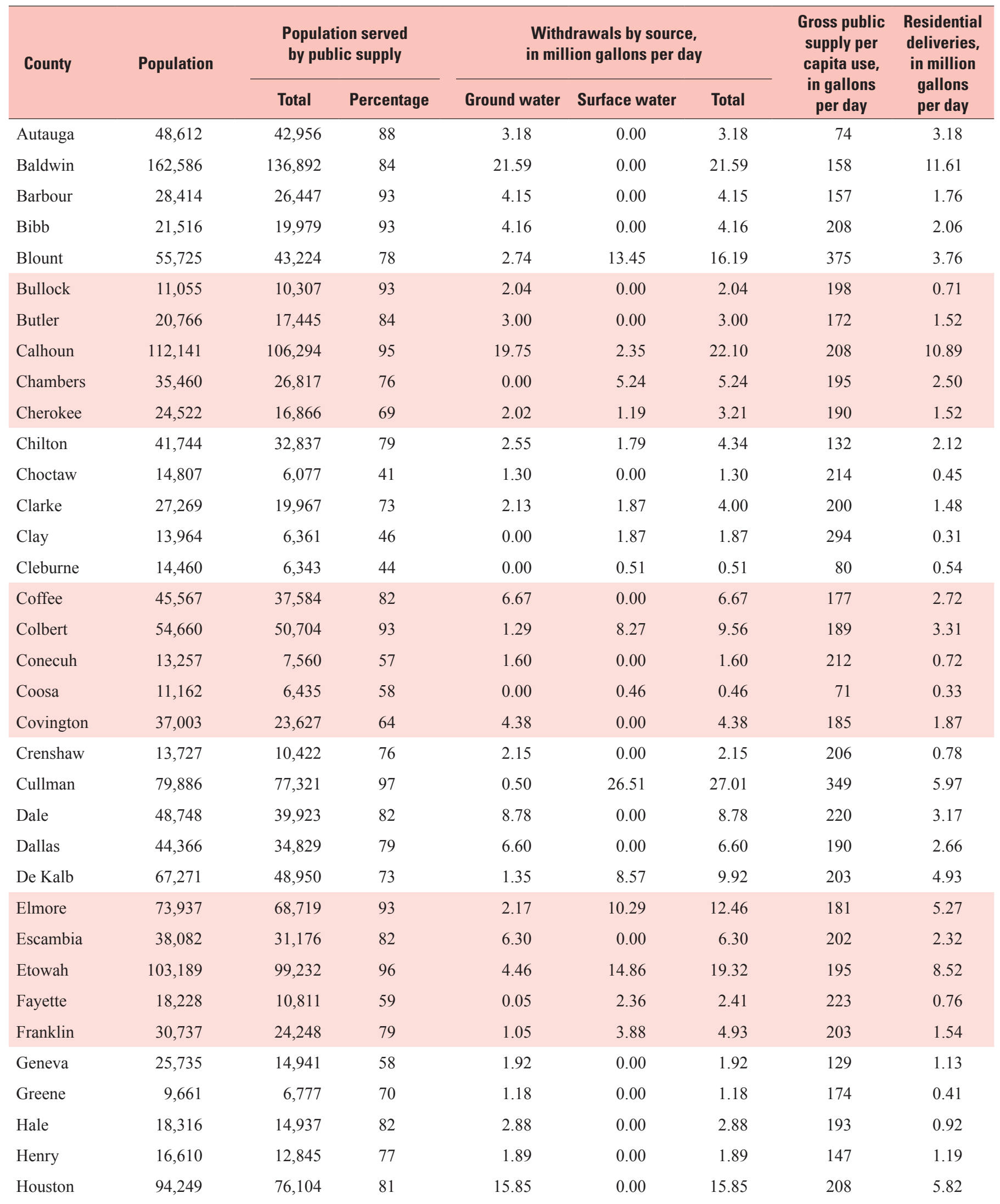


Table 11. Public-supply freshwater use by county, Alabama, 2005.-Continued

[Values may not sum to total estimated use(s) because of rounding]

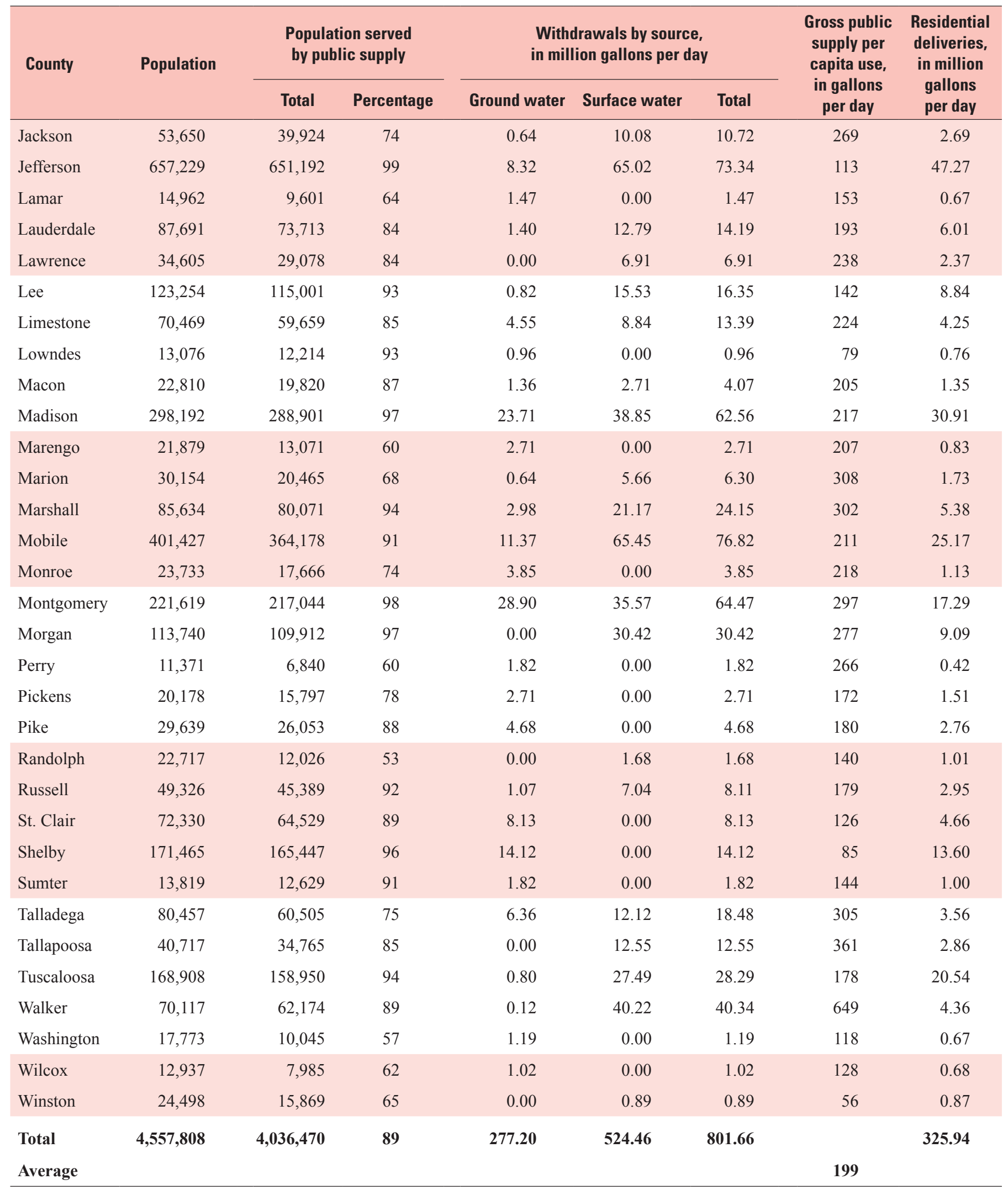


Table 12. Public-supply freshwater use by hydrologic subregion and subbasin, Alabama, 2005.

[Values may not sum to total estimated use(s) because of rounding]

\begin{tabular}{|c|c|c|c|c|}
\hline \multirow{2}{*}{$\begin{array}{l}\text { Hydrologic subregion } \\
\text { and subbasin }\end{array}$} & \multirow{2}{*}{$\begin{array}{c}\text { Total } \\
\text { population }\end{array}$} & \multicolumn{3}{|c|}{ Withdrawals by source, in million gallons per day } \\
\hline & & Ground water & Surface water & Total \\
\hline \multicolumn{5}{|l|}{ Apalachicola } \\
\hline 03130002 & 52,842 & 0.00 & 11.88 & 11.88 \\
\hline 03130003 & 95,496 & 3.45 & 7.04 & 10.49 \\
\hline 03130004 & 37,036 & 8.39 & 0.00 & 8.39 \\
\hline 03130012 & 24,348 & 1.64 & 0.00 & 1.64 \\
\hline Subtotal & 209,722 & 13.48 & 18.92 & 32.40 \\
\hline \multicolumn{5}{|c|}{ Choctawhatchee-Escambia } \\
\hline 03140103 & 19,015 & 1.06 & 0.00 & 1.06 \\
\hline 03140104 & 584 & 0.06 & 0.00 & 0.06 \\
\hline 03140106 & 34,750 & 4.06 & 0.00 & 4.06 \\
\hline 03140107 & 25,801 & 5.49 & 0.00 & 5.49 \\
\hline 03140201 & 146,125 & 23.42 & 0.00 & 23.42 \\
\hline 03140202 & 50,881 & 6.30 & 0.00 & 6.30 \\
\hline 03140203 & 6,195 & 0.52 & 0.00 & 0.52 \\
\hline 03140301 & 27,731 & 6.80 & 0.00 & 6.80 \\
\hline 03140302 & 13,291 & 1.60 & 0.00 & 1.60 \\
\hline 03140303 & 23,353 & 3.21 & 0.00 & 3.21 \\
\hline 03140304 & 26,655 & 3.81 & 0.00 & 3.81 \\
\hline 03140305 & 16,443 & 2.24 & 0.00 & 2.24 \\
\hline Subtotal & 390,824 & 58.57 & 0.00 & 58.57 \\
\hline \multicolumn{5}{|l|}{ Alabama } \\
\hline 03150105 & 41,579 & 2.02 & 2.12 & 4.14 \\
\hline 03150106 & 335,013 & 35.20 & 33.24 & 68.44 \\
\hline 03150107 & 123,826 & 4.21 & 10.96 & 15.17 \\
\hline 03150108 & 23,143 & 0.00 & 0.90 & 0.90 \\
\hline 03150109 & 68,184 & 0.00 & 19.09 & 19.09 \\
\hline 03150110 & 160,180 & 3.74 & 38.22 & 41.96 \\
\hline 03150201 & 322,442 & 42.16 & 10.40 & 52.56 \\
\hline 03150202 & 376,792 & 26.31 & 52.90 & 79.21 \\
\hline 03150203 & 30,670 & 2.92 & 0.00 & 2.92 \\
\hline 03150204 & 24,347 & 3.62 & 0.00 & 3.62 \\
\hline Subtotal & $1,506,176$ & 120.18 & 167.83 & 288.01 \\
\hline \multicolumn{5}{|l|}{ Mobile-Tombigbee } \\
\hline 03160101 & 3,832 & 0.23 & 0.00 & 0.23 \\
\hline 03160103 & 23,300 & 0.55 & 2.01 & 2.56 \\
\hline 03160105 & 19,232 & 1.46 & 2.46 & 3.92 \\
\hline
\end{tabular}


Table 12. Public-supply freshwater use by hydrologic subregion and subbasin, Alabama, 2005._-Continued

[Values may not sum to total estimated use(s) because of rounding]

\begin{tabular}{|c|c|c|c|c|}
\hline \multirow{2}{*}{$\begin{array}{l}\text { Hydrologic subregion } \\
\text { and subbasin }\end{array}$} & \multirow{2}{*}{$\begin{array}{c}\text { Total } \\
\text { population }\end{array}$} & \multicolumn{3}{|c|}{ Withdrawals by source, in million gallons per day } \\
\hline & & Ground water & Surface water & Total \\
\hline \multicolumn{5}{|c|}{ Mobile-Tombigbee (Continued) } \\
\hline 03160106 & 28,333 & 3.94 & 0.00 & 3.94 \\
\hline 03160107 & 16,506 & 0.55 & 0.00 & 0.55 \\
\hline 03160108 & 949 & 0.22 & 0.00 & 0.22 \\
\hline 03160109 & 132,396 & 0.52 & 53.96 & 54.48 \\
\hline 03160110 & 51,869 & 0.00 & 14.87 & 14.87 \\
\hline 03160111 & 329,844 & 3.32 & 12.24 & 15.56 \\
\hline 03160112 & 280,509 & 0.44 & 39.99 & 40.43 \\
\hline 03160113 & 101,984 & 5.49 & 0.00 & 5.49 \\
\hline 03160201 & 36,189 & 3.53 & 0.00 & 3.53 \\
\hline 03160202 & 7,296 & 0.00 & 0.00 & 0.00 \\
\hline 03160203 & 37,199 & 3.21 & 1.87 & 5.08 \\
\hline 03160204 & 195,350 & 8.24 & 0.48 & 8.72 \\
\hline 03160205 & 234,104 & 13.85 & 0.00 & 13.85 \\
\hline Subtotal & $1,498,892$ & 45.55 & 127.88 & 173.43 \\
\hline \multicolumn{5}{|l|}{ Pascagoula } \\
\hline 03170002 & 0 & 0.00 & 0.00 & 0.00 \\
\hline 03170003 & 0 & 0.00 & 0.00 & 0.00 \\
\hline 03170008 & 64,253 & 2.68 & 64.97 & 67.65 \\
\hline 03170009 & 14,406 & 0.62 & 0.00 & 0.62 \\
\hline Subtotal & 78,659 & 3.30 & 64.97 & 68.27 \\
\hline \multicolumn{5}{|c|}{ Middle Tennessee-Hiwassee } \\
\hline 06020001 & 2,482 & 0.66 & 0.00 & 0.66 \\
\hline Subtotal & 2,482 & 0.66 & 0.00 & 0.66 \\
\hline \multicolumn{5}{|l|}{ Middle Tennessee-Elk } \\
\hline 06030001 & 139,796 & 3.66 & 31.72 & 35.38 \\
\hline 06030002 & 513,383 & 28.87 & 74.26 & 103.13 \\
\hline 06030003 & 0 & 0.00 & 0.00 & 0.00 \\
\hline 06030004 & 16,750 & 0.00 & 8.84 & 8.84 \\
\hline 06030005 & 152,863 & 2.09 & 22.98 & 25.07 \\
\hline 06030006 & 33,623 & 0.82 & 7.05 & 7.87 \\
\hline Subtotal & 856,415 & 35.44 & 144.85 & 180.29 \\
\hline Total & $4,543,170$ & 277.18 & 524.45 & 801.63 \\
\hline
\end{tabular}




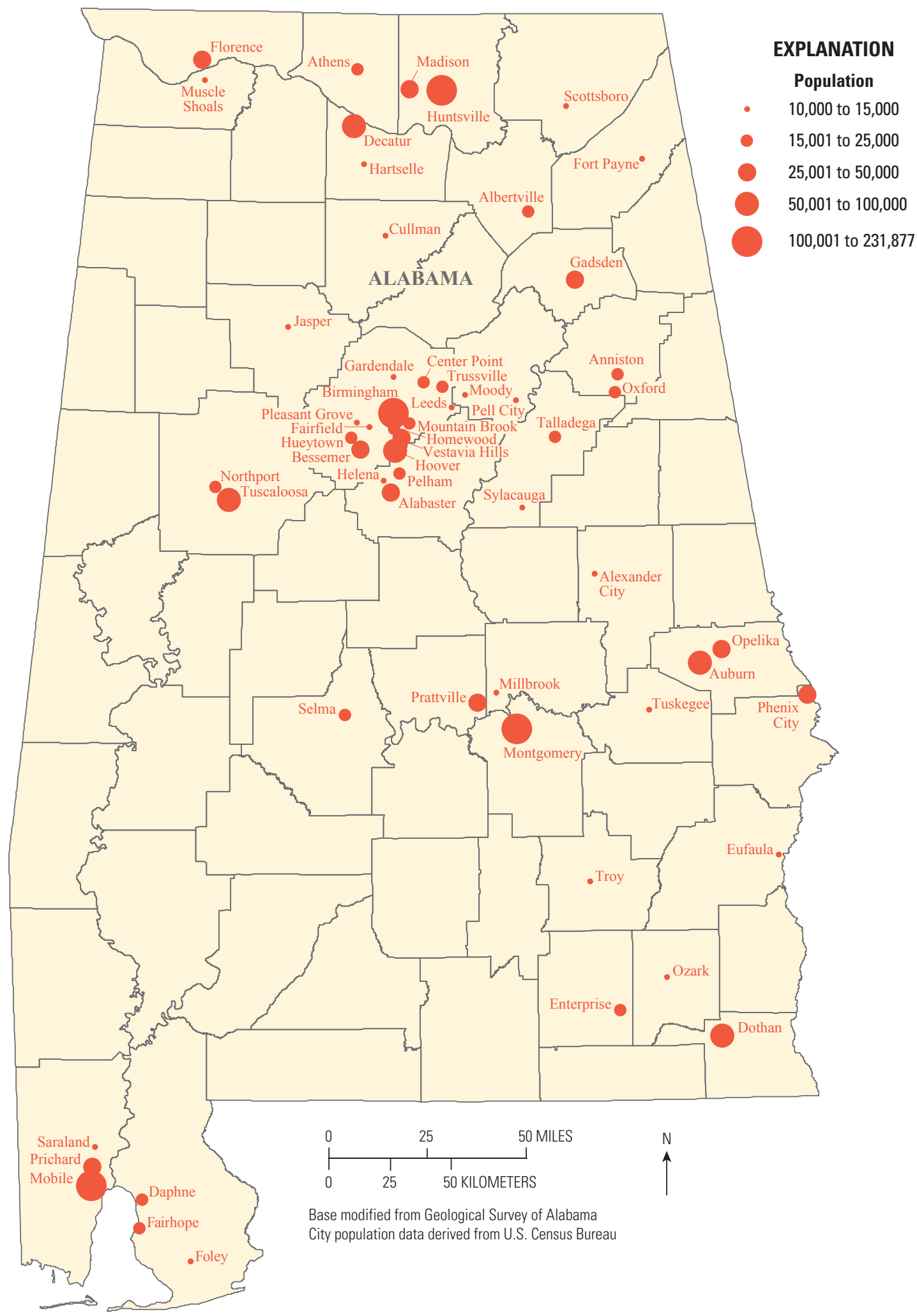

Figure 16. Alabama cities with populations of 10,000 and greater, 2005 . 
The rank and associated cumulative percentile of total public-supply withdrawals by county are shown in figure 17 . Mobile, Jefferson, Montgomery, and Madison Counties accounted for 35 percent of the public-supply withdrawals (table 11; figs. 15 and 17). The remaining 63 counties accounted for the remaining 65 percent of the public-supply withdrawals. For comparison purposes, shading in the choropleth map ranges in figure 15 corresponds to shading in the cumulative percentile ranges in figure 17.

The geographic distribution of the total, ground-water, and surface-water withdrawals for public supply by hydrologic subbasin is shown in figure 18. The rank and associated cumulative percentile of total public-supply withdrawals by subbasin are shown in figure 19. The Wheeler Lake (06030002, in the Middle Tennessee-Elk subregion, City of Huntsville), Cahaba (03150202, in the Alabama subregion, metropolitan Birmingham), Middle Coosa (03150106, in the Alabama subregion, Cities of Talladega and Anniston), Escatawpa (03170008, in the Pascagoula subregion, source of water for City of Mobile), Mulberry Fork (03160109, in the Mobile-Tombigbee subregion, Cities of Jasper and Cullman), and the Upper Alabama (03150201, in the Alabama subregion, Cities of Montgomery and Prattville) subbasins accounted for 53 percent of the public-supply withdrawals, and the remaining 47 subbasins accounted for the other 47 percent (table 12; figs. 18 and 19). Similar to figures 15 and 17 , the choropleth map shading in figure 18 corresponds to the percentile shading in figure 19.

Several sources of data were used to estimate publicsupply withdrawals, deliveries, and population served. A comprehensive list of public-suppliers was compiled from records from Alabama OWR, DWB-ADEM, ARWA, and USEPA-SDWIS. The primary sources for water withdrawals and public-supply deliveries were Alabama OWR and DWB-ADEM. Population served was estimated from U.S. Census estimates of population for 1990 and 2005, the number of housing units in 1990, and percentage of housing units on public supply in 1990. Details are in the "Public-Supply and Residential Water Use" and "Population Served and Self-Supplied Residential Population" sections in the "Data Compilation, Sources of Information, and Methodology" section in this report.

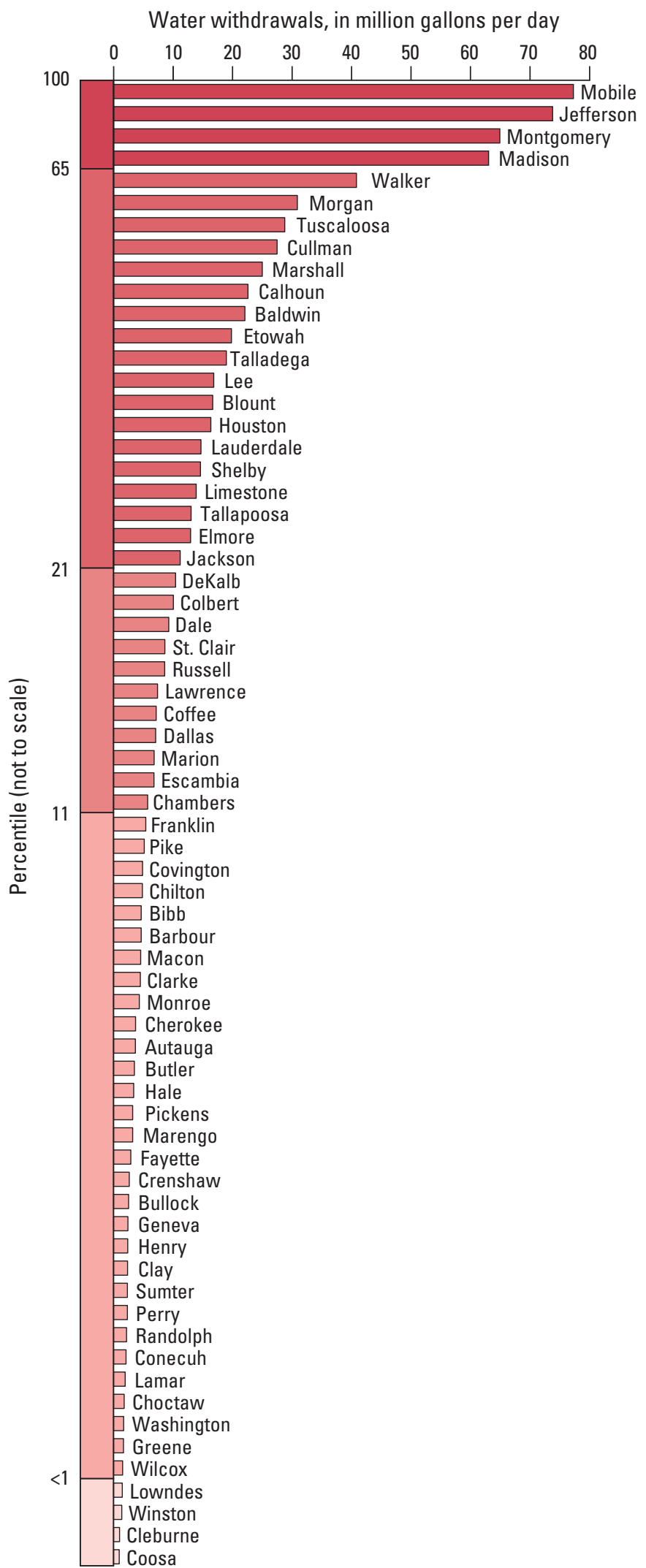

Figure 17. Public-supply water withdrawals by rank and percentile for counties in Alabama, 2005. 

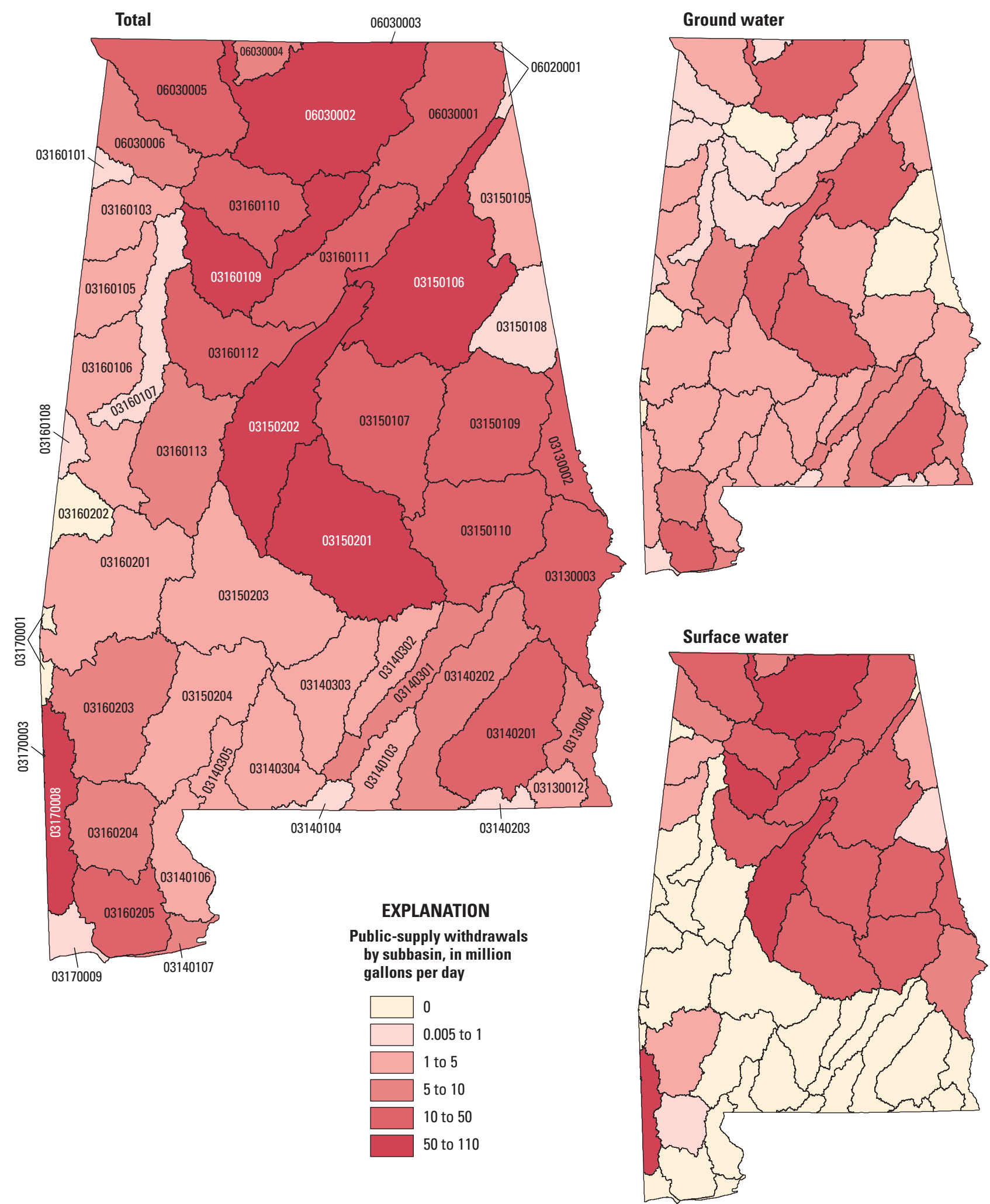

Figure 18. Public-supply withdrawals by source and hydrologic subbasin in Alabama, 2005. 


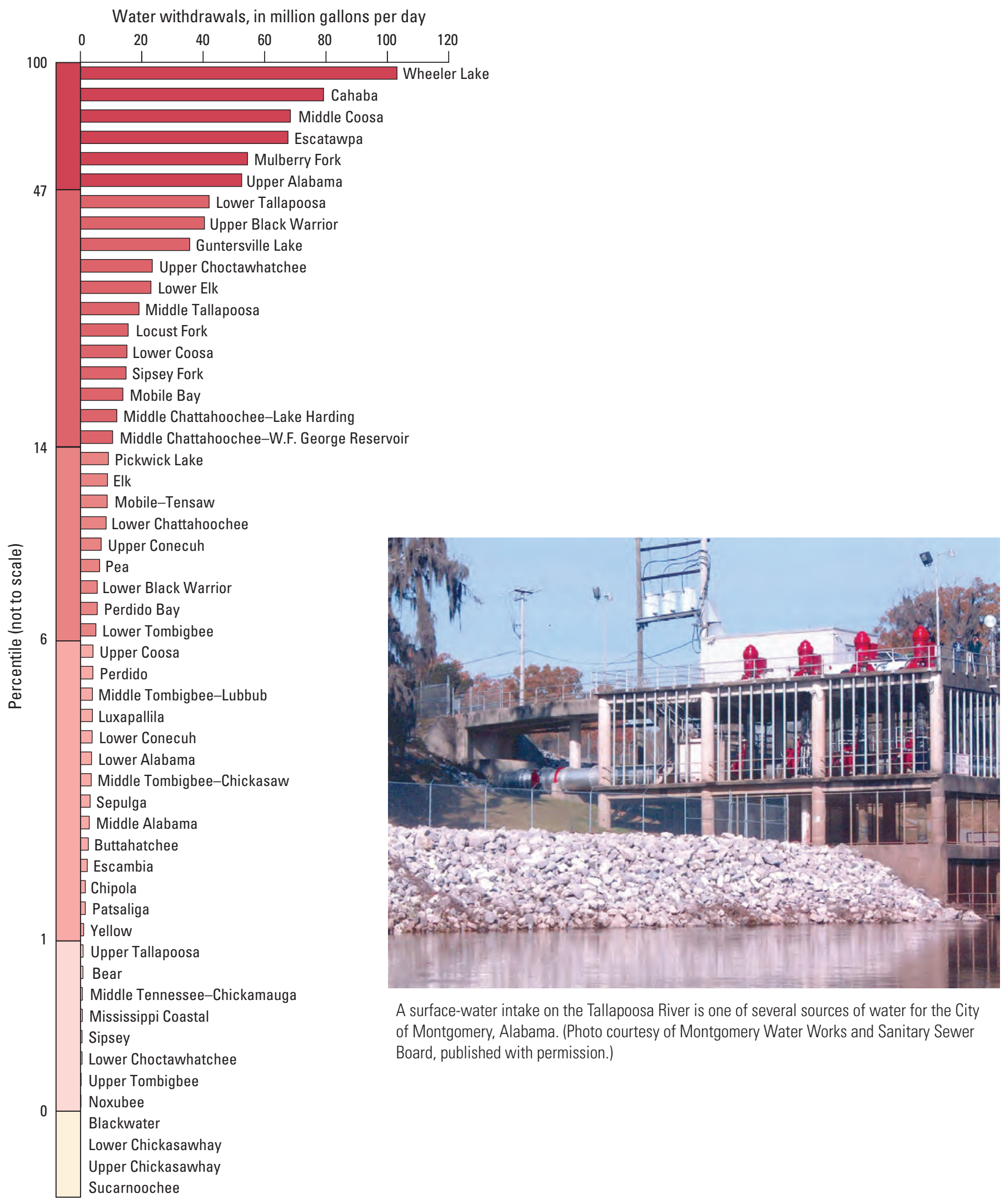

Figure 19. Public-supply water withdrawals by rank and percentile for subbasins in Alabama, 2005. 


\section{Residential}

Residential water refers to the water that is used for all indoor household purposes, such as drinking, preparing food, bathing, washing clothes and dishes, and flushing toilets, and outdoor purposes, such as watering lawns and gardens. Residential water use is defined in this report as public-supplied residential deliveries plus self-supplied residential withdrawals.

Public-supplied residential deliveries and self-supplied residential water withdrawals were $365 \mathrm{Mgal} / \mathrm{d}$ in 2005 (table 13). Public suppliers delivered 89 percent, or $326 \mathrm{Mgal} / \mathrm{d}$, of residential water. The remaining $39 \mathrm{Mgal} / \mathrm{d}$ of residential water was self-supplied from ground water. Self-supplied residential withdrawals were less than 1 percent of the total water withdrawals and about 2 percent of the withdrawals for all categories except thermoelectric power (table 5). About 11 percent of the population (or 521,338 people) relied on private wells for their drinking water.

The geographic distribution of ground-water withdrawals for self-supplied residential use, self-supplied residential population as a percentage of the total State population, and self-supplied residential population by county is shown in figures 20 and 21, respectively. The largest aggregated selfsupplied residential withdrawals were in Mobile and Baldwin Counties. These two counties represented about 14 percent of the total self-supplied residential withdrawals and 12 percent of the self-supplied residential population. Although Mobile
County had the largest number of people $(37,249)$ with private wells, that number represented only about 9 percent of the population of that county. Conversely, although a much smaller population in Choctaw County relied on private wells ( 8,730 people), this number represented about 59 percent of the county population - a much higher percentage than Mobile County.

Residential per capita use - public-supplied residential deliveries plus self-supplied residential withdrawals divided by the total population-was $80 \mathrm{gal} / \mathrm{d}$. Public-supplied residential per capita use-public-supplied residential deliveries divided by population served - was $81 \mathrm{gal} / \mathrm{d}$ and ranged from $49 \mathrm{gal} / \mathrm{d}$ for Clay County to $129 \mathrm{gal} / \mathrm{d}$ for Tuscaloosa County. Counties with small gallons per capita per day uses, such as Clay, Coosa, and Winston Counties, tended to be predominantly rural. Counties such as Tuscaloosa and Madison with greater gallons per capita per day use tended to be associated with urban and suburban areas. Self-supplied residential per capita use - self-supplied residential withdrawals divided by self-supplied residential population was $-75 \mathrm{gal} / \mathrm{d}$.

The sources of information and methodology for estimating public-supply residential deliveries, population served by public suppliers, self-supplied residential withdrawals, and self-supplied population are detailed in the "Public supply and Residential Water Use" and "Population Served and Self-Supplied Residential Population" sections in the "Data Compilation, Sources of Information, and Methodology" section of this report.

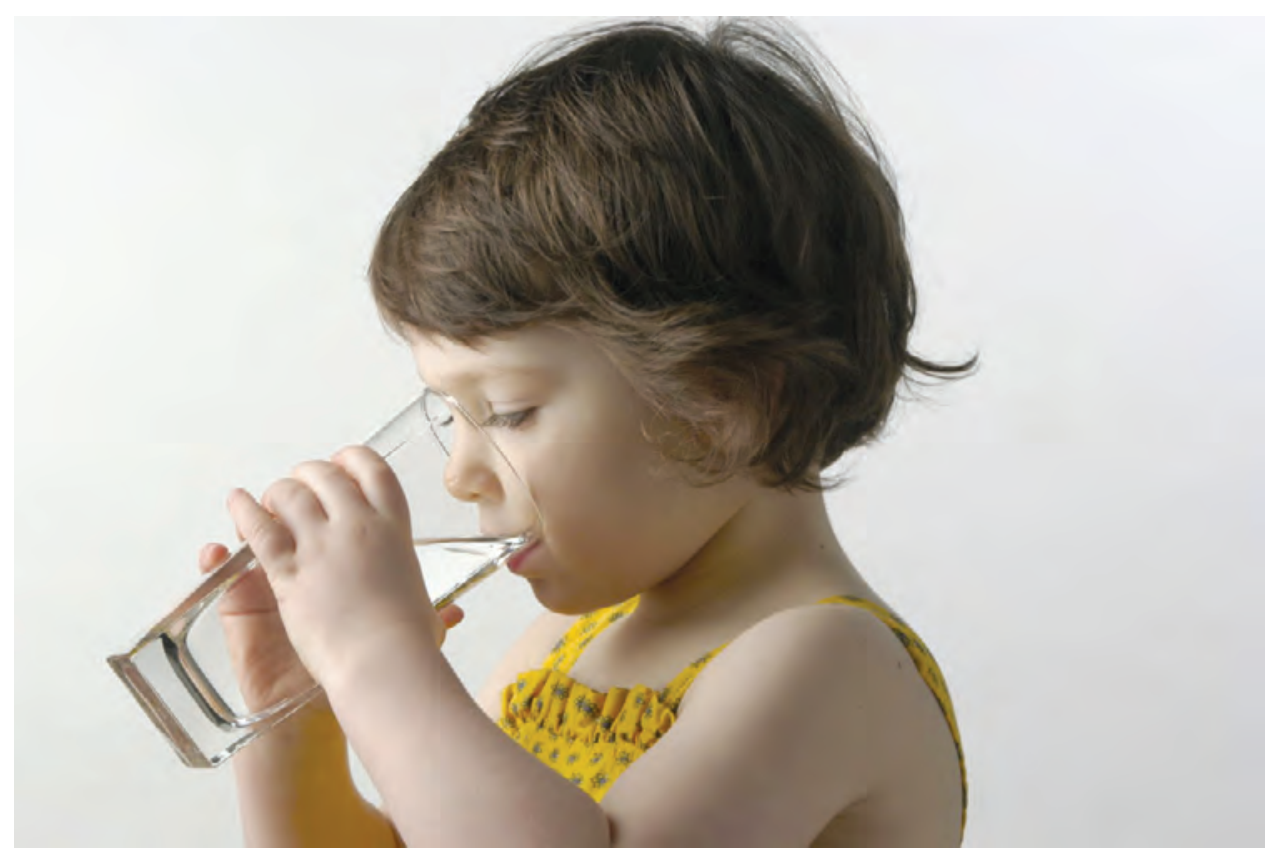

Public suppliers and private wells provide plentiful water to the residents and visitors of Alabama. (Photo courtesy of Glenn Phillips, published with permission.) 


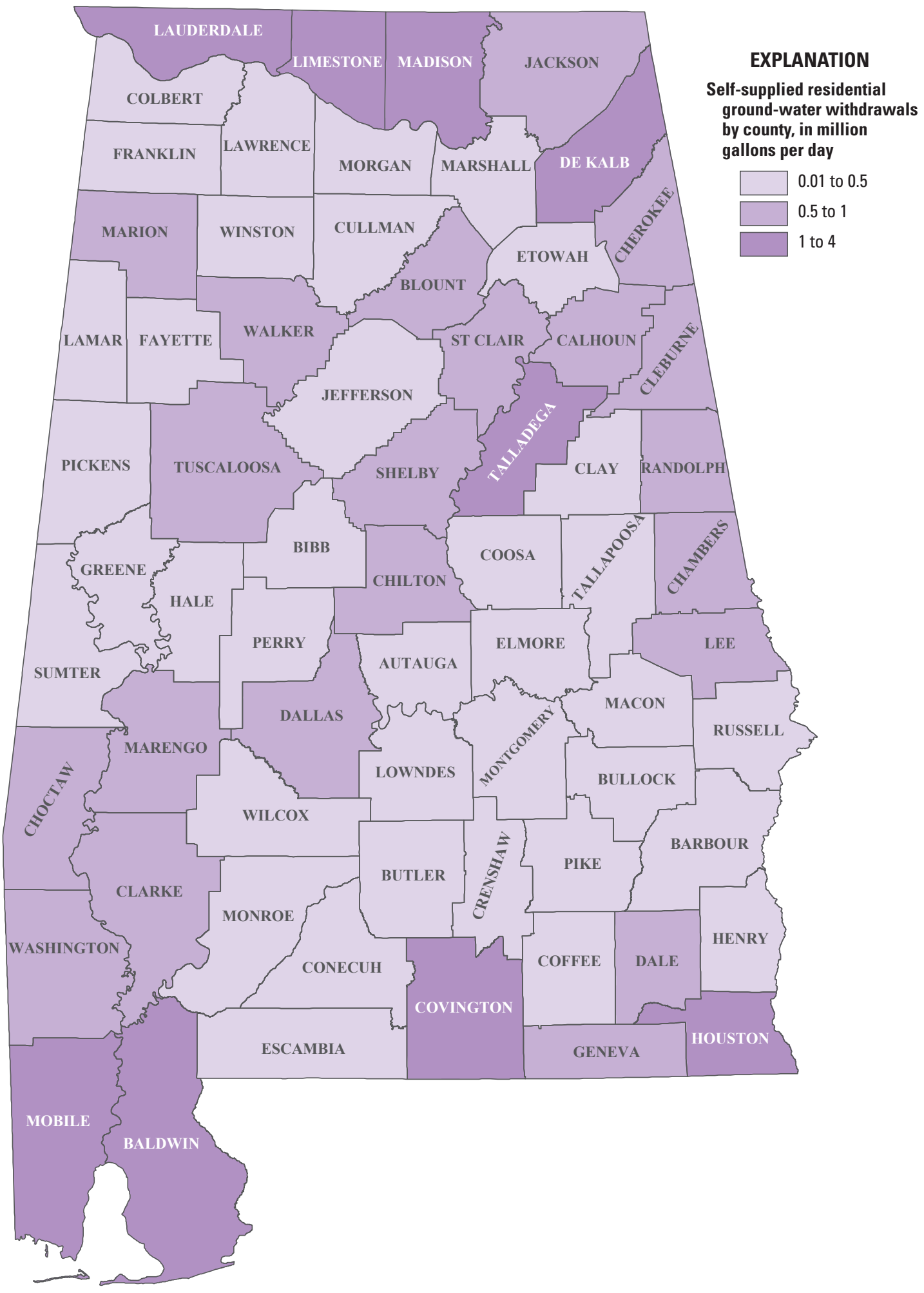

Figure 20. Self-supplied residential ground-water withdrawals by county in Alabama, 2005. 
Table 13. Residential freshwater use by county, Alabama, 2005.

[Values may not sum to total estimated use(s) because of rounding]

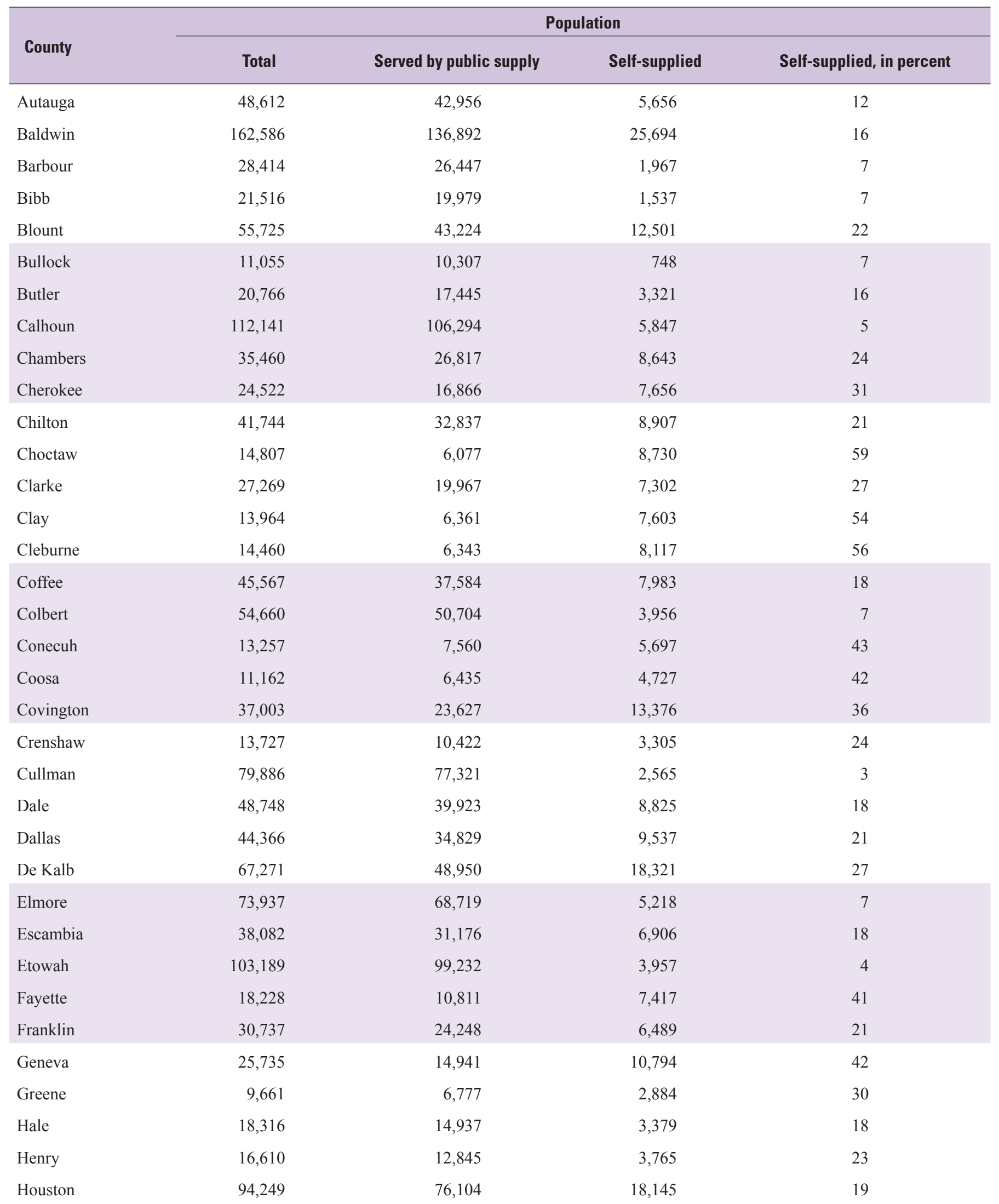


Table 13. Residential freshwater use by county, Alabama, 2005.-Continued

[Values may not sum to total estimated use(s) because of rounding]

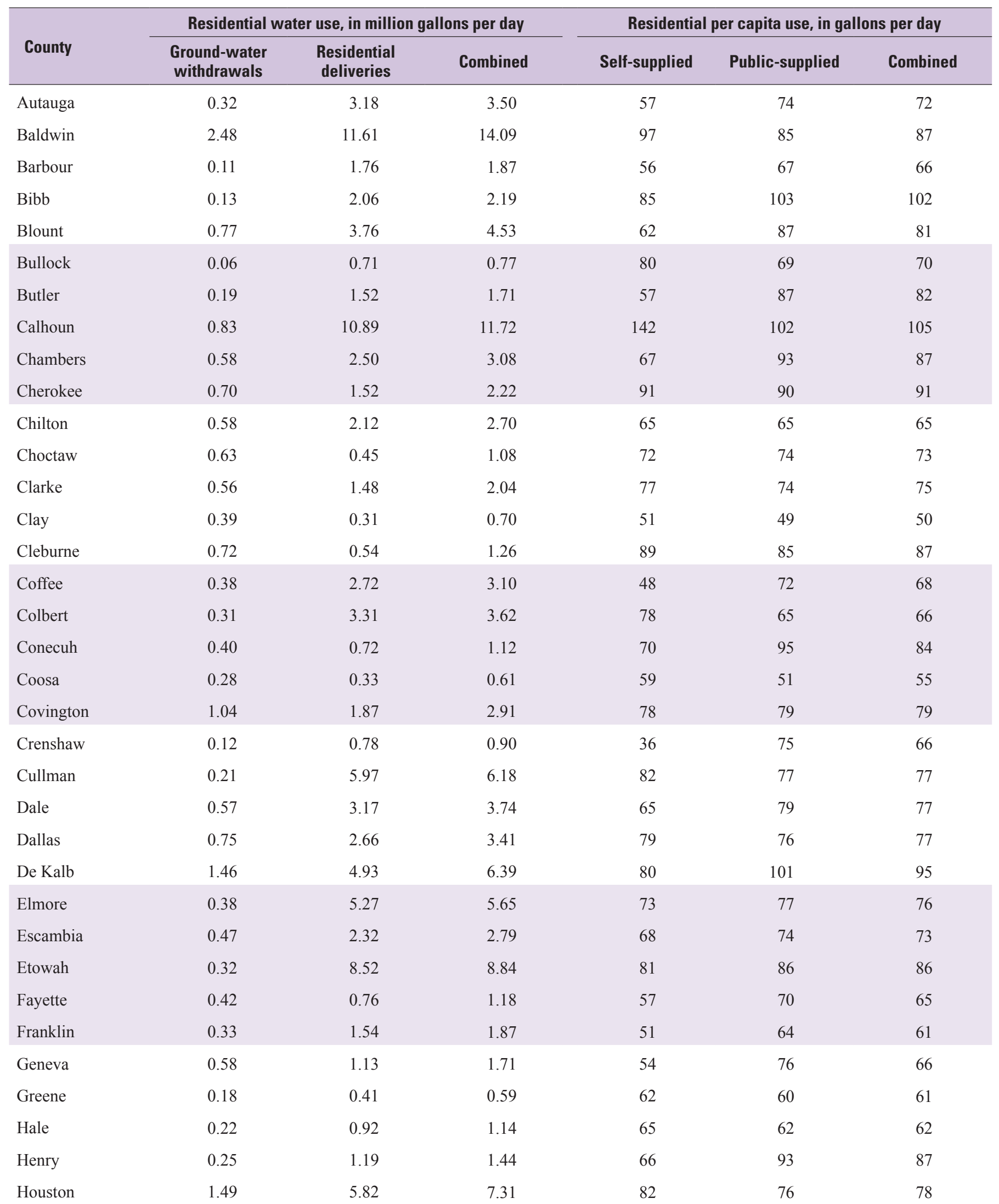


Table 13. Residential freshwater use by county, Alabama, 2005.-Continued

[Values may not sum to total estimated use(s) because of rounding]

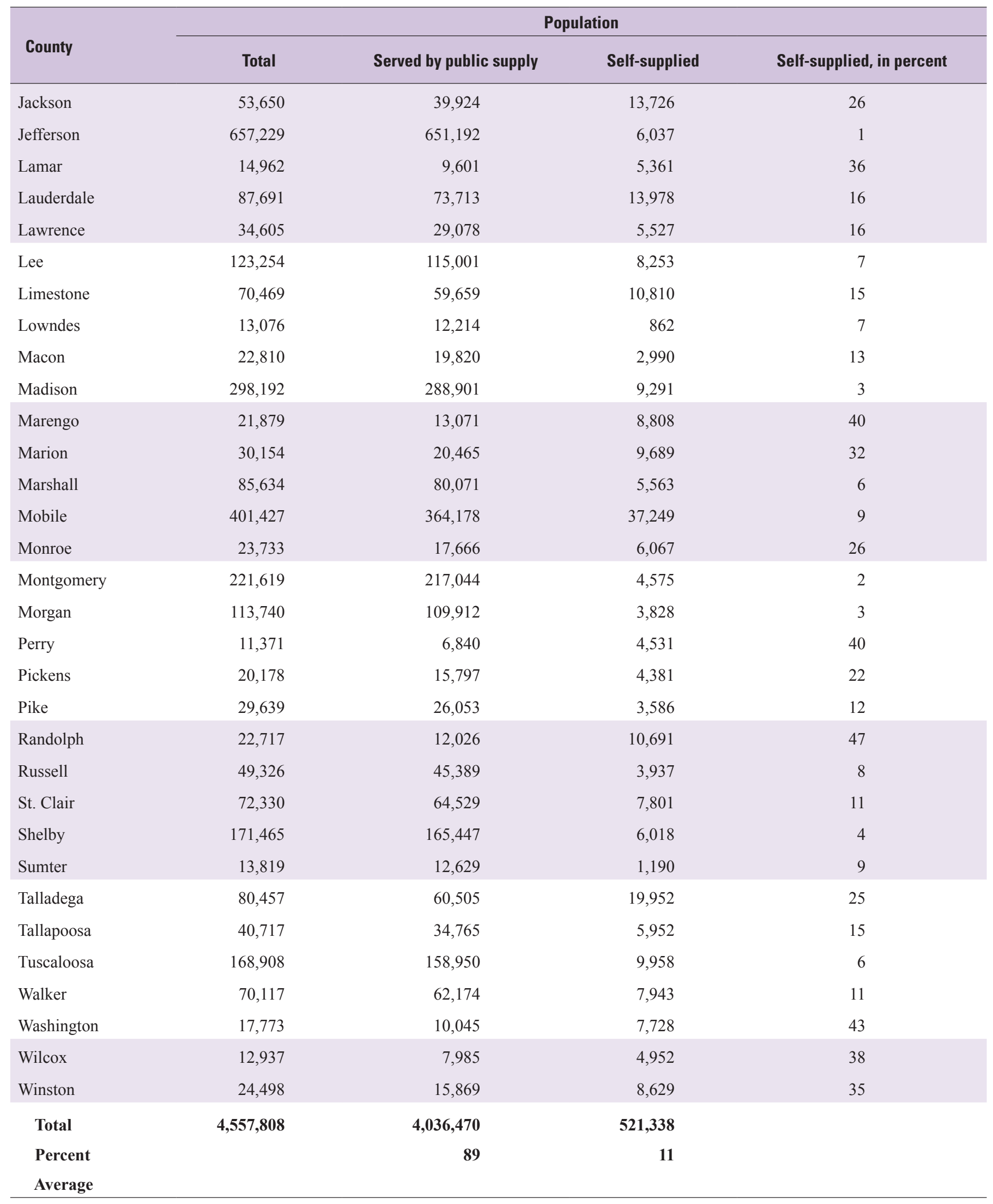


Table 13. Residential freshwater use by county, Alabama, 2005.-Continued

[Values may not sum to total estimated use(s) because of rounding]

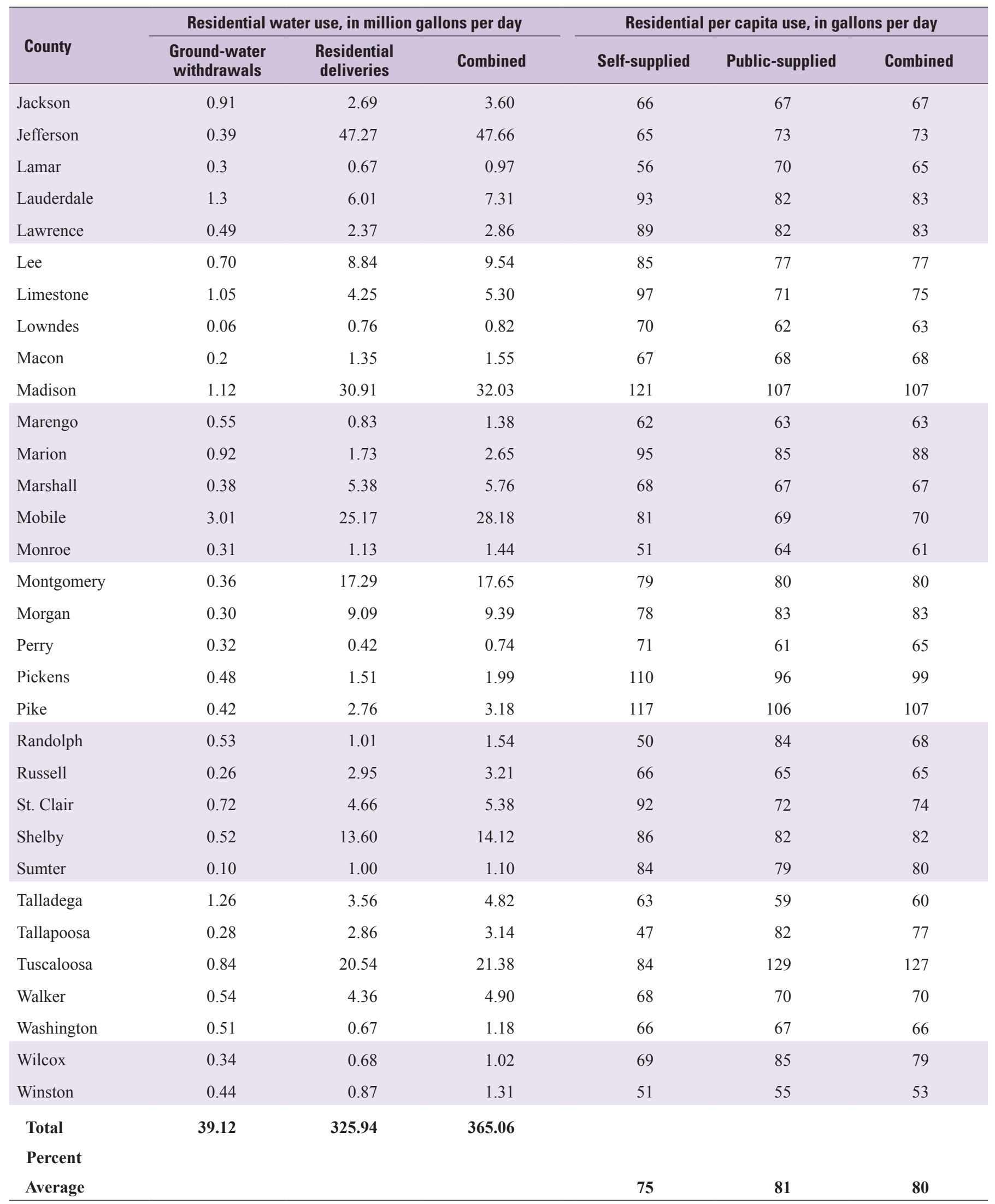



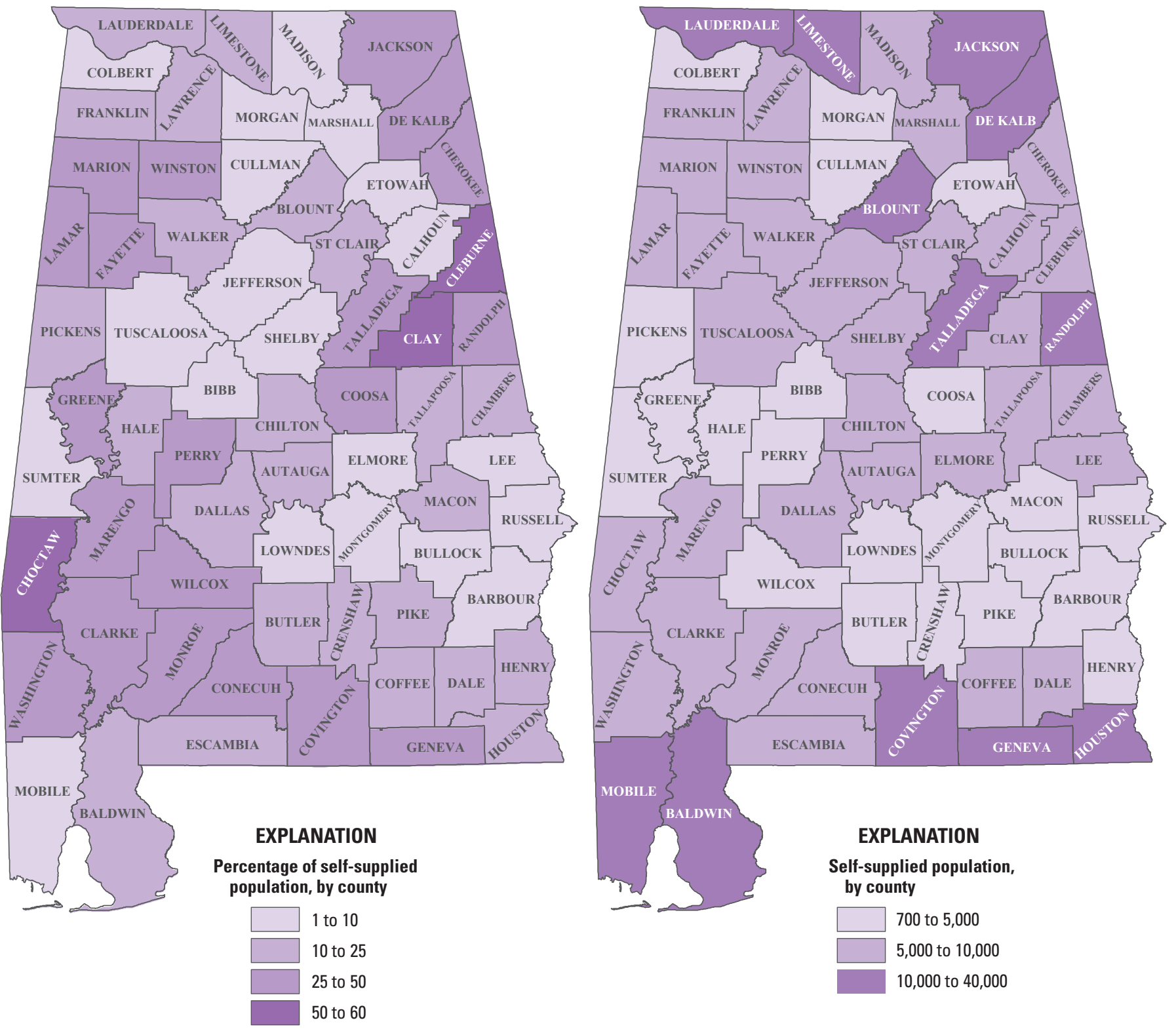

Self-supplied population, by county
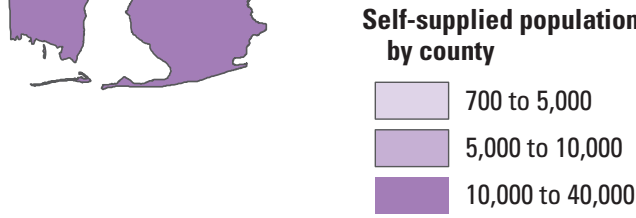

Figure 21. Self-supplied residential population as a percentage of total population and self-supplied residential population by county in Alabama, 2005. 


\section{Irrigation}

Irrigation water refers to water that is applied by an irrigation system to assist in the growing of crops and pastures or to maintain vegetative growth in recreational lands such as parks and golf courses. Irrigation includes water that is applied for pre-irrigation, frost protection, chemical application, weed control, field preparation, crop cooling, harvesting, dust suppression, the leaching of salts from the root zone, and water lost in conveyance. Conveyance loss was not reported for 2005. Although annual water-use data are expressed in terms of million gallons per day, irrigation water is applied, generally, only during part of each year and at variable rates; therefore, the actual rate of application during the growing season would be more than the daily rate expressed as million gallons per day.

Irrigation withdrawals and irrigated acres by irrigation system by county and subbasin are shown, respectively in tables 14 and 15. For 2005, total withdrawals were $161 \mathrm{Mgal} / \mathrm{d}$. Irrigation withdrawals were about 2 percent of total withdrawals and about 10 percent of total withdrawals for all categories excluding thermoelectric power (table 5). Of the total irrigation withdrawals, 54 percent, or $87 \mathrm{Mgal} / \mathrm{d}$, was from surface water, and the remaining 46 percent, or $74 \mathrm{Mgal} / \mathrm{d}$, was from ground water (fig. 22). Consumptive use was estimated to be 100 percent. About 135,800 acres were irrigated in 2005. Of this total acreage, about 97 percent, or 132,380 acres, was irrigated with sprinkler irrigation systems; more than 2 percent, or 3,250 acres, was irrigated with microirrigation systems; and less than 1 percent, or 170 acres, was irrigated with surface irrigation systems. Average application rates were calculated by dividing total irrigation withdrawals - determined separately for crops, (crops, nursery stock, and sod) and golf courses - for each county by the number of acres. The statewide average application rate was 1.33 acre-feet per acre per year. The highest application rate was for nursery stock, 3.74 acre-feet per acre per year.

The geographic distribution of total, ground-water, and surface-water withdrawals for irrigation by county and by hydrologic subbasin is shown respectively in figures 23 and 24. Nearly half of the counties (32 counties) withdrew less than $1 \mathrm{Mgal} / \mathrm{d}$ for irrigation. Baldwin County withdrew 27 percent ( $44 \mathrm{Mgal} / \mathrm{d}$ ) of the irrigation water and most of the water $(37 \mathrm{Mgal} / \mathrm{d}$ ) was from ground-water sources (table 14). Six counties (total $79 \mathrm{Mgal} / \mathrm{d}$ ) each withdrew more than $5 \mathrm{Mgal} / \mathrm{d}$, and as a group, withdrew nearly half of the irrigation total for the State. The Perdido subbasin (03140106, in the Choctawhatchee-Escambia subregion), which includes Baldwin County, withdrew the most water for irrigationabout 9 percent of the total. Five subbasins, each withdrawing $10.0 \mathrm{Mgal} / \mathrm{d}$ or more, accounted for about 37 percent of the estimated withdrawals (table 15).

About 33 percent $(43,970$ acres $)$ of the total irrigated acreage (135,800 acres), and about 37 percent of total crop irrigated acreage (40,280 acres of the 109,080 acres) were in Baldwin (primarily nursery stock and sod), Houston (primarily
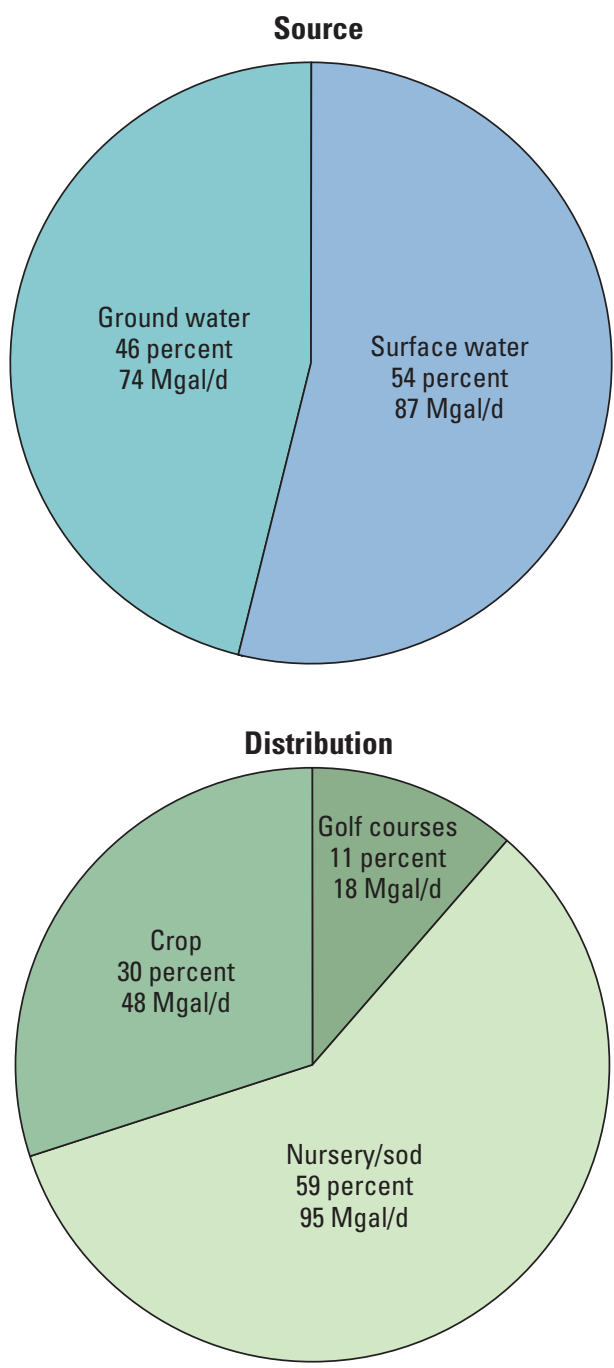

Figure 22. Source and distribution of water for irrigation use in Alabama, 2005. [Mgal/d, million gallons per day; values may not sum to total estimated use because of rounding]

cotton, peanuts, and vegetables), Limestone (primarily corn, cotton, nursery stock, and sod), and Geneva (primarily corn, cotton, and peanuts) Counties (U.S. Department of Agriculture, National Agricultural Statistics Service, 2004a; table 16). One half (median) of the counties statewide irrigated 640 acres or less. The range in acreage was from 80 acres in Coosa County to 16,400 acres in Baldwin County in 2005.

Nursery stock and sod are important to the agricultural economy of the State and in 2005 were the top commodity for cash receipts for crops and ranked third for overall farm commodities (U.S. Department of Agriculture, National Agricultural Statistics Service, 2006a). In 2005, nursery stock and sod accounted for 29 percent $(31,633$ acres) of the crop acreage statewide. About 39 percent of that acreage was in Baldwin County. In comparison to most crops in the State, all of the commercial nursery and sod and golf course acreages were irrigated; these businesses were located in nearly every county in Alabama. 


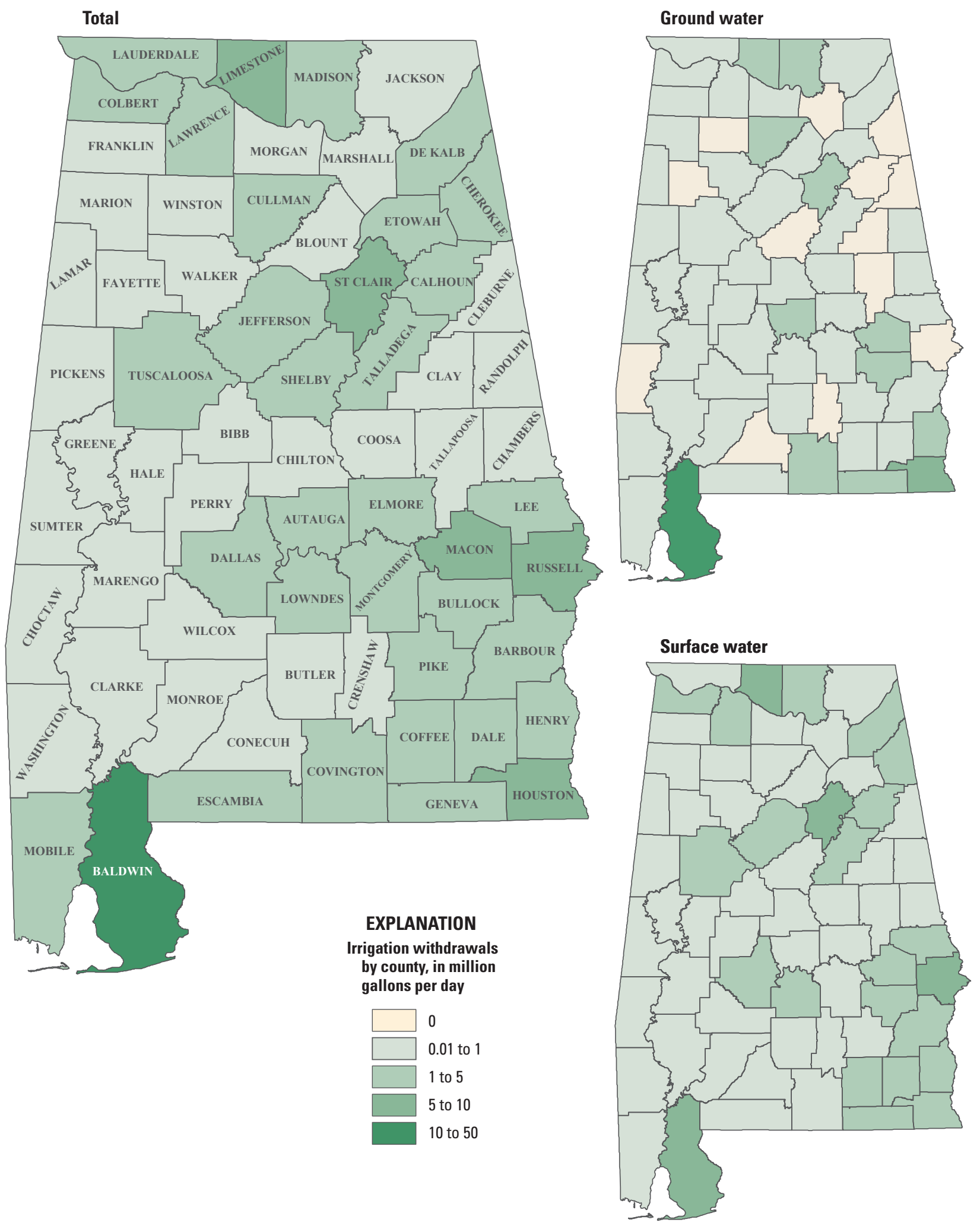

Figure 23. Irrigation withdrawals by source and county in Alabama, 2005. 

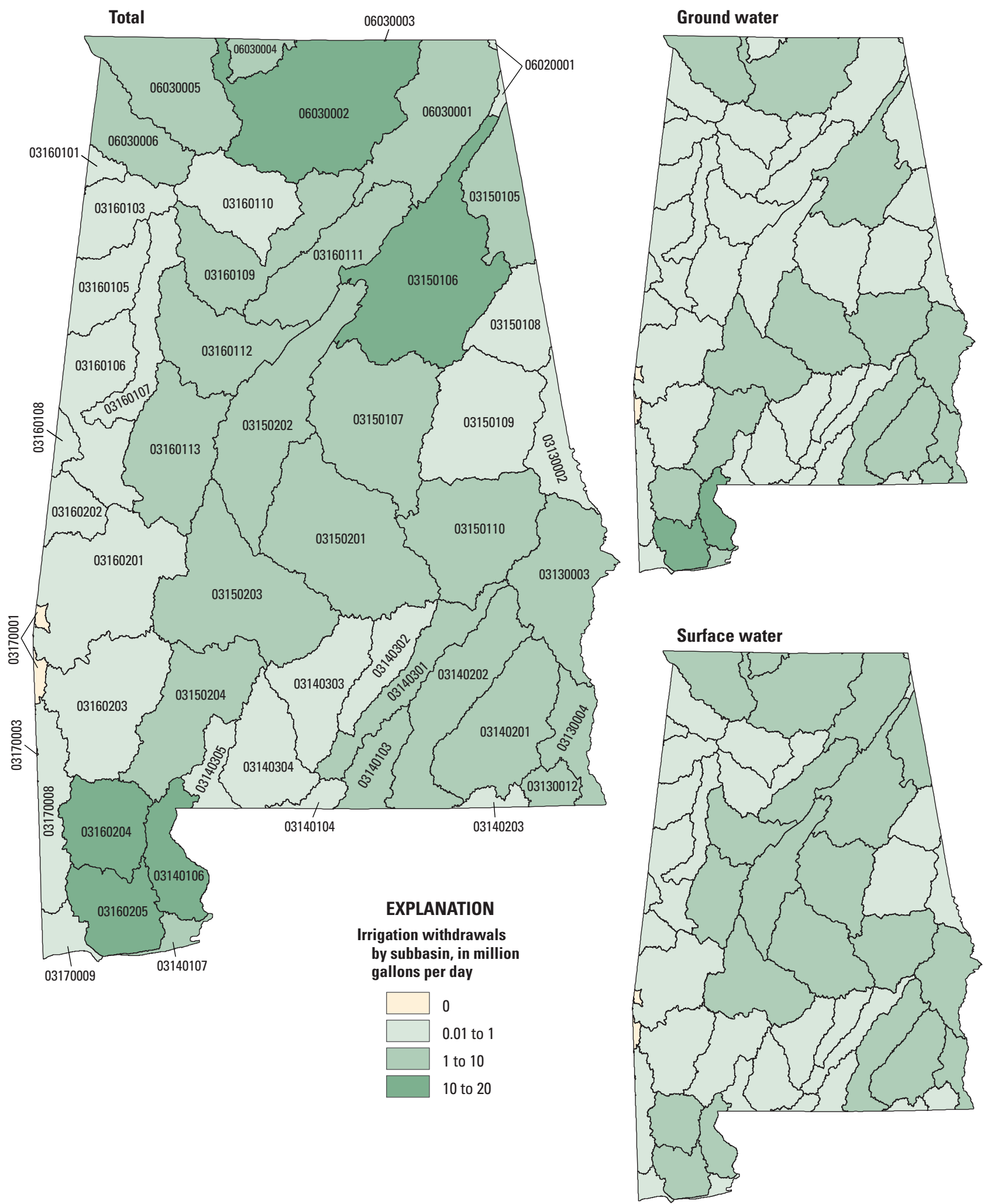

Figure 24. Irrigation withdrawals by source and subbasin in Alabama, 2005 . 
Table 14. Total irrigation freshwater withdrawals by county, Alabama, 2005.

[Values may not sum to total estimated use(s) or estimated acreage because of rounding]

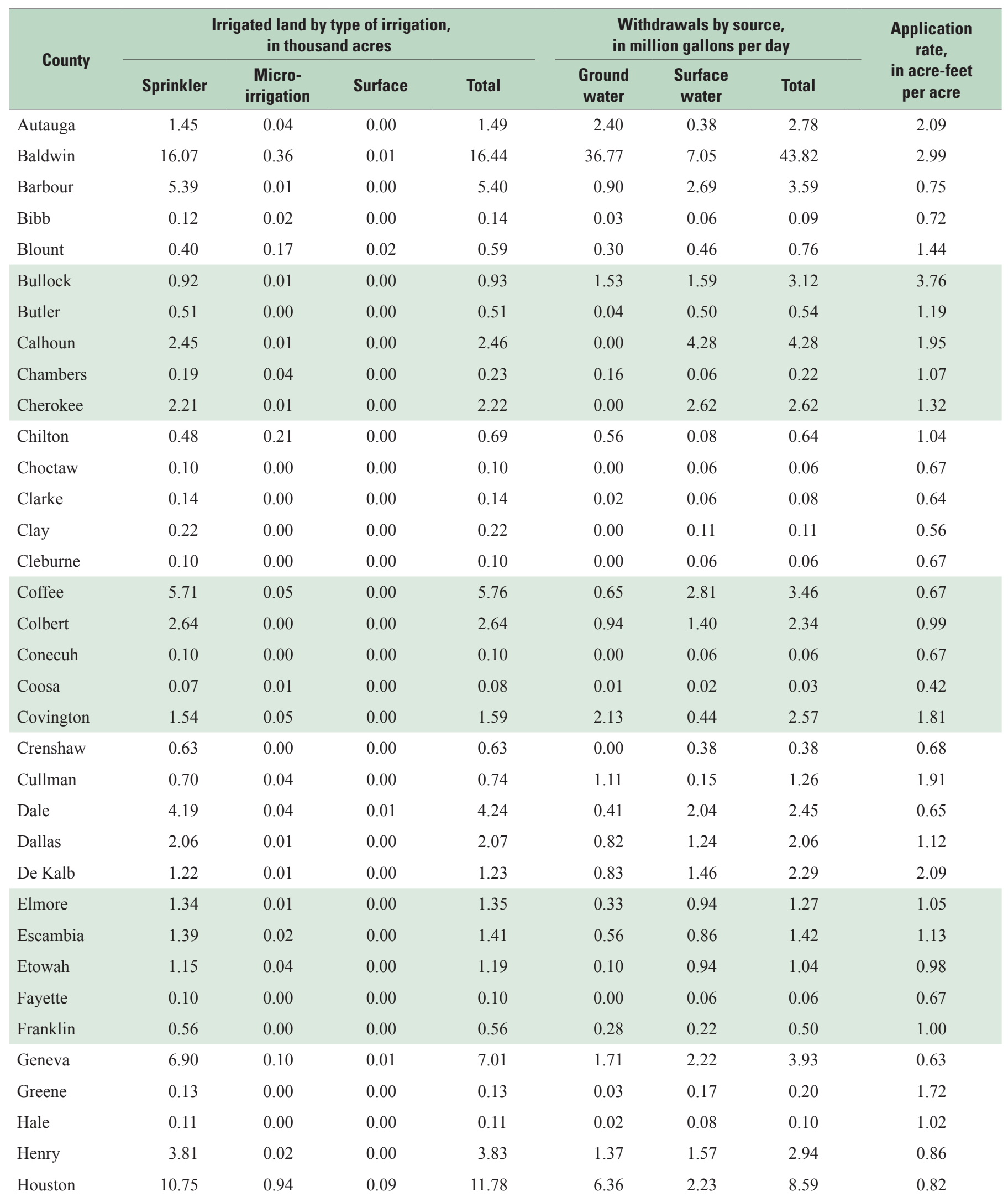


Table 14. Total irrigation freshwater withdrawals by county, Alabama, 2005.-Continued

[Values may not sum to total estimated use(s) or estimated acreage because of rounding]

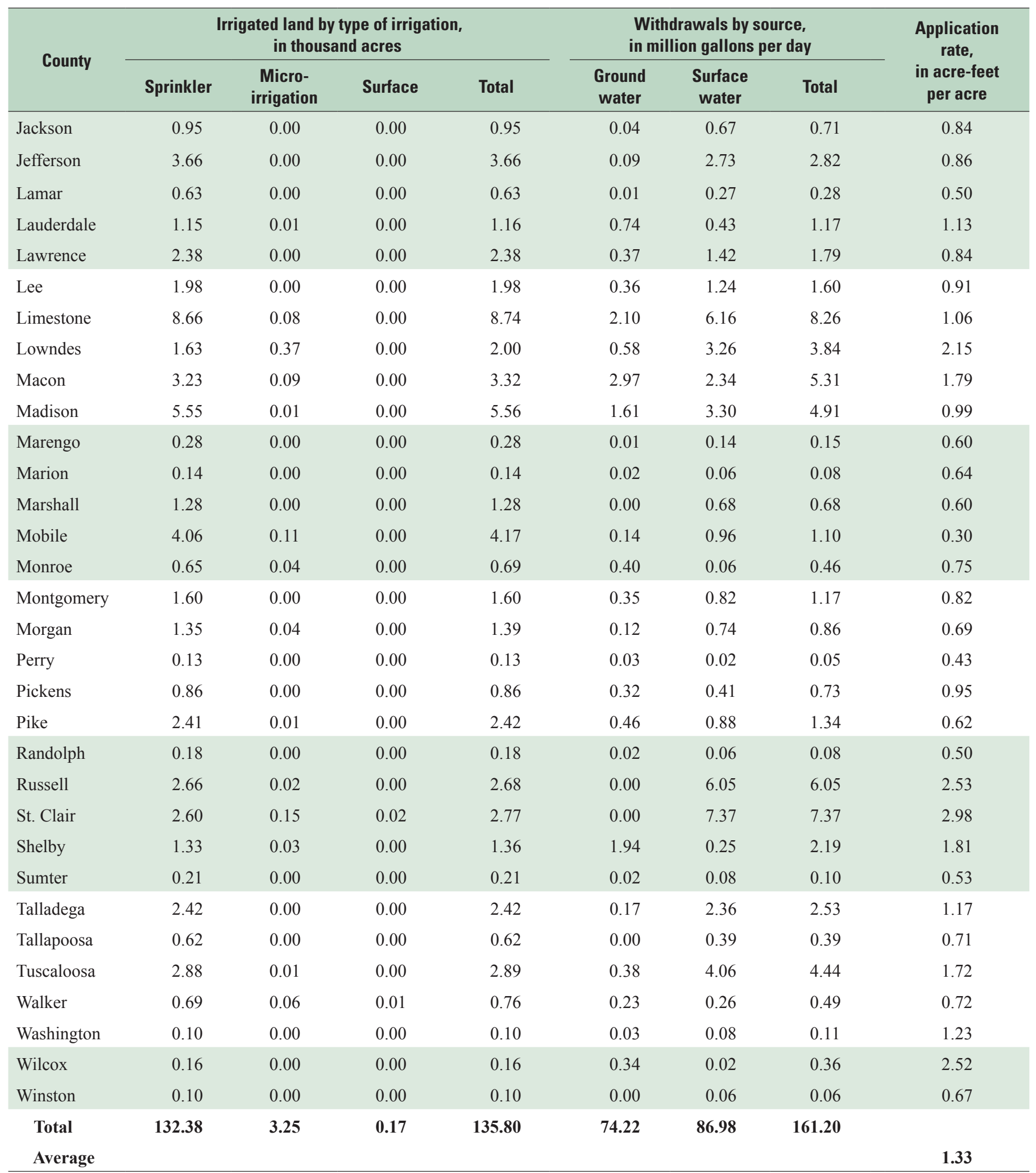


Table 15. Total irrigation freshwater withdrawals by hydrologic subregion and subbasin, Alabama, 2005.

[Values may not sum to total estimated use(s) because of rounding]

\begin{tabular}{|c|c|c|c|}
\hline \multirow{2}{*}{$\begin{array}{l}\text { Hydrologic subregion } \\
\text { and subbasin }\end{array}$} & \multicolumn{3}{|c|}{$\begin{array}{l}\text { Withdrawals by source, } \\
\text { in million gallons per day }\end{array}$} \\
\hline & $\begin{array}{l}\text { Ground } \\
\text { water }\end{array}$ & $\begin{array}{l}\text { Surface } \\
\text { water }\end{array}$ & Total \\
\hline \multicolumn{4}{|l|}{ Apalachicola } \\
\hline 03130002 & 0.19 & 0.39 & 0.58 \\
\hline 03130003 & 1.03 & 8.08 & 9.11 \\
\hline 03130004 & 3.40 & 1.87 & 5.27 \\
\hline 03130012 & 2.76 & 0.99 & 3.75 \\
\hline Subtotal & 7.38 & 11.33 & 18.71 \\
\hline \multicolumn{4}{|c|}{ Choctawhatchee-Escambia } \\
\hline 03140103 & 0.99 & 0.26 & 1.25 \\
\hline 03140104 & 0.18 & 0.09 & 0.27 \\
\hline 03140106 & 11.90 & 2.33 & 14.23 \\
\hline 03140107 & 3.10 & 0.59 & 3.69 \\
\hline 03140201 & 3.08 & 5.47 & 8.55 \\
\hline 03140202 & 2.01 & 4.04 & 6.05 \\
\hline 03140203 & 0.41 & 0.50 & 0.91 \\
\hline 03140301 & 0.98 & 0.91 & 1.89 \\
\hline 03140302 & 0.21 & 0.43 & 0.64 \\
\hline 03140303 & 0.20 & 0.56 & 0.76 \\
\hline 03140304 & 0.31 & 0.50 & 0.81 \\
\hline 03140305 & 0.16 & 0.21 & 0.37 \\
\hline Subtotal & 23.53 & 15.89 & 39.42 \\
\hline \multicolumn{4}{|l|}{ Alabama } \\
\hline 03150105 & 0.15 & 3.10 & 3.25 \\
\hline 03150106 & 2.14 & 7.91 & 10.05 \\
\hline 03150107 & 0.50 & 5.10 & 5.60 \\
\hline 03150108 & 0.37 & 0.15 & 0.52 \\
\hline 03150109 & 0.12 & 0.52 & 0.64 \\
\hline 03150110 & 3.85 & 4.22 & 8.07 \\
\hline 03150201 & 3.52 & 3.84 & 7.36 \\
\hline 03150202 & 0.42 & 3.49 & 3.91 \\
\hline 03150203 & 1.00 & 1.73 & 2.73 \\
\hline 03150204 & 3.13 & 0.64 & 3.77 \\
\hline Subtotal & 15.20 & 30.70 & 45.90 \\
\hline \multicolumn{4}{|l|}{ Mobile-Tombigbee } \\
\hline 03160101 & 0.03 & 0.03 & 0.06 \\
\hline 03160103 & 0.01 & 0.13 & 0.14 \\
\hline 03160105 & 0.02 & 0.23 & 0.25 \\
\hline
\end{tabular}

\begin{tabular}{|c|c|c|c|}
\hline \multirow{2}{*}{$\begin{array}{l}\text { Hydrologic subregion } \\
\text { and subbasin }\end{array}$} & \multicolumn{3}{|c|}{$\begin{array}{l}\text { Withdrawals by source, } \\
\text { in million gallons per day }\end{array}$} \\
\hline & $\begin{array}{l}\text { Ground } \\
\text { water }\end{array}$ & $\begin{array}{c}\text { Surface } \\
\text { water }\end{array}$ & Total \\
\hline \multicolumn{4}{|l|}{$\begin{array}{l}\text { Mobile-Tombigbee } \\
\text { (Continued) }\end{array}$} \\
\hline 03160106 & 0.28 & 0.41 & 0.69 \\
\hline 03160107 & 0.11 & 0.68 & 0.79 \\
\hline 03160108 & 0.01 & 0.02 & 0.03 \\
\hline 03160109 & 0.84 & 0.46 & 1.30 \\
\hline 03160110 & 0.55 & 0.38 & 0.93 \\
\hline 03160111 & 0.29 & 1.91 & 2.20 \\
\hline 03160112 & 0.24 & 2.97 & 3.21 \\
\hline 03160113 & 0.15 & 1.31 & 1.46 \\
\hline 03160201 & 0.02 & 0.20 & 0.22 \\
\hline 03160202 & 0.01 & 0.03 & 0.04 \\
\hline 03160203 & 0.16 & 0.13 & 0.29 \\
\hline 03160204 & 8.35 & 1.92 & 10.27 \\
\hline 03160205 & 10.32 & 2.18 & 12.50 \\
\hline Subtotal & 21.39 & 12.99 & 34.38 \\
\hline \multicolumn{4}{|l|}{ Pascagoula } \\
\hline 03170002 & 0.00 & 0.00 & 0.00 \\
\hline 03170003 & 0.00 & 0.00 & 0.00 \\
\hline 03170008 & 0.05 & 0.29 & 0.34 \\
\hline 03170009 & 0.02 & 0.15 & 0.17 \\
\hline Subtotal & 0.07 & 0.44 & 0.51 \\
\hline \multicolumn{4}{|l|}{$\begin{array}{l}\text { Middle Tennessee-- } \\
\text { Hiwassee }\end{array}$} \\
\hline 06020001 & 0.05 & 0.09 & 0.14 \\
\hline Subtotal & 0.05 & 0.09 & 0.14 \\
\hline \multicolumn{4}{|l|}{ Middle Tennessee-Elk } \\
\hline 06030001 & 0.50 & 1.72 & 2.22 \\
\hline 06030002 & 3.45 & 9.17 & 12.62 \\
\hline 06030003 & 0.00 & 0.00 & 0.00 \\
\hline 06030004 & 0.73 & 1.99 & 2.72 \\
\hline 06030005 & 1.44 & 1.98 & 3.42 \\
\hline 06030006 & 0.53 & 0.64 & 1.17 \\
\hline Subtotal & 6.65 & 15.50 & 22.15 \\
\hline Total & 74.27 & 86.94 & 161.21 \\
\hline
\end{tabular}




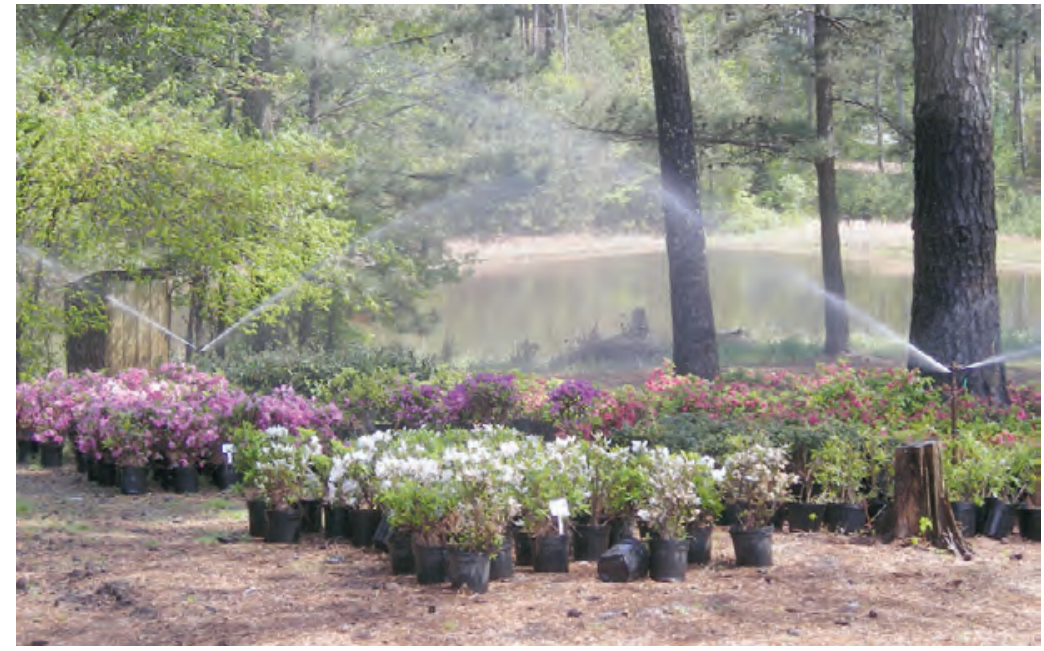

A series of stepped, gated, and spring-fed and rain-fed ponds supply irrigation water to a nursery in Cleburne County, Alabama. In 2005, nursery stock and sod sales were higher than for any other crop in Alabama. (Photo courtesy of Michael J. Harper, Alabama Office of Water Resources, published with permission.)

Sprinkler irrigation systems, like this lateral move system, provide supplementary water for crops such as the cotton grown in the Tennessee River watershed. (Photo courtesy of Larry Curtis, Auburn University, published with permission.)

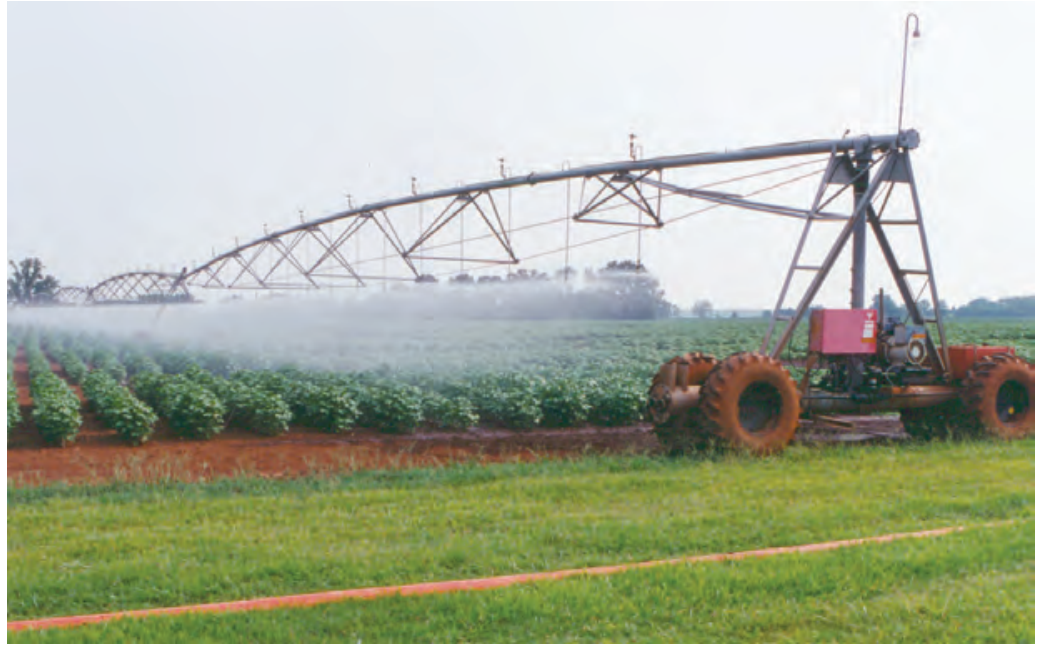

Golf course ponds collect rainfall and runoff. In addition to enhancing the beauty of the course and adding challenge to the game, water from ponds similar to the one pictured is used to maintain tees, fairways, greens, and landscaping. Shown is Craft Farms Golf Resort, Cypress Bend Golf Course, Foley, Alabama. (Photo courtesy of Alabama Bureau of Tourism \& Travel, published with permission.)

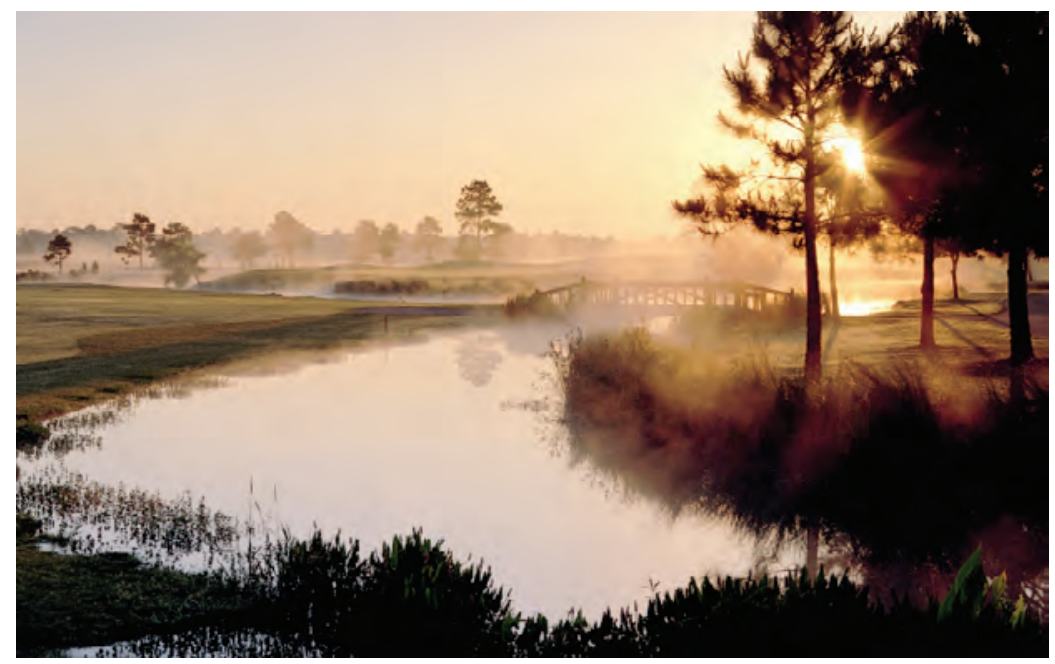


Table 16. Crop and golf course irrigated land and freshwater withdrawals by county, Alabama, 2005.

[Values may not sum to total estimated use(s) or estimated acreage because of rounding]

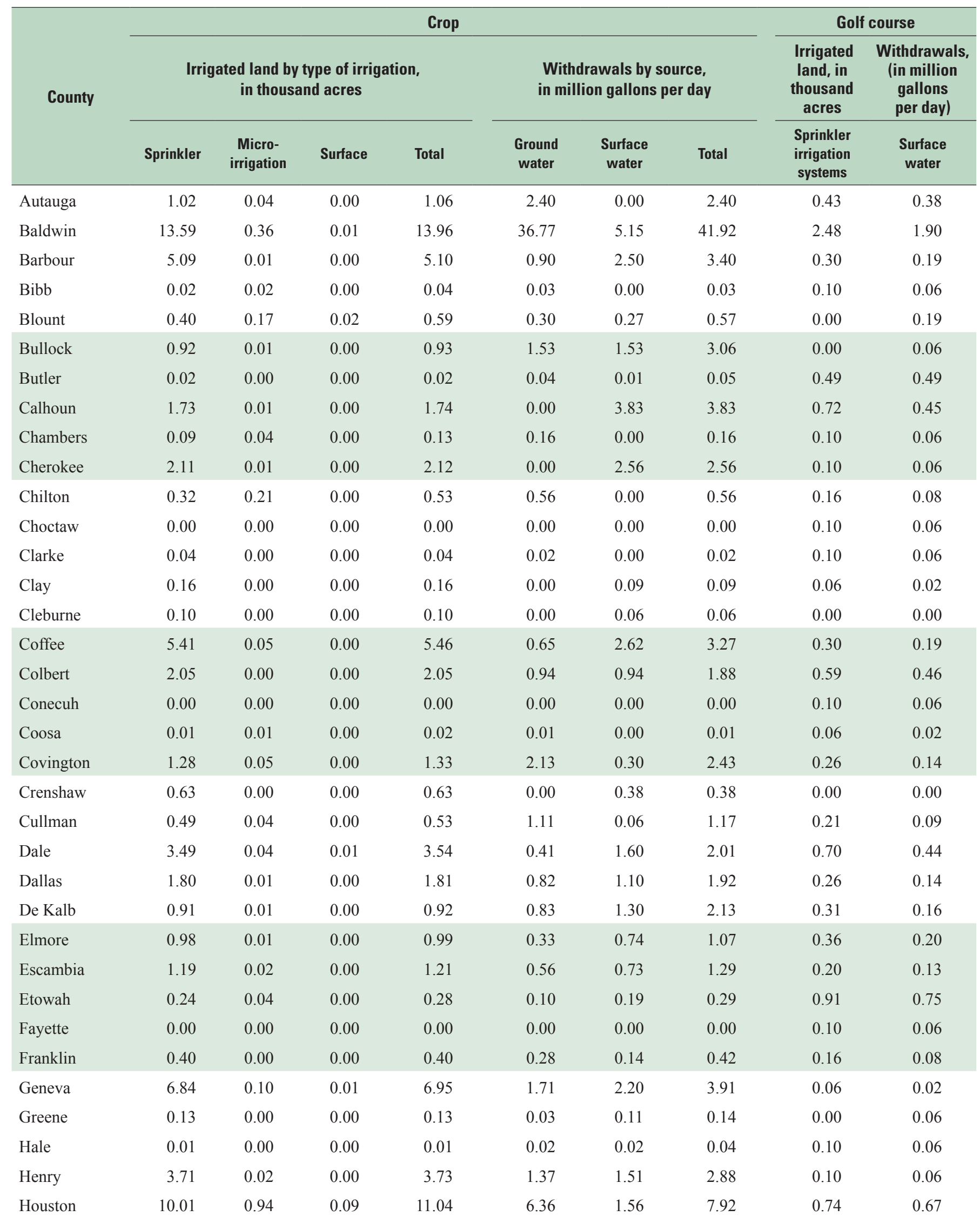


Table 16. Crop and golf course irrigated land and freshwater withdrawals by county, Alabama, 2005.—Continued

[Values may not sum to total estimated use(s) or estimated acreage because of rounding]

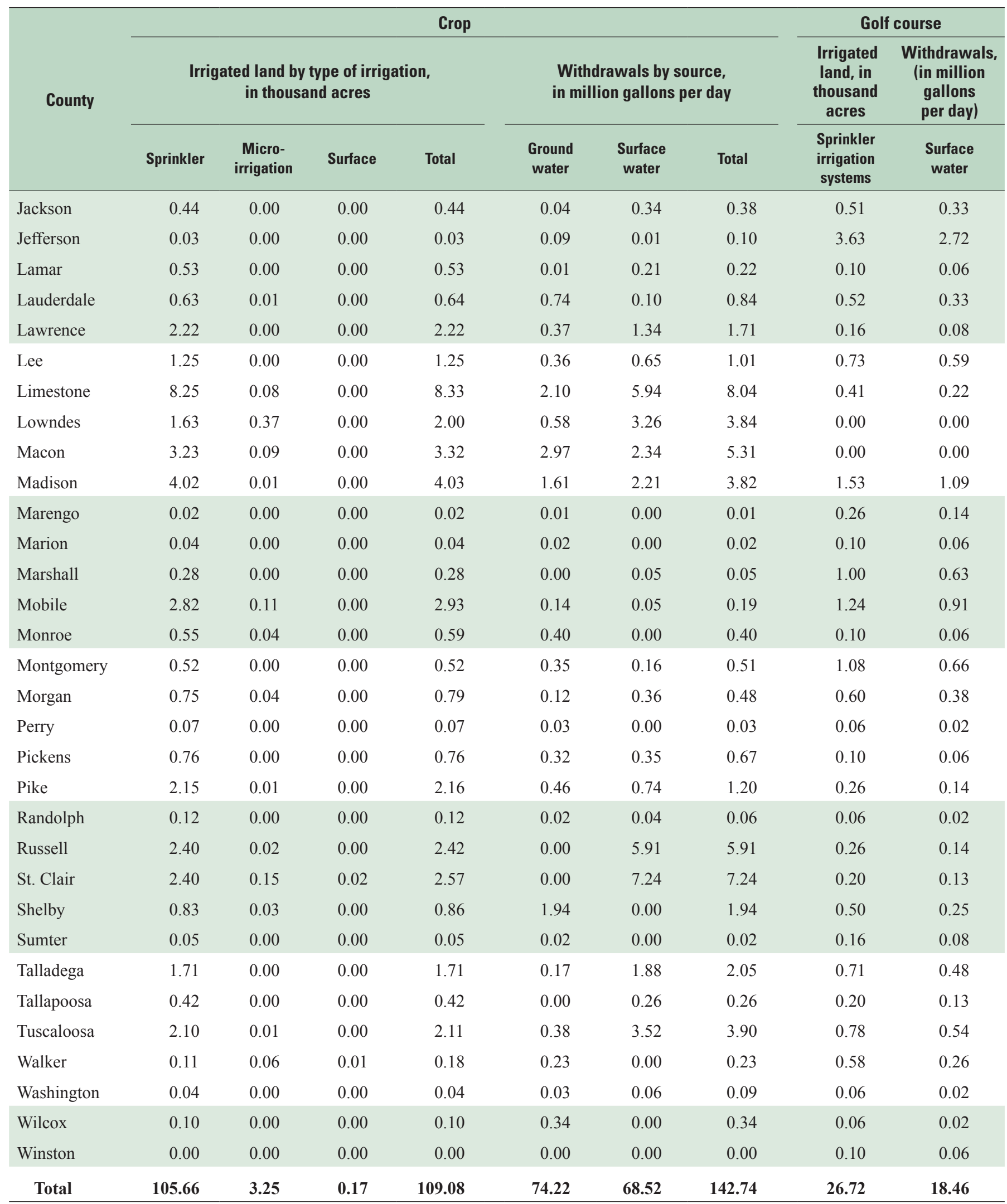


Golf courses applied an estimated $18 \mathrm{Mgal} / \mathrm{d}$ to 26,720 acres in 2005 (table 16). For this study, it was assumed that all golf course irrigation was from surface water and that the water was applied by sprinkler systems. Golf courses were classified as Tier 1, 2, or 3 (table 2) depending on a number of factors such as turf and landscape watering practices, which, are in turn, guided by the season of the year, antecedent soil moisture, weather conditions, and operational costs. Tier 1 golf courses water more extensively than Tier 2 and Tier 3 courses. The effect of precipitation on watering practices in 2005 is shown in figure 25 . A composite of average monthly watering by Tier is compared to statewide average rainfall amounts expressed as departure from normal in inches for 2005 (National Oceanic and Atmospheric Administration, 200[). The above-normal rainfall (4.5 inches above normal) in July 2005 associated with Hurricane Dennis reduced irrigation at all courses, but considerably more at the Tier 1 courses. For the Tier 1 courses, little irrigation water was applied in April because of above-normal rainfall; some irrigation was required during May because of below-normal rainfall; and less irrigation water was required during June compared to May as rainfall increased to above-normal; irrigation was higher in August than in July as rainfall amounts were comparatively less; below normal rainfall in September resulted in increased irrigation; and irrigation was required in October because of below-normal rainfall. The less maintained Tier 2 courses began to reduce irrigation after September. Tier 3 courses, which use relatively little water for irrigation, were, minimally affected by the rainfall amounts during 2005 .

Some irrigation withdrawals were reported to the OWR AWURP. Mostly irrigation withdrawals were estimated from ancillary data, such as crop type, State or regional crop application coefficients, and irrigated acreage. The sources for these ancillary data were an OWR golf course mail and telephone survey, Alabama Department of Agriculture and Industries listing of 2006-2007 certified nursery growers and nursery dealers, and the U.S. Department of Agriculture, National Agricultural Statistics Service censuses-Census of Agriculture (2002) and Farm and Ranch Survey (2003).

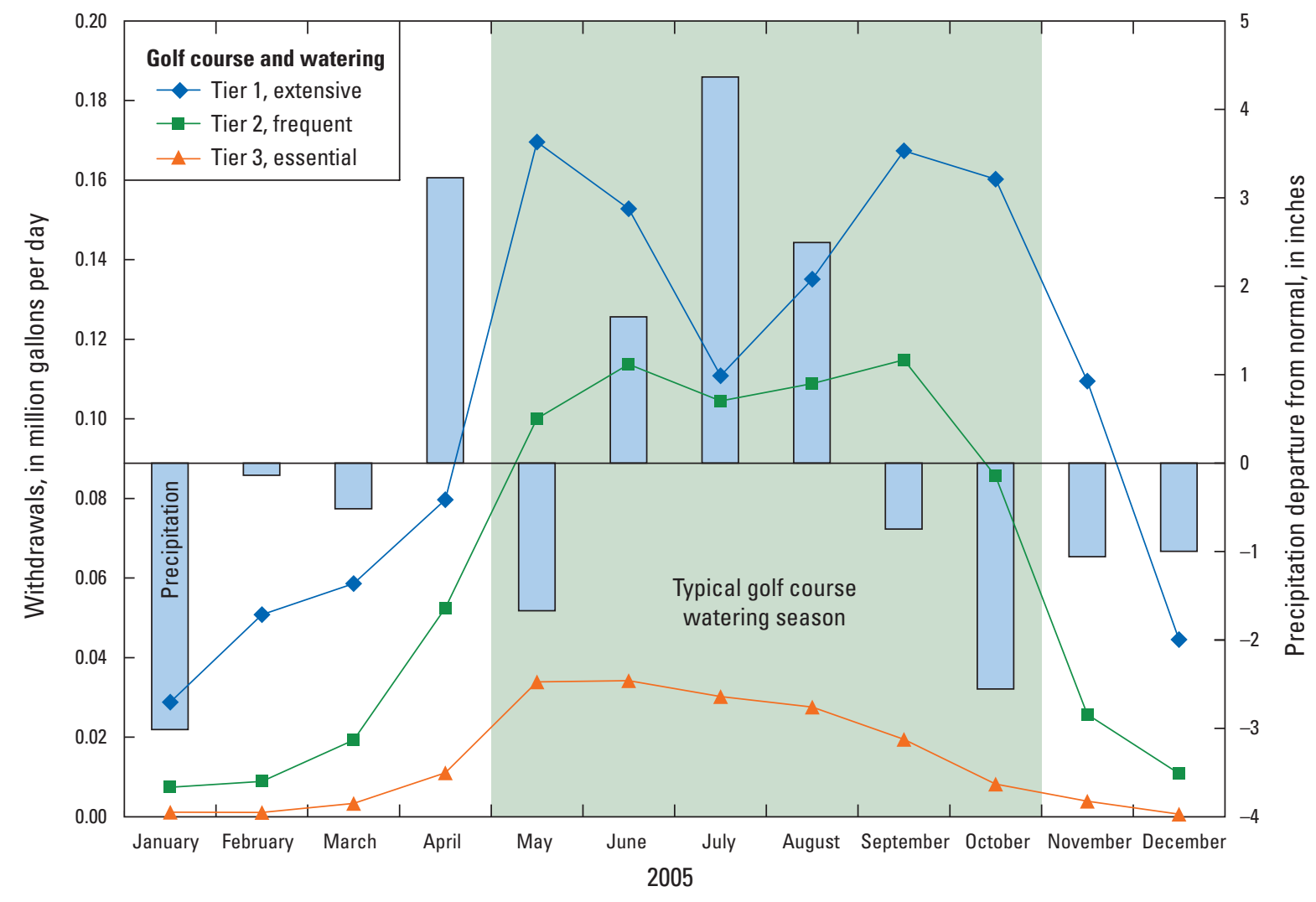

Figure 25. Comparison of seasonal water use by golf course type in Alabama, 2005. 


\section{Livestock}

Livestock water is water associated with livestock watering, feedlots, dairy operations, and other on-farm needs. The associated activities include cooling of the facilities for the animals and products, dairy sanitation and cleaning of facilities, animal waste-disposal systems, and incidental water loss. The primary livestock types in Alabama include poultry, beef cattle and calves, dairy cows and heifers, hogs and pigs, and horses and ponies. For 2005, all withdrawals were considered to be freshwater. The livestock category excludes on-farm residential use (residential category) and irrigation water use.

During 2005, livestock withdrawals were $28 \mathrm{Mgal} / \mathrm{d}$ (tables 17 and 18). Surface water was the source for 56 percent (16 Mgal/d) of the livestock withdrawals, and ground water was the source for the remaining 44 percent $(12 \mathrm{Mgal} / \mathrm{d})$ (fig. 26). Livestock withdrawals were less than 1 percent of total withdrawals and were nearly 2 percent of total withdrawals excluding thermoelectric power (table 5).

The geographic distribution of total, ground-water, and surface water withdrawals by county and by hydrologic subbasin is shown in figures 27 and 28. The counties with large water withdrawals for livestock mostly corresponded to the areas of Alabama with major producers of broilers, cattle and calves, and hogs and pigs (U.S. Department of Agriculture, National Agricultural Statistics Service, 2006a). Blount, Cullman, De Kalb, and Marshall Counties, the top four broiler chicken producers in Alabama, accounted for about 23 percent of the total livestock water withdrawals (U.S. Department of Agriculture, National Agricultural Statistics Service, 2006b). In 2005, a record number of broilers were raised in Alabama and cash receipts from broilers and eggs were about 80 percent of the livestock and poultry cash receipts and about 64 percent of the total agricultural commodity receipts. In 2002, Cullman County ranked second in the group of 3,078 counties in the United States in broiler production (U.S. Department of Agriculture, National Agricultural Statistics Service, 2002).

Ten of the hydrologic subbasins withdrew $1 \mathrm{Mgal} / \mathrm{d}$ or more and accounted for 55 percent $(15 \mathrm{Mgal} / \mathrm{d})$ of the total livestock withdrawals. The largest withdrawals by subregion occurred in the Mobile-Tombigbee (28 percent, or $7.8 \mathrm{Mgal} / \mathrm{d}$ ), Alabama (26 percent, or $7.3 \mathrm{Mgal} / \mathrm{d}$ ), and Middle Tennessee-Elk (24 percent, or 6.7 Mgal/d; table 18).

Estimates of livestock withdrawals by county were determined by the USGS-NWUIP as part of the national effort to estimate water use for the United States for 2005. Water withdrawals were calculated from the 2005 livestock census by USDA-NASS and statewide drinking water requirement coefficients as described in the "Livestock, Aquaculture, and Mining" section in the "Data Compilation, Sources of Information, and Methodology" section of this report.

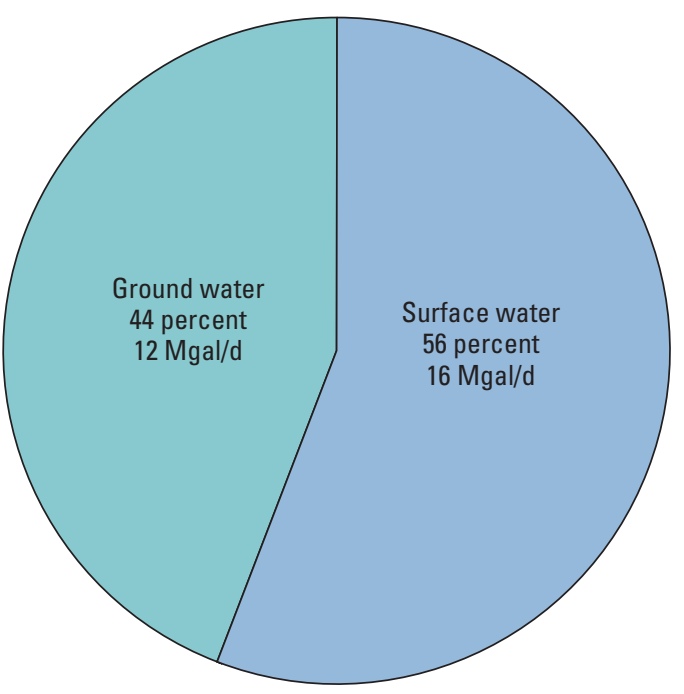

Figure 26. Source of water for livestock use in Alabama, 2005. [Mgal/d, million gallons per day; values may not sum to total estimated use because of rounding]

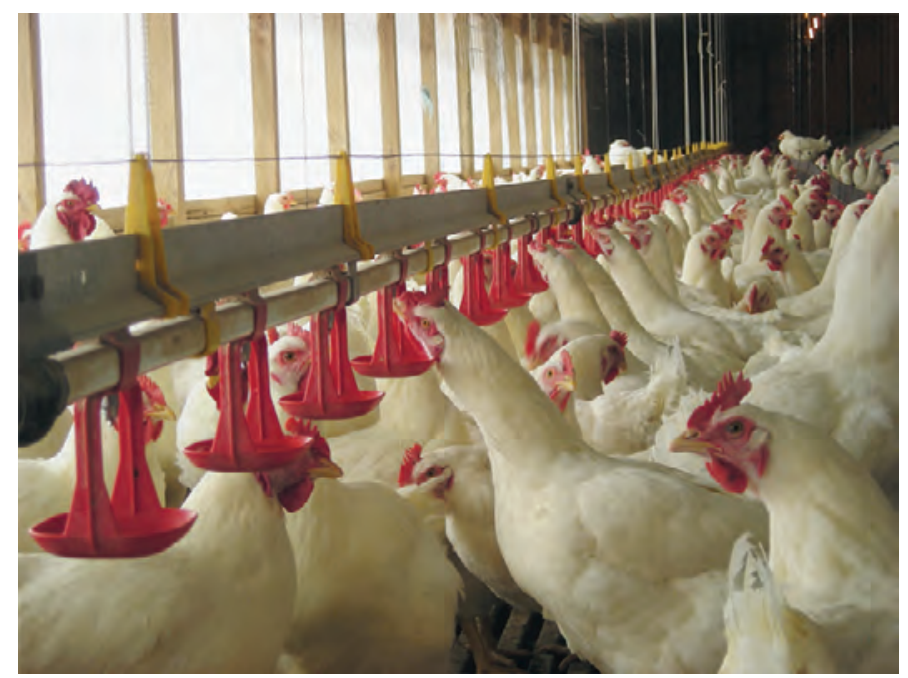

Breeder chickens in Cleburne County, Alabama. In 2005, the poultry industry was the leading agricultural business in Alabama (U.S. Department of Agriculture, National Agricultural Statistics Service, 2006a, photo by Michael J. Harper, Alabama Office of Water Resources) 

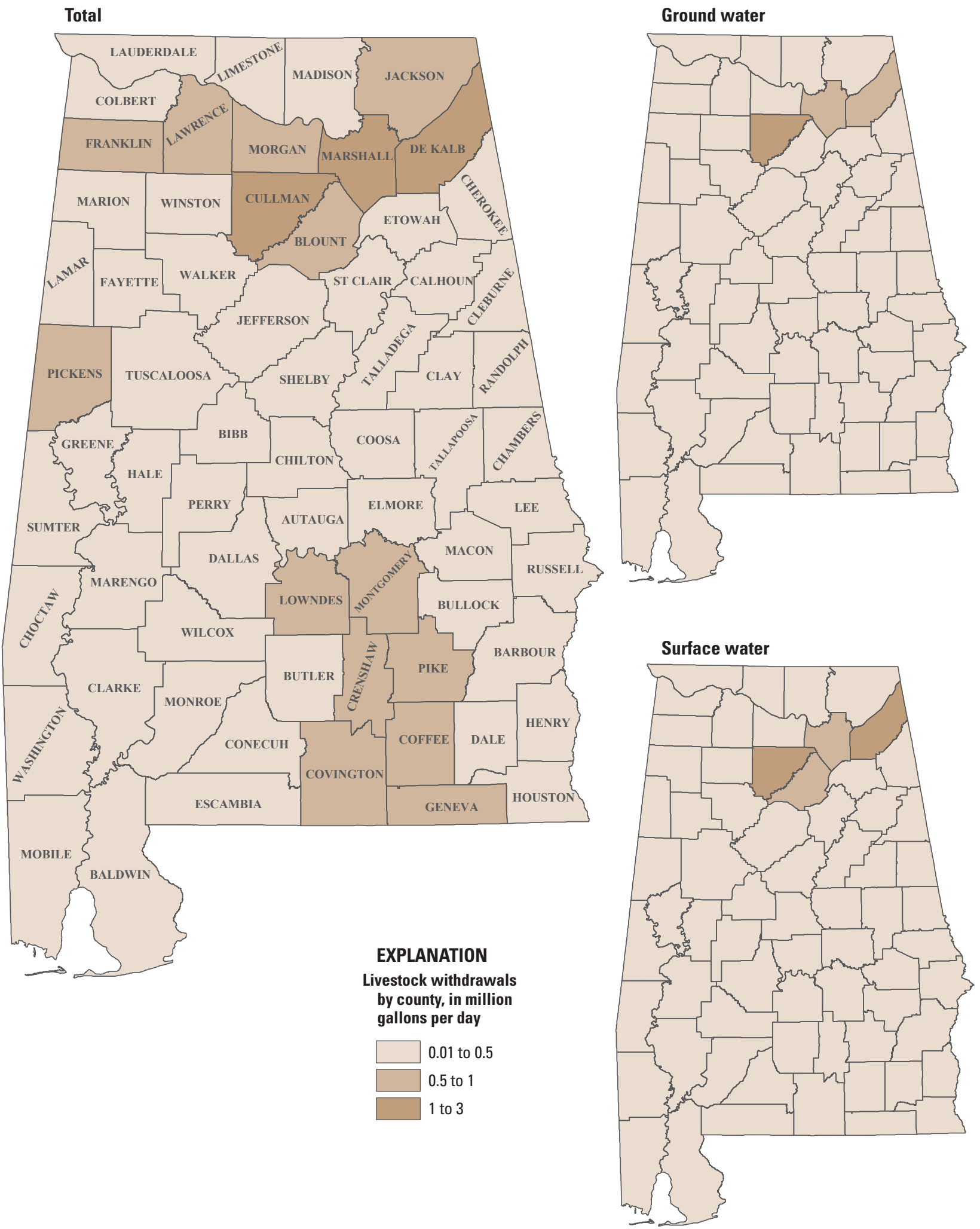

Figure 27. Livestock freshwater withdrawals by source and county in Alabama, 2005. 

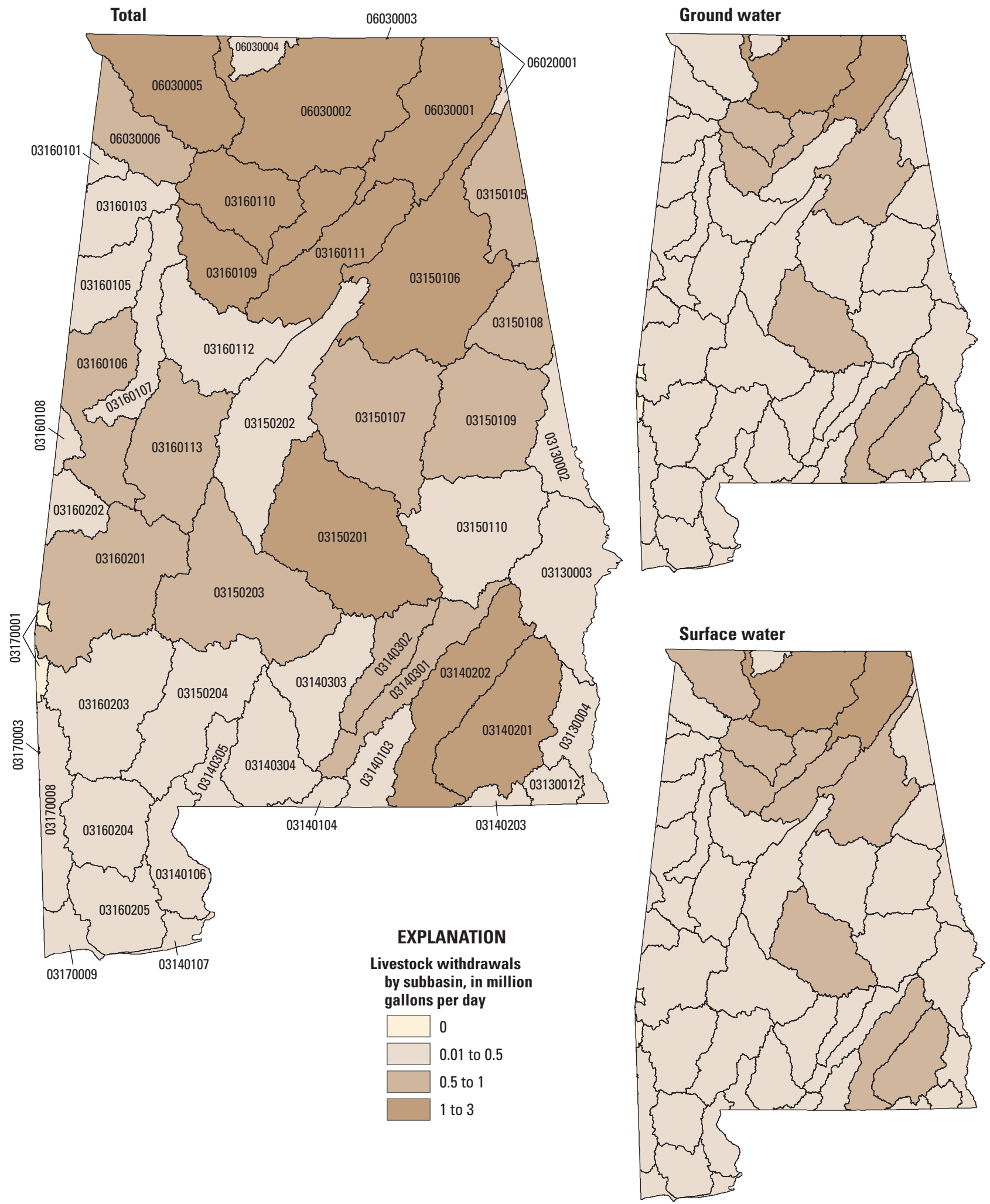

Figure 28. Livestock freshwater withdrawals by source and subbasin in Alabama, 2005. 
Table 17. Livestock freshwater withdrawals by county, Alabama, 2005.

[Values may not sum to total estimated use(s) because of rounding]

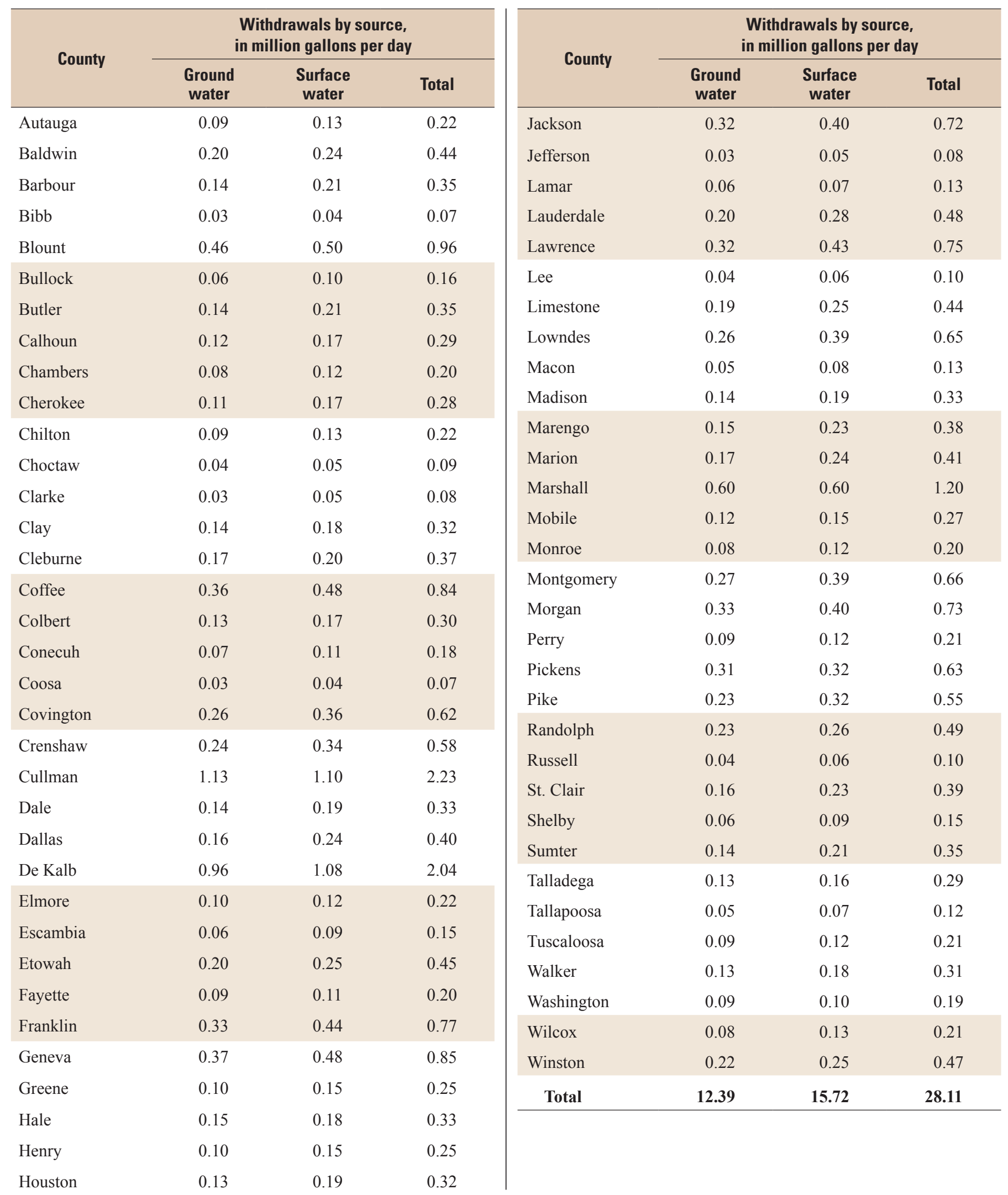


Table 18. Livestock freshwater withdrawals by hydrologic subregion and subbasin, Alabama, 2005.

[Values may not sum to total estimated use(s) because of rounding]

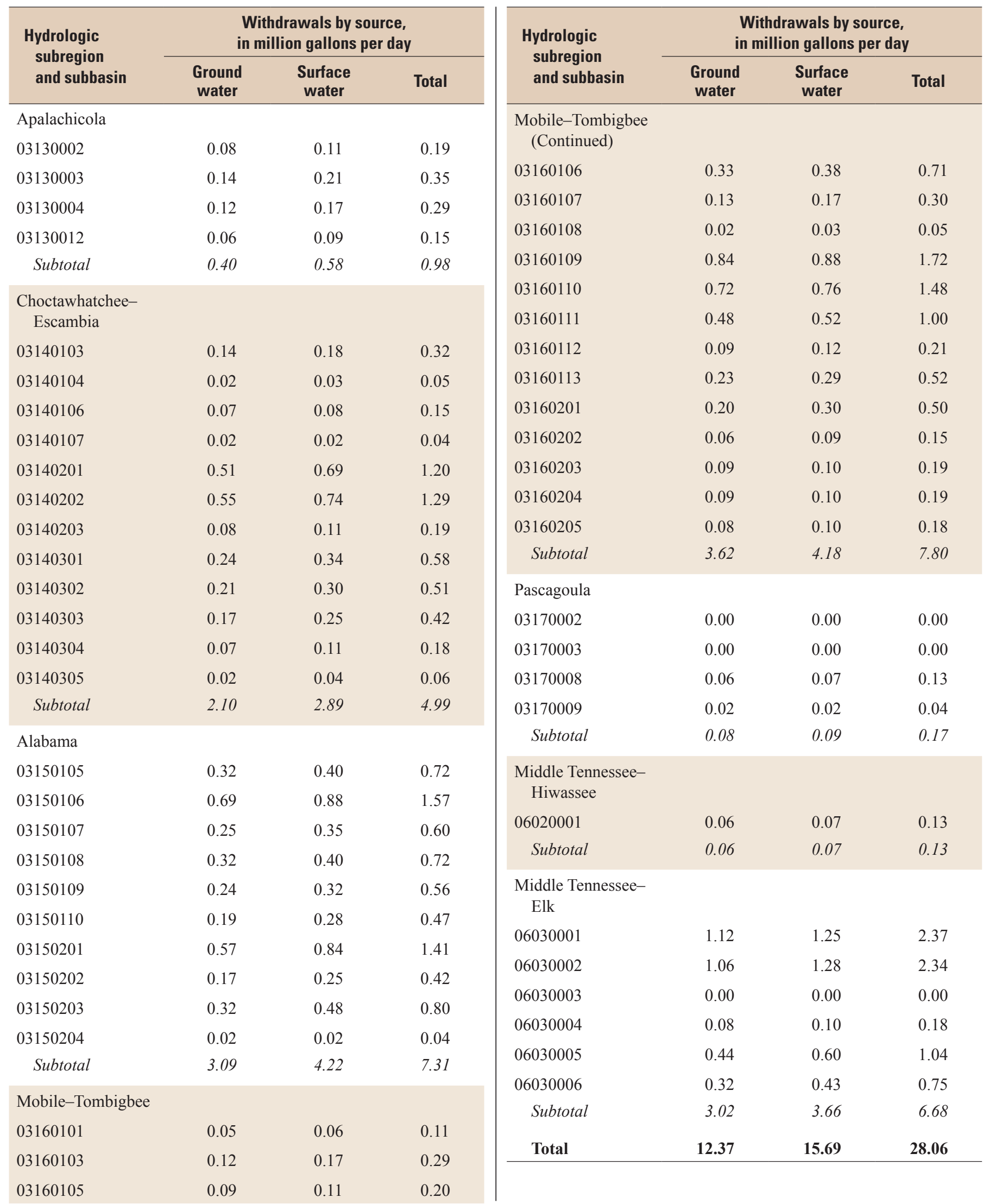




\section{Aquaculture}

Aquaculture water refers to water that is associated with the farming of organisms, such as finfish and shellfish, that live in water and offstream water withdrawals associated with fish hatcheries for food, restoration, conservation, or sport. Aquaculture occurs under controlled feeding, sanitation, and harvesting procedures primarily in ponds, flow-through raceways, and, to a lesser extent, cages, net pens, and closed-recirculation tanks. All withdrawals were considered to be freshwater.

Freshwater withdrawals for aquaculture are listed by county in table 19. For 2005, the quantity of water withdrawn for aquaculture was about $75 \mathrm{Mgal} / \mathrm{d}$. Ground water was the source for 54 percent of the total, or $41 \mathrm{Mgal} / \mathrm{d}$, and surface water was the source for the remaining 46 percent, or $34 \mathrm{Mgal} / \mathrm{d}$ (fig. 29). Aquaculture withdrawals were nearly 1 percent of total withdrawals and about 4 percent of total withdrawals for all categories excluding thermoelectric power (table 5).

The geographic distribution of total, ground-water, and surface-water withdrawals by county is shown in figure 30 . Greene, Hale, and Perry Counties, which are located in the west-central part of the State in an area of moderate climate, abundant water, and heavy clay soils ideal for constructing earthen ponds (Kidd and Lambeth, 1995; Boyd and others, 2000; Alabama Education Aquaculture Recreational Fishing, ALEARN, 2008), accounted for 61 percent (45 Mgal/d ) of the aquaculture withdrawals. Catfish farming predominates in this area where rainfall and runoff filled more than 75 percent of the ponds and water levels were maintained in dry weather by ground water (Boyd and others, 2000). Other ponds in the area were embankment ponds filled with ground water.

In 2005, the pond surface area in Alabama was 25,001 acres and approximately 230 catfish farms were operating (Alabama Cooperative Extension System, 2006). Alabama ranked second only to Mississippi in catfish production nationwide, and Hale County ranked sixth nationally among counties (U.S. Department of Agriculture, National Agricultural Statistics Service, 2006a). Although all water withdrawals were compiled as freshwater for this study, approximately 75 acres of ponds were filled with low-salinity ground water for the production of 4,000 pounds per acre of marine shrimp in west-central Alabama, including Greene County, and some catfish ponds in the area were filled with high-salinity (commonly 5,000 to 6,000 milligrams per liter) ground water derived from the Coker Formation (Boyd and others, 2000; McNevin and others, 2004; Boyd and others, 2006; Boyd and others, 2007).

Estimates of aquaculture water withdrawals by source of supply were determined by the USGS-NWUIP as part of the national effort to estimate water use for the United States for 2005. Water withdrawals were estimated from the commercial and non-commercial operations datasets produced by NASS for the 2005 Census of Aquaculture as described in the "Livestock, Aquaculture, and Mining" section in the "Data Compilation, Sources of Information, and Methodology" section of this report. Ground water and surface water were determined according to the USGS estimates for source of water for aquaculture for 2000 (U.S. Geological Survey, 2004).

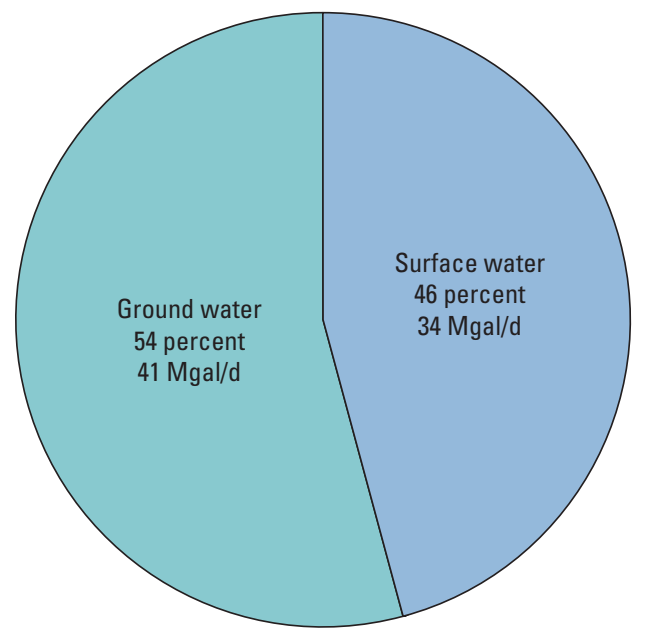

Figure 29. Source of water for aquaculture use in Alabama, 2005. [Mgal/d, million gallons per day; values may not sum to total estimated use because of rounding]

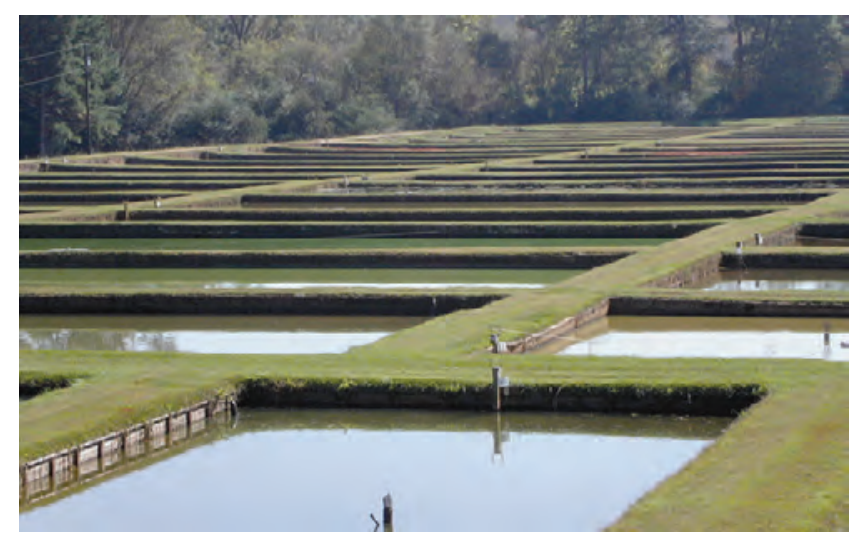

Catfish ponds built and operated by Auburn University. (Photo courtesy of Alan Wilson, Department of Fisheries and Allied Aquacultures at Auburn University, Auburn, Alabama, published with permission.)

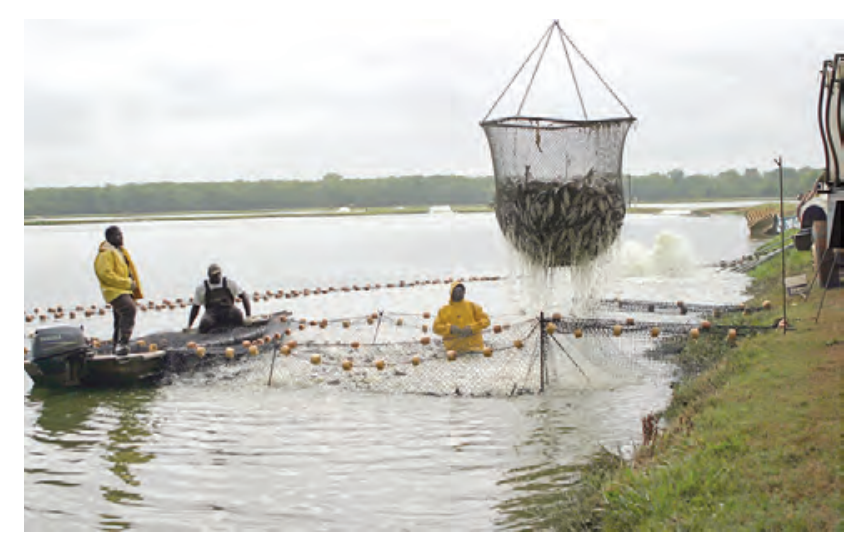

Catfish harvesting in Perry County, Alabama. In 2005, Alabama had about 25,000 water acres of fish farms where nearly 250 commercial farmers raised 25 different aquatic species. Farm-raised catfish was the dominant species, with Alabama ranking second in the United States in annual catfish sales (Alabama Farmers Federation, Alabama Catfish Producers, 2008; photo courtesy of Debra Davis, Alabama Farmers Federation, published with permission). 


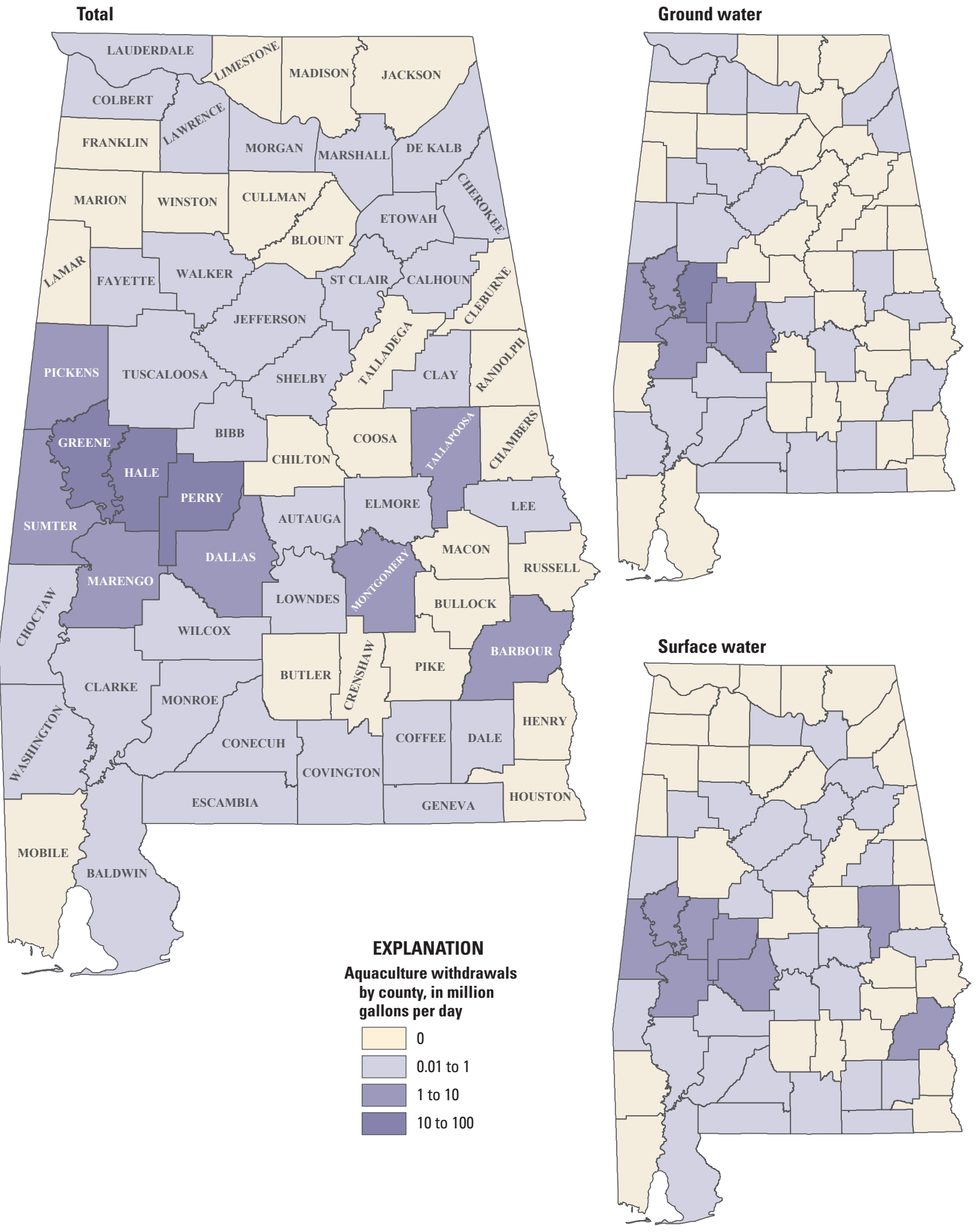

Figure 30. Aquaculture freshwater withdrawals by source and county in Alabama, 2005. 
Table 19. Aquaculture freshwater withdrawals by county, Alabama, 2005.

[Values may not sum to total estimated use(s) because of rounding]

\begin{tabular}{lll|}
\hline \multirow{3}{*}{ County } & \multicolumn{3}{c|}{$\begin{array}{c}\text { Withdrawals by source, } \\
\text { in million gallons per day }\end{array}$} \\
\cline { 2 - 3 } & Ground water $\quad$ Surface water & Total \\
\hline
\end{tabular}

\begin{tabular}{|lccc|}
\hline \multirow{2}{*}{ County } & \multicolumn{3}{c}{$\begin{array}{c}\text { Withdrawals by source, } \\
\text { in million gallons per day }\end{array}$} \\
\cline { 2 - 4 } & Ground water & Surface water & Total \\
\hline Jackson & 0.00 & 0.00 & 0.00 \\
Jefferson & 0.02 & 0.56 & 0.58 \\
Lamar & 0.00 & 0.00 & 0.00 \\
Lauderdale & 0.03 & 0.00 & 0.03 \\
Lawrence & 0.08 & 0.00 & 0.08 \\
\hline
\end{tabular}

\begin{tabular}{llll}
\hline Autauga & 0.15 & 0.15 & 0.30 \\
Baldwin & 0.00 & 0.05 & 0.05 \\
Barbour & 0.21 & 5.70 & 5.91 \\
Bibb & 0.00 & 0.36 & 0.36 \\
Blount & 0.00 & 0.00 & 0.00 \\
Bullock & 0.00 & 0.00 & 0.00 \\
Butler & 0.00 & 0.00 & 0.00 \\
Calhoun & 0.00 & 0.07 & 0.07 \\
Chambers & 0.00 & 0.00 & 0.00 \\
Cherokee & 0.39 & 0.00 & 0.39
\end{tabular}

$\begin{array}{llll}\text { Lee } & 0.05 & 0.10 & 0.15\end{array}$

$\begin{array}{llll}\text { Limestone } & 0.00 & 0.00 & 0.00\end{array}$

$\begin{array}{llll}\text { Lowndes } & 0.00 & 0.02 & 0.02\end{array}$

$\begin{array}{llll}\text { Macon } & 0.00 & 0.00 & 0.00\end{array}$

$\begin{array}{llll}\text { Madison } & 0.00 & 0.00 & 0.00\end{array}$

$\begin{array}{llll}\text { Chilton } & 0.00 & 0.00 & 0.00\end{array}$

$\begin{array}{llll}\text { Choctaw } & 0.00 & 0.08 & 0.08\end{array}$

$\begin{array}{llll}\text { Clarke } & 0.03 & 0.04 & 0.07\end{array}$

$\begin{array}{llll}\text { Clay } & 0.00 & 0.01 & 0.01\end{array}$

$\begin{array}{llll}\text { Cleburne } & 0.00 & 0.00 & 0.00\end{array}$

$\begin{array}{llll}\text { Coffee } & 0.48 & 0.26 & 0.74 \\ \text { Colbert } & 0.02 & 0.00 & 0.02 \\ \text { Conecuh } & 0.01 & 0.01 & 0.02 \\ \text { Coosa } & 0.00 & 0.00 & 0.00 \\ \text { Covington } & 0.10 & 0.10 & 0.20\end{array}$

$\begin{array}{llll}\text { Crenshaw } & 0.00 & 0.00 & 0.00 \\ \text { Cullman } & 0.00 & 0.00 & 0.00\end{array}$

$\begin{array}{lccc}\text { Cullman } & 0.00 & 0.00 & 0.00 \\ \text { Dale } & 0.00 & 0.10 & 0.10 \\ \text { Dallas } & 5.00 & 2.14 & 7.14 \\ \text { De Kalb } & 0.01 & 0.00 & 0.01 \\ \text { Elmore } & 0.00 & 0.18 & 0.18 \\ \text { Escambia } & 0.04 & 0.01 & 0.05 \\ \text { Etowah } & 0.00 & 0.02 & 0.02 \\ \text { Fayette } & 0.02 & 0.02 & 0.04 \\ \text { Franklin } & 0.00 & 0.00 & 0.00 \\ \text { Geneva } & 0.24 & 0.06 & 0.30 \\ \text { Greene } & 6.17 & 4.46 & 10.63 \\ \text { Hale } & 16.37 & 8.43 & 24.80 \\ \text { Henry } & 0.00 & 0.00 & 0.00 \\ \text { Houston } & 0.00 & 0.00 & 0.00\end{array}$

\begin{tabular}{|c|c|c|c|}
\hline IVIaUisoni & 0.00 & 0.00 & 0.00 \\
\hline Marengo & 2.00 & 1.64 & 3.64 \\
\hline Marion & 0.00 & 0.00 & 0.00 \\
\hline Marshall & 0.00 & 0.01 & 0.01 \\
\hline Mobile & 0.00 & 0.00 & 0.00 \\
\hline Monroe & 0.03 & 0.04 & 0.07 \\
\hline Montgomery & 0.55 & 0.59 & 1.14 \\
\hline Morgan & 0.05 & 0.05 & 0.10 \\
\hline Perry & 5.32 & 4.67 & 9.99 \\
\hline Pickens & 0.50 & 0.50 & 1.00 \\
\hline Pike & 0.00 & 0.00 & 0.00 \\
\hline Randolph & 0.00 & 0.00 & 0.00 \\
\hline Russell & 0.00 & 0.00 & 0.00 \\
\hline St. Clair & 0.00 & 0.03 & 0.03 \\
\hline Shelby & 0.00 & 0.05 & 0.05 \\
\hline Sumter & 2.10 & 2.19 & 4.29 \\
\hline Talladega & 0.00 & 0.00 & 0.00 \\
\hline Tallapoosa & 0.03 & 1.27 & 1.30 \\
\hline Tuscaloosa & 0.07 & 0.00 & 0.07 \\
\hline Walker & 0.02 & 0.07 & 0.09 \\
\hline Washington & 0.08 & 0.00 & 0.08 \\
\hline Wilcox & 0.34 & 0.34 & 0.68 \\
\hline Winston & 0.00 & 0.00 & 0.00 \\
\hline Total & 40.51 & 34.38 & 74.89 \\
\hline
\end{tabular}




\section{Industrial}

Industrial water is water used for fabrication, processing, washing, and cooling and includes such industries as chemical and allied products, food, paper and allied products, petroleum refining, and steel. Total industrial water use is the sum of public-supplied industrial and commercial deliveries and self-supplied industrial and commercial withdrawals. For this study, total industrial use and public-supplied industrial/ commercial deliveries were estimated at the State level only.

Self-supplied industrial withdrawals are listed by county and by hydrologic subbasin in tables 20 and 21, respectively. For 2005, self-supplied industrial withdrawals were $550 \mathrm{Mgal} / \mathrm{d}$, which is about 6 percent of total withdrawals and about 33 percent of total withdrawals excluding thermoelectric power (table 5). Surface water was the source for 95 percent (523 Mgal/d) of the withdrawals, and ground water was the source of the remaining 5 percent (28 Mgal/d; fig. 31). Statewide, combined public-supplied industrial and commercial deliveries were $355 \mathrm{Mgal} / \mathrm{d}$. Total industrial water use was $906 \mathrm{Mgal} / \mathrm{d}$.

The geographic distribution of total, ground-water, and surface-water withdrawals for self-supplied industrial use by county and by hydrologic subbasin is shown, respectively, in figures 32 and 33. Withdrawals for self-supplied industrial use occurred in 37 counties. About 90 percent of the total withdrawals and 88 percent of the surface-water withdrawals occurred in the 11 counties that withdrew more than $10 \mathrm{Mgal} / \mathrm{d}$ or more (fig. 32). The largest withdrawals occurred in Morgan, Colbert (primarily chemical and allied products), Lawrence, Monroe, and Talladega Counties (primarily paper and allied products), with withdrawals that were more than $50 \mathrm{Mgal} / \mathrm{d}$ each. Withdrawals in these counties accounted for about 57 percent (314 Mgal/d) of the total self-supplied industrial withdrawals.

The Middle Tennessee-Elk hydrologic subregion accounted for 39 percent (214 Mgal/d) of the total selfsupplied industrial withdrawals and 41 percent $(212 \mathrm{Mgal} / \mathrm{d})$ of the surface-water withdrawals, mostly by the chemical, paper, and the allied industries (table 21). Within the Middle Tennessee-Elk hydrologic subregion, the largest total withdrawals occurred in the Wheeler (06030002) and Pickwick Lake (06030005) subbasins. The largest groundwater withdrawals were in the Mobile-Tombigbee hydrologic subregion (13 Mgal/d; primarily paper and allied products) and accounted for about 48 percent of the statewide selfsupplied industrial ground-water withdrawals.

Paper and allied products (SIC 26, $304 \mathrm{Mgal} / \mathrm{d}$ ), chemical and allied products (SIC 28, $152 \mathrm{Mgal} / \mathrm{d}$ ), and lumber and wood products (SIC 24, $52 \mathrm{Mgal} / \mathrm{d}$ ) accounted for 92 percent of total self-supplied industrial withdrawals (fig. 34). Paper and allied products accounted for the largest self-supplied industrial surface-water withdrawals (301 Mgal/d), and chemical and allied products (12 Mgal/d) accounted for the largest self-supplied industrial ground-water withdrawals. The largest withdrawals for paper and allied products, SIC 26, occurred in Lawrence County. Detailed water use by SIC for counties and hydrologic subbasins can be found in Appendixes A and B, respectively.

A progressive shift in source of water for industrial and commercial use from self-supplied to public-supplied water has occurred from $1975(1,770 \mathrm{Mgal} / \mathrm{d}$, highest value of total industrial and commercial use since 1950) through 2005 (906 Mgal/d; Murray and Reeves, 1977; Solley and others, 1983; Solley and others, 1988; Solley and others, 1993; and Solley and others, 1998). The historical data show that publicsupply deliveries to the industrial and commercial sector have increased, for example, from about 15 percent of total industrial and commercial use in 1975, to about 25 percent in 1985, and about 40 percent in 2005 (Murray and Reeves, 1977; Solley and other, 1998). No public-supply delivery data were collected for 2000.

OWR AWURP was the source for site-specific industrial water withdrawal and ancillary data. The Alabama Directory of Manufacturers provided nearly all of the SIC codes for specific industries. Public-supply deliveries to commercial and industrial users were determined at a State level from the Alabama Water System Survey for 2005 (Appendix D). Details are in the "Thermoelectric Power and Industrial" section in the "Data Compilation, Sources of Information, and Methodology" section in this report.

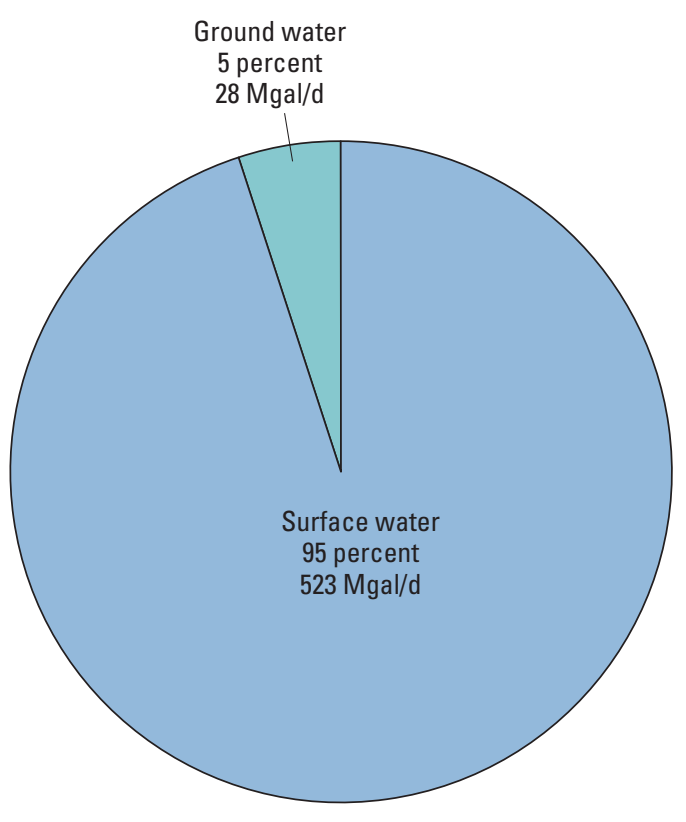

Figure 31. Source of water for self-supplied industrial use in Alabama, 2005. [Mgal/d, million gallons per day; values may not sum to total estimated use because of rounding] 


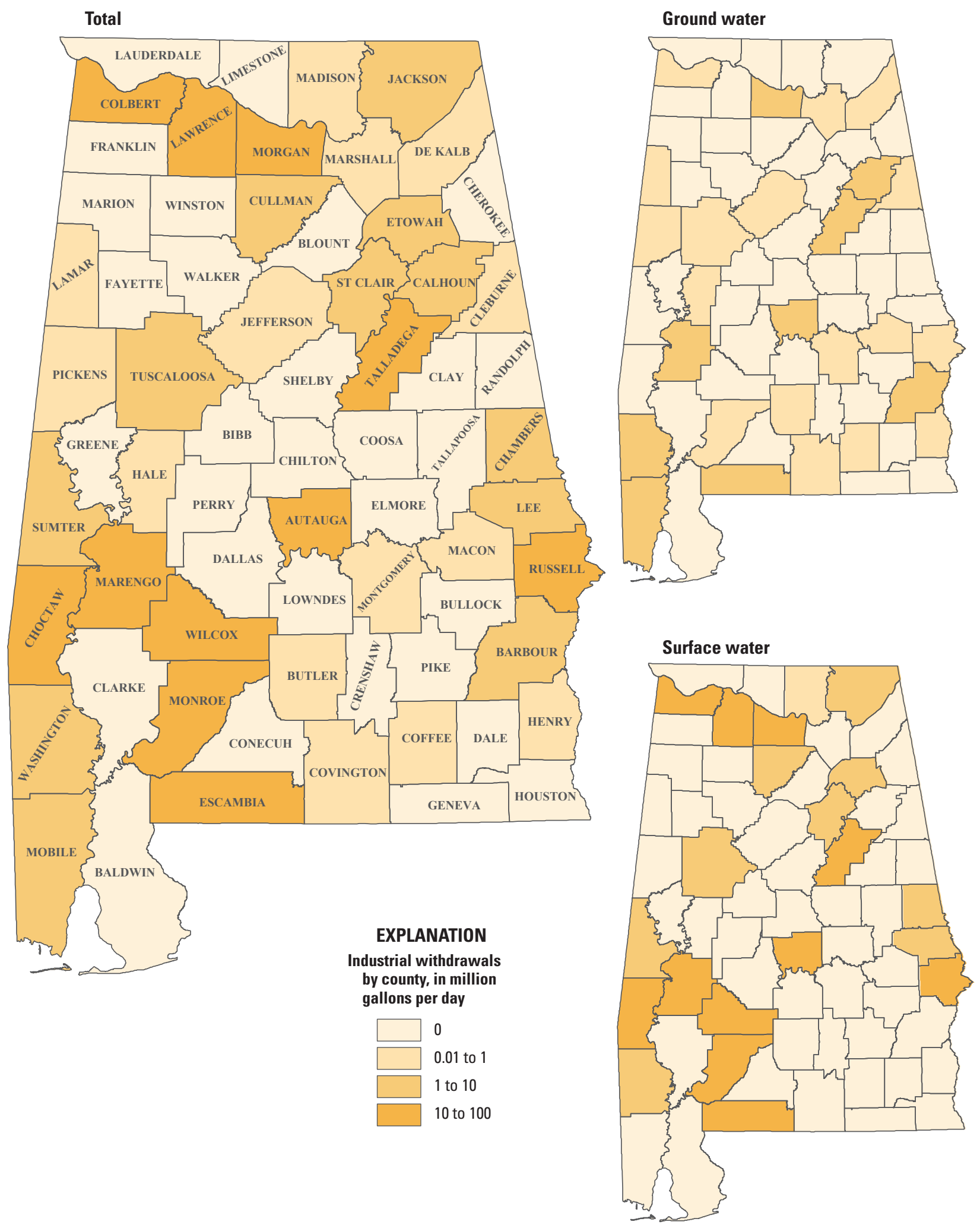

Figure 32. Self-supplied industrial freshwater withdrawals by county in Alabama, 2005. 

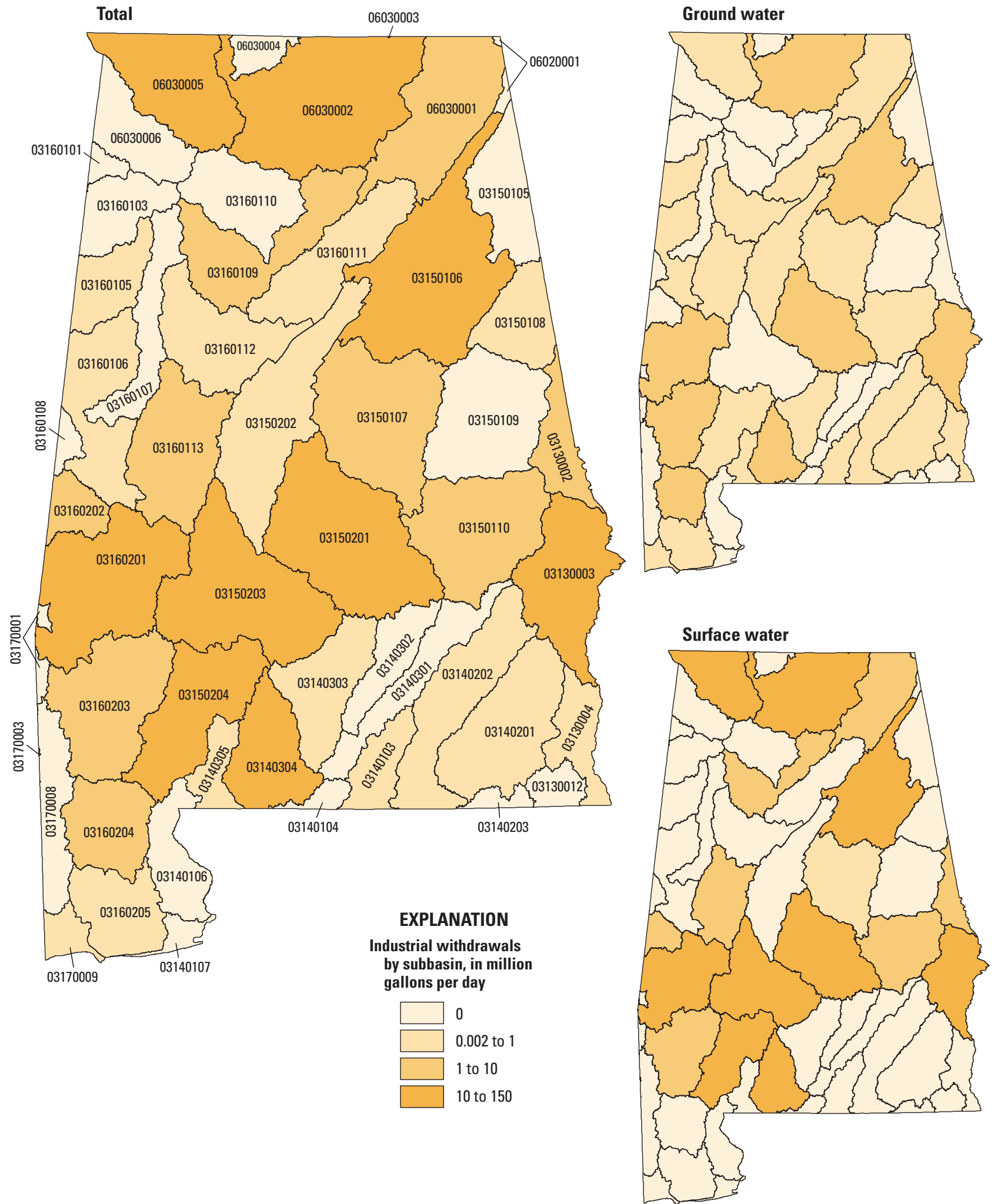

Figure 33. Self-supplied industrial freshwater withdrawals by subbasin in Alabama, 2005. 
Table 20. Self-supplied industrial freshwater withdrawals by county, Alabama, 2005.

[Values may not sum to total estimated use(s) because of rounding]

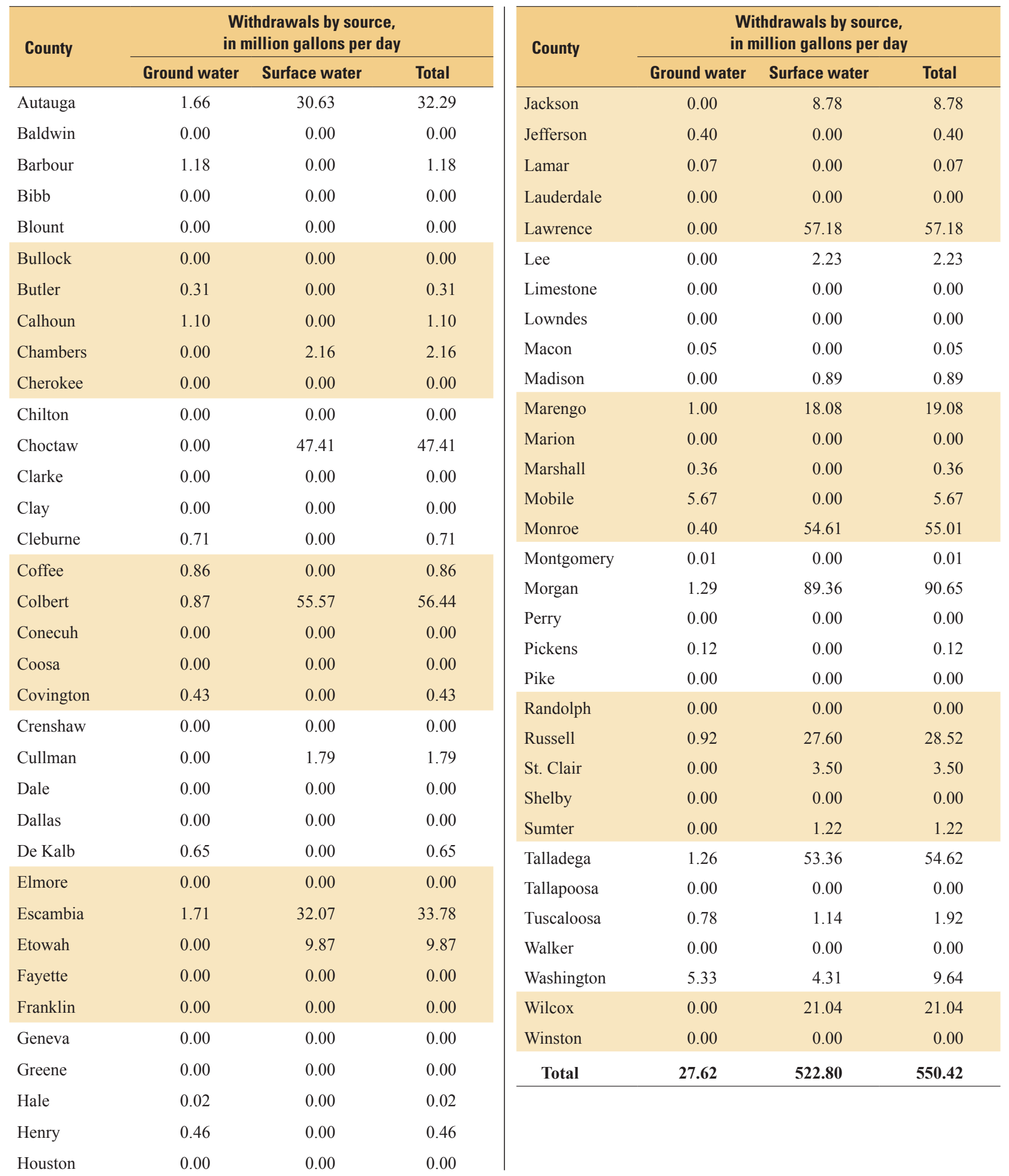


Table 21. Self-supplied industrial freshwater withdrawals by hydrologic subregion and subbasin, Alabama, 2005.

[Values may not sum to total estimated use(s) because of rounding]

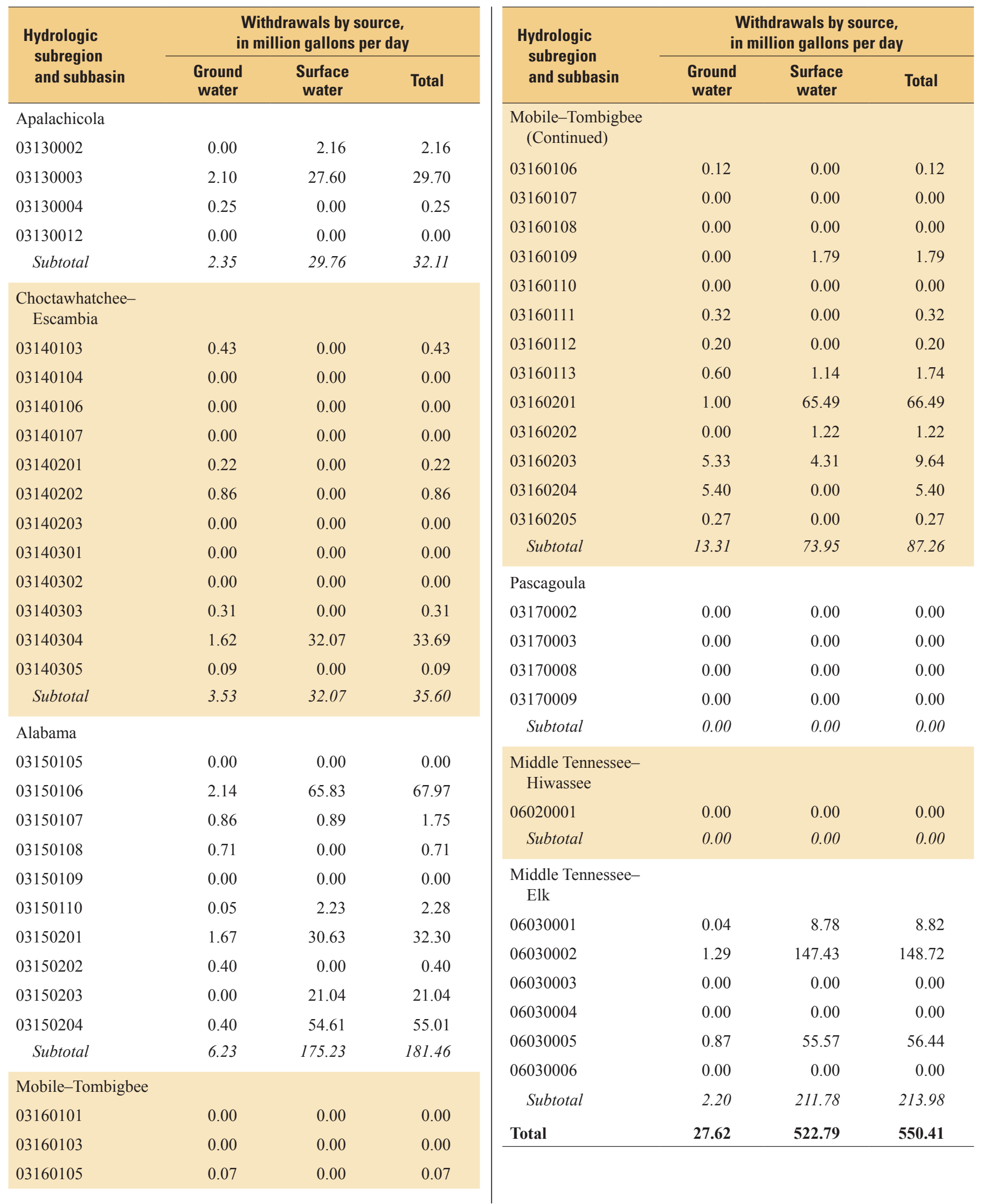




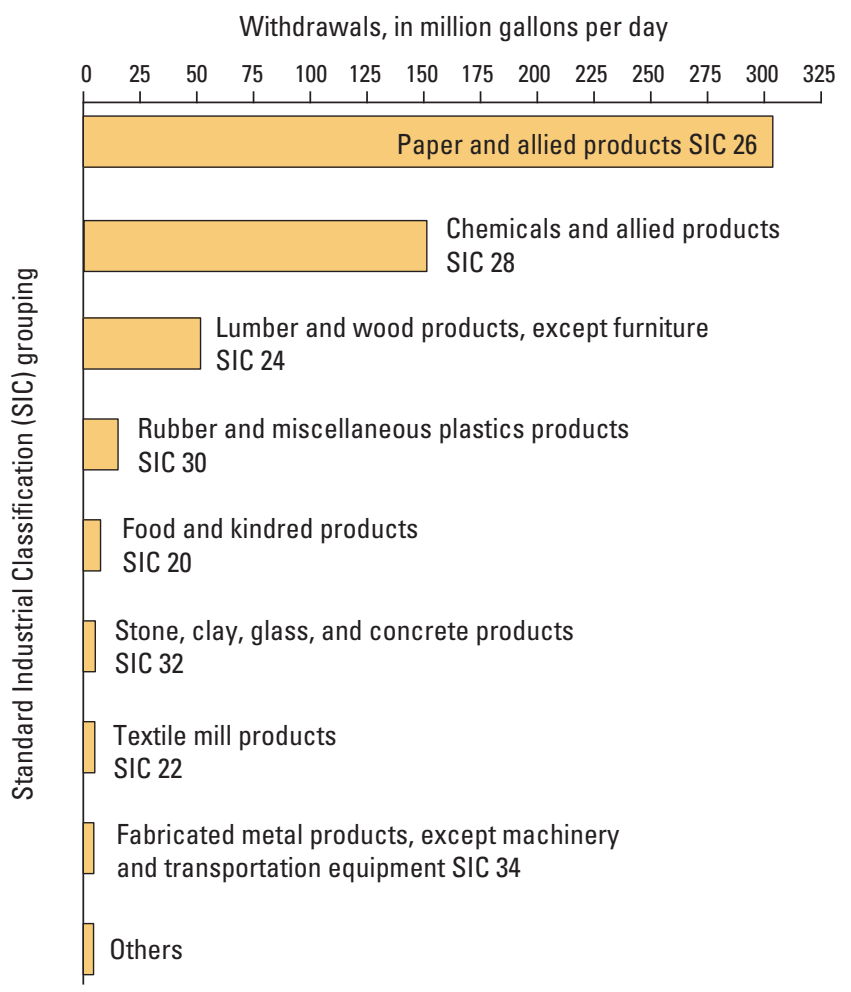

Figure 34. Distribution of total industrial withdrawals by Standard Industrial

Classification grouping in Alabama, 2005.

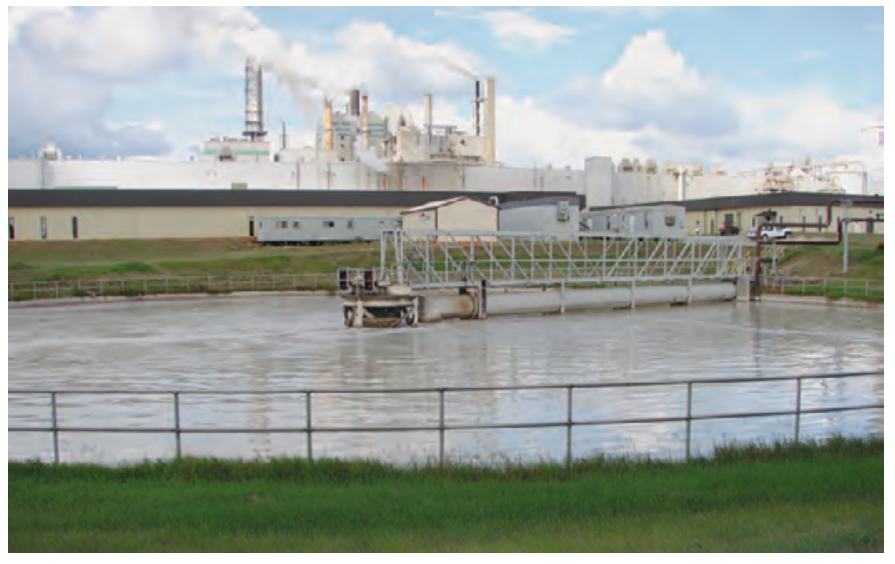

A primary clarifier removes waste fiber associated with paperboard production, Mahrt Mill, Cottonton, Alabama. (Photo courtesy of Tony Owen, MeadWestvaco Corporation, published with permission.)

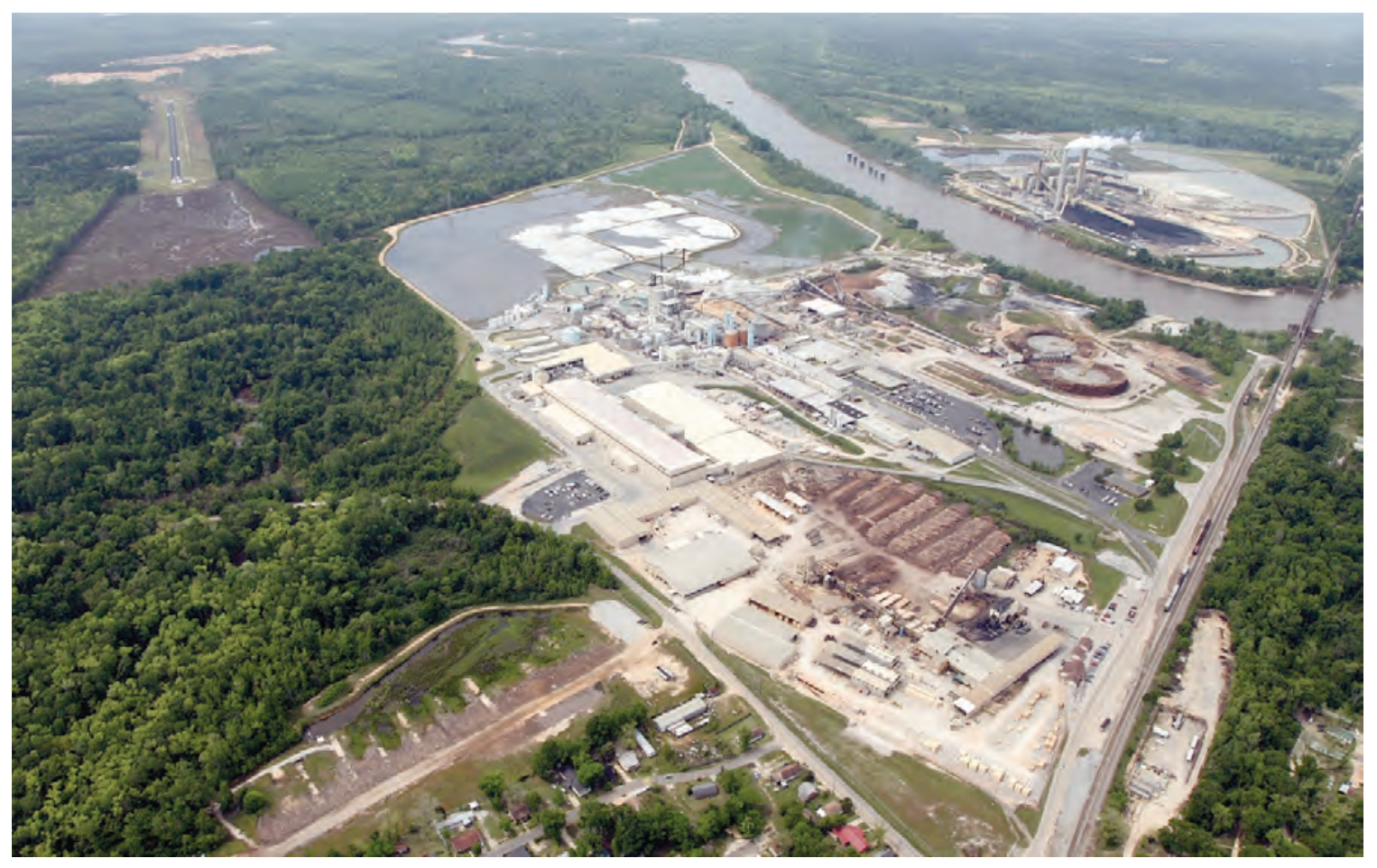

Boise Paper Mill in Jackson, Alabama. (Photo courtesy of Boise Papers, published with permission.) 


\section{Mining}

Mining water refers to water that is used for the extraction of naturally occurring minerals including solids, such as coal, sand, gravel, and other ores; liquids, such as crude petroleum; and gases, such as natural gas. Mining also includes uses associated with quarrying, milling, and other preparations customarily done at a mine site or as part of a mining activity. Mining water use does not include water associated with dewatering of an aquifer that is not put to beneficial use and also does not include water used in processing, such as smelting, refining petroleum, or slurry pipeline operations. These processing uses are included in the industrial category.

Mining water withdrawals are listed by county in table 22. For 2005, total mining withdrawals were $28 \mathrm{Mgal} / \mathrm{d}$, which is less than 1 percent of total withdrawals and nearly 2 percent of total withdrawals for all categories excluding thermoelectric power (table 5). Ground water was the source of about 70 percent $(20 \mathrm{Mgal} / \mathrm{d})$ of withdrawals, and surface water was the source of the remaining 30 percent $(8 \mathrm{Mgal} / \mathrm{d})$ (fig. 35). All water withdrawals were considered fresh although some low-salinity ground water has been tapped in parts of the State (Marlon Cook, Alabama Geological Survey, oral commun., January 2008).

The geographic distribution of total, ground-water, and surface-water withdrawals for mining use by county is shown in figure 36. Barbour, Jefferson, Montgomery, Shelby, Sumter, and Talladega Counties accounted for about half of the total mining water withdrawals. Most of the remaining counties withdrew less than $1.0 \mathrm{Mgal} / \mathrm{d}$, and 20 counties had no mining water use. Coal mining and coal-bed methane production are important to the mining economy in the State. Coal is mined in 17 of the northern counties, and most of the coal is used in-state as fuel for the thermoelectric plants and for coke for the steel industry (Richard Carroll, Alabama Geological Survey, oral commun., September 10, 2008; Geological Survey of Alabama, 2008a; fig. 36). No coal was mined in Cherokee County in 2005.
Coal-bed methane has been produced in Alabama since 1980 in Bibb, Fayette, Jefferson, Shelby, Tuscaloosa, and Walker Counties, primarily in the Black Warrior subregion (Geological Survey of Alabama, 2008a). In 2005, more than 67.6 million barrels of water (about $5.83 \mathrm{Mgal} / \mathrm{d}$ ) were produced along with 117 million cubic feet of gas (Geological Survey of Alabama, 2008b, c). The produced water estimate was determined at the State-level only, and is not included in the total mining withdrawals (table 22).

Mining water use was estimated by the USGS-NWUIP from per ton coefficients and from crude ore production in tons for 2004 from the USGS Minerals Information Team and coal production in tons from the DOE-EIA. The estimates were part of the USGS NWUIP national effort to estimate water use for the United States for 2005. Some mine site date were from OWR AWURP.

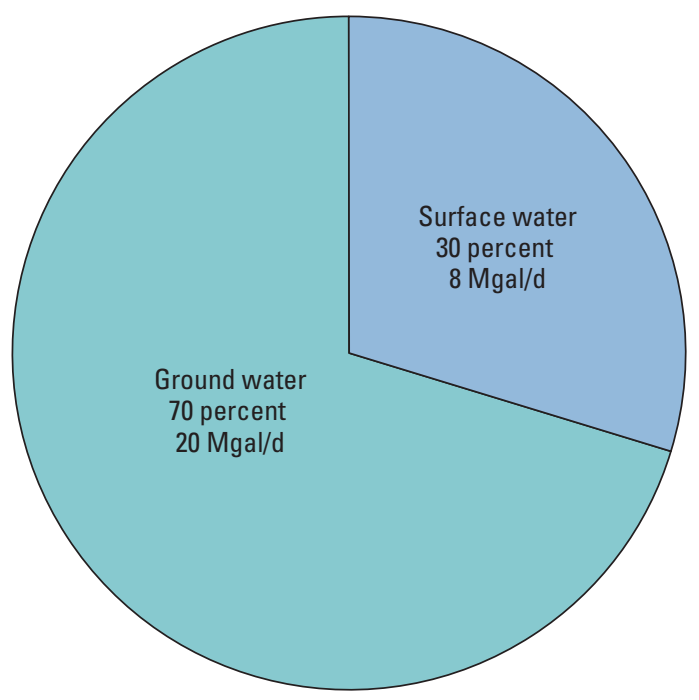

Figure 35. Source of water for mining use in Alabama, 2005. [Mgal/d, million gallons per day; values may not sum to total estimated use because of rounding] 


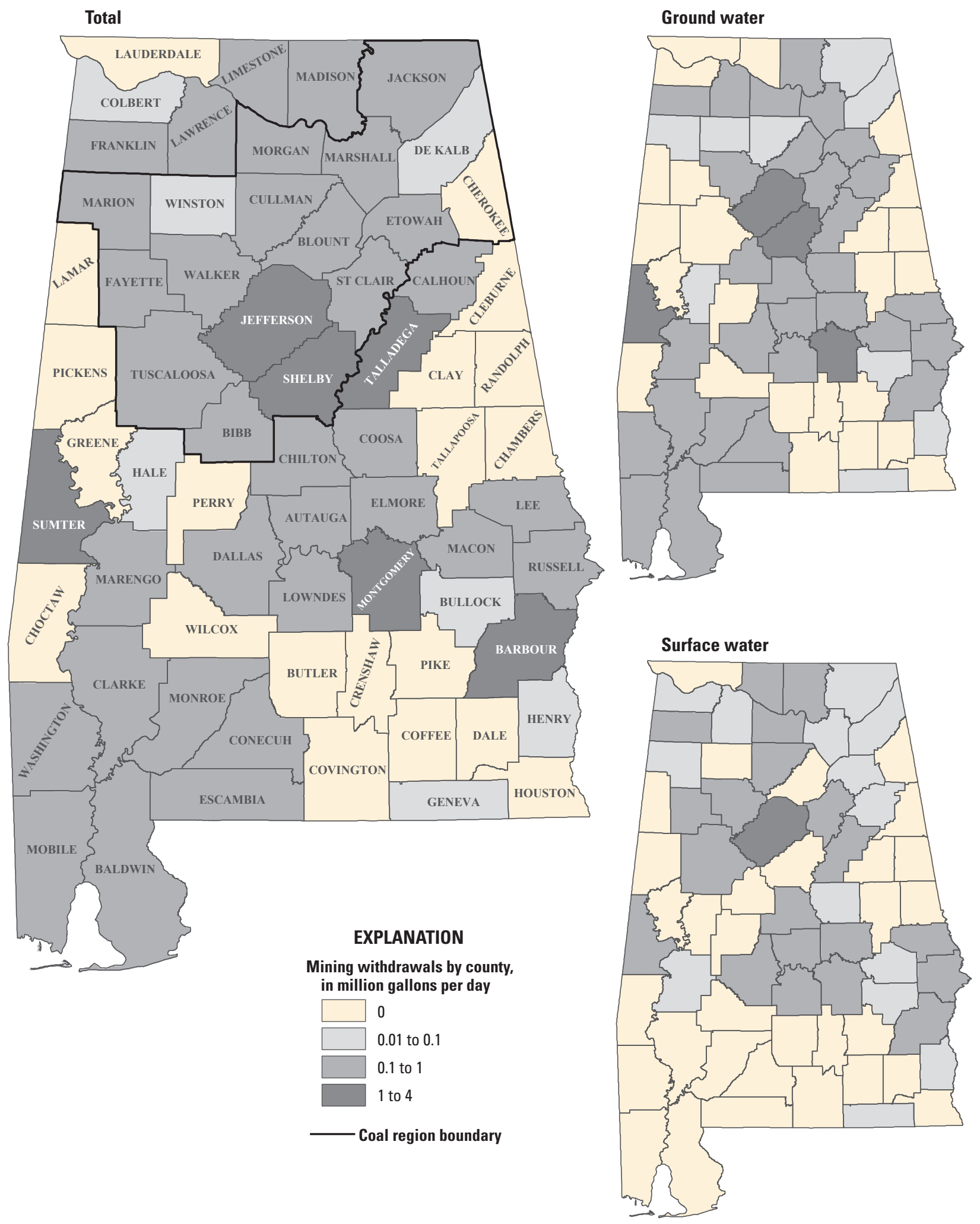

Figure 36. Mining freshwater withdrawals by county in Alabama, 2005. 
Table 22. Mining freshwater withdrawals by county, Alabama, 2005.

[Values may not sum to total estimated use(s) because of rounding]

\begin{tabular}{|c|c|c|c|}
\hline \multirow{2}{*}{ County } & \multicolumn{3}{|c|}{$\begin{array}{l}\text { Withdrawals by source, } \\
\text { in million gallons per day }\end{array}$} \\
\hline & $\begin{array}{l}\text { Ground } \\
\text { water }\end{array}$ & $\begin{array}{c}\text { Surface } \\
\text { water }\end{array}$ & Total \\
\hline Autauga & 0.29 & 0.14 & 0.43 \\
\hline Baldwin & 0.63 & 0.00 & 0.63 \\
\hline Barbour & 0.82 & 0.38 & 1.20 \\
\hline Bibb & 0.17 & 0.00 & 0.17 \\
\hline Blount & 0.27 & 0.00 & 0.27 \\
\hline Bullock & 0.04 & 0.02 & 0.06 \\
\hline Butler & 0.00 & 0.00 & 0.00 \\
\hline Calhoun & 0.19 & 0.09 & 0.28 \\
\hline Chambers & 0.00 & 0.00 & 0.00 \\
\hline Cherokee & 0.00 & 0.00 & 0.00 \\
\hline Chilton & 0.32 & 0.15 & 0.47 \\
\hline Choctaw & 0.00 & 0.00 & 0.00 \\
\hline Clarke & 0.11 & 0.00 & 0.11 \\
\hline Clay & 0.00 & 0.00 & 0.00 \\
\hline Cleburne & 0.00 & 0.00 & 0.00 \\
\hline Coffee & 0.00 & 0.00 & 0.00 \\
\hline Colbert & 0.00 & 0.05 & 0.05 \\
\hline Conecuh & 0.11 & 0.00 & 0.11 \\
\hline Coosa & 0.11 & 0.05 & 0.16 \\
\hline Covington & 0.00 & 0.00 & 0.00 \\
\hline Crenshaw & 0.00 & 0.00 & 0.00 \\
\hline Cullman & 0.04 & 0.12 & 0.16 \\
\hline Dale & 0.00 & 0.00 & 0.00 \\
\hline Dallas & 0.57 & 0.26 & 0.83 \\
\hline De Kalb & 0.04 & 0.02 & 0.06 \\
\hline Elmore & 0.21 & 0.10 & 0.31 \\
\hline Escambia & 0.67 & 0.00 & 0.67 \\
\hline Etowah & 0.11 & 0.05 & 0.16 \\
\hline Fayette & 0.00 & 0.80 & 0.80 \\
\hline Franklin & 0.39 & 0.18 & 0.57 \\
\hline Geneva & 0.02 & 0.01 & 0.03 \\
\hline Greene & 0.00 & 0.00 & 0.00 \\
\hline Hale & 0.04 & 0.00 & 0.04 \\
\hline Henry & 0.02 & 0.01 & 0.03 \\
\hline Houston & 0.00 & 0.00 & 0.00 \\
\hline
\end{tabular}

\begin{tabular}{|c|c|c|c|}
\hline \multirow{2}{*}{ County } & \multicolumn{3}{|c|}{$\begin{array}{l}\text { Withdrawals by source, } \\
\text { in million gallons per day }\end{array}$} \\
\hline & $\begin{array}{l}\text { Ground } \\
\text { water }\end{array}$ & $\begin{array}{c}\text { Surface } \\
\text { water }\end{array}$ & Total \\
\hline Jackson & 0.07 & 0.03 & 0.10 \\
\hline Jefferson & 1.93 & 1.47 & 3.40 \\
\hline Lamar & 0.00 & 0.00 & 0.00 \\
\hline Lauderdale & 0.00 & 0.00 & 0.00 \\
\hline Lawrence & 0.16 & 0.07 & 0.23 \\
\hline Lee & 0.26 & 0.12 & 0.38 \\
\hline Limestone & 0.00 & 0.50 & 0.50 \\
\hline Lowndes & 0.30 & 0.14 & 0.44 \\
\hline Macon & 0.12 & 0.06 & 0.18 \\
\hline Madison & 0.48 & 0.22 & 0.70 \\
\hline Marengo & 0.19 & 0.09 & 0.28 \\
\hline Marion & 0.04 & 0.09 & 0.13 \\
\hline Marshall & 0.19 & 0.09 & 0.28 \\
\hline Mobile & 0.46 & 0.00 & 0.46 \\
\hline Monroe & 0.11 & 0.00 & 0.11 \\
\hline Montgomery & 1.31 & 0.61 & 1.92 \\
\hline Morgan & 0.37 & 0.17 & 0.54 \\
\hline Perry & 0.00 & 0.00 & 0.00 \\
\hline Pickens & 0.00 & 0.00 & 0.00 \\
\hline Pike & 0.00 & 0.00 & 0.00 \\
\hline Randolph & 0.00 & 0.00 & 0.00 \\
\hline Russell & 0.46 & 0.22 & 0.68 \\
\hline St. Clair & 0.59 & 0.28 & 0.87 \\
\hline Shelby & 3.90 & 0.00 & 3.90 \\
\hline Sumter & 1.63 & 0.76 & 2.39 \\
\hline Talladega & 0.75 & 0.35 & 1.10 \\
\hline Tallapoosa & 0.00 & 0.00 & 0.00 \\
\hline Tuscaloosa & 0.00 & 0.25 & 0.25 \\
\hline Walker & 0.10 & 0.31 & 0.41 \\
\hline Washington & 0.91 & 0.00 & 0.91 \\
\hline Wilcox & 0.00 & 0.00 & 0.00 \\
\hline Winston & 0.06 & 0.00 & 0.06 \\
\hline Total & 19.56 & 8.26 & 27.82 \\
\hline
\end{tabular}


This series of photographs illustrates various uses of water for production processes and air-pollution control on mining sites in Alabama. (All photos courtesy of Joe Howle, Vulcan Construction Materials, published with permission.)

Production. Sand screw used to classify manufactured sand.

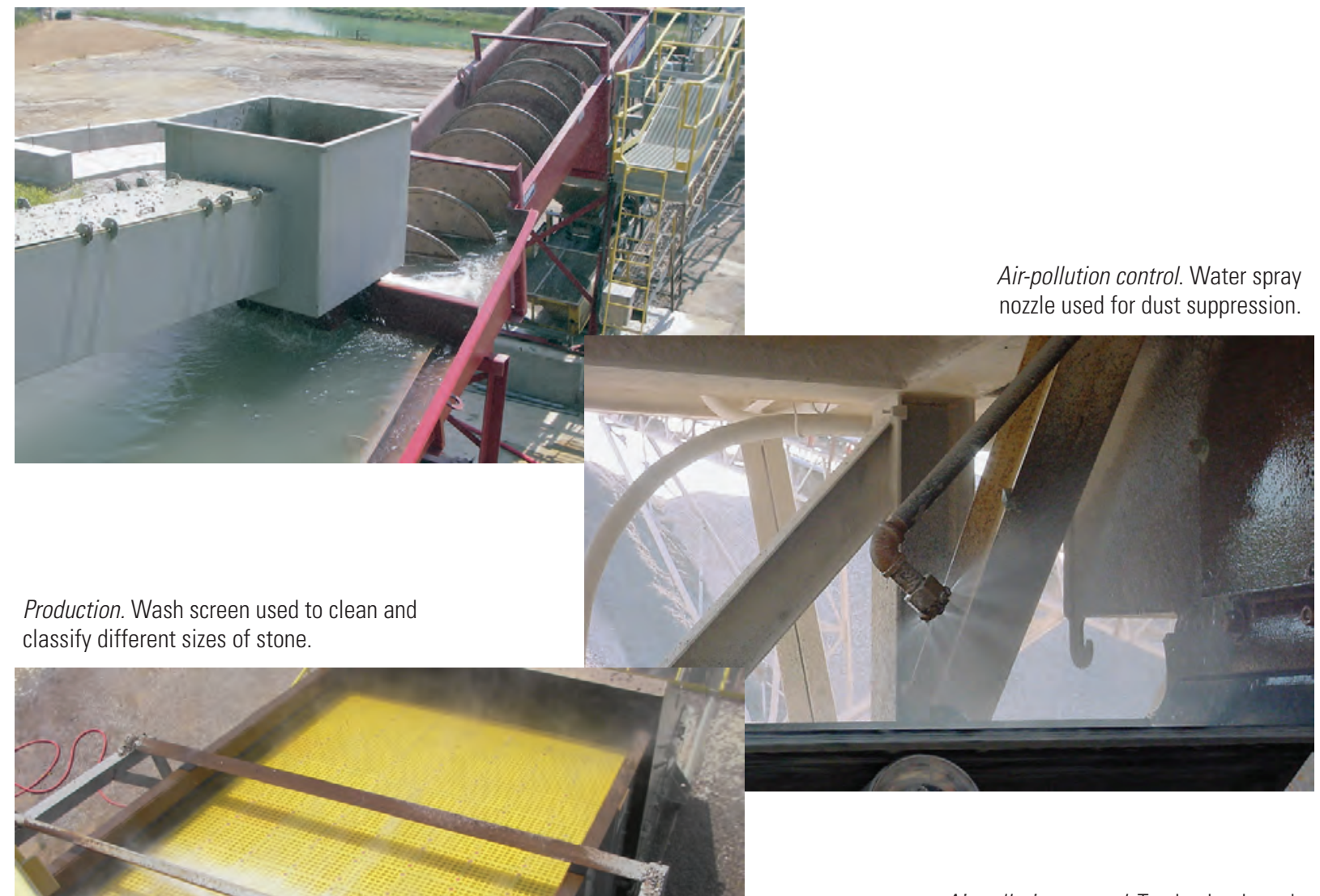

Air pollution control. Truck wheel wash

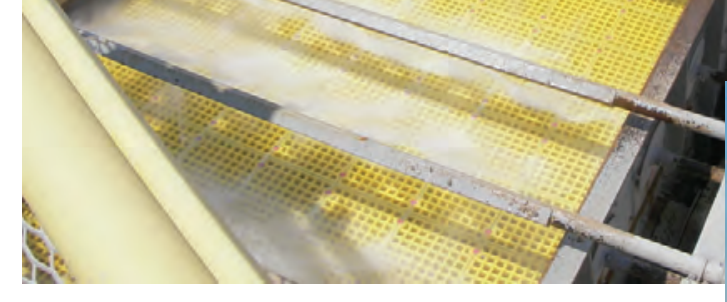
system used for dust suppression on roads.

Air pollution control. Water truck used for dust suppression on roads.

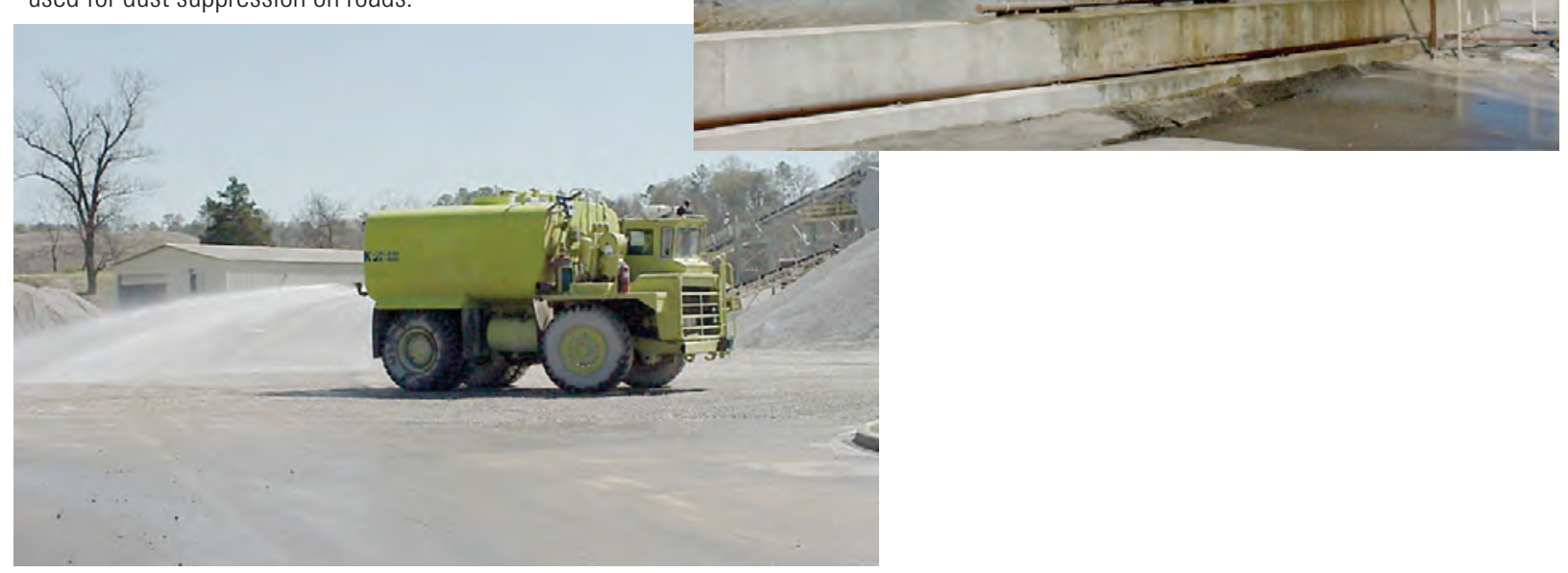




\section{Thermoelectric Power}

Thermoelectric-power water is water used in the process of generating electricity with steam-driven turbine generators and for other onsite needs. For 2005, thermoelectric-power water withdrawals were compiled by cooling-system type because cooling system type is the primary determinant for the amount of consumptive use relative to withdrawals. Oncethrough cooling (also known as open-loop cooling) refers to cooling systems in which water is withdrawn from a source, circulated through heat exchangers, and then returned to a surface-water body. Recirculating cooling (also known as closed-loop cooling) refers to cooling systems in which water is withdrawn from a source, circulated through heat exchangers, cooled, and then recycled. Subsequent water withdrawals for a recirculating-cooling system are used to replace water lost to evaporation, blowdown, drift, and leakage. Thermoelectricpower withdrawals were reported by the USGS by condenser cooling water use from 1950 to 1980, by fuel-type from 1985 through 1995, and by cooling type for 2000 and 2005 .

Total thermoelectric-power water withdrawals are listed by county and hydrologic subbasin in tables 23 and 24. Total thermoelectric-power water withdrawals by cooling type are listed by county and hydrologic subbasin in tables 25 and 26 . The total quantity of water withdrawn for thermoelectric power in 2005 was $8,274 \mathrm{Mgal} / \mathrm{d}$. Surface water was the source for more than 99 percent of the water. Ground water was the source for $0.22 \mathrm{Mgal} / \mathrm{d}$. Thermoelectric-power withdrawals accounted for 83 percent of total water withdrawals and 87 percent of total surface-water withdrawals. Thermoelectric-power plants that used self-supplied water produced 114,144 net gigawatt-hours of energy in 2005.

The geographic distribution of total, ground-water, and surface-water withdrawals for thermoelectric power by county and hydrologic subbasin are shown respectively in figures 37 and 38. Although some power generation occurs in every hydrologic subregion with the exception of Pascagoula, water was used in power generation in only 13 counties (tables 23 and 24). For the Middle Tennessee-Hiwassee subregion, power was generated in the State of Tennessee (fig. 3). The largest total and surface-water withdrawals were in Limestone, Jackson, Colbert (Middle Tennessee-Elk subregion), and Mobile (Mobile-Tombigbee subregion) Counties.

Power plants equipped with once-through cooling systems accounted for 98 percent of water withdrawals for thermoelectric power in Alabama (tables 25 and 26). The percentage of consumptive use from generating units with once-through cooling ranged from zero to nearly 7 percent (median, 0.1 percent) compared to the percentage of consumptive use from generating units with recirculating cooling, which ranged from about 30 percent to 65 percent (median 44 percent; Energy Information Administration, 2008). Recirculating-cooling units require less water. For 2005 , water use ranged from about $1.0 \mathrm{Mgal} / \mathrm{d}$ per recirculatingcooling generating unit to a little more than $40 \mathrm{Mgal} / \mathrm{d}$ per generating unit; water use ranged from slightly less than $60 \mathrm{Mgal} / \mathrm{d}$ to nearly $1,500 \mathrm{Mgal} / \mathrm{d}$ per once-through generating unit. A comparison of a once-through cooling plant to a recirculatingcooling plant showed that a once-through cooling generating unit typically used about 60 gallons of water to produce 1 kilowatthour (kWh) of electricity; a recirculating-cooling generating unit typically used about 20 gallons of water to produce $1 \mathrm{kWh}$ of electricity (Energy Information Administration, 2008).

Sources of data for thermoelectric power were OWRAWURP, DOE-EIA, and individual facilities. The AWURP eWater database included monthly average-daily water withdrawals, source of water, and location information. For 2005, steam-electric plants generating 100 megawatts or more provided cooling type, water withdrawal, return flow, and consumptive use by generating unit (except for nuclear power plants) to DOE-EIA and all power plants provided power generation by generating unit (Energy Information Administration, 2008, 2009a, b). Details are in the "Thermoelectric Power and Industrial" section in the "Data Compilation, Sources of Information, and Methodology" section in this report.

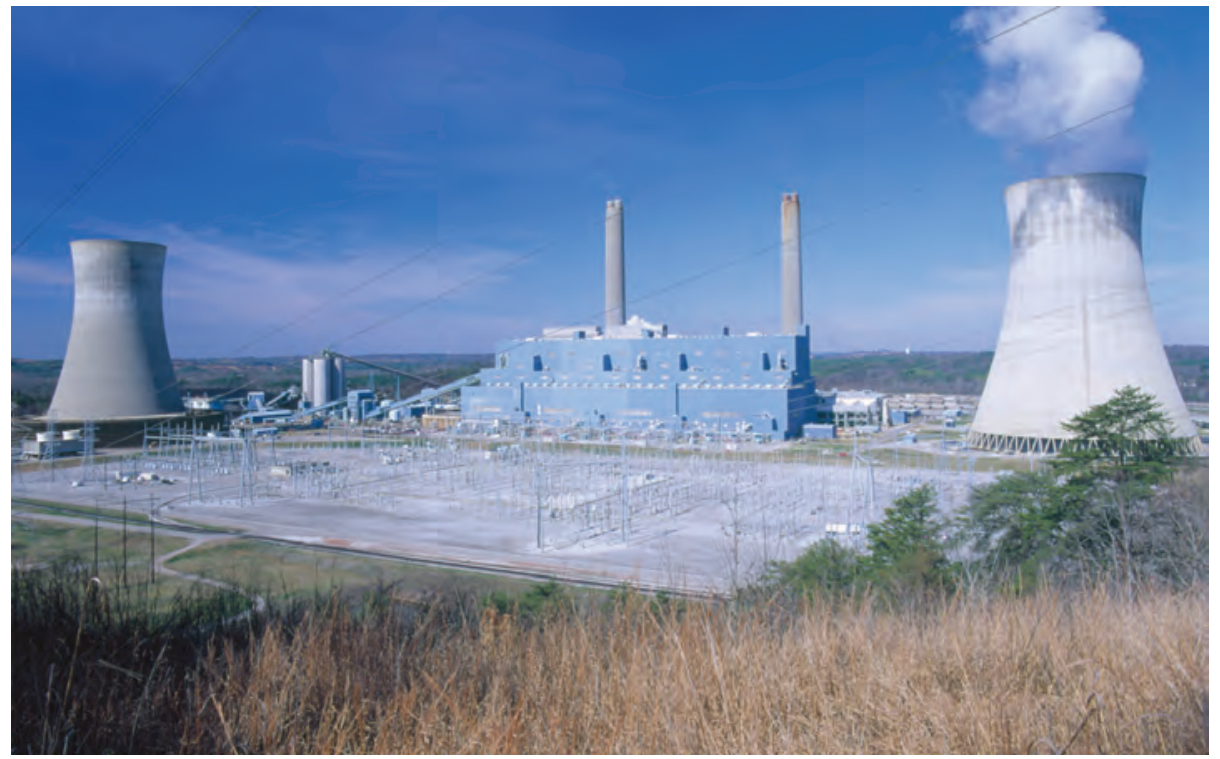

The coal-fired James $\mathrm{H}$.

Miller Steam Plant employs a recirculating-induced draft tower to cool water before release as return flow to the Mulberry Fork of the Black Warrior River. (Photo courtesy of Sheila A. Garrett, Alabama Power Company, published with permission.) 


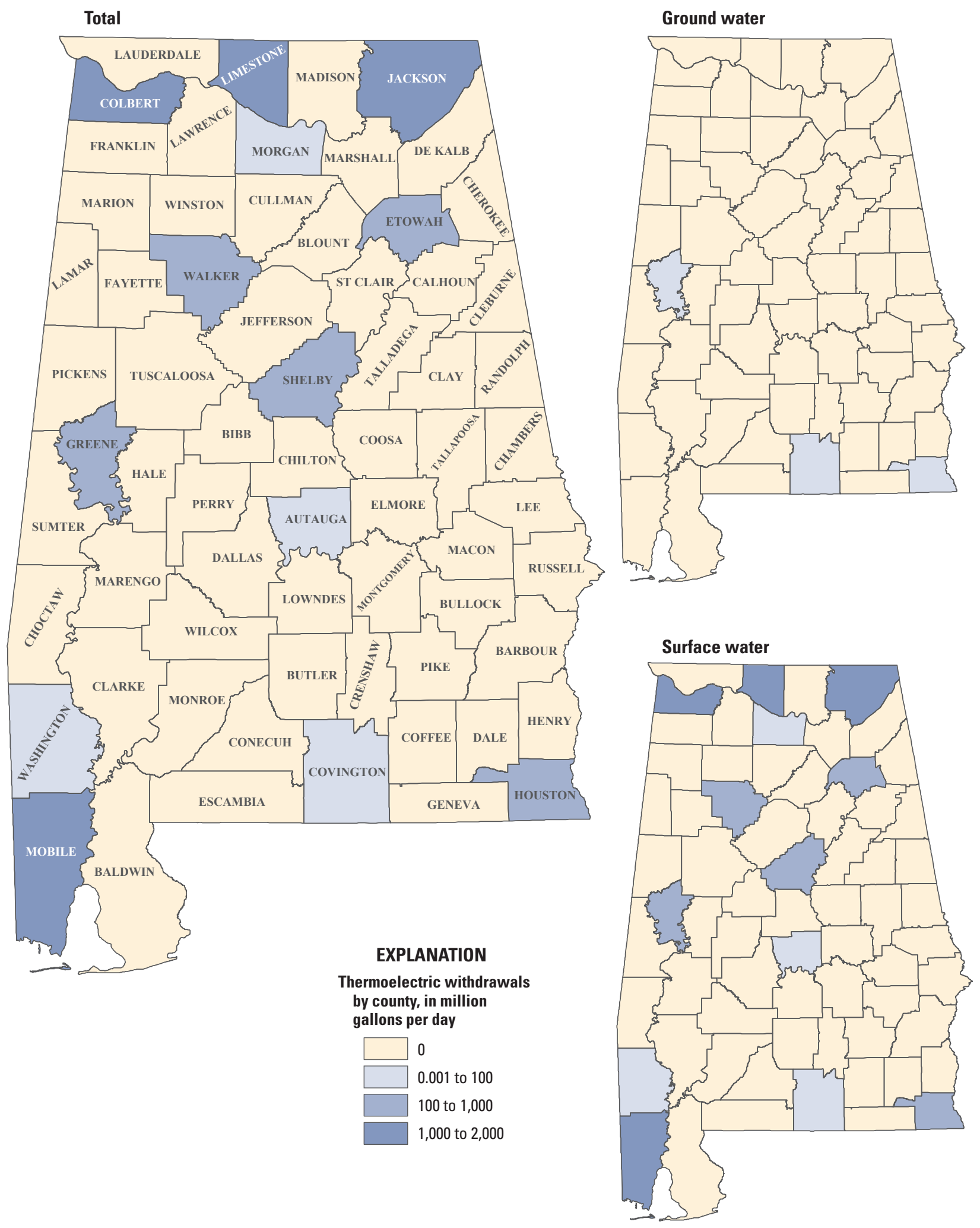

Figure 37. Thermoelectric-power freshwater withdrawals by source and county in Alabama, 2005. 

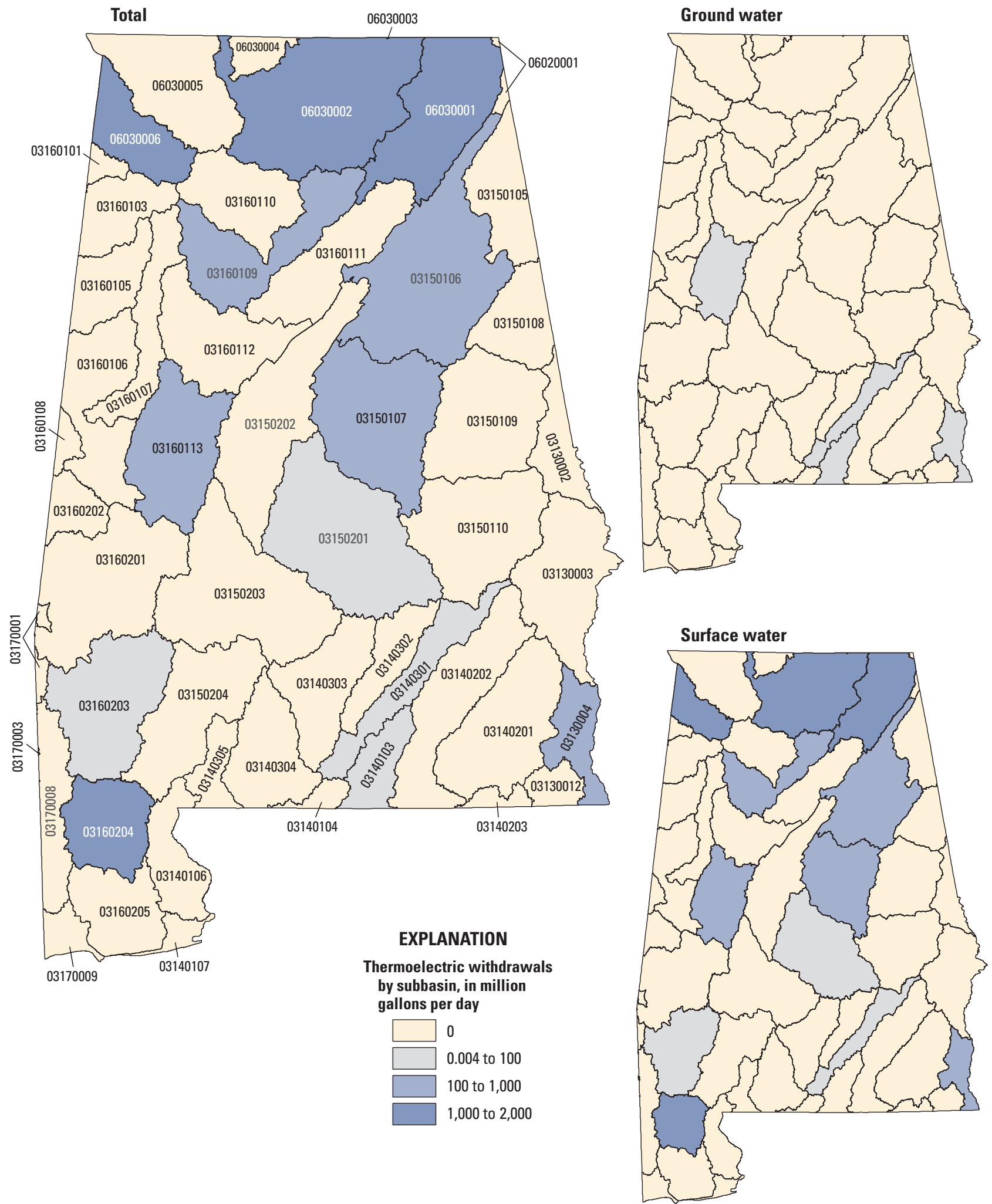

Figure 38. Thermoelectric-power freshwater withdrawals by source and subbasin in Alabama, 2005. 
Table 23. Total thermoelectric-power freshwater withdrawals by county, Alabama, 2005.

[Values may not sum to total estimated use(s) because of rounding]

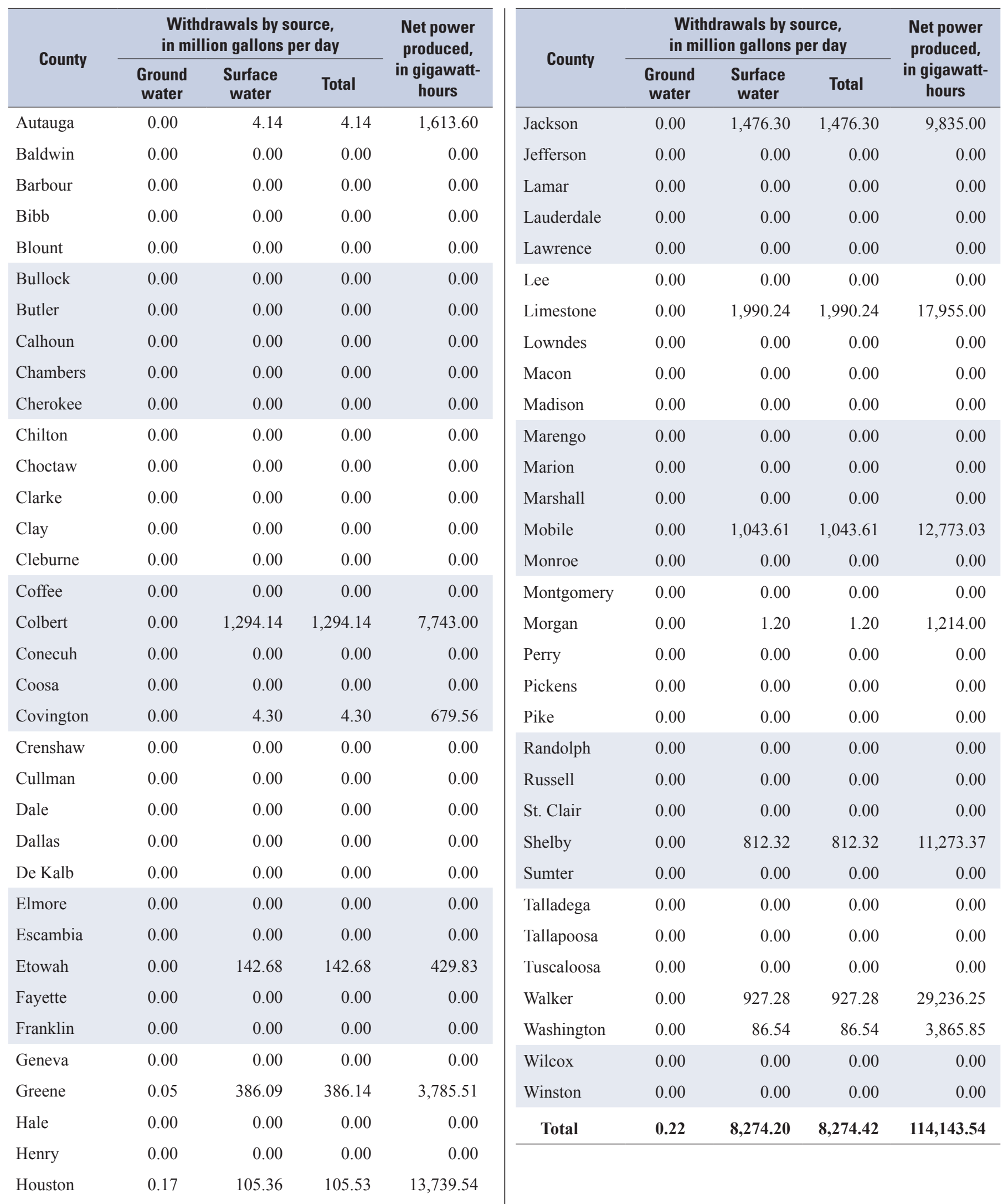


Table 24. Total thermoelectric-power freshwater withdrawals by hydrologic subregion and subbasin, Alabama, 2005.

[Values may not sum to total estimated use(s) because of rounding]

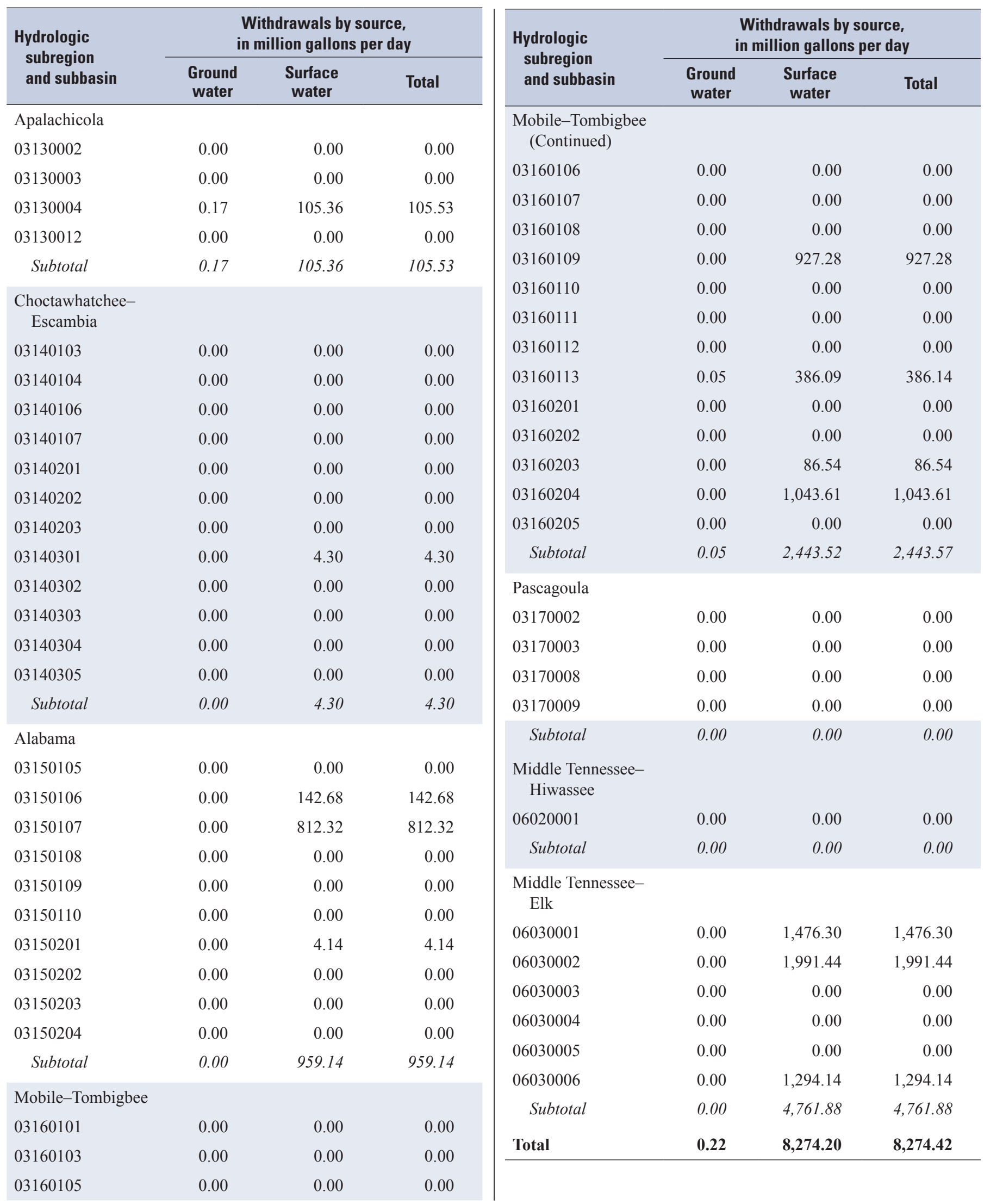


Table 25. Thermoelectric-power freshwater withdrawals by cooling type and by county, Alabama, 2005.

[Values may not sum to total estimated use(s) because of rounding]

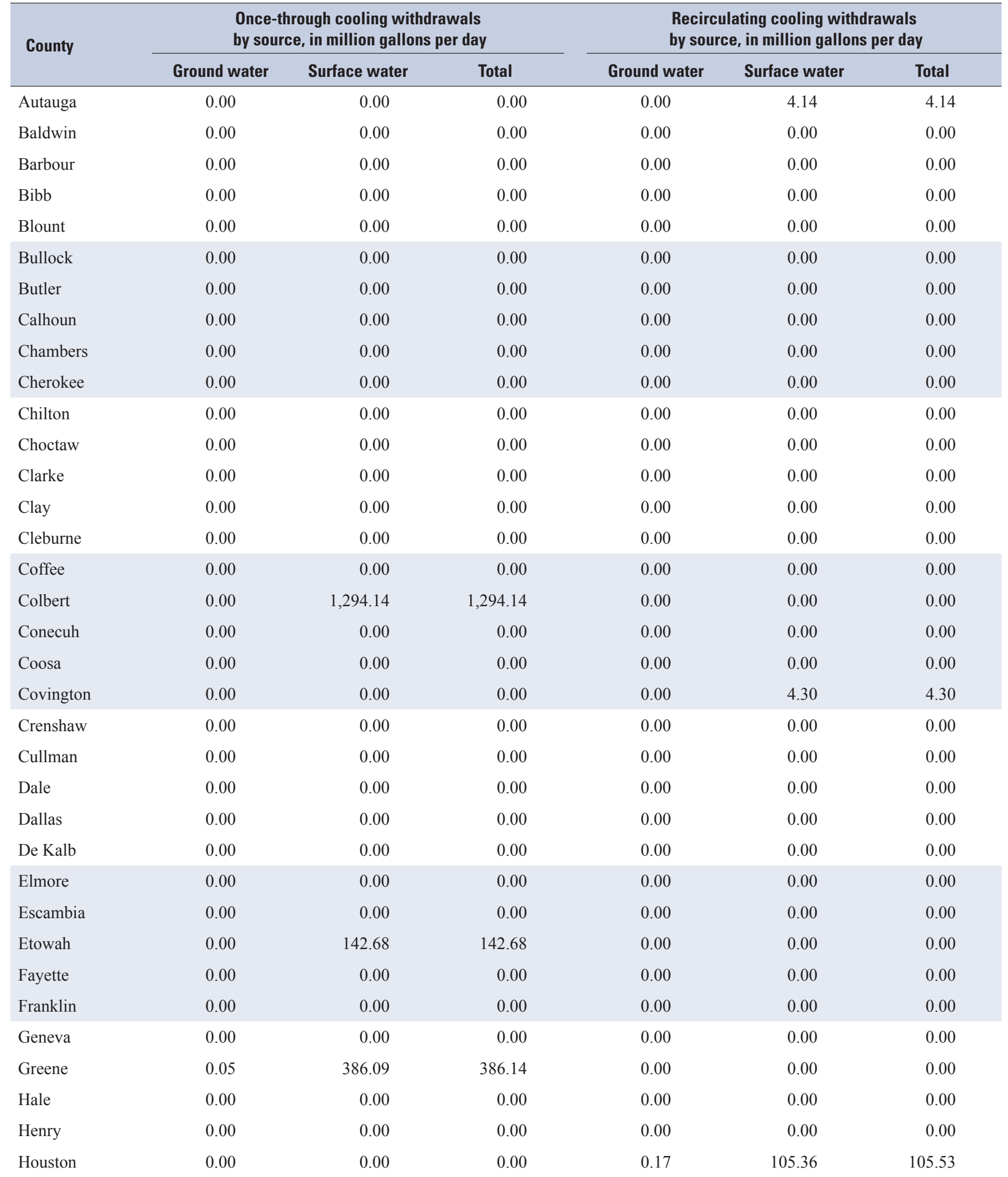


Table 25. Thermoelectric-power freshwater withdrawals by cooling type and by county, Alabama, 2005.—Continued

[Values may not sum to total estimated use(s) because of rounding]

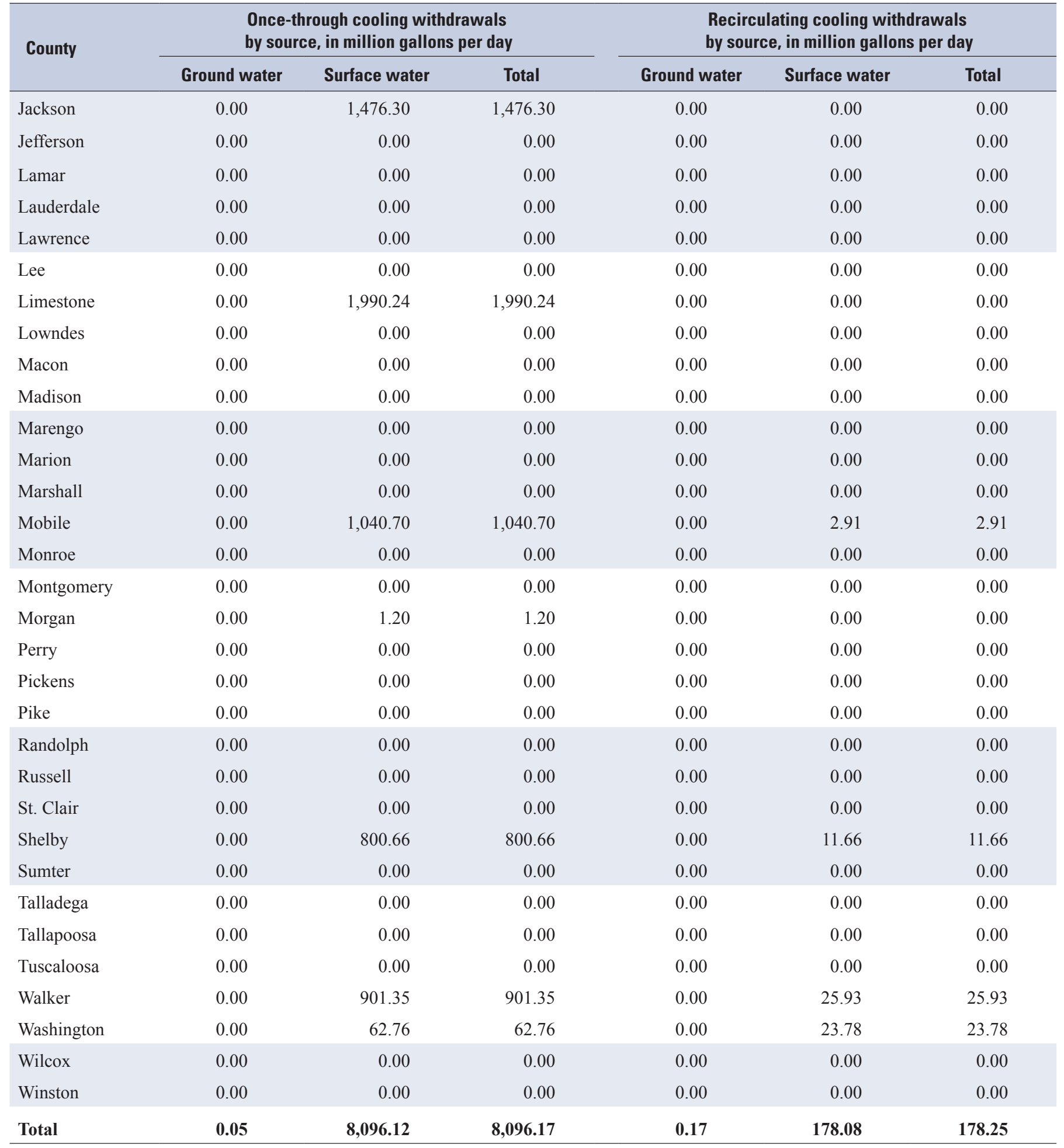


Table 26. Thermoelectric-power freshwater withdrawals by cooling type and by hydrologic subregion and subbasin, Alabama, 2005.

[Values may not sum to total estimated use(s) because of rounding]

\begin{tabular}{|c|c|c|c|c|c|c|}
\hline \multirow{2}{*}{$\begin{array}{l}\text { Hydrologic } \\
\text { subregion } \\
\text { and subbasin }\end{array}$} & \multicolumn{3}{|c|}{$\begin{array}{l}\text { Once-through cooling withdrawals } \\
\text { by source, in million gallons per day }\end{array}$} & \multicolumn{3}{|c|}{$\begin{array}{l}\text { Recirculating cooling withdrawals } \\
\text { by source, in million gallons per day }\end{array}$} \\
\hline & Ground water & Surface water & Total & Ground water & Surface water & Total \\
\hline 03130002 & 0.00 & 0.00 & 0.00 & 0.00 & 0.00 & 0.00 \\
\hline 03130003 & 0.00 & 0.00 & 0.00 & 0.00 & 0.00 & 0.00 \\
\hline 03130012 & 0.00 & 0.00 & 0.00 & 0.00 & 0.00 & 0.00 \\
\hline Subtotal & 0.00 & 0.00 & 0.00 & 0.17 & 105.36 & 105.53 \\
\hline \multicolumn{7}{|c|}{$\begin{array}{l}\text { Choctawhatchee- } \\
\text { Escambia }\end{array}$} \\
\hline 03140107 & 0.00 & 0.00 & 0.00 & 0.00 & 0.00 & 0.00 \\
\hline 03140201 & 0.00 & 0.00 & 0.00 & 0.00 & 0.00 & 0.00 \\
\hline 03140202 & 0.00 & 0.00 & 0.00 & 0.00 & 0.00 & 0.00 \\
\hline 03140203 & 0.00 & 0.00 & 0.00 & 0.00 & 0.00 & 0.00 \\
\hline 03140301 & 0.00 & 0.00 & 0.00 & 0.00 & 4.30 & 4.30 \\
\hline 03140302 & 0.00 & 0.00 & 0.00 & 0.00 & 0.00 & 0.00 \\
\hline 03140303 & 0.00 & 0.00 & 0.00 & 0.00 & 0.00 & 0.00 \\
\hline 03140304 & 0.00 & 0.00 & 0.00 & 0.00 & 0.00 & 0.00 \\
\hline \multicolumn{7}{|l|}{ Alabama } \\
\hline 03150107 & 0.00 & 800.66 & 800.66 & 0.00 & 11.66 & 11.66 \\
\hline 03150108 & 0.00 & 0.00 & 0.00 & 0.00 & 0.00 & 0.00 \\
\hline 03150109 & 0.00 & 0.00 & 0.00 & 0.00 & 0.00 & 0.00 \\
\hline 03150110 & 0.00 & 0.00 & 0.00 & 0.00 & 0.00 & 0.00 \\
\hline 03150201 & 0.00 & 0.00 & 0.00 & 0.00 & 4.14 & 4.14 \\
\hline 03150202 & 0.00 & 0.00 & 0.00 & 0.00 & 0.00 & 0.00 \\
\hline 03150203 & 0.00 & 0.00 & 0.00 & 0.00 & 0.00 & 0.00 \\
\hline 03150204 & 0.00 & 0.00 & 0.00 & 0.00 & 0.00 & 0.00 \\
\hline Subtotal & 0.00 & 943.34 & 943.34 & 0.00 & 15.80 & 15.80 \\
\hline \multicolumn{7}{|c|}{ Mobile-Tombigbee } \\
\hline 03160101 & 0.00 & 0.00 & 0.00 & 0.00 & 0.00 & 0.00 \\
\hline 03160103 & 0.00 & 0.00 & 0.00 & 0.00 & 0.00 & 0.00 \\
\hline 03160105 & 0.00 & 0.00 & 0.00 & 0.00 & 0.00 & 0.00 \\
\hline
\end{tabular}


Table 26. Thermoelectric-power freshwater withdrawals by cooling type and by hydrologic subregion and subbasin, Alabama, 2005. -Continued

[Values may not sum to total estimated use(s) because of rounding]

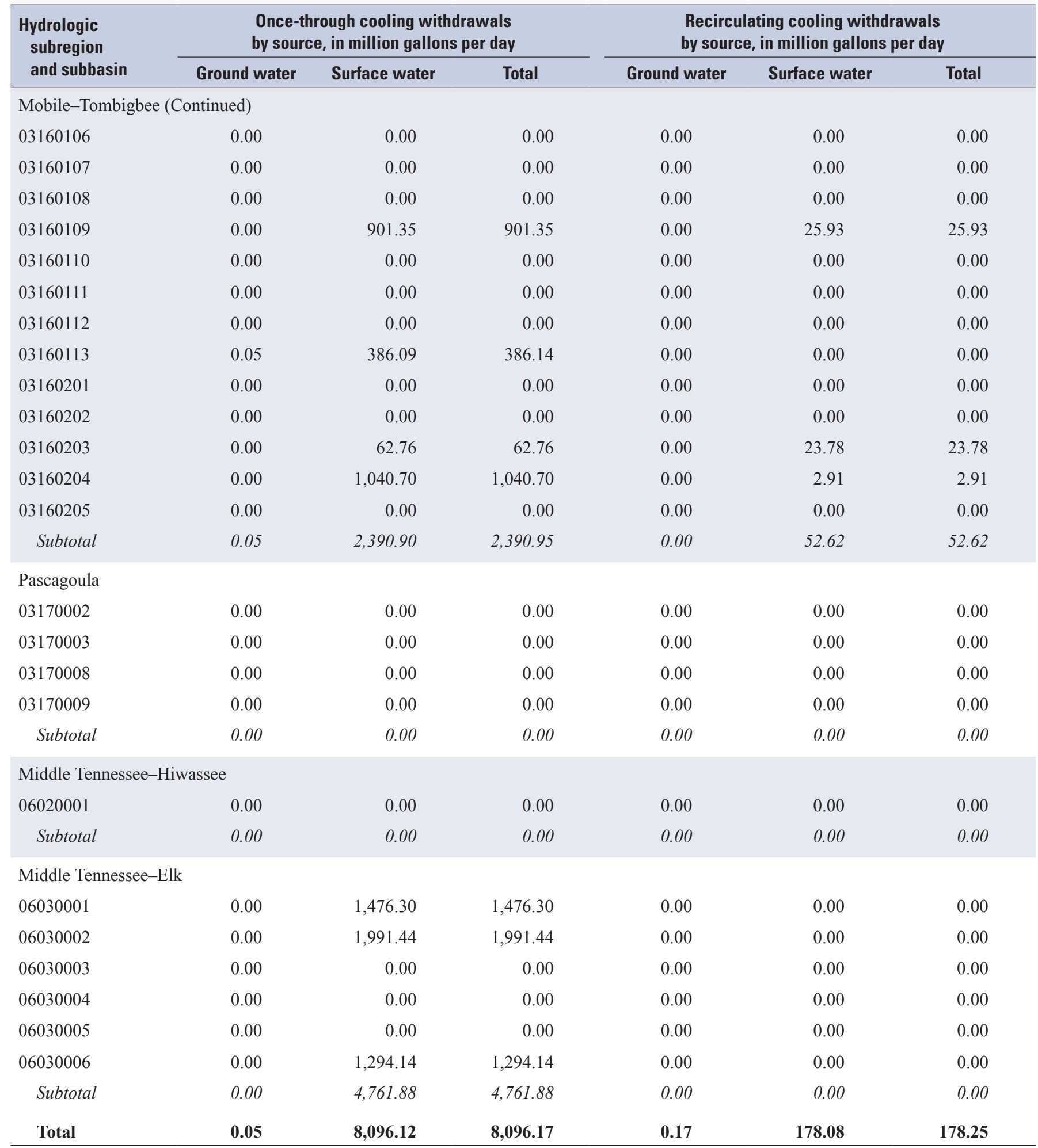




\section{Comparison of 2000 and 2005 Water-Use Data}

Data compiled across water-use categories in 2005, were more comprehensive than previous compilations for Alabama. The comparison of the 2000 and 2005 data in this section documents important changes within the water-use categories and is a beginning step in the process of assuring the quality of the data over time. As consistent methods are applied from year-to-year to collecting data and estimating water use, additional years of compilation could provide a better understanding of the trends in Alabama water use and the factors affecting the trends. Water withdrawals are affected by the day-to-day water needs. Over time, the water needs are influenced by changes in socioeconomic and demographic factors, weather conditions, and public policy.

\section{Total Water Use}

Overall, total water use in 2005 varied little from total use in 2000, although water withdrawals were estimated for livestock and mining for 2005, but not for 2000. In 1995, estimates of water withdrawals for these two categories amounted to $46 \mathrm{Mgal} / \mathrm{d}$, or less than 1 percent of the total water use. Even with that small omission in 2000, total water withdrawals decreased less than 1 percent in 2005 (9,958 Mgal/d) compared to 2000 (9,990 Mgal/d) (fig. 1). All water use reported in 2000 and 2005 was freshwater; however, some saline ground-water use $(9.1 \mathrm{Mal} / \mathrm{d})$ was reported for mining in 1995. Surface-water withdrawals decreased less than 5 percent, from $9,550 \mathrm{Mgal} / \mathrm{d}$ in 2000 to $9,467 \mathrm{Mgal} / \mathrm{d}$ in 2005. In contrast, ground-water withdrawals increased about 12 percent from $440 \mathrm{Mgal} / \mathrm{d}$ in 2000 to $491 \mathrm{Mgal} / \mathrm{d}$ in 2005.

\section{Public-Supply and Residential Water Use}

Total public-supply water withdrawals decreased 4 percent from $834 \mathrm{Mgal} / \mathrm{d}$ in 2000 to $802 \mathrm{Mgal} / \mathrm{d}$ in 2005 (table 27; Hutson and others, 2004a). Changes in groundwater withdrawals ranged from a decrease of $6.25 \mathrm{Mgal} / \mathrm{d}$ in Madison County to an increase of $7.8 \mathrm{Mgal} / \mathrm{d}$ in Montgomery County (table 27). Changes in surface-water withdrawals ranged from a decrease of $59.6 \mathrm{Mgal} / \mathrm{d}$ in Mobile County to an increase of $19.8 \mathrm{Mgal} / \mathrm{d}$ in Jefferson County. Further countyby-county comparisons can be made by using the aggregated county-level data for 2000 at http://water.usgs.gov/watuse.
The higher 2000 statewide value of $834 \mathrm{Mgal} / \mathrm{d}$ may reflect some increased warm-weather watering due to drought or a reduction in public-supplied deliveries to the industrial sector. Differences in the withdrawal estimates from 2000 to 2005 also can be attributed to a more complete inventory of the public suppliers, use of withdrawal data from both the AWURP database and USEPA MOR records from ADEM, application of GIS techniques and other mapping routines to better locate wells and intakes within the correct county and hydrologic subbasin, improved metering of water withdrawals at the facilities, and changes in water demand in 2005.

At the county level, based on the population served by the public suppliers as reported to DWB-ADEM and USEPASDWIS in 2005, the population served for a county often exceeded the county population, or was less than the population served as reported in the 1990 U.S. Census Bureau estimate of percentage of housing units on public supply. An alternative method was devised to estimate population served based on percentage of housing units on public supply, number of housing units in 1990, and 1990 and 2005 populations (U.S. Census Bureau, 1992, 2006). A change in methodology for determining population served by public suppliers also affected the estimate for self-supplied population as detailed in the section on "Population Served and Self-Supplied Population" in the "Data Compilation, Sources of Information, and Methodology" section of this report. Population served by public suppliers increased 13 percent from 3,579,550 in 2000 to $4,036,440$ in 2005 . The change in values partly was the result of a change in methodology and partly was caused by an actual change in population. The estimates of population served by county from 2000 to 2005 ranged from a decrease of 10,173 persons in Covington County to an increase of 55,192 persons in Jefferson County (U.S. Geological Survey, 2004).

Self-supplied population was computed as the difference between total population and population served. Because selfsupplied residential withdrawals were based on the estimate of the self-supplied population, any change in methodology for determining population served affects not only the estimate of the self-supplied population but also self-supplied residential withdrawals. The estimate for self-supplied population decreased 40 percent from 867,590 in 2000 to 521,350 in 2005, the difference partly being an artifact of the methodologies. Correspondingly, the self-supplied residential withdrawals declined about 50 percent (from $78.9 \mathrm{Mgal} / \mathrm{d}$ in 2000 to $39.12 \mathrm{Mgal} / \mathrm{d}$ in 2005). For 2000, data-entry errors for ground-water withdrawals for Autauga, Madison, Monroe, and Russell Counties resulted in a higher overall State-level self-supplied residential per capita use of $91 \mathrm{gal} / \mathrm{d}$ for 2000 (U.S. Geological Survey, 2004). The statewide residential self-supplied per capita use for 2005 was $75 \mathrm{gal} / \mathrm{d}$. 
Table 27. Comparison of 2000 and 2005 public-supply water use and self-supplied industrial water use, Alabama.

[Values may not sum to total estimated use(s) because of rounding. A negative number means less water was used in 2005 than 2000]

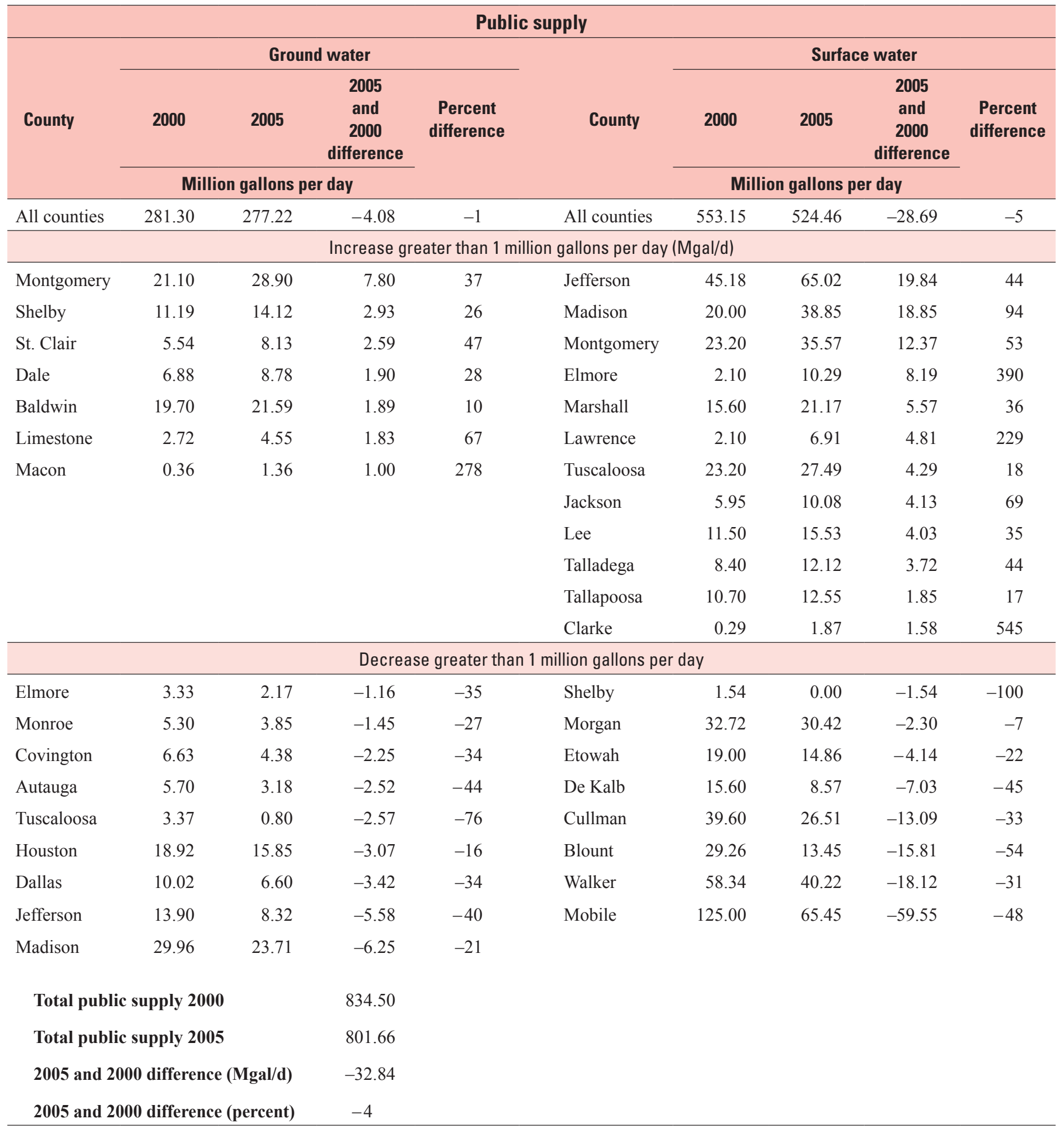


Table 27. Comparison of 2000 and 2005 public-supply water use and self-supplied industrial water use, Alabama.—Continued

[Values may not sum to total estimated use(s) because of rounding. A negative number means less water was used in 2005 than 2000; -, no value in 2000]

\begin{tabular}{|c|c|c|c|c|c|c|c|c|c|}
\hline \multicolumn{10}{|c|}{ Self-supplied industrial } \\
\hline \multirow[b]{2}{*}{ County } & \multicolumn{4}{|c|}{ Ground water } & \multirow[b]{2}{*}{ County } & \multicolumn{4}{|c|}{ Surface water } \\
\hline & 2000 & 2005 & $\begin{array}{c}2005 \\
\text { and } \\
2000 \\
\text { difference }\end{array}$ & $\begin{array}{c}\text { Percent } \\
\text { difference }\end{array}$ & & 2000 & 2005 & $\begin{array}{c}2005 \\
\text { and } \\
2000 \\
\text { difference }\end{array}$ & $\begin{array}{c}\text { Percent } \\
\text { difference }\end{array}$ \\
\hline \multicolumn{10}{|c|}{ Ground-water increase greater than 0.5 million gallons per day and surface water increase greater than 1 million gallons per day } \\
\hline \multirow[t]{3}{*}{ Russell } & 0.11 & 0.92 & 0.81 & 736 & Russell & 22.80 & 27.60 & 4.80 & 21 \\
\hline & & & & & Autauga & 26.60 & 30.63 & 4.03 & 15 \\
\hline & & & & & St. Clair & 0.00 & 3.50 & 3.50 & - \\
\hline \multicolumn{10}{|c|}{ Decrease greater than 1 million gallons per day } \\
\hline Baldwin & 0.79 & 0.00 & -0.79 & -100 & Escambia & 34.00 & 32.07 & -1.93 & -6 \\
\hline Conecuh & 0.82 & 0.00 & -0.82 & -100 & Wilcox & 23.00 & 21.04 & -1.96 & -9 \\
\hline Houston & 1.33 & 0.00 & -1.33 & -100 & Choctaw & 50.00 & 47.41 & -2.59 & -5 \\
\hline Morgan & 3.12 & 1.29 & -1.83 & -59 & Chambers & 5.70 & 2.16 & -3.54 & -62 \\
\hline Colbert & 3.00 & 0.87 & -2.13 & -71 & Monroe & 59.00 & 54.61 & -4.39 & -7 \\
\hline Coffee & 3.00 & 0.86 & -2.14 & -71 & Baldwin & 5.70 & 0.00 & -5.70 & -100 \\
\hline Washington & 9.17 & 5.33 & -3.84 & -42 & Mobile & 18.00 & 0.00 & -18.00 & -100 \\
\hline \multicolumn{3}{|c|}{ Total self-supplied industrial 2000} & 833.09 & & & & & & \\
\hline \multicolumn{3}{|c|}{ Total self-supplied industrial 2005} & 550.42 & & & & & & \\
\hline \multicolumn{3}{|c|}{2005 and 2000 difference (Mgal/d) } & -282.67 & & & & & & \\
\hline \multicolumn{3}{|c|}{2005 and 2000 difference (percent) } & -34 & & & & & & \\
\hline
\end{tabular}




\section{Irrigation and Aquaculture}

Water withdrawals for irrigation increased about $274 \mathrm{percent}$ from $43.1 \mathrm{Mgal} / \mathrm{d}$ in 2000 to $161.2 \mathrm{Mgal} / \mathrm{d}$ in 2005. Ground-water withdrawals increased about 412 percent, and surface-water withdrawals increased about 203 percent. The increase in estimated water withdrawals was the result of a more complete inventory of golf courses, nurseries, and sod farms by the Alabama OWR and the use of the USDA-NASS irrigation databases for 2002 and 2003. The changes in total irrigation water withdrawals by county ranged from a decrease of $1.16 \mathrm{Mgal} / \mathrm{d}$ in Greene County to an increase of $37.84 \mathrm{Mgal} / \mathrm{d}$ in Baldwin County (U.S. Geological Survey, 2004).

Total irrigated acreage from 2000 to 2005 increased about 94 percent from 70,010 acres to 135,800 acres, primarily as a result of the inclusion of more golf courses, nurseries, and sod farms. The changes in irrigated acreage ranged from a reduction of 2,040 acres in Greene County to an increase of 6,860 acres in Baldwin County (U.S. Geological Survey, 2004).

Aquaculture withdrawals were $10.4 \mathrm{Mgal} / \mathrm{d}$ in 2000 and $74.89 \mathrm{Mgal} / \mathrm{d}$ in 2005 . The change in water use was a result of the inclusion of more fish farms and fish hatcheries in the estimation, than in 2000. In 2000, 86 percent of the source of water was ground water (Hutson and others, 2004a). In 2005 , only 54 percent $(40.51 \mathrm{Mgal} / \mathrm{d})$ was ground water.

\section{Industrial}

In 2000, 57 self-supplied industries reported withdrawals to the AWURP compared with 66 industries in 2005. Although the number of industries increased in 2005, the amount of water withdrawals decreased 34 percent from $833 \mathrm{Mgal} / \mathrm{d}$ in 2000 to $550 \mathrm{Mgal} / \mathrm{d}$ in 2005 (table 27). Ground-water withdrawals were 51 percent less in 2005 (27.6 Mgal/d) than in 2000 (56 Mgal/d). Surface water withdrawals were 33 percent less in 2005 (523 Mgal/d) than in 2000 (777 Mgal/d). Several industries reported reduced withdrawals from 2000 to 2005. Possible reasons for reduced water withdrawals include reduced production, increased water conservation, or improved metering and reporting. Although drought conditions occurred in 2000, drought conditions to date have rarely, affected selfsupplied industrial withdrawals in Alabama. The changes in total self-supplied industrial withdrawals by county ranged from a decrease of about $85.8 \mathrm{Mgal} / \mathrm{d}$ (surface water) in Etowah County to an increase of $5.61 \mathrm{Mgal} / \mathrm{d}$ (combined surface and ground water) in Russell County (U.S.

Geological Survey, 2004).

\section{Thermoelectric Power}

Thermoelectric-power generation requires a large amount of water for cooling purposes. The amount of water depends on the amount of power generated, cooling-system type, and, for once-through cooling, the temperature of the receiving stream at the time of the planned cooling-water discharge. In 2000, total thermoelectric-power water withdrawals were $8,190 \mathrm{Mgal} / \mathrm{d}$ compared with 8,274 Mgal/d in 2005, which was an increase of about 1 percent. Ground-water withdrawals of $0.22 \mathrm{Mgal} / \mathrm{d}$ were reported in 2005, but none were reported in 2000 . 


\section{Summary}

Water use by source of supply and eight categories of use - public supply, self-supplied residential, irrigation, livestock, aquaculture, self-supplied industrial, mining, and thermoelectric power-was estimated for the State of Alabama for 2005. Site-specific data were used as a basis for estimates for public supply, public-supplied deliveries, self-supplied industrial, mining, thermoelectric power, and golf course, nursery, and sod irrigation. Aggregated county-level data were used as a basis for estimates for self-supplied residential, crop irrigation, livestock, and aquaculture.

Total water use was about 9,958 million gallons per day (Mgal/d) during 2005. Surface water was the source for about 95 percent of the total withdrawals $(9,467 \mathrm{Mgal} / \mathrm{d})$ and the remaining 5 percent $(491 \mathrm{Mgal} / \mathrm{d}$ ) was from ground water. More surface water than ground water was used in all categories except aquaculture, mining, and self-supplied residential. Estimated water withdrawals by category and in descending order were thermoelectric power, $8,274 \mathrm{Mgal} / \mathrm{d}$; public supply, $802 \mathrm{Mgal} / \mathrm{d}$; self-supplied industrial, $550 \mathrm{Mgal} / \mathrm{d}$; irrigation, $161 \mathrm{Mgal} / \mathrm{d}$; aquaculture, $75 \mathrm{Mgal} / \mathrm{d}$; self-supplied residential, $39 \mathrm{Mgal} / \mathrm{d}$; livestock, $28 \mathrm{Mgal} / \mathrm{d}$; and mining, $28 \mathrm{Mgal} / \mathrm{d}^{3}{ }^{3}$

A comparison of gallons per day per person of the total, public supply, public-supplied residential, and self-supplied residential water use shows that for water used to generate electricity, support industrial and agricultural activities, and provide drinking water $(9,958 \mathrm{Mgal} / \mathrm{d})$, per capita use was 2,185 gallons per day (gal/d) for the estimated 4.56 million residents in Alabama. For the public-supplied water delivered to the residential, industrial, and commercial sectors and public use and losses (802 Mgal/d), per capita use was $199 \mathrm{gal} / \mathrm{d}$ for the 4.04 million residents served by public supply. For the public-supplied residential deliveries (326 Mgal/d), per capita use was $81 \mathrm{gal} / \mathrm{d}$; and for self-supplied residential (39 Mgal/d), per capita use was $75 \mathrm{gal} / \mathrm{d}$ for the 0.52 million residents with private wells. Average residential per capita use was 80 gal/d.

Thermoelectric-power plants located in all but two of the seven hydrologic subregions in Alabama - the Pascagoula and the Tennessee-Hiwassee-withdrew 83 percent $(8,274 \mathrm{Mgal} / \mathrm{d})$ of the total water withdrawn to generate 114,144 net gigawatthours of energy. Surface water provided nearly all of the water $(8,274 \mathrm{Mgal} / \mathrm{d})$. About 98 percent of the thermoelectric-power withdrawals was used for once-through cooling. The percent consumptive use from once-through cooling generating units ranged from zero to nearly 7 percent (median, 0.1 percent) compared to recirculating-cooling generating units that have a consumptive use ranging from 30 to 65 percent (median, 44 percent). A comparison of a once-through cooling plant to a recirculating-cooling plant in Alabama shows that a oncethrough cooling unit typically uses about 60 gallons of water to produce 1 kilowatt-hour of electricity; a recirculatingcooling unit typically uses about 20 gallons of water to produce 1 kilowatt-hour of electricity.

Public-supply withdrawals were 8 percent of total freshwater withdrawals and 48 percent of total withdrawals for all categories excluding thermoelectric power. Surface-water sources provided 65 percent of the water, and ground water provided the remaining 35 percent. Public supply accounted for 56 percent of the total ground-water withdrawals in the State. Public-supply deliveries to residential customers were 41 percent of total public-supply withdrawals, or about $326 \mathrm{Mgal} / \mathrm{d}$; combined industrial and commercial deliveries were 44 percent, or about $355 \mathrm{Mgal} / \mathrm{d}$; and public use and losses accounted for the remaining 15 percent, or about $120 \mathrm{Mgal} / \mathrm{d}$. Mobile, Jefferson, Montgomery, Madison, and Walker Counties accounted for about 40 percent of publicsupply withdrawals and 39 percent of the population served.

Total industrial water use was $906 \mathrm{Mgal} / \mathrm{d}$ in 2005. Self-supplied industrial withdrawals were 6 percent of total withdrawals (550 Mgal/d) and 33 percent of total withdrawals excluding thermoelectric power. Surface water was the source for 95 percent of the self-supplied industrial water withdrawals. Statewide, combined public-supplied industrial and commercial deliveries were $355 \mathrm{Mgal} / \mathrm{d}$. Paper and allied products accounted for the largest self-supplied surfacewater withdrawals (301 Mgal/d), and chemical and allied products (12 Mgal/d) accounted for the largest self-supplied ground-water withdrawals. The largest withdrawals occurred in Morgan, Colbert (primarily chemical and allied products), Lawrence, Monroe, and Talladega (primarily paper and allied products) Counties with withdrawals that were more than $50 \mathrm{Mgal} / \mathrm{d}$ for each county. Withdrawals in these counties were 57 percent of the total self-supplied industrial withdrawals.

Irrigation withdrawals were about 2 percent of total withdrawals and about 10 percent of total withdrawals for all categories excluding thermoelectric power. More than half of the water, 54 percent, was from surface water. Baldwin County withdrew 27 percent (44 Mgal/d) of the irrigation water, primarily for nursery stock and sod. Most of that water (37 Mgal/d) was from ground water. About 135,800 acres of crops (food and feed crops, nursery stock

\footnotetext{
${ }^{3}$ Values may not sum to total estimated use(s) or acreage because of rounding.
} 
and sod) and golf courses were irrigated in 2005. Nursery stock and sod accounted for 29 percent of the irrigated crop acreage (31,633 of the 109,080 acres) statewide. Golf courses applied about $18 \mathrm{Mgal} / \mathrm{d}$ to 26,720 acres in 2005 . About 97 percent of the total acreage was irrigated with sprinkler irrigation systems. The statewide average application rate was 1.33 acre-feet per acre per year. The highest application rate, 3.74 acre-feet per acre per year, was for nursery stock.

Aquaculture withdrawals were less than 1 percent ( $75 \mathrm{Mgal} / \mathrm{d}$ ) of the total freshwater withdrawals and were about 4 percent of the total freshwater withdrawals excluding thermoelectric power. Ground water provided more than half, 54 percent, of the water used. All aquaculture withdrawals were considered fresh in 2005, although some ponds were filled with low-to-high salinity ground water.

Self-supplied residential withdrawals also were less than 1 percent (39 Mgal/d) of total water withdrawals, but about 2 percent of total water withdrawals for all categories excluding thermoelectric power. All of the water withdrawn for self-supplied residential purposes was from ground water. The largest self-supplied residential withdrawals were in Baldwin and Mobile Counties. These two counties represented about 14 percent of the total self-supplied residential withdrawals in Alabama and 12 percent of the self-supplied residential population.

Livestock withdrawals were less than 1 percent $(28 \mathrm{Mgal} / \mathrm{d})$ of the total freshwater withdrawals and were nearly 2 percent of the total freshwater withdrawals excluding thermoelectric power. Surface water was the source for more than half, 56 percent, of the water used. Two of the seven of the hydrologic subregions - the Mobile-Tombigbee (7.8 Mgal/d) and the Alabama (7.3 Mgal/d) - accounted for 54 percent of the livestock withdrawals.

Similarly, mining withdrawals were less than 1 percent of total water withdrawals ( $28 \mathrm{Mgal} / \mathrm{d}$ ) and nearly 2 percent of total water withdrawals for all categories excluding thermoelectric power. Ground water was the source of about 70 percent of mining withdrawals. All mining withdrawals were considered fresh in 2005 , although some low-salinity ground water has been tapped in parts of the State.

Most of the large water withdrawals were concentrated in a few counties. Limestone, Jackson, Colbert, and Mobile Counties accounted for 60 percent of the total withdrawalsprimarily to meet the cooling needs at thermoelectric-power plants. Excluding thermoelectric power, the largest withdrawals by county occurred in Morgan, Mobile, Jefferson, Talladega, and Madison Counties.
Water use was compiled by hydrologic subbasin for all categories except aquaculture, mining, and self-supplied residential. As a result of estimating fewer categories, total withdrawals by subbasin were $9,816 \mathrm{Mgal} / \mathrm{d}$ compared to total withdrawals by county. The Middle Tennessee-Elk subregion accounted for about 53 percent $(5,185 \mathrm{Mgal} / \mathrm{d})$ of the estimated total withdrawals by subregion. About 92 percent of that water use was for thermoelectric power, and more than 99 percent of the water was from surface water. Excluding thermoelectric power, the Middle Tennessee-Elk subregion accounted for 27 percent of the water withdrawals statewide. About 51 percent of the nonpower withdrawals in the Middle Tennessee-Elk subbasin was for self-supplied industrial use.

Overall, total water use in 2005 varied little from total use in 2000. Total water withdrawals decreased less than 1 percent from 2000 to 2005 (from 9,990 Mgal/d to $9,958 \mathrm{Mgal} / \mathrm{d}$, respectively). Surface-water withdrawals were about 5 percent less in 2005 than in 2000 (from 9,467 Mgal/d to $9,950 \mathrm{Mgal} / \mathrm{d}$, respectively). Ground-water withdrawals increased about 12 percent from 2000 to 2005 (from $440 \mathrm{Mgal} / \mathrm{d}$ to $491 \mathrm{Mgal} / \mathrm{d}$, respectively). By category, withdrawals for

- Public supply declined 4 percent from $834 \mathrm{Mgal} / \mathrm{d}$ in 2000 to $802 \mathrm{Mgal} / \mathrm{d}$ in 2005 .

- Self-supplied residential declined about 50 percent from $78.89 \mathrm{Mgal} / \mathrm{d}$ in 2000 to $39.12 \mathrm{Mgal} / \mathrm{d}$ in 2005 .

- Irrigation increased almost four-fold from $43 \mathrm{Mgal} / \mathrm{d}$ in 2000 to $161 \mathrm{Mgal} / \mathrm{d}$ in 2005 . Most of the increase was a result of the inclusion of more golf courses, nurseries, and sod farms in the water-use estimation. Over the same period, total irrigated acreage increased about 94 percent from 70,010 acres in 2000 to 135,800 acres in 2005 .

- Aquaculture increased more than six-fold from $10.4 \mathrm{Mgal} / \mathrm{d}$ in 2000 to $74.9 \mathrm{Mgal} / \mathrm{d}$ in 2005 . Most of the increase was the result of the inclusion of more fish farms and fish hatcheries in the wateruse estimation.

- Self-supplied industrial declined 34 percent from $833 \mathrm{Mgal} / \mathrm{d}$ in 2000 to $550 \mathrm{Mgal} / \mathrm{d}$ in 2005.

- Thermoelectric power increased about 1 percent from $8,190 \mathrm{Mgal} / \mathrm{d}$ in 2000 to $8,274 \mathrm{Mgal} / \mathrm{d}$ in 2005 .

Livestock and mining were not estimated in 2000. 


\section{Selected References}

Alabama Cooperative Extension System, 2006, 2005 Alabama aquaculture fact sheet, Ag Economic Series; accessed March 25, 2008, at http://www.aces.edu/dept/ fisheries/aquaculture/statistics.php/.

Alabama Department of Agriculture and Industries, Division of Plant Industry, 2007, Certified nursery growers and nursery dealers-2006-2007, p. 97.

Alabama Department of Economic and Community Affairs, Office of Water Resources, 2002, Alabama, the River State-A collection of historical essays exploring Alabama rivers, $43 \mathrm{p}$.

Alabama Development Office, 2004, Alabama industrial directory, 2003-2004: Montgomery Alabama, 557 p.

Alabama Education Aquaculture Recreational Fishing, ALEARN; accessed March 25, 2008, at http://www.aces.edu/dept/fisheries/aquaculture/.

Alabama Water Resources Act (Code of Alabama §9-10B), Acts 1993, No. 93-44, p. 78, §27.

Baker, R.M., 1989, Water availability in Jackson County, Alabama: Geological Survey of Alabama Special Map 209, 84 p., 2 pls.

Baker, R.M., Gillett, Blakeney, and Meng, P.M., 1982, Use of water in Alabama, 1980: Geological Survey of Alabama Information Series 59, $50 \mathrm{p}$.

Baker, R.M. and Mooty, W.S., 1987, Use of water in Alabama, 1985: Geological Survey of Alabama Information Series 59D, $51 \mathrm{p}$.

Baker, R.M. and Mooty, W.S, 1993, Use of water in Alabama, 1990: Geological Survey of Alabama Information Series 59E, $49 \mathrm{p}$.

Baker, R.M., and Moser, P.H., 1989, Water availability in DeKalb County, Alabama: Geological Survey of Alabama, Special Map 215, 71 p., 2 pls.

Boyd, C.A., Boyd, C.E., McNevin, A.A., and Rouse, D.B., 2006, Salt discharge from an inland farm for marine shrimp in Alabama: Journal of the World Aquaculture Society, v. 37 , no. 4 , p. $345-355$.

Boyd, C.A., Boyd, C.E., and Rouse, D.B., 2007a, Potassium adsorption by bottom soils in ponds for inland culture of marine shrimp in Alabama: Journal of the World Aquaculture Society, v. 38 , no. 1, p. 85-91.

Boyd, C.A., Boyd, C.E., and Rouse, D.B., 2007b, Potassium budget for inland, saline water shrimp ponds in Alabama: Aquacultural Engineering, v. 36, no. 1, p. 45-50.
Boyd, C.E., Queiroz, J., Lee, J., Rowan, M., Whitis, G.N., and Gross, A., 2000, Environmental assessment of channel catfish Ictalurus punctatus farming in Alabama: Journal of the World Aquaculture Society, v. 31, no. 4, p. 511-544.

Chapman, M.J., and Peck, M.F., 1997, Ground-water resources of the Middle Chattahoochee River basin in Georgia and Alabama, and Upper Flint River Basin in Georgia-Subarea 2 of the Apalachicola-ChattahoocheeFlint and Alabama-Coosa-Tallapoosa River basins: U.S. Geological Survey Open-File Report 96-492, 49 p.

DeJarnette, S.S., 1989, Geohydrology and susceptibility of major aquifers to surface contamination in Alabama; Area 10: U.S. Geological Survey Water-Resources Investigations Report 88-4077, 23 p.

Energy Information Administration, 2008, EIA-767 data files, annual steam-electric plant operation and design data; accessed November 6, 2008, at http://www.eia.doe.gov/ cneaf/electricity/page/eia 767.html.

Energy Information Administration, 2009a, Form EIA-906 and EIA-920 databases; accessed January 27, 2009, at $h t t p: / /$ www.eia.doe.gov/cneaf/electricity/page/eia906_920.html.

Energy Information Administration, 2009b, Electric power annual 2007-Data tables; accessed January 27, 2009, at $h t t p: / / w w w . e i a . d o e . g o v / c n e a f / e l e c t r i c i t y / e p a / e p a+$ sprdshts.html.

Geological Survey of Alabama, 2008a, Coal systems; accessed June 10, 2008, at http://www.gsa.state.al.us/ gsa/coal_sys.html.

Geological Survey of Alabama, 2008b, State of Alabama, calendar year coalbed methane production; accessed June 11, 2008, at http://www.gsa.state.al.us/documents/ prod_summaries/cbm_all.pdf.

Geological Survey of Alabama, 2008c, Alabama reaches natural gas production and revenue milestones; accessed January 27, 2009, at http://www.ogb.state.al.us/documents/ misc_ogb/milestones.pdf.

Hunter, J.A., 1991, Ground water availability in Limestone County, Alabama: Geological Survey of Alabama Special Map 226, 60 p., 2 pls.

Hutson, S.S., Barber, N.L., Kenny, J.F., Linsey, K.S., Lumia, D.S., and Maupin, M.A., 2004a, Estimated use of water in the United States in 2000: U.S. Geological Survey Circular $1268,46 \mathrm{p}$.

Hutson, S.S., Koroa, M.C., and Murphree, C.M., 2004b, Estimated use of water in the Tennessee River watershed in 2000 and projections of water use to 2030: U.S. Geological Survey Water-Resources Investigations Report 03-4302, $89 \mathrm{p}$. 
Journey, C.A., and Atkins, J.B., 1997, Ground water resources of the Tallapoosa River basin in Georgia and AlabamaSubarea 5 of the Apalachicola-Chattahoochee-Flint and Alabama-Coosa-Tallapoosa River basins: U.S. Geological Survey Open-File Report 96-433 48 p.

Kammerer, J.C., 1976, Water quantity requirements for public supplies and other uses, in Gehm, H.W., and Bregman, J.I., Handbook of water resources and pollution control: New York, N.Y., Van Norstrand Reinhold Co., p. 44-83.

Kidd, R.E., Atkins, J.B., and Scott, J.C., 1997, Ground-water resources of the Alabama River basin in Alabama-Subarea 8 of the Apalachicola-Chattahoochee-Flint and AlabamaCoosa-Tallapoosa River basins: U.S. Geological Survey Open-File Report 96-47353 p.

Kidd, R.E., and Lambeth, D.S., 1995, Hydrogeology and ground-water quality in the Black Belt area of west-central Alabama, and estimated use of water for aquaculture, 1990: U.S. Geological Survey Water-Resources Investigations Report 94-4074, 52 p.

Lineback, N.G., ed., 1973, Atlas of Alabama: Tuscaloosa, Alabama, University of Alabama Press, 138 p.

MacKichan, K.A., 1951, Estimated water use in the United States, 1950: U.S. Geological Survey Circular 115, 13 p.

MacKichan, K.A., 1957, Estimated water use in the United States, 1955: U.S. Geological Survey Circular 398, 18 p.

MacKichan, K.A., and Kammerer, J.C., 1961, Estimated water use in the United States, 1960: U.S. Geological Survey Circular 456, 26 p.

Mayer, G.C., 1997, Ground-water resources of the LowerMiddle Chattahoochee River basin in Georgia and Alabama, and Middle Flint River basin in Georgia-Subarea 3 of the Apalachicola-Chattahoochee-Flint and Alabama-CoosaTallapoosa River basins: U.S. Geological Survey Open-File Report 96-483, 47 p.

McNevin, A.A., Boyd, C.E., Silapajarn, O., and Silapajarn, K., December 2004, Ionic supplementation of pond waters for inland culture of marine shrimp, Journal of World Aquaculture, pp. 460-467.

Mooty, W.S., and Kidd, R.E., 1997, Ground-water resources of the Cahaba River basin in Alabama-Subarea 7 of the Apalachicola-Chattahoochee-Flint and AlabamaCoosa-Tallapoosa River basins: U.S. Geological Survey Open-File Report 96-470, 36 p.

Mooty, W.S., and Richardson, J.R., 1998, Water use in Alabama, 1995: U.S. Geological Survey Water-Resources Investigations Report 98-4154, 92 p.

Murray, C.R., 1968, Estimated water use in the United States, 1965: U.S. Geological Survey Circular 556, 53 p.
Murray, C.R., and Reeves, E.B., 1972, Estimated water use in the United States, 1970: U.S. Geological Survey Circular 676, 37 p.

Murray, C.R., and Reeves, E.B., 1977, Estimated water use in the United States, 1975: U.S. Geological Survey Circular 765, 37 p.

National Oceanic and Atmospheric Administration, 2009, Alabama state averaged precipitation data; accessed August 5, 2009, at http://www.sercc.com/climateinfo/ monthly_seasonal.html.

Peirce, L.B., 1972, Use of water in Alabama, 1970, with projections to 2020: Geological Survey of Alabama Information Series 42, 77 p.

Robinson, J.L., Journey, C.A., and Atkins, J.B., 1997, Groundwater resources of the Coosa River basin in Georgia and Alabama-Subarea 6 of the Apalachicola-ChattahoocheeFlint and Alabama-Coosa-Tallapoosa River basins: U.S. Geological Survey Open-File Report 96-177 53 p.

Ruddy, B.C., and Hitt, K.J., 1990, Summary of selected characteristics of large reservoirs in the United States and Puerto Rico, 1988: U.S. Geological Survey Open-File Report 90-163, p. 19-23.

Smajstrla, A.G., and Zazueta, F.S., 1995, Estimating crop irrigation requirements for irrigation system design and consumptive use permitting: Agricultural and Biological Engineering Department, Florida Cooperative Extension Service, Institute of Food and Agricultural Services, University of Florida, Document AE257, 4 p.; accessed December 31, 2008, at http://edis.ifas.ufl.edu/pdffiles/AE/ AE07800.pdf.

Solley, W.B., Chase, E.B., and Mann, W.B., IV, 1983, Estimated water use in the United States, 1980: U.S. Geological Survey Circular 1001, 56 p.

Solley, W.B., Merk, C.F., and Pierce, R.R., 1988, Estimated water use in the United States, 1985: U.S. Geological Survey Circular 1004, 82 p.

Solley, W.B., Pierce, R.R., and Perlman, H.A., 1993, Estimated water use in the United States, 1990: U.S. Geological Survey Circular 1081, 71 p.

Solley, W.B., Pierce, R.R., and Perlman, H.A., 1998, Estimated use of water in the United States in 1995: U.S. Geological Survey Circular 1200, 71 p.

TheGolfCourses.net. 2007, Golf courses in Alabama; accessed June 10, 2007 at http://www.thegolfcourses. net/golfcourses/AL/Alabama.htm. 
U.S. Census Bureau, 1992, 1990 Census of population and housing, summary of social, economic, and housing characteristics-Alabama: Washington, D.C., U.S. Department of Commerce report 1990 CPH-5-2, 218 p., Appendices A-F; accessed September 12, 2007, at http://www.census.gov/ prod/cen1990/cph5/cph-5-2.pdf.

U.S. Census Bureau, 2002, 2000 Census of population and housing, summary population and housing characteristicsAlabama: Washington, D.C., U.S. Department of Commerce report PHC-1-2, 229 p., Appendices A-H; accessed September 12, 2007, at http://www.census.gov/prod/ cen2000/phc-1-2.pdf.

U.S. Census Bureau, 2006, Annual estimates of the population for counties, April 1, 2000 to July 1, 2005 (Alabama); accessed March 21, 2006, at http://www.census.gov/popest/ counties/CO-EST2005-01.html.

U.S. Census Bureau, 2009, Cartographic boundary files, census block groups; accessed July 5, 2009, at http://www. census.gov/geo/www/cob/bg_metadata.html.

U.S. Census Bureau, Geography Division, 2001, Census 2000 TIGER/Line ${ }^{\circledR}$ Files; accessed June 10, 2007, at http://www. census.gov/geo/www/tiger/tiger $2 \mathrm{k} /$ tgr2000.html.

U.S. Department of Agriculture, 2004, Federal standards for delineation of hydrologic unit boundaries; version 2.0, October 1, 2004; accessed September 15, 2008, at ftp://ftp-fc.sc.egov.usda.gov/NCGC/products/watershed/ hu-standards.pdf.

U.S. Department of Agriculture, National Agricultural Statistics Service, 2002, Ranking of market value of ag products sold; accessed September 12, 2008, at http://www.agcensus. usda.gov/Publications/2002/Rankings_of_Market_Valuel Alabama/index.asp.
U.S. Department of Agriculture, National Agricultural Statistics Service, 2004a, 2002 Census of agriculture, Alabama, state and county data-Volume 1, Geographic area series, Part 1, AC-02-A-1; accessed September 12, 2007, at http://www.agcensus.usda.gov/Publications/2002/ Volume_1,_Chapter_1_State_Level/Alabama/index.asp.

U.S. Department of Agriculture, National Agricultural Statistics Service, 2004b, 2002 Census of agriculture, 2003 farm and ranch irrigation survey-Volume 3, Special studies, Part 1, AC-02-SS -1, 176 p.; accessed September 12, 2007, at http://www.agcensus.usda.gov/Publications/2002/FRIS/ index.asp.

U.S. Department of Agriculture, National Agricultural Statistics Service, 2006a, Alabama Agricultural Statistics: Bulletin 48, 96 p.

U.S. Department of Agriculture, National Agricultural Statistics Service, 2006b, U.S. poultry-Production and value, 2005 summary, $10 \mathrm{p}$.

U.S. Department of Agriculture, Soil Conservation Service, 1993, State of Alabama Hydrologic unit map with drainage areas by counties and sub-watershed, Appendices A-F.

U.S. Environmental Protection Agency, 2009, Safe drinking water query form for the State of Alabama; accessed January 27, 2009, at http://oaspub.epa.gov/enviro/sdw form_v2.create_page?state_abbr $=A L /$.

U.S. Geological Survey, 2004, Estimated use of water in the United States - County-level data for 2000; accessed June 10, 2008, at http://water.usgs.gov/watuse/data/2000/ index.html.

U.S. Geological Survey, 2007, Boundary descriptions and names of regions, subregions, accounting units and cataloging units (Region 03); accessed November 26, 2008, at http://water.usgs.gov/GIS/huc_name.html\#Region03. 


\section{Glossary}

The following terms pertain to or are referenced in the text.

\begin{abstract}
Alabama Water Use Reporting Program All public water systems and major non-public and irrigation water users who have the capacity to withdraw 100,000 gallons per day or more of surface or ground water in Alabama are required to register with the Alabama Office of Water Resources. A Certificate of Use is issued to each user who is then required to report their usage annually. See also eWater.
\end{abstract}

aggregated data summarized values for a specific data element either by spatial area or category of use.

aquaculture water use water use associated with the farming of organisms, such as finfish and shellfish, that live in water and offstream water use associated with fish hatcheries. See also fish farm water use, fish hatchery water use, and offstream use.

census block group U.S. Census Bureau census accounting unit that generally contains between 600 and 3,000 people, with an optimum size of 1,500 people (U.S. Census, 2009).

choropleth map a data map that presents data values as discrete areal ranges.

closed-loop cooling See recirculating cooling.

commercial water use water for motels, hotels, restaurants, office buildings, other commercial facilities, and military and nonmilitary institutions. Water may be obtained from a public supplier or may be self-supplied. See also nonresidential water use, publicsupply deliveries, public-supply water use, and offstream use.

community water system water system furnishing water year-round to at least 25 people or having a minimum of 15 connections. See also public-supply deliveries, non-community water system, public-supply water use, and public supplier.

consumptive crop irrigation requirement the amount of water, in addition to rainfall, that must be applied to meet a crop's evapotranspiration needs without significant reduction in yield (Smajstrla and Zazueta, 2002). See also irrigation water use. consumptive use the part of water withdrawn that is evaporated, transpired, incorporated into products or crops, consumed by humans or livestock, or otherwise removed from the environment. Consumptive use also is referred to as water consumed.

conveyance loss water that is lost in transit from a pipe, canal, conduit, or ditch by leakage or evaporation. Generally, the water is not available for further use; however, leakage from an irrigation ditch, for example, may percolate to a ground-water source and be available for further use. See also irrigation water use.

cooling system an equipment system that provides water for cooling purposes, such as for condensers at power plants or at factories, and includes water intakes and outlets, cooling towers, and ponds, pumps, and pipes. See also cooling-system type, industrial water use, once-through cooling, recirculating cooling, thermoelectric-power water use.

cooling-system type once-through or recirculating are cooling system types. See also cooling system, industrial water use, oncethrough cooling, recirculating cooling, and thermoelectric-power water use.

delivery-release the amount of water delivered to the point of use and the amount released after use; the difference between these amounts is usually the same as consumptive use. See also consumptive use.

domestic water use See total residential water use.

eWater the client server application developed and maintained by the Alabama Office of Water Resources to support the Alabama Water Use Reporting Program. See also Alabama Water Use Reporting Program

fish farm water use water used for the production of finfish and shellfish under controlled feeding, sanitation, and harvesting procedures for commercial purposes. Water use by fish farms is classified in the aquaculture category. See also aquaculture water use and fish hatchery water use.

fish hatchery water use water used for raising fish for later release and in association with the 
operation of fish hatcheries or fishing preserves. Fish hatchery water use is classified in the aquaculture category. See also aquaculture water use and fish farm water use.

freshwater water that contains less than 1,000 milligrams per liter $(\mathrm{mg} / \mathrm{L})$ of dissolved salts; generally, more than $500 \mathrm{mg} / \mathrm{L}$ of dissolved solids is undesirable for drinking and for many industrial uses. See also saline water.

geographic information system a computer system designed to collect, manage, manipulate, analyze, and display spatially referenced data. A GIS includes both attribute and geospatial data.

gross per capita use total amount of water withdrawn for all uses including generating electricity and residential, commercial, industrial, and agricultural purposes divided by the total population. See also gross publicsupply per capita use; public-supplied residential per capita use; residential per capita use; and, self-supplied residential per capita use.

gross public-supply per capita use total amount of water billed by a public supplier for all uses including generating electricity, residential, commercial, industrial, public and agricultural purposes, and losses divided by the number of people served by a public supplier. This statistic normalizes deliveries from a public supplier by population served and can be used to compare the relative size of nonresidential deliveries among public suppliers. A high statistical value could indicate large deliveries to the nonresidential sector. See also gross per capita use, public-supplied residential per capita use, residential per capita use, and self-supplied residential per capita use.

industrial water use water used for fabrication, processing, washing, and cooling and includes such industries as chemical and allied products, food, mining, paper and allied products, petroleum refining, and steel. See also cooling system, cooling-system type, mining water use, public-supply deliveries, nonresidential water use, offstream use, publicsupply water use, thermoelectric-power water use, and total industrial water use.

instream use water that is used, but not withdrawn, from a surface-water source for such purposes as hydroelectric-power generation, navigation, water-quality improvement, fish propagation, and recreation. See also offstream use and water use. irrigation water use water that is applied by an irrigation system to assist in the growing of crops and pastures or to maintain vegetative growth in recreational lands such as parks and golf courses. Irrigation includes water that is applied for preirrigation, frost protection, chemical application, weed control, field preparation, crop cooling, harvesting, dust suppression, the leaching of salts from the root zone, and water lost in conveyance. See also conveyance loss, microirrigation system, sprinkler irrigation system, surface irrigation system, and offstream use.

livestock water use water for livestock watering, feedlots, dairy operations, and other on-farm needs. Types of livestock include dairy cows and heifers, beef cattle and calves, sheep and lambs, goats, hogs and pigs, horses and poultry. See also offstream use.

microirrigation system an irrigation system that wets only a discrete portion of the soil surface in the vicinity of the plant by means of applicators, such as orifices, emitters, porous tubing, and perforated pipe operated under low pressure. The applicators can be placed on or below the surface of the ground or can be suspended from supports. See also irrigation water use, sprinkler irrigation system, and surface irrigation system.

mining water use water use for the extraction of naturally occurring minerals including solids, such as coal, sand, gravel, and other ores; liquids, such as crude petroleum; and gases, such as natural gas. Also includes uses associated with quarrying, milling, and other preparations customarily done at the mine site or as part of a mining activity. Does not include water associated with dewatering of the aquifer that is not put to beneficial use. Also does not include water used in processing, such as smelting, refining petroleum, or slurry pipeline operations. These processing uses are included in industrial water use. See also industrial water use and offstream use.

monthly operation report monthly data report of average daily water withdrawals or water purchases submitted by each public supplier to the Alabama Department of Environmental Management.

non-community water system water system furnishing water to fewer than 25 people or fewer than 15 connections, but not year-round. See also community water supplier, publicsupply deliveries, public-supply water use, and public supplier. 
non-public a water-use classification in the Alabama Water Use Reporting Program system for a water-using entity that is neither a public supplier nor an irrigator.

nonresidential water use water delivered from a public supplier to commercial, industrial or thermoelectric power customers. See also commercial water use, industrial water use, public-supply water use, and residential water use.

offstream use water withdrawn or diverted from a ground-water or surface-water source for aquaculture water use, commercial water use, irrigation water use, livestock water use, mining water use, public-supply water use, industrial water use, residential water use, thermoelectric power, and other uses. See also entries for each of the previously mentioned uses and self-supplied water use.

once-through cooling process in which the water is withdrawn from a source, circulated through the heat exchangers, and then returned to a body of water at a higher temperature. Once-through cooling systems may be referred to as open-loop systems. See also cooling system, industrial water use, recirculating cooling, and thermoelectric-power water use.

public-supplied residential per capita use total amount of public-supply withdrawals for residential, commercial, industrial, and thermoelectric-power purposes and public use and losses divided by the associated population served by a public supply. See also gross per capita use, gross public supply per capita use, residential per capita use, and self-supplied residential per capita use.

public supplier See community water system. public-supply deliveries amount of water delivered from a public supplier to users for residential, commercial, industrial, thermoelectric-power, or public-use purposes. See also commercial water use, industrial water use, public-supply water use, public water use, residential water use, and thermoelectric-power water use.

public-supply water use water withdrawn, treated, and distributed by public suppliers. Public suppliers provide water for a variety of uses such as residential, commercial, industrial, thermoelectric power, and public water use. See also commercial water use, domestic water use, industrial water use, public-supply deliveries, public water use, thermoelectric-power water use, total industrial water use, and offstream use.

public use and losses water supplied from a public supplier and used for such purposes as firefighting, street washing, flushing of water lines, and maintaining municipal parks and swimming pools. See also public-supply deliveries and public-supply water use.

public water system See community water system or public supplier.

recirculating cooling cooling process where water is withdrawn from a source, circulated through heat exchangers, then cooled, and recycled. Subsequent water withdrawals are used to replace water lost to evaporation, blowdown, drift, and leakage and, accordingly, results in a much smaller return flow than once-through cooling. Related terms include closed-loop cooling and contact cooling. See also closed-loop cooling, cooling system, cooling-system type, industrial water use, and thermoelectric-power water use.

reclaimed wastewater wastewater treatment plant effluent that has been diverted for beneficial use before it reaches a natural waterway or aquifer. See also water use.

residential per capita use public-supplied residential deliveries plus self-supplied residential withdrawals divided by total population. See also gross per capita use, gross public-supply per capita use, publicsupplied residential per capita use, and self-supplied residential per capita use.

residential water use water used for indoor household purposes, such as drinking, preparing food, bathing, washing clothes and dishes, and flushing toilets and outdoor purposes, such as watering lawns and gardens. Residential water use is the combined publicsupplied residential deliveries and self-supplied residential withdrawals. Residential water use is the same as domestic water use, but is the preferred term for this report. See also domestic water use, public-supply deliveries, publicsupply water use, and offstream use.

return flow water that reaches a ground-water or surface-water source after release from the point of use and thus becomes available for further use. See also water use.

saline water water that contains 1,000 milligrams per liter or more of dissolved salts. See also freshwater. 
self-supplied residential per capita use

total amount of water withdrawn for selfsupplied residential purposes divided by the associated self-supplied residential population. See also gross per capita use, gross publicsupply per capita use, public-supplied residential per capita use, and residential per capita use.

self-supplied water use water withdrawn from a ground-water or surface-water source by a user rather than being obtained from a public supply. See also offstream use.

site-specific data data for an individual water-using entity.

sprinkler irrigation system an irrigation system in which water is applied by means of perforated pipes or nozzles operated under pressure so as to form a spray pattern. See also irrigation water use, microirrigation system, and surface irrigation system.

Standard Industrial Classification (SIC) codes four-digit codes established by the Office of Management and Budget, published in 1987, and used in the classification of businesses by type of activity in which they are engaged.

surface irrigation system irrigation by means of flood, furrow, or gravity. Flood irrigation is the application of irrigation water in which the entire soil surface is covered by ponded water. Furrow is a partial surface-flooding method of irrigation normally used with clean-tilled crops in which water is applied in furrows or rows of sufficient capacity to contain the design irrigation stream. Gravity is an irrigation method in which water is not pumped, but flows in ditches or pipes and is distributed by gravity. See also irrigation water use, microirrigation system, and sprinkler irrigation system.

thermoelectric-power water use water used in the process of generating electricity with steam-driven turbine generators. The total water use is a combination of publicsupply deliveries to thermoelectric-power plants and self-supplied thermoelectric-power withdrawals. For this report, thermoelectricpower water use refers only to self-supplied thermoelectric-power withdrawals. See also cooling system, cooling-system type, oncethrough cooling, public-supply water use, recirculating cooling, and offstream use.

total industrial water use self-supplied industrial withdrawals plus public-supplied industrial and commercial deliveries.

See also public-supply water use.

total residential water use self-supplied residential withdrawals plus public-supplied residential deliveries. See also public-supply water use.

wastewater-treatment return flow water returned to the hydrologic system by wastewater-treatment facilities. See also water use.

water transfer artificial conveyance of water from one area to another.

water use (1) in a restrictive sense, the term refers to water that is used for a specific purpose, such as for residential use, irrigation, thermoelectric-power cooling, or industrial processing. In this report, the quantity of water use for a specific category is the water withdrawal by that category of users, and public supply is considered a category of water use. (2) More broadly, water use pertains to the interaction of humans with and their influence on the hydrologic cycle, and includes elements such as water withdrawal, delivery, consumptive use, wastewater release, reclaimed wastewater, return flow, and instream use. See also offstream use and instream use.

water-use transaction a water-use activity that is a water withdrawal, water delivery, water release, return flow, or water transfer. See also delivery-release, return flow, wastewater-treatment return flow, water transfer, or water withdrawal.

water withdrawal water removed from the ground-water or diverted from a surface-water source for use. See also offstream use and self-supplied water use.

watt-hour (Wh) an electrical energy unit of measure equal to 1 watt of power supplied to, or taken from, an electric circuit for 1 hour. 


\section{Appendix A. Alabama Water Use by County}

The following one-page summaries of water-use information by county present withdrawals by water-use category, public supplier, and major Standard Industrial Classification (SIC) groups, a pie chart of the distribution of total withdrawals by water-use category, and a map that shows the location of the county within the State. See the first example on the following county page for Autauga. No attempt was made to interpret the water use indicated on the pie chart on an individual basis. Also listed are totals for population, population served by public supply, per capita use, acres irrigated, land area, and water area. The per capita use is the average daily amount of water delivered from a public supplier to residential customers plus the average daily self-supplied residential withdrawals divided by the total population of the county.

In each of the county summaries, a table lists average daily withdrawals for the categories of use. If there are no withdrawals for a particular category, that category is not listed. The withdrawals are totaled by source of water used ground water [GW]) or (surface water $[\mathrm{SW}]$ by category, and the percentage of use is indicated.

Each public supplier is listed by the county in which the withdrawal occurs; therefore, a public supplier may be listed in more than one county depending on the location of its water sources. For example, Birmingham WW\&SB withdraws surface water from Blount, Cullman, Jefferson, and Walker Counties and is, therefore, listed on each of the corresponding county pages.

In the tables for category, public supplier, and SIC groupings, a value of 0.00 million gallons per day $(\mathrm{Mgal} / \mathrm{d})$ was used if the withdrawal was less than $0.01 \mathrm{Mgal} / \mathrm{d}$. As a result, some totaled withdrawals from these tables may be less than the totals shown for public supply or industry in the water-use-category table. Numbers were summed using three-decimal places and then rounded to two decimal places for the final number. Numbers may not sum to total withdrawals because of rounding. "Residential" refers to self-supplied residential withdrawals.

A table of withdrawals by SIC code lists withdrawals by ground water (GW) or surface water (SW). The SIC groupings include the water-use categories of commercial (SIC codes 79 and 91), industrial (SIC codes 20 through 40), mining (SIC code 13), and thermoelectric power (SIC code 49). 


\section{Autauga}

Population: 48,612

Population served by public supply: 42,956

Per capita use (gallons per person per day): 72

Acres irrigated: 1,490

Land area: 596.0 square miles

Water area: 8.5 square miles

Withdrawals, in million gallons per day (Mgal/d) and percent $(\%)$ [Percents are rounded to nearest whole number]

\begin{tabular}{lrrr}
\hline Category & GW & SW & Totals \\
\hline Public Supply & 3.18 & 0.00 & 3.18 \\
Residential & $100 \%$ & $0 \%$ & \\
Irrigation & 0.32 & .00 & 0.32 \\
& 100 & 0 & \\
Aquaculture & 2.40 & .38 & 2.78 \\
& 86 & 14 & \\
Livestock & .15 & .15 & .30 \\
Industrial & 50 & 50 & \\
& .09 & .13 & .22 \\
Mining & 40 & 60 & \\
& 1.66 & 30.63 & 32.29 \\
Thermoelectric & 5 & 95 & \\
TOTALS & .29 & .14 & .43 \\
& 68 & 32 & \\
\hline
\end{tabular}

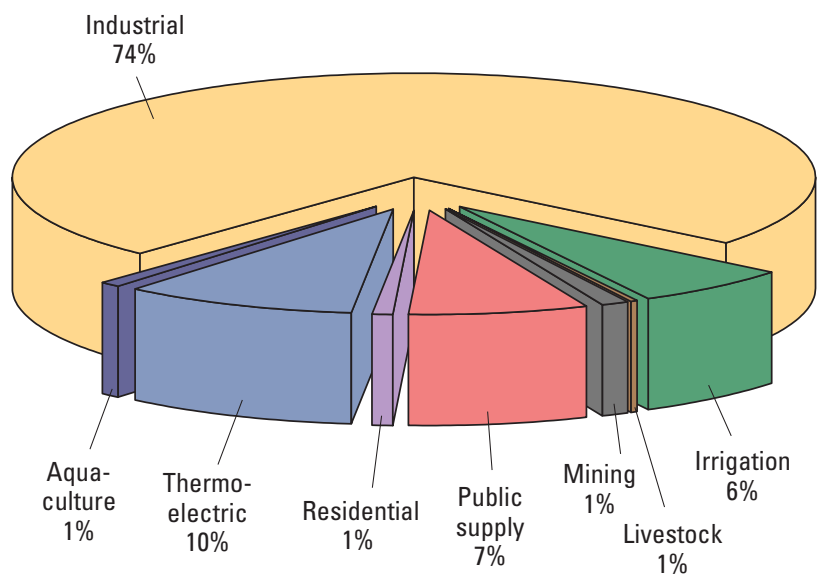

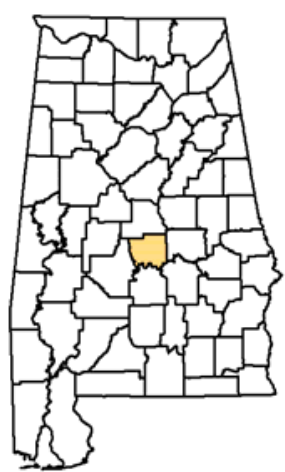

Withdrawals by public supplier, in Mgal/d

\begin{tabular}{lrrr}
\hline Public Supplier & GW & SW & Totals \\
\hline Autauga County Water Authority & 0.48 & 0.00 & 0.48 \\
Autaugaville Water System & .18 & .00 & .18 \\
Billingsley Water System & .12 & .00 & .12 \\
Prattville Water Works Board & 2.12 & .00 & 2.12 \\
West Autauga Water Authority & .29 & .00 & .29 \\
\hline
\end{tabular}

Withdrawals by Standard Industrial Classification, in Mgal/d

\begin{tabular}{lcrr}
\hline Standard Industrial Classification & GW & SW & Totals \\
\hline 26 Paper and Allied Products & 1.66 & 30.63 & 32.29 \\
49 Electric, Gas, and Sanitary & 0.00 & 4.14 & 4.14 \\
$\quad$ Services & & & \\
\hline
\end{tabular}




\section{Baldwin}

Population: 162,586

Population served by public supply: 136,892

Per capita use (gallons per person per day): 87

Acres irrigated: 16,440

Land area: 1,596.4 square miles

Water area: 430.6 square miles

Withdrawals, in million gallons per day (Mgal/d) and percent $(\%)$ [Percents are rounded to nearest whole number]

\begin{tabular}{lrrr}
\hline Category & GW & SW & Totals \\
\hline Public Supply & 21.59 & 0.00 & 21.59 \\
& $100 \%$ & $0 \%$ & \\
Residential & 2.48 & .00 & 2.48 \\
& 100 & 0 & \\
Irrigation & 36.77 & 7.05 & 43.82 \\
& 84 & 16 & \\
Aquaculture & 0.00 & .05 & 0.05 \\
& 0 & 100 & \\
Livestock & .20 & .24 & .44 \\
& 46 & 54 & \\
Mining & .63 & .00 & .63 \\
& 100 & 0 & \\
\cline { 2 - 4 } TOTALS & 61.67 & 7.34 & 69.01 \\
& $89 \%$ & $11 \%$ & \\
\hline
\end{tabular}

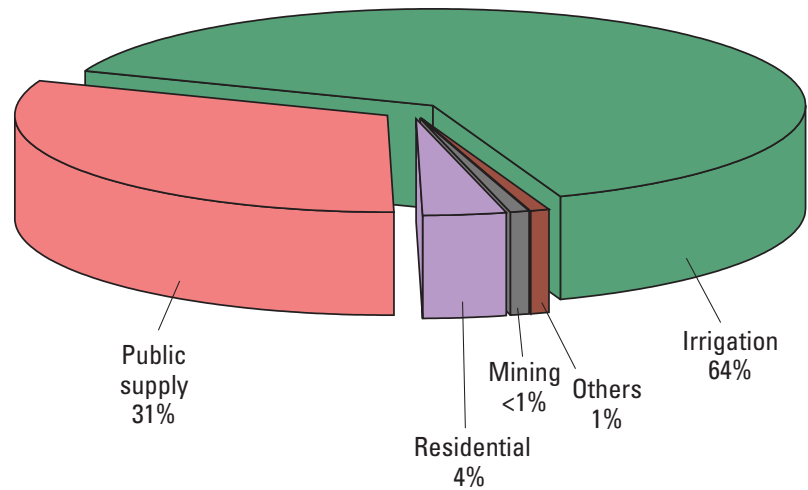

Withdrawals by Standard Industrial Classification, in Mgal/d None Standard Industrial Classification GW

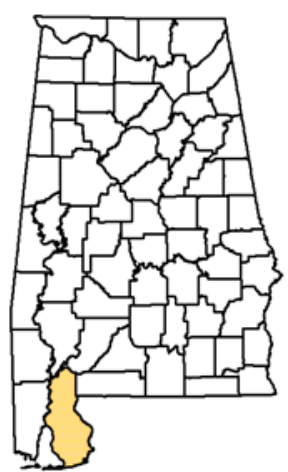

Withdrawals by public supplier, in Mgal/d

\begin{tabular}{lrrr}
\hline Public Supplier & GW & SW & Totals \\
Belforest Water System & 0.36 & 0.00 & 0.36 \\
Daphne Utilities Board & 3.42 & .00 & 3.42 \\
Elberta & .08 & .00 & .08 \\
Fairhope & 3.94 & .00 & 3.94 \\
Foley Utilities Board & 2.70 & .00 & 2.70 \\
Gulf Shores Utilities & 3.23 & .00 & 3.23 \\
Loxley & .76 & .00 & .76 \\
North Baldwin Utilities & 2.51 & .00 & 2.51 \\
Orange Beach Water, Sewer \& & 2.76 & .00 & 2.76 \\
Fire Protection & & & \\
Perdido Bay Water, Sewer \& Fire & .47 & .00 & .47 \\
Protection District & & & \\
Robertsdale & .74 & .00 & .74 \\
Silverhill & .12 & .00 & .12 \\
Spanish Fort Water System & .41 & .00 & .41 \\
Summerdale Water Department & .10 & .00 & .10 \\
\hline
\end{tabular}

Standard Industrial Classification $\quad$ GW $\quad$ SW $\quad$ Totals




\section{Barbour}

Population: 28,414

Population served by public supply: 26,447

Per capita use (gallons per person per day): 66

Acres irrigated: 5,400

Land area: 884.9 square miles

Water area: 19.6 square miles

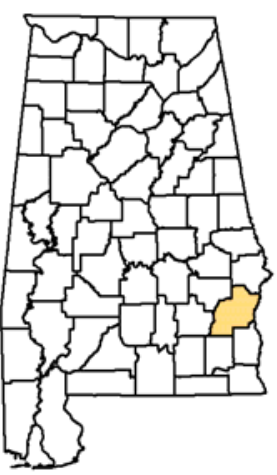

Withdrawals, in million gallons per day (Mgal/d) and percent $(\%)$ [Percents are rounded to nearest whole number]

\begin{tabular}{lrrr}
\hline Category & GW & SW & Totals \\
\hline Public Supply & 4.15 & 0.00 & 4.15 \\
Residential & $100 \%$ & $0 \%$ & \\
& 0.11 & .00 & 0.11 \\
Irrigation & 100 & 0 & \\
& .90 & 2.69 & 3.59 \\
Aquaculture & 25 & 75 & \\
& .21 & 5.70 & 5.91 \\
Livestock & 4 & 96 & \\
& .14 & .21 & .35 \\
Industrial & 41 & 59 & \\
& 1.18 & .00 & 1.18 \\
Mining & 100 & 0 & \\
TOTALS & .82 & .38 & 1.20 \\
& 68 & 32 & \\
\cline { 2 - 4 } & 7.51 & 8.98 & 16.49 \\
& $46 \%$ & $54 \%$ & \\
\hline
\end{tabular}

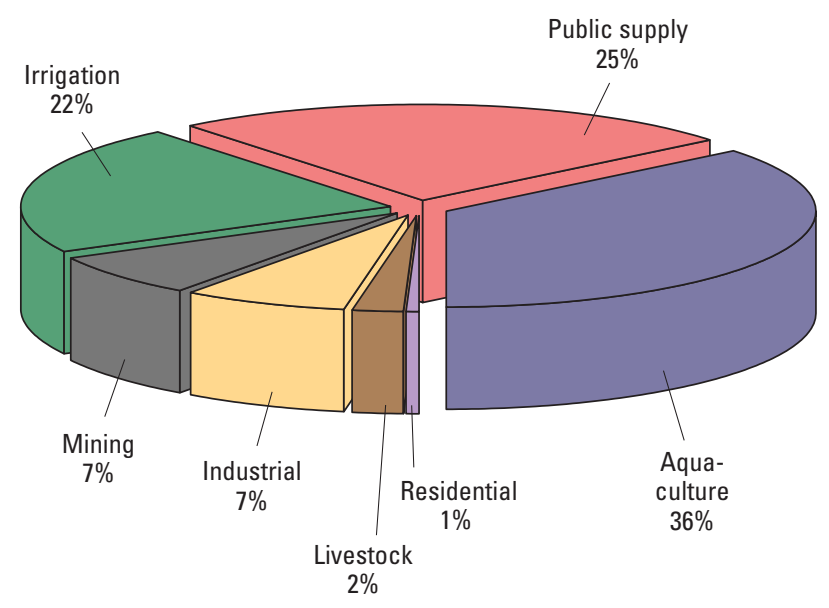

\section{Withdrawals by public supplier, in $\mathrm{Mgal} / \mathrm{d}$}

\begin{tabular}{lrrr}
\hline Public Supplier & GW & SW & Totals \\
\hline Baker Hill Water Authority & 0.64 & 0.00 & 0.64 \\
Clayton Water Works and Sewer & .37 & .00 & .37 \\
Board & & & \\
Clio & .49 & .00 & .49 \\
Cowikee Water Authority & .10 & .00 & .10 \\
Eufaula Water Works and Sewer & 2.33 & .00 & 2.33 \\
Board & & & \\
Louisville Water Works & .14 & .00 & .14 \\
West Barbour County Water & .07 & .00 & .07 \\
Authority & & & \\
\hline
\end{tabular}

Withdrawals by Standard Industrial Classification, in Mgal/d

\begin{tabular}{lccr}
\hline Standard Industrial Classification & GW & SW & Totals \\
\hline 20 Food and Kindred Products & 1.18 & 0.00 & 1.18 \\
\hline
\end{tabular}




\section{Bibb}

Population: 21,516

Population served by public supply: 19,979

Per capita use (gallons per person per day): 102

Acres irrigated: 140

Land area: 623.0 square miles

Water area: 3.1 square miles

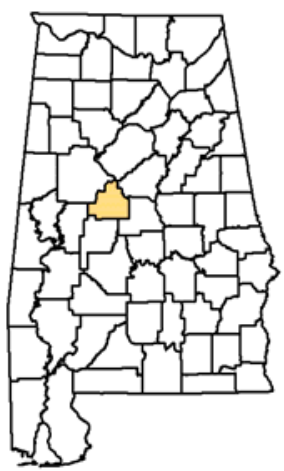

Withdrawals, in million gallons per day $(\mathrm{Mgal} / \mathrm{d})$ and percent (\%) [Percents are rounded to nearest whole number]

\begin{tabular}{lrrr}
\hline Category & GW & SW & Totals \\
\hline Public Supply & 4.16 & 0.00 & 4.16 \\
& $100 \%$ & $0 \%$ & \\
Residential & 0.13 & .00 & 0.13 \\
& 100 & 0 & \\
Irrigation & .03 & .06 & .09 \\
& 34 & 66 & \\
Aquaculture & .00 & .36 & .36 \\
& 0 & 100 & \\
Livestock & .03 & .04 & .07 \\
& 41 & 59 & \\
Mining & .17 & .00 & .17 \\
& 100 & 0 & \\
TOTALS & 4.52 & 0.46 & 4.98 \\
& $91 \%$ & $9 \%$ & \\
\hline
\end{tabular}

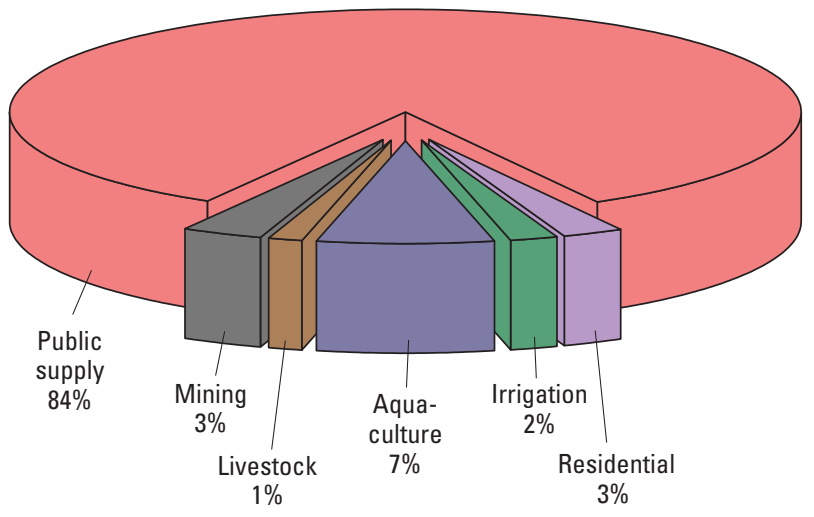

Withdrawals by public supplier, in Mgal/d

\begin{tabular}{lrrr}
\hline Public Supplier & GW & SW & Totals \\
\hline Brent Utilities Board & 1.00 & 0.00 & 1.00 \\
Centreville Water \& Sewer Board & 0.80 & .00 & 0.80 \\
Citizens' Water Service, Inc. & .96 & .00 & .96 \\
Green Pond Water System & .54 & .00 & .54 \\
Warrior River Water Authority & .45 & .00 & .45 \\
West Blocton Water Works & .42 & .00 & .42 \\
\hline
\end{tabular}

Withdrawals by Standard Industrial Classification, in Mgal/d Standard Industrial Classification $\mathrm{GW} \quad \mathrm{SW}$ Totals

None 


\section{Blount}

Population: 55,725

Population served by public supply: 43,224

Per capita use (gallons per person per day): 81

Acres irrigated: 590

Land area: 645.6 square miles

Water area: 5.0 square miles

Withdrawals, in million gallons per day (Mgal/d) and percent $(\%)$ [Percents are rounded to nearest whole number]

\begin{tabular}{lrrr}
\hline Category & GW & SW & Totals \\
\hline Public Supply & 2.74 & 13.45 & 16.19 \\
Residential & $17 \%$ & $83 \%$ & \\
Irrigation & 0.77 & 0.00 & 0.77 \\
& 100 & 0 & \\
Livestock & .30 & .46 & .76 \\
& 40 & 60 & \\
Mining & .46 & .50 & .96 \\
& 48 & 52 & \\
TOTALS & .27 & .00 & .27 \\
& 100 & 0 & \\
\cline { 2 - 3 } & 4.54 & 14.41 & 18.95 \\
& $24 \%$ & $76 \%$ & \\
\hline
\end{tabular}

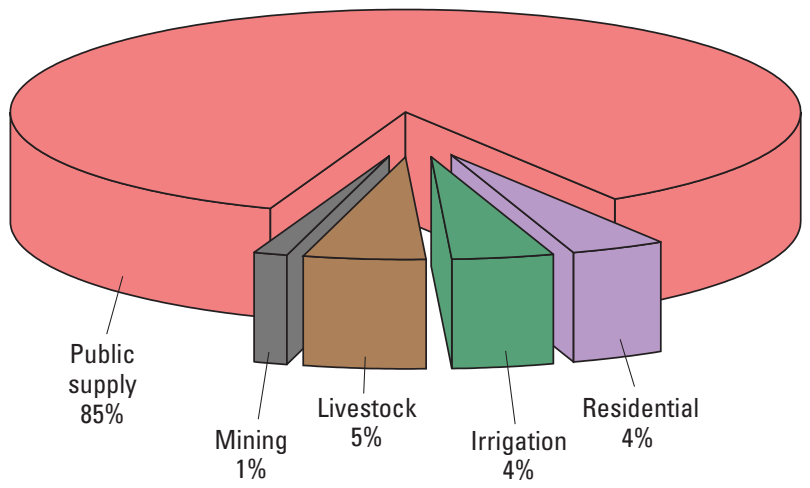

Withdrawals by Standard Industrial Classification, in Mgal/d \begin{tabular}{llll}
\hline Standard Industrial Classification & GW & SW & Totals
\end{tabular}

None

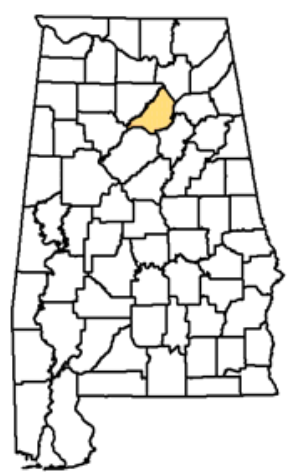

Withdrawals by public supplier, in Mgal/d

\begin{tabular}{lrrr}
\hline Public Supplier & GW & SW & Totals \\
\hline Allgood Water Works & 0.00 & 0.06 & 0.06 \\
Altoona Water \& Sewer & .12 & .00 & .12 \\
Birmingham WW\&SB & .00 & 11.38 & 11.38 \\
Blount County Water Authority & .00 & 1.21 & 1.21 \\
Blountsville Utility Board & .47 & .00 & .47 \\
Cleveland Water Works & .33 & .00 & .33 \\
Nectar Water Department & .19 & .00 & .19 \\
Oneonta Utilities Board & 1.44 & .80 & 2.24 \\
Snead & .18 & .00 & .18 \\
\hline
\end{tabular}




\section{Bullock}

Population: 11,055

Population served by public supply: 10,307

Per capita use (gallons per person per day): 70

Acres irrigated: 930

Land area: 625.0 square miles

Water area: 1.0 square mile

Withdrawals, in million gallons per day (Mgal/d) and percent (\%) [Percents are rounded to nearest whole number]

\begin{tabular}{lrrr}
\hline Category & GW & SW & Totals \\
\hline Public Supply & 2.04 & 0.00 & 2.04 \\
Residential & $100 \%$ & $0 \%$ & \\
& 0.06 & .00 & 0.06 \\
Irrigation & 100 & 0 & \\
& 1.53 & 1.59 & 3.12 \\
Livestock & 49 & 51 & \\
& .06 & .10 & .16 \\
Mining & 39 & 61 & \\
& .04 & .02 & .06 \\
TOTALS & 68 & 32 & \\
\cline { 2 - 4 } & 3.73 & 1.71 & 5.44 \\
\hline
\end{tabular}

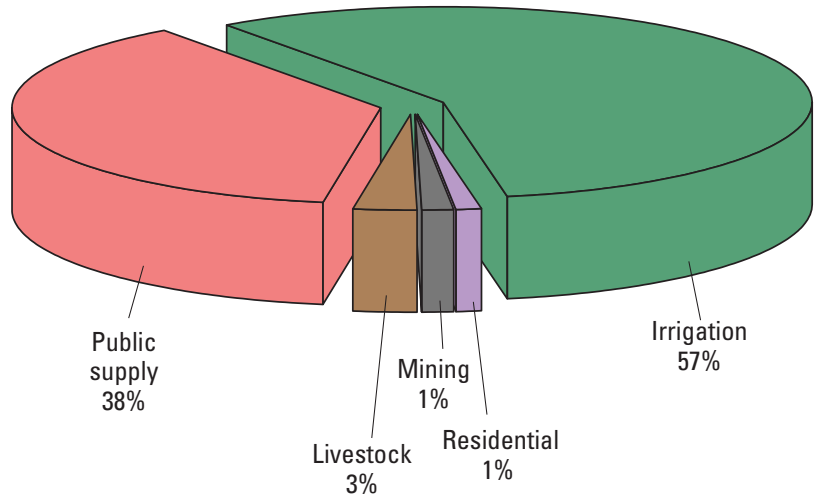

Withdrawals by Standard Industrial Classification, in Mgal/d

\begin{tabular}{llll}
\hline Standard Industrial Classification & GW & SW & Totals
\end{tabular}

None 


\section{Butler}

Population: 20,766

Population served by public supply: 17,445

Per capita use (gallons per person per day): 82

Acres irrigated: 510

Land area: 776.9 square miles

Water area: 1.1 square miles

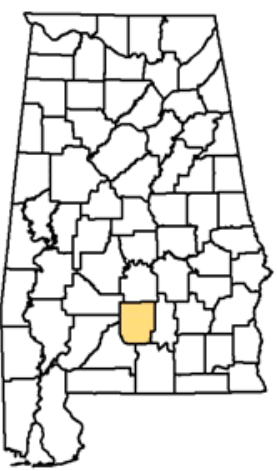

Withdrawals, in million gallons per day (Mgal/d) and percent (\%) [Percents are rounded to nearest whole number]

\begin{tabular}{lrrr}
\hline Category & GW & SW & Totals \\
\hline Public Supply & 3.00 & 0.00 & 3.00 \\
Residential & $100 \%$ & $0 \%$ & \\
& 0.19 & .00 & 0.19 \\
Irrigation & 100 & 0 & \\
& .04 & .50 & .54 \\
Livestock & 8 & 92 & \\
& .14 & .21 & .35 \\
Industrial & 40 & 60 & \\
& .31 & .00 & .31 \\
TOTALS & 100 & 0 & \\
\cline { 2 - 3 } & 3.68 & 0.71 & 4.39 \\
& $84 \%$ & $16 \%$ & \\
\hline
\end{tabular}

\section{Withdrawals by public supplier, in $\mathrm{Mgal} / \mathrm{d}$}

\begin{tabular}{lrrr}
\hline Public Supplier & GW & SW & Totals \\
\hline Butler County Water Authority & 1.16 & 0.00 & 1.16 \\
$\begin{array}{l}\text { Fort Deposit (The Water Works } \\
\text { and Sewer Board of the Town of) }\end{array}$ & 0.19 & .00 & 0.19 \\
$\begin{array}{l}\text { Georgiana Water Works and } \\
\text { Sewer Board }\end{array}$ & .31 & .00 & .31 \\
$\begin{array}{l}\text { Greenville Water Works and } \\
\text { Sewer Board }\end{array}$ & 1.21 & .00 & 1.21 \\
McKenzie - Town Hall (Town of) & .13 & .00 & .13 \\
\hline
\end{tabular}

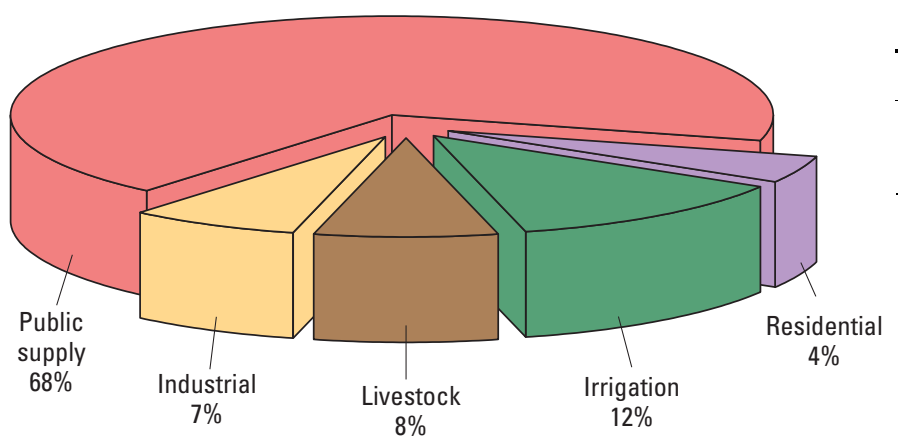

Withdrawals by Standard Industrial Classification, in Mgal/d

\begin{tabular}{lllr}
\hline Standard Industrial Classification & GW & SW & Totals \\
\hline $\begin{array}{l}\text { 24 Lumber and Wood } \\
\text { Products, Except Furniture }\end{array}$ & 0.31 & 0.00 & 0.31 \\
\hline
\end{tabular}




\section{Calhoun}

\section{Population: 112,141}

Population served by public supply: 106,294

Per capita use (gallons per person per day): 105

Acres irrigated: 2,460

Land area: 608.5 square miles

Water area: 3.9 square miles

Withdrawals, in million gallons per day (Mgal/d) and percent (\%) [Percents are rounded to nearest whole number]

\begin{tabular}{lrrr}
\hline Category & GW & SW & Totals \\
\hline Public Supply & 19.75 & 2.35 & 22.10 \\
Residential & $89 \%$ & $11 \%$ & \\
& 0.83 & 0.00 & 0.83 \\
Irrigation & 100 & 0 & \\
& .00 & 4.28 & 4.28 \\
Aquaculture & 0 & 100 & \\
& .00 & .07 & .07 \\
Livestock & 0 & 100 & \\
& .12 & .17 & .29 \\
Industrial & 42 & 58 & \\
& 1.10 & .00 & 1.10 \\
Mining & 100 & 0 & \\
& .19 & .09 & .28 \\
TOTALS & 68 & 32 & \\
\cline { 2 - 3 } & 21.99 & 6.96 & 28.95 \\
\hline
\end{tabular}

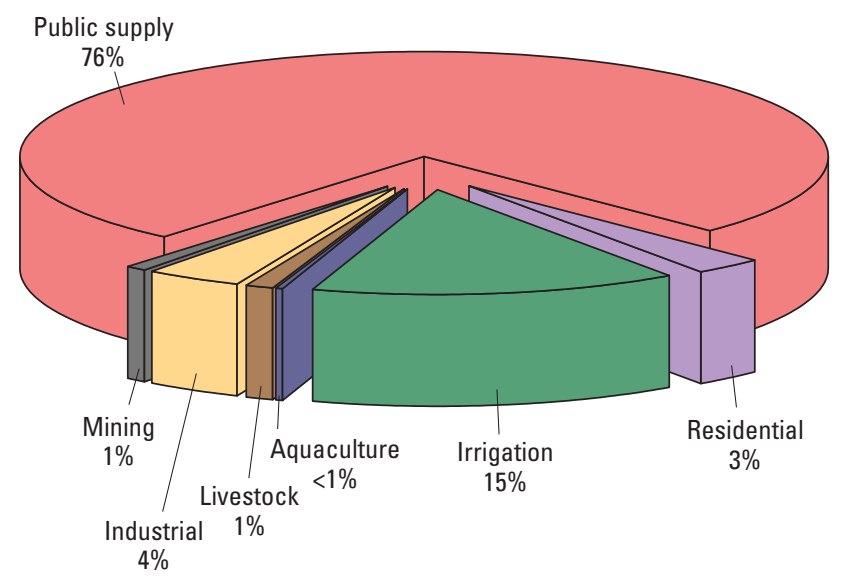

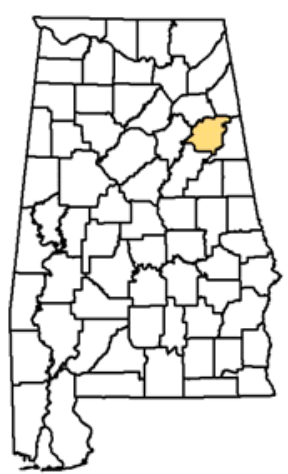

Withdrawals by public supplier, in $\mathrm{Mgal} / \mathrm{d}$

\begin{tabular}{|c|c|c|c|}
\hline Public Supplier & GW & SW & Totals \\
\hline $\begin{array}{l}\text { Anniston Water Works and Sewer } \\
\text { Board }\end{array}$ & 11.91 & 0.08 & 11.99 \\
\hline Calhoun County Water Authority & 3.08 & .00 & 3.08 \\
\hline $\begin{array}{l}\text { Jacksonville Water Works \& } \\
\text { Sewer Board }\end{array}$ & 0.00 & 1.34 & 1.34 \\
\hline $\begin{array}{l}\text { Oxford Water Works and Sewer } \\
\text { Board }\end{array}$ & 4.04 & .00 & 4.04 \\
\hline $\begin{array}{l}\text { Piedmont Water Works and Sewer } \\
\text { Board }\end{array}$ & .00 & .93 & 0.93 \\
\hline Weaver & .72 & .00 & .72 \\
\hline
\end{tabular}

Withdrawals by Standard Industrial Classification, in Mgal/d

\begin{tabular}{lrrr}
\hline Standard Industrial Classification & GW & \multicolumn{1}{c}{ SW } & Totals \\
\hline 20 Food and Kindred Products & 0.43 & 0.00 & 0.43 \\
26 Paper and Allied Products & .53 & .00 & .53 \\
33 Primary Metal Industries & .14 & .00 & .14 \\
\hline
\end{tabular}




\section{Chambers}

Population: 35,460

Population served by public supply: 26,817

Per capita use (gallons per person per day): 87

Acres irrigated: 230

Land area: 597.2 square miles

Water area: 5.9 square miles

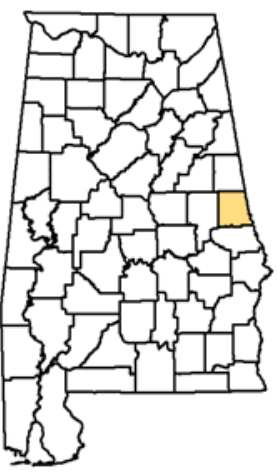

Withdrawals, in million gallons per day (Mgal/d) and percent (\%) [Percents are rounded to nearest whole number]

\begin{tabular}{lrrr}
\hline Category & GW & SW & Totals \\
\hline Public Supply & 0.00 & 5.24 & 5.24 \\
Residential & $0 \%$ & $100 \%$ & \\
& .58 & 0.00 & 0.58 \\
Irrigation & 100 & 0 & \\
& .16 & .06 & .22 \\
Livestock & 72 & 28 & \\
& .08 & .12 & .20 \\
Industrial & 40 & 60 & \\
& .00 & 2.16 & 2.16 \\
TOTALS & 0 & 100 & \\
\cline { 2 - 3 } & 0.82 & 7.58 & 8.40 \\
& $10 \%$ & $90 \%$ & \\
\hline
\end{tabular}

Withdrawals by public supplier, in Mgal/d

\begin{tabular}{lrrr}
\hline Public Supplier & GW & SW & Totals \\
\hline $\begin{array}{l}\text { Chattahoochee Valley Water } \\
\begin{array}{l}\text { Supply District } \\
\text { Lafayette }\end{array}\end{array}$ & 0.00 & 4.72 & 4.72 \\
\hline
\end{tabular}

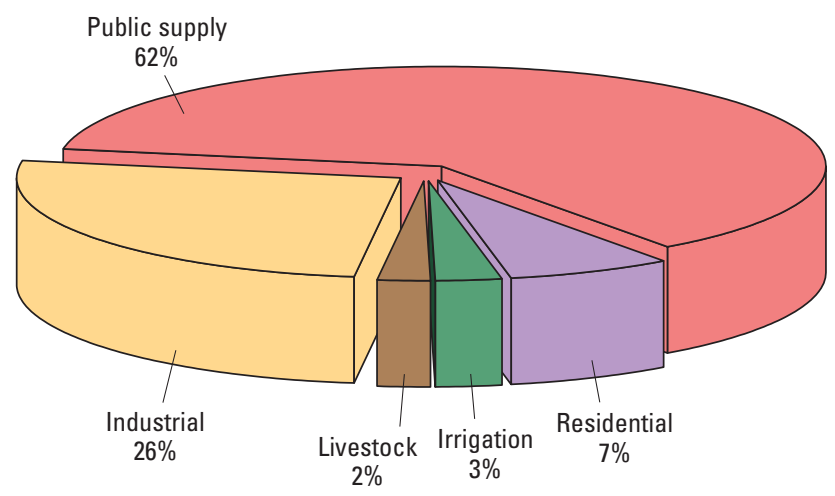

Withdrawals by Standard Industrial Classification, in Mgal/d

\begin{tabular}{lllr}
\hline Standard Industrial Classification & GW & SW & Totals \\
\hline 23 Apparel and Other & 0.00 & 2.16 & 2.16 \\
$\quad$ Finished Products Made & & & \\
$\quad \begin{array}{l}\text { From Fabrics and Similar } \\
\text { Materials }\end{array}$ & & & \\
\hline
\end{tabular}




\section{Cherokee}

Population: 24,522

Population served by public supply: 16,866

Per capita use (gallons per person per day): 91

Acres irrigated: 2,220

Land area: 553.1 square miles

Water area: 46.8 square miles

Withdrawals, in million gallons per day (Mgal/d) and percent $(\%)$ [Percents are rounded to nearest whole number]

\begin{tabular}{lrrr}
\hline Category & GW & SW & Totals \\
\hline Public Supply & 2.02 & 1.19 & 3.21 \\
& $63 \%$ & $37 \%$ & \\
Residential & 0.70 & 0.00 & 0.70 \\
& 100 & 0 & \\
Irrigation & .00 & 2.62 & 2.62 \\
& 0 & 100 & \\
Aquaculture & .39 & .00 & .39 \\
& 100 & 0 & \\
Livestock & .11 & .17 & .28 \\
& 40 & 60 & \\
Mining & .00 & .00 & .00 \\
& 60 & 40 & \\
TOTALS & 3.22 & 3.98 & 7.20 \\
& $45 \%$ & $55 \%$ & \\
\hline
\end{tabular}

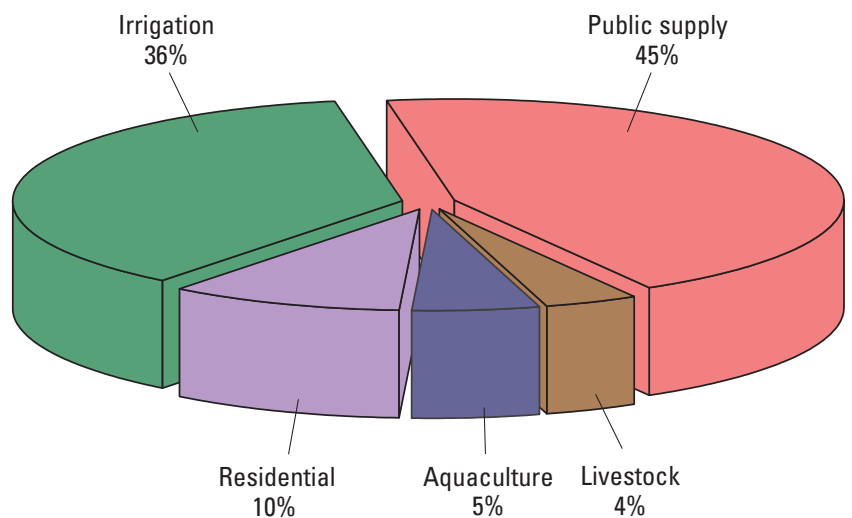

28

00

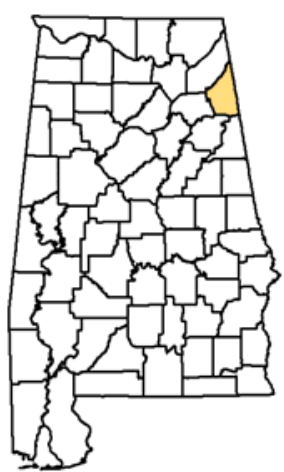

Withdrawals by public supplier, in Mgal/d

\begin{tabular}{lrrr}
\hline Public Supplier & GW & SW & Totals \\
\hline Centre Water Works \& Sewer & 0.00 & 1.19 & 1.19 \\
Board & & & \\
Cherokee County Water Authority & .97 & 0.00 & 0.97 \\
$\begin{array}{l}\text { Northeast Alabama Water, Sewer } \\
\text { \& F.P.A. }\end{array}$ & 1.06 & .00 & 1.06 \\
\hline
\end{tabular}

Withdrawals by Standard Industrial Classification, in Mgal/d

Standard Industrial Classification $\quad$ GW $\quad$ SW $\quad$ Totals

None 


\section{Chilton}

Population: 41,744

Population served by public supply: 32,837

Per capita use (gallons per person per day): 65

Acres irrigated: 690

Land area: 694.0 square miles

Water area: 6.8 square miles

Withdrawals, in million gallons per day (Mgal/d) and percent $(\%)$ [Percents are rounded to nearest whole number]

\begin{tabular}{lrrr}
\hline Category & GW & SW & Totals \\
\hline Public Supply & 2.55 & 1.79 & 4.34 \\
Residential & $59 \%$ & $41 \%$ & \\
Irrigation & 0.58 & 0.00 & 0.58 \\
& 100 & 0 & \\
Livestock & .56 & .08 & .64 \\
& 88 & 12 & \\
Mining & .09 & .13 & .22 \\
& 40 & 60 & \\
TOTALS & .32 & .15 & .47 \\
& 68 & 32 & \\
\hline
\end{tabular}

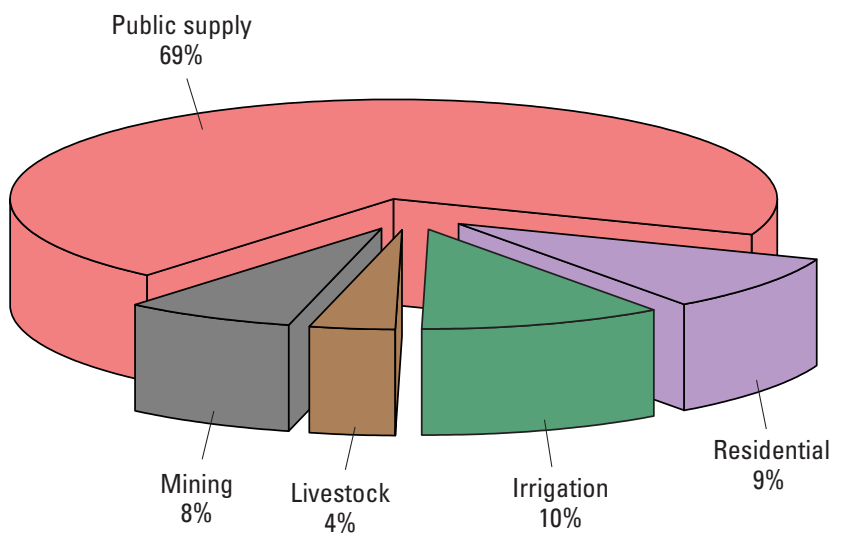

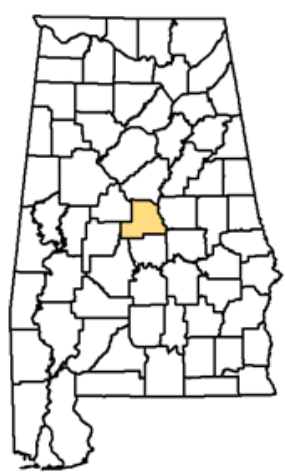

Withdrawals by public supplier, in Mgal/d

\begin{tabular}{lcrr}
\hline Public Supplier & GW & SW & Totals \\
\hline Chilton Water Authority & 1.84 & 0.00 & 1.84 \\
Clanton Waterworks \& Sewer & 0.00 & 1.79 & 1.79 \\
Board & & & \\
Thorsby & .71 & .00 & 0.71 \\
\hline
\end{tabular}

Withdrawals by Standard Industrial Classification, in $\mathrm{Mgal} / \mathrm{d}$

\begin{tabular}{llll}
\hline Standard Industrial Classification & $\mathrm{GW}$ & SW & Totals
\end{tabular}

None 


\section{Choctaw}

Population: 14,807

Population served by public supply: 6,077

Per capita use (gallons per person per day): 73

Acres irrigated: 100

Land area: 913.5 square miles

Water area: 7.3 square miles

Withdrawals, in million gallons per day (Mgal/d) and percent (\%) [Percents are rounded to nearest whole number]

\begin{tabular}{lrrr}
\hline Category & GW & SW & Totals \\
\hline Public Supply & 1.30 & 0.00 & 1.30 \\
Residential & $100 \%$ & $0 \%$ & \\
& 0.63 & .00 & 0.63 \\
Irrigation & 100 & 0 & \\
& .00 & .06 & .06 \\
Aquaculture & 5 & 95 & \\
Livestock & .00 & .08 & .08 \\
Industrial & 0 & 100 & \\
& .04 & .05 & .09 \\
TOTALS & 40 & 60 & \\
& .00 & 47.41 & 47.41 \\
& 0 & 100 & \\
\cline { 2 - 4 } & 1.97 & 47.60 & 49.57 \\
\cline { 2 - 4 } & $4 \%$ & $96 \%$ & \\
\hline
\end{tabular}

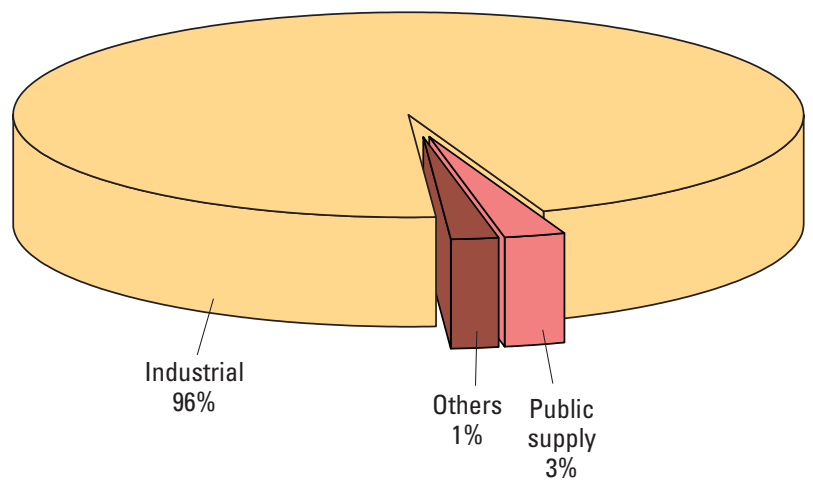

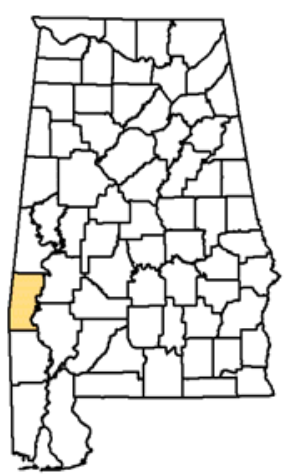

Withdrawals by public supplier, in Mgal/d

\begin{tabular}{lrrr}
\hline Public Supplier & GW & SW & Totals \\
\hline Butler Utilities Board & 0.42 & 0.00 & 0.42 \\
Gilbertown Utilities Board & .44 & .00 & .44 \\
North Choctaw Water Authority & .28 & .00 & .28 \\
Pennington Utilities Board & .16 & .00 & .16 \\
\hline
\end{tabular}

Withdrawals by Standard Industrial Classification, in Mgal/d

\begin{tabular}{lccc}
\hline Standard Industrial Classification & GW & SW & Totals \\
\hline 26 Paper and Allied Products & 0.00 & 47.41 & 47.41 \\
\hline
\end{tabular}




\section{Clarke}

Population: 27,269

Population served by public supply: 19,967

Per capita use (gallons per person per day): 75

Acres irrigated: 140

Land area: 1,238.4 square miles

Water area: 14.1 square miles

Withdrawals, in million gallons per day (Mgal/d) and percent $(\%)$ [Percents are rounded to nearest whole number]

\begin{tabular}{lrrr}
\hline Category & GW & SW & Totals \\
\hline Public Supply & 2.13 & 1.87 & 4.00 \\
Residential & $53 \%$ & $47 \%$ & \\
Irrigation & 0.56 & 0.00 & 0.56 \\
& 100 & 0 & \\
Aquaculture & .02 & .06 & .08 \\
& 21 & 79 & \\
Livestock & .03 & .04 & .07 \\
& 43 & 57 & \\
Mining & .03 & .05 & .08 \\
& 38 & 62 & \\
TOTALS & .11 & .00 & .11 \\
& 100 & 0 & \\
\cline { 2 - 3 } & 2.88 & 2.02 & 4.90 \\
\hline
\end{tabular}

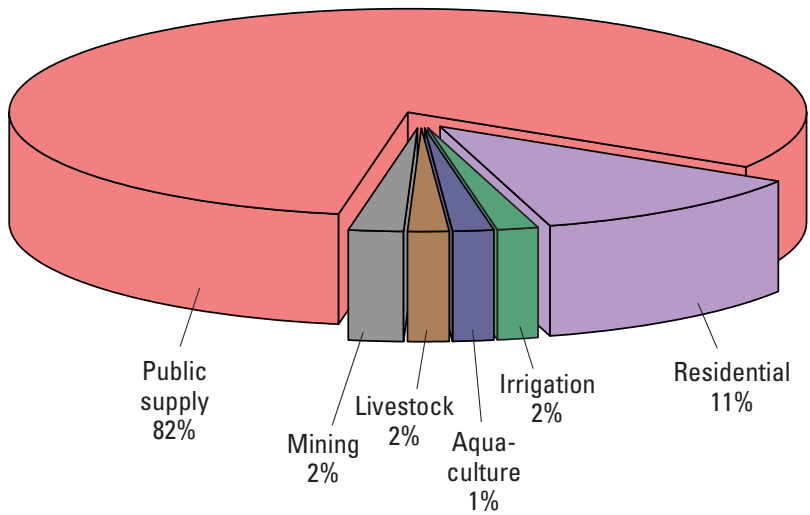

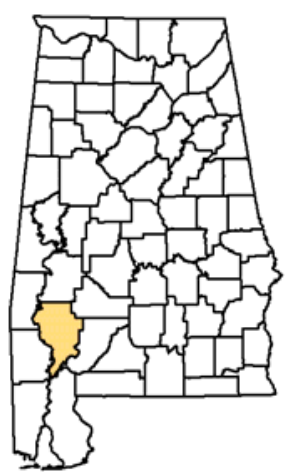

Withdrawals by public supplier, in Mgal/d

\begin{tabular}{lrrr}
\hline Public Supplier & GW & SW & Totals \\
\hline Coffeeville Water Works & 0.18 & 0.00 & 0.18 \\
Fulton (Utilities Board of the & .12 & .00 & .12 \\
Town of) & & & \\
Grove Hill Water Works Board & .68 & .00 & .68 \\
Jackson Water and Sewer Board & 1.16 & 1.87 & 3.03 \\
\hline
\end{tabular}

Withdrawals by Standard Industrial Classification, in Mgal/d

Standard Industrial Classification $\mathrm{GW} \quad \mathrm{SW}$ Totals

None 


\section{Clay}

Population: 13,964

Population served by public supply: 6,361

Per capita use (gallons per person per day): 50

Acres irrigated: 220

Land area: 605.1 square miles

Water area: 0.9 square mile

Withdrawals, in million gallons per day (Mgal/d) and percent $(\%)$ [Percents are rounded to nearest whole number]

\begin{tabular}{lrrr}
\hline Category & GW & SW & Totals \\
\hline Public Supply & 0.00 & 1.87 & 1.87 \\
Residential & $0 \%$ & $100 \%$ & \\
& .39 & 0.00 & 0.39 \\
Irrigation & 100 & 0 & \\
& .00 & .11 & .11 \\
Aquaculture & 0 & 100 & \\
& .00 & .01 & .01 \\
Livestock & 0 & 100 & \\
& .14 & .18 & .32 \\
TOTALS & 43 & 57 & \\
\cline { 2 - 4 } & 0.53 & 2.17 & 2.70 \\
\hline
\end{tabular}

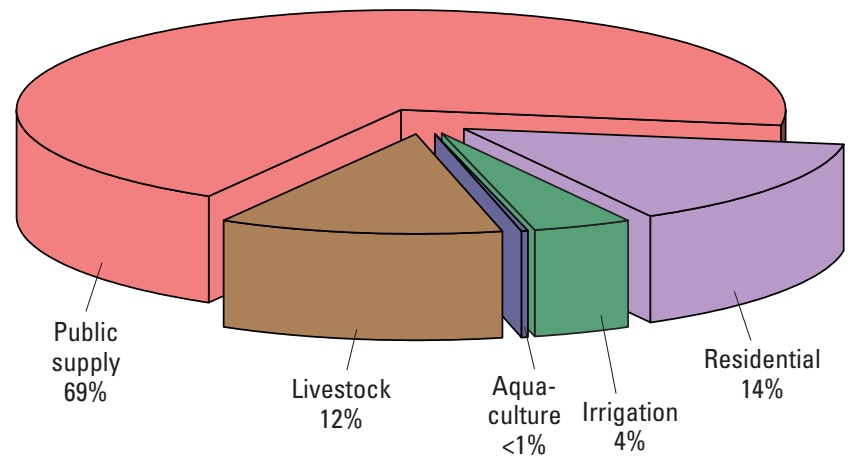

Withdrawals by Standard Industrial Classification, in Mgal/d

\begin{tabular}{llll}
\hline Standard Industrial Classification & GW & SW & Totals
\end{tabular}

None 


\section{Cleburne}

Population: 14,460

Population served by public supply: 6,343

Per capita use (gallons per person per day): 87

Acres irrigated: 100

Land area: 560.2 square miles

Water area: 0.8 square mile

Withdrawals, in million gallons per day (Mgal/d) and percent (\%) [Percents are rounded to nearest whole number]

\begin{tabular}{lrrr}
\hline Category & GW & SW & Totals \\
\hline Public Supply & 0.00 & 0.51 & 0.51 \\
Residential & $0 \%$ & $100 \%$ & \\
Irrigation & .72 & .00 & .72 \\
& 100 & 0 & \\
Livestock & .00 & .06 & .06 \\
& 0 & 100 & \\
Industrial & .17 & .20 & .37 \\
TOTALS & 46 & 54 & \\
& .71 & .00 & .71 \\
& 100 & 0 & \\
\cline { 2 - 4 } & 1.60 & 0.77 & 2.37 \\
\cline { 2 - 4 } & $68 \%$ & $32 \%$ & \\
\hline
\end{tabular}

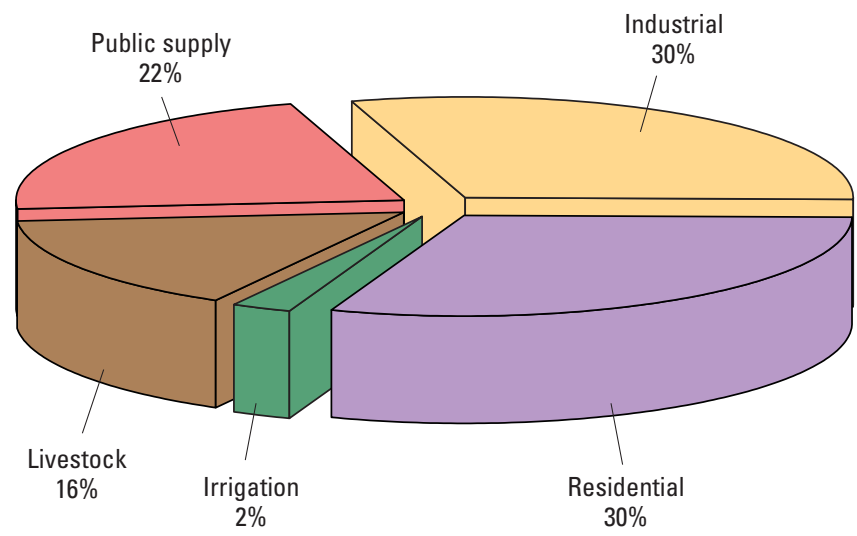

37

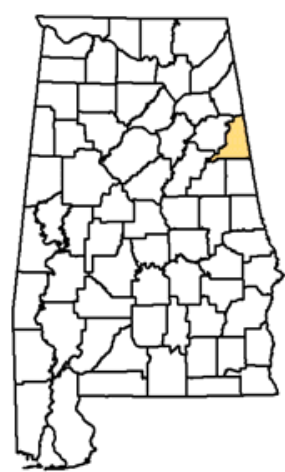

Withdrawals by public supplier, in Mgal/d

\begin{tabular}{lrrr}
\hline Public Supplier & GW & SW & Totals \\
\hline Heflin Water Works & 0.00 & 0.51 & 0.51 \\
\hline
\end{tabular}

\begin{tabular}{lllr}
\hline Standard Industrial Classification & GW & SW & Totals \\
\hline 20 Food and Kindred Products & 0.71 & 0.00 & 0.71 \\
\hline
\end{tabular}




\section{Coffee}

Population: 45,567

Population served by public supply: 37,584

Per capita use (gallons per person per day): 68

Acres irrigated: 5,760

Land area: 679.0 square miles

Water area: 1.5 square miles

Withdrawals, in million gallons per day (Mgal/d) and percent $(\%)$ [Percents are rounded to nearest whole number]

\begin{tabular}{lrrr}
\hline Category & GW & SW & Totals \\
\hline Public Supply & 6.67 & 0.00 & 6.67 \\
& $100 \%$ & $0 \%$ & \\
Residential & 0.38 & .00 & 0.38 \\
& 100 & 0 & \\
Irrigation & .65 & 2.81 & 3.46 \\
& 19 & 81 & \\
Aquaculture & .48 & .26 & .74 \\
& 65 & 35 & \\
Livestock & .36 & .48 & .84 \\
& 43 & 57 & \\
Industrial & .86 & .00 & .86 \\
& 100 & 0 & \\
TOTALS & 9.40 & 3.55 & 12.95 \\
& $73 \%$ & $27 \%$ & \\
\hline
\end{tabular}

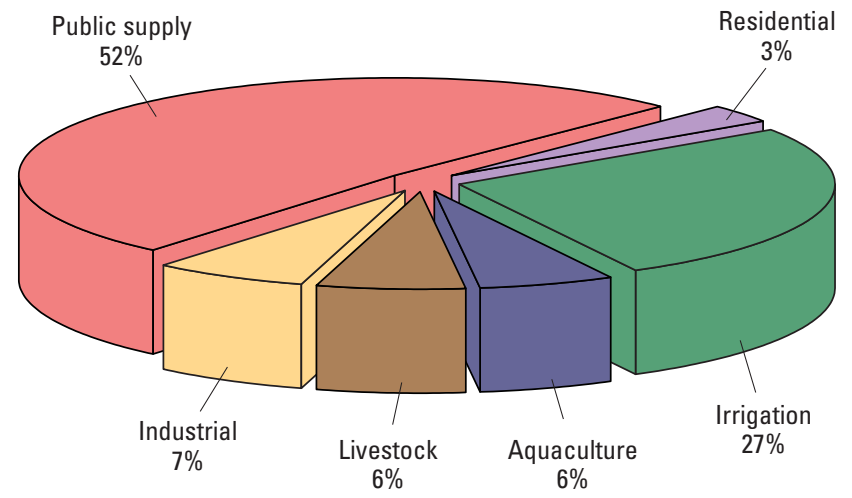

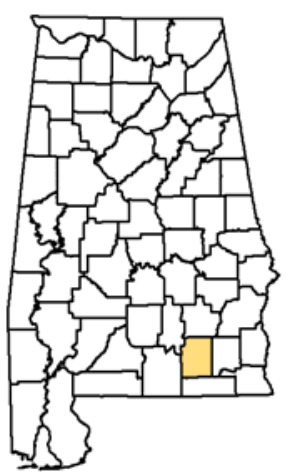

Withdrawals by public supplier, in Mgal/d

\begin{tabular}{lrrr}
\hline Public Supplier & GW & SW & Totals \\
\hline Coffee County Water Authority & 0.17 & 0.00 & 0.17 \\
Elba Water and Electric Board & .62 & .00 & .62 \\
Enterprise Water Works Board & 4.58 & .00 & 4.58 \\
Jack Water System, Inc. & .08 & .00 & .08 \\
Kinston & .02 & .00 & .02 \\
New Brockton Water \& Sewer & .61 & .00 & .61 \\
Board & & & \\
New Hope Water System, Inc. & .07 & .00 & .07 \\
Opp Utilities Board & .52 & .00 & .52 \\
\hline
\end{tabular}

Withdrawals by Standard Industrial Classification, in Mgal/d

\begin{tabular}{lccr}
\hline Standard Industrial Classification & GW & SW & Totals \\
\hline 20 Food and Kindred Products & 0.86 & 0.00 & 0.86 \\
\hline
\end{tabular}




\section{Colbert}

Population: 54,660

Population served by public supply: 50,704

Per capita use (gallons per person per day): 66

Acres irrigated: 2,640

Land area: 594.5 square miles

Water area: 29.1 square miles

Withdrawals, in million gallons per day (Mgal/d) and percent $(\%)$ [Percents are rounded to nearest whole number]

\begin{tabular}{|c|c|c|c|}
\hline Category & GW & SW & Totals \\
\hline \multirow[t]{2}{*}{ Public Supply } & 1.29 & 8.27 & 9.56 \\
\hline & $13 \%$ & $87 \%$ & \\
\hline \multirow[t]{2}{*}{ Residential } & 0.31 & 0.00 & 0.31 \\
\hline & 100 & 0 & \\
\hline \multirow[t]{2}{*}{ Irrigation } & .94 & 1.40 & 2.34 \\
\hline & 40 & 60 & \\
\hline \multirow[t]{2}{*}{ Aquaculture } & .02 & .00 & .02 \\
\hline & 100 & 0 & \\
\hline \multirow[t]{2}{*}{ Livestock } & .13 & .17 & .30 \\
\hline & 43 & 57 & \\
\hline \multirow[t]{2}{*}{ Industrial } & .87 & 55.57 & 56.44 \\
\hline & 2 & 98 & \\
\hline \multirow[t]{2}{*}{ Mining } & .00 & .05 & .05 \\
\hline & 0 & 100 & \\
\hline \multirow[t]{2}{*}{ Thermoelectric } & .00 & $1,294.14$ & $1,294.14$ \\
\hline & 0 & 100 & \\
\hline \multirow[t]{2}{*}{ TOTALS } & 3.56 & $1,359.60$ & $1,363.16$ \\
\hline & $0 \%$ & $100 \%$ & \\
\hline
\end{tabular}

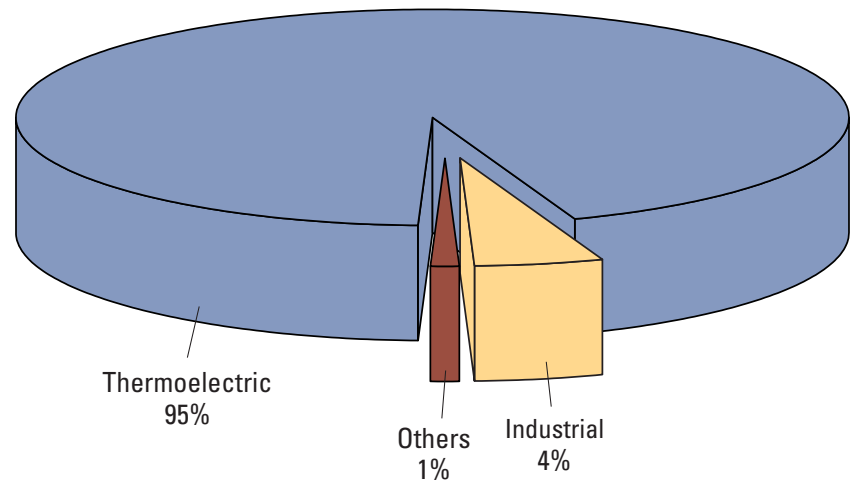

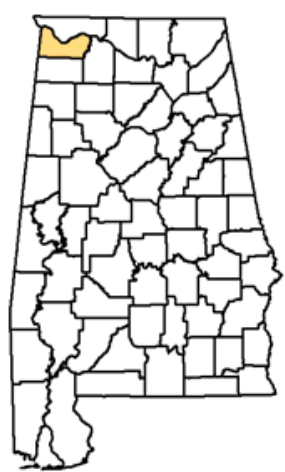

Withdrawals by public supplier, in Mgal/d

\begin{tabular}{lrrr}
\hline Public Supplier & GW & SW & Totals \\
\hline $\begin{array}{l}\text { Cherokee Waterworks and Gas } \\
\text { Board }\end{array}$ & 0.00 & 0.36 & 0.36 \\
Hawk Pride Mountain Water & 1.06 & .00 & 1.06 \\
System & & & \\
Leighton Water \& Sewer Board & .23 & .00 & .23 \\
Muscle Shoals Utilities Board & .00 & 4.09 & 4.09 \\
Sheffield Utilities & .00 & 1.98 & 1.98 \\
Tuscumbia - Water Department & .00 & 1.84 & 1.84 \\
\hline
\end{tabular}

Withdrawals by Standard Industrial Classification, in Mgal/d

\begin{tabular}{lrrr}
\hline Standard Industrial Classification & GW & SW & Totals \\
\hline 26 Paper and Allied Products & 0.00 & 3.30 & 3.30 \\
28 Chemicals and Allied & .00 & 48.55 & 48.55 \\
$\quad$ Products & & & \\
34 Fabricated Metal Products, & .87 & 3.72 & 4.59 \\
$\quad \begin{array}{l}\text { Except Machinery and } \\
\text { Transportation Equipment }\end{array}$ & & & \\
$\begin{array}{l}\text { 49 Electric, Gas, and Sanitary } \\
\quad \text { Services }\end{array}$ & .00 & $1,294.14$ & $1,294.14$ \\
\hline
\end{tabular}




\section{Conecuh}

Population: 13,257

Population served by public supply: 7,560

Per capita use (gallons per person per day): 84

Acres irrigated: 100

Land area: 850.8 square miles

Water area: 1.7 square miles

Withdrawals, in million gallons per day (Mgal/d) and percent $(\%)$ [Percents are rounded to nearest whole number]

\begin{tabular}{lrrr}
\hline Category & GW & SW & Totals \\
\hline Public Supply & 1.60 & 0.00 & 1.60 \\
Residential & $100 \%$ & $0 \%$ & \\
& 0.40 & .00 & 0.40 \\
Irrigation & 100 & 0 & \\
& .00 & .06 & .06 \\
Aquaculture & 0 & 100 & \\
& .01 & .01 & .02 \\
Livestock & 50 & 50 & \\
& .07 & .11 & .18 \\
Mining & 40 & 60 & \\
& .11 & .00 & .11 \\
TOTALS & 100 & 0 & \\
\cline { 2 - 4 } & 2.19 & 0.18 & 2.37 \\
\hline
\end{tabular}

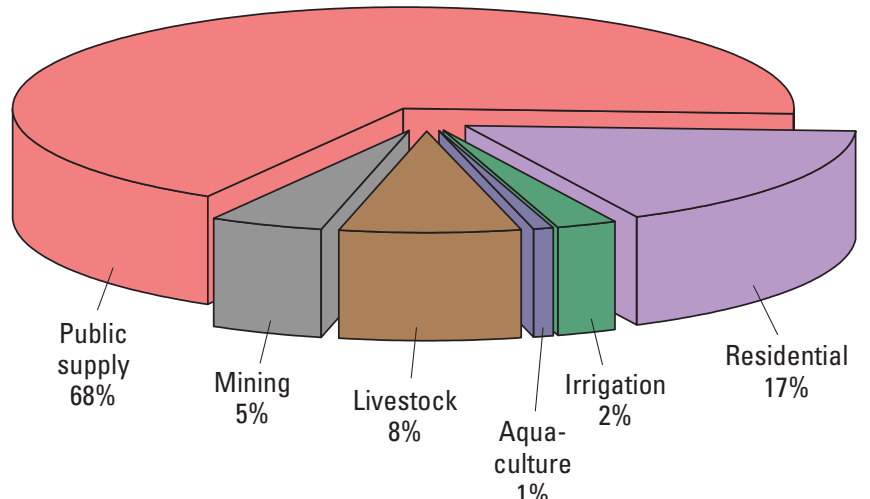

Withdrawals by Standard Industrial Classification, in Mgal/d

\begin{tabular}{llll}
\hline Standard Industrial Classification & GW & SW & Totals
\end{tabular}

None 


\section{Coosa}

Population: 11,162

Population served by public supply: 6,435

Per capita use (gallons per person per day): 55

Acres irrigated: 80

Land area: 652.4 square miles

Water area: 13.9 square miles

Withdrawals, in million gallons per day (Mgal/d) and percent (\%) [Percents are rounded to nearest whole number]

\begin{tabular}{lrrr}
\hline Category & GW & SW & Totals \\
\hline Public Supply & 0.00 & 0.46 & 0.46 \\
Residential & $0 \%$ & $100 \%$ & \\
Irrigation & .28 & .00 & .28 \\
& 100 & 0 & \\
Livestock & .01 & .02 & .03 \\
& 44 & 56 & \\
Mining & .03 & .04 & .07 \\
TOTALS & 42 & 58 & \\
& .11 & .05 & .16 \\
& 69 & 31 & \\
\cline { 1 - 3 } & 0.43 & 0.57 & 1.00 \\
\hline
\end{tabular}

Withdrawals by public supplier, in Mgal/d

\begin{tabular}{lrrr}
\hline Public Supplier & GW & SW & Totals \\
\hline $\begin{array}{l}\text { Goodwater Water Works and } \\
\text { Sewer Board }\end{array}$ & 0.00 & 0.46 & 0.46 \\
\hline
\end{tabular}

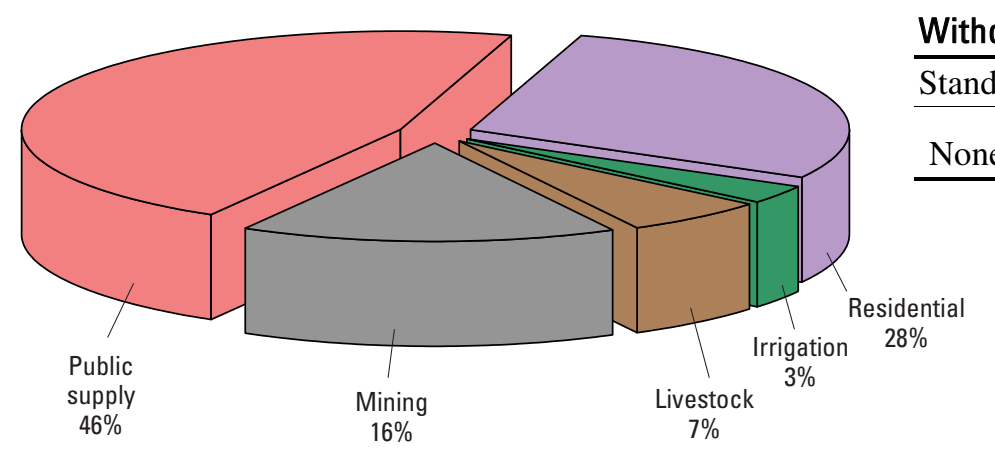

Withdrawals by Standard Industrial Classification, in Mgal/d Standard Industrial Classification $\quad$ GW $\quad$ SW $\quad$ Totals

None 


\section{Covington}

Population: 37,003

Population served by public supply: 23,627

Per capita use (gallons per person per day): 79

Acres irrigated: 1,590

Land area: 1,033.8 square miles

Water area: 10.1 square miles

Withdrawals, in million gallons per day (Mgal/d) and percent (\%) [Percents are rounded to nearest whole number]

\begin{tabular}{|c|c|c|c|}
\hline Category & GW & SW & Totals \\
\hline \multirow[t]{2}{*}{ Public Supply } & 4.38 & 0.00 & 4.38 \\
\hline & $100 \%$ & $0 \%$ & \\
\hline \multirow[t]{2}{*}{ Residential } & 1.04 & .00 & 1.04 \\
\hline & 100 & 0 & \\
\hline \multirow[t]{2}{*}{ Irrigation } & 2.13 & .44 & 2.57 \\
\hline & 83 & 17 & \\
\hline \multirow[t]{2}{*}{ Aquaculture } & 0.10 & .10 & 0.20 \\
\hline & 50 & 50 & \\
\hline \multirow[t]{2}{*}{ Livestock } & .26 & .36 & .62 \\
\hline & 42 & 58 & \\
\hline \multirow[t]{2}{*}{ Industrial } & .43 & .00 & .43 \\
\hline & 100 & 0 & \\
\hline \multirow[t]{2}{*}{ Mining } & .00 & .00 & .00 \\
\hline & 100 & 0 & \\
\hline \multirow[t]{2}{*}{ Thermoelectric } & .00 & 4.30 & 4.30 \\
\hline & 0 & 100 & \\
\hline \multirow[t]{2}{*}{ TOTALS } & 8.34 & $\overline{5.20}$ & 13.54 \\
\hline & $62 \%$ & $38 \%$ & \\
\hline
\end{tabular}

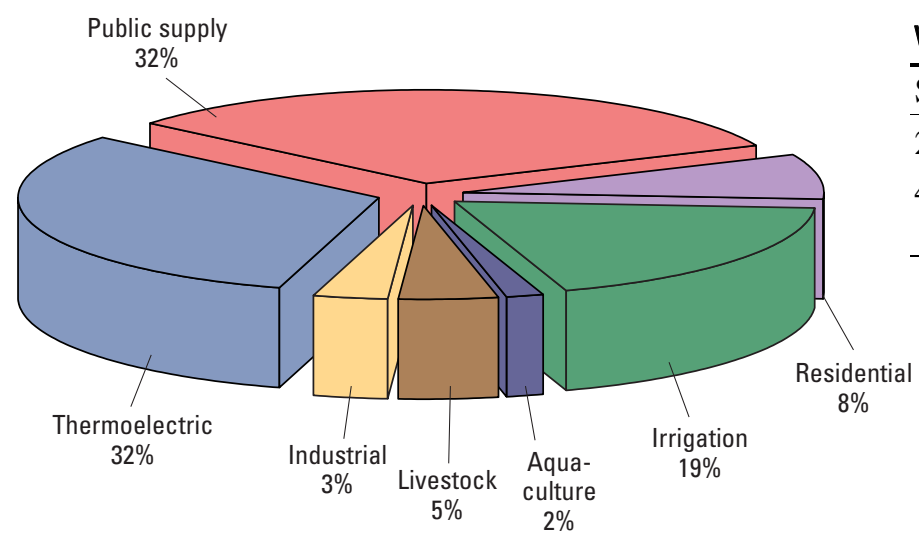

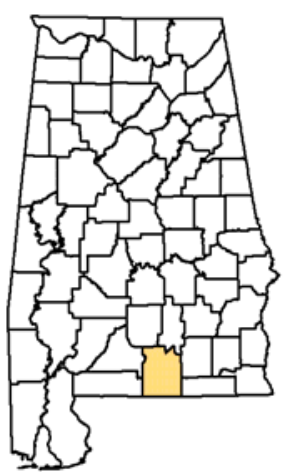

Withdrawals by public supplier, in Mgal/d

\begin{tabular}{lrrr}
\hline Public Supplier & GW & SW & Totals \\
\hline Andalusia Water Works Board & 2.42 & 0.00 & 2.42 \\
Covington County Water & 0.64 & .00 & 0.64 \\
Department & & & \\
Florala Water Works \& Sewer & .39 & .00 & .39 \\
Board & & & \\
Lockhart & .07 & .00 & .07 \\
Opp Utilities Board & .69 & .00 & .69 \\
Red Level & .06 & .00 & .06 \\
River Falls & .10 & .00 & .10 \\
\hline
\end{tabular}

Withdrawals by Standard Industrial Classification, in Mgal/d

\begin{tabular}{lrrr}
\hline Standard Industrial Classification & GW & SW & Totals \\
\hline 22 Textile Mill Products & 0.43 & 0.00 & 0.43 \\
49 Electric, Gas, and Sanitary & .00 & 4.30 & 4.30 \\
$\quad$ Services & & & \\
\hline
\end{tabular}




\section{Crenshaw}

Population: 13,727

Population served by public supply: 10,422

Per capita use (gallons per person per day): 66

Acres irrigated: 630

Land area: 609.6 square miles

Water area: 1.3 square miles

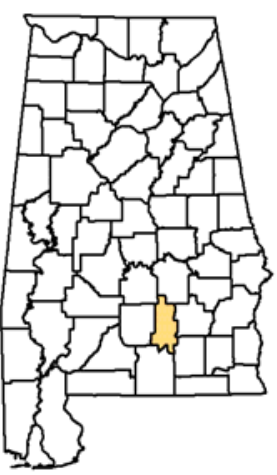

Withdrawals, in million gallons per day (Mgal/d) and percent (\%) [Percents are rounded to nearest whole number]

\begin{tabular}{lrrr}
\hline Category & GW & SW & Totals \\
\hline Public Supply & 2.15 & 0.00 & 2.15 \\
& $100 \%$ & $0 \%$ & \\
Residential & 0.12 & .00 & 0.12 \\
Irrigation & 100 & 0 & \\
& .00 & .38 & .38 \\
Livestock & 0 & 100 & \\
& .24 & .34 & .58 \\
TOTALS & 41 & 59 & \\
\cline { 2 - 4 } & 2.51 & 0.72 & 3.23 \\
\hline
\end{tabular}

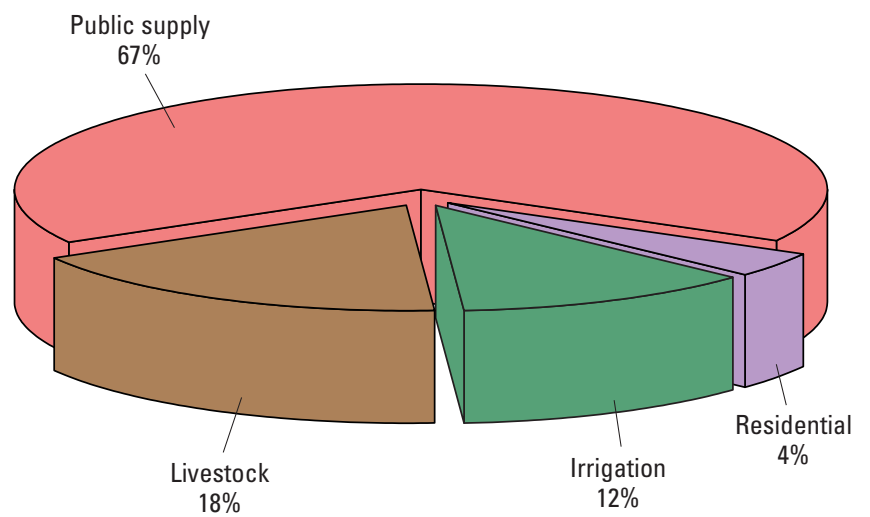

\section{Withdrawals by public supplier, in $\mathrm{Mgal} / \mathrm{d}$}

\begin{tabular}{lrrr}
\hline Public Supplier & GW & SW & Totals \\
\hline Brantley & 0.22 & 0.00 & 0.22 \\
Dozier Water Works & .04 & .00 & .04 \\
Glenwood & .01 & .00 & .01 \\
Luverne Water Works and Sewer & .42 & .00 & .42 \\
Board & & & \\
Quint-Mar Water Authority & .59 & .00 & .59 \\
Rutledge & .06 & .00 & .06 \\
Sellers Station Water System, Inc. & .14 & .00 & .14 \\
South Crenshaw County Water & .67 & .00 & .67 \\
Authority & & & \\
\hline
\end{tabular}

Withdrawals by Standard Industrial Classification, in Mgal/d \begin{tabular}{llll}
\hline Standard Industrial Classification & GW & SW & Totals
\end{tabular}

None 


\section{Cullman}

Population: 79,886

Population served by public supply: 77,321

Per capita use (gallons per person per day): 77

Acres irrigated: 740

Land area: 738.4 square miles

Water area: 16.4 square miles

Withdrawals, in million gallons per day (Mgal/d) and percent (\%) [Percents are rounded to nearest whole number]

\begin{tabular}{lrrr}
\hline Category & GW & SW & Totals \\
\hline Public Supply & 0.50 & 26.51 & 27.01 \\
& $2 \%$ & $98 \%$ & \\
Residential & .21 & 0.00 & 0.21 \\
& 100 & 0 & \\
Irrigation & 1.11 & .15 & 1.26 \\
& 88 & 12 & \\
Livestock & 1.13 & 1.10 & 2.23 \\
& 51 & 49 & \\
Industrial & .00 & 1.79 & 1.79 \\
& 0 & 100 & \\
Mining & .04 & .12 & .16 \\
& 24 & 76 & \\
TOTALS & 2.99 & 29.67 & 32.66 \\
& $9 \%$ & $91 \%$ & \\
\hline
\end{tabular}

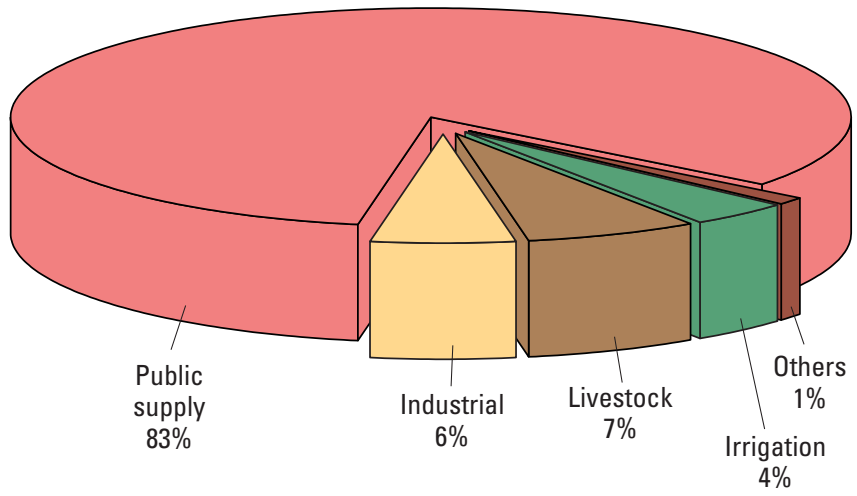

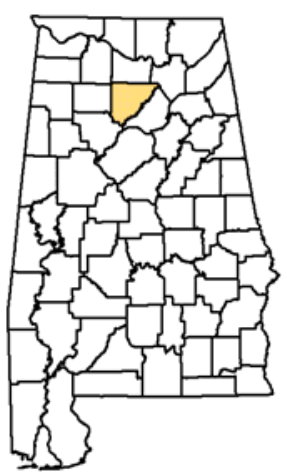

Withdrawals by public supplier, in Mgal/d

\begin{tabular}{lrrr}
\hline Public Supplier & GW & SW & Totals \\
\hline Birmingham WW\&SB & 0.00 & 13.98 & 13.98 \\
Cullman & .00 & 12.53 & 12.53 \\
Hanceville Water and Sewer Board & .50 & 0.00 & 0.50 \\
\hline
\end{tabular}

Withdrawals by Standard Industrial Classification, in Mgal/d

\begin{tabular}{lccr}
\hline Standard Industrial Classification & GW & SW & Totals \\
\hline 20 Food and Kindred Products & 0.00 & 1.79 & 1.79 \\
\hline
\end{tabular}




\section{Dale}

Population: 48,748

Population served by public supply: 39,923

Per capita use (gallons per person per day): 77

Acres irrigated: 4,240

Land area: 561.1 square miles

Water area: 1.6 square miles

Withdrawals, in million gallons per day (Mgal/d) and percent $(\%)$ [Percents are rounded to nearest whole number]

\begin{tabular}{lrrr}
\hline Category & GW & SW & Totals \\
\hline Public Supply & 8.78 & 0.00 & 8.78 \\
Residential & $100 \%$ & $0 \%$ & \\
Irrigation & 0.57 & .00 & 0.57 \\
& 100 & 0 & \\
Aquaculture & .41 & 2.04 & 2.45 \\
& 17 & 83 & \\
Livestock & .00 & .10 & .10 \\
TOTALS & 0 & 100 & \\
& .14 & .19 & .33 \\
& 42 & 58 & \\
\hline
\end{tabular}

Withdrawals by public supplier, in Mgal/d

\begin{tabular}{lrrr}
\hline Public Supplier & GW & SW & Totals \\
\hline Ariton Water Department & 0.10 & 0.00 & 0.10 \\
Dale County Water Authority & .45 & .00 & .45 \\
Daleville & .86 & .00 & .86 \\
Dothan Water System & .78 & .00 & .78 \\
Level Plains(Town of) & .27 & .00 & .27 \\
Midland City & .31 & .00 & .31 \\
Newton Water and Sewer Board & .18 & .00 & .18 \\
Ozark Utilities Board & 2.35 & .00 & 2.35 \\
Pinckard & .10 & .00 & .10 \\
U.S. Army Fort Rucker & 3.39 & .00 & 3.39 \\
\hline
\end{tabular}

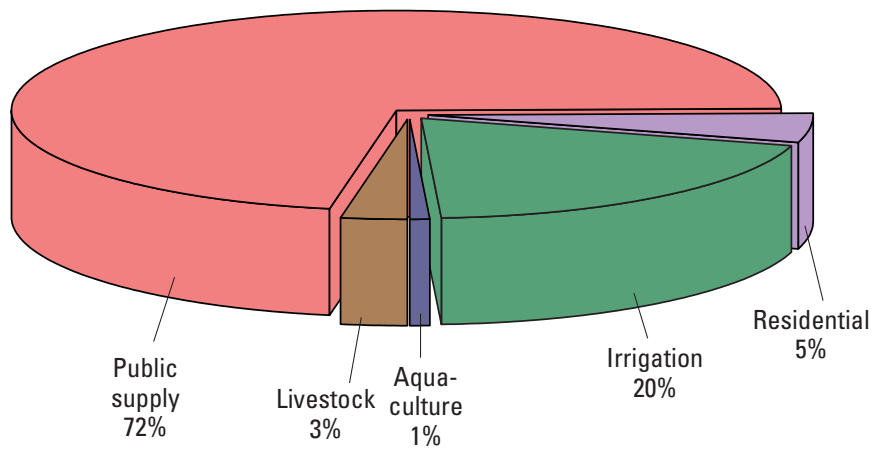

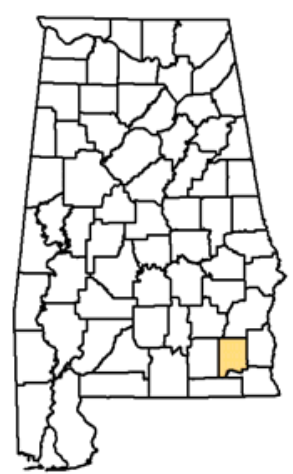

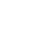




\section{Dallas}

Population: 44,366

Population served by public supply: 34,829

Per capita use (gallons per person per day): 77

Acres irrigated: 2,070

Land area: 980.7 square miles

Water area: 12.7 square miles

Withdrawals, in million gallons per day (Mgal/d) and percent (\%) [Percents are rounded to nearest whole number]

\begin{tabular}{lrrr}
\hline Category & GW & SW & Totals \\
\hline Public Supply & 6.60 & 0.00 & 6.60 \\
Residential & $100 \%$ & $0 \%$ & \\
& 0.75 & .00 & 0.75 \\
Irrigation & 100 & 0 & \\
& .82 & 1.24 & 2.06 \\
Aquaculture & 40 & 60 & \\
& 5.00 & 2.14 & 7.14 \\
Livestock & 70 & 30 & \\
& .16 & .24 & .40 \\
Mining & 40 & 60 & \\
& .57 & .26 & .83 \\
TOTALS & 68 & 32 & \\
& 13.90 & 3.88 & 17.78 \\
& $78 \%$ & $22 \%$ & \\
\hline
\end{tabular}

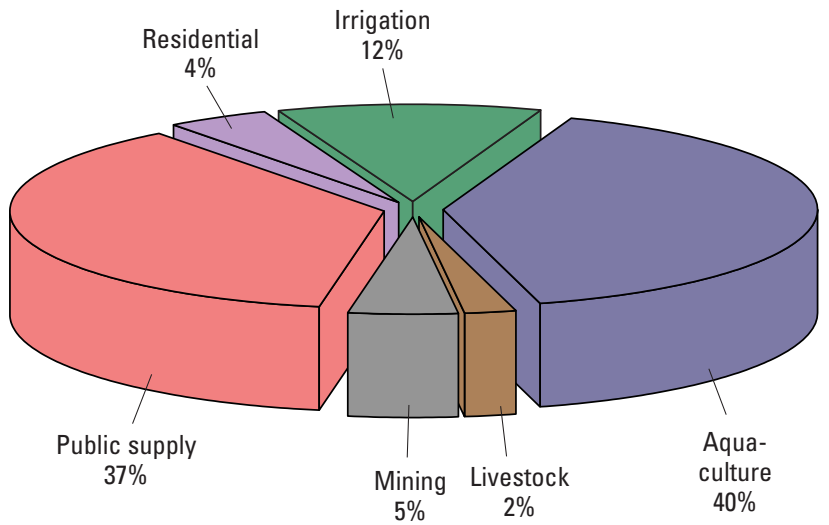

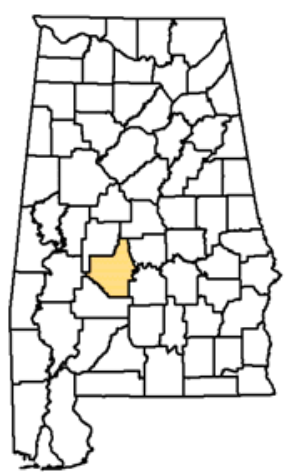

Withdrawals by public supplier, in Mgal/d

\begin{tabular}{lrrr}
\hline Public Supplier & GW & SW & Totals \\
\hline Dallas County Water \& Sewer & 0.79 & 0.00 & 0.79 \\
Authority & & & \\
North Dallas Water Authority & .97 & .00 & .97 \\
Plantersville Water Board & .09 & .00 & .09 \\
Selma Water Works \& Sewer & 4.06 & .00 & 4.06 \\
Board & & & \\
South Dallas Water Authority & .45 & .00 & .45 \\
West Dallas Water Authority & .23 & .00 & .23 \\
\hline
\end{tabular}

Withdrawals by Standard Industrial Classification, in Mgal/d

Standard Industrial Classification $\mathrm{GW} \quad$ SW Totals

None 


\section{De Kalb}

Population: 67,271

Population served by public supply: 48,950

Per capita use (gallons per person per day): 95

Acres irrigated: 1,230

Land area: 777.9 square miles

Water area: 0.7 square miles

Withdrawals, in million gallons per day (Mgal/d) and percent $(\%)$ [Percents are rounded to nearest whole number]

\begin{tabular}{lrrr}
\hline Category & GW & SW & Totals \\
\hline Public Supply & 1.35 & 8.57 & 9.92 \\
& $14 \%$ & $86 \%$ & \\
Residential & 1.46 & 0.00 & 1.46 \\
& 100 & 0 & \\
Irrigation & 0.83 & 1.46 & 2.29 \\
& 36 & 64 & \\
Aquaculture & .01 & .00 & 0.01 \\
& 100 & 0 & \\
Livestock & .96 & 1.08 & 2.04 \\
& 47 & 53 & \\
Industrial & .65 & .00 & .65 \\
& 100 & 0 & \\
Mining & .04 & .02 & .06 \\
& 69 & 31 & \\
TOTALS & 5.30 & 11.13 & 16.43 \\
& $32 \%$ & $68 \%$ & \\
\hline
\end{tabular}

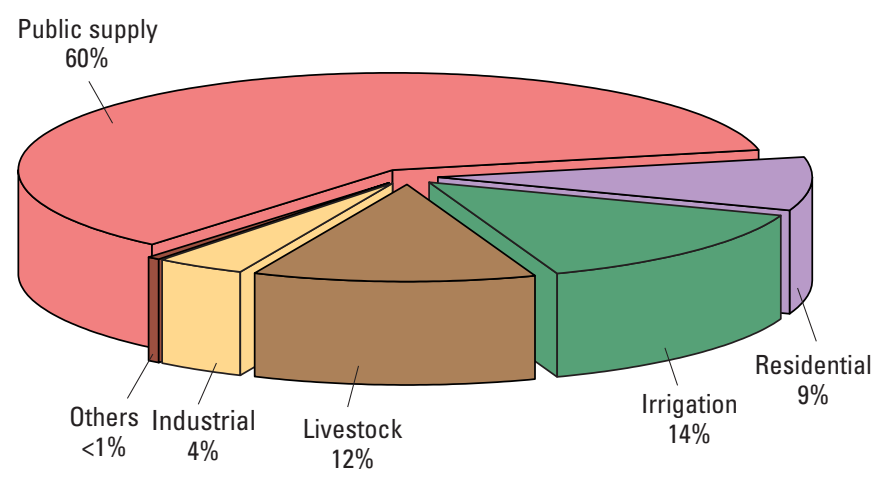

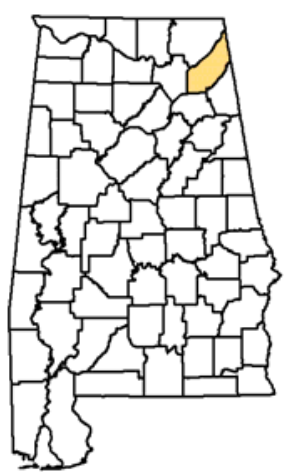

Withdrawals by public supplier, in Mgal/d

\begin{tabular}{lrrr}
\hline Public Supplier & GW & SW & Totals \\
\hline Crossville Water Board & 0.04 & 0.00 & 0.04 \\
Fort Payne Water Works Board & .00 & 8.57 & 8.57 \\
Northeast Alabama Water, Sewer & .65 & .00 & .65 \\
\& F.P.A. & & & \\
Valley Head Water Works Board & .66 & .00 & .66 \\
\hline
\end{tabular}

Withdrawals by Standard Industrial Classification, in Mgal/d

\begin{tabular}{lccr}
\hline Standard Industrial Classification & GW & SW & Totals \\
\hline 20 Food and Kindred Products & 0.65 & 0.00 & 0.65 \\
\hline
\end{tabular}




\section{Elmore}

Population: 73,937

Population served by public supply: 68,719

Per capita use (gallons per person per day): 76

Acres irrigated: 1,350

Land area: 621.3 square miles

Water area: 36.0 square miles

Withdrawals, in million gallons per day (Mgal/d) and percent (\%) [Percents are rounded to nearest whole number]

\begin{tabular}{lrrr}
\hline Category & GW & SW & Totals \\
\hline Public Supply & 2.17 & 10.29 & 12.46 \\
Residential & $17 \%$ & $83 \%$ & \\
& 0.38 & 0.00 & 0.38 \\
Irrigation & 100 & 0 & \\
& .33 & .94 & 1.27 \\
Aquaculture & 26 & 74 & \\
Livestock & .00 & .18 & .18 \\
& 0 & 100 & \\
Mining & .10 & .12 & .22 \\
& 44 & 56 & \\
TOTALS & .21 & .10 & .31 \\
& 68 & 32 & \\
\hline
\end{tabular}

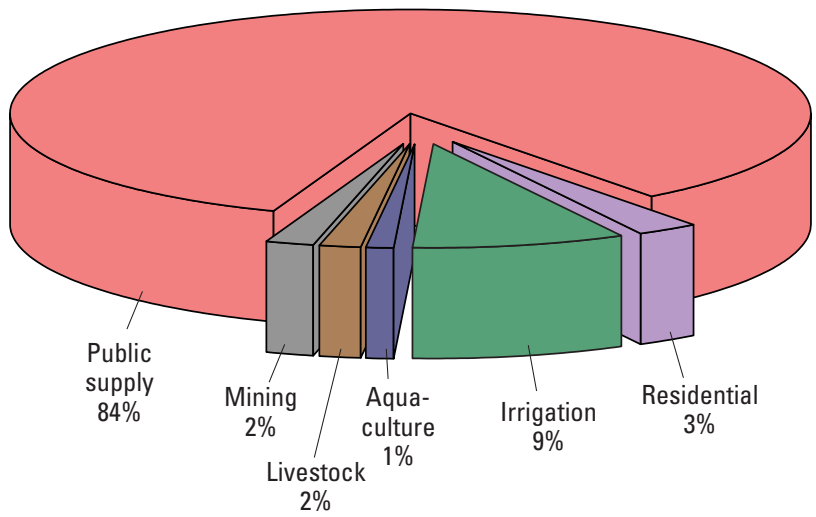

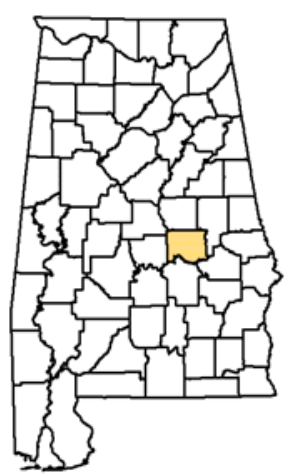

Withdrawals by public supplier, in Mgal/d

\begin{tabular}{lrrr}
\hline Public Supplier & GW & SW & Totals \\
\hline Central Elmore Water \& Sewer & 0.00 & 4.83 & 4.83 \\
Authority & & & \\
Elmore Water Authority & .74 & 0.00 & 0.74 \\
Five Star Water Supply & .00 & 5.46 & 5.46 \\
Holtville Water System, Inc. & .12 & .00 & .12 \\
Marbury Water System & .58 & .00 & .58 \\
Millbrook Utility System & .21 & .00 & .21 \\
Prattville Water Works Board & .17 & .00 & .17 \\
Tri-Community Water System & .35 & .00 & .35 \\
\hline
\end{tabular}

Withdrawals by Standard Industrial Classification, in Mgal/d Standard Industrial Classification $\mathrm{GW} \quad \mathrm{SW}$ Totals

None 


\section{Escambia}

Population: 38,082

Population served by public supply: 31,176

Per capita use (gallons per person per day): 73

Acres irrigated: 1,410

Land area: 947.4 square miles

Water area: 5.6 square miles

Withdrawals, in million gallons per day (Mgal/d) and percent $(\%)$ [Percents are rounded to nearest whole number]

\begin{tabular}{lrrr}
\hline Category & GW & SW & Totals \\
\hline Public Supply & 6.30 & 0.00 & 6.30 \\
Residential & $100 \%$ & $0 \%$ & \\
Irrigation & 0.47 & .00 & 0.47 \\
& 100 & 0 & \\
Aquaculture & .56 & .86 & 1.42 \\
& 39 & 61 & \\
Livestock & .04 & .01 & .05 \\
Industrial & 76 & 24 & \\
& .06 & .09 & .15 \\
Mining & 40 & 60 & \\
& 1.71 & 32.07 & 33.78 \\
TOTALS & 5 & 95 & \\
& .67 & .00 & .67 \\
\hline
\end{tabular}

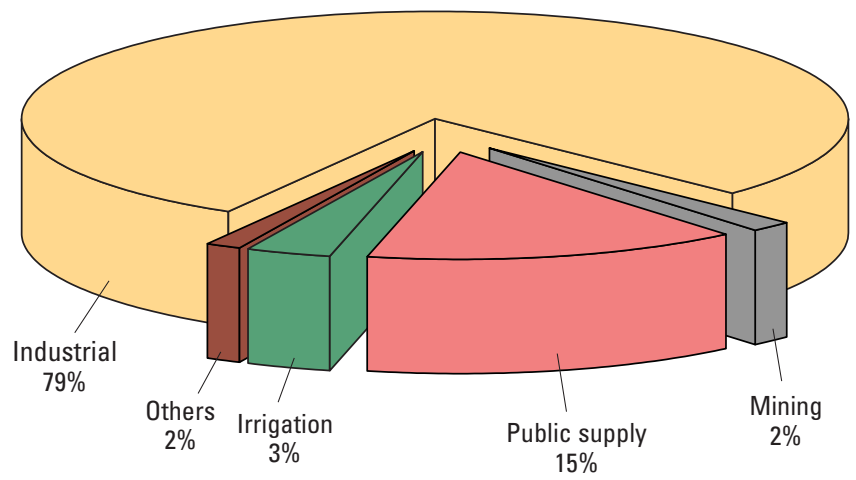

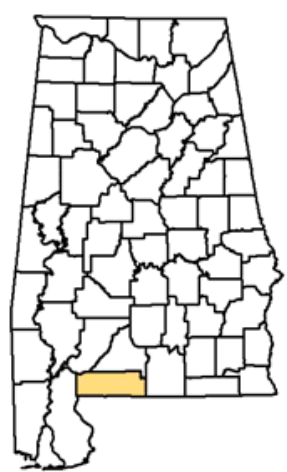

Withdrawals by public supplier, in Mgal/d

\begin{tabular}{lrrr}
\hline Public Supplier & GW & SW & Totals \\
\hline Atmore Utility Board & 2.94 & 0.00 & 2.94 \\
Brewton Water Works Board & 1.48 & .00 & 1.48 \\
Canoe Water and Fire Protection & 0.08 & .00 & 0.08 \\
Authority & & & \\
East Brewton Water and Sewer & .30 & .00 & .30 \\
Board & & & \\
Flomaton & .22 & .00 & .22 \\
Freemanville Water System, Inc. & .43 & .00 & .43 \\
Huxford Water \& Fire Protection & .06 & .00 & .06 \\
Authority & & & \\
McCall Water System & .61 & .00 & .61 \\
Pollard & .02 & .00 & .02 \\
Ridge Road Water Authority & .12 & .00 & .12 \\
Riverview Water System & .05 & .00 & .05 \\
\hline
\end{tabular}

Withdrawals by Standard Industrial Classification, in Mgal/d

\begin{tabular}{lcrr}
\hline Standard Industrial Classification & GW & SW & Totals \\
\hline 24 Lumber and Wood & 1.17 & 0.00 & 1.17 \\
$\quad$ Products, Except Furniture & & & \\
26 Paper and Allied Products & 0.27 & 32.07 & 32.34 \\
$\begin{array}{l}\text { 28 Chemicals and Allied } \\
\quad \begin{array}{l}\text { Products } \\
\text { 29 Petroleum Refining and }\end{array}\end{array}$ & .18 & .00 & 0.18 \\
$\quad$ Related Industries & .09 & .00 & .09 \\
\hline
\end{tabular}




\section{Etowah}

Population: 103,189

Population served by public supply: 99,232

Per capita use (gallons per person per day): 86

Acres irrigated: 1,190

Land area: 534.8 square miles

Water area: 13.9 square miles

Withdrawals, in million gallons per day (Mgal/d) and percent $(\%)$ [Percents are rounded to nearest whole number]

\begin{tabular}{|c|c|c|c|}
\hline Category & GW & SW & Totals \\
\hline \multirow[t]{2}{*}{ Public Supply } & 4.46 & 14.86 & 19.32 \\
\hline & $23 \%$ & $77 \%$ & \\
\hline \multirow[t]{2}{*}{ Residential } & 0.32 & 0.00 & 0.32 \\
\hline & 100 & 0 & \\
\hline \multirow[t]{2}{*}{ Irrigation } & .10 & .94 & 1.04 \\
\hline & 10 & 90 & \\
\hline \multirow[t]{2}{*}{ Aquaculture } & .00 & .02 & .02 \\
\hline & 0 & 100 & \\
\hline \multirow[t]{2}{*}{ Livestock } & .20 & .25 & .45 \\
\hline & 44 & 56 & \\
\hline \multirow[t]{2}{*}{ Industrial } & .00 & 9.87 & 9.87 \\
\hline & 0 & 100 & \\
\hline \multirow[t]{2}{*}{ Mining } & .11 & .05 & .16 \\
\hline & 68 & 32 & \\
\hline \multirow[t]{2}{*}{ Thermoelectric } & .00 & 142.68 & 142.68 \\
\hline & 0 & 100 & \\
\hline \multirow[t]{2}{*}{ TOTALS } & $\overline{5.19}$ & 168.67 & 173.86 \\
\hline & $3 \%$ & $97 \%$ & \\
\hline
\end{tabular}

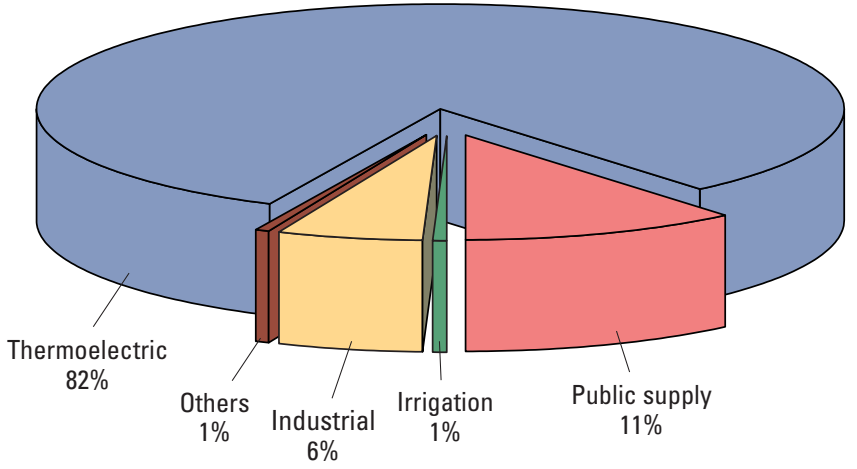

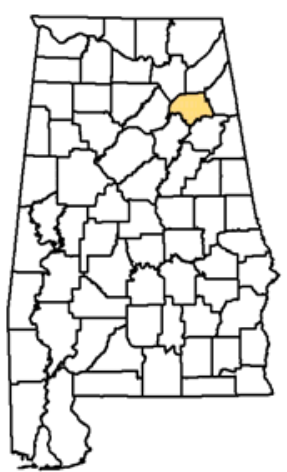

Withdrawals by public supplier, in Mgal/d

\begin{tabular}{lrrr}
\hline Public Supplier & GW & SW & Totals \\
\hline Attalla Water Works Board & 1.16 & 0.00 & 1.16 \\
Gadsden Water Works \& Sewer & 0.00 & 14.86 & 14.86 \\
Board & & & \\
Glencoe Water and Sewer Works & .72 & .00 & 0.72 \\
Hokes Bluff Water Board & .88 & .00 & .88 \\
Southside Water Works \& Sewer & .78 & .00 & .78 \\
Board & & & \\
Walnut Grove & .09 & .00 & .09 \\
West Etowah County Water \& & .83 & .00 & .83 \\
Fire Protection Authority & & & \\
\hline
\end{tabular}

Withdrawals by Standard Industrial Classification, in Mgal/d

\begin{tabular}{lccr}
\hline Standard Industrial Classification & GW & SW & Totals \\
\hline $\begin{array}{l}30 \text { Rubber and Miscellaneous } \\
\text { Plastics Products }\end{array}$ & 0.00 & 9.87 & 9.87 \\
$\begin{array}{l}\text { 49 Electric, Gas, and Sanitary } \\
\text { Services }\end{array}$ & .00 & 142.68 & 142.68 \\
\hline
\end{tabular}




\section{Fayette}

Population: 18,228

Population served by public supply: 10,811

Per capita use (gallons per person per day): 65

Acres irrigated: 100

Land area: 627.7 square miles

Water area: 1.7 square miles

Withdrawals, in million gallons per day (Mgal/d) and percent $(\%)$ [Percents are rounded to nearest whole number]

\begin{tabular}{lrrr}
\hline Category & GW & SW & Totals \\
\hline Public Supply & 0.05 & 2.36 & 2.41 \\
Residential & $2 \%$ & $98 \%$ & \\
Irrigation & .42 & 0.00 & 0.42 \\
& 100 & 0 & \\
Aquaculture & .00 & .06 & .06 \\
Livestock & 0 & 100 & \\
& .02 & .02 & .04 \\
Mining & 50 & 50 & \\
& .09 & .11 & .20 \\
TOTALS & 45 & 55 & \\
& .00 & .80 & .80 \\
& 0 & 100 & \\
\cline { 2 - 4 } & 0.58 & 3.35 & 3.93 \\
\hline
\end{tabular}

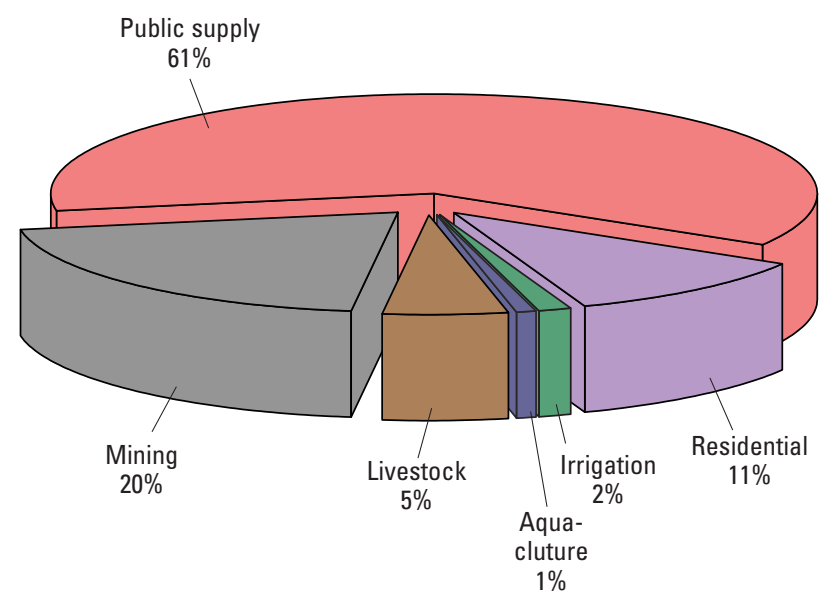

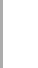

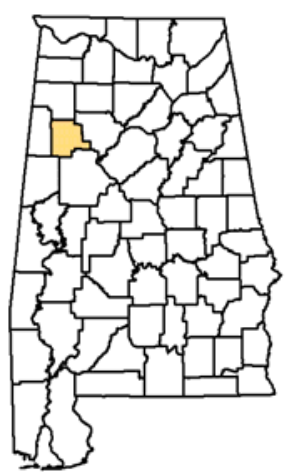

Withdrawals by public supplier, in Mgal/d

\begin{tabular}{lrrr}
\hline Public Supplier & GW & SW & Totals \\
\hline Berry & 0.00 & 0.38 & 0.38 \\
Fayette Water Board & .00 & 1.98 & 1.98 \\
Glen Allen & .05 & .00 & .05 \\
\hline
\end{tabular}

Withdrawals by Standard Industrial Classification, in Mgal/d

\begin{tabular}{llll}
\hline Standard Industrial Classification & $\mathrm{GW}$ & SW & Totals
\end{tabular}

\section{None}




\section{Franklin}

Population: 30,737

Population served by public supply: 24,248

Per capita use (gallons per person per day): 61

Acres irrigated: 560

Land area: 635.6 square miles

Water area: 10.9 square miles

Withdrawals, in million gallons per day (Mgal/d) and percent (\%) [Percents are rounded to nearest whole number]

\begin{tabular}{lrrr}
\hline Category & GW & SW & Totals \\
\hline Public Supply & 1.05 & 3.88 & 4.93 \\
Residential & $21 \%$ & $79 \%$ & \\
& 0.33 & 0.00 & 0.33 \\
Irrigation & 100 & 0 & \\
& .28 & .22 & .50 \\
Livestock & 56 & 44 & \\
& .33 & .44 & .77 \\
Mining & 43 & 57 & \\
& .39 & .18 & .57 \\
TOTALS & 68 & 32 & \\
\cline { 2 - 4 } & 2.38 & 4.72 & 7.10 \\
\hline
\end{tabular}

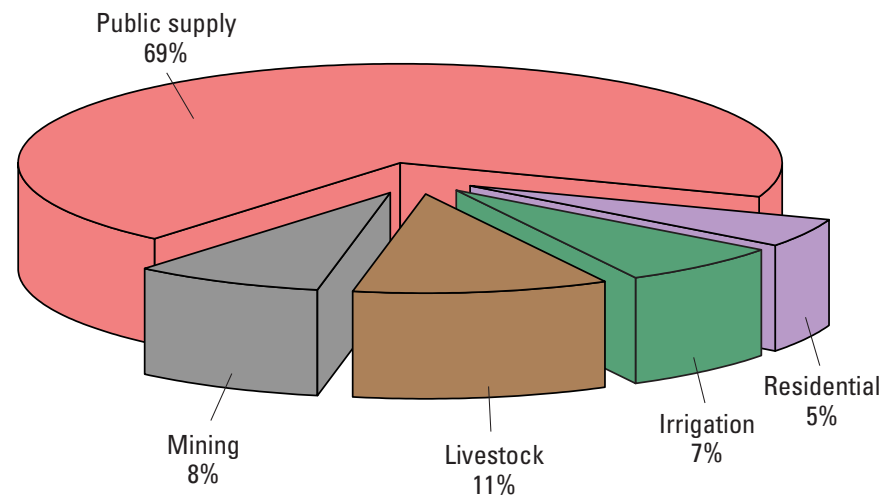

Withdrawals by Standard Industrial Classification, in Mgal/d

None

\begin{tabular}{llll}
\hline Standard Industrial Classification & GW & SW & Totals
\end{tabular}

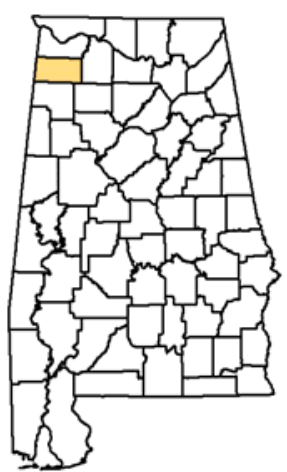

Withdrawals by public supplier, in Mgal/d

\begin{tabular}{lrrr}
\hline Public Supplier & GW & SW & Totals \\
\hline Red Bay Water \& Gas Board & 0.63 & 0.00 & 0.63 \\
Russellville Water \& Sewer Board & .32 & 3.88 & 4.20 \\
Vina Waterworks Board & .10 & .00 & .10 \\
\hline
\end{tabular}

Standard Industrial Classification $\quad$ GW $\quad$ SW Totals 


\section{Geneva}

Population: 25,735

Population served by public supply: 14,941

Per capita use (gallons per person per day): 66

Acres irrigated: 7,010

Land area: 576.3 square miles

Water area: 2.6 square miles

Withdrawals, in million gallons per day (Mgal/d) and percent (\%) [Percents are rounded to nearest whole number]

\begin{tabular}{lrrr}
\hline Category & GW & SW & Totals \\
\hline Public Supply & 1.92 & 0.00 & 1.92 \\
& $100 \%$ & $0 \%$ & \\
Residential & 0.58 & .00 & 0.58 \\
& 100 & 0 & \\
Irrigation & 1.71 & 2.22 & 3.93 \\
& 43 & 57 & \\
Aquaculture & .24 & .06 & .30 \\
Livestock & 80 & 20 & \\
& .37 & .48 & .85 \\
Mining & 44 & 56 & \\
& .02 & .01 & .03 \\
TOTALS & 69 & 31 & \\
& 4.84 & 2.77 & 7.61 \\
\hline
\end{tabular}

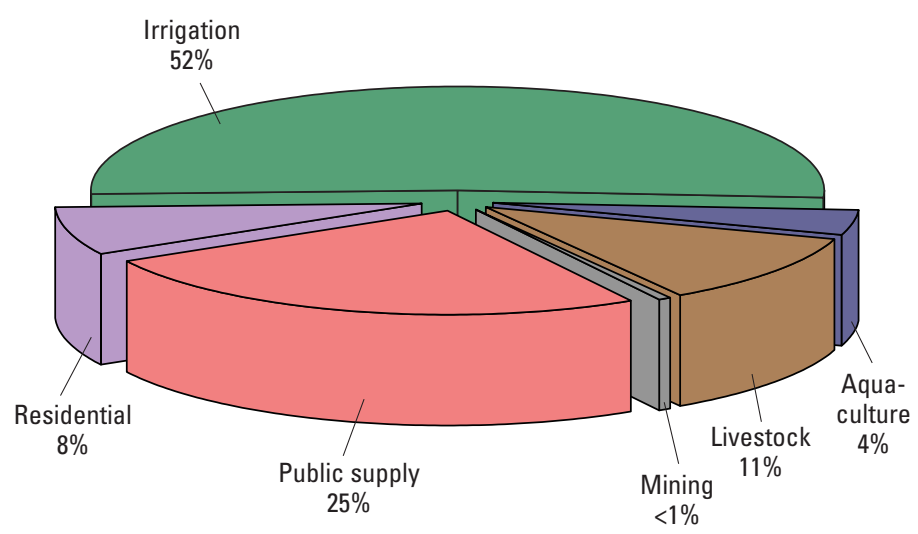

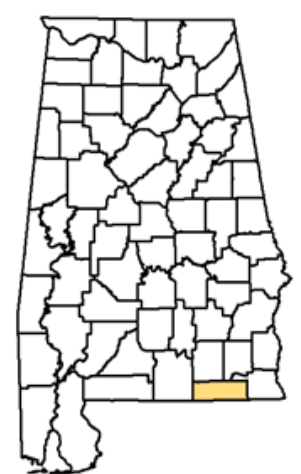

Withdrawals by public supplier, in Mgal/d

\begin{tabular}{lrrr}
\hline Public Supplier & GW & SW & Totals \\
\hline Bellwood Water \& F.P.A. & 0.02 & 0.00 & 0.02 \\
Black Water Works & .02 & .00 & .02 \\
Coffee Springs (Town of) & .03 & .00 & .03 \\
Geneva Water Works & .53 & .00 & .53 \\
Hartford & .39 & .00 & .39 \\
Malvern & .12 & .00 & .12 \\
North Geneva County Water & .02 & .00 & .02 \\
Authority & & & \\
Samson & .28 & .00 & .28 \\
Slocomb Water Works & .24 & .00 & .24 \\
Taylor (Town of) & .27 & .00 & .27 \\
\hline
\end{tabular}

Withdrawals by Standard Industrial Classification, in Mgal/d Standard Industrial Classification $\quad$ GW $\quad$ SW $\quad$ Totals

None 


\section{Greene}

Population: 9,661

Population served by public supply: 6,777

Per capita use (gallons per person per day): 61

Acres irrigated: 130

Land area: 645.9 square miles

Water area: 14.1 square miles

Withdrawals, in million gallons per day $(\mathrm{Mgal} / \mathrm{d})$ and percent (\%) [Percents are rounded to nearest whole number]

\begin{tabular}{lrrr}
\hline Category & GW & SW & Totals \\
\hline Public Supply & 1.18 & 0.00 & 1.18 \\
& $100 \%$ & $0 \%$ & \\
Residential & 0.18 & .00 & 0.18 \\
& 100 & 0 & \\
Irrigation & .03 & .17 & .20 \\
& 14 & 86 & \\
Aquaculture & 6.17 & 4.46 & 10.63 \\
& 58 & 42 & \\
Livestock & .10 & .15 & .25 \\
& 41 & 59 & \\
Thermoelectric & .05 & 386.09 & 386.14 \\
TOTALS & 0 & 100 & \\
\cline { 2 - 4 } & 7.71 & 390.87 & 398.58 \\
& $2 \%$ & $98 \%$ & \\
\hline
\end{tabular}

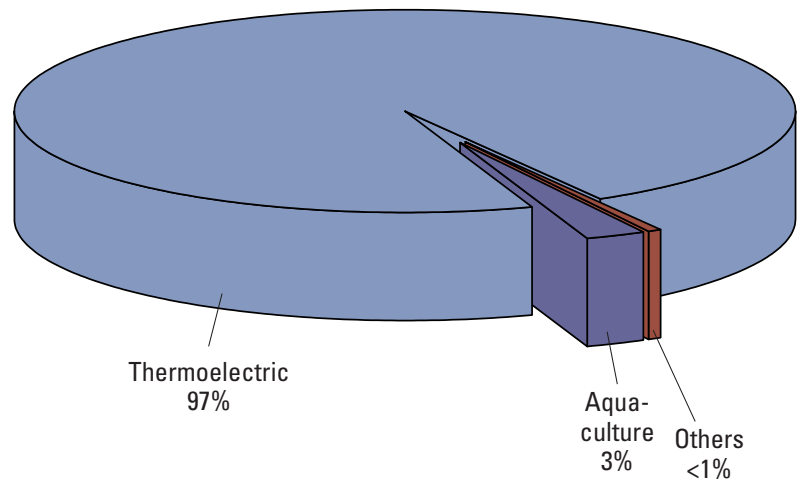

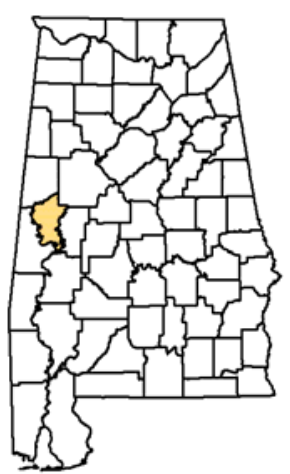

Withdrawals by public supplier, in Mgal/d

\begin{tabular}{lrrr}
\hline Public Supplier & GW & SW & Totals \\
\hline Eutaw Water Department & 1.04 & 0.00 & 1.04 \\
Forkland Water System & 0.10 & .00 & 0.10 \\
Greene County Housing Authority & .05 & .00 & .05 \\
\hline
\end{tabular}

Withdrawals by Standard Industrial Classification, in Mgal/d

\begin{tabular}{lcrr}
\hline Standard Industrial Classification & GW & SW & Totals \\
\hline $\begin{array}{l}49 \text { Electric, Gas, and Sanitary } \\
\text { Services }\end{array}$ & 0.05 & 386.09 & 386.14 \\
\hline
\end{tabular}




\section{Hale}

Population: 18,316

Population served by public supply: 14,937

Per capita use (gallons per person per day): 62

Acres irrigated: 110

Land area: 643.7 square miles

Water area: 12.7 square miles

Withdrawals, in million gallons per day (Mgal/d) and percent $(\%)$ [Percents are rounded to nearest whole number]

\begin{tabular}{lrrr}
\hline Category & GW & SW & Totals \\
\hline Public Supply & 2.88 & 0.00 & 2.88 \\
Residential & $100 \%$ & $0 \%$ & \\
Irrigation & 0.22 & .00 & 0.22 \\
& 100 & 0 & \\
Aquaculture & .02 & .08 & .10 \\
& 20 & 80 & \\
Livestock & 16.37 & 8.43 & 24.80 \\
Industrial & 66 & 34 & \\
& .15 & .18 & .33 \\
Mining & 45 & 55 & \\
& .02 & .00 & .02 \\
TOTALS & 100 & 0 & \\
& .04 & .00 & .04 \\
\hline
\end{tabular}

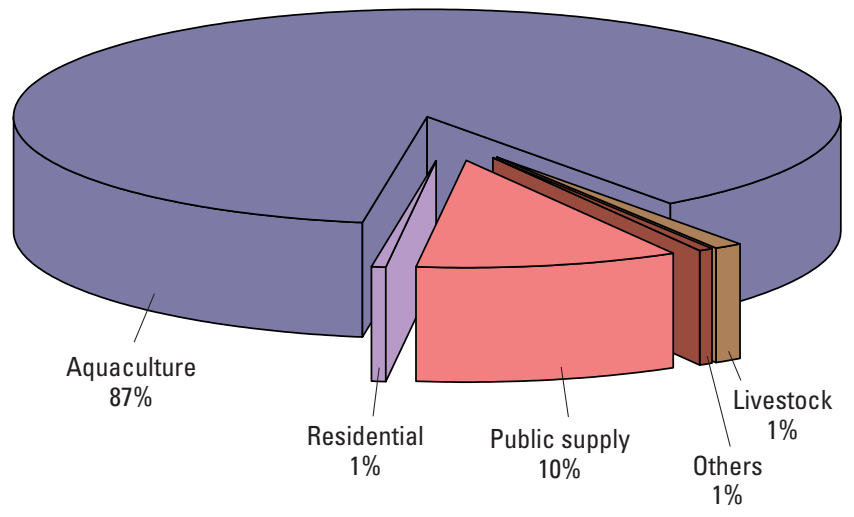

Withdrawals by Standard Industrial Classification, in Mgal/d

\begin{tabular}{lllr}
\hline Standard Industrial Classification & GW & SW & Totals \\
\hline $\begin{array}{l}\text { 24 Lumber and Wood } \\
\text { Products, Except Furniture }\end{array}$ & 0.02 & 0.00 & 0.02 \\
\hline
\end{tabular}




\section{Henry}

Population: 16,610

Population served by public supply: 12,845

Per capita use (gallons per person per day): 87

Acres irrigated: 3,830

Land area: 561.8 square miles

Water area: 6.5 square miles

Withdrawals, in million gallons per day (Mgal/d) and percent (\%) [Percents are rounded to nearest whole number]

\begin{tabular}{lrrr}
\hline Category & GW & SW & Totals \\
\hline Public Supply & 1.89 & 0.00 & 1.89 \\
Residential & $100 \%$ & $0 \%$ & \\
& 0.25 & .00 & 0.25 \\
Irrigation & 100 & 0 & \\
& 1.37 & 1.57 & 2.94 \\
Livestock & 47 & 53 & \\
& .10 & .15 & .25 \\
Industrial & 41 & 59 & \\
& .46 & .00 & .46 \\
Mining & 100 & 0 & \\
& .02 & .01 & .03 \\
TOTALS & 67 & 33 & \\
& 4.09 & 1.73 & 5.82 \\
& $70 \%$ & $30 \%$ & \\
\hline
\end{tabular}

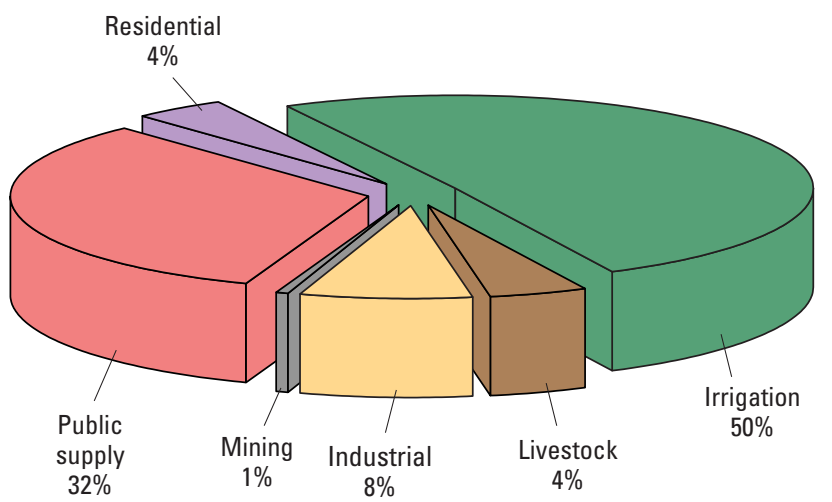

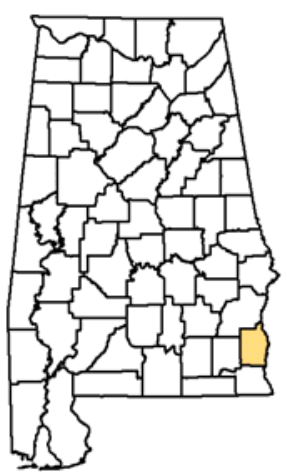

Withdrawals by public supplier, in $\mathrm{Mgal} / \mathrm{d}$

\begin{tabular}{lrrr}
\hline Public Supplier & GW & SW & Totals \\
Abbeville Waterworks and Sewer & 0.64 & 0.00 & 0.64 \\
Board & & & \\
Headland Water Works Board & .44 & .00 & .44 \\
Henry County Water Authority & .67 & .00 & .67 \\
Newville & .13 & .00 & .13 \\
\hline
\end{tabular}

Withdrawals by Standard Industrial Classification, in Mgal/d

\begin{tabular}{lccr}
\hline Standard Industrial Classification & GW & SW & Totals \\
\hline 20 Food and Kindred Products & 0.46 & 0.00 & 0.46 \\
\hline
\end{tabular}




\section{Houston}

Population: 94,249

Population served by public supply: 76,104

Per capita use (gallons per person per day): 78

Acres irrigated: 11,780

Land area: 580.4 square miles

Water area: 1.3 square miles

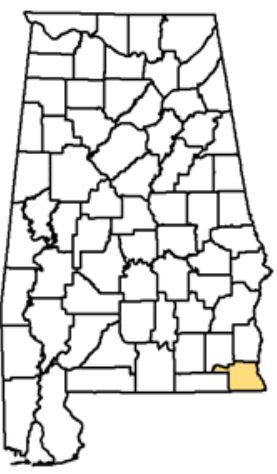

Withdrawals, in million gallons per day (Mgal/d) and percent (\%) [Percents are rounded to nearest whole number]

\begin{tabular}{lrrr}
\hline Category & GW & SW & Totals \\
\hline Public Supply & 15.85 & 0.00 & 15.85 \\
Residential & $100 \%$ & $0 \%$ & \\
& 1.49 & .00 & 1.49 \\
Irrigation & 100 & 0 & \\
& 6.36 & 2.23 & 8.59 \\
Livestock & 74 & 26 & \\
& 0.13 & .19 & 0.32 \\
Thermoelectric & 41 & 59 & \\
& .17 & 105.36 & 105.53 \\
TOTALS & 0 & 100 & \\
\cline { 2 - 3 } & 24.00 & 107.78 & 131.78 \\
& $18 \%$ & $82 \%$ & \\
\hline
\end{tabular}

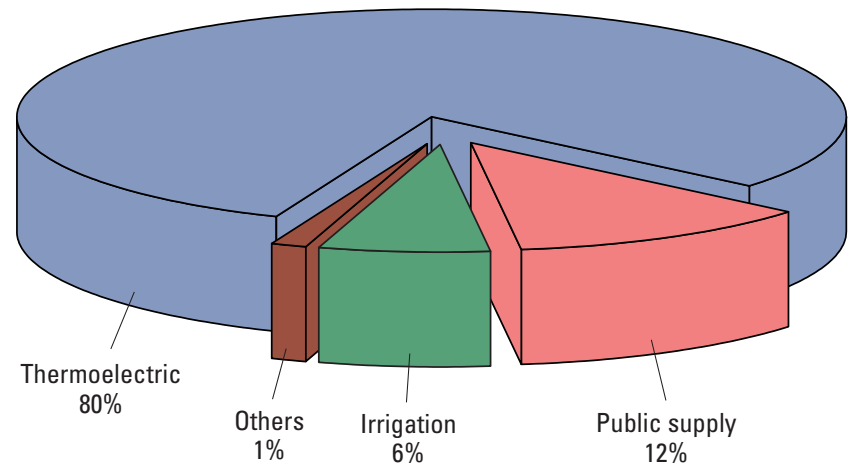

\section{Withdrawals by public supplier, in $\mathrm{Mgal} / \mathrm{d}$}

\begin{tabular}{lrrr}
\hline Public Supplier & GW & SW & Totals \\
\hline Ashford Water Works & 0.33 & 0.00 & 0.33 \\
Columbia Water Works \& Sewer & .07 & .00 & .07 \\
Board & & & \\
Cottonwood & .22 & .00 & .22 \\
Cowarts & .32 & .00 & .32 \\
Dothan Water System & 14.07 & .00 & 14.07 \\
Gordon Water Works & .05 & .00 & .05 \\
Houston County Water Authority & .25 & .00 & .25 \\
Kinsey & .16 & .00 & .16 \\
Taylor (Town of) & .20 & .00 & .20 \\
Webb Water System & .17 & .00 & .17 \\
\hline
\end{tabular}

Withdrawals by Standard Industrial Classification, in Mgal/d

\begin{tabular}{lcrr}
\hline Standard Industrial Classification & GW & SW & Totals \\
\hline $\begin{array}{l}49 \text { Electric, Gas, and Sanitary } \\
\text { Services }\end{array}$ & 0.17 & 105.36 & 105.53 \\
\hline
\end{tabular}




\section{Jackson}

Population: 53,650

Population served by public supply: 39,924

Per capita use (gallons per person per day): 67

Acres irrigated: 950

Land area: 1,078.7 square miles

Water area: 48.0 square miles

Withdrawals, in million gallons per day (Mgal/d) and percent (\%) [Percents are rounded to nearest whole number]

\begin{tabular}{lrrr}
\hline Category & GW & SW & Totals \\
\hline Public Supply & 0.64 & 10.08 & 10.72 \\
Residential & $6 \%$ & $94 \%$ & \\
& .91 & 0.00 & 0.91 \\
Irrigation & 100 & 0 & \\
& .04 & .67 & .71 \\
Livestock & 5 & 95 & \\
& .32 & .40 & .72 \\
Industrial & 44 & 56 & \\
& .00 & 8.78 & 8.78 \\
Mining & 0 & 100 & \\
& .07 & .03 & .10 \\
Thermoelectric & 68 & 32 & \\
& .00 & $1,476.30$ & $1,476.30$ \\
TOTALS & 0 & 100 & \\
\cline { 2 - 4 } & 1.98 & $1,496.26$ & $1,498.24$ \\
\hline
\end{tabular}

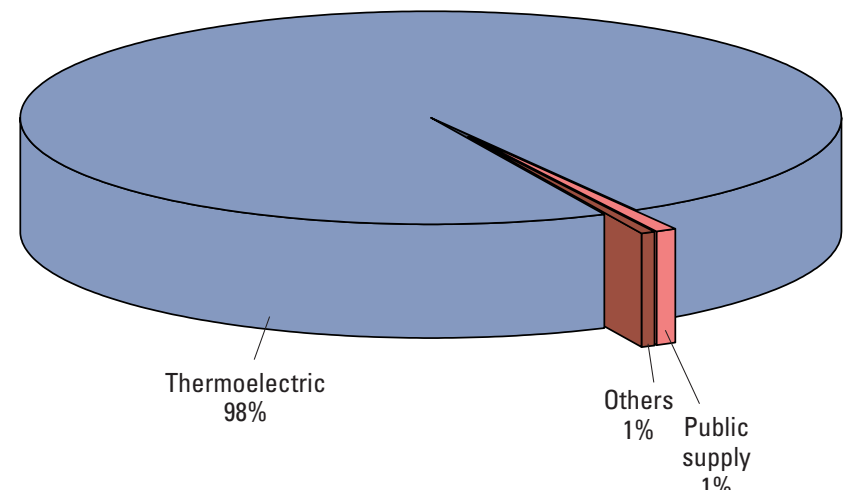

8.78

10

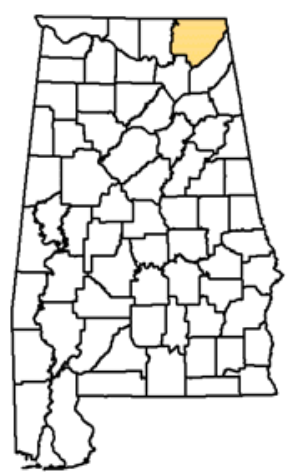

Withdrawals by public supplier, in Mgal/d

\begin{tabular}{lrrr}
\hline Public Supplier & GW & SW & Totals \\
\hline Bridgeport Utilities Board & 0.20 & 2.36 & 2.56 \\
Pisgah & .09 & 0.00 & 0.09 \\
Scottsboro Water Board & .00 & 4.66 & 4.66 \\
Section \& Dutton Water Boards & .00 & 3.06 & 3.06 \\
Stevenson Utilities Board & .34 & .00 & .34 \\
\hline
\end{tabular}

72




\section{Jefferson}

Population: 657,229

Population served by public supply: 651,192

Per capita use (gallons per person per day): 73

Acres irrigated: 3,660

Land area: 1,112.6 square miles

Water area: 11.2 square miles

Withdrawals, in million gallons per day (Mgal/d) and percent (\%) [Percents are rounded to nearest whole number]

\begin{tabular}{lrrr}
\hline Category & GW & SW & Totals \\
\hline Public Supply & 8.32 & 65.02 & 73.34 \\
Residential & $11 \%$ & $89 \%$ & \\
Irrigation & 0.39 & 0.00 & 0.39 \\
& 100 & 0 & \\
Aquaculture & .09 & 2.73 & 2.82 \\
& 3 & 97 & \\
Livestock & .02 & .56 & .58 \\
Industrial & 3 & 97 & \\
& .03 & .05 & .08 \\
Mining & 40 & 60 & \\
& .40 & .00 & .40 \\
TOTALS & 100 & 0 & \\
& 1.93 & 1.47 & 3.40 \\
\cline { 2 - 3 } & 57 & 43 & \\
\cline { 2 - 4 } & 11.18 & 69.83 & 81.01 \\
& $14 \%$ & $86 \%$ & \\
\hline
\end{tabular}

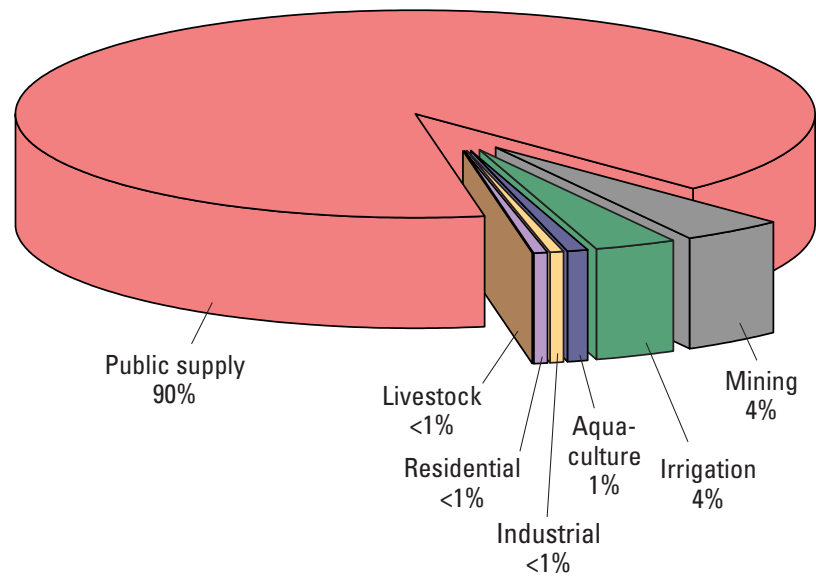

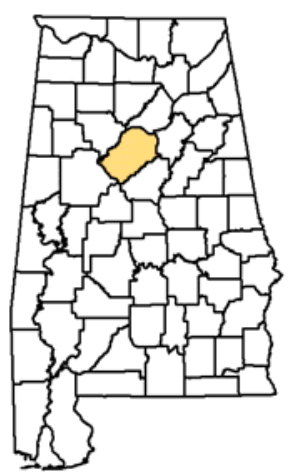

Withdrawals by public supplier, in Mgal/d

\begin{tabular}{lrrr}
\hline Public Supplier & GW & SW & Totals \\
\hline Bessemer (G.U.S.C.) & 0.00 & 9.56 & 9.56 \\
Birmingham WW\&SB & .00 & 52.90 & 52.90 \\
Irondale Water System & 1.36 & 0.00 & 1.36 \\
Leeds & 1.21 & .00 & 1.21 \\
Trussville Utilities Board & 4.82 & .00 & 4.82 \\
Warrior River Water Authority & .93 & 2.56 & 3.49 \\
\hline
\end{tabular}

Withdrawals by Standard Industrial Classification, in Mgal/d

\begin{tabular}{lllr}
\hline Standard Industrial Classification & GW & SW & Totals \\
\hline $\begin{array}{l}32 \text { Stone, Clay, Glass, and } \\
\text { Concrete Products }\end{array}$ & 0.40 & 0.00 & 0.40 \\
\hline
\end{tabular}




\section{Lamar}

Population: 14,962

Population served by public supply: 9,601

Per capita use (gallons per person per day): 65

Acres irrigated: 630

Land area: 604.9 square miles

Water area: 0.6 square mile

Withdrawals, in million gallons per day (Mgal/d) and percent (\%) [Percents are rounded to nearest whole number]

\begin{tabular}{lrrr}
\hline Category & GW & SW & Totals \\
\hline Public Supply & 1.47 & 0.00 & 1.47 \\
Residential & $100 \%$ & $0 \%$ & \\
& 0.30 & .00 & 0.30 \\
Irrigation & 100 & 0 & \\
& .01 & .27 & .28 \\
Livestock & 2 & 98 & \\
& .06 & .07 & .13 \\
Industrial & 45 & 55 & \\
& .07 & .00 & .07 \\
TOTALS & 100 & 0 & \\
\cline { 2 - 4 } & 1.91 & 0.34 & 2.25 \\
& $85 \%$ & $15 \%$ & \\
\hline
\end{tabular}

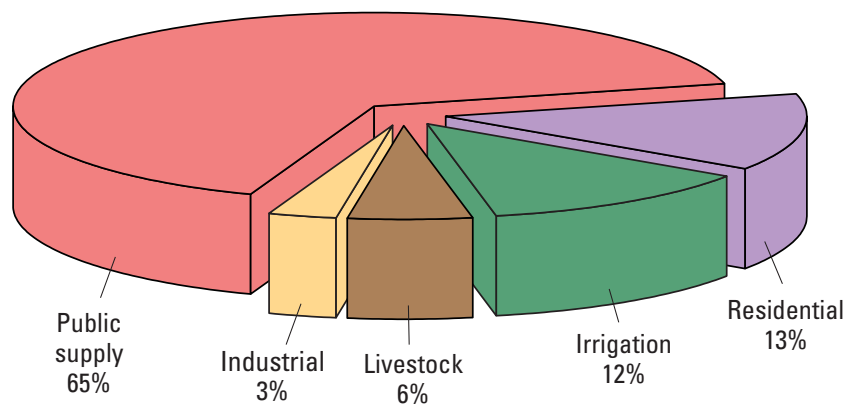

Withdrawals by Standard Industrial Classification, in Mgal/d

\begin{tabular}{lllr}
\hline Standard Industrial Classification & GW & SW & Totals \\
\hline $\begin{array}{l}\text { 24 Lumber and Wood } \\
\text { Products, Except Furniture }\end{array}$ & 0.07 & 0.00 & 0.07 \\
\hline
\end{tabular}




\section{Lauderdale}

Population: 87,691

Population served by public supply: 73,713

Per capita use (gallons per person per day): 83

Acres irrigated: 1,160

Land area: 669.5 square miles

Water area: 49.3 square miles

Withdrawals, in million gallons per day (Mgal/d) and percent (\%) [Percents are rounded to nearest whole number]

\begin{tabular}{lrrr}
\hline Category & GW & SW & Totals \\
\hline Public Supply & 1.40 & 12.79 & 14.19 \\
Residential & $10 \%$ & $90 \%$ & \\
& 1.30 & 0.00 & 1.30 \\
Irrigation & 100 & 0 & \\
& 0.74 & .43 & 1.17 \\
Aquaculture & 63 & 37 & \\
& .03 & .00 & 0.03 \\
Livestock & 100 & 0 & \\
TOTALS & .20 & .28 & .48 \\
& 41 & 59 & \\
\cline { 2 - 3 } & 3.67 & 13.50 & 17.17 \\
\hline
\end{tabular}

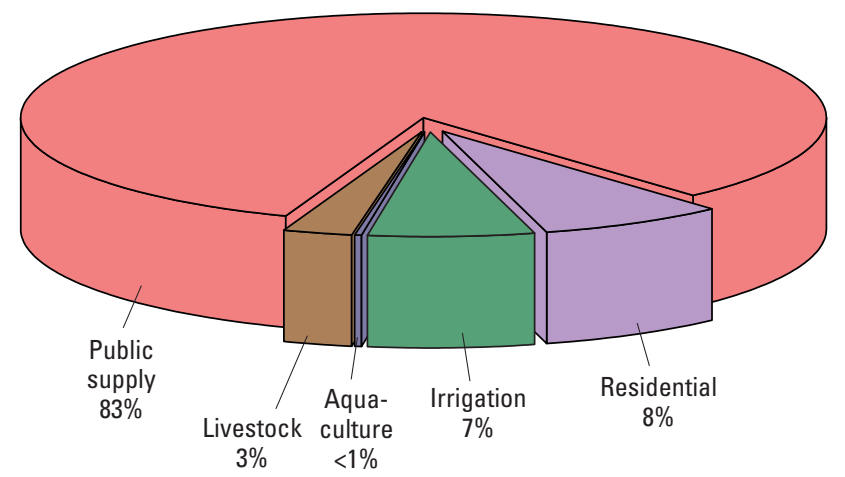

Withdrawals by Standard Industrial Classification, in Mgal/d Standard Industrial Classification $\mathrm{GW} \quad \mathrm{SW}$ Totals

None

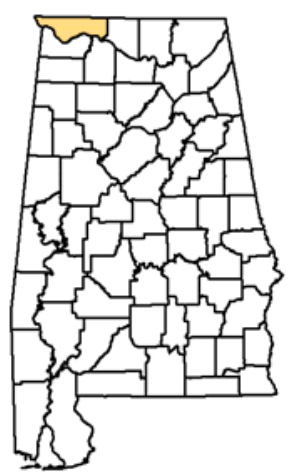

Withdrawals by public supplier, in Mgal/d

\begin{tabular}{lrrr}
\hline Public Supplier & GW & SW & Totals \\
\hline Florence Water \& Sewer & 0.31 & 12.79 & 13.10 \\
Department & & & \\
Greenhill Water System & .49 & 0.00 & 0.49 \\
Rogersville Water \& Sewer Board & .60 & .00 & .60 \\
\hline
\end{tabular}

Sewer Board




\section{Lawrence}

Population: 34,605

Population served by public supply: 29,078

Per capita use (gallons per person per day): 83

Acres irrigated: 2,380

Land area: 693.4 square miles

Water area: 24.7 square miles

Withdrawals, in million gallons per day (Mgal/d) and percent (\%) [Percents are rounded to nearest whole number]

\begin{tabular}{lrrr}
\hline Category & GW & SW & Totals \\
\hline Public Supply & 0.00 & 6.91 & 6.91 \\
Residential & $0 \%$ & $100 \%$ & \\
& .49 & 0.00 & 0.49 \\
Irrigation & 100 & 0 & \\
& .37 & 1.42 & 1.79 \\
Aquaculture & 21 & 79 & \\
& .08 & .00 & .08 \\
Livestock & 100 & 0 & \\
& .32 & .43 & .75 \\
Industrial & 42 & 58 & \\
& .00 & 57.18 & 57.18 \\
Mining & 0 & 100 & \\
& .16 & .07 & .23 \\
TOTALS & 68 & 32 & \\
\cline { 2 - 4 } & 1.42 & 66.01 & 67.43 \\
\hline
\end{tabular}

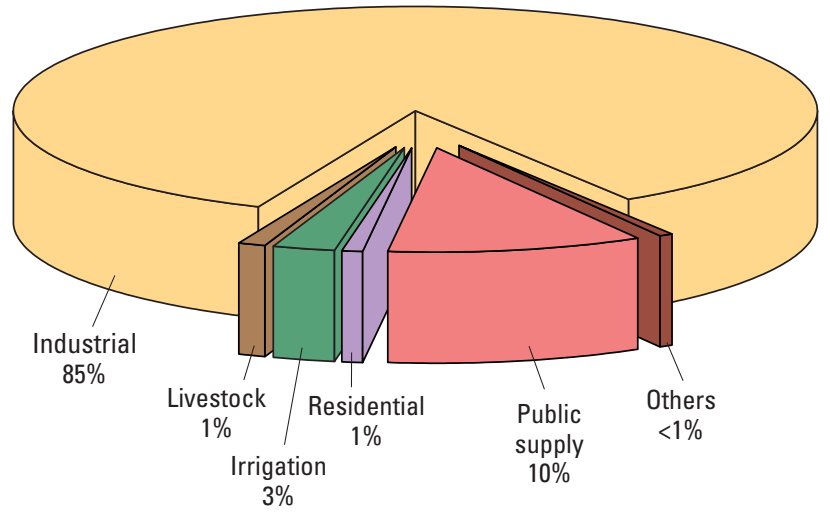

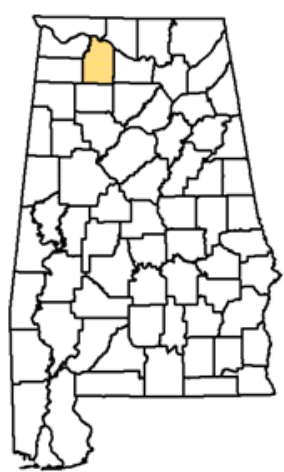

Withdrawals by public supplier, in Mgal/d

\begin{tabular}{lrrr}
\hline Public Supplier & GW & SW & Totals \\
\hline Moulton Water Works Board & 0.00 & 1.92 & 1.92 \\
West Morgan East Lawrence & .00 & 4.99 & 4.99 \\
Water \& Sewer Authority & & & \\
\hline
\end{tabular}

Water \& Sewer Authority

Withdrawals by Standard Industrial Classification, in Mgal/d

\begin{tabular}{lccc}
\hline Standard Industrial Classification & GW & SW & Totals \\
\hline 26 Paper and Allied Products & 0.00 & 57.18 & 57.18 \\
\hline
\end{tabular}




\section{Lee}

Population: 123,254

Population served by public supply: 115,001

Per capita use (gallons per person per day): 77

Acres irrigated: 1,980

Land area: 608.7 square miles

Water area: 6.8 square miles

Withdrawals, in million gallons per day (Mgal/d) and percent $(\%)$ [Percents are rounded to nearest whole number]

\begin{tabular}{lrrr}
\hline Category & GW & SW & Totals \\
\hline Public Supply & 0.82 & 15.53 & 16.35 \\
Residential & $5 \%$ & $95 \%$ & \\
Irrigation & .70 & 0.00 & 0.70 \\
Aquaculture & 100 & 0 & \\
& .36 & 1.24 & 1.60 \\
Livestock & 22 & 78 & \\
& .05 & .10 & .15 \\
Industrial & 33 & 67 & \\
& .04 & .06 & .10 \\
Mining & 39 & 61 & \\
& .00 & 2.23 & 2.23 \\
TOTALS & 0 & 100 & \\
& .26 & .12 & .38 \\
& 68 & 32 & \\
\cline { 2 - 3 } & 2.23 & 19.28 & 21.51 \\
\cline { 2 - 4 } & $10 \%$ & $90 \%$ & \\
\hline
\end{tabular}

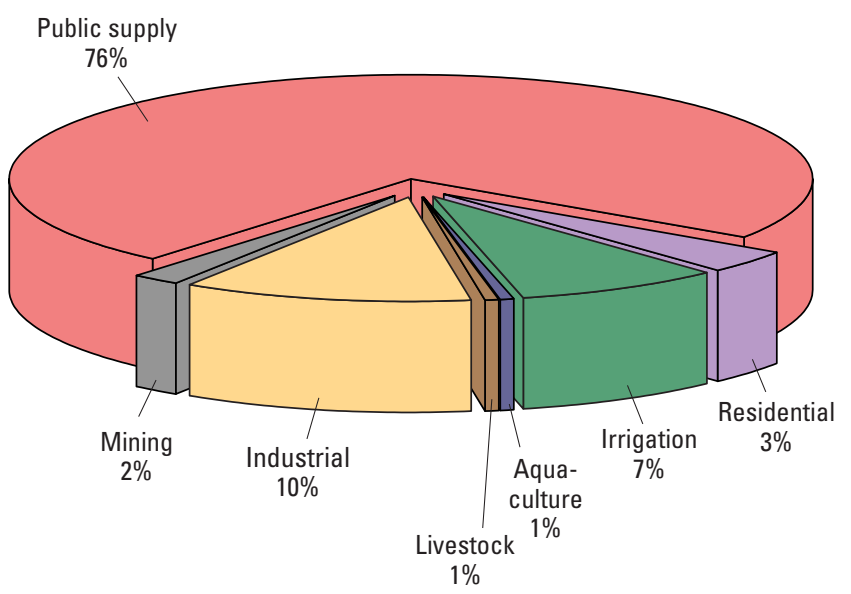

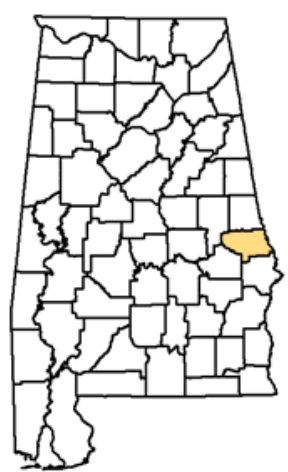

Withdrawals by public supplier, in Mgal/d

\begin{tabular}{lrrr}
\hline Public Supplier & GW & SW & Totals \\
\hline Auburn Water Works Board & 0.07 & 5.75 & 5.82 \\
Beauregard Water Authority & .75 & 0.00 & 0.75 \\
Opelika Water Works Board & .00 & 7.48 & 7.48 \\
Smiths Station Water System & .00 & 2.29 & 2.29 \\
\hline
\end{tabular}

Withdrawals by Standard Industrial Classification, in Mgal/d

\begin{tabular}{lccr}
\hline Standard Industrial Classification & GW & SW & Totals \\
\hline 22 Textile Mill Products & 0.00 & 2.23 & 2.23 \\
\hline
\end{tabular}




\section{Limestone}

Population: 70,469

Population served by public supply: 59,659

Per capita use (gallons per person per day): 75

Acres irrigated: 8,740

Land area: 568.1 square miles

Water area: 39.0 square miles

Withdrawals, in million gallons per day (Mgal/d) and percent $(\%)$ [Percents are rounded to nearest whole number]

\begin{tabular}{lrrr}
\hline Category & GW & SW & Totals \\
\hline Public Supply & 4.55 & 8.84 & 13.39 \\
& $34 \%$ & $66 \%$ & \\
Residential & 1.05 & 0.00 & 1.05 \\
& 100 & 0 & \\
Irrigation & 2.10 & 6.16 & 8.26 \\
& 25 & 75 & \\
Livestock & 0.19 & .25 & 0.44 \\
& 44 & 56 & \\
Mining & .00 & .50 & .50 \\
& 0 & 100 & \\
Thermoelectric & .00 & $1,990.24$ & $1,990.24$ \\
& 0 & 100 & \\
\cline { 2 - 4 } TOTALS & 7.89 & $2,005.99$ & $2,013.88$ \\
& $0 \%$ & $100 \%$ & \\
\hline
\end{tabular}

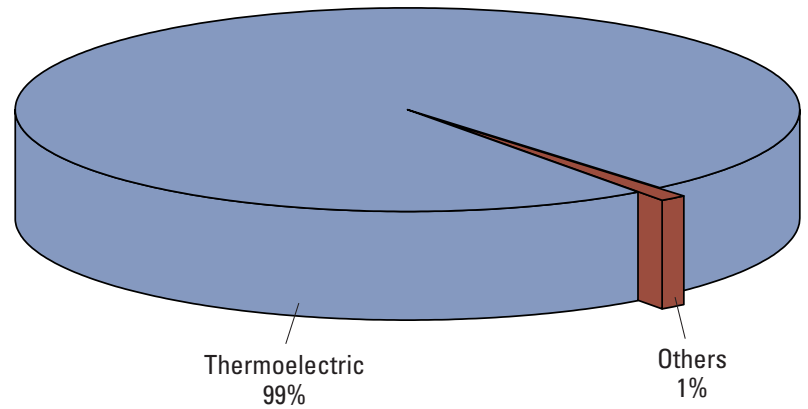

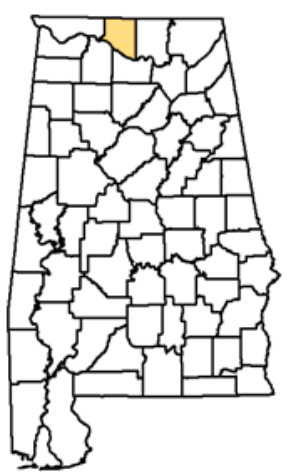

Withdrawals by public supplier, in Mgal/d

\begin{tabular}{lrrr}
\hline Public Supplier & GW & SW & Totals \\
\hline Ardmore Water System & 0.20 & 0.00 & 0.20 \\
Athens Utilities & .00 & 5.74 & 5.74 \\
Limestone County Water Authority & 2.44 & 3.10 & 5.54 \\
Madison Water and Wastewater & 1.88 & .00 & 1.88 \\
Board & & & \\
Swan Creek Community & .03 & .00 & .03 \\
\hline
\end{tabular}

Withdrawals by Standard Industrial Classification, in Mgal/d

\begin{tabular}{lcrr}
\hline Standard Industrial Classification & GW & SW & Totals \\
\hline $\begin{array}{l}49 \text { Electric, Gas, and Sanitary } \\
\text { Services }\end{array}$ & 0.00 & $1,990.24$ & $1,990.24$ \\
\hline
\end{tabular}




\section{Lowndes}

Population: 13,076

Population served by public supply: 12,214

Per capita use (gallons per person per day): 63

Acres irrigated: 2,000

Land area: 717.9 square miles

Water area: 7.1 square miles

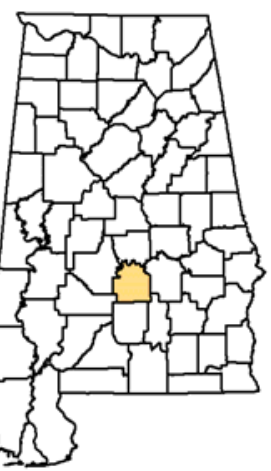

Withdrawals, in million gallons per day (Mgal/d) and percent (\%) [Percents are rounded to nearest whole number]

\begin{tabular}{lrrr}
\hline Category & GW & SW & Totals \\
\hline Public Supply & 0.96 & 0.00 & 0.96 \\
Residential & $100 \%$ & $0 \%$ & \\
& .06 & .00 & .06 \\
Irrigation & 100 & 0 & \\
& .58 & 3.26 & 3.84 \\
Aquaculture & 15 & 85 & \\
Livestock & .00 & .02 & .02 \\
Mining & 0 & 100 & \\
& .26 & .39 & .65 \\
TOTALS & 40 & 60 & \\
& .30 & .14 & .44 \\
& 68 & 32 & \\
\hline
\end{tabular}

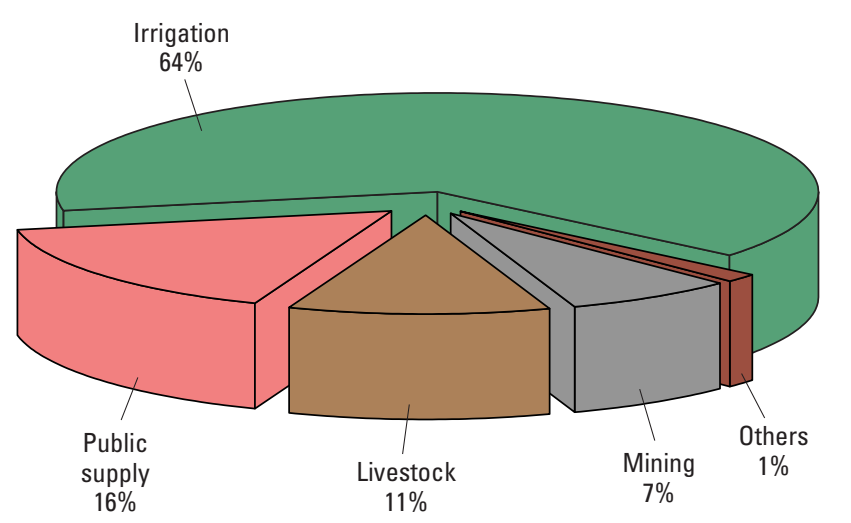

65 44
Withdrawals by public supplier, in Mgal/d

\begin{tabular}{lrrr}
\hline Public Supplier & GW & SW & Totals \\
\hline Hayneville & 0.33 & 0.00 & 0.33 \\
Lowndes County Water Authority & .27 & .00 & .27 \\
Lowndesboro & .06 & .00 & .06 \\
Mosses Water Authority & .16 & .00 & .16 \\
White Hall & .15 & .00 & .15 \\
\hline
\end{tabular}




\section{Macon}

Population: 22,810

Population served by public supply: 19,820

Per capita use (gallons per person per day): 68

Acres irrigated: 3,320

Land area: 610.5 square miles

Water area: 2.7 square miles

Withdrawals, in million gallons per day (Mgal/d) and percent (\%) [Percents are rounded to nearest whole number]

\begin{tabular}{lrrr}
\hline Category & GW & SW & Totals \\
\hline Public Supply & 1.36 & 2.71 & 4.07 \\
Residential & $33 \%$ & $67 \%$ & \\
& 0.20 & 0.00 & 0.20 \\
Irrigation & 100 & 0 & \\
& 2.97 & 2.34 & 5.31 \\
Livestock & 56 & 44 & \\
& .05 & .08 & .13 \\
Industrial & 40 & 60 & \\
& .05 & .00 & .05 \\
Mining & 100 & 0 & \\
& .12 & .06 & .18 \\
TOTALS & 69 & 31 & \\
\cline { 2 - 4 } & 4.75 & 5.19 & 9.94 \\
& $48 \%$ & $52 \%$ & \\
\hline
\end{tabular}

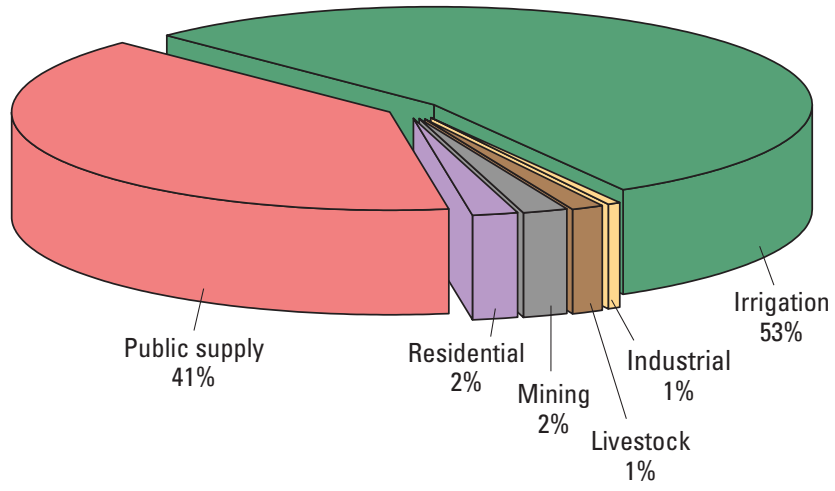

Withdrawals by Standard Industrial Classification, in Mgal/d

\begin{tabular}{lllr}
\hline Standard Industrial Classification & GW & SW & Totals \\
\hline $\begin{array}{l}79 \text { Amusement and } \\
\text { Recreation Services }\end{array}$ & 0.05 & 0.00 & 0.05 \\
\hline
\end{tabular}

Withdrawals by public supplier, in $\mathrm{Mgal} / \mathrm{d}$

\begin{tabular}{lrrr}
\hline Public Supplier & GW & SW & Totals \\
\hline Loachapoka Water Authority & 0.65 & 0.00 & 0.65 \\
Macon County Water Authority & .52 & .00 & .52 \\
Star Mindingall Water Authority & .20 & .00 & .20 \\
Tuskegee Utilities & .00 & 2.71 & 2.71 \\
\hline
\end{tabular}
, 


\section{Madison}

Population: 298,192

Population served by public supply: 288,901

Per capita use (gallons per person per day): 107

Acres irrigated: 5,560

Land area: 804.9 square miles

Water area: 7.9 square miles

Withdrawals, in million gallons per day (Mgal/d) and percent $(\%)$ [Percents are rounded to nearest whole number]

\begin{tabular}{lrrr}
\hline Category & GW & SW & Totals \\
\hline Public Supply & 23.71 & 38.85 & 62.56 \\
Residential & $38 \%$ & $62 \%$ & \\
& 1.12 & 0.00 & 1.12 \\
Irrigation & 100 & 0 & \\
& 1.61 & 3.30 & 4.91 \\
Aquaculture & 33 & 67 & \\
& 0.00 & .00 & 0.00 \\
Livestock & 100 & 0 & \\
& .14 & .19 & .33 \\
Industrial & 43 & 57 & \\
& .00 & .89 & .89 \\
Mining & 0 & 100 & \\
& .48 & .22 & .70 \\
TOTALS & 68 & 32 & \\
\cline { 2 - 4 } & 27.06 & 43.45 & 70.51 \\
\hline
\end{tabular}

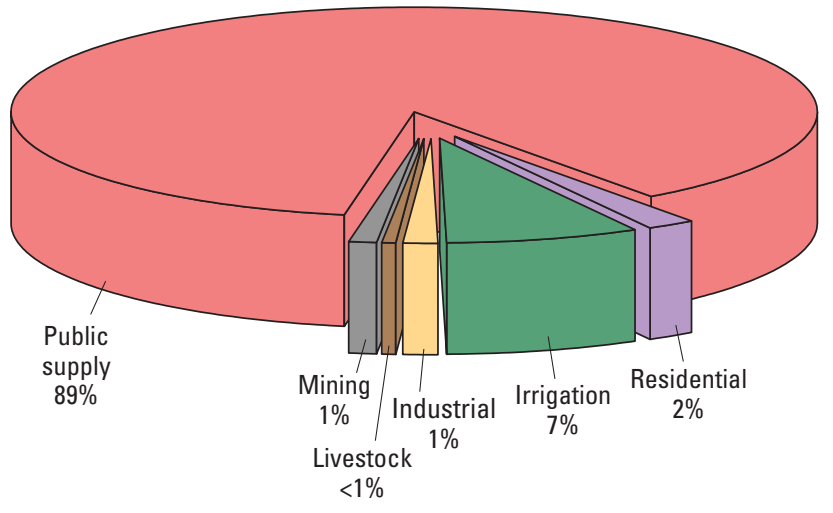

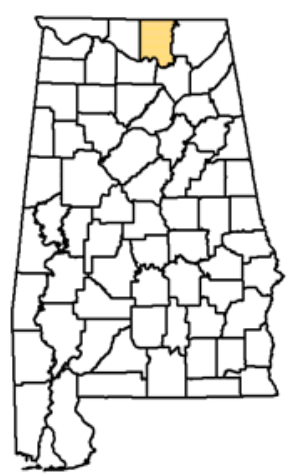

Withdrawals by public supplier, in Mgal/d

\begin{tabular}{|c|c|c|c|}
\hline Public Supplier & GW & SW & Totals \\
\hline Harvest-Monrovia Water Authority & 3.99 & 0.00 & 3.99 \\
\hline $\begin{array}{l}\text { Huntsville Utilities Water } \\
\text { Department }\end{array}$ & 7.82 & 31.01 & 38.83 \\
\hline $\begin{array}{l}\text { Madison County Water } \\
\text { Department }\end{array}$ & 7.02 & .00 & 7.02 \\
\hline $\begin{array}{l}\text { Madison Water and Wastewater } \\
\text { Board }\end{array}$ & 4.04 & .00 & 4.04 \\
\hline $\begin{array}{l}\text { Owens Cross Roads Water } \\
\text { Authority }\end{array}$ & 0.84 & .00 & 0.84 \\
\hline $\begin{array}{l}\text { U.S. Army Missle Command } \\
\text { (Redstone Arsenal) }\end{array}$ & .00 & 7.84 & 7.84 \\
\hline
\end{tabular}

Withdrawals by Standard Industrial Classification, in Mgal/d

\begin{tabular}{lccr}
\hline Standard Industrial Classification & GW & SW & Totals \\
\hline $\begin{array}{l}32 \text { Stone, Clay, Glass, and } \\
\text { Concrete Products }\end{array}$ & 0.00 & 0.89 & 0.89 \\
\hline
\end{tabular}




\section{Marengo}

Population: 21,879

Population served by public supply: 13,071

Per capita use (gallons per person per day): 63

Acres irrigated: 280

Land area: 977.0 square miles

Water area: 5.8 square miles

Withdrawals, in million gallons per day (Mgal/d) and percent (\%) [Percents are rounded to nearest whole number]

\begin{tabular}{lrrr}
\hline Category & GW & SW & Totals \\
\hline Public Supply & 2.71 & 0.00 & 2.71 \\
Residential & $100 \%$ & $0 \%$ & \\
& 0.55 & .00 & 0.55 \\
Irrigation & 100 & 0 & \\
& .01 & .14 & .15 \\
Aquaculture & 5 & 95 & \\
& 2.00 & 1.64 & 3.64 \\
Livestock & 55 & 45 & \\
& .15 & .23 & .38 \\
Industrial & 40 & 60 & \\
& 1.00 & 18.08 & 19.08 \\
Mining & 5 & 95 & \\
& .19 & .09 & .28 \\
TOTALS & 68 & 32 & \\
\cline { 2 - 4 } & 6.61 & 20.18 & 26.79 \\
\hline
\end{tabular}

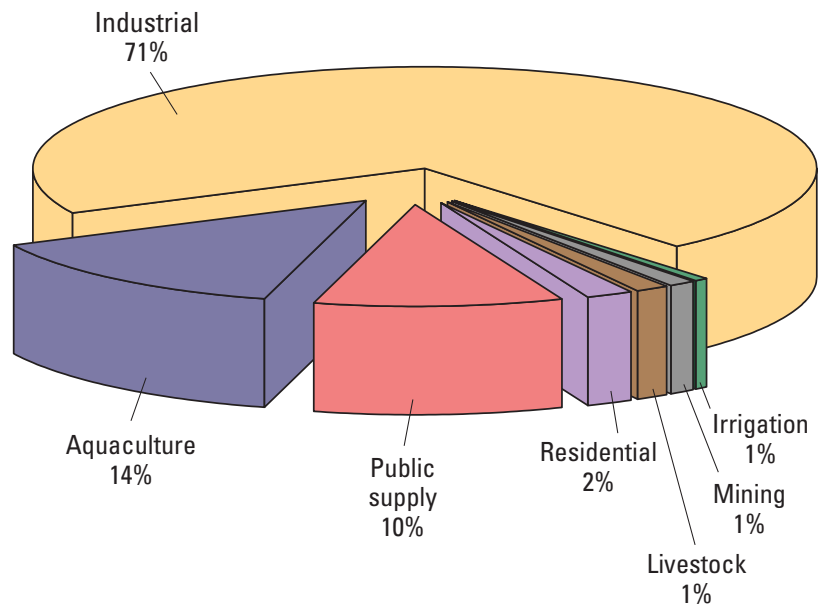

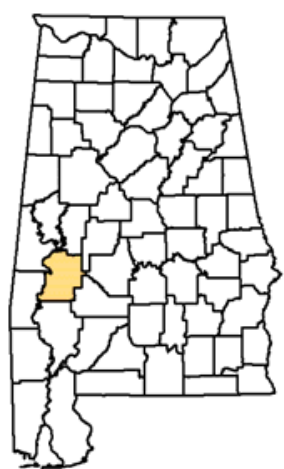

Withdrawals by public supplier, in Mgal/d

\begin{tabular}{lrrr}
\hline Public Supplier & GW & SW & Totals \\
\hline Demopolis Water \& Sewer Board & 1.98 & 0.00 & 1.98 \\
Faunsdale & 0.05 & .00 & 0.05 \\
Linden Utilities Board & .24 & .00 & .24 \\
Myrtlewood Water System & .25 & .00 & .25 \\
Sweet Water Water System & .04 & .00 & .04 \\
Thomaston Water \& Gas Board & .16 & .00 & .16 \\
\hline
\end{tabular}




\section{Marion}

Population: 30,154

Population served by public supply: 20,465

Per capita use (gallons per person per day): 88

Acres irrigated: 140

Land area: 741.4 square miles

Water area: 2.2 square miles

Withdrawals, in million gallons per day (Mgal/d) and percent $(\%)$ [Percents are rounded to nearest whole number]

\begin{tabular}{lrrr}
\hline Category & GW & SW & Totals \\
\hline Public Supply & 0.64 & 5.66 & 6.30 \\
Residential & $10 \%$ & $90 \%$ & \\
Irrigation & .92 & 0.00 & 0.92 \\
& 100 & 0 & \\
Livestock & .02 & .06 & .08 \\
& 21 & 79 & \\
Mining & .17 & .24 & .41 \\
& 41 & 59 & \\
TOTALS & .04 & .09 & .13 \\
& 28 & 72 & \\
\hline
\end{tabular}

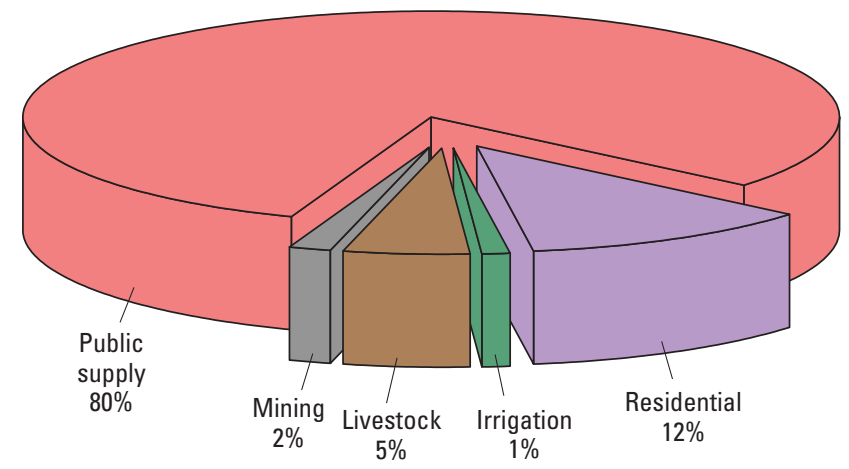

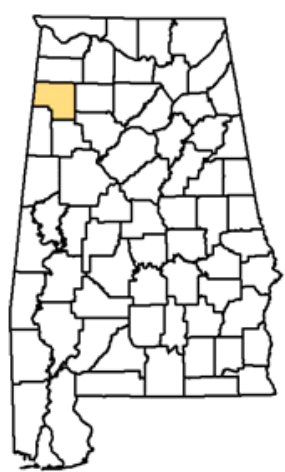

Withdrawals by public supplier, in Mgal/d

\begin{tabular}{lrrr}
\hline Public Supplier & GW & SW & Totals \\
\hline Brilliant & 0.10 & 0.00 & 0.10 \\
Guin Water Works and Sewer & .00 & .69 & .69 \\
Board & & & \\
Hamilton Waterworks \& Sewer & .00 & 1.32 & 1.32 \\
Board & & & \\
Hodges Water Department & .20 & .00 & .20 \\
Twin Water Authority & .06 & .00 & .06 \\
Upper Bear Creek Water & .00 & 3.17 & 3.17 \\
Treatment Plant & & & \\
Winfield Water Works \& Sewer & .28 & .48 & .76 \\
Board & & & \\
\hline
\end{tabular}

Withdrawals by Standard Industrial Classification, in Mgal/d \begin{tabular}{llll}
\hline Standard Industrial Classification & $\mathrm{GW}$ & SW & Totals
\end{tabular}

None 


\section{Marshall}

Population: 85,634

Population served by public supply: 80,071

Per capita use (gallons per person per day): 67

Acres irrigated: 1,280

Land area: 567.1 square miles

Water area: 56.1 square miles

Withdrawals, in million gallons per day (Mgal/d) and percent (\%) [Percents are rounded to nearest whole number]

\begin{tabular}{lrrr}
\hline Category & GW & SW & Totals \\
\hline Public Supply & 2.98 & 21.17 & 24.15 \\
& $12 \%$ & $88 \%$ & \\
Residential & 0.38 & 0.00 & 0.38 \\
& 100 & 0 & \\
Irrigation & .00 & .68 & .68 \\
& 0 & 100 & \\
Aquaculture & .00 & .01 & .01 \\
& 0 & 100 & \\
Livestock & .60 & .60 & 1.20 \\
& 50 & 50 & \\
Industrial & .36 & .00 & .36 \\
& 100 & 0 & \\
Mining & .19 & .09 & .28 \\
TOTALS & 68 & 32 & \\
\cline { 2 - 4 } & 4.51 & 22.55 & 27.06 \\
\hline
\end{tabular}

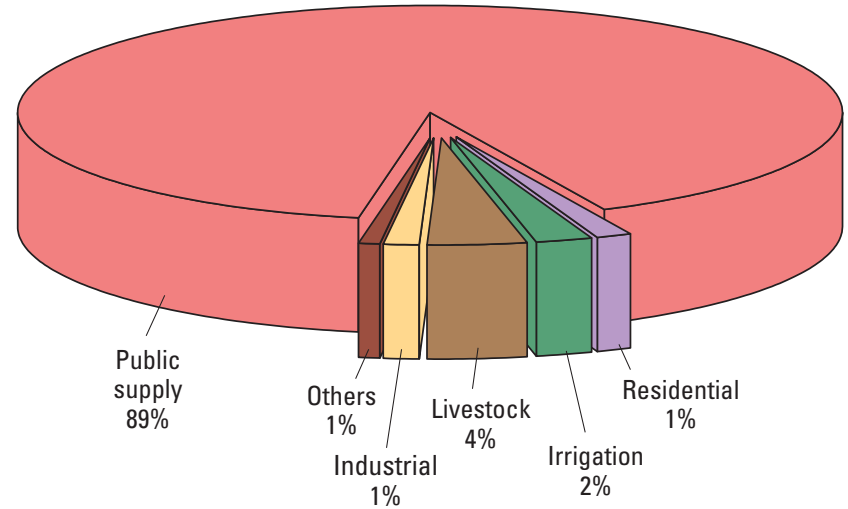

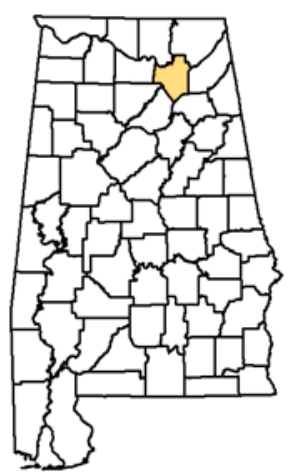

Withdrawals by public supplier, in $\mathrm{Mgal} / \mathrm{d}$

\begin{tabular}{lrrr}
\hline Public Supplier & GW & SW & Totals \\
\hline Albertville Municipal Utilities & 0.00 & 11.64 & 11.64 \\
Board & & & \\
Arab Water Works Board & .00 & 4.30 & 4.30 \\
$\begin{array}{l}\text { Douglas Water and Fire Protection } \\
\text { Guntersville Water Works and }\end{array}$ & 2.33 & 0.00 & 2.33 \\
Sewer Board & .65 & 2.66 & 3.31 \\
$\begin{array}{l}\text { North Marshall Utilities } \\
\text { Northeast Alabama Water, Sewer }\end{array}$ & .00 & 1.20 & 1.20 \\
\& F.P.A. & .00 & 1.36 & 1.36 \\
& & & \\
\end{tabular}

Withdrawals by Standard Industrial Classification, in Mgal/d

\begin{tabular}{lllr}
\hline Standard Industrial Classification & GW & SW & Totals \\
\hline 20 Food and Kindred Products & 0.36 & 0.00 & 0.36 \\
\hline
\end{tabular}




\section{Mobile}

Population: 401,427

Population served by public supply: 364,178

Per capita use (gallons per person per day): 70

Acres irrigated: 4,170

Land area: 1,233.1 square miles

Water area: 410.9 square miles

Withdrawals, in million gallons per day (Mgal/d) and percent $(\%)$ [Percents are rounded to nearest whole number]

\begin{tabular}{lrrr}
\hline Category & GW & SW & Totals \\
\hline Public Supply & 11.37 & 65.45 & 76.82 \\
Residential & $15 \%$ & $85 \%$ & \\
& 3.01 & 0.00 & 3.01 \\
Irrigation & 100 & 0 & \\
& 0.14 & .96 & 1.10 \\
Aquaculture & 13 & 87 & \\
Livestock & .00 & .00 & 0.00 \\
& 100 & 0 & \\
Industrial & .12 & .15 & .27 \\
& 46 & 54 & \\
Mining & 5.67 & .00 & 5.67 \\
Thermoelectric & 100 & 0 & \\
& .46 & .00 & .46 \\
TOTALS & 100 & 0 & \\
& .00 & $1,043.61$ & $1,043.61$ \\
\cline { 2 - 4 } & 0 & 100 & \\
\hline
\end{tabular}

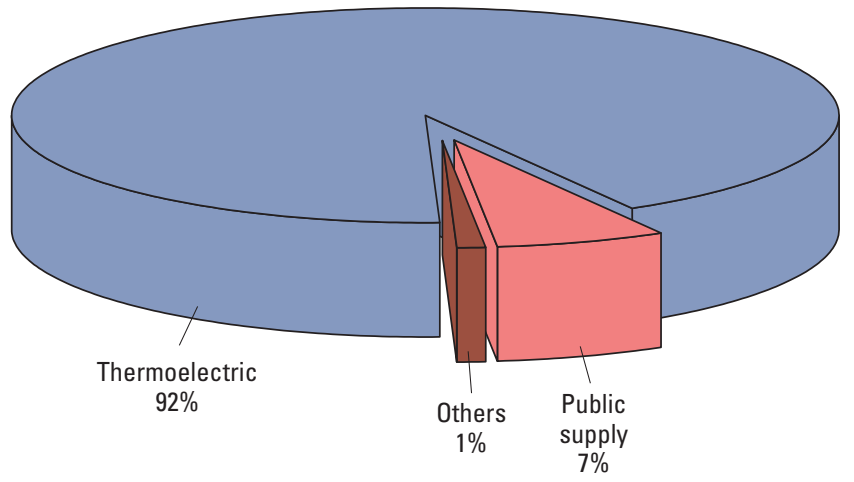

Withdrawals by public supplier, in Mgal/d

\begin{tabular}{lrrr}
\hline Public Supplier & GW & SW & Totals \\
\hline Bayou La Batre Utilities Board & 0.62 & 0.00 & 0.62 \\
Grand Bay Water Works Board & .94 & .00 & .94 \\
Kushla Water System & .45 & .00 & .45 \\
Le Moyne Water System, Inc. & .40 & .00 & .40 \\
MCB Water Authority, Inc. & .14 & .00 & .14 \\
Mobile Board of Water and Sewer & .00 & 65.45 & 65.45 \\
Commissioners & & & \\
Mobile County W S \& F & 3.71 & .00 & 3.71 \\
Protection Authority & & & \\
Mt. Vernon & .26 & .00 & .26 \\
Saraland Water System & 1.47 & .00 & 1.47 \\
Satsuma & .56 & .00 & .56 \\
South Alabama Utilities & 1.62 & .00 & 1.62 \\
St. Elmo - Irvington Water & .89 & .00 & .89 \\
Authority & & & \\
Turnerville Water \& Fire & .32 & .00 & .32 \\
Protection District & & & \\
\hline
\end{tabular}

Withdrawals by Standard Industrial Classification, in Mgal/d

\begin{tabular}{lrrr}
\hline Standard Industrial Classification & GW & SW & Totals \\
\hline 13 Oil and Gas Extraction & 0.12 & 0.00 & 0.12 \\
20 Food and Kindred Products & .00 & .00 & .00 \\
28 Chemicals and Allied & 5.17 & .00 & 5.17 \\
$\quad \begin{array}{l}\text { Products } \\
29 \text { Petroleum Refining and }\end{array}$ & .23 & .00 & .23 \\
$\quad \begin{array}{l}\text { Related Industries } \\
\text { 32 Stone, Clay, Glass, and }\end{array}$ & .15 & .00 & .15 \\
$\quad \begin{array}{l}\text { Concrete Products } \\
\text { 49 Electric, Gas, and Sanitary } \\
\quad \text { Services }\end{array}$ & .00 & $1,043.61$ & $1,043.61$ \\
\hline
\end{tabular}




\section{Monroe}

Population: 23,733

Population served by public supply: 17,666

Per capita use (gallons per person per day): 61

Acres irrigated: 690

Land area: 1,025.9 square miles

Water area: 8.7 square miles

Withdrawals, in million gallons per day (Mgal/d) and percent (\%) [Percents are rounded to nearest whole number]

\begin{tabular}{lrrr}
\hline Category & GW & SW & Totals \\
\hline Public Supply & 3.85 & 0.00 & 3.85 \\
Residential & $100 \%$ & $0 \%$ & \\
& 0.31 & .00 & 0.31 \\
Irrigation & 100 & 0 & \\
& .40 & .06 & .46 \\
Aquaculture & 86 & 14 & \\
& .03 & .04 & .07 \\
Livestock & 49 & 51 & \\
& .08 & .12 & .20 \\
Industrial & 40 & 60 & \\
& .40 & 54.61 & 55.01 \\
Mining & 1 & 99 & \\
& .11 & .00 & .11 \\
TOTALS & 100 & 0 & \\
\cline { 2 - 4 } & 5.18 & 54.83 & 60.01 \\
\hline
\end{tabular}

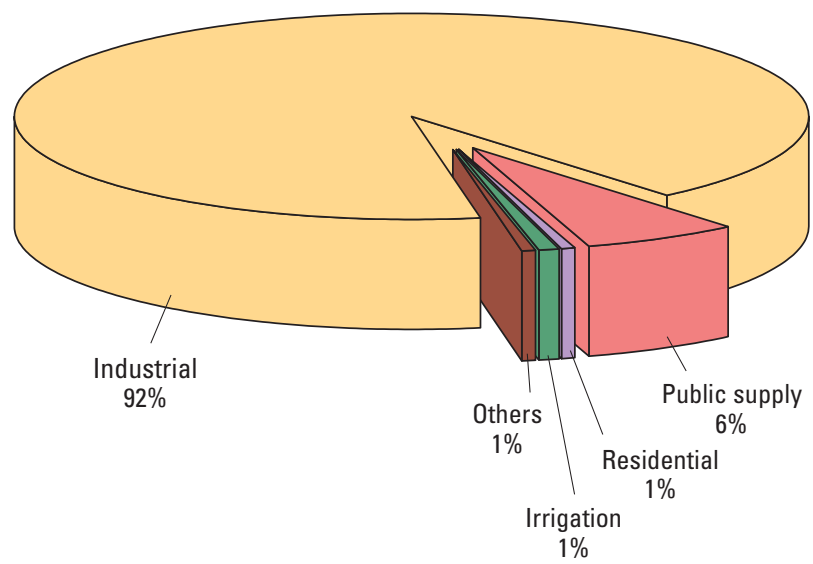

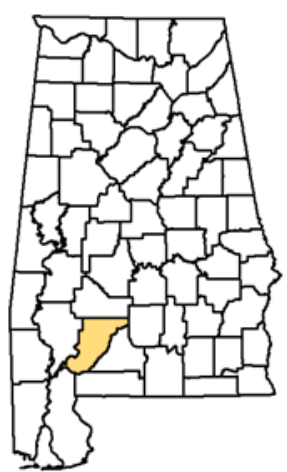

Withdrawals by public supplier, in Mgal/d

\begin{tabular}{lrrr}
\hline Public Supplier & GW & SW & Totals \\
\hline Beatrice Water System & 0.08 & 0.00 & 0.08 \\
Excel & .30 & .00 & .30 \\
Frisco City Water Works Board & .23 & .00 & .23 \\
Monroeville Water Works Board & 2.58 & .00 & 2.58 \\
Southwest Alabama Water & .40 & .00 & .40 \\
Authority & & & \\
Uriah Water System & .27 & .00 & .27 \\
\hline
\end{tabular}

Withdrawals by Standard Industrial Classification, in Mgal/d

\begin{tabular}{lccr}
\hline Standard Industrial Classification & GW & SW & Totals \\
\hline $\begin{array}{l}\text { 24 Lumber and Wood } \\
\text { Products, Except Furniture }\end{array}$ & 0.40 & 0.00 & 0.40 \\
26 Paper and Allied Products & .00 & 54.61 & 54.61 \\
\hline
\end{tabular}




\section{Montgomery}

Population: 221,619

Population served by public supply: 217,044

Per capita use (gallons per person per day): 80

Acres irrigated: 1,600

Land area: 789.8 square miles

Water area: 10.0 square miles

Withdrawals, in million gallons per day (Mgal/d) and percent (\%) [Percents are rounded to nearest whole number]

\begin{tabular}{lrrr}
\hline Category & GW & SW & Totals \\
\hline Public Supply & 28.90 & 35.57 & 64.47 \\
Residential & $45 \%$ & $55 \%$ & \\
Irrigation & 0.36 & 0.00 & 0.36 \\
& 100 & 0 & \\
Aquaculture & .35 & .82 & 1.17 \\
& 30 & 70 & \\
Livestock & .55 & .59 & 1.14 \\
Industrial & 48 & 52 & \\
& .27 & .39 & .66 \\
Mining & 41 & 59 & \\
& .01 & .00 & .01 \\
TOTALS & 100 & 0 & \\
& 1.31 & .61 & 1.92 \\
\hline
\end{tabular}

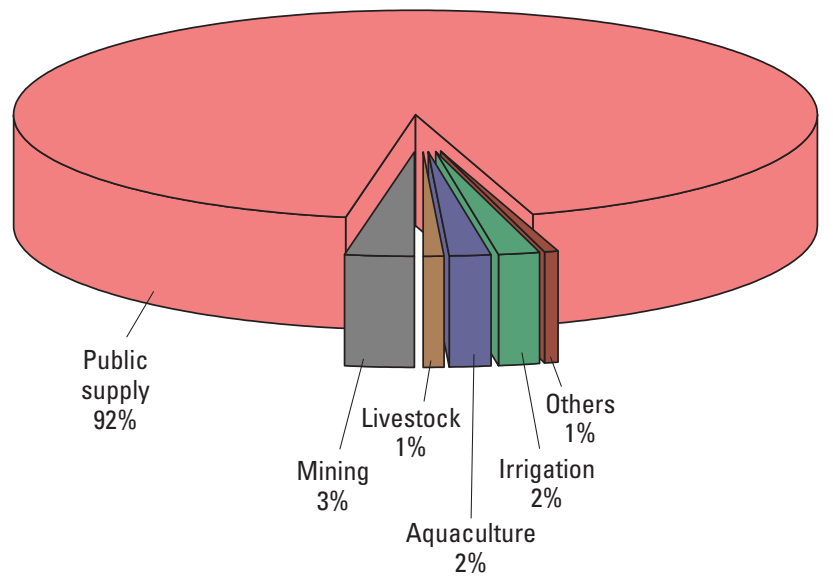

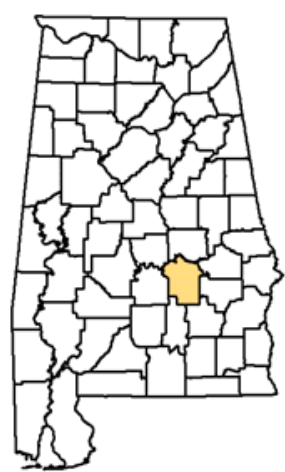

Withdrawals by public supplier, in Mgal/d

\begin{tabular}{lrrr}
\hline Public Supplier & GW & SW & Totals \\
\hline East Montgomery Water, Sewer, & 1.59 & 0.00 & 1.59 \\
\& Fire Protection Authority & & & \\
Montgomery Water Works and & 26.58 & 35.57 & 62.15 \\
Sewer Board & & & \\
Oak Hills Water Company & 0.04 & .00 & 0.04 \\
Pilgrim Providence Water and F. & .04 & .00 & .04 \\
P. A. & & & \\
Pine Level Water Authority & .22 & .00 & .22 \\
Pintlala Water System, Inc. & .27 & .00 & .27 \\
Ramer Water Co., Inc. & .14 & .00 & .14 \\
Sellers Station Water System, Inc. & .01 & .00 & .01 \\
\hline
\end{tabular}

Withdrawals by Standard Industrial Classification, in Mgal/d

\begin{tabular}{lllr}
\hline Standard Industrial Classification & GW & SW & Totals \\
\hline $\begin{array}{l}\text { 91 Executive, Legislative, } \\
\text { and General Government, }\end{array}$ & 0.01 & 0.00 & 0.01 \\
$\quad$ Except Finance & & & \\
\end{tabular}




\section{Morgan}

Population: 113,740

Population served by public supply: 109,912

Per capita use (gallons per person per day): 83

Acres irrigated: 1,390

Land area: 582.2 square miles

Water area: 16.8 square miles

Withdrawals, in million gallons per day (Mgal/d) and percent (\%) [Percents are rounded to nearest whole number]

\begin{tabular}{lrrr}
\hline Category & GW & SW & Totals \\
\hline Public Supply & 0.00 & 30.42 & 30.42 \\
Residential & $0 \%$ & $100 \%$ & \\
& .30 & 0.00 & 0.30 \\
Irrigation & 100 & 0 & \\
& .12 & .74 & .86 \\
Aquaculture & 14 & 86 & \\
Livestock & .05 & .05 & .10 \\
& 50 & 50 & \\
Industrial & .33 & .40 & .73 \\
& 45 & 55 & \\
Mining & 1.29 & 89.36 & 90.65 \\
& 1 & 99 & \\
Thermoelectric & .37 & .17 & .54 \\
& 68 & 32 & \\
TOTALS & .00 & 1.20 & 1.20 \\
& 0 & 100 & \\
\cline { 2 - 4 } & 2.46 & 122.34 & 124.80 \\
\hline
\end{tabular}

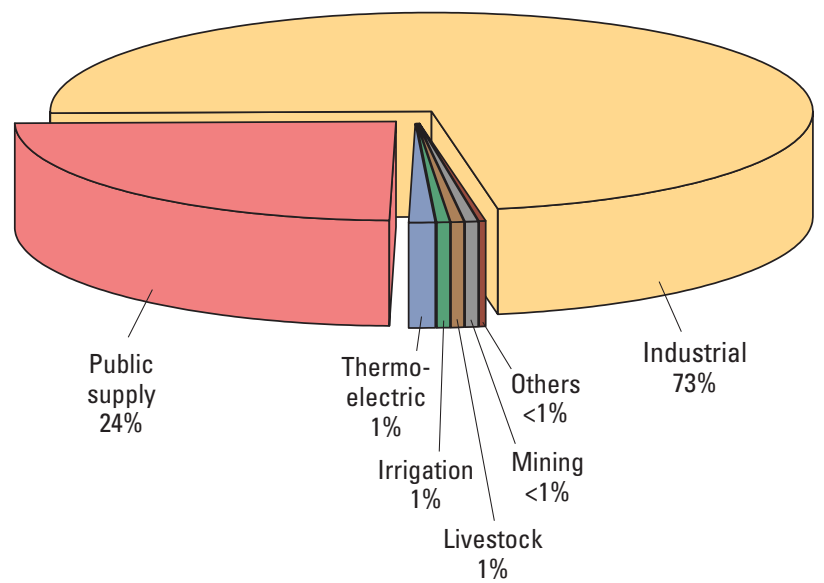

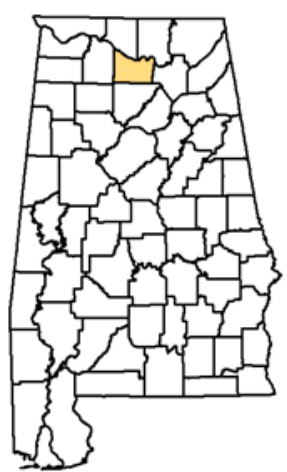

Withdrawals by public supplier, in Mgal/d

\begin{tabular}{lrrr}
\hline Public Supplier & GW & SW & Totals \\
\hline Decatur Utilities & 0.00 & 30.42 & 30.42 \\
\hline
\end{tabular}

Withdrawals by Standard Industrial Classification, in Mgal/d

\begin{tabular}{lcrr}
\hline Standard Industrial Classification & GW & SW & Totals \\
\hline 20 Food and Kindred Products & 1.14 & 0.00 & 1.14 \\
28 Chemicals and Allied & 0.16 & 84.08 & 84.24 \\
$\quad$ Products & & & \\
$\begin{array}{l}30 \text { Rubber and Miscellaneous } \\
\quad \text { Plastics Products }\end{array}$ & .00 & 5.28 & 5.28 \\
$\begin{array}{l}\text { 49 Electric, Gas, and Sanitary } \\
\quad \text { Services }\end{array}$ & .00 & 1.20 & 1.20 \\
\hline
\end{tabular}




\section{Perry}

Population: 11,371

Population served by public supply: 6,840

Per capita use (gallons per person per day): 65

Acres irrigated: 130

Land area: 719.5 square miles

Water area: 4.6 square miles

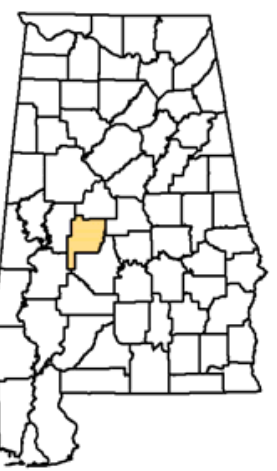

Withdrawals, in million gallons per day $(\mathrm{Mgal} / \mathrm{d})$ and percent (\%) [Percents are rounded to nearest whole number]

\begin{tabular}{lrrr}
\hline Category & GW & SW & Totals \\
\hline Public Supply & 1.82 & 0.00 & 1.82 \\
Residential & $100 \%$ & $0 \%$ & \\
Irrigation & 0.32 & .00 & 0.32 \\
& 100 & 0 & \\
Aquaculture & .03 & .02 & .05 \\
& 66 & 34 & \\
Livestock & 5.32 & 4.67 & 9.99 \\
& 53 & 47 & \\
TOTALS & .09 & .12 & .21 \\
& 42 & 58 & \\
\cline { 2 - 4 } & 7.58 & 4.81 & 12.39 \\
& $61 \%$ & $39 \%$ & \\
\hline
\end{tabular}

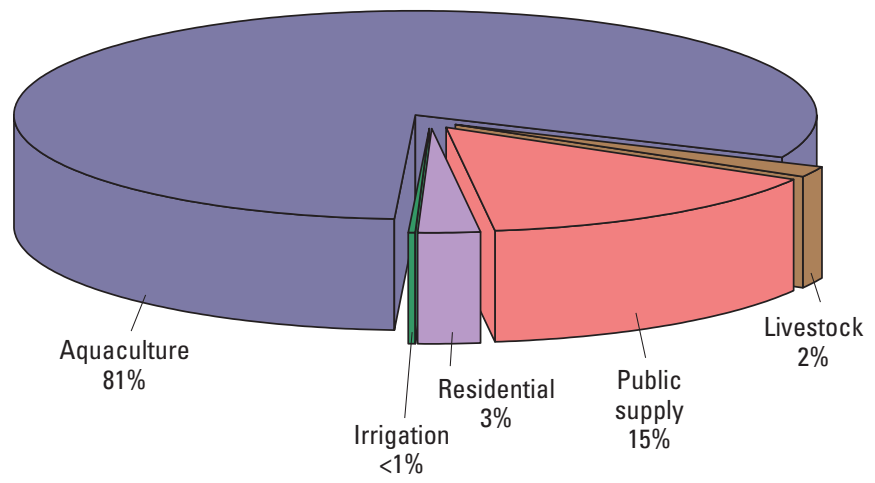

Withdrawals by public supplier, in Mgal/d

\begin{tabular}{lrrr}
\hline Public Supplier & GW & SW & Totals \\
\hline Marion (City of) Water Department & 0.82 & 0.00 & 0.82 \\
Perry County Water Authority & .16 & .00 & .16 \\
Uniontown Utilities Board & .84 & .00 & .84 \\
\hline
\end{tabular}

Withdrawals by Standard Industrial Classification, in Mgal/d

Standard Industrial Classification $\mathrm{GW} \quad \mathrm{SW}$ Totals

None 


\section{Pickens}

Population: 20,178

Population served by public supply: 15,797

Per capita use (gallons per person per day): 99

Acres irrigated: 860

Land area: 881.4 square miles

Water area: 8.6 square miles

Withdrawals, in million gallons per day (Mgal/d) and percent (\%) [Percents are rounded to nearest whole number]

\begin{tabular}{lrrr}
\hline Category & GW & SW & Totals \\
\hline Public Supply & 2.71 & 0.00 & 2.71 \\
Residential & $100 \%$ & $0 \%$ & \\
& 0.48 & .00 & 0.48 \\
Irrigation & 100 & 0 & \\
& .32 & .41 & .73 \\
Aquaculture & 44 & 56 & \\
& .50 & .50 & 1.00 \\
Livestock & 50 & 50 & \\
& .31 & .32 & .63 \\
Industrial & 49 & 51 & \\
& .12 & .00 & .12 \\
TOTALS & 100 & 0 & \\
& 4.44 & 1.23 & 5.67 \\
& $78 \%$ & $22 \%$ & \\
\hline
\end{tabular}

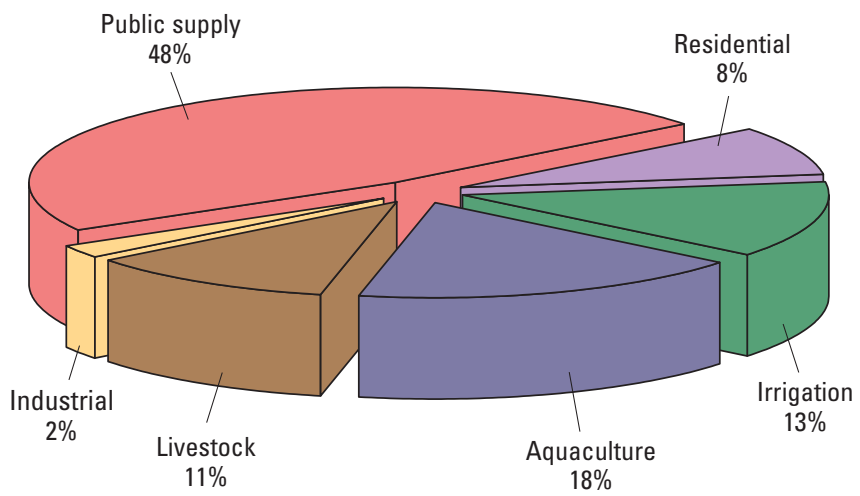

Withdrawals by Standard Industrial Classification, in Mgal/d

\begin{tabular}{lllr}
\hline Standard Industrial Classification & GW & SW & Totals \\
\hline $\begin{array}{l}\text { 24 Lumber and Wood } \\
\text { Products, Except Furniture }\end{array}$ & 0.12 & 0.00 & 0.12 \\
\hline
\end{tabular}

Withdrawals by public supplier, in Mgal/d

\begin{tabular}{lrrr}
\hline Public Supplier & GW & SW & Totals \\
\hline Aliceville Water and Sewer Board & 0.77 & 0.00 & 0.77 \\
Gordo & .44 & .00 & .44 \\
Pickens County Water Authority & 1.12 & .00 & 1.12 \\
Reform & .37 & .00 & .37 \\
\hline
\end{tabular}

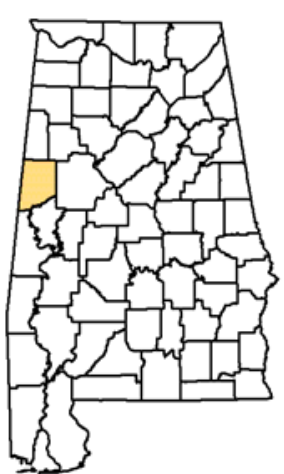

12

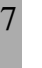

\section{.}




\section{Pike}

Population: 29,639

Population served by public supply: 26,053

Per capita use (gallons per person per day): 107

Acres irrigated: 2,420

Land area: 671.0 square miles

Water area: 1.1 square miles

Withdrawals, in million gallons per day (Mgal/d) and percent $(\%)$ [Percents are rounded to nearest whole number]

\begin{tabular}{lrrr}
\hline Category & GW & SW & Totals \\
\hline Public Supply & 4.68 & 0.00 & 4.68 \\
Residential & $100 \%$ & $0 \%$ & \\
Irrigation & 0.42 & .00 & 0.42 \\
& 100 & 0 & \\
Aquaculture & .46 & .88 & 1.34 \\
& 34 & 66 & \\
Livestock & .00 & .00 & .00 \\
TOTALS & 50 & 50 & \\
& .23 & .32 & .55 \\
& 41 & 59 & \\
\cline { 2 - 4 } & 5.79 & 1.20 & 6.99 \\
\hline
\end{tabular}

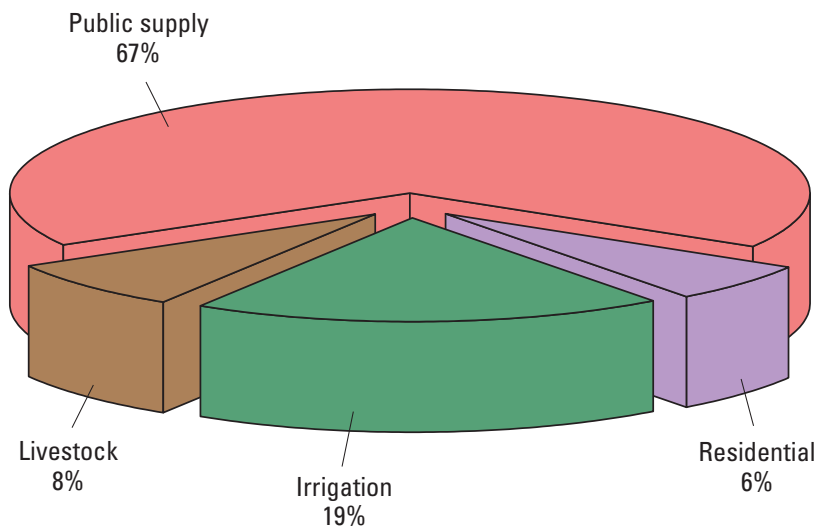

Withdrawals by public supplier, in Mgal/d

\begin{tabular}{lrrr}
\hline Public Supplier & GW & SW & Totals \\
\hline Brundidge & 0.42 & 0.00 & 0.42 \\
Goshen & .05 & .00 & .05 \\
Pike County Water Authority & 1.16 & .00 & 1.16 \\
Troy Utility Department & 3.06 & .00 & 3.06 \\
\hline
\end{tabular}

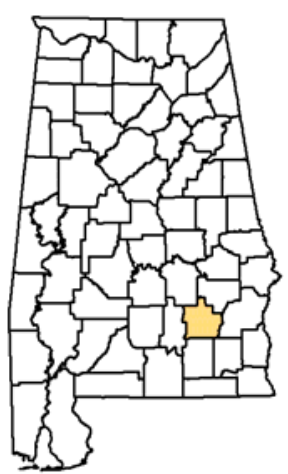

Withdrawals by Standard Industrial Classification, in Mgal/d \begin{tabular}{llll}
\hline Standard Industrial Classification & $\mathrm{GW}$ & SW & Totals
\end{tabular}

None 


\section{Randolph}

Population: 22,717

Population served by public supply: 12,026

Per capita use (gallons per person per day): 68

Acres irrigated: 180

Land area: 581.1 square miles

Water area: 3.1 square miles

Withdrawals, in million gallons per day (Mgal/d) and percent (\%) [Percents are rounded to nearest whole number]

\begin{tabular}{lrrr}
\hline Category & GW & SW & Totals \\
\hline Public Supply & 0.00 & 1.68 & 1.68 \\
Residential & $0 \%$ & $100 \%$ & \\
& .53 & 0.00 & 0.53 \\
Irrigation & 100 & 0 & \\
& .02 & .06 & .08 \\
Livestock & 27 & 73 & \\
& .23 & .26 & .49 \\
Mining & 46 & 54 & \\
& .00 & .00 & .00 \\
TOTALS & 75 & 25 & \\
\cline { 2 - 4 } & 0.78 & 2.00 & 2.78 \\
\hline
\end{tabular}

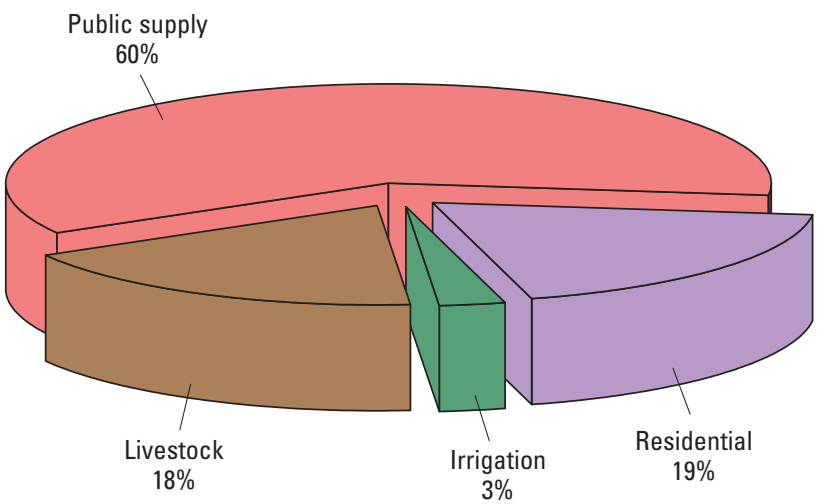

Withdrawals by Standard Industrial Classification, in Mgal/d

\begin{tabular}{llll}
\hline Standard Industrial Classification & GW & SW & Totals
\end{tabular}

None

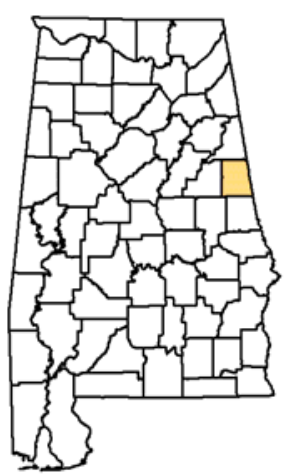

Withdrawals by public supplier, in Mgal/d

\begin{tabular}{lrrr}
\hline Public Supplier & GW & SW & Totals \\
\hline Roanoke Utilities Board & 0.00 & 1.29 & 1.29 \\
Wedowee Gas, Water \& Sewer & .00 & 0.39 & 0.39 \\
\hline
\end{tabular}
49 - 


\section{Russell}

Population: 49,326

Population served by public supply: 45,389

Per capita use (gallons per person per day): 65

Acres irrigated: 2,680

Land area: 641.3 square miles

Water area: 6.1 square miles

Withdrawals, in million gallons per day (Mgal/d) and percent $(\%)$ [Percents are rounded to nearest whole number]

\begin{tabular}{lrrr}
\hline Category & GW & SW & Totals \\
\hline Public Supply & 1.07 & 7.04 & 8.11 \\
Residential & $13 \%$ & $87 \%$ & \\
& 0.26 & 0.00 & 0.26 \\
Irrigation & 100 & 0 & \\
& .00 & 6.05 & 6.05 \\
Livestock & 0 & 100 & \\
& .04 & .06 & .10 \\
Industrial & 41 & 59 & \\
& .92 & 27.60 & 28.52 \\
Mining & 3 & 97 & \\
& .46 & .22 & .68 \\
TOTALS & 68 & 32 & \\
\cline { 2 - 4 } & 2.75 & 40.97 & 43.72 \\
\hline
\end{tabular}

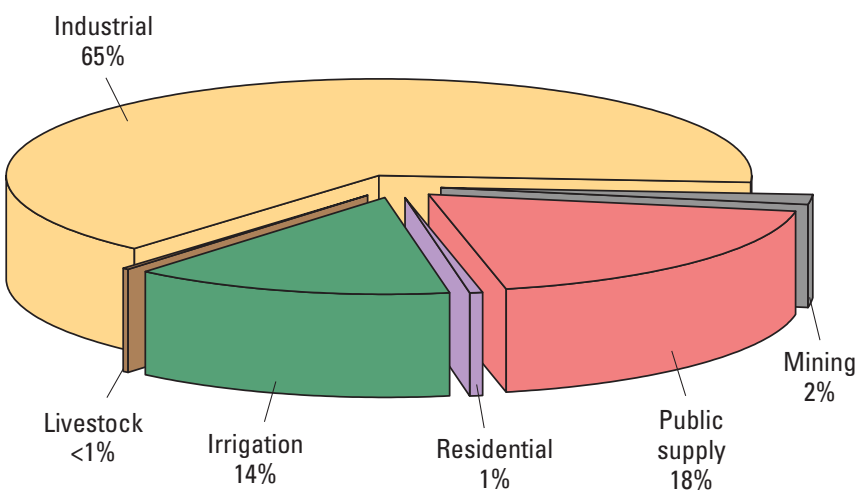

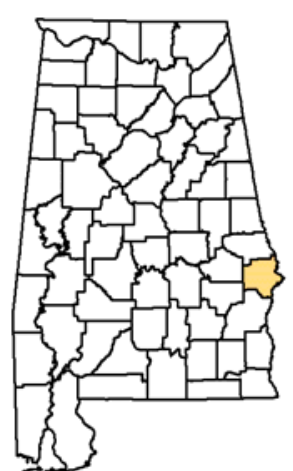

Withdrawals by public supplier, in Mgal/d

\begin{tabular}{lrrr}
\hline Public Supplier & GW & SW & Totals \\
\hline Ft. Mitchell Water System, Inc. & 0.54 & 0.00 & 0.54 \\
Hurtsboro Water and Sewer Board & .08 & .00 & .08 \\
Phenix City Utilities & .00 & 7.04 & 7.04 \\
Russell County Water Authority & .44 & .00 & .44 \\
\hline
\end{tabular}

Withdrawals by Standard Industrial Classification, in Mgal/d

\begin{tabular}{|c|c|c|c|}
\hline Standard Industrial Classification & GW & SW & Totals \\
\hline $\begin{array}{l}24 \text { Lumber and Wood } \\
\text { Products, Except Furniture }\end{array}$ & 0.92 & 27.60 & 28.52 \\
\hline $\begin{array}{l}32 \text { Stone, Clay, Glass, and } \\
\text { Concrete Products }\end{array}$ & .00 & 0.00 & 0.00 \\
\hline
\end{tabular}




\section{St. Clair}

Population: 72,330

Population served by public supply: 165,447

Per capita use (gallons per person per day): 74

Acres irrigated: 2,770

Land area: 633.8 square miles

Water area: 19.9 square miles

Withdrawals, in million gallons per day (Mgal/d) and percent (\%) [Percents are rounded to nearest whole number]

\begin{tabular}{lrrr}
\hline Category & GW & SW & Totals \\
\hline Public Supply & 8.13 & 0.00 & 8.13 \\
Residential & $100 \%$ & $0 \%$ & \\
& 0.72 & .00 & 0.72 \\
Irrigation & 100 & 0 & \\
& .00 & 7.37 & 7.37 \\
Aquaculture & 0 & 100 & \\
& .00 & .03 & .03 \\
Livestock & 0 & 100 & \\
& .16 & .23 & .39 \\
Industrial & 41 & 59 & \\
& .00 & 3.50 & 3.50 \\
Mining & 0 & 100 & \\
& .59 & .28 & .87 \\
TOTALS & 68 & 32 & \\
\cline { 2 - 4 } & 9.60 & 11.41 & 21.01 \\
& $46 \%$ & $54 \%$ & \\
\hline
\end{tabular}
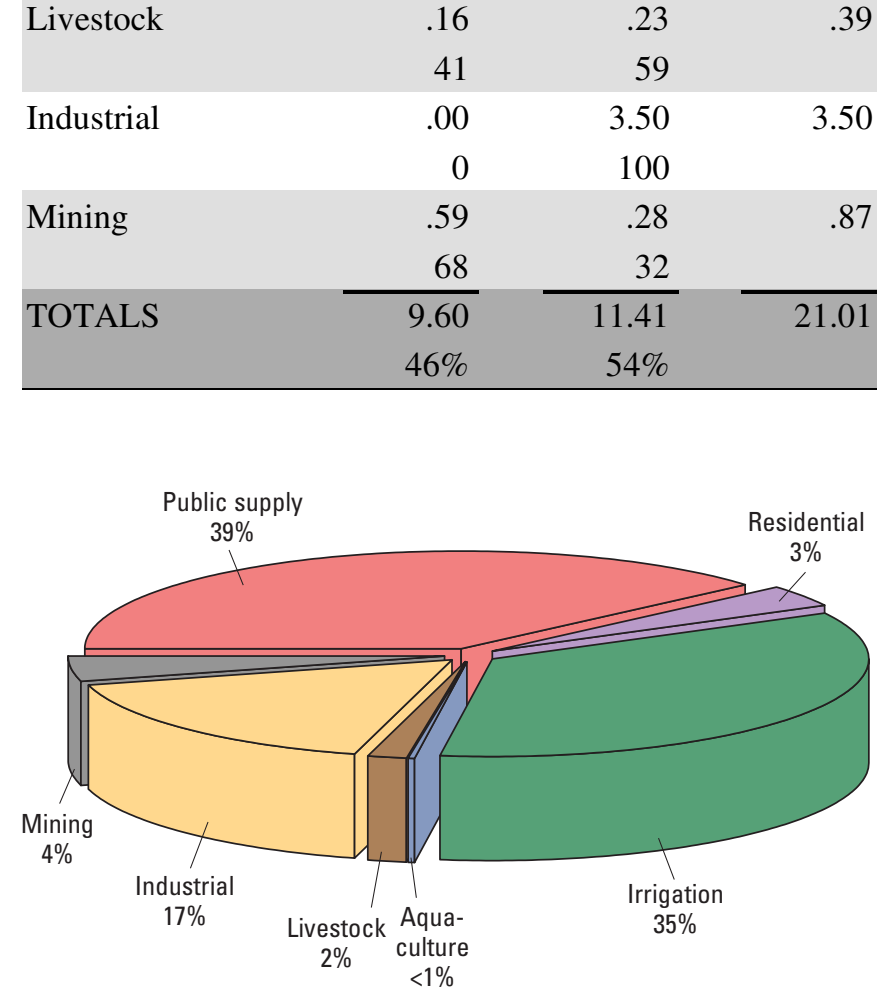

87

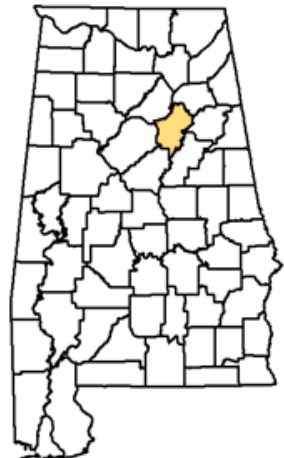

Withdrawals by public supplier, in Mgal/d

\begin{tabular}{lrrr}
\hline Public Supplier & GW & SW & Totals \\
\hline Leeds & 0.99 & 0.00 & 0.99 \\
New London Water Authority & .52 & .00 & .52 \\
Odenville Utilities Board & 2.79 & .00 & 2.79 \\
Pell City & 2.30 & .00 & 2.30 \\
Ragland Water Works Board & .50 & .00 & .50 \\
Springville & .45 & .00 & .45 \\
Wattsville Water Authority & .58 & .00 & .58 \\
\hline
\end{tabular}

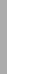




\section{Shelby}

Population: 171,465

Population served by public supply: 64,529

Per capita use (gallons per person per day): 82

Acres irrigated: 1,360

Land area: 794.7 square miles

Water area: 14.8 square miles

Withdrawals, in million gallons per day (Mgal/d) and percent (\%) [Percents are rounded to nearest whole number]

\begin{tabular}{|c|c|c|c|}
\hline Category & GW & SW & Totals \\
\hline \multirow[t]{2}{*}{ Public Supply } & 14.12 & 0.00 & 14.12 \\
\hline & $100 \%$ & $0 \%$ & \\
\hline \multirow[t]{2}{*}{ Residential } & 0.52 & .00 & 0.52 \\
\hline & 100 & 0 & \\
\hline \multirow[t]{2}{*}{ Irrigation } & 1.94 & .25 & 2.19 \\
\hline & 89 & 11 & \\
\hline \multirow[t]{2}{*}{ Aquaculture } & .00 & .05 & .05 \\
\hline & 0 & 100 & \\
\hline \multirow[t]{2}{*}{ Livestock } & .06 & .09 & .15 \\
\hline & 41 & 59 & \\
\hline \multirow[t]{2}{*}{ Mining } & 3.90 & .00 & 3.90 \\
\hline & 100 & 0 & \\
\hline \multirow[t]{2}{*}{ Thermoelectric } & .00 & 812.32 & 812.32 \\
\hline & 0 & 100 & \\
\hline \multirow[t]{2}{*}{ TOTALS } & 20.54 & 812.71 & 833.25 \\
\hline & $2 \%$ & $98 \%$ & \\
\hline
\end{tabular}

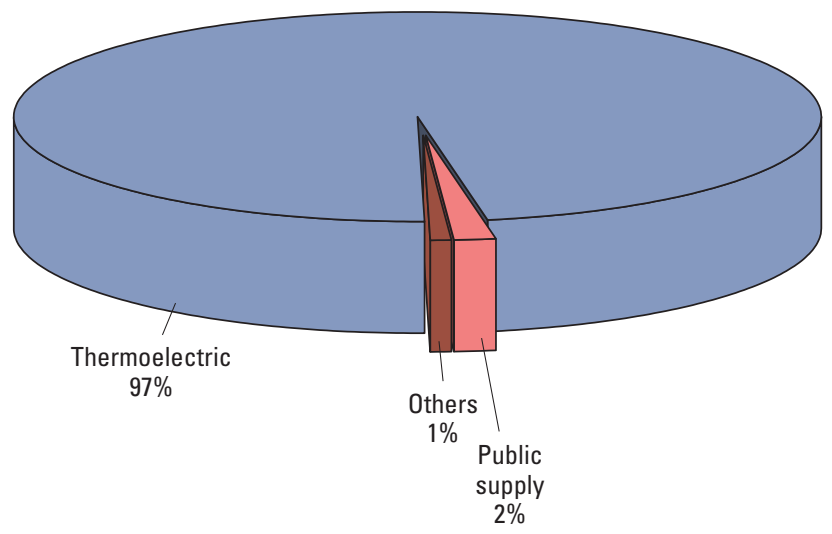

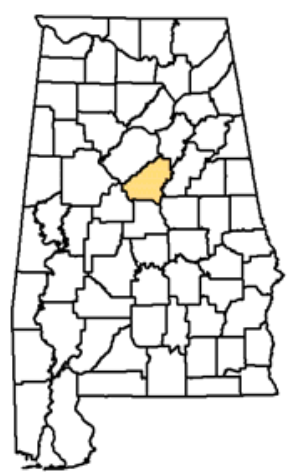

Withdrawals by public supplier, in $\mathrm{Mgal} / \mathrm{d}$

\begin{tabular}{lrrr}
\hline Public Supplier & GW & SW & Totals \\
\hline Alabaster Water Board & 3.71 & 0.00 & 3.71 \\
Calera & 1.77 & .00 & 1.77 \\
Columbiana Water Works Board & 1.37 & .00 & 1.37 \\
Harpersville Water Board & 0.23 & .00 & 0.23 \\
Helena Utility Board & 1.46 & .00 & 1.46 \\
Indian Springs School & .08 & .00 & .08 \\
Montevallo Water Works \& Sewer & 1.30 & .00 & 1.30 \\
Board & & & \\
Pelham Water Works & 3.10 & .00 & 3.10 \\
Vincent Water Board & .24 & .00 & .24 \\
Wilsonville Waterworks - Town of & .31 & .00 & .31 \\
Wilsonville & & & \\
Wilton & .54 & .00 & .54 \\
\hline
\end{tabular}

Withdrawals by Standard Industrial Classification, in Mgal/d

\begin{tabular}{llrr}
\hline Standard Industrial Classification & GW & SW & Totals \\
\hline $\begin{array}{l}\text { 49 Electric, Gas, and Sanitary } \\
\text { Services }\end{array}$ & 0.00 & 812.32 & 812.32 \\
\hline
\end{tabular}




\section{Sumter}

Population: 13,819

Population served by public supply: 12,629

Per capita use (gallons per person per day): 80

Acres irrigated: 210

Land area: 904.9 square miles

Water area: 8.4 square miles

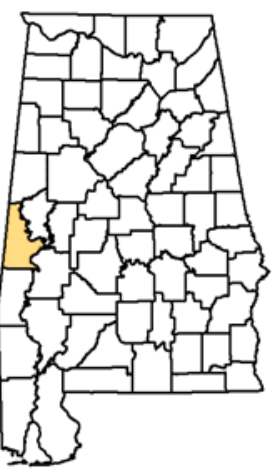

Withdrawals, in million gallons per day (Mgal/d) and percent (\%) [Percents are rounded to nearest whole number]

\begin{tabular}{lrrr}
\hline Category & GW & SW & Totals \\
\hline Public Supply & 1.82 & 0.00 & 1.82 \\
Residential & $100 \%$ & $0 \%$ & \\
& 0.10 & .00 & 0.10 \\
Irrigation & 100 & 0 & \\
& .02 & .08 & .10 \\
Aquaculture & 20 & 80 & \\
& 2.10 & 2.19 & 4.29 \\
Livestock & 49 & 51 & \\
& .14 & .21 & .35 \\
Industrial & 40 & 60 & \\
& .00 & 1.22 & 1.22 \\
Mining & 0 & 100 & \\
& 1.63 & .76 & 2.39 \\
TOTALS & 68 & 32 & \\
\cline { 2 - 4 } & 5.81 & 4.46 & 10.27 \\
& $57 \%$ & $43 \%$ & \\
\hline
\end{tabular}

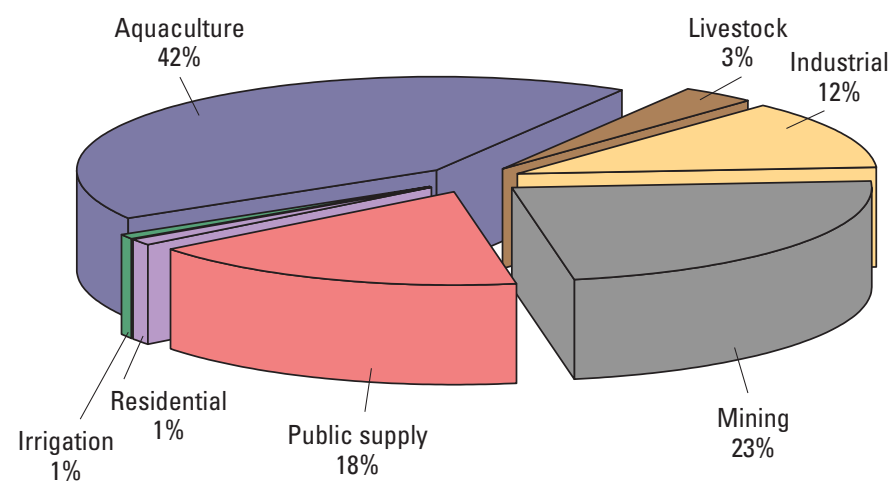

Withdrawals by public supplier, in Mgal/d

\begin{tabular}{lrrr}
\hline Public Supplier & GW & SW & Totals \\
\hline Livingston Utility Board & 0.76 & 0.00 & 0.76 \\
Sumter County Water Authority & 1.06 & .00 & 1.06 \\
\hline
\end{tabular}

0

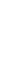




\section{Talladega}

Population: 80,457

Population served by public supply: 60,505

Per capita use (gallons per person per day): 60

Acres irrigated: 2,420

Land area: 739.5 square miles

Water area: 20.7 square miles

Withdrawals, in million gallons per day (Mgal/d) and percent (\%) [Percents are rounded to nearest whole number]

\begin{tabular}{lrrr}
\hline Category & GW & SW & Totals \\
\hline Public Supply & 6.36 & 12.12 & 18.48 \\
Residential & $34 \%$ & $66 \%$ & \\
& 1.26 & 0.00 & 1.26 \\
Irrigation & 100 & 0 & \\
& 0.17 & 2.36 & 2.53 \\
Livestock & 7 & 93 & \\
& .13 & .16 & 0.29 \\
Industrial & 45 & 55 & \\
& 1.26 & 53.36 & 54.62 \\
Mining & 2 & 98 & \\
& .75 & .35 & 1.10 \\
TOTALS & 68 & 32 & \\
\cline { 2 - 4 } & 9.93 & 68.35 & 78.28 \\
\hline
\end{tabular}

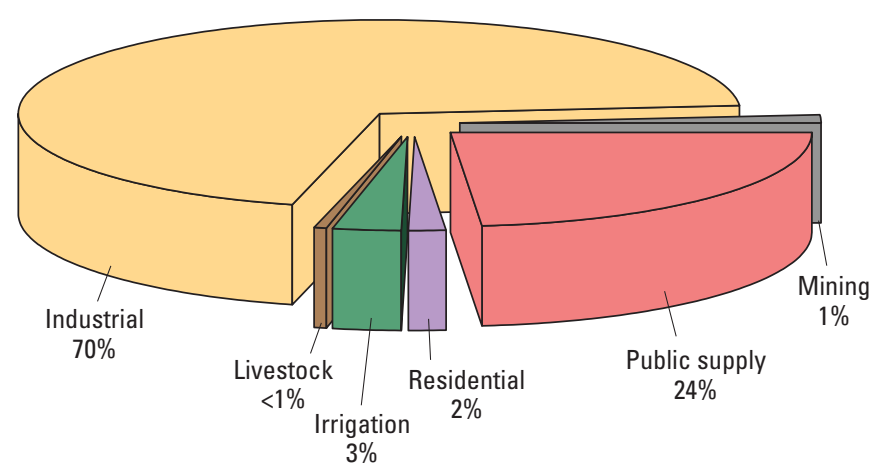

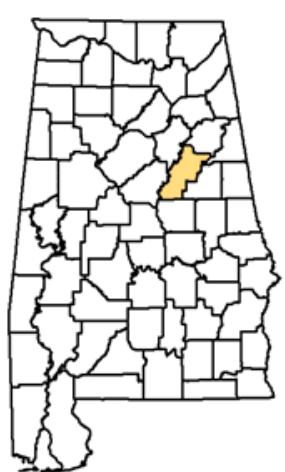

Withdrawals by public supplier, in Mgal/d

\begin{tabular}{lrrr}
\hline Public Supplier & GW & SW & Totals \\
\hline Central Talladega County Water & 0.26 & 0.00 & 0.26 \\
District & & & \\
Childersburg Water, Sewer \& Gas & 1.16 & .00 & 1.16 \\
Board & & & \\
Fayetteville Water Authority & .26 & .00 & .26 \\
Lincoln & 1.26 & .00 & 1.26 \\
Munford Water Authority, Inc. & .18 & .00 & .18 \\
Sycamore Water and Sewer & .13 & .00 & .13 \\
Authority & & & \\
Sylacauga Utilities Board & .28 & 3.25 & 3.53 \\
Talladega County Water Dept. & .00 & .81 & .81 \\
Talladega Water Works \& Sewer & 2.80 & 1.62 & 4.42 \\
Board & & & \\
Talladega/Shelby Water Treatment & .00 & 6.44 & 6.44 \\
Plant & & & \\
Water Works, Inc. & .03 & .00 & .03 \\
\hline
\end{tabular}

Withdrawals by Standard Industrial Classification, in Mgal/d

\begin{tabular}{lcrr}
\hline Standard Industrial Classification & GW & SW & Totals \\
\hline 22 Textile Mill Products & 1.26 & 0.89 & 2.15 \\
26 Paper and Allied Products & 0.00 & 52.46 & 52.46 \\
\hline
\end{tabular}




\section{Tallapoosa}

Population: 40,717

Population served by public supply: 34,765

Per capita use (gallons per person per day): 77

Acres irrigated: 620

Land area: 717.9 square miles

Water area: 48.3 square miles

Withdrawals, in million gallons per day (Mgal/d) and percent (\%) [Percents are rounded to nearest whole number]

\begin{tabular}{lrrr}
\hline Category & GW & SW & Totals \\
\hline Public Supply & 0.00 & 12.55 & 12.55 \\
& $0 \%$ & $100 \%$ & \\
Residential & .28 & 0.00 & 0.28 \\
& 100 & 0 & \\
Irrigation & .00 & .39 & .39 \\
& 0 & 100 & \\
Aquaculture & .03 & 1.27 & 1.30 \\
& 2 & 98 & \\
Livestock & .05 & .07 & .12 \\
& 44 & 56 & \\
\cline { 2 - 4 } TOTALS & 0.36 & 14.28 & 14.64 \\
& $2 \%$ & $98 \%$ & \\
\hline
\end{tabular}

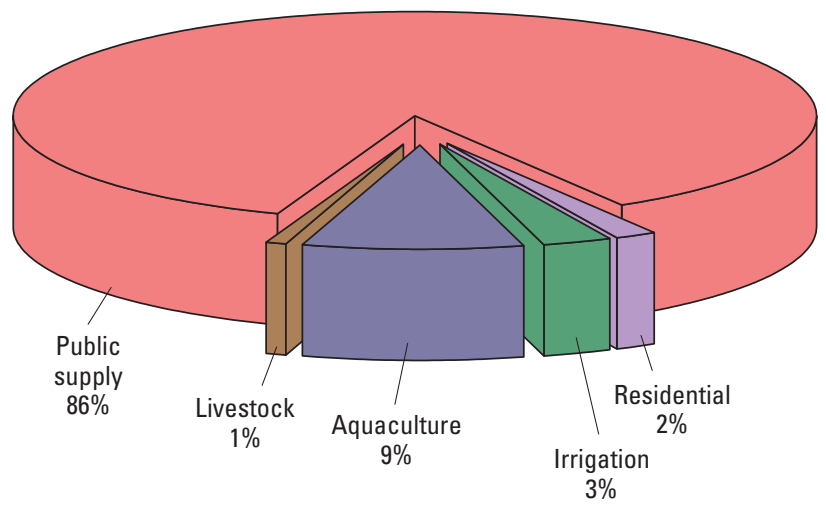

Withdrawals by Standard Industrial Classification, in Mgal/d Standard Industrial Classification $\mathrm{GW} \quad$ SW Totals

None

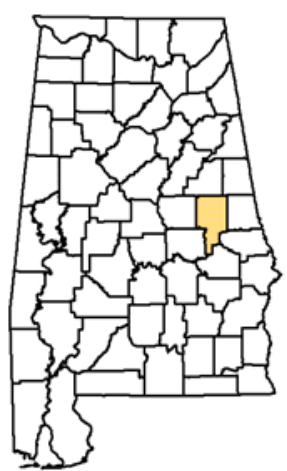

Withdrawals by public supplier, in Mgal/d

\begin{tabular}{lrrr}
\hline Public Supplier & GW & SW & Totals \\
\hline Alexander City Water Department & 0.00 & 10.57 & 10.57 \\
Tallassee & .00 & 1.98 & 1.98 \\
\hline
\end{tabular}

39

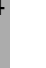




\section{Tuscaloosa}

Population: 168,908

Population served by public supply: 158,950

Per capita use (gallons per person per day): 127

Acres irrigated: 2,890

Land area: 1,324.4 square miles

Water area: 26.9 square miles

Withdrawals, in million gallons per day (Mgal/d) and percent (\%) [Percents are rounded to nearest whole number]

\begin{tabular}{lrrr}
\hline Category & GW & SW & Totals \\
\hline Public Supply & 0.80 & 27.49 & 28.29 \\
Residential & $3 \%$ & $97 \%$ & \\
Irrigation & .84 & 0.00 & 0.84 \\
& 100 & 0 & \\
Aquaculture & .38 & 4.06 & 4.44 \\
& 9 & 91 & \\
Livestock & .07 & .00 & .07 \\
Industrial & 100 & 0 & \\
& .09 & .12 & .21 \\
Mining & 43 & 57 & \\
& .78 & 1.14 & 1.92 \\
TOTALS & 41 & 59 & \\
& .00 & .25 & .25 \\
\hline
\end{tabular}

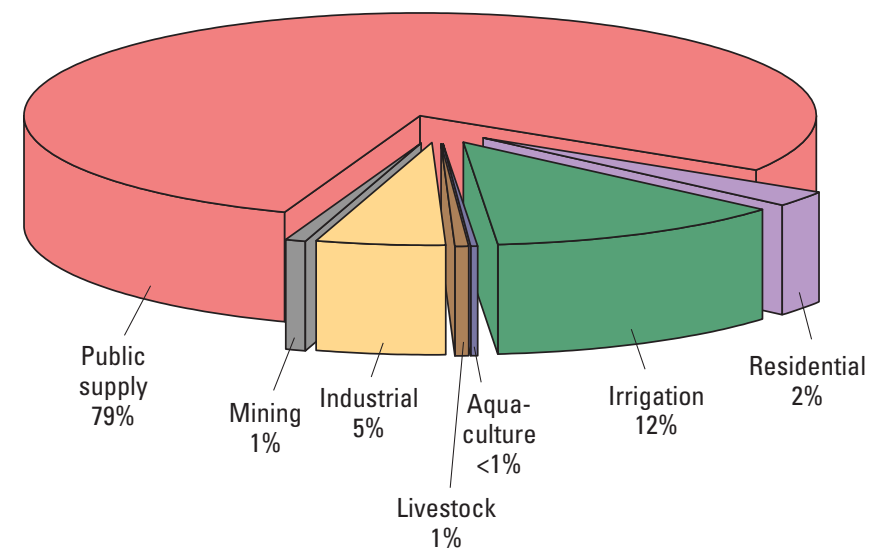

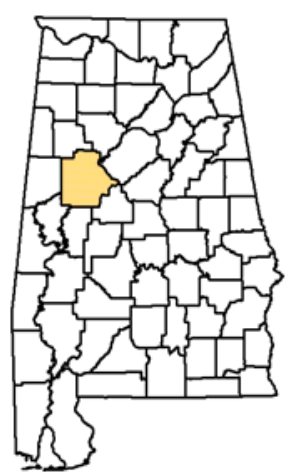

Withdrawals by public supplier, in Mgal/d

\begin{tabular}{lrrr}
\hline Public Supplier & GW & SW & Totals \\
\hline Buhl, Elrod and Holman Water & 0.27 & 0.00 & 0.27 \\
Authority & & & \\
Coker Water Authority & .32 & .00 & .32 \\
Green Pond Water System & .20 & .00 & .20 \\
Northport & .00 & 3.39 & 3.39 \\
Tuscaloosa Water and Sewer & .00 & 24.10 & 24.10 \\
Department & & & \\
\hline
\end{tabular}

Withdrawals by Standard Industrial Classification, in Mgal/d

\begin{tabular}{|c|c|c|c|}
\hline Standard Industrial Classification & GW & SW & Totals \\
\hline $\begin{array}{l}29 \text { Petroleum Refining and } \\
\text { Related Industries }\end{array}$ & 0.78 & 0.98 & 1.76 \\
\hline $\begin{array}{l}30 \text { Rubber and Miscellaneous } \\
\text { Plastics Products }\end{array}$ & .00 & .16 & 0.16 \\
\hline
\end{tabular}




\section{Walker}

Population: 70,117

Population served by public supply: 62,174

Per capita use (gallons per person per day): 70

Acres irrigated: 760

Land area: 794.4 square miles

Water area: 10.9 square miles

Withdrawals, in million gallons per day (Mgal/d) and percent (\%) [Percents are rounded to nearest whole number]

\begin{tabular}{lrrr}
\hline Category & GW & SW & Totals \\
\hline Public Supply & 0.12 & 40.22 & 40.34 \\
Residential & $0 \%$ & $100 \%$ & \\
Irrigation & .54 & 0.00 & 0.54 \\
& 100 & 0 & \\
Aquaculture & .23 & .26 & .49 \\
& 46 & 54 & \\
Livestock & .02 & .07 & .09 \\
Mining & 25 & 75 & \\
& .13 & .18 & .31 \\
Thermoelectric & 42 & 58 & .41 \\
& .10 & .31 & \\
TOTALS & 25 & 75 & 927.28 \\
& .00 & 927.28 & \\
\hline
\end{tabular}

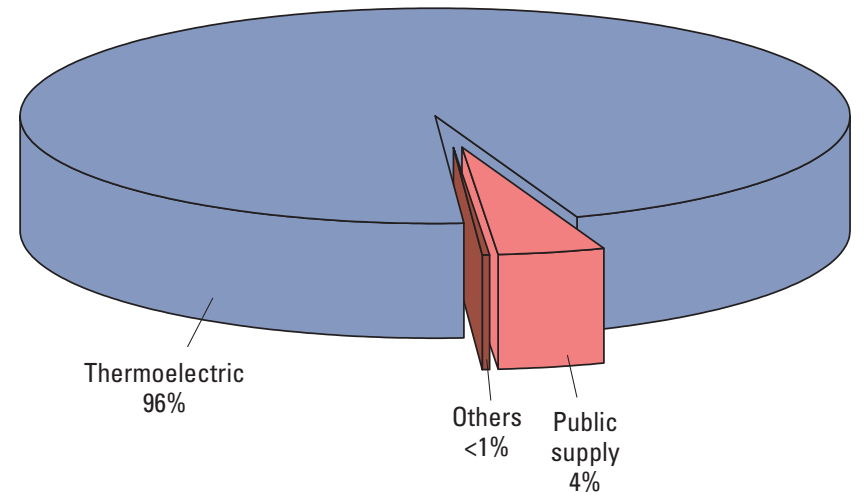

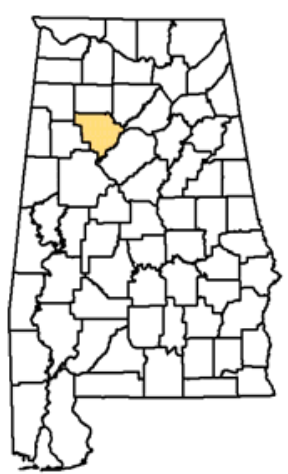

Withdrawals by public supplier, in Mgal/d

\begin{tabular}{lrrr}
\hline Public Supplier & GW & SW & Totals \\
\hline Birmingham WW\&SB & 0.00 & 28.71 & 28.71 \\
Eldridge Water Department & .12 & 0.00 & 0.12 \\
Jasper Waterworks and Sewer & .00 & 11.51 & 11.51 \\
Board & & & \\
\hline
\end{tabular}

Withdrawals by Standard Industrial Classification, in Mgal/d

\begin{tabular}{lcrr}
\hline Standard Industrial Classification & GW & SW & Totals \\
\hline $\begin{array}{l}\text { 49 Electric, Gas, and Sanitary } \\
\text { Services }\end{array}$ & 0.00 & 927.28 & 927.28 \\
\hline
\end{tabular}




\section{Washington}

Population: 17,773

Population served by public supply: 10,045

Per capita use (gallons per person per day): 66

Acres irrigated: 100

Land area: 1,080.7 square miles

Water area: 7.9 square miles

Withdrawals, in million gallons per day (Mgal/d) and percent (\%) [Percents are rounded to nearest whole number]

\begin{tabular}{|c|c|c|c|}
\hline Category & GW & SW & Totals \\
\hline \multirow[t]{2}{*}{ Public Supply } & 1.19 & 0.00 & 1.19 \\
\hline & $100 \%$ & $0 \%$ & \\
\hline \multirow[t]{2}{*}{ Residential } & 0.51 & .00 & 0.51 \\
\hline & 100 & 0 & \\
\hline \multirow[t]{2}{*}{ Irrigation } & .03 & .08 & .11 \\
\hline & 26 & 74 & \\
\hline \multirow[t]{2}{*}{ Aquaculture } & .08 & .00 & .08 \\
\hline & 100 & 0 & \\
\hline \multirow[t]{2}{*}{ Livestock } & .09 & .10 & .19 \\
\hline & 48 & 52 & \\
\hline \multirow[t]{2}{*}{ Industrial } & 5.33 & 4.31 & 9.64 \\
\hline & 55 & 45 & \\
\hline \multirow[t]{2}{*}{ Mining } & .91 & .00 & .91 \\
\hline & 100 & 0 & \\
\hline \multirow[t]{2}{*}{ Thermoelectric } & .00 & 86.54 & 86.54 \\
\hline & 0 & 100 & \\
\hline \multirow[t]{2}{*}{ TOTALS } & $\overline{8.14}$ & 91.03 & 99.17 \\
\hline & $8 \%$ & $92 \%$ & \\
\hline
\end{tabular}

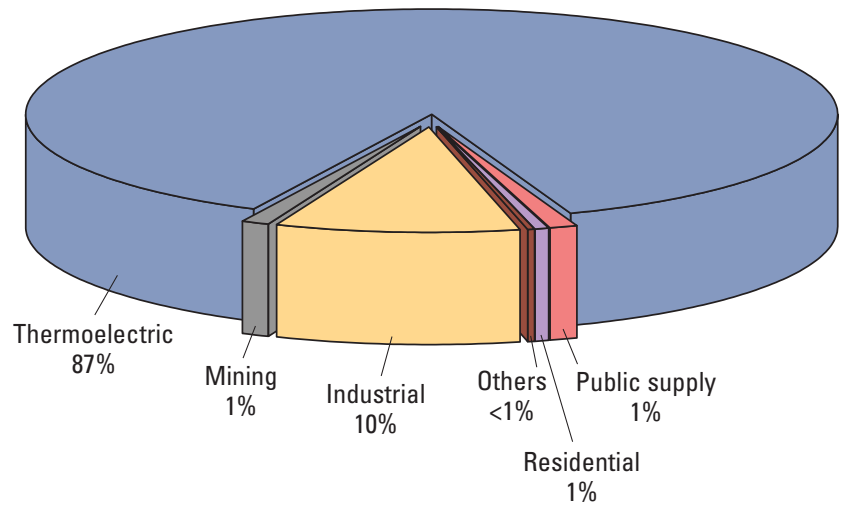

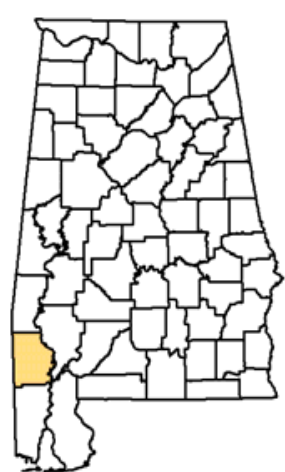

Withdrawals by public supplier, in $\mathrm{Mgal} / \mathrm{d}$

\begin{tabular}{lrrr}
\hline Public Supplier & GW & SW & Totals \\
\hline Chatom Utilities Board & 0.24 & 0.00 & 0.24 \\
$\begin{array}{l}\text { Deer Park - Vinegar Bend Water } \\
\text { \& Fire Protection }\end{array}$ & .11 & .00 & .11 \\
Frankville Water \& Fire Protection & .09 & .00 & .09 \\
Authority & & & \\
Leroy Water Authority & .16 & .00 & .16 \\
McIntosh Water \& Fire Protection & .35 & .00 & .35 \\
Authority & & & \\
Millry Water Works & .14 & .00 & .14 \\
St. Stephens Water System & .05 & .00 & .05 \\
Wagarville Water System, Inc. & .04 & .00 & .04 \\
\hline
\end{tabular}

Withdrawals by Standard Industrial Classification, in Mgal/d

\begin{tabular}{lccr}
\hline Standard Industrial Classification & GW & SW & Totals \\
\hline $\begin{array}{l}28 \text { Chemicals and Allied } \\
\begin{array}{l}\text { Products } \\
\text { Electric, Gas, and Sanitary }\end{array}\end{array}$ & 5.33 & 4.31 & 9.64 \\
\begin{tabular}{l} 
Services \\
\hline
\end{tabular} & 0.00 & 86.54 & 86.54 \\
\hline
\end{tabular}




\section{Wilcox}

Population: 12,937

Population served by public supply: 7,985

Per capita use (gallons per person per day): 79

Acres irrigated: 160

Land area: 888.7 square miles

Water area: 18.8 square miles

Withdrawals, in million gallons per day (Mgal/d) and percent (\%) [Percents are rounded to nearest whole number]

\begin{tabular}{lrrr}
\hline Category & GW & SW & Totals \\
\hline Public Supply & 1.02 & 0.00 & 1.02 \\
Residential & $100 \%$ & $0 \%$ & \\
& 0.34 & .00 & 0.34 \\
Irrigation & 100 & 0 & \\
& .34 & .02 & .36 \\
Aquaculture & 96 & 4 & \\
Livestock & .34 & .34 & .68 \\
& 50 & 50 & \\
Industrial & .08 & .13 & .21 \\
& 40 & 60 & \\
TOTALS & .00 & 21.04 & 21.04 \\
& 0 & 100 & \\
\cline { 2 - 4 } & 2.12 & 21.53 & 23.65 \\
& $9 \%$ & $91 \%$ & \\
\hline
\end{tabular}

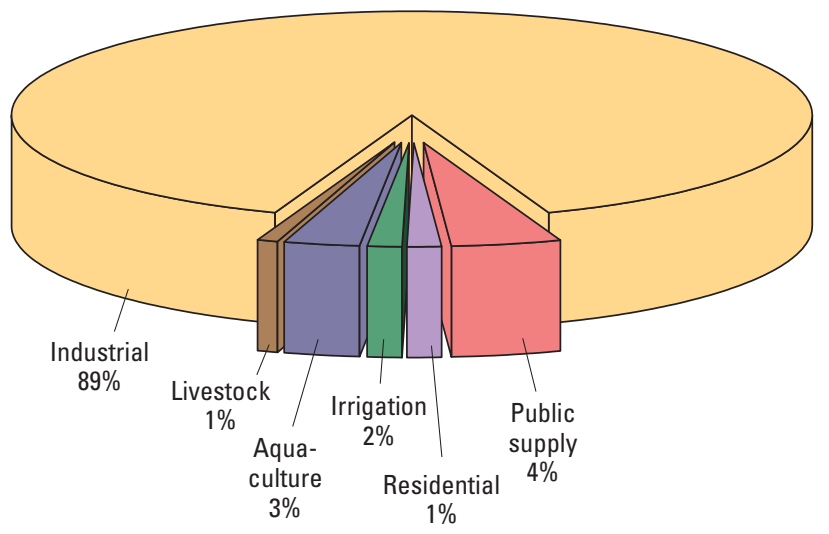

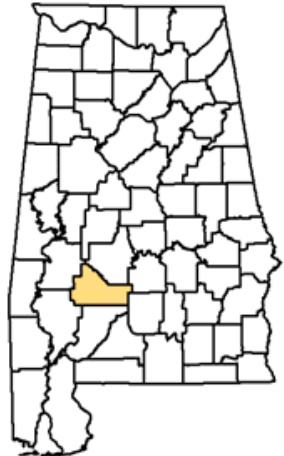

Withdrawals by public supplier, in Mgal/d

\begin{tabular}{lrrr}
\hline Public Supplier & GW & SW & Totals \\
\hline Camden & 0.43 & 0.00 & 0.43 \\
Millers Ferry Water Authority & .08 & .00 & .08 \\
Pine Apple Waterworks & .02 & .00 & .02 \\
Wilcox County Water System & .50 & .00 & .50 \\
\hline
\end{tabular}

Withdrawals by Standard Industrial Classification, in Mgal/d

\begin{tabular}{lccc}
\hline Standard Industrial Classification & GW & SW & Totals \\
\hline $\begin{array}{l}\text { 24 Lumber and Wood } \\
\text { Products, Except Furniture }\end{array}$ & 0.00 & 21.04 & 21.04 \\
\hline
\end{tabular}




\section{Winston}

Population: 24,498

Population served by public supply: 15,869

Per capita use (gallons per person per day): 53

Acres irrigated: 100

Land area: 614.4 square miles

Water area: 17.4 square miles

Withdrawals, in million gallons per day (Mgal/d) and percent $(\%)$ [Percents are rounded to nearest whole number]

\begin{tabular}{lrrr}
\hline Category & GW & SW & Totals \\
\hline Public Supply & 0.00 & 0.89 & 0.89 \\
Residential & $0 \%$ & $100 \%$ & \\
& .44 & .00 & .44 \\
Irrigation & 100 & 0 & \\
Livestock & .00 & .06 & .06 \\
& 0 & 100 & \\
Mining & .22 & .25 & .47 \\
TOTALS & 46 & 54 & \\
& .06 & .00 & .06 \\
& 100 & 0 & \\
\cline { 2 - 3 } & 0.72 & 1.21 & 1.92 \\
& $37 \%$ & $63 \%$ & \\
\hline
\end{tabular}

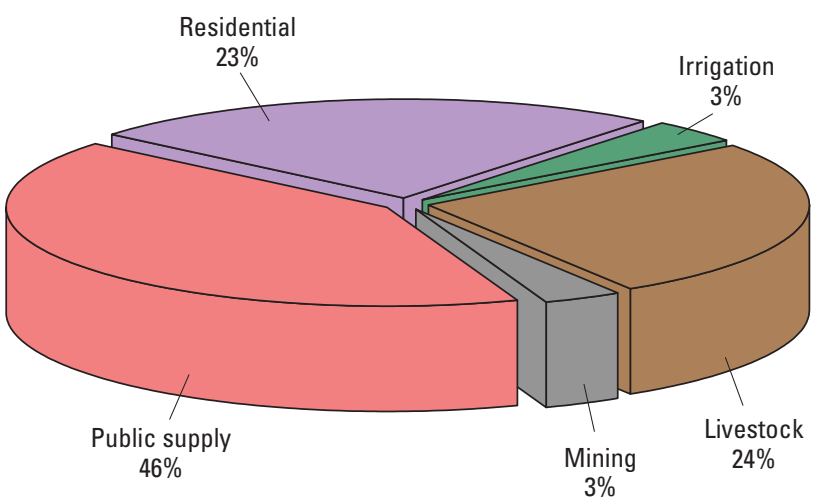

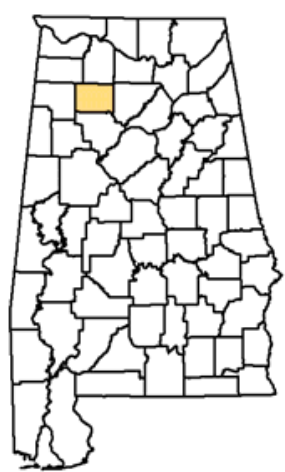

Withdrawals by public supplier, in Mgal/d

\begin{tabular}{lrrr}
\hline Public Supplier & GW & SW & Totals \\
\hline Arley Water Works & 0.00 & 0.89 & 0.89 \\
\hline
\end{tabular}




\section{Appendix B. Alabama Water Use by Subbasin}

The following one-page summaries of water-use information by hydrologic subbasin present withdrawals by public suppliers, major Standard Industrial Classification (SIC) groups, and water-use categories. See the first example on the following Middle ChattahoocheeLake Harding page. Population and land area totals also are listed along with a map that shows the location of the subbasin within the State.

In each of the summaries, a table lists average daily withdrawals for the water-use categories in the subbasin. If there are no withdrawals for a particular category, that category is not listed. The withdrawals are totaled by source of water used (ground water [GW] or surface water $[\mathrm{SW}]$ ) and by category, and the percentage of source used is indicated.

Each public supplier is listed by the subbasin in which the withdrawal occurs. Therefore, a public supplier may be listed in more than one subbasin depending on the location of its water sources. For example, Birmingham WW\&SB withdraws water from the Upper Coosa (03150105), Mulberry (03160109), Sipsey Fork (03160110), and Locust (03160111) subbasins and is, therefore, listed on each of the corresponding subbasin pages.

In the tables, public suppliers, categories, and major SIC groups were listed as withdrawing 0.00 million gallons per day (Mgal/d) if the withdrawal was less than $0.01 \mathrm{Mgal} / \mathrm{d}$. As a result, some totaled withdrawals from these tables may be less than the totals for public supply or industry in the water-use-category table. Numbers were summed using three-decimal places and then rounded to two decimal places for the final number. Numbers may not sum to total withdrawals because of rounding. No site-specific water withdrawals were reported for the Upper Chickasawhay (0317002, land area 65.1 square miles), Lower Chickasawhay (0317003, land area 0.7 square mile), or Upper Elk (0603003, land area 0.4 square mile) subbasins, and no water-withdrawal estimates were determined for the aquaculture, livestock, mining, or selfsupplied residential categories because of the relatively small land areas of these subbasins.

Major SIC groups include the water-use categories of commercial (SIC codes 79 and 91), industrial (SIC codes 20 through 40), mining (SIC code 13), and thermoelectric power (SIC code 49). 


\section{Middle Chattahoochee- Lake Harding}

03130002

Population: 52,842

Land Area: 559.6 square miles

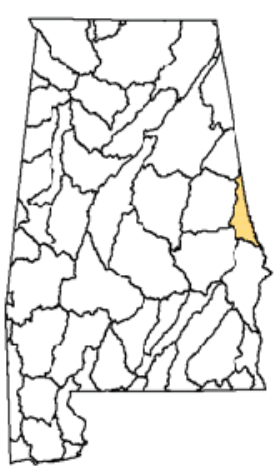

Withdrawals by public supplier, in million gallons per day (Mgal/d)

\begin{tabular}{lccc}
\hline Public Supplier & GW & SW & Totals \\
\hline Chattahoochee Valley Water & 0.00 & 4.72 & 4.72 \\
$\quad$ Supply District & & & \\
Opelika Water Works Board & .00 & 4.87 & 4.87 \\
Smiths Station Water System & .00 & 2.29 & 2.29 \\
\hline
\end{tabular}

Withdrawals by Standard Industrial Classification, in Mgal/d

\begin{tabular}{lrrr}
\hline Standard Industrial Classification & GW & SW & Totals \\
\hline 23 Apparel and Other & 0.00 & 2.16 & 2.16 \\
$\quad$ Finished Products Made & & & \\
From Fabrics and Similar & & & \\
$\quad$ Materials & & & \\
\hline
\end{tabular}

Withdrawals, in $\mathrm{Mgal} / \mathrm{d}$ and percent $(\%)$

\begin{tabular}{|c|c|c|c|}
\hline Category & GW & SW & Totals \\
\hline \multirow[t]{2}{*}{ Public Supply } & 0.00 & 11.88 & 11.88 \\
\hline & $0 \%$ & $100 \%$ & \\
\hline \multirow[t]{2}{*}{ Irrigation } & .19 & 0.39 & 0.58 \\
\hline & 33 & 67 & \\
\hline \multirow[t]{2}{*}{ Livestock } & .08 & .11 & .19 \\
\hline & 42 & 58 & \\
\hline \multirow[t]{2}{*}{ Industrial } & .00 & 2.16 & 2.16 \\
\hline & 0 & 100 & \\
\hline \multirow[t]{2}{*}{ TOTALS } & 0.27 & 14.54 & 14.81 \\
\hline & $2 \%$ & $98 \%$ & \\
\hline
\end{tabular}

Middle ChattahoocheeWalter F. George Reservoir

03130003

Population: 95,496

Land Area: 1,427.1 square miles

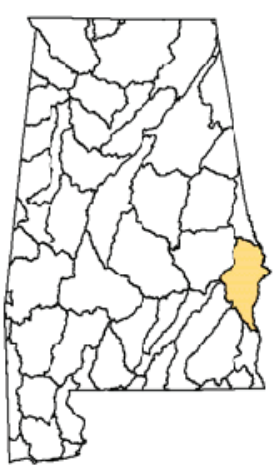

Withdrawals by public supplier, in million gallons per day (Mgal/d)

\begin{tabular}{llll}
\hline Public Supplier & GW & SW & Totals \\
\hline
\end{tabular}

$\begin{array}{llll}\text { Baker Hill Water Authority } & 0.22 & 0.00 & 0.22\end{array}$

$\begin{array}{llll}\text { Cowikee Water Authority } & .10 & .00 & .10\end{array}$

$\begin{array}{llll}\text { Eufaula Water Works and Sewer Board } & 2.06 & .00 & 2.06\end{array}$

$\begin{array}{llll}\text { Ft. Mitchell Water System, Inc. } & .54 & .00 & .54\end{array}$

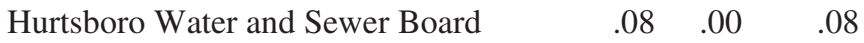

$\begin{array}{llll}\text { Phenix City Utilities } & .00 & 7.04 & 7.04\end{array}$

\begin{tabular}{llll} 
Russell County Water Authority & .44 & .00 & .44 \\
\hline
\end{tabular}

Withdrawals by Standard Industrial Classification, in Mgal/d

\begin{tabular}{lrrr}
\hline Standard Industrial Classification & GW & SW & Totals \\
\hline 20 Food and Kindred Products & 1.18 & 0.00 & 1.18 \\
24 Lumber and Wood & 0.92 & 27.60 & 28.52 \\
$\quad \begin{array}{l}\text { Products, Except Furniture } \\
\text { 32 Stone, Clay, Glass, and }\end{array}$ & .00 & .00 & 0.00 \\
$\quad$ Concrete Products & & & \\
\hline
\end{tabular}

Withdrawals, in Mgal/d and percent (\%)

\begin{tabular}{lrrr}
\hline Category & GW & SW & Totals \\
\hline Public Supply & 3.45 & 7.04 & 10.49 \\
& $33 \%$ & $67 \%$ & \\
Irrigation & 1.03 & 8.08 & 9.11 \\
& 11 & 89 & \\
Livestock & 0.14 & 0.21 & 0.35 \\
& 41 & 59 & \\
Industrial & 2.10 & 27.60 & 29.70 \\
& 7 & 93 & \\
\cline { 2 - 4 } TOTALS & 6.72 & 42.93 & 49.65 \\
& $14 \%$ & $86 \%$ & \\
\hline
\end{tabular}




\section{Lower Chattahoochee}

\section{4}

Population: 37,036

Land Area: 583.8 square miles

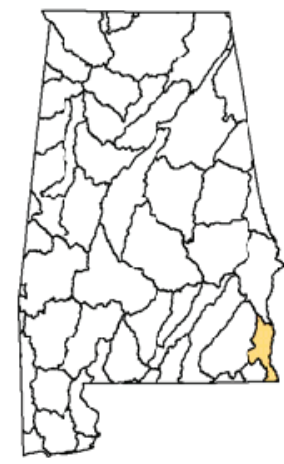

Withdrawals by public supplier, in million gallons per day (Mgal/d)

\begin{tabular}{lrrr}
\hline Public Supplier & GW & SW & Totals \\
\hline Abbeville Waterworks and Sewer Board & 0.61 & 0.00 & 0.61 \\
Ashford Water Works & .14 & .00 & .14 \\
Columbia Water Works \& Sewer Board & .07 & .00 & .07 \\
Cowarts & .24 & .00 & .24 \\
Dothan Water System & 5.94 & .00 & 5.94 \\
Gordon Water Works & .05 & .00 & .05 \\
Headland Water Works Board & .21 & .00 & .21 \\
Henry County Water Authority & .67 & .00 & .67 \\
Kinsey & .16 & .00 & .16 \\
Newville & .13 & .00 & .13 \\
Webb Water System & .17 & .00 & .17 \\
\hline
\end{tabular}

Withdrawals by Standard Industrial Classification, in Mgal/d

\begin{tabular}{lrrr}
\hline Standard Industrial Classification & GW & SW & Totals \\
\hline 20 Food and Kindred Products & 0.25 & 0.00 & 0.25 \\
49 Electric, Gas, and Sanitary Services & .17 & 105.36 & 105.53 \\
\hline
\end{tabular}

Withdrawals, in Mgal/d and percent (\%)

\begin{tabular}{lrrr}
\hline Category & GW & SW & Totals \\
\hline Public Supply & 8.39 & 0.00 & 8.39 \\
& $100 \%$ & $0 \%$ & \\
Irrigation & 3.40 & 1.87 & 5.27 \\
Livestock & 65 & 35 & \\
& 0.12 & .17 & 0.29 \\
Industrial & 41 & 59 & \\
& .24 & .00 & .24 \\
Thermoelectric & 100 & 0 & \\
& .17 & 105.36 & 105.53 \\
TOTALS & 0 & 100 & \\
\cline { 2 - 3 } & 12.32 & 107.40 & 119.72 \\
\hline
\end{tabular}

\section{Chipola}

\section{2}

Population: 24,348

Land Area: 259.1 square miles

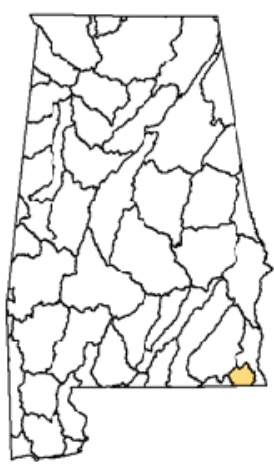

Withdrawals by public supplier, in million gallons per day (Mgal/d)

\begin{tabular}{lrrr}
\hline Public Supplier & GW & SW & Totals \\
\hline Ashford Water Works & 0.19 & 0.00 & 0.19 \\
Cottonwood & .22 & .00 & .22 \\
Cowarts & .08 & .00 & .08 \\
Dothan Water System & .70 & .00 & .70 \\
Houston County Water Authority & .25 & .00 & .25 \\
Taylor (Town of) & .20 & .00 & .20 \\
\hline
\end{tabular}

Withdrawals by Standard Industrial Classification, in Mgal/d

Standard Industrial Classification

None

GW SW Totals

Withdrawals, in Mgal/d and percent (\%)

\begin{tabular}{lrrr}
\hline Category & GW & SW & Totals \\
\hline Public Supply & 1.64 & 0.00 & 1.64 \\
& $100 \%$ & $0 \%$ & \\
Irrigation & 2.76 & .99 & 3.75 \\
& 74 & 26 & \\
Livestock & 0.06 & .09 & 0.15 \\
& 41 & 59 & \\
\cline { 2 - 4 } \cline { 3 - 4 } TOTALS & 4.46 & 1.08 & 5.54 \\
& $81 \%$ & $19 \%$ & \\
& & &
\end{tabular}




\section{Yellow}

\section{3}

Population: 19,015

Land Area: 513.7 square miles

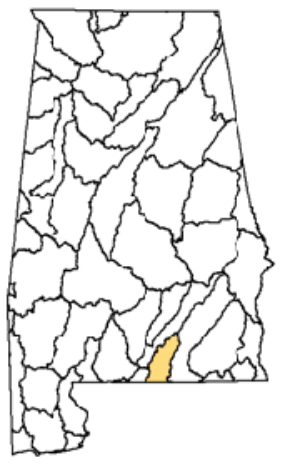

Withdrawals by public supplier, in million gallons per day (Mgal/d)

Public Supplier

Andalusia Water Works Board GW SW Totals

Covington County Water Department

$\begin{array}{lll}0.14 & 0.00 \quad 0.14\end{array}$

Lockhart

$.16 \quad .00$

.16

Opp Utilities Board

$.69 \quad .00 \quad .69$

Withdrawals by Standard Industrial Classification, in Mgal/d

\begin{tabular}{lrrr}
\hline Standard Industrial Classification & GW & SW & Totals \\
\hline 22 Textile Mill Products & 0.43 & 0.00 & 0.43 \\
49 Electric, Gas, and Sanitary & .00 & .00 & .00 \\
$\quad$ Services & & & \\
\hline
\end{tabular}

Withdrawals, in Mgal/d and percent (\%)

\begin{tabular}{lrrr}
\hline Category & GW & SW & Totals \\
\hline Public Supply & 1.06 & 0.00 & 1.06 \\
Irrigation & $100 \%$ & $0 \%$ & \\
& 0.99 & .26 & 1.25 \\
Livestock & 79 & 21 & \\
& .14 & .19 & 0.33 \\
Industrial & 42 & 58 & \\
& .43 & .00 & .43 \\
TOTALS & 100 & 0 & \\
\cline { 2 - 3 } & 2.62 & 0.45 & 3.07 \\
\hline
\end{tabular}

\section{Blackwater}

03140104

Population: 584

Land Area: 145.4 square miles

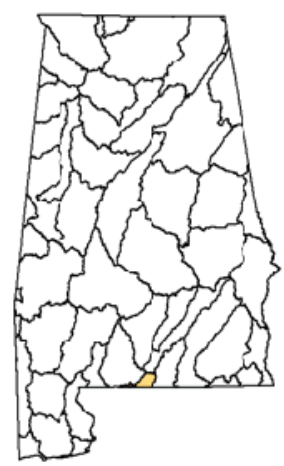

Withdrawals by public supplier, in million gallons per day (Mgal/d)

\begin{tabular}{lccc}
\hline Public Supplier & GW & SW & Totals \\
\hline Covington County Water Department & 0.06 & 0.00 & 0.06 \\
\hline
\end{tabular}

Withdrawals by Standard Industrial Classification, in Mgal/d Standard Industrial Classification $\quad$ GW $\quad$ SW Totals

None

Withdrawals, in $\mathrm{Mgal} / \mathrm{d}$ and percent (\%)

\begin{tabular}{|c|c|c|c|}
\hline Category & GW & SW & Totals \\
\hline \multirow[t]{2}{*}{ Public Supply } & 0.06 & 0.00 & 0.06 \\
\hline & $100 \%$ & $0 \%$ & \\
\hline \multirow[t]{2}{*}{ Irrigation } & .18 & .09 & .27 \\
\hline & 67 & 33 & \\
\hline \multirow[t]{2}{*}{ Livestock } & .02 & .03 & .05 \\
\hline & 40 & 60 & \\
\hline \multirow[t]{2}{*}{ TOTALS } & 0.26 & 0.12 & 0.38 \\
\hline & $68 \%$ & $32 \%$ & \\
\hline
\end{tabular}




\section{Perdido}

\section{6}

Population: 34,750

Land Area: 680.0 square miles

\section{Public Supplier}

Atmore Utility Board

Loxley

North Baldwin Utilities

Robertsdale

Summerdale Water Department

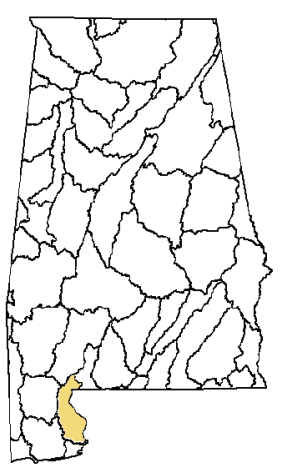

Withdrawals by Standard Industrial Classification, in Mgal/d

Standard Industrial Classification GW SW Totals

None

Withdrawals, in Mgal/d and percent (\%)

\begin{tabular}{lrrr}
\hline Category & GW & SW & Totals \\
\hline Public Supply & 4.06 & 0.00 & 4.06 \\
& $100 \%$ & $0 \%$ & \\
Irrigation & 11.90 & 2.33 & 14.23 \\
& 84 & 16 & \\
Livestock & 0.07 & .08 & 0.15 \\
& 45 & 55 & \\
\cline { 2 - 4 } TOTALS & 16.03 & 2.41 & 18.44 \\
& $87 \%$ & $13 \%$ & \\
\hline
\end{tabular}

\section{Perdido Bay}

03140107

Population: 25,801

Land Area: 162.3 square miles

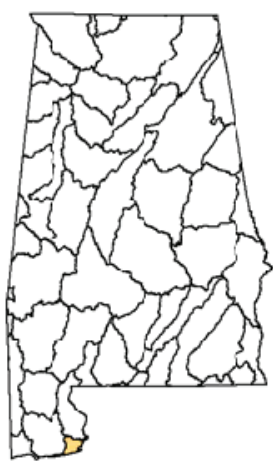

Withdrawals by public supplier, in million gallons per day (Mgal/d)

\begin{tabular}{lrrr}
\hline Public Supplier & GW & SW & Totals \\
\hline Elberta & 0.08 & 0.00 & 0.08 \\
Foley Utilities Board & 1.29 & .00 & 1.29 \\
Gulf Shores Utilities & 1.00 & .00 & 1.00 \\
Orange Beach Water, Sewer \& & 2.64 & .00 & 2.64 \\
$\quad$ Fire Protection & & & \\
Perdido Bay Water, Sewer \& & .47 & .00 & .47 \\
$\quad$ Fire Protection District & & & \\
\hline
\end{tabular}

Withdrawals by Standard Industrial Classification, in Mgal/d Standard Industrial Classification $\quad$ GW $\quad$ SW Totals

None

Withdrawals, in Mgal/d and percent $(\%)$

\begin{tabular}{lrrr}
\hline Category & GW & SW & Totals \\
\hline Public Supply & 5.49 & 0.00 & 5.49 \\
& $100 \%$ & $0 \%$ & \\
Irrigation & 3.10 & .59 & 3.69 \\
& 84 & 16 & \\
Livestock & 0.02 & .02 & 0.04 \\
& 46 & 54 & \\
\cline { 2 - 4 } \cline { 3 - 4 } TOTALS & 8.61 & 0.61 & 9.22 \\
& $93 \%$ & $7 \%$ & \\
\hline
\end{tabular}




\section{Upper Choctawhatchee}

03140201

Population: 146,125

Land Area: 1,543.0 square miles

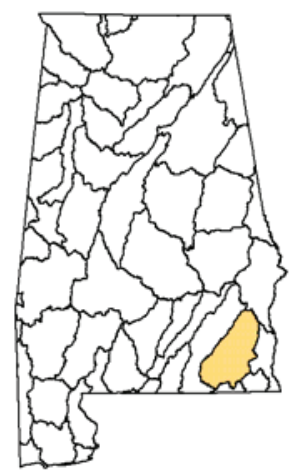

Withdrawals by public supplier, in million gallons per day (Mgal/d)

\begin{tabular}{|c|c|c|c|c|c|c|c|}
\hline Public Supplier & GW & SW & Totals & Public Supplier-Continued & GW & SW & Totals \\
\hline Abbeville Waterworks and Sewer Board & 0.04 & 0.00 & 0.04 & Midland City & .31 & .00 & .31 \\
\hline Ariton Water Department & .08 & .00 & .08 & New Brockton Water \& Sewer Board & .46 & .00 & .46 \\
\hline Baker Hill Water Authority & .43 & .00 & .43 & Newton Water and Sewer Board & .18 & .00 & .18 \\
\hline Bellwood Water \& F.P.A. & .02 & .00 & .02 & North Geneva County Water Authority & .02 & .00 & .02 \\
\hline Clayton Water Works and Sewer Board & .08 & .00 & .08 & Ozark Utilities Board & 2.35 & .00 & 2.35 \\
\hline Clio & .49 & .00 & .49 & Pinckard & .10 & .00 & .10 \\
\hline Coffee Springs (Town of) & .03 & .00 & .03 & Slocomb Water Works & .04 & .00 & .04 \\
\hline Dale County Water Authority & .45 & .00 & .45 & Taylor (Town of) & .27 & .00 & .27 \\
\hline Daleville & .86 & .00 & .86 & U.S. Army Fort Rucker & 3.39 & .00 & 3.39 \\
\hline Dothan Water System & 8.21 & .00 & 8.21 & & & & \\
\hline Enterprise Water Works Board & 4.58 & .00 & 4.58 & & & & \\
\hline Geneva Water Works & .18 & .00 & .18 & & & & \\
\hline Hartford & .10 & .00 & .10 & & & & \\
\hline Headland Water Works Board & .23 & .00 & .23 & & & & \\
\hline Level Plains (Town of) & .27 & .00 & .27 & & & & \\
\hline Louisville Water Works & .14 & .00 & .14 & & & & \\
\hline Malvern & .12 & .00 & .12 & & & & \\
\hline
\end{tabular}

Withdrawals by Standard Industrial Classification, in Mgal/d

Withdrawals, in Mgal/d and percent (\%)

\begin{tabular}{|c|c|c|c|c|c|c|c|}
\hline Standard Industrial Classification & GW & SW & Totals & Category & GW & SW & Totals \\
\hline \multirow[t]{10}{*}{20 Food and Kindred Products } & 0.22 & 0.00 & 0.22 & Public Supply & 23.42 & 0.00 & 23.42 \\
\hline & & & & & $100 \%$ & $0 \%$ & \\
\hline & & & & Irrigation & 3.08 & 5.47 & 8.55 \\
\hline & & & & & 36 & 64 & \\
\hline & & & & Livestock & 0.51 & .70 & 1.21 \\
\hline & & & & & 42 & 58 & \\
\hline & & & & Industrial & .22 & .00 & 0.22 \\
\hline & & & & & 100 & 0 & \\
\hline & & & & TOTALS & 27.23 & 6.17 & 33.40 \\
\hline & & & & & $82 \%$ & $18 \%$ & \\
\hline
\end{tabular}




\section{Pea}

03140202

Population: 50,881

Land Area: 1,444.6 square miles

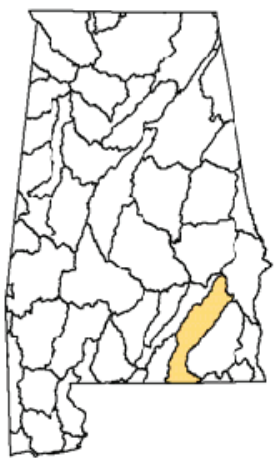

Withdrawals by public supplier, in million gallons per day (Mgal/d)

\begin{tabular}{lrrr}
\hline Public Supplier & GW & SW & Totals \\
\hline Ariton Water Department & 0.02 & 0.00 & 0.02 \\
Brundidge & .42 & .00 & .42 \\
Clayton Water Works and Sewer Board & .29 & .00 & .29 \\
Coffee County Water Authority & .17 & .00 & .17 \\
Elba Water and Electric Board & .61 & .00 & .61 \\
Eufaula Water Works and Sewer Board & .27 & .00 & .27 \\
Florala Water Works \& Sewer Board & .39 & .00 & .39 \\
Geneva Water Works & .33 & .00 & .33 \\
Jack Water System, Inc. & .08 & .00 & .08 \\
Kinston & .02 & .00 & .02 \\
New Brockton Water \& Sewer Board & .14 & .00 & .14 \\
New Hope Water System, Inc. & .07 & .00 & .07 \\
Opp Utilities Board & .52 & .00 & .52 \\
Pike County Water Authority & .64 & .00 & .64 \\
Samson & .28 & .00 & .28 \\
Troy Utility Department & 1.98 & .00 & 1.98 \\
West Barbour County Water Authority & .07 & .00 & .07 \\
\hline
\end{tabular}

Withdrawals by Standard Industrial Classification, in Mgal/d

\begin{tabular}{lrrr}
\hline Standard Industrial Classification & GW & SW & Totals \\
\hline 20 Food and Kindred Products & 0.86 & 0.00 & 0.86 \\
\hline
\end{tabular}

Withdrawals, in Mgal/d and percent (\%)

\begin{tabular}{lrrr}
\hline Category & GW & SW & Totals \\
\hline Public Supply & 6.30 & 0.00 & 6.30 \\
& $100 \%$ & $0 \%$ & \\
Irrigation & 2.01 & 4.04 & 6.05 \\
& 33 & 67 & \\
Livestock & 0.55 & .74 & 1.29 \\
& 42 & 58 & \\
Industrial & .86 & .00 & 0.86 \\
& 100 & 0 & \\
TOTALS & 9.72 & 4.78 & 14.50 \\
& $67 \%$ & $33 \%$ & \\
\hline
\end{tabular}

\section{Lower Choctawhatchee}

03140203

Population: 6,195

Land Area: 134.3 square miles

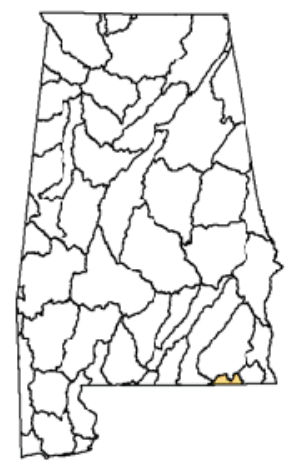

Withdrawals by public supplier, in million gallons per day (Mgal/d)

\begin{tabular}{lrrr}
\hline Public Supplier & GW & SW & Totals \\
\hline Black Water Works & 0.02 & 0.00 & 0.02 \\
Geneva Water Works & .02 & .00 & .02 \\
Hartford & .28 & .00 & .28 \\
Slocomb Water Works & .20 & .00 & .20 \\
\hline
\end{tabular}

Withdrawals by Standard Industrial Classification, in Mgal/d

Standard Industrial Classification $\quad$ GW $\quad$ SW $\quad$ Totals

None

Withdrawals, in Mgal/d and percent (\%)

\begin{tabular}{lrrr}
\hline Category & GW & SW & Totals \\
\hline Public Supply & 0.52 & 0.00 & 0.52 \\
& $100 \%$ & $0 \%$ & \\
Irrigation & .41 & .50 & .91 \\
& 45 & 55 & \\
Livestock & .08 & .11 & .19 \\
& 44 & 56 & \\
\cline { 2 - 4 } TOTALS & 1.01 & 0.61 & 1.62 \\
& $62 \%$ & $38 \%$ & \\
\hline
\end{tabular}




\section{Upper Conecuh}

\section{1}

Population: 27,731
Land Area: 836.1 square miles

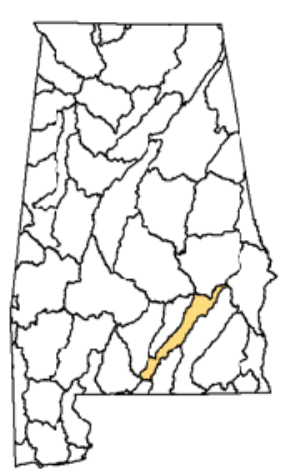

Withdrawals by public supplier, in million gallons per day (Mgal/d)

\begin{tabular}{lrrr}
\hline Public Supplier & GW & SW & Totals \\
\hline Andalusia Water Works Board & 2.28 & 0.00 & 2.28 \\
Brantley & 0.22 & .00 & 0.22 \\
Covington County Water Department & .32 & .00 & .32 \\
Dozier Water Works & .04 & .00 & .04 \\
Glenwood & .01 & .00 & .01 \\
Goshen & .05 & .00 & .05 \\
Pike County Water Authority & .52 & .00 & .52 \\
River Falls & .10 & .00 & .10 \\
South Bullock County Water Authority & .46 & .00 & .46 \\
South Crenshaw County Water Authority & .67 & .00 & .67 \\
Troy Utility Department & 1.08 & .00 & 1.08 \\
Union Springs Utilities Board & 1.06 & .00 & 1.06 \\
\hline
\end{tabular}

Withdrawals by Standard Industrial Classification, in Mgal/d

\begin{tabular}{lrrr}
\hline Standard Industrial Classification & GW & SW & Totals \\
\hline 49 Electric, Gas, and Sanitary Services & 0.00 & 4.30 & 4.30 \\
\hline
\end{tabular}

Withdrawals, in Mgal/d and percent (\%)

\begin{tabular}{lrrr}
\hline Category & GW & SW & Totals \\
\hline Public Supply & 6.80 & 0.00 & 6.80 \\
Irrigation & $100 \%$ & $0 \%$ & \\
& 0.98 & .91 & 1.89 \\
Livestock & 52 & 48 & \\
Thermoelectric & .24 & .34 & 0.58 \\
& 41 & 59 & \\
TOTALS & .00 & 4.30 & 4.30 \\
\cline { 2 - 3 } & 0 & 100 & \\
\cline { 2 - 4 } & 8.02 & 5.55 & 13.57 \\
\hline
\end{tabular}

\section{Patsaliga}

03140302

Population: 13,291

Land Area: 599.6 square miles

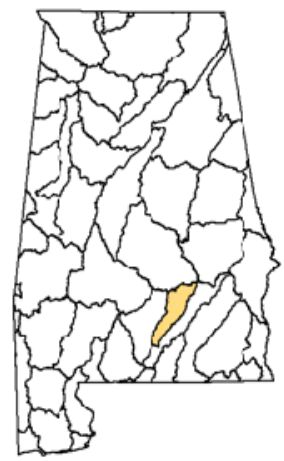

Withdrawals by public supplier, in million gallons per day (Mgal/d)

\begin{tabular}{lrrr}
\hline Public Supplier & GW & SW & Totals \\
\hline Covington County Water Department & 0.10 & 0.00 & 0.10 \\
Luverne Water Works and Sewer Board & .42 & .00 & .42 \\
Pine Level Water Authority & .22 & .00 & .22 \\
Quint-Mar Water Authority & .59 & .00 & .59 \\
Ramer Water Co., Inc. & .14 & .00 & .14 \\
Red Level & .06 & .00 & .06 \\
Rutledge & .06 & .00 & .06 \\
\hline
\end{tabular}

Withdrawals by Standard Industrial Classification, in Mgal/d \begin{tabular}{llll}
\hline Standard Industrial Classification & GW & SW & Totals
\end{tabular} None

Withdrawals, in $\mathrm{Mgal} / \mathrm{d}$ and percent (\%)

\begin{tabular}{lrrr}
\hline Category & GW & SW & Totals \\
\hline Public Supply & 1.60 & 0.00 & 1.60 \\
Irrigation & $100 \%$ & $0 \%$ & \\
& 0.21 & .43 & 0.64 \\
Livestock & 33 & 67 & \\
& .21 & .30 & .51 \\
TOTALS & 41 & 59 & \\
\cline { 2 - 3 } & 2.02 & 0.73 & 2.75 \\
\hline
\end{tabular}




\section{Sepulga}

\section{3}

Population: 23,353

Land Area: 1,048.4 square miles

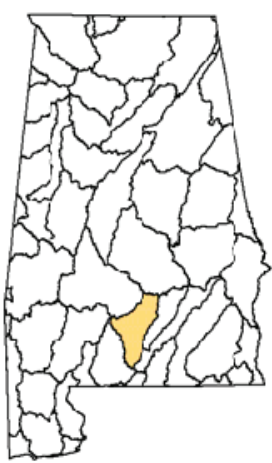

Withdrawals by public supplier, in million gallons per day (Mgal/d)

\begin{tabular}{lrrr}
\hline Public Supplier & GW & SW & Totals \\
\hline Butler County Water Authority & 1.16 & 0.00 & 1.16 \\
Fort Deposit (The Water Works and & 0.19 & .00 & 0.19 \\
$\quad \quad$ Sewer Board of the Town of) & & & \\
Georgiana Water Works and & .31 & .00 & .31 \\
$\quad$ Sewer Board & & & \\
$\quad$ Greenville Water Works and & 1.21 & .00 & 1.21 \\
$\quad$ Sewer Board & & & \\
$\begin{array}{l}\text { McKenzie - Town Hall (Town of) } \\
\text { Owassa/Brownville Water and F.P.A. Inc. }\end{array}$ & .13 & .00 & .13 \\
\end{tabular}

Withdrawals by Standard Industrial Classification, in Mgal/d

\begin{tabular}{lrrr}
\hline Standard Industrial Classification & GW & SW & Totals \\
\hline $\begin{array}{l}\text { 24 Lumber and Wood } \\
\text { Products, Except Furniture }\end{array}$ & 0.31 & 0.00 & 0.31 \\
\hline
\end{tabular}

Withdrawals, in Mgal/d and percent (\%)

\begin{tabular}{lrrr}
\hline Category & GW & SW & Totals \\
\hline Public Supply & 3.21 & 0.00 & 3.21 \\
Irrigation & $100 \%$ & $0 \%$ & \\
& 0.20 & .56 & 0.76 \\
Livestock & 26 & 74 & \\
Industrial & .17 & .25 & .42 \\
& 41 & 59 & \\
TOTALS & .31 & .00 & .31 \\
\cline { 2 - 3 } & 100 & 0 & \\
\cline { 2 - 4 } & 3.89 & 0.81 & 4.70 \\
\hline
\end{tabular}

\section{Lower Conecuh}

03140304

Population: 26,655

Land Area: 998.9 square miles

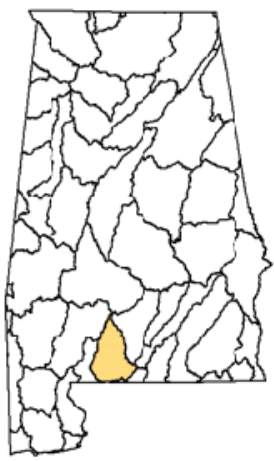

Withdrawals by public supplier, in million gallons per day (Mgal/d)

\begin{tabular}{lrrr}
\hline Public Supplier & GW & SW & Totals \\
\hline Brewton Water Works Board & 1.48 & 0.00 & 1.48 \\
East Brewton Water and Sewer Board & 0.30 & .00 & 0.30 \\
Evergreen (City of) & 1.18 & .00 & 1.18 \\
Fairview Water System & .06 & .00 & .06 \\
Hamden Ridge P/A, Inc. & .11 & .00 & .11 \\
McCall Water System & .50 & .00 & .50 \\
Pollard & .02 & .00 & .02 \\
Ridge Road Water Authority & .12 & .00 & .12 \\
Riverview Water System & .05 & .00 & .05 \\
\hline
\end{tabular}

Withdrawals by Standard Industrial Classification, in Mgal/d

\begin{tabular}{lrrr}
\hline Standard Industrial Classification & GW & SW & Totals \\
\hline 24 Lumber and Wood & 1.17 & 0.00 & 1.17 \\
$\quad$ Products, Except Furniture & & & \\
26 Paper and Allied Products & 0.27 & 32.07 & 32.34 \\
28 Chemicals and Allied Products & .19 & .00 & 0.19 \\
\hline
\end{tabular}

Withdrawals, in Mgal/d and percent (\%)

\begin{tabular}{|c|c|c|c|}
\hline Category & GW & SW & Totals \\
\hline \multirow[t]{2}{*}{ Public Supply } & 3.81 & 0.00 & 3.81 \\
\hline & $100 \%$ & $0 \%$ & \\
\hline \multirow[t]{2}{*}{ Irrigation } & 0.31 & .50 & 0.81 \\
\hline & 38 & 62 & \\
\hline \multirow[t]{2}{*}{ Livestock } & .07 & .11 & .18 \\
\hline & 40 & 60 & \\
\hline \multirow[t]{2}{*}{ Industrial } & 1.62 & 32.07 & 33.69 \\
\hline & 5 & 95 & \\
\hline \multirow[t]{2}{*}{ TOTALS } & 5.81 & 32.68 & 38.49 \\
\hline & $15 \%$ & $85 \%$ & \\
\hline
\end{tabular}




\section{Escambia}

03140305

Population: 16,443

Land Area: 362.0 square miles

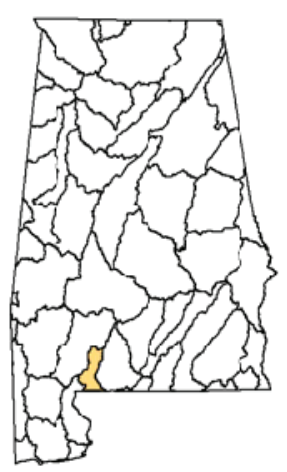

Withdrawals by public supplier, in million gallons per day (Mgal/d)

Public Supplier

Atmore Utility Board GW SW Totals

Canoe Water and Fire Protection

$\begin{array}{lll}1.07 & 0.00 \quad 1.07\end{array}$

Authority

Excel

$0.08 \quad .00 \quad 0.08$

Flomaton

$.30 \quad .00 \quad .30$

Freemanville Water System, Inc.

McCall Water System

$.22 \quad .00$

.22

Repton

$.43 \quad .00$

.43

$.11 \quad .00$

.11

$.04 \quad .00 \quad .04$

Withdrawals by Standard Industrial Classification, in Mgal/d

\begin{tabular}{lrrr}
\hline Standard Industrial Classification & GW & SW & Totals \\
\hline $\begin{array}{l}29 \\
\text { Petroleum Refining and } \\
\text { Related Industries }\end{array}$ & 0.09 & 0.00 & 0.09 \\
\hline
\end{tabular}

Withdrawals, in Mgal/d and percent (\%)

\begin{tabular}{lrrr}
\hline Category & GW & SW & Totals \\
\hline Public Supply & 2.24 & 0.00 & 2.24 \\
Irrigation & $100 \%$ & $0 \%$ & \\
& 0.16 & .21 & 0.37 \\
Livestock & 43 & 57 & \\
& .02 & .04 & .06 \\
Industrial & 40 & 60 & \\
& .09 & .00 & .09 \\
TOTALS & 100 & 0 & \\
\cline { 2 - 3 } & 2.51 & 0.25 & 2.76 \\
\hline
\end{tabular}

\section{Upper Coosa}

\section{5}

Population: 41,579

Land Area: 850.0 square miles

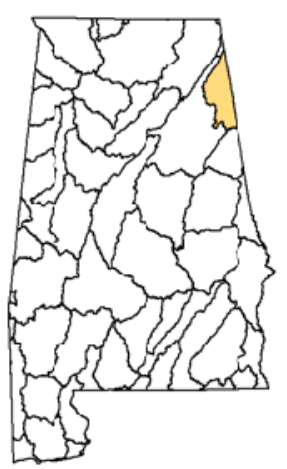

Withdrawals by public supplier, in million gallons per day (Mgal/d)

\begin{tabular}{lrrr}
\hline Public Supplier & GW & SW & Totals \\
\hline Centre Water Works \& Sewer Board & 0.00 & 1.19 & 1.19 \\
Cherokee County Water Authority & .97 & 0.00 & 0.97 \\
Northeast Alabama Water, Sewer \& F.P.A. & 1.06 & .00 & 1.06 \\
Piedmont Water Works and Sewer Board & .00 & .93 & .93 \\
\hline
\end{tabular}

Withdrawals by Standard Industrial Classification, in Mgal/d Standard Industrial Classification $\quad$ GW $\quad$ SW Totals

None

Withdrawals, in $\mathrm{Mgal} / \mathrm{d}$ and percent (\%)

\begin{tabular}{|c|c|c|c|}
\hline Category & GW & SW & Totals \\
\hline \multirow[t]{2}{*}{ Public Supply } & 2.02 & 2.12 & 4.14 \\
\hline & $49 \%$ & $51 \%$ & \\
\hline \multirow[t]{2}{*}{ Irrigation } & 0.15 & 3.10 & 3.25 \\
\hline & 5 & 95 & \\
\hline \multirow[t]{2}{*}{ Livestock } & .32 & 0.40 & 0.72 \\
\hline & 44 & 56 & \\
\hline \multirow[t]{2}{*}{ TOTALS } & 2.49 & 5.62 & 8.11 \\
\hline & $31 \%$ & $69 \%$ & \\
\hline
\end{tabular}




\section{Middle Coosa}

03150106

Population: 335,013

Land Area: 2,583.3 square miles

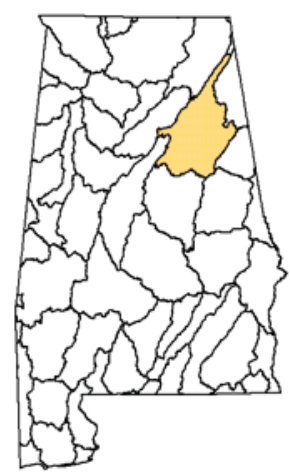

Withdrawals by public supplier, in million gallons per day (Mgal/d)

\begin{tabular}{|c|c|c|c|c|c|c|c|}
\hline Public Supplier & GW & SW & Totals & Public Supplier-Continued & GW & SW & Totals \\
\hline Anniston Water Works and Sewer Board & 11.91 & 0.08 & 11.99 & Odenville Utilities Board & 1.85 & .00 & 1.85 \\
\hline Ashville Water and Sewer & 0.00 & .00 & 0.00 & Oxford Water Works and Sewer Board & 4.04 & .00 & 4.04 \\
\hline Attalla Water Works Board & 1.16 & .00 & 1.16 & Pell City & 2.30 & .00 & 2.30 \\
\hline Calhoun County Water Authority & 3.08 & .00 & 3.08 & Ragland Water Works Board & .50 & .00 & .50 \\
\hline Childersburg Water, Sewer \& Gas Board & .25 & .00 & .25 & Southside Water Works \& Sewer Board & .78 & .00 & .78 \\
\hline Fort Payne Water Works Board & .00 & 8.10 & 8.10 & Springville & .45 & .00 & .45 \\
\hline Gadsden Water Works \& Sewer Board & .00 & 14.86 & 14.86 & Talladega County Water Dept. & .00 & .81 & .81 \\
\hline Glencoe Water and Sewer Works & .72 & .00 & .72 & Talladega Water Works \& Sewer Board & 2.80 & 1.62 & 4.42 \\
\hline Hokes Bluff Water Board & .88 & .00 & .88 & Talladega/Shelby Water Treatment Plant & .00 & 6.44 & 6.44 \\
\hline Jacksonville Water Works \& & .00 & 1.34 & 1.34 & Vincent Water Board & .24 & .00 & .24 \\
\hline Sewer Board & & & & Water Works, Inc. & .03 & .00 & .03 \\
\hline Lincoln & 1.26 & .00 & 1.26 & Wattsville Water Authority & .58 & .00 & .58 \\
\hline Munford Water Authority, Inc. & .18 & .00 & .18 & Weaver & .72 & .00 & .72 \\
\hline New London Water Authority & .52 & .00 & .52 & West Etowah County Water \& Fire & .31 & .00 & .31 \\
\hline Northeast Alabama Water, Sewer \& F.P.A. & .65 & .00 & .65 & Protection Authority & & & \\
\hline
\end{tabular}

Withdrawals by Standard Industrial Classification, in Mgal/d

\begin{tabular}{|c|c|c|c|c|c|c|c|}
\hline Standard Industrial Classification & GW & SW & Totals & Category & GW & SW & Totals \\
\hline 20 Food and Kindred Products & 1.08 & 0.00 & 1.08 & \multirow[t]{2}{*}{ Public Supply } & 35.20 & 33.24 & \multirow[t]{2}{*}{68.44} \\
\hline 22 Textile Mill Products & 0.40 & .00 & 0.40 & & $51 \%$ & $49 \%$ & \\
\hline 26 Paper and Allied Products & .53 & 52.47 & 53.00 & \multirow[t]{2}{*}{ Irrigation } & 2.14 & 7.91 & \multirow[t]{2}{*}{10.05} \\
\hline 30 Rubber and Miscellaneous & .00 & 9.87 & 9.87 & & 21 & 79 & \\
\hline Plastics Products & & & & \multirow[t]{2}{*}{ Livestock } & 0.69 & 0.87 & \multirow[t]{2}{*}{1.56} \\
\hline 32 Stone, Clay, Glass, and & .00 & 3.49 & 3.49 & & 44 & 56 & \\
\hline Concrete Products & & & & \multirow[t]{2}{*}{ Industrial } & 2.14 & 65.83 & \multirow[t]{2}{*}{67.97} \\
\hline 33 Primary Metal Industries & .14 & .00 & .14 & & 3 & 97 & \\
\hline $\begin{array}{l}49 \text { Electric, Gas, and Sanitary } \\
\text { Services }\end{array}$ & .00 & 142.68 & 142.68 & \multirow[t]{2}{*}{ Thermoelectric } & .00 & 142.68 & \multirow[t]{2}{*}{142.68} \\
\hline & & & & & 0 & 100 & \\
\hline & & & & \multirow[t]{2}{*}{ TOTALS } & 40.17 & 250.53 & \multirow[t]{2}{*}{290.70} \\
\hline & & & & & $14 \%$ & $86 \%$ & \\
\hline
\end{tabular}




\section{Lower Coosa}

03150107

Population: 123,826

Land Area: 1,961.0 square miles

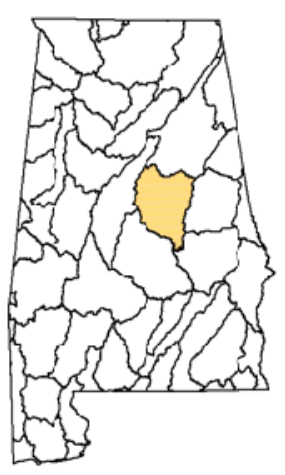

Withdrawals by public supplier, in million gallons per day (Mgal/d)

\begin{tabular}{lrrr}
\hline Public Supplier & GW & SW & Totals \\
\hline Central Talladega County Water District & 0.26 & 0.00 & 0.26 \\
Childersburg Water, Sewer \& Gas Board & .91 & .00 & .91 \\
Clanton Waterworks \& Sewer Board & .00 & 1.79 & 1.79 \\
Columbiana Water Works Board & 1.37 & .00 & 1.37 \\
Five Star Water Supply & .00 & 5.46 & 5.46 \\
Goodwater Water Works and Sewer Board & .00 & .46 & .46 \\
Harpersville Water Board & .23 & .00 & .23 \\
Sycamore Water and Sewer Authority & .13 & .00 & .13 \\
Sylacauga Utilities Board & .28 & 3.25 & 3.53 \\
Thorsby & .71 & .00 & .71 \\
Wilsonville Waterworks - Town & .31 & .00 & .31 \\
$\quad$ of Wilsonville & & & \\
\hline
\end{tabular}

Withdrawals by Standard Industrial Classification, in Mgal/d

\begin{tabular}{lrrr}
\hline Standard Industrial Classification & GW & SW & Totals \\
\hline 22 Textile Mill Products & 0.86 & 0.89 & 1.75 \\
49 Electric, Gas, and Sanitary Services & .00 & 812.32 & 812.32 \\
\hline
\end{tabular}

Withdrawals, in Mgal/d and percent (\%)

\begin{tabular}{lrrr}
\hline Category & GW & SW & Totals \\
\hline Public Supply & 4.21 & 10.96 & 15.17 \\
Irrigation & $28 \%$ & $72 \%$ & \\
& 0.50 & 5.10 & 5.60 \\
Livestock & 9 & 91 & \\
Industrial & .25 & 0.35 & 0.60 \\
& 42 & 58 & \\
Thermoelectric & .86 & .89 & 1.75 \\
& 49 & 51 & \\
TOTALS & .00 & 812.32 & 812.32 \\
& 0 & 100 & \\
\cline { 2 - 4 } & 5.82 & 829.62 & 835.44 \\
\end{tabular}

\section{Upper Tallapoosa}

03150108

Population: 23,143

Land Area: 743.3 square miles

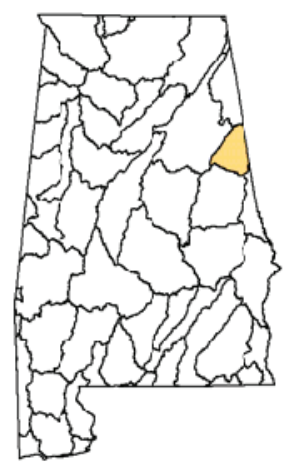

Withdrawals by public supplier, in million gallons per day (Mgal/d)

\begin{tabular}{lrrr}
\hline Public Supplier & GW & SW & Totals \\
\hline Heflin Water Works & 0.00 & 0.51 & 0.51 \\
Wedowee Gas, Water \& Sewer & .00 & .39 & .39 \\
\hline
\end{tabular}

Withdrawals by Standard Industrial Classification, in Mgal/d \begin{tabular}{llll}
\hline Standard Industrial Classification & GW & SW & Totals
\end{tabular}

\begin{tabular}{llll}
\hline 20 Food and Kindred Products & 0.71 & 0.00 & 0.71 \\
\hline
\end{tabular}

Withdrawals, in Mgal/d and percent (\%)

\begin{tabular}{lrrr}
\hline Category & GW & SW & Totals \\
\hline Public Supply & 0.00 & 0.90 & 0.90 \\
& $0 \%$ & $100 \%$ & \\
Irrigation & .37 & .15 & .52 \\
& 71 & 29 & \\
Livestock & .32 & .40 & .72 \\
& 44 & 56 & \\
Industrial & .71 & .00 & .71 \\
& 100 & 0 & \\
TOTALS & 1.40 & 1.45 & 2.85 \\
& $49 \%$ & $51 \%$ & \\
\hline
\end{tabular}




\section{Middle Tallapoosa}

\section{9}

Population: 68,184

Land Area: 1,589.4 square miles

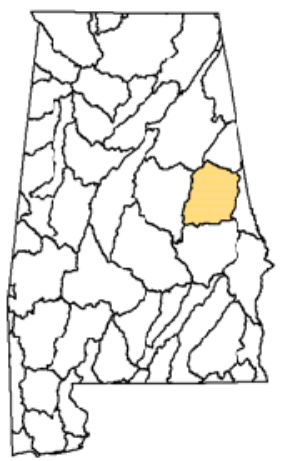

Withdrawals by public supplier, in million gallons per day (Mgal/d)

\begin{tabular}{lrrr}
\hline Public Supplier & GW & SW & Totals \\
\hline Alexander City Water Department & 0.00 & 10.57 & 10.57 \\
Central Elmore Water \& Sewer Authority & .00 & 4.83 & 4.83 \\
Clay County Water Authority & .00 & 1.87 & 1.87 \\
Lafayette & .00 & 0.53 & 0.53 \\
Roanoke Utilities Board & .00 & 1.29 & 1.29 \\
\hline
\end{tabular}

Withdrawals by Standard Industrial Classification, in Mgal/d \begin{tabular}{llll}
\hline Standard Industrial Classification & GW & SW & Totals
\end{tabular} None

Withdrawals, in Mgal/d and percent (\%)

\begin{tabular}{lrrr}
\hline Category & GW & SW & Totals \\
\hline Public Supply & 0.00 & 19.09 & 19.09 \\
Irrigation & $0 \%$ & $100 \%$ & \\
& .12 & 0.52 & 0.64 \\
Livestock & 19 & 81 & \\
& .24 & .32 & .56 \\
TOTALS & 44 & 56 & \\
\cline { 2 - 3 } & 0.36 & 19.93 & 20.29 \\
\hline
\end{tabular}

\section{Lower Tallapoosa}

03150110

Population: 160,180

Land Area: 1,690.3 square miles

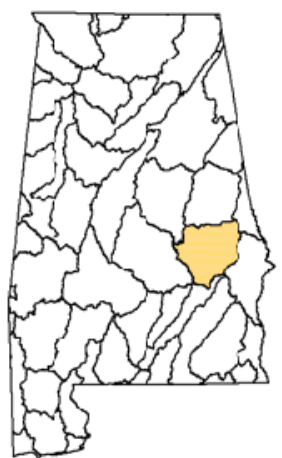

Withdrawals by public supplier, in million gallons per day (Mgal/d)

\begin{tabular}{lrrr}
\hline Public Supplier & GW & SW & Totals \\
\hline Auburn Water Works Board & 0.07 & 5.75 & 5.82 \\
Beauregard Water Authority & .75 & 0.00 & 0.75 \\
East Montgomery Water, Sewer, \& Fire & 1.03 & .00 & 1.03 \\
$\quad$ Protection Authority & & & \\
Loachapoka Water Authority & .65 & .00 & .65 \\
Macon County Water Authority & .52 & .00 & .52 \\
Montgomery Water Works and Sewer Board & .00 & 25.17 & 25.17 \\
Opelika Water Works Board & .00 & 2.61 & 2.61 \\
South Bullock County Water Authority & .03 & .00 & .03 \\
Star Mindingall Water Authority & .20 & .00 & .20 \\
Tallassee & .00 & 1.98 & 1.98 \\
Tuskegee Utilities & .00 & 2.71 & 2.71 \\
Union Springs Utilities Board & .50 & .00 & .50 \\
\hline
\end{tabular}

Withdrawals by Standard Industrial Classification, in Mgal/d

\begin{tabular}{llll}
\hline Standard Industrial Classification & GW & SW & Totals
\end{tabular}

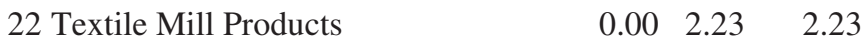

\begin{tabular}{llll}
79 & Amusement and Recreation Services $\quad .05$ & 0.00 & 0.05 \\
\hline
\end{tabular}

Withdrawals, in Mgal/d and percent (\%)

\begin{tabular}{lrrr}
\hline Category & GW & SW & Totals \\
\hline Public Supply & 3.74 & 38.22 & 41.96 \\
& $9 \%$ & $91 \%$ & \\
Irrigation & 3.85 & 4.22 & 8.07 \\
& 48 & 52 & \\
Livestock & 0.19 & 0.28 & 0.47 \\
& 41 & 59 & \\
Industrial & .05 & 2.23 & 2.28 \\
& 2 & 98 & \\
TOTALS & 7.83 & 44.95 & 52.78 \\
& $15 \%$ & $85 \%$ & \\
\hline
\end{tabular}




\section{Upper Alabama}

\section{1}

Population: 322,442

Land Area: 2,387.0 square miles

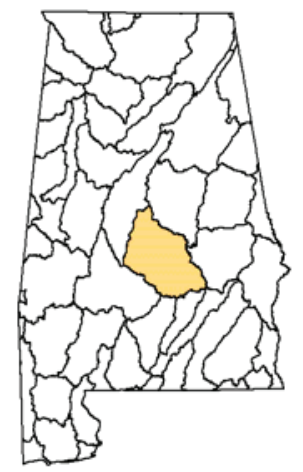

Withdrawals by public supplier, in million gallons per day (Mgal/d)

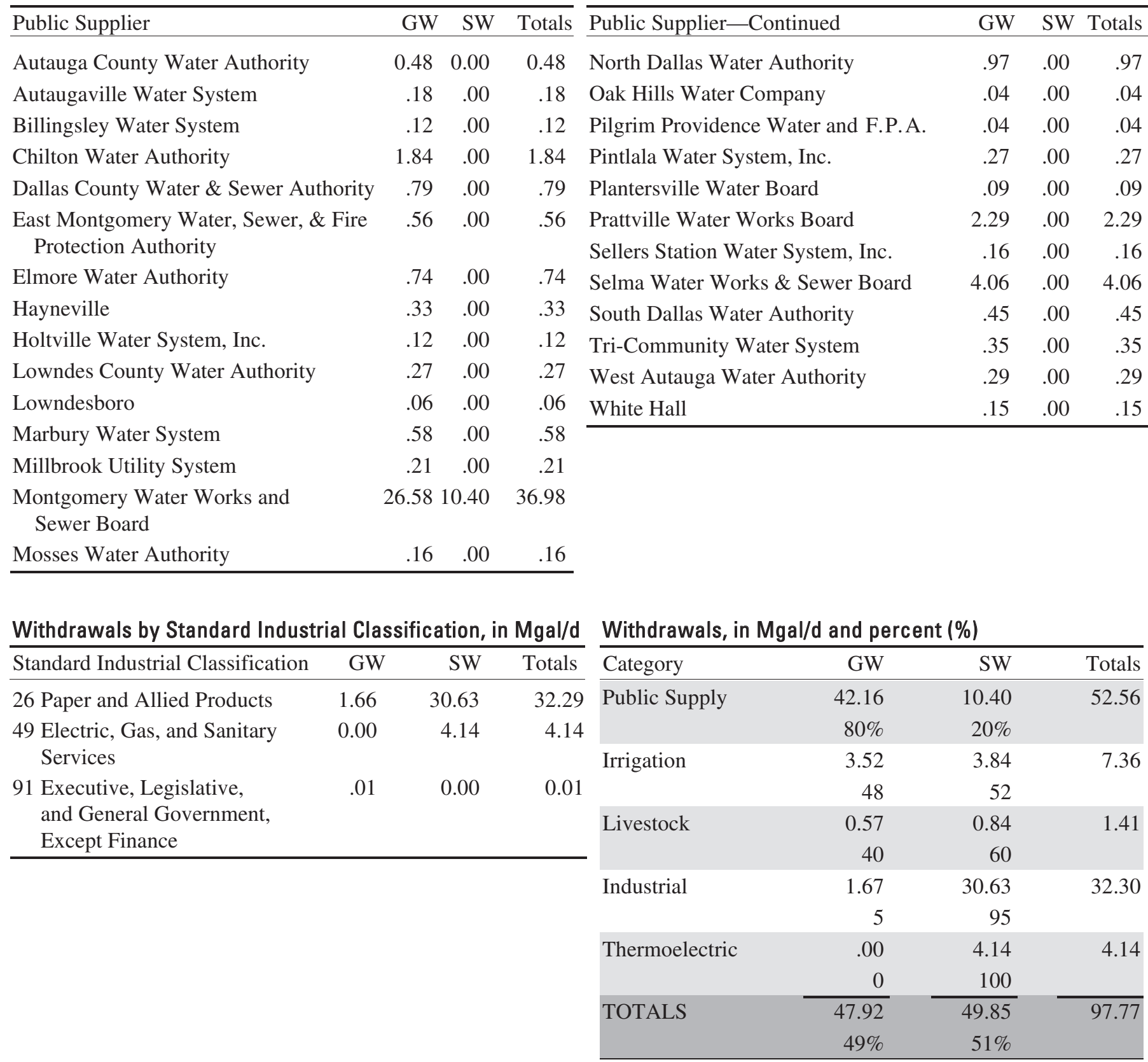




\section{Cahaba}

03150202

Population: 376,792

Land Area: 1,822.7 square miles

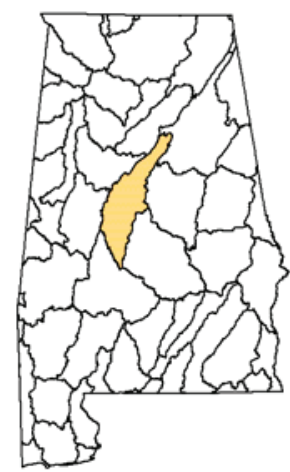

Withdrawals by public supplier, in million gallons per day (Mgal/d)

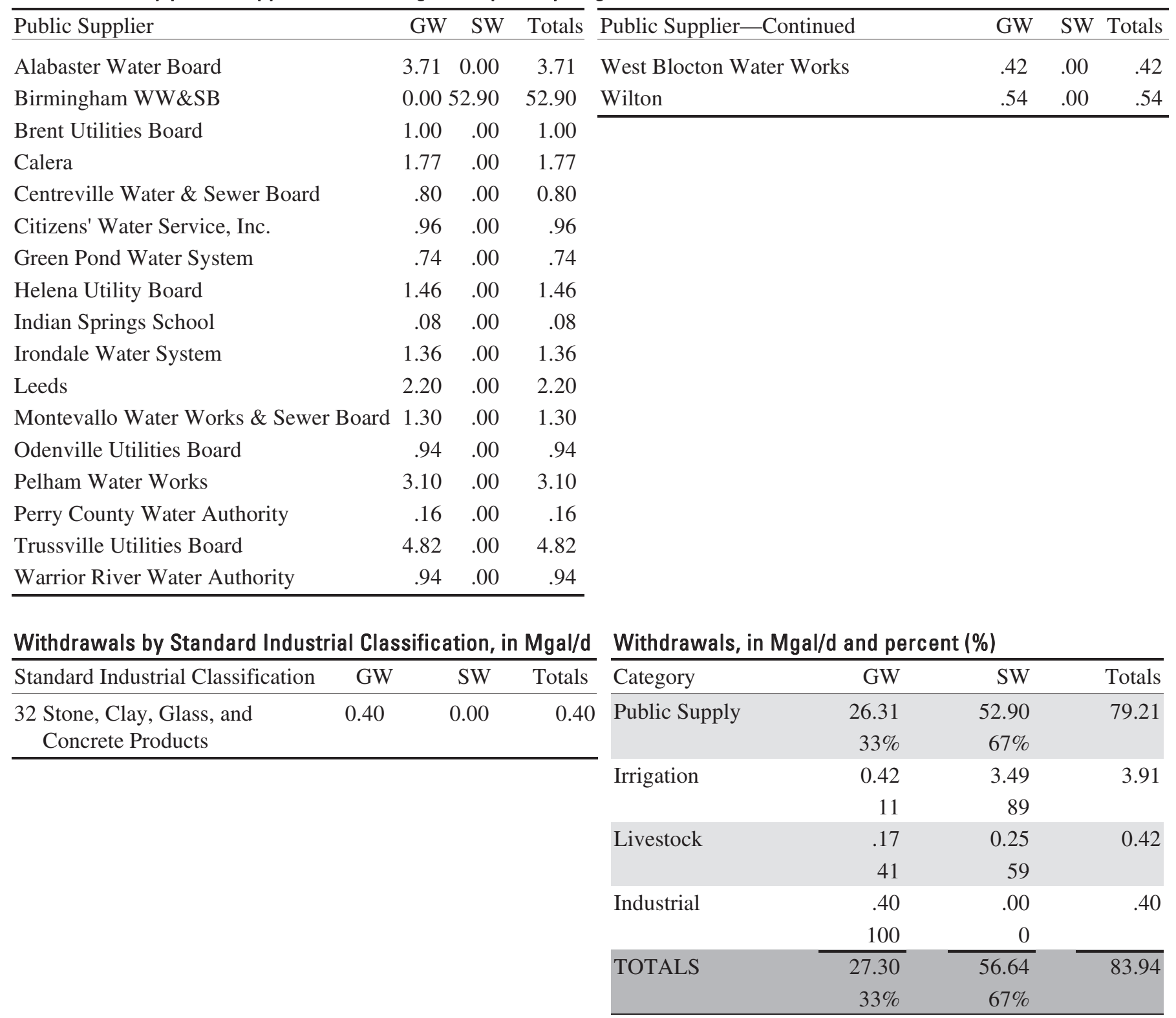




\section{Middle Alabama}

03150203

Population: 30,670

Land Area: 2,227.9 square miles

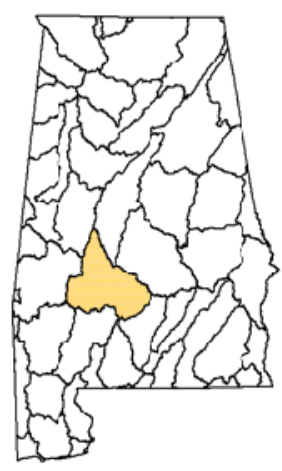

Withdrawals by public supplier, in million gallons per day (Mgal/d)

\begin{tabular}{lrrr}
\hline Public Supplier & GW & SW & Totals \\
\hline Camden & 0.43 & 0.00 & 0.43 \\
Marion (City of) Water Department & .82 & .00 & .82 \\
Millers Ferry Water Authority & .08 & .00 & .08 \\
Pine Apple Waterworks & .02 & .00 & .02 \\
Uniontown Utilities Board & .84 & .00 & .84 \\
West Dallas Water Authority & .23 & .00 & .23 \\
Wilcox County Water System & .50 & .00 & .50 \\
\hline
\end{tabular}

Withdrawals by Standard Industrial Classification, in Mgal/d

\begin{tabular}{lrrr}
\hline Standard Industrial Classification & GW & SW & Totals \\
\hline $\begin{array}{l}\text { 24 Lumber and Wood } \\
\text { Products, Except Furniture }\end{array}$ & 0.00 & 21.04 & 21.04 \\
\hline
\end{tabular}

Withdrawals, in Mgal/d and percent (\%)

\begin{tabular}{lrrr}
\hline Category & GW & SW & Totals \\
\hline Public Supply & 2.92 & 0.00 & 2.92 \\
Irrigation & $100 \%$ & $0 \%$ & \\
& 1.00 & 1.73 & 2.73 \\
Livestock & 37 & 63 & \\
& 0.32 & .48 & 0.80 \\
Industrial & 40 & 60 & \\
& .00 & 21.04 & 21.04 \\
TOTALS & 0 & 100 & \\
\cline { 2 - 4 } & 4.24 & 23.25 & 27.49 \\
\hline
\end{tabular}

\section{Lower Alabama}

03150204

Population: 24,347

Land Area: 1,397.5 square miles

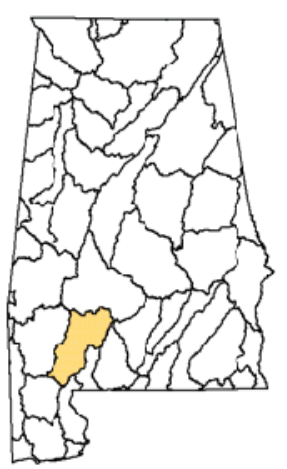

Withdrawals by public supplier, in million gallons per day (Mgal/d)

\begin{tabular}{lrrr}
\hline Public Supplier & GW & SW & Totals \\
\hline Beatrice Water System & 0.08 & 0.00 & 0.08 \\
Frisco City Water Works Board & .23 & .00 & .23 \\
Huxford Water \& Fire Protection & .06 & .00 & .06 \\
$\quad$ Authority & & & \\
Monroeville Water Works Board & 2.58 & .00 & 2.58 \\
Southwest Alabama Water Authority & .40 & .00 & .40 \\
Uriah Water System & .27 & .00 & .27 \\
\hline
\end{tabular}

Withdrawals by Standard Industrial Classification, in Mgal/d

\begin{tabular}{lrrr}
\hline Standard Industrial Classification & GW & SW & Totals \\
\hline $\begin{array}{l}\text { 24 Lumber and Wood } \\
\begin{array}{l}\text { Products, Except Furniture } \\
\text { 26 Paper and Allied Products }\end{array}\end{array}$ & 0.40 & 0.00 & 0.40 \\
\hline
\end{tabular}

Withdrawals, in Mgal/d and percent (\%)

\begin{tabular}{lrrr}
\hline Category & GW & SW & Totals \\
\hline Public Supply & 3.62 & 0.00 & 3.62 \\
Irrigation & $100 \%$ & $0 \%$ & \\
& 3.13 & .64 & 3.77 \\
Livestock & 83 & 17 & \\
& 0.02 & .02 & 0.04 \\
Industrial & 44 & 56 & \\
& .40 & 54.61 & 55.01 \\
TOTALS & 1 & 99 & \\
\cline { 2 - 3 } & 7.17 & 55.27 & 62.44 \\
& $11 \%$ & $89 \%$ & \\
\hline
\end{tabular}




\section{Upper Tombigbee}

\section{1}

Population: 3,832

Land Area: 125.0 square miles

Withdrawals by public supplier, in million gallons per day (Mgal/d)

\begin{tabular}{lrrr}
\hline Public Supplier & GW & SW & Totals \\
\hline Red Bay Water \& Gas Board & 0.13 & 0.00 & 0.13 \\
Vina Waterworks Board & .10 & .00 & .10 \\
\hline
\end{tabular}

Withdrawals by Standard Industrial Classification, in Mgal/d

\begin{tabular}{llll}
\hline Standard Industrial Classification & GW & SW & Totals \\
\hline None & & & \\
\hline
\end{tabular}

Withdrawals, in Mgal/d and percent (\%)

\begin{tabular}{|c|c|c|c|}
\hline Category & GW & SW & Totals \\
\hline \multirow[t]{2}{*}{ Public Supply } & 0.23 & 0.00 & 0.23 \\
\hline & $100 \%$ & $0 \%$ & \\
\hline \multirow[t]{2}{*}{ Irrigation } & .03 & .03 & .06 \\
\hline & 50 & 50 & \\
\hline \multirow[t]{2}{*}{ Livestock } & .05 & .06 & .11 \\
\hline & 43 & 57 & \\
\hline \multirow[t]{2}{*}{ TOTALS } & 0.31 & 0.09 & 0.40 \\
\hline & $78 \%$ & $22 \%$ & \\
\hline
\end{tabular}

\section{Buttahatchee}

03160103

Population: 23,300

Land Area: 666.7 square miles

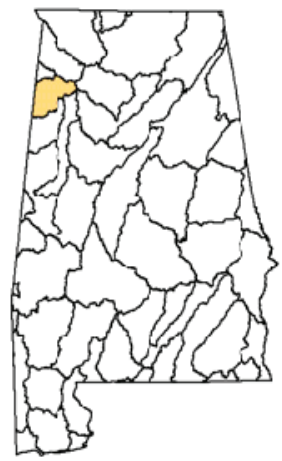

Withdrawals by public supplier, in million gallons per day (Mgal/d)

\begin{tabular}{lrrr}
\hline Public Supplier & GW & SW & Totals \\
\hline Detroit Water Department & 0.03 & 0.00 & 0.03 \\
Guin Water Works and Sewer Board & .00 & .69 & .69 \\
Hamilton Waterworks \& Sewer Board & .00 & 1.32 & 1.32 \\
Hodges Water Department & .20 & .00 & .20 \\
Sulligent & .32 & .00 & .32 \\
\hline
\end{tabular}

Withdrawals by Standard Industrial Classification, in Mgal/d Standard Industrial Classification $\quad$ GW $\quad$ SW Totals

None

Withdrawals, in Mgal/d and percent (\%)

\begin{tabular}{lrrr}
\hline Category & GW & SW & Totals \\
\hline Public Supply & 0.55 & 2.01 & 2.56 \\
Irrigation & $21 \%$ & $79 \%$ & \\
& .01 & 0.13 & 0.14 \\
Livestock & 7 & 93 & \\
& .12 & .17 & .29 \\
TOTALS & 42 & 58 & \\
\cline { 2 - 4 } \cline { 3 - 4 } & 0.68 & 2.31 & 2.99 \\
& $23 \%$ & $77 \%$ & \\
\hline
\end{tabular}




\section{Luxapallila}

03160105

Population: 19,232

Land Area: 661.8 square miles

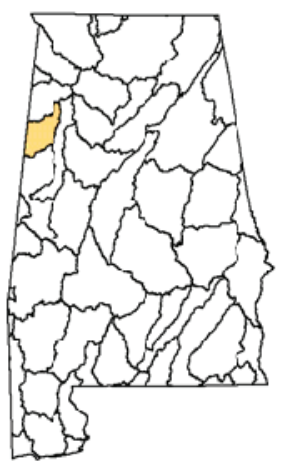

Withdrawals by public supplier, in million gallons per day (Mgal/d)

\begin{tabular}{lrrr}
\hline Public Supplier & GW & SW & Totals \\
\hline Fayette Water Board & 0.00 & 1.98 & 1.98 \\
Kennedy & .16 & 0.00 & 0.16 \\
Millport & .21 & .00 & .21 \\
Twin Water Authority & .06 & .00 & .06 \\
Vernon Water \& Sewer & .75 & .00 & .75 \\
Winfield Water Works \& Sewer Board & .28 & .48 & .76 \\
\hline
\end{tabular}

Withdrawals by Standard Industrial Classification, in Mgal/d

\begin{tabular}{lrrr}
\hline Standard Industrial Classification & GW & SW & Totals \\
\hline $\begin{array}{l}\text { 24 Lumber and Wood } \\
\text { Products, Except Furniture }\end{array}$ & 0.07 & 0.00 & 0.07 \\
\hline
\end{tabular}

Withdrawals, in Mgal/d and percent (\%)

\begin{tabular}{lrrr}
\hline Category & GW & SW & Totals \\
\hline Public Supply & 1.46 & 2.46 & 3.92 \\
Irrigation & $37 \%$ & $63 \%$ & \\
& 0.02 & 0.23 & 0.25 \\
Livestock & 8 & 92 & \\
Industrial & .09 & .11 & .20 \\
& 45 & 55 & \\
TOTALS & .07 & .00 & .07 \\
& 100 & 0 & \\
\cline { 2 - 3 } & 1.64 & 2.80 & 4.44 \\
\hline
\end{tabular}

\section{Middle Tombigbee- Lubbub}

\section{6}

Population: 28,333

Land Area: 1,272.7 square miles

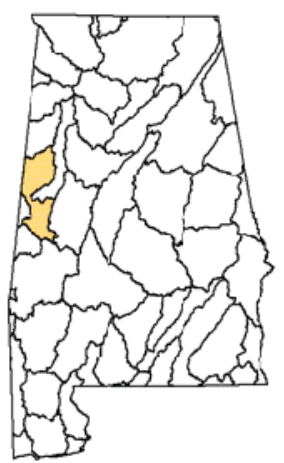

Withdrawals by public supplier, in million gallons per day (Mgal/d)

\begin{tabular}{lrrr}
\hline Public Supplier & GW & SW & Totals \\
\hline Aliceville Water and Sewer Board & 0.77 & 0.00 & 0.77 \\
Eutaw Water Department & .38 & .00 & .38 \\
Forkland Water System & .10 & .00 & .10 \\
Gordo & .44 & .00 & .44 \\
Livingston Utility Board & .76 & .00 & .76 \\
Pickens County Water Authority & 1.12 & .00 & 1.12 \\
Reform & .37 & .00 & .37 \\
\hline
\end{tabular}

Withdrawals by Standard Industrial Classification, in Mgal/d

Standard Industrial Classification $\quad$ GW $\quad$ SW Totals

\begin{tabular}{llll}
\hline 24 Lumber and Wood & 0.12 & 0.00 & 0.12
\end{tabular}

Products, Except Furniture

Withdrawals, in Mgal/d and percent (\%)

\begin{tabular}{lrrr}
\hline Category & GW & SW & Totals \\
\hline Public Supply & 3.94 & 0.00 & 3.94 \\
Irrigation & $100 \%$ & $0 \%$ & \\
& 0.28 & .41 & 0.69 \\
Livestock & 41 & 59 & \\
& .33 & .38 & .71 \\
Industrial & 46 & 54 & \\
& .12 & .00 & .12 \\
TOTALS & 100 & 0 & \\
\cline { 2 - 4 } & 4.67 & 0.79 & 5.46 \\
\hline
\end{tabular}


Sipsey

03160107

Population: 16,506

Land Area: 786.6 square miles

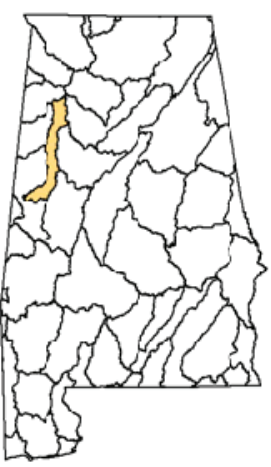

Withdrawals by public supplier, in million gallons per day (Mgal/d)

\begin{tabular}{lrrr}
\hline Public Supplier & GW & SW & Totals \\
\hline Brilliant & 0.10 & 0.00 & 0.10 \\
Buhl, Elrod and Holman Water Authority & .27 & .00 & .27 \\
Eldridge Water Department & .12 & .00 & .12 \\
Glen Allen & .05 & .00 & .05 \\
\hline
\end{tabular}

Withdrawals by Standard Industrial Classification, in Mgal/d

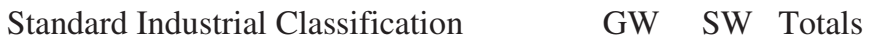

None

Withdrawals, in Mgal/d and percent (\%)

\begin{tabular}{|c|c|c|c|}
\hline Category & GW & SW & Totals \\
\hline \multirow[t]{2}{*}{ Public Supply } & 0.55 & 0.00 & 0.55 \\
\hline & $100 \%$ & $0 \%$ & \\
\hline \multirow[t]{2}{*}{ Irrigation } & .11 & .68 & .79 \\
\hline & 14 & 86 & \\
\hline \multirow[t]{2}{*}{ Livestock } & .13 & .17 & .30 \\
\hline & 45 & 55 & \\
\hline \multirow[t]{2}{*}{ TOTALS } & 0.79 & 0.85 & 1.64 \\
\hline & $48 \%$ & $52 \%$ & \\
\hline
\end{tabular}

\section{Noxubee}

03160108

Population: 949

Land Area: 139.0 square miles

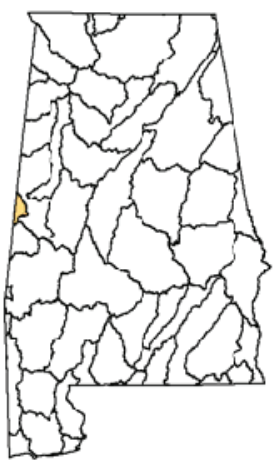

Withdrawals by public supplier, in million gallons per day (Mgal/d)

\begin{tabular}{lccc}
\hline Public Supplier & GW & SW & Totals \\
\hline Sumter County Water Authority & 0.22 & 0.00 & 0.22 \\
\hline
\end{tabular}

Withdrawals by Standard Industrial Classification, in Mgal/d

$\begin{array}{llll}\text { Standard Industrial Classification } & \text { GW } & \text { SW } & \text { Totals }\end{array}$

None

Withdrawals, in Mgal/d and percent (\%)

\begin{tabular}{lrrr}
\hline Category & GW & SW & Totals \\
\hline Public Supply & 0.22 & 0.00 & 0.22 \\
Irrigation & $100 \%$ & $0 \%$ & \\
& .01 & .02 & .03 \\
Livestock & 33 & 67 & \\
& .02 & .03 & .05 \\
TOTALS & 42 & 58 & \\
\cline { 2 - 4 } & 0.25 & 0.05 & 0.30 \\
& $83 \%$ & $17 \%$ & \\
\hline
\end{tabular}




\section{Mulberry}

03160109

Population: 132,396

Land Area: 1,370.9 square miles

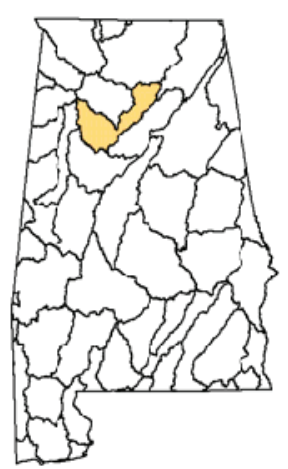

Withdrawals by public supplier, in million gallons per day (Mgal/d)

\begin{tabular}{lrrr}
\hline Public Supplier & GW & SW & Totals \\
\hline Birmingham WW\&SB & 0.00 & 28.71 & 28.71 \\
Blount County Water Authority & .00 & 1.21 & 1.21 \\
Blountsville Utility Board & .02 & 0.00 & 0.02 \\
Cullman & .00 & 12.53 & 12.53 \\
Hanceville Water and Sewer Board & .50 & .00 & .50 \\
Jasper Waterworks and Sewer Board & .00 & 11.51 & 11.51 \\
\hline
\end{tabular}

Withdrawals by Standard Industrial Classification, in Mgal/d

\begin{tabular}{lrrr}
\hline Standard Industrial Classification & GW & SW & Totals \\
\hline 20 Food and Kindred Products & 0.00 & 1.79 & 1.79 \\
49 Electric, Gas, and Sanitary Services & .00 & 927.28 & 927.28 \\
\hline
\end{tabular}

Withdrawals, in Mgal/d and percent (\%)

\begin{tabular}{lrrr}
\hline Category & GW & SW & Totals \\
\hline Public Supply & 0.52 & 53.96 & 54.48 \\
Irrigation & $1 \%$ & $99 \%$ & \\
& .84 & 0.46 & 1.30 \\
Livestock & 65 & 35 & \\
Industrial & .84 & .88 & 1.72 \\
& 49 & 51 & \\
Thermoelectric & .00 & 1.79 & 1.79 \\
& 0 & 100 & \\
TOTALS & .00 & 927.28 & 927.28 \\
& 0 & 100 & \\
\cline { 2 - 3 } & 2.20 & 984.37 & 986.57 \\
\hline
\end{tabular}

\section{Sipsey Fork}

\section{0}

Population: 51,869

Land Area: 996.2 square miles

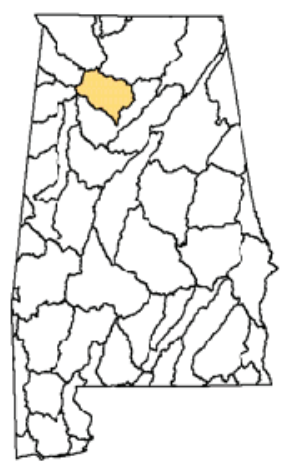

Withdrawals by public supplier, in million gallons per day (Mgal/d)

\begin{tabular}{lrrr}
\hline Public Supplier & GW & SW & Totals \\
\hline Arley Water Works & 0.00 & 0.89 & 0.89 \\
Birmingham WW\&SB & .00 & 13.98 & 13.98 \\
\hline
\end{tabular}

Withdrawals by Standard Industrial Classification, in Mgal/d \begin{tabular}{llll}
\hline Standard Industrial Classification & GW & SW & Totals
\end{tabular}

None

Withdrawals, in Mgal/d and percent (\%)

\begin{tabular}{lrrr}
\hline Category & GW & SW & Totals \\
\hline Public Supply & 0.00 & 14.87 & 14.87 \\
& $0 \%$ & $100 \%$ & \\
Irrigation & .55 & 0.38 & 0.93 \\
& 59 & 41 & \\
Livestock & .72 & .76 & 1.48 \\
& 49 & 51 & \\
\cline { 2 - 3 } \cline { 3 - 4 } TOTALS & 1.27 & 16.01 & 17.28 \\
& $7 \%$ & $93 \%$ & \\
\hline
\end{tabular}




\section{Locust}

\section{1}

Population: 329,844

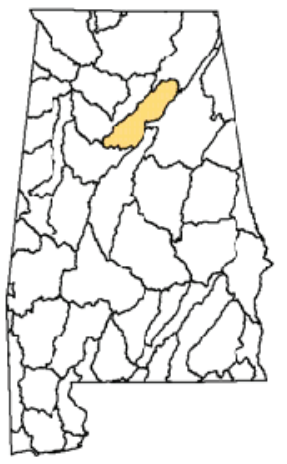

Withdrawals by public supplier, in million gallons per day (Mgal/d)

Public Supplier

Allgood Water Works GW SW Totals

Altoona Water \& Sewer

$\begin{array}{lll}0.00 & 0.06 & 0.06\end{array}$

Birmingham WW\&SB

Blountsville Utility Board

$\begin{array}{rrr}.12 & .00 & .12\end{array}$

$.0011 .38 \quad 11.38$

Cleveland Water Works

$\begin{array}{lll}.44 & .00 & .44\end{array}$

$\begin{array}{lll}.33 & .00 & .33\end{array}$

Nectar Water Department

$.19 \quad .00$

.19

Oneonta Utilities Board

$1.44 \quad .80$
.18

2.24

Snead

$\begin{array}{lll}.18 & .00 & .18\end{array}$

Walnut Grove

$\begin{array}{lll}.09 & .00 & .09\end{array}$

West Etowah County Water \& Fire

$.52 \quad .00$

.52
Land Area: 1,208.7 square miles

\section{Upper Black Warrior}

\section{2}

Population: 280,509

Land Area: 1,245.4 square miles

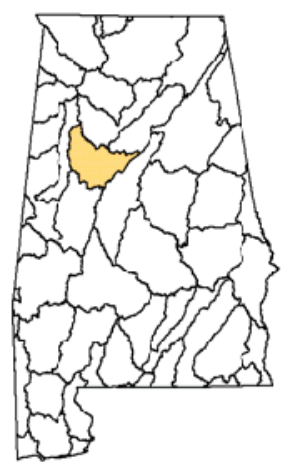

Withdrawals by public supplier, in million gallons per day (Mgal/d)

\begin{tabular}{lrrr}
\hline Public Supplier & GW & SW & Totals \\
\hline Berry & 0.00 & 0.38 & 0.38 \\
Bessemer (G.U.S.C.) & .00 & 9.56 & 9.56 \\
Northport & .00 & 3.39 & 3.39 \\
Tuscaloosa Water and Sewer Department & .00 & 24.10 & 24.10 \\
Warrior River Water Authority & .44 & 2.56 & 3.00 \\
\hline
\end{tabular}

Withdrawals by Standard Industrial Classification, in Mgal/d

Standard Industrial Classification

29 Petroleum Refining and GW SW Totals

\begin{tabular}{llll}
\hline Standard Industrial Classification & GW & SW & Totals
\end{tabular}

20 Food and Kindred Products

$\begin{array}{lll}0.32 & 0.00 & 0.32\end{array}$

Withdrawals, in Mgal/d and percent (\%)

\begin{tabular}{lrrr}
\hline Category & GW & SW & Totals \\
\hline Public Supply & 3.32 & 12.24 & 15.56 \\
& $21 \%$ & $79 \%$ & \\
Irrigation & 0.29 & 1.91 & 2.20 \\
& 13 & 87 & \\
Livestock & .48 & 0.52 & 1.00 \\
& 48 & 52 & \\
Industrial & .32 & .00 & 0.32 \\
& 100 & 0 & \\
\cline { 2 - 4 } TOTALS & 4.41 & 14.67 & 19.08 \\
& $23 \%$ & $77 \%$ & \\
\hline
\end{tabular}

Withdrawals, in Mgal/d and percent (\%)

\begin{tabular}{lrrr}
\hline Category & GW & SW & Totals \\
\hline Public Supply & 0.44 & 39.99 & 40.43 \\
& $1 \%$ & $99 \%$ & \\
Irrigation & .24 & 2.97 & 3.21 \\
& 7 & 93 & \\
Livestock & .09 & 0.12 & 0.21 \\
& 44 & 56 & \\
Industrial & .20 & .00 & .20 \\
& 100 & 0 & \\
\cline { 2 - 3 } TOTALS & 0.97 & 43.08 & 44.05 \\
& $2 \%$ & $98 \%$ & \\
\hline
\end{tabular}




\section{Lower Black Warrior}

\section{3}

Population: 101,984

Land Area: 1,452.8 square miles

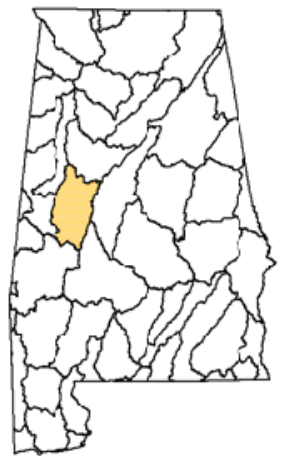

Withdrawals by public supplier, in million gallons per day (Mgal/d)

\begin{tabular}{lrrr}
\hline Public Supplier & GW & SW & Totals \\
\hline Coker Water Authority & 0.32 & 0.00 & 0.32 \\
Demopolis Water \& Sewer Board & 1.27 & .00 & 1.27 \\
Eutaw Water Department & .66 & .00 & .66 \\
Faunsdale & .05 & .00 & .05 \\
Fayetteville Water Authority & .26 & .00 & .26 \\
Greene County Housing Authority & .05 & .00 & .05 \\
Greensboro Utilities Board & .90 & .00 & .90 \\
Hale County Water Authority & .63 & .00 & .63 \\
Moundville & 1.35 & .00 & 1.35 \\
\hline
\end{tabular}

Withdrawals by Standard Industrial Classification, in Mgal/d

\begin{tabular}{lrrr}
\hline Standard Industrial Classification & GW & SW & Totals \\
\hline $\begin{array}{l}\text { 24 Lumber and Wood } \\
\quad \text { Products, Except Furniture }\end{array}$ & 0.02 & 0.00 & 0.02 \\
$\begin{array}{l}29 \text { Petroleum Refining and } \\
\quad \text { Related Industries }\end{array}$ & .58 & .98 & 1.56 \\
$\begin{array}{l}\text { 30 Rubber and Miscellaneous } \\
\quad \text { Plastics Products }\end{array}$ & .00 & .15 & .15 \\
$\begin{array}{l}\text { 49 Electric, Gas, and Sanitary Services } \\
\text { Eles }\end{array}$ & .05 & 386.09 & 386.14 \\
\hline
\end{tabular}

Withdrawals, in Mgal/d and percent (\%)

\begin{tabular}{lrrr}
\hline Category & GW & SW & Totals \\
\hline Public Supply & 5.49 & 0.00 & 5.49 \\
Irrigation & $100 \%$ & $0 \%$ & \\
& 0.15 & 1.31 & 1.46 \\
Livestock & 10 & 90 & \\
& .23 & .29 & 0.52 \\
Industrial & 44 & 56 & \\
Thermoelectric & .60 & 1.14 & 1.74 \\
& 35 & 65 & \\
TOTALS & .05 & 386.09 & 386.14 \\
& 0 & 100 & \\
\cline { 2 - 3 } & 6.52 & 388.83 & 395.35 \\
\end{tabular}

\section{Middle Tombigbee- Chickasaw}

03160201

Population: 36,189

Land Area: 2,039.9 square miles

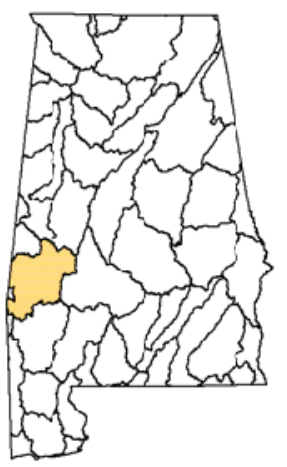

Withdrawals by public supplier, in million gallons per day (Mgal/d)

\begin{tabular}{lrrr}
\hline Public Supplier & GW & SW & Totals \\
\hline Butler Utilities Board & 0.42 & 0.00 & 0.42 \\
Demopolis Water \& Sewer Board & .70 & .00 & .70 \\
Gilbertown Utilities Board & .44 & .00 & .44 \\
Linden Utilities Board & .24 & .00 & .24 \\
Myrtlewood Water System & .25 & .00 & .25 \\
North Choctaw Water Authority & .28 & .00 & .28 \\
Pennington Utilities Board & .16 & .00 & .16 \\
Sumter County Water Authority & .84 & .00 & .84 \\
Sweet Water Water System & .04 & .00 & .04 \\
Thomaston Water \& Gas Board & .16 & .00 & .16 \\
\hline
\end{tabular}

Withdrawals by Standard Industrial Classification, in Mgal/d

Standard Industrial Classification $\quad$ GW $\quad$ SW Totals

\begin{tabular}{llll}
\hline 26 Paper and Allied Products & 0.00 & 62.51 & 62.51
\end{tabular}

28 Chemicals and Allied Products $\quad 1.00 \quad 2.98 \quad 3.98$

Withdrawals, in $\mathrm{Mgal} / \mathrm{d}$ and percent (\%)

\begin{tabular}{lrrr}
\hline Category & GW & SW & Totals \\
\hline Public Supply & 3.53 & 0.00 & 3.53 \\
Irrigation & $100 \%$ & $0 \%$ & \\
& 0.02 & .20 & 0.22 \\
Livestock & 9 & 91 & \\
& .20 & .30 & .50 \\
Industrial & 40 & 60 & \\
& 1.00 & 65.49 & 66.49 \\
TOTALS & 2 & 98 & \\
\cline { 2 - 4 } & 4.75 & 65.99 & 70.74 \\
& $7 \%$ & $93 \%$ & \\
\hline
\end{tabular}




\section{Sucarnoochee}

03160202

Population: 7,296

Land Area: 383.8 square miles

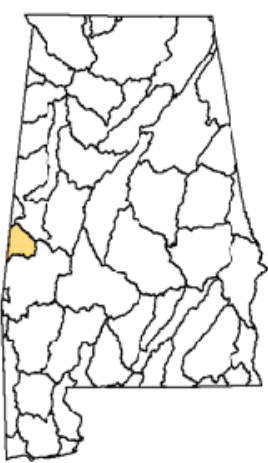

Withdrawals by public supplier, in million gallons per day (Mgal/d)

\begin{tabular}{llll}
\hline Public Supplier & GW & SW & Totals \\
\hline
\end{tabular}

None

Withdrawals by Standard Industrial Classification, in Mgal/d

\begin{tabular}{lccc}
\hline Standard Industrial Classification & GW & SW & Totals \\
\hline $\begin{array}{l}\text { 32 Stone, Clay, Glass, and } \\
\text { Concrete Products }\end{array}$ & 0.00 & 1.22 & 1.22 \\
\hline & & &
\end{tabular}

Withdrawals, in Mgal/d and percent (\%)

\begin{tabular}{lrrr}
\hline Category & GW & SW & Totals \\
\hline Irrigation & 0.00 & 0.03 & 0.03 \\
Livestock & $0 \%$ & $100 \%$ & \\
Industrial & .06 & .09 & .15 \\
& 40 & 60 & \\
TOTALS & .00 & 1.22 & 1.22 \\
& 0 & 100 & \\
\cline { 2 - 3 } & 0.06 & 1.34 & 1.40 \\
\hline
\end{tabular}

\section{Lower Tombigbee}

03160203

Population: 37,199

Land Area: 1,617.7 square miles

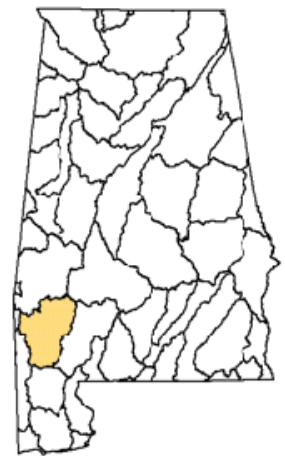

Withdrawals by public supplier, in million gallons per day (Mgal/d)

\begin{tabular}{lrrr}
\hline Public Supplier & GW & SW & Totals \\
Chatom Utilities Board & 0.24 & 0.00 & 0.24 \\
Coffeeville Water Works & .18 & .00 & .18 \\
Frankville Water \& Fire Protection Authority & .09 & .00 & .09 \\
Fulton (Utilities Board of the Town of) & .12 & .00 & .12 \\
Grove Hill Water Works Board & .68 & .00 & .68 \\
Jackson Water and Sewer Board & 1.16 & 1.87 & 3.03 \\
Leroy Water Authority & .16 & .00 & .16 \\
McIntosh Water \& Fire Protection Authority & .35 & .00 & .35 \\
Millry Water Works & .14 & .00 & .14 \\
St. Stephens Water System & .05 & .00 & .05 \\
Wagarville Water System, Inc. & .04 & .00 & .04 \\
\hline
\end{tabular}

Withdrawals by Standard Industrial Classification, in Mgal/d

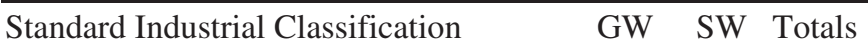

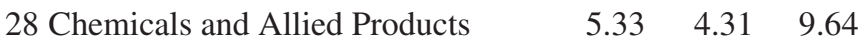

49 Electric, Gas and Sanitary Services $\quad 0.00 \quad 86.54 \quad 86.54$

Withdrawals, in Mgal/d and percent (\%)

\begin{tabular}{lrrr}
\hline Category & GW & SW & Totals \\
\hline Public Supply & 3.21 & 1.87 & 5.08 \\
& $63 \%$ & $37 \%$ & \\
Irrigation & 0.16 & 0.13 & 0.29 \\
& 55 & 45 & \\
Livestock & .09 & .10 & .19 \\
& 46 & 54 & \\
Industrial & 5.33 & 4.31 & 9.64 \\
& 55 & 45 & \\
Thermoelectric & .00 & 86.54 & 86.54 \\
& 0 & 100 & \\
\cline { 2 - 4 } TOTALS & 8.79 & 92.95 & 101.74 \\
& $9 \%$ & $91 \%$ & \\
\hline
\end{tabular}




\section{Mobile-Tensaw}

03160204

Population: 195,350

Land Area: 966.8 square miles

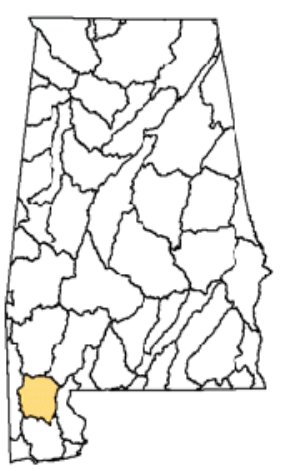

Withdrawals by public supplier, in million gallons per day (Mgal/d)

\begin{tabular}{lrrr}
\hline Public Supplier & GW & SW & Totals \\
\hline Daphne Utilities Board & 2.94 & 0.00 & 2.94 \\
Kushla Water System & 0.45 & .00 & 0.45 \\
Le Moyne Water System, Inc. & .40 & .00 & .40 \\
MCB Water Authority, Inc. & .14 & .00 & .14 \\
Mobile Board of Water and Sewer Comm. & .00 & .48 & .48 \\
Mt. Vernon & .26 & .00 & .26 \\
North Baldwin Utilities & .81 & .00 & .81 \\
Saraland Water System & 1.47 & .00 & 1.47 \\
Satsuma & .56 & .00 & .56 \\
Spanish Fort Water System & .41 & .00 & .41 \\
St. Elmo - Irvington Water Authority & .51 & .00 & .51 \\
Turnerville Water \& Fire Protection District & .32 & .00 & .32 \\
\hline
\end{tabular}

Withdrawals by Standard Industrial Classification, in Mgal/d

\begin{tabular}{lrrr}
\hline Standard Industrial Classification & GW & SW & Totals \\
\hline 28 Chemicals and Allied Products & 5.17 & 0.00 & 5.17 \\
29 Petroleum Refining and & 0.23 & .00 & 0.23
\end{tabular}

Related Industries

49 Electric, Gas, and Sanitary Services .00 1,043.61 1,043.61

Withdrawals, in Mgal/d and percent (\%)

\begin{tabular}{lrrr}
\hline Category & GW & SW & Totals \\
\hline Public Supply & 8.24 & 0.48 & 8.72 \\
& $94 \%$ & $6 \%$ & \\
Irrigation & 8.35 & 1.92 & 10.27 \\
& 81 & 19 & \\
Livestock & 0.09 & .10 & 0.19 \\
& 46 & 54 & \\
Industrial & 5.40 & .00 & 5.40 \\
& 100 & 0 & \\
Thermoelectric & .00 & $1,043.61$ & $1,043.61$ \\
& 0 & 100 & \\
\cline { 2 - 4 } TOTALS & 22.08 & $1,046.11$ & $1,068.19$ \\
& $2 \%$ & $98 \%$ & \\
\hline
\end{tabular}

\section{Mobile Bay}

03160205

Population: 234,104

Land Area: 873.5 square miles

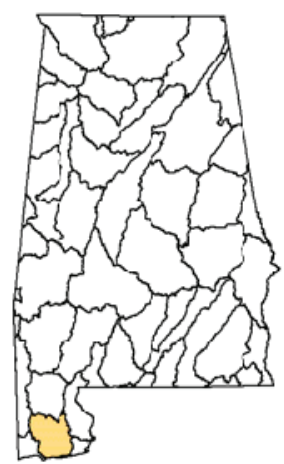

Withdrawals by public supplier, in million gallons per day (Mgal/d)

\begin{tabular}{lrrr}
\hline Public Supplier & GW & SW & Totals \\
\hline Belforest Water System & 0.36 & 0.00 & 0.36 \\
Daphne Utilities Board & .49 & .00 & .49 \\
Fairhope & 3.94 & .00 & 3.94 \\
Foley Utilities Board & 1.40 & .00 & 1.40 \\
Gulf Shores Utilities & 2.23 & .00 & 2.23 \\
Loxley & .62 & .00 & .62 \\
Mobile County W S \& F Protection Authority & 3.71 & .00 & 3.71 \\
Orange Beach Water, Sewer \& Fire Protection & .12 & .00 & .12 \\
Robertsdale & .48 & .00 & .48 \\
Silverhill & .12 & .00 & .12 \\
St. Elmo - Irvington Water Authority & .38 & .00 & .38 \\
\hline
\end{tabular}

Withdrawals by Standard Industrial Classification, in Mgal/d

Standard Industrial Classification $\quad$ GW $\quad$ SW Totals

\begin{tabular}{llll}
\hline 13 Oil and Gas Extraction & 0.12 & 0.00 & 0.12
\end{tabular}

$\begin{array}{llll}32 & \text { Stone, Clay, Glass, and } & .15 & .00\end{array}$

Concrete Products

Withdrawals, in Mgal/d and percent (\%)

\begin{tabular}{lrrr}
\hline Category & GW & SW & Totals \\
\hline Public Supply & 13.85 & 0.00 & 13.85 \\
& $100 \%$ & $0 \%$ & \\
Irrigation & 10.32 & 2.18 & 12.50 \\
& 83 & 17 & \\
Livestock & 0.08 & .10 & 0.18 \\
& 46 & 54 & \\
Industrial & .27 & .00 & .27 \\
& 100 & 0 & \\
\cline { 2 - 4 } TOTALS & 24.52 & 2.28 & 26.80 \\
& $91 \%$ & $9 \%$ & \\
\hline
\end{tabular}




\section{Escatawpa}

03170008

Population: 64,253

Land Area: 702.2 square miles

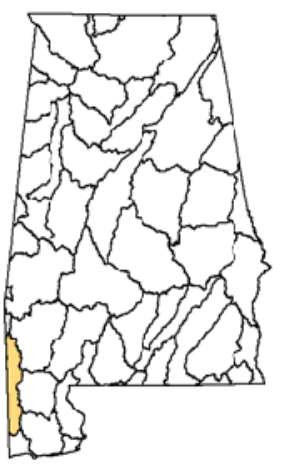

Withdrawals by public supplier, in million gallons per day (Mgal/d)

Public Supplier GW SW Totals

Deer Park - Vinegar Bend Water \&

$\begin{array}{lll}0.11 & 0.00 \quad 0.11\end{array}$

Fire Protection

Grand Bay Water Works Board

$\begin{array}{rrr}.94 & .00 & .94\end{array}$

Mobile Board of Water and Sewer

$.0064 .97 \quad 64.97$

Commissioners

South Alabama Utilities

$\begin{array}{lll}1.62 & .00 & 1.62\end{array}$

St. Elmo - Irvington Water Authority

\begin{tabular}{lll}
$.00 \quad .00 \quad .00$ \\
\hline
\end{tabular}

Withdrawals by Standard Industrial Classification, in Mgal/d

Standard Industrial Classification

GW SW Totals

None

Withdrawals, in Mgal/d and percent (\%)

\begin{tabular}{lrrr}
\hline Category & GW & SW & Totals \\
\hline Public Supply & 2.68 & 64.97 & 67.65 \\
& $4 \%$ & $96 \%$ & \\
Irrigation & 0.05 & 0.29 & 0.34 \\
& 15 & 85 & \\
Livestock & .06 & .06 & .12 \\
& 47 & 53 & \\
\cline { 2 - 4 } TOTALS & 2.79 & 65.32 & 68.11 \\
& $4 \%$ & $96 \%$ & \\
\hline
\end{tabular}

\section{Mississippi Coastal}

03170009

Population: 14,406

Land Area: 241.5 square miles

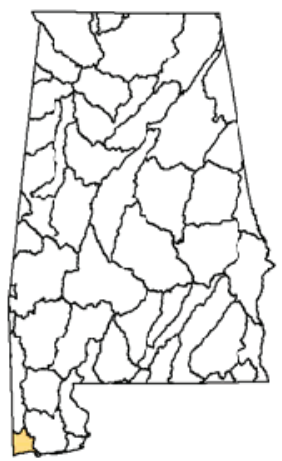

Withdrawals by public supplier, in million gallons per day (Mgal/d)

\begin{tabular}{llll}
\hline Public Supplier & GW & SW & Totals \\
\hline
\end{tabular}

\begin{tabular}{llll} 
Bayou La Batre Utilities Board & 0.62 & 0.00 & 0.62 \\
\hline
\end{tabular}

Withdrawals by Standard Industrial Classification, in Mgal/d

Standard Industrial Classification $\quad$ GW $\quad$ SW Totals

\begin{tabular}{llll}
\hline 20 Food and Kindred Products & 0.00 & 0.00 & 0.00
\end{tabular}

Withdrawals, in Mgal/d and percent (\%)

\begin{tabular}{lrrr}
\hline Category & GW & SW & Totals \\
\hline Public Supply & 0.62 & 0.00 & 0.62 \\
& $100 \%$ & $0 \%$ & \\
Irrigation & .00 & .15 & .15 \\
& 0 & 100 & \\
Livestock & .02 & .02 & .04 \\
& 45 & 55 & \\
\cline { 2 - 4 } TOTALS & 0.64 & 0.17 & 0.81 \\
& $79 \%$ & $21 \%$ & \\
\hline
\end{tabular}




\section{Middle Tennessee- Chickamauga}

06020001

Population: 2,482

Land Area: 53.8 square miles

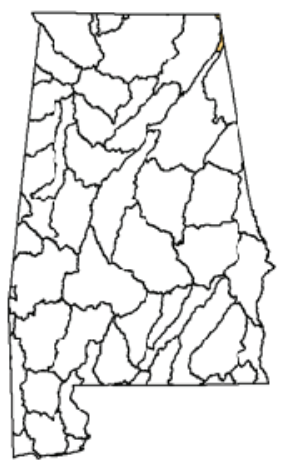

Withdrawals by public supplier, in million gallons per day (Mgal/d)

\begin{tabular}{lccc}
\hline Public Supplier & GW & SW & Totals \\
\hline Valley Head Water Works Board & 0.66 & 0.00 & 0.66 \\
\hline
\end{tabular}

Withdrawals by Standard Industrial Classification, in Mgal/d

Standard Industrial Classification $\quad$ GW $\quad$ SW Totals

None

Withdrawals, in Mgal/d and percent (\%)

\begin{tabular}{lrrr}
\hline Category & GW & SW & Totals \\
\hline Public Supply & 0.66 & 0.00 & 0.66 \\
Irrigation & $100 \%$ & $0 \%$ & \\
& .05 & .09 & .14 \\
Livestock & 36 & 64 & \\
& .06 & .07 & .13 \\
TOTALS & 47 & 53 & \\
\cline { 2 - 3 } & 0.77 & 0.16 & 0.93 \\
\hline
\end{tabular}

\section{Guntersville Lake}

06030001

Population: 139,796

Land Area: 1,646.7 square miles

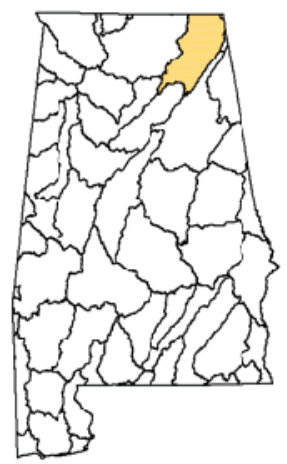

Withdrawals by public supplier, in million gallons per day (Mgal/d)

Public Supplier

GW SW Totals

Albertville Municipal Utilities Board

Arab Water Works Board

$0.0011 .64 \quad 11.64$

Bridgeport Utilities Board

$\begin{array}{lll}.00 & 4.30 & 4.30\end{array}$

Crossville Water Board

$\begin{array}{lll}.20 & 2.36 & 2.56\end{array}$

Douglas Water and Fire Protection

$\begin{array}{lll}.04 & 0.00 & 0.04\end{array}$

Fort Payne Water Works Board

$\begin{array}{lll}2.33 \quad .00 & 2.33\end{array}$

Guntersville Water Works and Sewer Board

$.00 \quad .47$

.47

North Marshall Utilities

$.65 \quad 2.66$

3.31

Northeast Alabama Water, Sewer \& F.P.A.

$.00 \quad 1.20$

1.20

Pisgah

$\begin{array}{lll}.00 & 1.36 & 1.36\end{array}$

Scottsboro Water Board

$.09 \quad .00 \quad .09$

Section \& Dutton Water Boards

$\begin{array}{lll}.00 & 4.66 & 4.66\end{array}$

Stevenson Utilities Board

$.00 \quad 3.06 \quad 3.06$

$.34 \quad .00 \quad .34$

Withdrawals by Standard Industrial Classification, in Mgal/d

Standard Industrial Classification $\quad$ GW $\quad$ SW $\quad$ Totals

\begin{tabular}{llll}
\hline 20 Food and Kindred Products & 0.04 & 0.00 & 0.04
\end{tabular}

$\begin{array}{llrr}22 \text { Textile Mill Products } & .00 & .25 & .25 \\ 26 \text { Paper and Allied Products } & .00 & 8.53 & 8.53\end{array}$

49 Electric, Gas, and Sanitary Services $\quad .00 \quad 1,476.30 \quad 1,476.30$

\begin{tabular}{lrrr} 
Withdrawals, in Mgal/d and percent (\%) & \\
\hline Category & GW & SW & Totals \\
\hline Public Supply & 3.66 & 31.72 & 35.38 \\
& $10 \%$ & $90 \%$ & \\
Irrigation & 0.50 & 1.72 & 2.22 \\
Livestock & 23 & 77 & \\
Industrial & 1.12 & 1.25 & 2.37 \\
& 47 & 53 & \\
Thermoelectric & .04 & 8.78 & 8.82 \\
TOTALS & 0 & 100 & \\
& .00 & $1,476.30$ & $1,476.30$ \\
\cline { 2 - 4 } & 0 & 100 & \\
\cline { 2 - 4 } & 5.32 & $1,519.77$ & $1,525.09$ \\
\hline
\end{tabular}




\section{Wheeler Lake}

06030002

Population: 513,383

Land Area: 2,663.1 square miles

Withdrawals by public supplier, in million gallons per day (Mgal/d)

\begin{tabular}{lrrr}
\hline Public Supplier & GW & SW & Totals \\
\hline Ardmore Water System & 0.20 & 0.00 & 0.20 \\
Decatur Utilities & .00 & 30.42 & 30.42 \\
Harvest-Monrovia Water Authority & 3.99 & .00 & 3.99 \\
Huntsville Utilities Water Department & 7.82 & 31.01 & 38.83 \\
Limestone County Water Authority & 2.44 & .00 & 2.44 \\
Madison County Water Department & 7.02 & .00 & 7.02 \\
Madison Water and Wastewater Board & 5.92 & .00 & 5.92 \\
Owens Cross Roads Water Authority & .84 & .00 & .84 \\
Rogersville Water \& Sewer Board & .60 & .00 & .60 \\
Swan Creek Community & .03 & .00 & .03 \\
U.S. Army Missle Command & .00 & 7.84 & 7.84 \\
$\quad$ Redstone Arsenal) & & & \\
West Morgan East Lawrence Water \& & .00 & 4.99 & 4.99 \\
$\quad$ Sewer Authority & & & \\
\hline
\end{tabular}

Withdrawals by Standard Industrial Classification, in Mgal/d

\begin{tabular}{|c|c|c|c|c|c|c|c|}
\hline Standard Industrial Classification & GW & SW & Totals & Category & GW & SW & Totals \\
\hline 20 Food and Kindred Products & 1.14 & 0.00 & 1.14 & \multirow[t]{2}{*}{ Public Supply } & 28.87 & 74.26 & \multirow[t]{2}{*}{103.13} \\
\hline 26 Paper and Allied Products & 0.00 & 57.18 & 57.18 & & $28 \%$ & $72 \%$ & \\
\hline \multirow{2}{*}{$\begin{array}{l}28 \text { Chemicals and Allied } \\
\text { Products }\end{array}$} & \multirow[t]{2}{*}{.15} & \multirow[t]{2}{*}{84.08} & \multirow[t]{2}{*}{84.23} & \multirow[t]{2}{*}{ Irrigation } & 3.45 & 9.17 & \multirow[t]{2}{*}{12.62} \\
\hline & & & & & 27 & 73 & \\
\hline \multirow{2}{*}{$\begin{array}{l}30 \text { Rubber and Miscellaneous } \\
\text { Plastics Products }\end{array}$} & \multirow[t]{2}{*}{.00} & \multirow[t]{2}{*}{5.28} & \multirow[t]{2}{*}{5.28} & \multirow[t]{2}{*}{ Livestock } & 1.06 & 1.28 & \multirow[t]{2}{*}{2.34} \\
\hline & & & & & 45 & 55 & \\
\hline \multirow{2}{*}{$\begin{array}{l}32 \text { Stone, Clay, Glass, and } \\
\text { Concrete Products }\end{array}$} & .00 & .89 & 0.89 & \multirow[t]{2}{*}{ Industrial } & 1.29 & 147.43 & \multirow[t]{2}{*}{148.72} \\
\hline & \multirow{2}{*}{.00} & \multirow{2}{*}{$1,991.44$} & \multirow{2}{*}{$1,991.44$} & & 1 & 99 & \\
\hline \multirow{4}{*}{$\begin{array}{l}49 \text { Electric, Gas, and Sanitary } \\
\text { Services }\end{array}$} & & & & \multirow[t]{2}{*}{ Thermoelectric } & 0.00 & $1,991.44$ & \multirow[t]{2}{*}{$1,991.44$} \\
\hline & & & & & 0 & 100 & \\
\hline & & & & TOTALS & 34.67 & $2,223.58$ & $2,258.25$ \\
\hline & & & & & $2 \%$ & $98 \%$ & \\
\hline
\end{tabular}

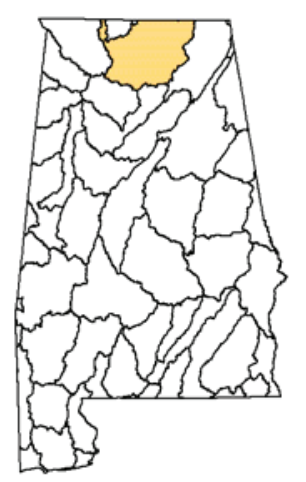

Withdrawals, in Mgal/d and percent (\%) 


\section{Lower Elk}

06030004

Population: 16,750

Land Area: 250.0 square miles

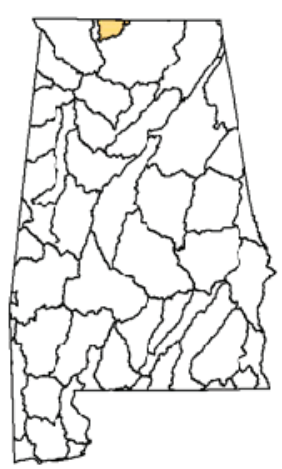

Withdrawals by public supplier, in million gallons per day (Mgal/d)

\begin{tabular}{lrcc}
\hline Public Supplier & GW & SW & Totals \\
\hline Athens Utilities & 0.00 & 5.74 & 5.74 \\
Limestone County Water Authority & .00 & 3.10 & 3.10 \\
\hline
\end{tabular}

Withdrawals by Standard Industrial Classification, in Mgal/d

Standard Industrial Classification $\quad$ GW $\quad$ SW Totals

None

Withdrawals, in Mgal/d and percent (\%)

\begin{tabular}{lrrr}
\hline Category & GW & SW & Totals \\
\hline Public Supply & 0.00 & 8.84 & 8.84 \\
Irrigation & $0 \%$ & $100 \%$ & \\
& .73 & 1.99 & 2.72 \\
Livestock & 27 & 73 & \\
& .08 & 0.10 & 0.18 \\
TOTALS & 44 & 56 & \\
\cline { 2 - 3 } & 0.81 & 10.93 & 11.74 \\
\hline
\end{tabular}

\section{Pickwick Lake}

\section{5}

Population: 152,863

Land Area: 1,411.9 square miles

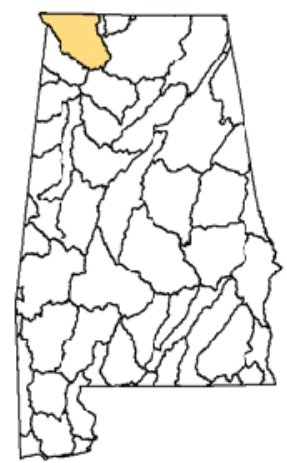

Withdrawals by public supplier, in million gallons per day (Mgal/d)

\begin{tabular}{lrrr}
\hline Public Supplier & GW & SW & Totals \\
\hline Cherokee Waterworks and Gas Board & 0.00 & 0.36 & 0.36 \\
Florence Water \& Sewer Department & .31 & 12.79 & 13.10 \\
Greenhill Water System & .49 & .00 & .49 \\
Hawk Pride Mountain Water System & 1.06 & .00 & 1.06 \\
Leighton Water \& Sewer Board & .23 & .00 & .23 \\
Moulton Water Works Board & .00 & 1.92 & 1.92 \\
Muscle Shoals Utilities Board & .00 & 4.09 & 4.09 \\
Sheffield Utilities & .00 & 1.98 & 1.98 \\
Tuscumbia - Water Department & .00 & 1.84 & 1.84 \\
\hline
\end{tabular}

Withdrawals by Standard Industrial Classification, in Mgal/d

\begin{tabular}{lrrr}
\hline Standard Industrial Classification & GW & SW & Totals \\
\hline 26 Paper and Allied Products & 0.00 & 3.30 & 3.30 \\
28 Chemicals and Allied Products & .00 & 48.55 & 48.55 \\
34 Fabricated Metal Products, Except & .87 & 3.72 & 4.59 \\
Machinery and Transportation Equipment & & \\
49 Electric, Gas, and Sanitary Services & .00 & $1,294.14$ & $1,294.14$ \\
\hline
\end{tabular}

Withdrawals, in Mgal/d and percent (\%)

\begin{tabular}{lrrr}
\hline Category & GW & SW & Totals \\
\hline Public Supply & 2.09 & 22.98 & 25.07 \\
& $8 \%$ & $92 \%$ & \\
Irrigation & 1.44 & 1.98 & 3.42 \\
& 42 & 58 & \\
Livestock & 0.44 & 0.60 & 1.04 \\
& 42 & 58 & \\
Industrial & .87 & 55.57 & 56.44 \\
& 2 & 98 & \\
Thermoelectric & .00 & $1,294.14$ & $1,294.14$ \\
& 0 & 100 & \\
\cline { 2 - 4 } TOTALS & 4.84 & $1,375.27$ & $1,380.11$ \\
& $0 \%$ & $100 \%$ & \\
\hline
\end{tabular}




\section{Bear}

06030006

Population: 33,623

Land Area: 795.5 square miles

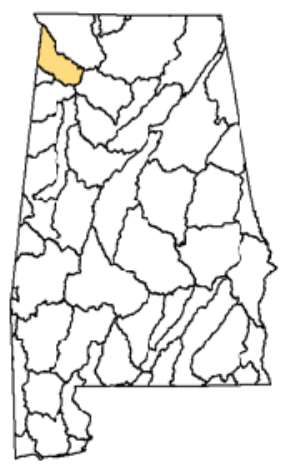

Withdrawals by public supplier, in million gallons per day (Mgal/d)

\begin{tabular}{lrcc}
\hline Public Supplier & GW & SW & Totals \\
\hline Red Bay Water \& Gas Board & 0.50 & 0.00 & 0.50 \\
Russellville Water \& Sewer Board & .32 & 3.88 & 4.20 \\
Upper Bear Creek Water Treatment Plant & .00 & 3.17 & 3.17 \\
\hline
\end{tabular}

Withdrawals by Standard Industrial Classification, in Mgal/d

Standard Industrial Classification $\quad$ GW $\quad$ SW $\quad$ Totals

None

Withdrawals, in Mgal/d and percent (\%)

\begin{tabular}{lrrr}
\hline Category & GW & SW & Totals \\
\hline Public Supply & 0.82 & 7.05 & 7.87 \\
& $10 \%$ & $90 \%$ & \\
Irrigation & .53 & 0.64 & 1.17 \\
& 45 & 55 & \\
Livestock & .32 & .43 & 0.75 \\
& 43 & 57 & \\
\cline { 2 - 4 } TOTALS & 1.67 & 8.12 & 9.79 \\
& $17 \%$ & $83 \%$ & \\
\hline
\end{tabular}





\section{Appendix C. Hydrologic Regions, Subregions, and Subbasins in Alabama}

The Mobile and Tennessee Rivers are the major river systems in Alabama. Within Alabama, the Mobile River comprises 46 subbasins and five subregions and the Tennessee River comprises 7 subbasins and two subregions. The hydrographic classification scheme used for this report and in the following table (C-1) is from the USDA, Soil Conservation Service publication, State of Alabama Hydrologic Unit Map with drainage areas by county and sub-watershed, March 1993; Federal standards for delineation of hydrologic unit boundaries; version 2.0, October 1, 2004; and, http://water.usgs.gov/GIS/huc name.html\#Region03, accessed November 26, 2008. Table $\mathrm{C}-1$ lists by hydrologic region, each subregion and associated subbasins by eight-digit hydrologic unit code and name. 
Table C-1. Eight-digit hydrologic unit codes and corresponding subbasin and subregion names, Alabama.

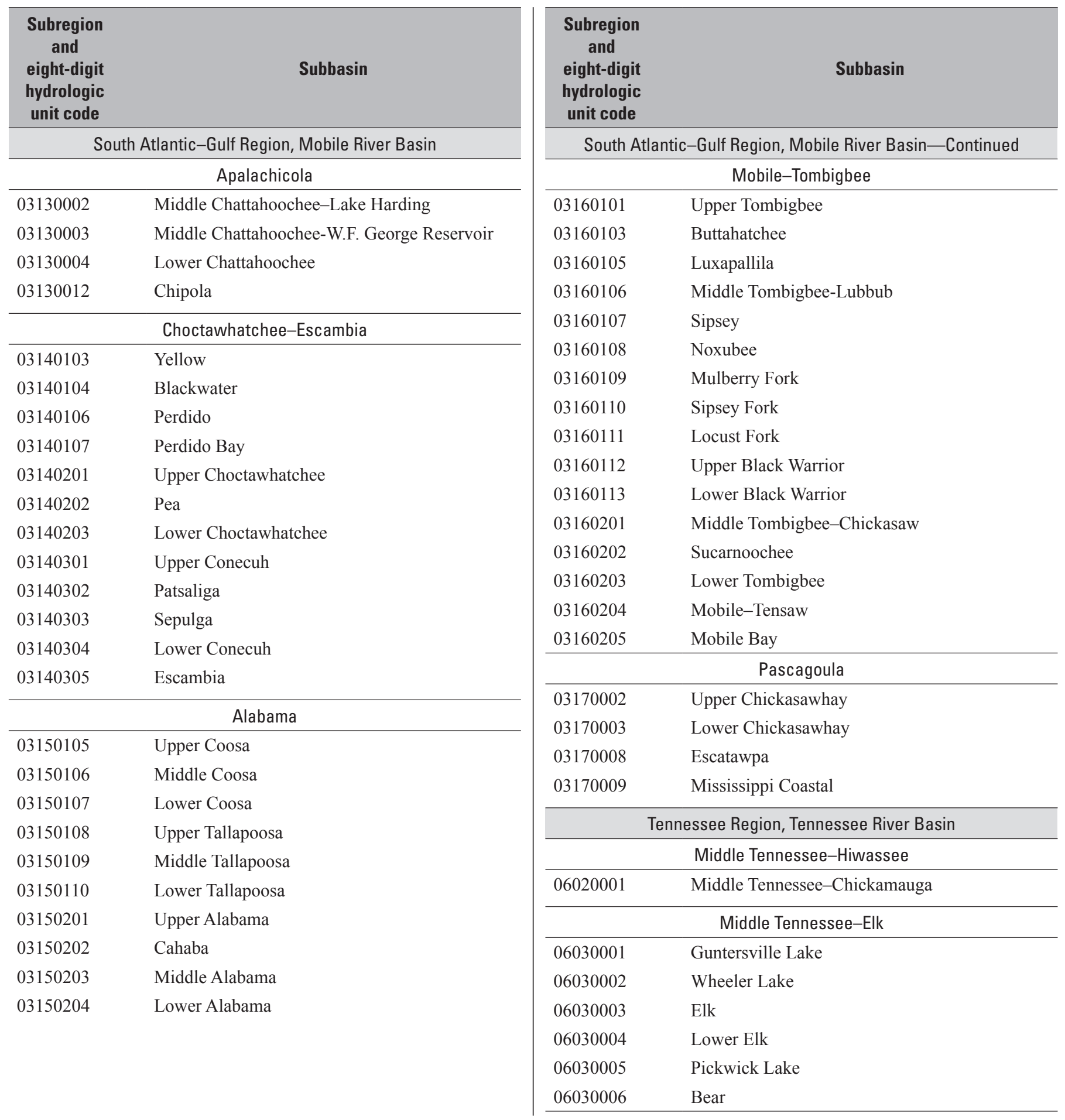




\section{Appendix D. Public-Supplier Survey Form}

Each of the 547 public suppliers was surveyed to determine the amount of water delivered to residential, commercial, and industrial customers and public use and losses. The 547 public suppliers surveyed either withdrew their own water from a ground-water or surface-water source, or purchased water, or relied on a combination of sources that could include ground water, surface water, or purchased water. Public suppliers differ as to how water is accounted for within the system, and the questions in the survey (fig. D-1) cover the range of possible combinations of customer billing classes. 
Figure D-1. Alabama Office of Water Resources, 2005 Alabama Water System Survey form.

\section{ALABAMA DEPARTMENT OF ECONOMIC \& COMMUNITY AFFAIRS (ADECA) OFFICE OF WATER RESOURCES \\ 401 Adams Avenue, Suite 434 \\ Montgomery, Alabama 36104 \\ (334) 242-5499}

\section{Alabama Water System Survey on 2005 Water-Use Data \\ Water distributed to the residential, commercial, industrial, and other accounting classes during 2005. \\ Instructions are on the last page.}

PART A. WATER-SUPPLY SYSTEM

1. System Name:

OWR COU\#:

ADEM PWSID\#:

2. Water Use Reporting Period. Check one.

a. For calendar year January 2005-December 2005

b. For fiscal year July 1, 2004-June 30, 2005

c. Month: Year:

3. Water Volume Units (For Information Requested Below)

a. Check one: gallons million gallons thousand gallons percentage

b. Total water distributed including water sold to other watersupply systems

c. Total amount of water sold to other water-supply systems Number of water-supply systems to which water was sold Or, percentage of water sold to other water-supply systems

d. Total amount of water sold to residential customers Number of billed residential accounts for period of record Or, percentage of water sold to residential customers

e. Total amount of water sold to commercial customers Number of billed commercial accounts for period of record Or, percentage of water sold to commercial customers

f. Total amount of water sold to industrial customers Number of billed industrial accounts for period of record Or, percentage of water sold to industrial customers

(Note: Complete $\mathbf{G}$ or $\mathbf{H}$ if your billing accounts are not separated into the three customer classes (residential, commercial, industrial). 
Figure D-1. Alabama Office of Water Resources, 2005 Alabama Water System Survey form.-Continued

g. If commercial and industrial billing accounts are combined into a single customer class, report the following.

Total amount of water sold to combined commercial and industrial accounts for period of record

Number of billed combined commercial, and industrial accounts for period of record

Or, percentage of water sold to combined commercial and industrial accounts

h. If residential, commercial and industrial billing accounts are combined into a single customer class, report the following.

Total amount of water sold to combined residential, commercial, and industrial accounts for period of record Number of billed combined residential, commercial, and industrial accounts for period of record

i. Total amount of water used for purposes such as firefighting, line flushing, maintenance, and other public uses or losses

Or, percentage of water for other purposes such as firefighting, etc.

\section{PART B. FACILITY/CONTACT INFORMATION}

4. Indicate the individual to contact for further information (e.g., system manager, operator, billing manager, etc.):

Name: Title:

Phone: Fax:

e-mail: Date: 
Figure D-1. Alabama Office of Water Resources, 2005 Alabama Water System Survey form.-Continued

\section{Instructions:}

\section{PART A. WATER-SUPPLY SYSTEM}

Question 2. Water Use Reporting Period

2a., 2b., and 2c. Information is requested for 2005. Calendar year information is preferred over fiscal year information, although fiscal year summaries, because they are more common, are acceptable. If calendar or fiscal year summary information is simply not available, select a month of typical usage for 2005, preferably a month that has minimum outdoor usage, and write in the month and year.

\section{Question 3. Water Distribution}

The term "water distribution" is used generally and refers to water that is distributed, delivered, or sold to residential, commercial, or industrial customers; other water-supply systems; used for firefighting, flushing lines, water processing, or other purposes; or, water lost in the distribution system.

3a. Indicate the type of units (gallons, thousand gallons, or million gallons) of water reported for this survey. Alternatively, you may report the percent of water used by the customer class. For example, residential customers may account for about 90 percent of the water (3d.). About 2 percent may be used for commercial and industrial purposes (3e.-3g.). The remaining 8 percent may be used for firefighting, flushing lines, or may be lost to the system (3i.).

$\underline{3 b .}$ Total amount of water for distribution refers to water that is sold to residential, commercial, and industrial customers; other water-supply systems; used for firefighting, flushing lines, water processing, or other purposes; and, lost in the distribution system.

3e., $3 \mathrm{f} .$, and $3 \mathrm{~g}$. If industrial and commercial customers are classified separately for billing purposes, indicate the amount of water sold and number of bills as indicated by $3 \mathrm{e}$. and $3 \mathrm{f}$. If industrial and commercial customers are summarized together, but can be separated from the residential customers, use $3 \mathrm{~g}$. to indicate water sold and number of bills to customers.

3h. If residential, commercial, and industrial customers are summarized together for billing purposes indicate the amount of water sold and number of bills as indicated by $3 \mathrm{~b}$. and $3 \mathrm{c}$. Estimate percentages for $3 \mathrm{c} .-3 \mathrm{~g}$., and $3 \mathrm{i}$. 


\section{Appendix E. Hydroelectric Dams}

Table E-1 provides the dam name, county and community location, year completed, generating capacity in kilowatt-hours, reservoir surface area, and length of shoreline for each hydroelectric power plant. Figure E-1 shows locations of the hydroelectric dams and their respective river. Alabama Electric Cooperative, Alabama Power Company, TVA, and USACE manage 21 hydroelectric dams on the Tennessee, Black Warrior, Coosa, Tallapoosa, Alabama, and Conecuh Rivers. Georgia Power Company and the USACE manage six hydroelectric dams on the Chattahoochee River bordering Alabama. 
Table E-1. Hydroelectric dams in Alabama, 2005.

[Location indicates the nearest city to the dam, not necessarily the location of the dam or the business offices; kWh, kilowatt-hour; AL, Alabama; TVA, Tennessee Valley Authority; APCO, Alabama Power Company; USACE, U.S. Army Corps of Engineers; GA, Georgia; GPCO, Georgia Power Company; AEC, Alabama Electric Cooperative]

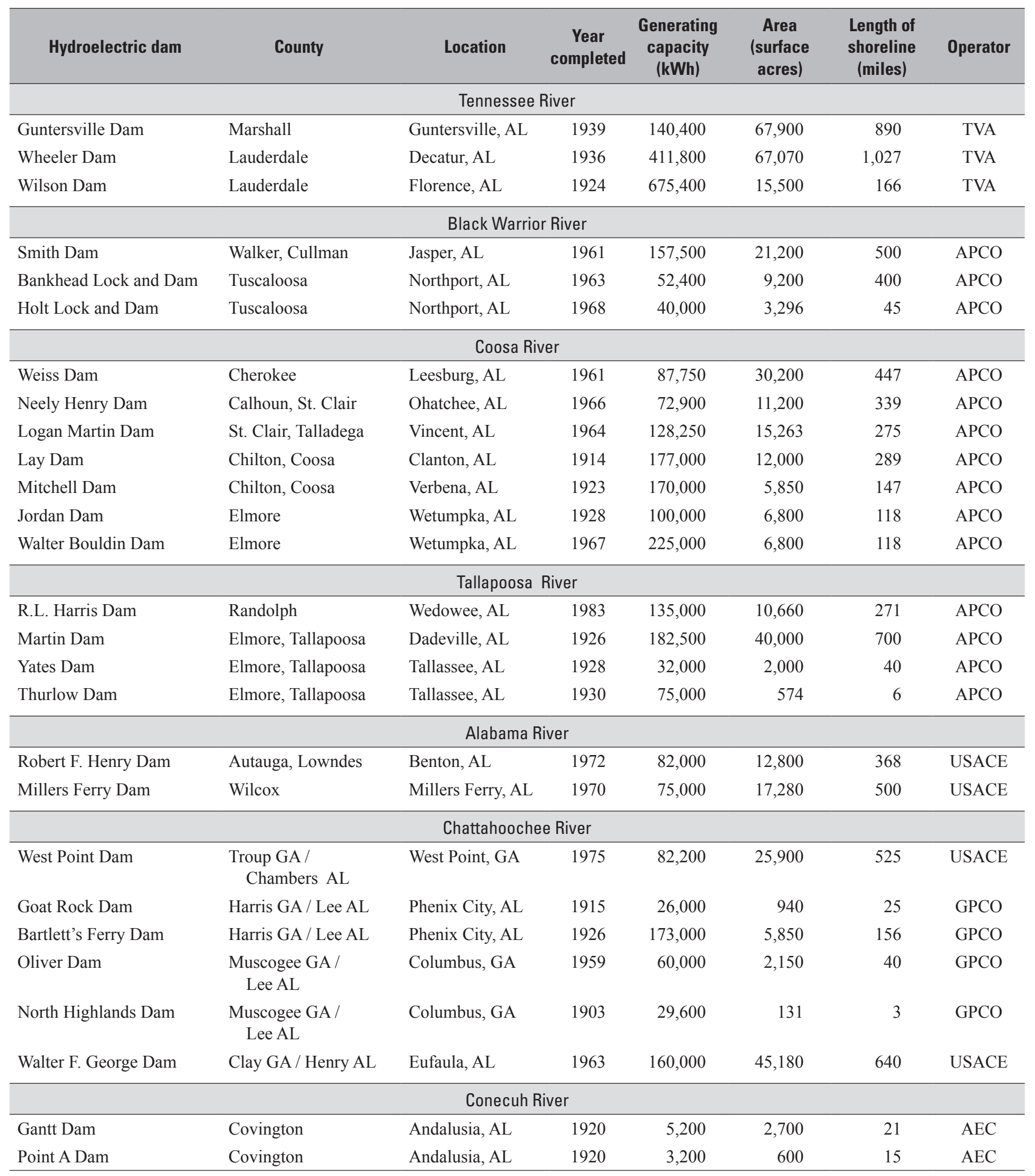




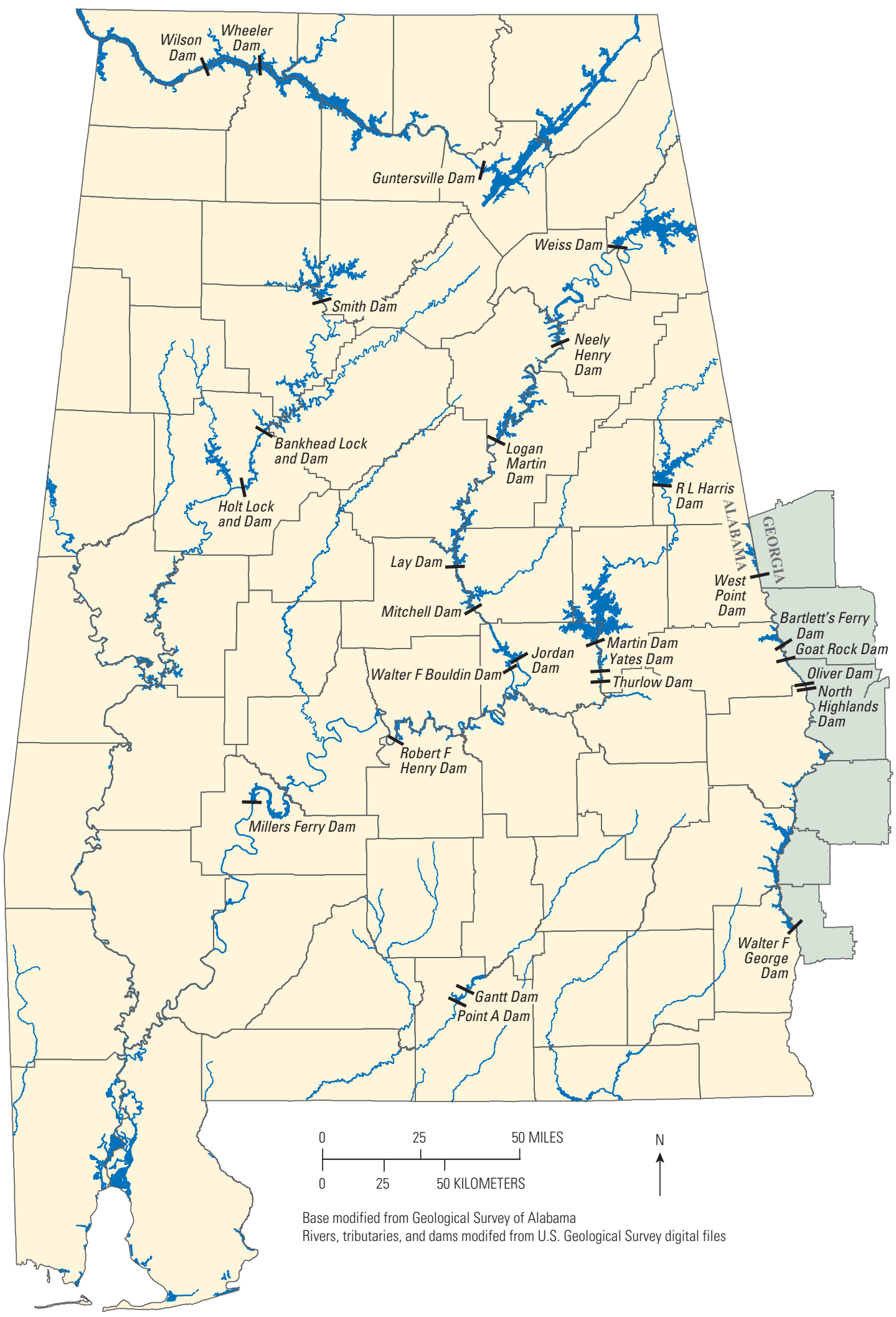

Figure E-1. Hydroelectric dams in Alabama, 2005. 
Manuscript approved on July 15, 2009

For more information about this publication contact: Susan S. Hutson U.S. Geological Survey

The University of Memphis, Ground Water Institute 300 Engineering Admininstration Building

Memphis, TN 38152

Phone: 901-246-5330

e-mail: sshutson@usgs.gov

Edited by Kimberly A. Waltenbaugh

Cartography and layout by Caryl J. Wipperfurth 
